\title{
Waarom vrouwen van apen houden : een liefdesgeschiedenis in cultuur en wetenschap
}

Citation for published version (APA):

Jensen, S. E. (2002). Waarom vrouwen van apen houden : een liefdesgeschiedenis in cultuur en wetenschap. [Doctoral Thesis, Maastricht University]. Bakker. https://doi.org/10.26481/dis.20020913sj

Document status and date:

Published: 01/01/2002

DOI:

10.26481/dis.20020913sj

Document Version:

Publisher's PDF, also known as Version of record

\section{Please check the document version of this publication:}

- A submitted manuscript is the version of the article upon submission and before peer-review. There can be important differences between the submitted version and the official published version of record.

People interested in the research are advised to contact the author for the final version of the publication, or visit the DOI to the publisher's website.

- The final author version and the galley proof are versions of the publication after peer review.

- The final published version features the final layout of the paper including the volume, issue and page numbers.

Link to publication

\footnotetext{
General rights rights.

- You may freely distribute the URL identifying the publication in the public portal. please follow below link for the End User Agreement:

www.umlib.nl/taverne-license

Take down policy

If you believe that this document breaches copyright please contact us at:

repository@maastrichtuniversity.nl

providing details and we will investigate your claim.
}

Copyright and moral rights for the publications made accessible in the public portal are retained by the authors and/or other copyright owners and it is a condition of accessing publications that users recognise and abide by the legal requirements associated with these

- Users may download and print one copy of any publication from the public portal for the purpose of private study or research.

- You may not further distribute the material or use it for any profit-making activity or commercial gain

If the publication is distributed under the terms of Article $25 \mathrm{fa}$ of the Dutch Copyright Act, indicated by the "Taverne" license above, 
Waarom vrouwen van apen houden 



\section{Waarom vrouwen van apen houden}

Een liefdesgeschiedenis in cultuur en wetenschap

Academisch Proefschrift ter verkrijging van de graad van doctor aan de Universiteit Maastricht op gezag van de Rector Magnificus

Prof. dr. A.C. Nieuwenhuijzen Kruseman volgens het besluit van het College van Decanen, in het openbaar te verdedigen op vrijdag 13 september 2002 om 16.00 uur

door

Stine Eilskov Jensen

Geboren te Hillerød (Denemarken) 
Promotores:

Prof. dr. W. Kusters

Prof. dr. J. van Dijck (Universiteit van Amsterdam)

\author{
Beoordelingscommissie: \\ Prof. dr. M.J.H. Meijer (voorzitter) \\ Dr. A. Kluveld (Universiteit voor Humanistiek) \\ Prof. dr. A. Mol (Universiteit Twente) \\ Prof. dr. H. Pott (Erasmus Universiteit Rotterdam) \\ Prof. dr. G. Verstraete
}


De vraag wie ben ik die dicteert hij.

De zin der dingen

het saldo, de vooruitgang

dat zijn zijn fantomen.

Laat je niet verblinden door trots

door schaamte, door de levens van grote mannen.

Laat je niet verleiden

door het fatsoen, de loopbaan

de vijf betoverende codes van de jeugd.

Hou op met piekeren

Schuif de boeken opzij

Zeg alle afspraken

alle lezingen, alle bezoek af.

De aap staat op de agenda.

De aap is prioriteit no. I

De wil tot weten, het zwarte hart.

De aap is de baas.

Fragment uit: K. Michel, Ja! Naakt als de stenen (1989) 



\section{Inhoud}

Woord vooraf II

Inleiding - De vrouw en de aap I4

I De vele gedaantes van de aap - Het denken over de ander

'Primatology is simian orientalism' 2I

Norm en ander 25

Ambiguiteit $\quad 28$

De aap: mens of dier? $\quad 32$

De ander ontmoet de ander 40

De aap als verhaal $\quad 45$

2 Verhalen over apen en vrouwen - De relatie tussen

cultuur en wetenschap $\quad 48$

Primatologie als verhaal $\quad 48$

Wetenschap als leespraktijk $\quad 54$

De lust tot lezen in tekst gevat $\quad 5^{8}$

Intertekstualiteit 63

Wiens verhalen? 67

Het verhaal als aap $7 \mathrm{I}$

3 Waarom een man een aap vermoordt - Mijn aap schreit van Albert Helman $\quad 75$

De moord op een aap $\quad 75$

Denkhoofd of eethoofd? $8 \mathrm{I}$

Travesti's van het ik 83

Missing link 89 


\section{Aap, mens en God 92}

Ecce simius! De aap als Christusfiguur

Ambiguïteit vermoord Ioo

'Aap, in het diepst van hun gedachten'. Mijn aap lacht

${ }_{4}$ Gorilla's tussen feit en fictie - De tragische dood

van King Kong $\quad 108$

Kongfrontatie $\quad$ 108

Gorilla: moordzuchtig monster of zachtaardige reus? III

King Kong (1933) II5

Kong als Ander I2I

Van Son of Kong tot Queen Kong I28

Gorilla's uit de mist $\quad 133$

'It was beauty killed the beast' $\quad 136$

Gorilla's tussen feit en fictie $\quad{ }_{13} 8$

5 Waarom wetenschapsters van apen houden - De representatieindustrie rondom Jane Goodall, Dian Fossey en

Biruté Galdikas I4I

Reprise: the beauty and the beast I4I

De apenonderzoekster als bemiddelaar $\quad \mathbf{1 4 3}$

De populair-wetenschappelijke autobiografieën van Jane Goodall, Dian Fossey en Biruté Galdikas $\quad$ I50

Mensapen: menselijker dan de mens? $\quad$ 157

Moord uit liefde in Brazzaville Beach $\quad \mathrm{r63}$

Karaktermoord in Gorillas in the Mist 171

Een rechtszaak tegen fictie: The Follow en Gone Wild Barbie bij de bonobo's 183

6 De aap als ideale man en nieuwe mens - Het Great Ape Project 190

De soorten voorbij 190

De retoriek van het GAP $\quad 192$

'Cultural' of 'scientific' text? 200

Terug naar het paradijs in De vrouw en de aap $\quad 205$

Van rape-ape tot ideale man $2 \mathrm{I} 2$

De laatste mannelijke man 218

Literatuur in de lachspiegel $\quad 222$

De Literatuur voorbij $\quad 226$ 
7 Waarom vrouwen van apen houden - Slotbeschouwing

Weg met het dualisme! 229

Een spiegelpaleis van apen in Ian McEwans 'Reflections of a Kept Ape' 232

De lezer als aap 239

'Cultuur' volgens Frans de Waal 243

Een liefdesgeschiedenis in cultuur en wetenschap

247

De toekomst als aap

252

Noten 259

Bibliografie $\quad 308$

Fotoverantwoording $\quad 325$

Summary $\quad 326$

Personenregister 333

Curriculum vitae $\quad 336$ 



\section{Woord vooraf}

Reader, praise the authors of this book!

All things considered - you ought to look;

But if you look, you ought not look too long -

Ten thousand fucking monkeys wrote this song.

Ten thousand fucking monkeys! Yes it's true -

Perhaps they were bored, and had nothing else to do;

And though it's said they can neither think nor write

Ten thousand fucking monkeys sure can type.

They've scanned the pertinent literatures

And made all the requisite erasures:

They've adapted, stolen, borrowed, and begged

From the works of the featherless biped.

And if there's nothing great about their pong -

Ten thousand fucking monkeys can't be wrong.

Vrij naar: 'Ten Thousand Fucking Monkeys Rap About Their Work' (1999)

van Justin Clemens.

De schrijver is als een aap. Hij vlooit, herhaalt en herneemt verhalen, doet anderen na en schept op zijn beurt een wereld. De schrijver is vele apen. Hij is een echo van allen die haar voorgingen of bijstonden. Op deze plaats wil ik een aantal mensen bedanken voor hun inspiratie, hulp en steun tijdens het schrijven van dit boek. 
Zonder alle medeschrijvers die bereid waren reacties en aanwijzingen te geven, zou dit boek er niet zijn geweest.

Van mijn promotor Wiel Kusters leerde ik dat niet alleen de schrijver, maar ook de lezer een aap is. Die vlooit, herhaalt en herneemt verhalen. Met elke herlezing tot in detail waaiert een verhaal oneindig rijk uit: er ontstaan nieuwe waarnemingen, wegen, werelden. Samen met Wiel las en herlas ik verhalen. Het geduld en interpretatieplezier van Wiel dwingt grote bewondering en respect af. Ik ben hem zeer dankbaar voor de tijd die hij heeft genomen om het leesplezier op mij over te dragen. José van Dijck, co-promotor, richtte de aandacht op de structuur en argumentatieve lijn, en stelde steeds op het juiste moment kritische vragen. Dankbaar ben ik voor de scherpzinnige suggesties, het optimisme en het vertrouwen dat ze me gaf. Als de schrijver een na-aper is, dan waren zij de sushimeesters bij wie ik de kunst probeerde af te kijken.

Daarnaast gaat mijn waardering uit naar de medewerkers van de Faculteit der Cultuurwetenschappen in Maastricht, in het bijzonder de vakgroep Letteren en Kunst, die voor een plezierige werkomgeving zorgden. Marietje Kardaun, Jan Baetens, Maarten Doorman, René Gabriëls en Karin Bijsterveld bedank ik voor hun commentaar op afzonderlijke hoofdstukken. Hugo Paulissen en Sjoerd Stoffels bedank ik voor hun hulp bij het verzamelen en opmaken van de afbeeldingen. Ook elders bevonden zich mensen die zich voor mijn project geïnteresseerd hebben. Michiel van Kempen, Mineke Bosch, Herman van Well en Maaike Meijer bedank ik voor hun commentaar op hoofdstuk drie en Jan Hein Furnée voor zijn zorgvuldige redactiewerk op een artikel dat aan de basis stond voor hoofdstuk vier. Raymond Corbey ben ik dankbaar voor zijn enthousiasme en belangstelling voor mijn project: hij voorzag mij niet alleen van talloze literatuurtips, maar nodigde mij ook op het juiste moment uit om zijn collegereeks in Tilburg over apen bij te wonen. Margaret Meredith bedank ik voor het corrigeren van de Engelse samenvatting. David van Reybrouck leerde ik pas in de afrondende fase kennen - de eerste promovendus die ik na vier jaar tegenkwam en ook 'iets met apen' deed! Hartelijk dank voor een plezierige correspondentie vol irrelevante ('ík heb Jane Goodall gekust, jij?') en relevante informatie-uitwisseling omtrent vrouwen en apen.

Van alle apen lijkt de proefschriftschrijver het meest op een orang-oetan: teruggetrokken, geïsoleerd en vaak met die gekwelde 
en verstrooide blik. Het solitaire bestaan van een proefschriftschrijver zou bij vlagen ondragelijk zijn, ware het niet dat hij af en toe een lotgenoot treft om het leed mee te delen. Naast de wTMc-opleiding, onder de ontspannen begeleiding van Arie Rip en Barend van der Meulen, was het commentaar van de leden van de aio-pizza een onmisbare en plezierige leerschool: hartelijk dank aan Marco Goud, Ruud Hendriks, Jessica Slijkhuis, David Hamers, Anique Hommels, Peter Peters en Eric Lemmens. Ruth Mourik bedank ik daarnaast ook als de fijnste kamergenote die ik maar had kunnen wensen. Op de paar vierkante meter die wij bijna vijf jaar deelden, zijn veel bijzondere gesprekken gevoerd over alles wat ons bezighield: koeien, apen, de liefde en heel het leven. Ruth Benschop bedank ik, behalve voor haar warme vriendschap, ook voor het zorgvuldige en adequate commentaar op een eerste versie van dit boek.

Dan zijn er nog vriendinnen en vrienden die me hebben gesteund met informatie, telefoontjes, krantenknipsels, mail, muziek en aandacht. Veel dank aan Ingrid Tigchelaar, Jessica Slijkhuis (Jalla!), Kor Grit, Katja Rodenburg, Michiel van Well, Marina van Haalen, Martine Maassen, Harm Nijboer, Carolien Oomes, Saskia Plass, Geraldine Woestenenk, Ivo van Hilvoorde, Paul Harts, Quinten van Katwijk, Leo Wolthers, Margreet Boersma, Annegien van Hagen, Annegreeth Lameijer (Queen Kong!) en Monique Huyskes.

Tot slot wil ik mijn familie noemen: Niels Eilskov Jensen, Kirsten Ehler en Lis Eilskov Jensen. Maar bovenal gaat mijn dank uit naar Lotte Jensen. Lotte, toen wij klein waren, hadden we samen één aap die wij moesten delen. De houten mini-Kong werd meerdere malen door een van ons gekidnapt, totdat ik een 'aap of my own' kreeg. Mini-Kong en Curious George zitten tot op de dag van vandaag tevreden in de vensterbank, de een in Utrecht, de ander in Maastricht/ Amsterdam. 


\section{Inleiding}

\section{De vrouw en de aap}

Ze knikte naar het lid.

'De pieleman,' zei ze.

De aap strekte een arm uit, legde de achterkant van zijn ene hand tegen haar been en schoof hem voorzichtig onder haar jurk omhoog. Madelene voelde in haar schoot de warmte van zijn hand, maar hij raakte haar niet aan. Hij keek haar vragend aan.

'Kriebelientie,' zei ze hees, bij wijze van uitleg.

Zonder de blik van het dier los te laten, lichtte ze haar jurk op, tot haar borsten vrijkwamen. Langzaam boog de aap zich naar voren, boog zijn hoofd, als een rituele groet, en nam haar tepel tussen zijn tanden.

Hij richtte zich op, en ze keken elkaar in de ogen zoals geen levende wezens naar elkaar kijken. Toen pakte hij haar slipje beet, heel voorzichtig, met handen die zelfs in het aardedonker met zekerheid onderscheid maakten tussen satijn en glanskatoen, en trok het uit. Madelene liet zich naar achteren glijden, nog steeds in slowmotion, en de aap kwam achter haar aan.

Deze opmerkelijke liefdesscène is te lezen in De vrouw en de aap (1996) van de Deense schrijver Peter Høeg. In deze roman maken we kennis met de wetenschapper Adam Burden. Hij heeft het zo druk met zijn carrière in de zoölogie, dat hij zijn vrouw, de beeldschone Madelene, volkomen verwaarloost. Uit onvrede dwarsboomt zij de wetenschappelijke experimenten van haar man door Erasmus, een aap van een onbekende hogere soort en het object van zijn onderzoek, te bevrijden. Madelene wordt hartstochtelijk verliefd op de aap. Erasmus neemt Madelene mee naar een paradij- 
selijk bos, waar ze de gelukkigste tijd van haar leven doorbrengt. Daar speelt zich ook de bovenstaande liefdesscène af. De erotische ontmoeting is bijzonder, bijna buitenaards; ze kijken elkaar aan 'zoals geen levende wezens naar elkaar kijken'. Madelenes echtgenoot is vreselijk jaloers en overweegt de aap te doden. Maar hij ziet in dat zijn vrouw gelukkiger is met de aap. Madelene, inmiddels zwanger van het dier, vertrekt met Erasmus naar een bosrijke omgeving in het Noorden.

De bizarre vrijpartij wekte mijn nieuwsgierigheid. Waarom verkiest een vrouw een aap boven haar echtgenoot? Al spoedig kwam ik erachter dat Madelene niet de enige vrouw is in de westerse literatuur- en filmgeschiedenis die haar geluk vindt bij een aap. De bestiale vrijpartij lijkt op het eerste gezicht absurd, maar wie op zoek gaat, ontdekt in de westerse cultuur veel meer voorbeelden van seksuele relaties tussen vrouwen en mannelijke apen. Om enkele voorbeelden te noemen: de film King Kong (r933) toont ons een gorilla die hopeloos verliefd is op Ann, een mooi blond meisje. De gorilla moet het, tot groot verdriet van de kijker die met hem is gaan sympathiseren, aan het eind van de film bekopen met de dood, in de remake (1976) geniet Jessica Lange in haar rol van Ann met volle teugen van de aandacht van de gorilla. Ze laat zich door hem baden in een waterval en bij afwezigheid van een föhn in de jungle, blaast King Kong zachtjes haar haren droog. In de film Max Mon Amour (1987) zoekt Margaret haar toevlucht tot een chimpansee. Haar overspelige echtgenoot Peter is erg bang dat de chimpansee een betere minnaar is dan hijzelf. Maar zijn grootste vrees is dat het zijn vrouw niet alleen om de seks gaat; dat ze echte liefde voor de aap voelt. Dat Peter Høegs Madelene voor een aap valt, is dus niet uniek.

Niet alleen in de culturele verbeelding, maar ook in de hedendaagse primatologie - het wetenschappelijke onderzoek naar apen, mensapen en mensen - treft men een innige band aan tussen vrouwen en apen. In vergelijking met andere natuurwetenschappen en subdisciplines binnen de biologie, zijn er opmerkelijk veel vrouwen werkzaam in de primatologie. ${ }^{1}$ Iedere apensoort lijkt bovendien zijn eigen toegewijde vrouw te hebben. Chimpansees hebben hun Jane Goodall, gorilla's danken hun beschermde status aan Dian Fossey, orang-oetans horen bij Biruté Galdikas, wier bijnaam 'moeder van de apen' luidt. Shirley Strum staat bekend als de vrouw van de ba- 
vianen, en Ellen van Krunkelsven is door de Vlaamse journalist Dirk Draulans uitverkoren tot 'barbie van de bonobo's' (Draulans 1998: 107). Niet alleen hebben zij hun liefde voor apen verwoord in (populair-)wetenschappelijke boeken; ook werden zij geportretteerd in romans, films, documentaires en biografieën.

De ontmoeting tussen de vrouw en de aap is zo op het eerste gezicht voor meerdere interpretaties vatbaar. De relatie kan erotisch getint zijn, zoals in King Kong of in De vrouw en de aap. Of het is die van een onderzoeker met haar onderzoeksobject aap $(M / v)$ dat overigens als subject benaderd wordt. Deze relatie wordt soms weer gezien als een moeder-kindrelatie, wanneer de vrouwelijke primatologen voor de apen zorgen als waren zij hun kinderen. Het thema van de vrouw en de aap is het onderwerp van dit boek. Daarin maak ik een reis langs de beeldvorming van de liefdesgeschiedenis tussen de vrouw en de aap in een selectie van korte verhalen, romans, films en (populaire) wetenschap van de twintigste eeuw. De centrale vraag van dit boek luidt: hoe kunnen we de relatie tussen de vrouw en de aap interpreteren? Met andere woorden: wat voor een betekenis kunnen we geven aan het terugkerende thema van de vrouw en de aap? Tevens stel ik de vraag of en hoe het thema in de loop van de tijd een andere invulling krijgt en hoe we veranderingen in de beeldvorming kunnen begrijpen. Spelen maatschappelijke, culturele en wetenschappelijke ontwikkelingen daarbij een rol, en zo ja, welke?

Om deze vragen te beantwoorden, onderzoek ik hoe het thema van de vrouw en de aap in een aantal teksten en beelden vorm krijgt en welke betekenis eraan kan worden toegekend door mij en door anderen. ${ }^{2}$ Daartoe heb ik een afbakening gemaakt. Om te beginnen heb ik ervoor gekozen om mij te richten op een aantal specifieke voorbeelden van relaties tussen de vrouw en de aap in de westerse cultuur $^{3}$ van de twintigste eeuw. Het thema van de vrouw en de aap is echter veel ouder. $\mathrm{Al}$ in de eerste eeuw circuleerde in het Oosten een erotische vertelling over een prinses en een reuzenaap in Duizend-en-één-nacht, die vermoedelijk de inspiratie heeft gevormd voor westerse verhalen over vrouw-aaprelaties. ${ }^{4}$ De kunsthistoricus H.W. Janson, die in zijn boek Apes and Ape Lore in the Middle Ages and the Renaissance (1952) een uitvoerige inventarisatie van de historische wortels van erotische voorstellingen van vrouwen met apen in de Oudheid, Middeleeuwen en Renaissance gaf, ${ }^{5}$ vermoedt dat 
deze tekst vertaald is in de elfde eeuw, in het Westen ging circuleren, en de inspiratie vormde voor bijvoorbeeld Voltaires Candide ( \pm 1759), waarin twee vrouwen een aap als geliefde hebben. ${ }^{6}$

Hoewel ik, wanneer nodig, op deze lange traditie zal teruggrijpen, beperk ik mij om pragmatische redenen tot de twintigste eeuw. Dat is op zich al een aanzienlijke tijdspanne, waarbinnen een enorme hoeveelheid materiaal voorhanden is. Ik heb gekozen voor een relatief klein corpus, omdat mijn doel niet zozeer generaliserend is, alswel gericht op de bijzonderheid en de betekenisvolle meerduidigheid van individuele teksten. Achtereenvolgens zijn de belangrijkste voorbeelden die ik bespreek de roman Mijn aap schreit (1928) van Albert Helman, de film King Kong (1933), de band tussen de vrouwelijke primatologen en apen (tussen r96o en 1998) en de roman De vrouw en de aap (1996) van Peter Høeg. Hoewel het niet mijn bedoeling is een algemene en definitieve geschiedenis van de vrouw en de aap te schrijven (als dat al mogelijk zou zijn) en ik eerder wil laten zien op welke wijze de relatie tussen de vrouw en de aap in verschillende periodes naar voren komt, hoop ik door de chronologische opzet toch enig inzicht te krijgen in een mogelijke ontwikkeling of eventuele verandering in de beeldvorming.

De verhalen komen uit Nederland, Denemarken, Engeland en de Verenigde Staten. ${ }^{7}$ Sommige beelden zijn zo beroemd, dat ze deel uitmaken van ons culturele geheugen, zoals de film King Kong; andere verhalen zijn gekozen omdat ze in het kader van het thema de vrouw en de aap nieuwe betekenisaspecten krijgen, zoals het in de vergetelheid geraakte Mijn aap schreit van Albert Helman. De keuze voor verschillende media, zoals de roman, het korte verhaal, speelfilm en (populaire) wetenschap is bedoeld om de reikwijdte van het thema de vrouw en de aap zichtbaar te maken en om onderlinge ('intertekstuele') verbanden te kunnen onderzoeken, bijvoorbeeld tussen literaire en wetenschappelijke teksten. ${ }^{8}$

De verhalen en films bestrijken de periode tussen 1928 , het publicatiejaar van Mijn aap schreit, en 1996, het jaar dat De vrouw en de aap verschijnt. Gekozen is voor Mijn aap schreit als startpunt, omdat in dit verhaal de ontmoeting tussen een aap en een vrouw de hoofdpersoon ertoe aanzet te reflecteren over enkele grote vragen van het leven: wie is de mens, waar komt hij vandaan en wat is zijn aard? Het verhaal geeft vorm aan de impact van het darwinistische gedachtegoed op een fictief individu, een mannelijk personage in dit 
geval. Mijn aap schreit maakt de worsteling van de man met de belangrijkste kentering van de status van de aap in de westerse cultuur - van vijand naar naaste familielid - in alle ernst voelbaar. In De vrouw en de aap komt de aap naar voren als ideale man en minnaar van de vrouw. Dat roept de vraag op wat zich in de tussentijd heeft afgespeeld.

Mijn benadering van de verhalen is te karakteriseren als ideologiekritisch (hoe worden bepaalde conventies herhaald en wat zijn daarvan de implicaties) en contextueel (hoe kun je de teksten betekenisvol situeren, bijvoorbeeld door verbanden te leggen met andere relevante teksten). Daarbij probeer ik echter oog te houden voor het specifieke, de ambiguïteiten en de nuances van de individuele tekst, die steeds het uitgangspunt vormt voor het stellen van interpretatieve vragen. De verhalen zijn een reflectie van en geven vorm aan veranderende maatschappelijke denkbeelden, maar ze zijn ook om literaire redenen de moeite waard. Mijn leeswijze is gebaseerd op een kruisbestuiving tussen de ideeën van meerdere denkers: de Amerikaanse cultuurcritica Donna Haraway, de kunsthistoricus H.W. Janson, de filosofe Annemarie Mol en de letterkundige Maaike Meijer. Hun werk komt aan de orde in de eerste twee hoofdstukken, waarin een aanzet wordt gedaan tot theorievorming over de verhouding tussen vrouw en aap. Hoewel zij hier disciplinair gekarakteriseerd worden, gaan zij allen interdisciplinair te werk. Dat laatste geldt ook voor dit boek, waarin ik inzichten uit wetenschapsonderzoek, filosofie, literatuurwetenschap en culturele studies combineer.

Het eerste hoofdstuk gaat in op de vraag waarom steeds (mannetjes)apen en blanke vrouwen in die combinatie opduiken. ${ }^{9}$ Met de aap is iets bijzonders aan de hand. Van alle dieren lijkt de aap het meest op de mens, maar hij is geen mens. ${ }^{10}$ Vanwege deze ambivalente positie is de aap de aangewezen figuur om angsten en dromen op te projecteren. Vragen als 'waar komt de mens vandaan' en 'wat is de status en de aard van de mens' zijn terugkerende obsessies in onze cultuur die via de aap worden onderzocht of tot uitdrukking gebracht. Verhalen over apen - of ze nu in een roman of een wetenschappelijke tekst vorm krijgen - zeggen dan ook veel of misschien zelfs meer over de mensen die ze vertellen dan over de apen. Apen spelen een belangrijke rol in het bepalen van wat wij verstaan onder menselijk, dierlijk, vrouwelijk, mannelijk, seksualiteit, zwart, wit, natuur en cultuur. Maar daarmee is nog niet duidelijk waarom ook 
vrouwen opduiken in de verhalen over apen. Met behulp van het begrip 'ambiguïteit' reflecteer ik op de relatie tussen de aap en de vrouw, die net als de aap, bekendstaat als 'ander'.

In het tweede hoofdstuk zet ik mijn leeswijze uiteen en ga ik in op de vraag hoe verhalen over de aap en de vrouw te lezen. Het opmerkelijke gegeven dat de relatie tussen de vrouw en de aap niet alleen terug te vinden is in fictie, bijvoorbeeld romans en films, maar ook in de wetenschapspraktijk, genereert de volgende vragen: waarom keert de band tussen de vrouw en de aap zowel terug in culturele uitingsvormen als in de wetenschapspraktijk? Zegt dat iets over de relatie tussen cultuur en wetenschap, en zo ja wat? ${ }^{11}$ De termen 'cultuur' en 'wetenschap' zijn het onderwerp geweest van talloze studies en definities, en het gaat mij niet om het vaststellen van nieuwe definities of het meten van wederzijdse invloed. Door de relatie tussen 'feit' en 'fictie' centraal te stellen, hoop ik wel inzicht te krijgen in de wijze waarop beide velden, al dan niet op verschillende wijze, vormgeven aan wat een aap is en wat een vrouw. Door verschillende lees- en interpretatietheorieën met elkaar te vergelijken, formuleer ik ten slotte de benadering die ik heb gekozen om verhalen over vrouwen en apen uit verschillende velden met elkaar in gesprek te brengen, namelijk door fictie te interpreteren in het licht van wetenschappelijke ontwikkelingen (zoals die hun neerslag vinden in teksten) en omgekeerd wetenschap te plaatsen in een bredere culturele context.

De hoofdstukken drie tot en met zeven zijn gecentreerd rondom de analyse, interpretatie en receptiegeschiedenis van een specifiek verhaal - een kort verhaal, een roman, een film of een (populair-) wetenschappelijke tekst - uit de westerse cultuur, waarin voor de vrouw en de aap hoofdrollen zijn weggelegd. Hoofdstuk drie bevat een interpretatie van Mijn aap schreit. Een korte roman (1928) van Albert Helman, waarin een jongeman zijn huisdier, een aap die het buitengewoon goed met vrouwen kan vinden, vermoordt. Hoofdstuk vier is opgezet rondom de film King Kong (1933), de bekendste apenfilm die er ooit gemaakt is. In hoofdstuk vijf ga ik in op het hoge aantal vrouwen in de primatologie. Ik analyseer verhalen van en over Jane Goodall, Dian Fossey en Biruté Galdikas. William Boyds roman Brazzaville Beach (1990) en de film Gorillas in the Mist (r992) zijn daarvan de bekendste. In hoofdstuk zes kom ik terug op Peter Høegs roman De vrouw en de aap (1996), die ik lees in de con- 
text van het Great Ape Project, waarin gepleit wordt voor de toekenning van mensenrechten aan mensapen. In het laatste hoofdstuk komen de lijnen van de voorgaande hoofdstukken samen aan de hand van een confrontatie met twee teksten waarin nagedacht wordt over de relatie tussen mensen en apen. In Ian McEwans verrassende korte verhaal 'Reflections of a Kept Ape' dat al in 1978 werd geschreven, maar pas in 1997 door een herdruk zijn weg naar een breder publiek vond, overpeinst een aap zijn liefde voor een schrijfster. In de tweede tekst, The Ape and the Sushi Master. Cultural Reflections of a Primatologist (200I) reflecteert een apenonderzoeker, Frans de Waal, over zijn vakgebied. In het boek van De Waal staat niet het thema van de vrouw en de aap centraal, maar wel markeert dit boek een belangrijke omslag in het wetenschappelijke denken over mensen en apen ná De vrouw en de aap. De Waal beargumenteert dat apen cultuur hebben. In mijn reflectie op de reflecties van De Waal en McEwans aap belanden we op de laatste bladzijden van dit boek in een duizelingwekkend spiegelpaleis van apen, waarin men zich kan afvragen of er nog wel een verschil gemaakt kan worden tussen 'mens' en 'aap', 'zwart' en 'wit', 'man' en 'vrouw', 'cultuur' en 'natuur', 'feit' en 'fictie', 'literatuur' en 'wetenschap'. Terwijl de man overpeinst of er nog hoop is voor de menselijke cultuur, omarmen vrouwen en apen elkaar hartstochtelijk en zien ze een toekomst vóor zich waarin ambiguïteit zegeviert. 


\title{
De vele gedaantes van de aap
}

\author{
Het denken over de ander
}

All of nature talks to me

If I could just figure out what it was trying to tell me

Lauri Anderson, 'Sharkey's Day', Mister Heartbreak (1984)

'PRIMATOLOGY IS SIMIAN ORIENTALISM'

In 1989 verschijnt Primate Visions. Gender, Race and Nature in the World of Modern Science van Donna Haraway. Het is een lijvig boek met op de voorkant een afbeelding van een ontmoeting tussen een donkere, harige chimpanseehand en een blanke vrouwenhand. De mensenhand behoort toe aan de Britse primatologe Jane Goodall. Voor het eerst schudt zij de hand met een wilde chimpansee in Tanzania. Haraway ontleent deze afbeelding aan een advertentie van een oliemaatschappij, die deze in 1984 op haar beurt ontleende aan het tijdschrift National Geographic. De advertentie wordt in Primate Visions uitvoerig besproken en dient als kapstok om vragen op te werpen naar de politieke en historische betekenis van deze aanraking. Waarom is het een blanke vrouwenhand? Wat moet een oliemaatschappij met deze afbeelding?

De reclame van het oliebedrijf onthult volgens Haraway dat het bedrijf zich na de grote energiecrisis en enkele schandalen wil associëren met een milieuvriendelijke aanpak. Het associeert zich met deze afbeelding ook met de ars erotica van de wetenschap, waarbij de blanke vrouwelijke hand van Goodall de communicatie en aan- 
raking met de 'wildernis' representeert (Haraway 1989: 136). Maar, zo vraagt Haraway zich terecht af, waarom kan in dit geval nu juist een blanke vrouw het beste 'de mensheid' vertegenwoordigen? Om deze vraag te beantwoorden, oppert Haraway de volgende stelling, een van de belangrijkste stellingen van Primate Visions: wij kunnen het niet over apen hebben, zonder het ook over onszelf te hebben. Of we het nu willen of niet, onze verhalen over apen zeggen misschien iets over de apen, maar nog veel meer over de mensen die ze vertellen. ${ }^{1}$ De reclame vertelt ons bijvoorbeeld iets over het zelfbeeld van de oliemaatschappij: zij staan een betere toekomst voor, waarin anderen niet worden 'uitgebuit', maar waarin samenwerking en contact wordt gezocht. Een 'zachte', vrouwelijke hand kan het beste deze toenadering zoeken.

De advertentie is slechts een van de vele voorbeelden uit Primate Visions. In zijn geheel is Primate Visions te lezen als een cultuurkritische geschiedenis van de primatologie. ${ }^{2}$ Daarbij vat Haraway het begrip 'wetenschap' ruim op: zij rekent niet alleen 'strikt' canonieke wetenschappelijke bronnen tot haar materiaal, maar ook documentaires, films, advertenties (zoals die van de oliemaatschappij), ansichtkaarten, romans en tentoonstellingen. De titel Primate Visions doet denken aan twee bekende en omvangrijke basiswerken in de primatologie: Primate Societies (B. Smuts et al. 1987) en Primate Behavior (I. DeVore 1965). Haraway schaart zich met haar titel tussen deze standaardwerken, met de pretentie om visies op primaten in kaart te brengen. 'Visions' geeft niet alleen aan dat primatologie vooral een activiteit is waarin waarnemen, kijken en bekeken worden centraal staan, maar het meervoud wijst er tevens op dat het Haraway gaat om meerdere perspectieven, meerdere gezichtspunten op de primatologie. De ondertitel geeft Haraways thematische en politieke invalshoek via trefwoorden weer, namelijk 'gender', 'race' en 'nature' in de wereld van de moderne wetenschap. ${ }^{3}$

'How are love, power, and science intertwined in the constructions of nature in the late twentieth century?' Met deze vraag opent Primate Visions. Daarmee positioneert Haraway zich in een notendop niet alleen als een Foucaultiaan, door ervan uit te gaan dat macht en wetenschap nauw verbonden zijn met elkaar, maar ook als een constructivist door te spreken van 'constructions of nature.' Deze vraag wordt gevolgd door een reeks andere vragen. 'What may count as nature for late industrial people? What forms does love of 
nature take in particular historical contexts? For whom and at what cost? In what specific places, out of which social and intellectual desire? How do the terrible marks of gender and race enable and constrain love and knowledge in particular cultural traditions, including the modern natural sciences? Who may contest for what the body of nature will be?' (I) Deze vragen liggen aan de basis van de manier waarop ze haar geschiedenis van de primatologie schrijft en hoe ze haar materiaal heeft benaderd. Samenvattend gaat het haar vooral om de vraag 'wat telt voor wie en ten koste van wie als natuur'. Daarmee geeft Haraway aan dat ze 'natuur' niet opvat als een essentie, een onproblematische plek die aangewezen en gelokaliseerd kan worden, maar als een door gender, kleur en wetenschap vormgegeven constructie die steeds aan verandering onderhevig is.

'Apen' vallen onder 'natuur' en worden derhalve ook door gender, kleur en wetenschap geconstrueerd. Apen spelen volgens Haraway een belangrijke rol in het vertellen van verhalen over wie 'wij' zijn.

Especially western people produce stories about primates while simultaniously telling stories about the relations of nature and culture, animal and human, body and mind, origin and future. Indeed, from the start, in the mid-eighteenth century, the primate order has been built on tales about these dualisms and their scientific resolution. (5)

De primatologie is een vakgebied waar in termen van dualismen wordt 'onderhandeld' over de menselijke identiteit, wie mensen zijn, waar ze vandaan komen en waar ze naartoe gaan. 'It is the negotiation of the time of origins, the origin of the family, the boundary between self and other, hominid and hominoid, human and animal.' (Haraway r989: 284)

Haraway noemt de primatologie 'simian orientalism'. Ze verwijst daarmee naar de term oriëntalisme die in 1978 door Edward Said werd geïntroduceerd en waarmee hij doelde op de functie die de Oriënt lange tijd heeft gehad voor het Westen, namelijk als reflexieve spiegel. Said bekritiseert het westerse discours, waarin de Oriënt (en de islam) vaak wordt voorgesteld als een homogene identiteit waaraan de westerling zich kan spiegelen. In feite, zo stelt Said, vindt er een co-constructie plaats: noch het Westen, noch de Oriënt zijn vastliggende entiteiten. Ze worden in relatie tot elkaar gedefi- 
nieerd. Apen vormen volgens Haraway een soortgelijke spiegel voor de mensen. Ze zijn de ander waarlangs de mens een zelfbeeld construeert. Dat zelfbeeld is westers, rationeel, blank en mannelijk:

Simian orientalism means that western primatology has been about the construction of the self from the raw material of the other, the appropriation of nature in the production of culture, the ripening of the human from the soil of the animal, the clarity of white from the obscurity of color, the issue of man from the body of woman, the elaboration of gender from the resource of sex, the emergence of mind by the activation of body. (II)

De identiteitsconstructie van de blanke westerse man vindt steeds plaats door een beroep te doen op wat hij niet zou zijn. De 'aap' dient als grondstof voor zijn zelfdefinitie, en fungeert als 'ruwe' ander, als projectiefiguur en afzetpunt. De aap representeert daarbij dierlijkheid, wildheid, vrouwelijkheid, natuurlijkheid, lichamelijkheid, primitiviteit en seksualiteit. ${ }^{5}$ Dat betekent echter wel dat die begrippen in dat proces van betekenisgeving ook eerst ingevuld moeten worden. Haraway wijst er net als Saïd op dat apen en de daarmee geassocieerde kenmerken zoals dierlijkheid en primitiviteit geen vaststaande bronnen zijn waaruit geput kan worden, maar dat de binaire polen elkaar constitueren, en dat bovendien het onderscheid tussen mens en aap gekoppeld wordt aan andere elkaar constituerende dichotomieën, zoals cultuur-natuur, man-vrouw, geest-lichaam. Derhalve is natuur geen 'vaste' grondstof voor cultuur, sekse is niet de grondstof voor gender enzovoort. ${ }^{6}$ De 'norm' en de 'ander' of de 'afwijking' constitueren elkaar, stelt Haraway in navolging van Foucault.

Haraways stelling roept een aantal vragen op. In hoeverre fungeert de aap inderdaad als projectiefiguur en afzetpunt? En voor wie fungeert de aap als projectiefiguur? Is de aap inderdaad vooral 'ander' ten opzichte van de blanke westerse man, zoals Haraway schrijft? Terugdenkend aan de voorkant van Primate Visions, waarop een vrouwenhand en een apenhand elkaar ontmoeten, is het interessant je af te vragen hoe de witte westerse vrouw haar identiteit construeert. Is niet ook de vrouw bij uitstek een projectiefiguur in de westerse cultuur? Wat gebeurt er wanneer 'de aap' en 'de vrouw', beiden een culturele 'ander', elkaar ontmoeten? Ha- 
raways ideeën worden bovendien overwegend vanuit een synchroon perspectief beschreven. Is het altijd zo geweest dat apen voor westerlingen als exotische projectiefiguur fungeren, zoals de Oriënt dat ook deed, of zijn er historische ontwikkelingen zichtbaar geweest in het westerse denken over apen? Hoe verklaart Haraway veranderingen in het aap- dan wel vrouw- en manbeeld? Dit hoofdstuk staat in het teken van deze vragen. Eerst ga ik in op het binaire denken, vervolgens op ambiguitteit (die van de aap in het bijzonder) en tot slot op de ambiguïteit die ontstaat wanneer vrouwen en apen met elkaar in ontmoeting worden gebracht.

\section{NORM EN ANDER}

Om de wereld te begrijpen categoriseren en oordelen we voortdurend. Mens, dier of ding? Een mens? Man of vrouw? Wit of zwart? Jong of oud? Mooi of lelijk? Een dier? Wat voor soort dier? Een aap? Wat voor soort aap, mensaap of anders? Een ding? Wat voor ding? Een gebruiksvoorwerp of een sierstuk? Mooi of lelijk? Praktisch of nutteloos? Het reduceren van wat we waarnemen gebeurt vaak in structurerende opposities, en gaat gepaard met hiërarchisch denken en oordelen in termen van 'norm' en 'ander'.

De tweede helft van de twintigste eeuw heeft in het teken gestaan van de emancipatie van de ander. De ander kent in de westerse cultuur vele gedaanten, bijvoorbeeld de vrouw, het dier, de zwarte, de Ier, de jood, de primitieve, de zot, de zwerver of de homoseksueel. Binnen de universiteiten wordt de aandacht voor de ander gewaarborgd en geïnstitutionaliseerd door middel van diverse 'anderen-studies', onder meer genderstudies, homostudies en lesbische studies, black en ethnic studies, religious studies, en, van meer recente datum, disability studies, waarin aandacht gevraagd wordt voor mensen met een bepaalde handicap. ${ }^{7}$ De afgelopen decennia zijn talloze studies verschenen waarin aangetoond wordt hoe de menselijke 'ander' in al haar verschijningsvormen ten onrechte geobjectiveerd en gestereotypeerd is, en vaak als projectiescherm dient om de norm in stand te houden. Opvallend is dat de (geconstrueerde) ander ten opzichte van de (geconstrueerde) norm steeds dezelfde associaties genereert. Net als de aap, is bijvoor- 
beeld 'de vrouw' gebruikt als 'grondstof' voor identiteitsvorming van de westerse blanke man (die daarmee op zijn beurt een stereotype werd). Veel feministische studies van de afgelopen decennia hebben laten zien hoe vrouwen en vrouwelijkheid vaak op stereotiepe wijze gerepresenteerd worden als bijvoorbeeld gevoelsmatig, moederlijk of lustobject (zie bijvoorbeeld Meijer 1996).

Wie een aantal van deze cultuurkritische studies naast elkaar legt, ziet een opvallende overeenkomst in de eigenschappen die aan 'de ander' worden toegeschreven. Uit onderstaande vier voorbeelden uit dergelijke studies, waaronder Haraways opvatting van de aap als projectiefiguur, blijkt dat definities van 'anderen' zijn geconstrueerd via opvattingen over wat een vrouw, een zwarte, en natuur(lijk) is:

[...] Simian 'orientalist' discourse must first construct the terms: animal, nature, body, primitive, female. Traditionally associated with lewd meanings, sexual lust, and the unrestrained body, monkeys and apes mirror humans in a complex play of distortions over centuries of western commentary on these troubling doubles. (Haraway 1989: II)

Since woman was designated as the originator of sexual sin, black women were naturally seen as the embodiment of female evil and sexual lust. (hooks rg8r: 33)

Primitives are like children, the tropes say. Primitives are our untamed selves, our id forces-libidinous, irrational, violent, dangerous. Primitives are mystics, in tune with nature, part of its harmonies. Primitives are free. Primitives exist at the the lowest cultural level' (Torgovnick 1990: 8).

Allereerst heeft men van oudsher allerlei eigenschappen aan narren toegekend die in onze ogen zeer eigen zijn aan zwakzinnigen, zoals scheelzien, muzikaliteit, lachlust, een lakse moraal, geknoei met voedsel en gesnotter van eeuwige snotneuzen [...] Zwakzinnigen voor dierlijk of duivels uitmaken is ondenkbaar geworden; soms wordt de menswaardigheid van hun bestaan echter wel degelijk betwijfeld. (Mans 1998: 24, 42) 
Bovenstaande voorbeelden laten zien hoe 'anderen', in de gedaante van de aap, de zwarte vrouw, de primitieve en de zwakzinnige met vergelijkbare objectiverende eigenschappen wordt geassocieerd. ${ }^{8}$ Ze treden allen op als 'karikaturen' van de norm, als mindere mensen met dierlijke en kinderlijke trekken, een gebrekkig verstand en een overmatige gerichtheid op het lichamelijke, met name seksualiteit.

De kritische studies waaruit deze voorbeelden komen, laten stuk voor stuk zien dat er steeds hetzelfde mechanisme ten grondslag ligt aan identiteitsvorming: het denken in dualismen die zich hiërarchisch ten op zichte van elkaar verhouden, in een norm en de afwijking daarvan. De belangrijkste terugkerende binaire opposities die de grondstof voor het 'anders-zijn' vormen, zijn opvattingen over gender, soort, kleur en seksualiteit. De ander, in welke gedaante dan ook, wordt steeds voorgesteld in termen van 'vrouwelijkheid', 'dierlijkheid', 'primitiviteit' en kenmerkt zich door 'afwijkend seksueel gedrag'. De ander wordt steeds in termen van deze elkaar versterkende en oproepende ketens van opposities geconstrueerd en 'vastgepind', hetgeen opgevat kan worden als een poging de ander, die kennelijk verklaring en uitleg behoeft, te beheersen en te controleren.

Deze definities van 'anderen' laten niet zien wie de ander is, maar onthullen wie 'we' zelf willen zijn. In feite is er sprake van een co-constructie: norm en ander constitueren elkaar. In toenemende mate is ook 'de norm' onderwerp van studie geworden. Richard Dyer (1997) liet het geconstrueerde karakter van 'witheid' zien, 'mannelijkheid' is in toenemende mate onderwerp van constructivistisch onderzoek (Smith r996), en ook naar heteroseksualiteit is onderzoek gedaan (Ingraham 1999). Ook de constructie van de soortnorm 'menselijkheid', is onderzocht (Cartmill r993).

In het algemeen geldt dat er binnen vrijwel alle 'anderenstudies' dezelfde ontwikkeling is geweest in het nadenken over de ander (Buikema en Smelik 1993: 17-29). Eerst staan ze in het teken van gelijkheidsdenken, waarin gepoogd wordt om het verschil op te heffen, denk aan pleidooien voor gelijke kansen voor vrouwen en zwarten. Binnen de volgende fase, het verschildenken, wordt het anderszijn benadrukt, denk aan leuzen als proud to be gay, liever lesbisch en black is beautiful. Omdat het gevaar van essentialistisch denken hierbij echter opnieuw op de loer ligt, benadrukt het deconstructiedenken de taligheid en geconstrueerdheid van norm én an- 
der. Ook voor de dierenemancipatie geldt dat er sprake is geweest van een protest tegen de objectivering van het dier (Noske 1992), naar een aandacht voor het bijzondere van dieren en wat we van hun 'anders-zijn' zouden kunnen leren - denk aan spirituele dierenromans als The Horse Whisperer (1995) van Nicholas Evans of Ishmael (1992) van Daniel Quinn - naar een deconstructivistische wending waarin vooral de talige constructie van menselijkheid en dierlijkheid centraal staat (Haraway 1989). Het veld van emancipatoire studies van het dier zou je animal studies kunnen noemen.

Hoewel verschillende 'anderen' dezelfde connotaties meekrijgen, zijn 'anderen', alleen al op grond van een andere geschiedenis, niet over een kam te scheren. Dieren zijn bijvoorbeeld andere 'anderen' dan vrouwen of homo's. Mensen zijn noodzakelijkerwijs de woordvoerders van dieren, omdat deze zelf niet kunnen uitdrukken wat hun eisen zijn. Dit geldt voor de natuur in het algemeen, al worden er wel pogingen gedaan om te communiceren met de natuur, denk aan de pogingen die ondernomen zijn om apen te leren praten of met ze te communiceren. ${ }^{9} \mathrm{Wij}$ kunnen ons wel proberen voor te stellen wat dieren zouden zeggen, als zij konden praten; literatuur en film bieden de mogelijkheid om dieren een stem te geven. Op de rol van verhalen kom ik later terug. Eerst ga ik verder in op de constructie van norm en ander en iets wat zich daaraan lijkt te ontrekken: ambiguïteit.

\section{AMBIGUÏTEIT}

Their eyes are all asking

Are you in or are you out?

And I think, o man

What is this about

Tonight you can't put me

Up on any shelf

Ani DiFranco, 'In or Out', Imperfectly (1992)

Sommige dieren, mensen of dingen stellen binair denken op de proef. Ze laten zich moeilijk categoriseren als congruent met de 
'norm' of als 'ander'. Ze zijn in de ogen van sommigen ambivalent of ambigu, dat wil zeggen, voor meer dan één interpretatie vatbaar. Etymologisch gezien betekenen ambivalent en ambigu respectievelijk 'twee-waarden hebbend' en 'twee-snijdend'; ze worden vaak door elkaar gebruikt om 'tweeslachtigheid' of 'dubbelzinnigheid' aan te duiden. Volgens Van der Geest (1995) is er echter een gevoelsmatig onderscheid tussen ambivalentie en ambiguiteit. Hij wijst erop dat 'ambivalent' meestal in negatieve zin wordt gebruikt, en synoniem is met 'onvolwassen' of 'besluiteloos' of 'tegenstrijdige beweringen doend'. Aan 'ambiguïteit' kleeft niet die negatieve connotatie. Omdat deze term in het dagelijkse taalgebruik bovendien wordt gebruikt voor meerduidigheid (niet alleen tweeduidigheid), en in die zin een bredere term is dan ambivalentie, maak ik een praktisch onderscheid tussen beide, en spreek ik in dit onderzoek van ambiguiteit, tenzij ambivalentie wordt bedoeld..$^{10}$

Ambiguitteit is bijvoorbeeld aanwezig als iets of iemand zich niet helder laat categoriseren in termen van gender, kleur, seksualiteit en soort. Het valt noch samen met de norm, noch volledig met de ander. Wat gender betreft, valt te denken aan groepen die 'typisch' mannelijke eigenschappen combineren met kenmerken of taken die gewoonlijk aan vrouwen worden toegeschreven. Waartoe behoort de vrouwelijke wetenschapper, die met haar intellectuele beroep indruist tegen het beeld van de lichamelijke en zorgende vrouw? En wat te doen met de feministische man, de misogyne of seksistische vrouw of de man die 'huisvrouw' is? En hoe categoriseer je een meisje dat dol is op pornografie? Of de 'genderbenders', dat wil zeggen mannen met een vrouwelijk uiterlijk of vrouwelijke eigenschappen en vrouwen met een mannelijk voorkomen? Wat kleur betreft, valt te denken aan de zwarte wetenschapper, de racistische zwarte of de 'colorbenders' (denk aan Michael Jackson). De norm van de heteroseksualiteit (gedefinieerd in relatie tot homoseksualiteit), wordt 'geproblematiseerd' door biseksuelen, hermafrodieten en transseksuelen. Dan zijn er nog categorieën die de soortgrens ter discussie stellen. Te denken valt bijvoorbeeld aan de cyborg, een hybride van mens en ding. Ook zijn er mensen aan wie 'dingachtige' kenmerken worden toegeschreven, zoals aan de autist (Hendriks 2000) of aan mensen die in coma liggen en afhankelijk zijn van apparatuur om in leven te blijven. Dan zijn er ook mensen aan wie dierlijke kenmerken 
worden toeschreven, bijvoorbeeld bepaalde stammen die 'primitief' worden genoemd. Bovenstaande groepen hebben gemeenschappelijk dat zij noch tot de ene, noch tot de andere categorie gerekend kunnen worden, maar ook geen optelsom zijn van allebei. In bovenstaande voorbeelden heb ik gender, kleur, seksualiteit en soort uit elkaar getrokken, maar vaak is ambiguilteit ook nog eens het resultaat van een verwarrende intersectie of combinatie van al deze binaire opposities.

$\mathrm{Zij}$ die zowel binnen als buiten de dominante orde vallen, worden in de feministische theorievorming 'outsiders within' of 'social contradictions' (Collins I99I), 'oxymoronic subject' (Haraway I989) of 'conceptual anomaly' (Kondo r99o) genoemd. Juist omdat ze binair denken ter discussie stellen, of de grenzen die dichotomisch denken oplegt aan den lijve ervaren, is er veel geschreven over al deze 'tussenfiguren', onder meer over feministische mannen (Jardine \& Smith 1989), 'genderbenders' (Smelik r993), 'colorbenders' (zie Schutte 1999 over Michael Jackson), biseksuelen (Garber 1995) en mensen die tussen twee culturen in staan, bijvoorbeeld de 'Amerikaanse Japanner' (Kondo I990). Dergelijke onderzoeken richten zich meestal tegen het dualistische denken. De ideologische inzet is het scheppen van denk- en leefruimte voor groepen die zich niet (willen) laten reduceren tot het een of het ander. Uit deze studies komt vaak naar voren dat ambiguitteit veel mensen een ongemakkelijk gevoel geeft, dat het iets is waarmee men moeilijk om kan gaan.

In 'Petit Bâteau. Belevenissen van een intellectuele moeder' constateert de filosofe Annemarie Mol nog iets belangrijks, namelijk dat ambiguïteit altijd berust op een toeschouwersoordeel. Mol beschrijft de wisselende en veelzeggende reacties in haar omgeving op haar zwangerschap als intellectuele vrouw. Twee medewetenschappers reageren als volgt: 'Ik had dat van jou niet verwacht, dat je kinderen wou. Jij bent zo'n intellectueel' en 'Stom [...] het is niet goed voor je produktie'. (Mol 1993: 13). Een andere collega vraagt wat ze zal doen als ze de baby heeft, hoe ze het met haar werk zal regelen. Een man in het park beschouwt haar voornamelijk als seksueel wezen: 'Was het lekker?' roept hij haar jolig toe als hij haar met een dikke buik voorbij ziet komen. Uit de reacties van haar collega's maakt Mol op dat ze kennelijk twee zaken in zich verenigt die tegengesteld zijn: een baby en een brein. De man 
in het park beschouwt haar voornamelijk als een seksueel wezen, hetgeen op zich verrassend is, omdat moederschap en sexy-zijn vaak als elkaar uitsluitende categorieën worden beschouwd. ${ }^{11} \mathrm{De}$ ambiguìteit die zij als intellectuele moeder belichaamt, wordt zichtbaar door de reacties. Ambiguïteit is een toeschouwersoordeel. $\mathrm{Zij}$ is met haar lichaam het onderwerp geworden van een betekenisstrijd.

Uit Mols verslag wordt ook duidelijk hoe sommige mensen omgaan met ambiguitteit De collega-wetenschappers proberen de spanning op te lossen door de balans naar één kant door te laten slaan. Mol zal moeten stoppen met het produceren van wetenschappelijke artikelen nu ze een baby krijgt, beide zal niet gaan. ${ }^{12}$ Mol kan wel een baby krijgen en wetenschapper zijn, maar het is wellicht verstandig om zorgtaken uit te besteden als ze wetenschappelijke artikelen en boeken wil blijven produceren. Men tracht de ambiguïteit op te heffen door haar in de richting van de ene of de andere categorie te duwen.

Wanneer de ambiguïteit wordt opgemerkt en benoemd, levert dit meestal een cultureel interpretatieprobleem op. De waardering voor ambiguitteit is afhankelijk van tijd en persoon. ${ }^{13}$ Ambiguiteit hoeft natuurlijk niet altijd een probleem te zijn. Wanneer dat echter wel het geval is, kan een aantal strategieën worden toegepast om het probleem te hanteren. ${ }^{\mu}$ Ambiguïteit kan worden opgeheven door te proberen iets of iemand in de ene of in de andere categorie te duwen, haar of hem vragen een keuze te maken. Soms gaat dit gepaard met het diskwalificeren van een bepaald aspect. Naast het opheffen van ambiguitteit door middel van reductie zijn er nog andere mogelijkheden. Ambiguitteit kan ook worden opgeheven door haar uit te roeien, door de gehele persoon te negeren, of te doden. ${ }^{15}$ Tot slot kan ook het idealiseren, het heilig verklaren of het toekennen van een goddelijke, bovenmenselijke status, geïnterpreteerd worden als een poging tot het opheffen van ambiguiteit, omdat het een wezen als het ware 'boven' of 'buiten' de realiteit plaatst. Paradoxaal genoeg is het benoemen, aanwijzen en begrijpen van ambiguïteit gestoeld op het vermogen tot dualistisch denken. Het aanwijzen en lokaliseren van ambiguiteit impliceert in zekere zin altijd het herhalen van dualismen. Ambiguïteit bestaat bij de gratie van binair denken.

Bovenstaande voorbeelden betroffen ambiguiteit in termen van 
gender, kleur, seksualiteit en soort. In de volgende paragraaf ga ik verder in op soort. Dit boek gaat immers over een diersoort die in zijn geheel als ambigu te boek staat, de aap. Waarom wordt er over de aap geschreven en gedacht als een ambigu dier?

\section{DE AAP: MENS OF DIER?}

'Primates are not nicely boxed' (13), schrijft Haraway in Primate Visions. Geen enkel dier lijkt zo op de mens als de aap, en geen ander dier wordt in zo veel verschillende disciplines bestudeerd: de zoölogie, de cognitiewetenschappen, de psychologie en de taalwetenschap. Opmerkelijk is dat, wie iets over apen te weten wil komen, niet alleen bij de natuurwetenschappen terechtkomt, maar ook bij de menswetenschappen. Institutioneel gezien is er een scheiding tussen de natuurwetenschappen, waarbinnen ook dieren bestudeerd worden, en de menswetenschappen, maar apen overschrijden die grens, en stellen hem daarmee ook ter discussie. Veel kennisaanspraken met betrekking tot apen worden ook juist uitgevochten tussen mens- en natuurwetenschappelijke vakgebieden, bijvoorbeeld tussen psychiatrie en zoölogie, antropologie en biologie, taalwetenschap en biologie (Haraway 1989: 14). De verwarring die apen oproepen, wordt in de literatuur vooral begrepen en geanalyseerd als een ambivalentie van soort: behoort de aap tot de mensen of de dieren? En andersom: is de mens een aapachtige of niet? ${ }^{16}$

De discussie omtrent de mensachtigheid van de aap concentreert zich vooral op de mensaap. Mensapen, hun naam zegt het al, vertonen een opvallende gelijkenis met mensen. Er zijn vier soorten mensapen: gorilla's, chimpansees, orang-oetans en bonobo's. ${ }^{~}$ De hiërarchie die tussen de vier mensapen wordt aangebracht, is meestal gekoppeld aan hun gelijkenis met de mens. Het genetisch materiaal van de twee mensapen van het geslacht 'pan', de chimpansee en de bonobo, toont een gelijkenis van bijna 99 procent met de mens (De Waal 1998), en zij worden tegenwoordig om deze reden beschouwd als de dieren die het dichtst bij de mens staan. Hun uiterlijke, genetische en gedragsgelijkenis maken dat met name deze twee mensaapsoorten een spiegel voor de mens vormen en ge- 
bruikt worden als verklaringsmodel om na te denken over de oorsprong en de aard van de mens. ${ }^{18}$

De geschiedenis van de totstandkoming van de hiërarchie, classificatie en rangorde van de verschillende apensoorten geeft aan, hoe de voortdurende worsteling met de positie van de mensaap zich afspeelt in termen van soort-ambivalentie. Discussies over mensapen zijn gefixeerd op de vraag hoe menselijk ze zijn. De geschiedenis van de culturele en wetenschappelijke verbeelding van de aap laat zich karakteriseren als een voortdurende slingerbeweging tussen discontinuïteit (apen verschillen van mensen) en continuïteit (apen lijken op mensen). Zij die kiezen voor een discontinuïteitsmodel, dat wil zeggen het verschil tussen mens en aap benadrukken, stellen menselijke uniciteit veilig. $\mathrm{Zij}$ die continuilteit tussen mens en aap verdedigen doen dat op tweeërlei wijze: door te wijzen op de 'aapachtigheid' van de mens en/of de 'menselijkheid' van de aap. Dat zal ik hieronder verder toelichten.

Tot aan de twintigste eeuw kleefde er in de westerse cultuur een negatieve connotatie aan apen, die golden als monsterlijke wezens. In de oudheid stonden apen te boek als figura diaboli, duivelsfiguren of zondaars. Ze representeerden bedrog, obsceniteit, lachwekkendheid, gierigheid en ijdelheid (Janson 1952). De voorstelling van de aap als duivel resulteerde erin, dat 'aap' een scheldwoord was voor vijanden van het christendom en voor lachwekkende, lelijke, gierige of ijdele mensen. De negatieve stereotypering van apen bereikte een hoogtepunt in de negentiende eeuw toen het evolutiedenken van Darwin op gang raakte. ${ }^{19}$ Geen enkele wetenschapper heeft zo'n revolutie in het denken over de oorsprong van de mens teweeggebracht als Darwin, de grondlegger van de evolutietheorie. ${ }^{20}$ In 1859 publiceerde hij On the Origin of Species, een werk dat een grote rol vervulde in wat later de darwinistische revolutie zou worden genoemd. Enkele fundamentele grondbeginselen van zijn tijd werden door Darwin omvergeworpen. Hij ontzenuwde bijvoorbeeld de gedachte dat soorten onveranderlijk zouden zijn, de idee dat elke soort individueel zou zijn geschapen en dat de mens de kroon op de schepping zou zijn. Door te postuleren dat soorten veranderlijk zijn, ontdeed hij het soortbegrip van het essentialisme. Hij ging nog een stap verder: hij verbond de verschillende soorten met elkaar door te stellen dat alle levensvormen afstamden van een gemeenschappelijke 


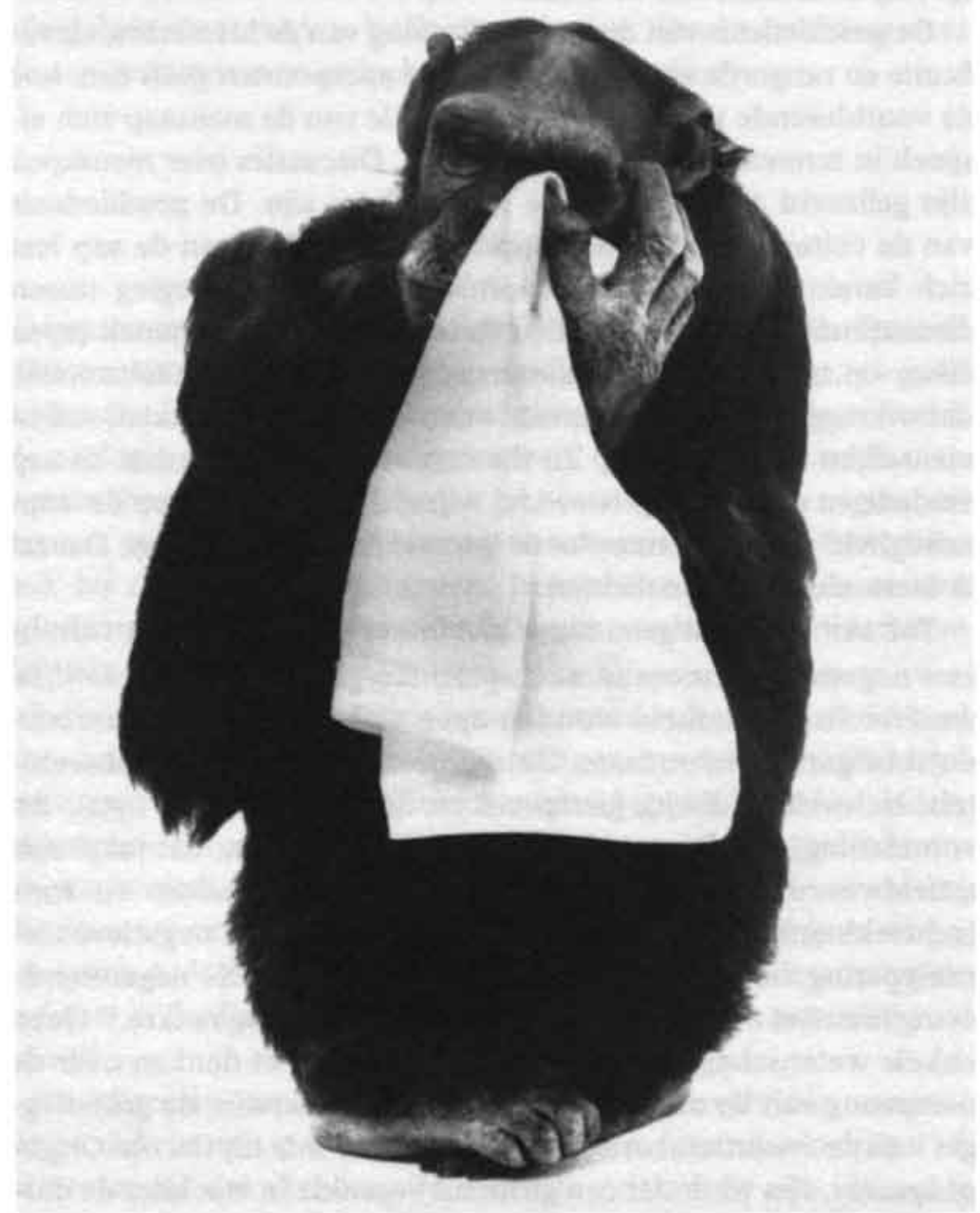

I 'Basics'. Foto: Dave Gray. In Rails, maart r998. De aap treedt hier op als fotomodel om onderbroeken en broeken te verkopen. Het spreekwoord luidt: 'Al draagt de aap een gouden ring, het is en blijft een lelijk ding.' Door een aap als fotomodel te gebruiken om kleding te verkopen is enerzijds de suggestie: deze kleding is mooi, ook als een aap het aanheeft. Behalve dat het om 'basic' kledingstukken gaat, wordt de naakte aap hier ook op esthetische wijze als 'basic' mens opgevoerd. 


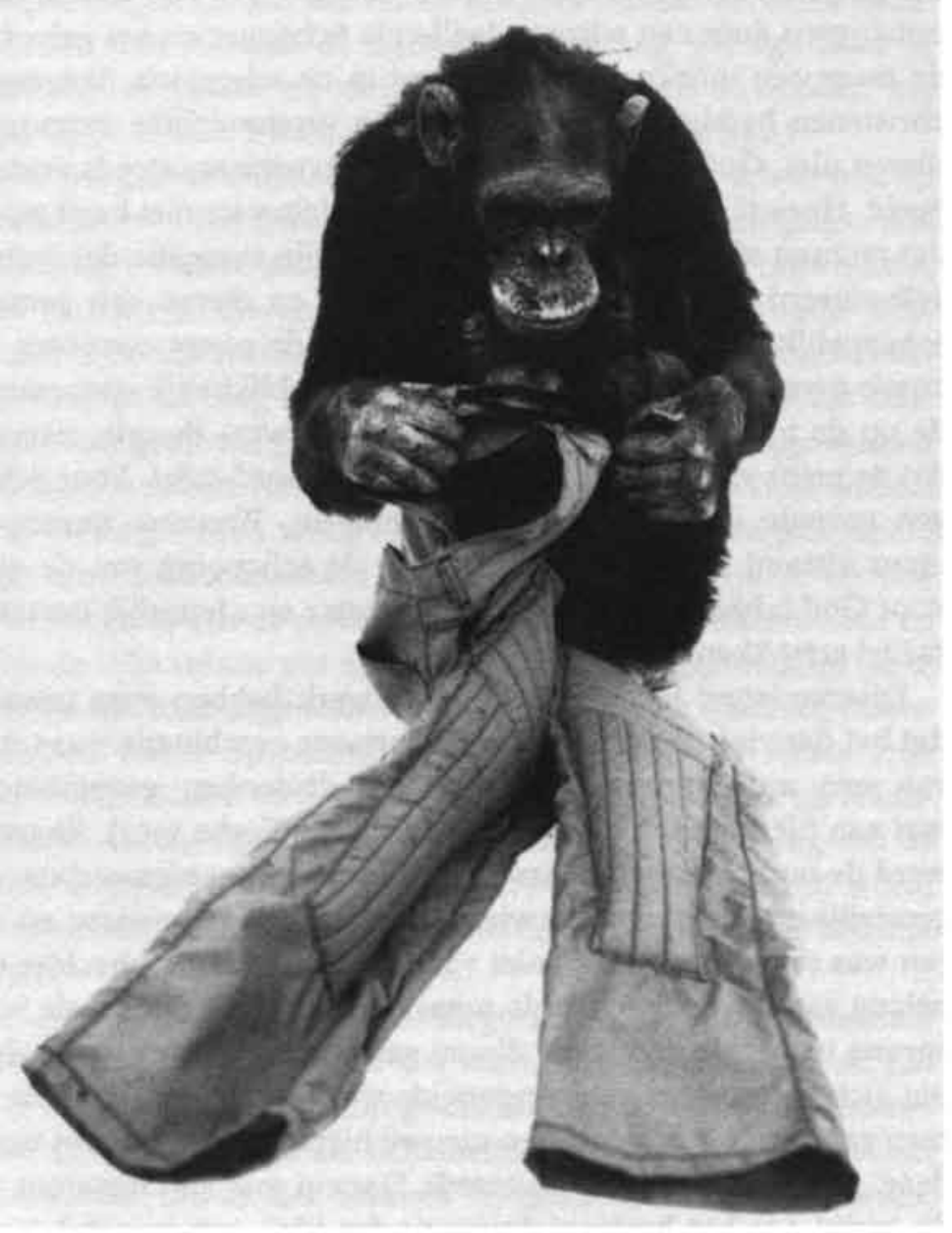

2 'Basics' (1998). Foto: Dave Gray.

voorouder. Tegenover metafysische begrippen als bestemming en lot, plaatste hij noties als toeval en waarschijnlijkheid. Volgens Darwin was er sprake van ontwikkeling en verandering van de soorten door middel van succesvolle adaptaties.

Darwins evolutietheorie had grote consequenties voor de christelijke geloofsopvatting. Darwin ging in tegen vier steunpilaren van het christelijke dogma, te weten het geloof in een constante wereld, 
het geloof in een geschapen wereld, het geloof in een wereld die is ontworpen door een wijze welwillende Schepper en het geloof dat de mens een unieke positie inneemt in de schepping. Volgens de christenen hadden mensen een ziel en verstandelijke vermogens, dieren niet. God verdween binnen het darwinisme steeds meer uit beeld. Hoewel Darwin in On the Origin of Species niet heeft gezegd dat mensen afstammen van apen, leidde zijn suggestie dat mensen geëvolueerd zouden zijn en dat mensen en dieren een gemeenschappelijke voorouder hadden ertoe dat de eerste openbare discussie over Darwins boek in 1860 zich ogenblikkelijk concentreerde op de mogelijke consequenties van Darwins theorie, namelijk dat de mens van apen zou afstammen (Howard 1982). Voor gelovigen vormde deze gedachte een probleem. Wanneer immers de mens afstamt van de aap, dan wordt de schepping van de mens door God (althans, wanneer men Genesis I en 2 letterlijk neemt) in twijfel getrokken.

Diverse latere lezers van Darwins werk hebben erop gewezen dat het darwinistische denken een curieuze combinatie was (en is) van een anti-essentialistisch continuïteitsdenken gecombineerd met een hiërarchisch denken (bijvoorbeeld Noske 1992). Enerzijds werd de oude hiërarchie tussen mens en dier omvergeworpen. Het geestelijke verschil dat Darwin constateert tussen mensen en dieren was er een van graad, niet van hoedanigheid. Hij hechtte veel belang aan opvoeding, die de mens de geestelijke en morele voorsprong ten opzichte van de dieren gaf en die de mens kon helpen om zich te vervolmaken. Anderzijds werd, door te denken in termen van een levensketen, een nieuwe hiërarchie ingebracht tussen 'laag' en 'hoog'. Ook introduceerde Darwin met zijn metafoor van de 'strijd om het bestaan' ('struggle for life') een verschil tussen goed of minder goed aangepast ('struggle of the fittest'). Uit zijn latere theorieën over seksuele selectie in The Descent of Man, and Selection in Relation to Sex (1870) bleek dat Darwin vrouwen tot de minder goed aangepasten, de 'zwakkeren', rekende. Vrouwen hadden een lagere rang, fysiek en mentaal. Mensen waren dus verder dan apen geëvolueerd, maar in die ontwikkeling stonden de mannen bovenaan, terwijl de ontwikkeling van vrouwen was gestagneerd (Noske 1992: 95). Een soortgelijke redenering gold voor blanken en zwarten. Darwin beschouwde de 'wilde' rassen analoog met de diersoorten als lagere ontwikkelingsstadia van het blanke 
ras. Opvattingen aangaande ras en geslacht werden gecombineerd. De blanke man stond in de levensketen aan top, gevolgd door de blanke vrouw, zij aan zij met de zwarte man, en daaronder, het dichtst bij de dieren, kwam de zwarte vrouw (Noske 1992)

Door het graduele denken makte het darwinisme echter ook op allerlei manieren het denken in ambigue categorieën mogelijk. Wie van mening is dat de soort mens zich geleidelijk heeft ontwikkeld, en dat mensen en dieren een gemeenschappelijke voorouder hebben, ziet zich bijvoorbeeld voor een nieuw probleem gesteld: het vinden van de missing link tussen mens en aap (een term die Darwin zelf overigens niet gebruikte) ${ }^{21}$ Ook werd de vraag opgeworpen of niet ook vrouwen verder zouden kunnen evolueren door middel van opvoeding. ${ }^{22}$ Men vroeg zich voorts af hoe de doelgerichtheid van de mens en doelloosheid van de natuur zich tot elkaar verhielden. In hoeverre was de mens onderworpen aan de natuurwetten en had hij de vrije ruimte om zich, door middel van opvoeding, los te worstelen van wetmatigheden? Het gaat hier om de spanning tussen erfelijkheid versus opvoeding en gedetermineerdheid versus vrije wil, of wel de nature versus nurture discussie. De nadruk op seksuele selectie en tegelijkertijd de mogelijkheid tot verbetering van de soorten, wierp de vraag op in hoeverre de mens gedreven wordt door instincten en in hoeverre de mens een verstandelijk en zedelijk wezen is.

De confrontatie met ambigue categorieën kan angst inboezemen en mondde uit in een obsessie met zuiverheid (Van der Laarse, Labrie \& Melching 1998). Sommige christelijke gelovigen beschouwden de aap bijvoorbeeld als lichamelijk en gedreven door instinct en probeerden zelf zo 'lichaamloos' en 'geestelijk' mogelijk te leven, door bijvoorbeeld een kuisheidsideaal na te streven. De gedachte dat men verwant zou zijn aan dit verwerpelijke ongeremde wezen, was schokkend. Ook het denken in zuivere categorieën over wat de man of de vrouw is en behoort te doen, dook na publicatie van Darwins geschriften steeds meer op in politiek, literatuur en wetenschap (Van der Laarse, Labrie \& Melching 1998). Voor de vrouw golden schoonheid en moederschap als de belangrijkste kwaliteiten. Enerzijds was de vrouw een wezen dat minder hoog ontwikkeld was dan de man, maar anderzijds verleende deze hogere staat van primitiviteit haar ook een aantal kwaliteiten die de beschaafde man in de loop van zijn evolutie was kwijtgeraakt. De 'lager' geble- 
ven wezens waren in dit opzicht de meerdere van de man. 'Eenvoudige mensen, primitieve volken, kinderen, grijsaards, vrouwen en dichters, zij staan het dichtst bij de natuur en zij zijn dan ook wijzer dan velen die zich op hun geleerdheid laten voorstaan'; zo vat Kemperink (I999: 20) de consequenties van Darwins denken samen.

Ofschoon men in de christelijke traditie apen soms nog altijd associeert met iets afgrijselijks en laags ${ }^{23}$, is, mede door de evolutietheorie, de nadruk steeds meer komen te liggen op de continuïteit tussen mens en aap. In het algemeen zijn in de twintigste eeuw de menselijkheid van de aap en de aapachtigheid van de mens steeds meer benadrukt, en is er een beweging waarneembaar van discontinuïteit naar continuïteit. Darwins gedachtegoed ontketende een revolutie in het denken over soort en het benadrukken van de continuïteit tussen mensen en dieren zette zich verder voort in de loop van de twintigste eeuw. In 1993 bereikte het continuïteitsdenken een hoogtepunt met de publicatie van The Great Ape Project (Cavalieri \& Singer 1993), een manifest van een groep wetenschappers die ervoor pleitte aan mensapen dezelfde rechten toe te kennen als aan mensen, en mensapen als 'personen' te aanvaarden. ${ }^{24}$ In dit boek wordt de omslag in het denken over soort in de afgelopen eeuw zichtbaar via de interpretaties van romans als Mijn aap schreit (1928) en De vrouw en de aap (1996).

Binnen de hedendaagse primatologie komt het continuïteitsdenken tot uitdrukking in twee verschillende strategieën. De eerste is te beargumenteren en te laten zien dat mensen als apen zijn. Te denken valt aan het werk van Desmond Morris, die over de mens sprak als de 'naakte aap', en dat van de Nederlandse bioloog Midas Dekkers, die in zijn boeken en televisieprogramma's ook steeds weer laat zien hoe aapachtig (of dierlijk in het algemeen) het gedrag van mensen is. De andere strategie is te laten zien hoe menselijk apen, met name de mensapen, zijn. Het werk van onder meer Frans de Waal, Dian Fossey en Jane Goodall is representatief voor deze zienswijze. Goodall liet in de jaren zestig zien dat gereedschapsgebruik en gereedschapsvervaardiging niet uitsluitend voorbehouden waren aan de mens. Toen haar professor Louis Leakey het nieuws vernam, sprak hij: 'Nu moeten we werktuig of mens opnieuw definiëren, of chimpansees als mensen aanvaarden' (Goodall I99I: 24). ${ }^{25}$ De homo faber bleek niet uniek, er was ook een pan faber. Ook de mens als unieke homo symbolicus moest worden gere- 


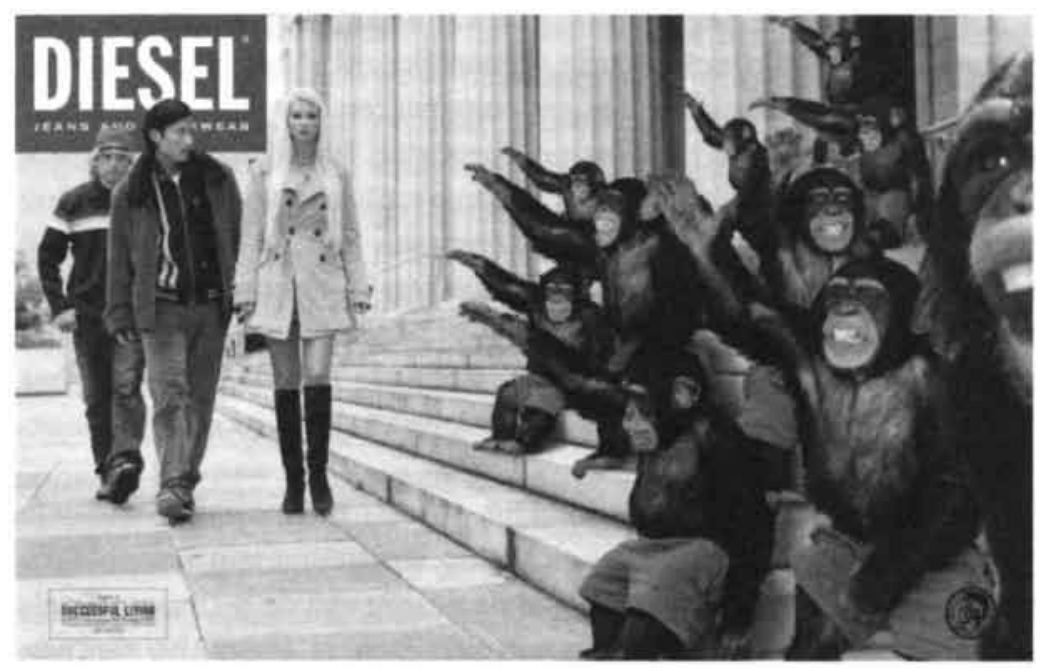

3 Reclame van Diesel. Dat de mens zou afstammen van de aap, tast de grens tussen puur menselijk en puur dierlijk aan. De zuivere mens wordt hierbij soms tegenover het dierlijke, het afschrikwekkende geplaatst. Chimpansees brengen hier de Hitlergroet. Zij apen elkaar na. Een perfecte 'Germaanse' blondine ziet ze niet, maar een Aziatisch uitziende jongen kijkt angstig naar ze. Hij voelt zich klaarblijkelijk aangesproken. Diesel suggereert dat zij kleding voor iedereen maken en dat Diesel-dragers geen na-apers zijn.

lativeerd; uit diverse onderzoeken uit de jaren zeventig naar taalgebruik onder chimpansees bleek dat ook zij in staat waren om symbolen te leren gebruiken (Patterson \& Linden r98I, Terrace r979, Rumbaugh 1977). In de jaren tachtig richtte men zich onder meer op de cognitieve vermogens van apen, zoals zelfherkenning en zelfbewustzijn, in de jaren negentig op emoties van dieren, waaronder apen (Masson \& McCarthy 1997), en op een besef van goed en kwaad en moraal (Cavalieri \& Singer 1993, De Waal 1998). Zelfs het anatomische kenmerk van het rechtop lopen bleek niet voorbehouden aan de mens. Frans de Waal (1998) liet zien dat de bonobo soms ook rechtop loopt. Of apen al dan niet beschikken over cultuur, bijvoorbeeld of zij gevoel hebben voor muziek zoals mensen dat hebben (Wright, Rivera, Hulse, Shyan \& Neiworth 2000), een gevoel voor humor of religieuze gevoelens, is nog altijd een actuele vraag (De Waal 20or). ${ }^{26}$ 
De poging om te begrijpen wie of wat de aap is, gebeurt dus vaak in termen van zijn vermeende menselijkheid. Niet alleen wetenschappers worstelen hiermee en construeren mogelijke antwoorden op de vraag hoe mensen en apen zich tot elkaar verhouden, maar de vraag is ook prominent in onze culturele verbeelding. Hoe wordt in de culturele verbeelding omgegaan met de 'mirror-quality' van apen? Hoe gaan schrijvers, filmmakers in vergelijking met wetenschappers om met iets dat tegelijkertijd vreemd en vertrouwd is, op de mens lijkt, maar niet gelijk is aan de mens? Tonen zij het 'mensachtige' van de aap, het aapachtige van de mens of beide tegelijkertijd?

Dat de mensaap niet gemakkelijk in een dichotomisch schema valt onder te brengen, blijkt ook uit de worsteling van romanciers, filmmakers en wetenschappers met de positie van de mensaap. Zoals we in de volgende hoofdstukken zullen zien, is er sprake van een voortdurende slingerbeweging, van discontinuiteitsdenken naar continuiteitsdenken en vice versa, en worden veelvuldig pogingen gedaan om de ambivalentie van de mensaap (mens of dier?) te reduceren tot eenduidigheid (de mensaap is een mens of de mensaap is een dier).

Enerzijds tart de aap de soortgrens tussen mens en dier, maar anderzijds is het op een specifieke wijze benoemen van ambivalentie op zichzelf al een bedwingende activiteit, een poging om de aap te begrijpen als primair het een of het ander. Wanneer we een woord of een naam geven aan ambivalente figuren, richt dat woord zich op één aspect van een dichotomie, denk aan mensaap of biseksueel. Bij de mensaap vragen we ons dus in eerste instantie niet af of het een mannetje of een vrouwtje is, maar of zij/hij behoort tot de mensen of de dieren. ${ }^{27}$

\section{DE ANDER ONTMOET DE ANDER}

Wanneer we geconfronteerd worden met een onduidelijkheid, dan proberen we die meestal te benoemen en op te lossen. Bij de mensaap gaat het daarbij om de soortgrens: behoort deze tot de apen of de mensen? Het bepalen van die grens is niet een abstracte filosofische exercitie; er zijn concrete materiële praktijken in het geding: 
mag je (mens)apenvlees eten of niet? Mag je het hart of de nieren van een aap gebruiken voor transplantatie? Mag je een aap doodschieten of heeft een mensaap bepaalde rechten? Waar, kortom, begint het dierlijke, en waar houdt het menselijke op?

Volgens Cartmill (1990) hebben de westerse paleontologie, primatologie, biologie en filosofie in het teken gestaan van de zoektocht naar hét kenmerkende verschil tussen mens en dier. Het continuïteitsdenken is in die zin slechts een schijn, want continuilteit is altijd de uitkomst van een onderzoek naar discontinuïteit. Toen bijvoorbeeld bleek dat niet alleen mensen, maar ook gorilla's en chimpansees konden beschikken over het vermogen om symbolen te hanteren, werd gepoogd het verschil tussen mensen en mensapen te onderzoeken door 'talig vermogen' te verfijnen tot 'syntactische vermogens', maar ook hier bleken sommige mensapen toe in staat (Savage-Rumbaugh \& Lewin 1994). Dergelijke onderzoeken die gespitst zijn op verschil, begrijpt Cartmill als een poging van de mens om de hiërarchie in stand te houden. De mensachtigheid van de mensaap in het bijzonder, en het dier in het algemeen, vormt een bedreiging voor de mens:

Supposedly unique human features are uniquely human by definition rather than as a matter of empirical fact. Much scientific effort and ingenuity has gone into redefining such characteristics whenever discoveries about other animals have posed a threat to human uniqueness. (Cartmill r990: I)

De hoeveelheid verschillende wetenschapsgebieden met ieder hun specifieke claims rondom apen ondergraaft de mogelijkheid van een onomstreden claim rondom 'de aard van de aap'. Cartmill betoogt dat de grens tussen mens en dier niet essentialistisch vast te stellen is. Die verandert in de tijd en per vakgebied. Haraway laat dit zien voor de aap: de aap is een constructie, de aap bestaat niet. Desalniettemin wordt de aap steeds gedefinieerd en geclassificeerd, en doen mensen voortdurend uitspraken over wat een aap is, door deze te onderscheiden van de mens en door een poging soorten van elkaar te scheiden.

Wie zich verdiept in definities van de vrouw, stuit, net als bij de aap, op een soortgelijke gefixeerdheid, namelijk op sekseverschillen. Noties over 'de vrouw' of 'vrouwelijkheid' impliceren ook een op- 
vatting over 'de man' en 'mannelijkheid'. Annemarie Mol laat in haar artikel 'Wie weet wat een vrouw is. Over de verschillen en verhoudingen tussen wetenschappen' (1983) zien hoe verschillende vakgebieden met elkaar strijden over de definitie van de vrouw. Ze stuit op een enorme hoeveelheid verschillende opvattingen die elkaar bovendien soms tegenspreken. Net als bij de aap, zien we hier opnieuw dat het gevecht zich afspeelt tussen natuur- en menswetenschappelijke benaderingen. In dit voorbeeld strijden de socialisatiesociologie en de genetica om de betekenis van de vrouw.

Is een vrouw nu werkelijk een wezen met twee $\mathrm{x}$-chromosomen? De socialisatiesociologie vertelt een ander verhaal: een vrouw is een wezen dat als kind behandeld is als een meisje, dat alsmaar geleerd heeft hoe ze vrouw moest worden en het zo is geworden. 'Twee X-chromosomen bezitten' is beslist niet hetzelfde als 'geleerd hebben een vrouw te zijn'. Zijn het verschillende aspekten die de ware vrouw allebei vertoont? Of zijn het tegenstrijdige definities? (Io)

Maar niet alleen de genetica en de socialisatiesociologie weten wat een vrouw is; de psychoanalyse, de anatomie en de endocrinologie weten dat bijvoorbeeld ook. Mol concludeert:

Er bestaat geen uniform gehanteerde kategorie vrouw/elijk: in één eeuw niet, in één kultuur niet, op één plaats niet, en zelfs niet binnen het instituut dat zichzelf als toppunt van koherentie presenteert: de wetenschap. (22)

De vrouw, kortom, bestaat niet. Mol rekt het denken over wie of wat de vrouw is op tot een veelheid van definities. Hoewel de vrouw niet bestaat, wordt ze toch voortdurend vastgepind en gekoppeld aan datgene wat niet-mannelijk is. Een oneindige definitiemachine probeert vast te stellen wie of wat de vrouw is. Deze machine is tegelijkertijd een projectiemachine, een verlangen- en angstmachine. De stroom van definities getuigt van een zekere onrust, van voortdurende pogingen om 'de vrouw' vast te leggen. We weten niet wat een vrouw is, maar we willen en proberen het wel voortdurend te bepalen. Onschuldig zijn die definities niet. Het zijn niet zomaar gedachtespelletjes; de definities vinden hun weerslag 
anp. $m$. (apen), 1. vierhandig zoogdier van de onderorde, Anthropoidea, van de orde der Primaten; de aap lijkt in uiterlij $\mathrm{k}$ en in sommige handelingen veel op de mens en geldt daarom (als karikatuur) voor lelijk en ook als boosaardig; luie aap, lori (1.); -in vele zegsw.: een gezicht als een aap, zeer lelijk; -een aangeklede aap, een bespottelijk lelijk mens, (ook) iem. die opzichtig gekleed is; - kin. deren zijn apen, bootsen na wat ze van anderen zien;iemands aap zijn, hem in alles volgen;-voor aap staan, iem. voor aap zetten, voor gek; - (gew.) iem. voor de aap hotiden, voor de gek; - (gew.) de aap van het spel zijn, het kind van de rekening;-aap! aap van een jongen! deug. niet! kwajongen!; (gew.) men moet een oude aap geen smoelen leren trekken, geen raad of lessen geven aan iem. die ouder, ervarener of bevoegder is; - hij maakt er een aap van, hij houdt er zich maar oppervlakkig mee bezig; hij maakt zich ervan af; - (w.g.) hij dient daar als een aap in de porseleinkast, kan daar alleen maar onheil aanrichten; (gew.) als een aap in een spel kegels, ook in

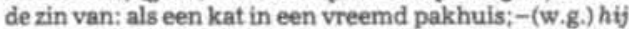
haspelt ermee als een aap in een lint- (of garen-) winkel, hij stuurt alles in de war; -hij heeft (houdt) de aap in de mouw, verbergt zijn streken, zijn slinkse oogmerken;daar kwam (keek) de aap uit de mouw, toen bleek zijn eigenlijke bedoeling:-aap. wat heb je mooie jongen spe. len (tegen zijn zin, meestal door de omstandigheden genoodzaakt) iem. vleien en flikflooien om hem gunstig te stemmen, niet tegenspreken om verdere onaangenaam. heden te voorkomen;-als apen hoge klimmen willen, ziet men gauw hun blote billen, wie boven zijn macht reikt , of zich boven zijn stand beweegt, maakt zich spoe. dig belachelijk; - al draagt een aap een gouden ring, het is en blijft een lelijk ding, fraaie kleren maken alleen de man niet; - (gemeenz) nou zulje een aap zien neuken, nu zul je wat meemaken, lets spectaculairs zien;- dat ware de aap gevlooid, gezegd van een onbegonnen werk; wat ga je doen! ik ga de aap vlooien en jij kunt de zak ophouden, gemeenz tot een al te nieuwsgierige gezegd:(gew.) 't is om apen te schieten, dat is al te gek; - (gew.) die gaat apen vangen, gezegd van iem. met heel grote schoenen; (gew.) een klap van een lamme aap krijgen, een onverwachte opmerking, reactie, belediging te horen krijgen:-(gemeenz) zich een aap schrikken, geweldig schrikken; evenzo: zich een aap lachen;-in de aap gelogeerd $z i j n$, (tegen verwachting) in moeilijkheden geraakt, er slecht aan toe zijn; -2 . buitgemaakte of opgespaarde som gelds, schat: $h$ ij heeft de aap beet, binnen, thuis, weg: inz. van een erfenis; - de aap aanspreken, zijn spaarpenningen gebruiken;- de aap vlooien, zijn spaarpenningen tellen, of: de buit binnenhalen;-3. (gew.) klompje neusvuil; -4 . (gew.) heiblok; -5 . tekenaap of pantograaf; -6 . (scheepst., veroud.) stormbezaanstagzeil, stormaap; - 7. aap op een stok, (bij heiers) een trekhei waarbij het blok langs eén leider gaat.

4 Lemma 'aap' uit Van Dale. 
in ons materiële bestaan. Ze bepalen bijvoorbeeld wat er wel of niet in de winkel ligt voor vrouwen en welke medische behandelingen toegepast worden. ${ }^{28}$ Een soortgelijk verhaal kan men vertellen over kleur en over seksualiteit. Net als bij de aap betekent de fixatie op gender, kleur, seksualiteit en soort, een reductie van ambiguïteit (of sterker nog: onbepaaldheid) tot ambivalentie.

Terug nu naar de representatie van de vrouw en de aap. De aap is onbepaald en het brandpunt van veel definities, maar wij begrijpen de aap als een ambivalent dier (menselijk en dierlijk). Ook de vrouw is overladen met definities. Wat gebeurt er als de vrouw en de aap met elkaar in ontmoeting gebracht worden? In plaats van, zoals vaak gebeurt, de representatie van een bepaalde sociale categorie te onderzoeken (zoals de representatie van de vrouw, het dier), vraag ik me af wat er gebeurt in de representatie van de ontmoeting tussen twee 'anderen', in dit geval de vrouw en de aap, zoals die in cultuur en wetenschap wordt geconstrueerd. ${ }^{29}$ Ontstaat er een hiërarchische verwarring of een (theoretisch) conflict, omdat deze 'anderen' ten opzichte van de norm dezelfde associaties genereren, bijvoorbeeld 'vrouwelijk', 'door instinct geleid' of 'lichamelijk'? Herkennen zij elkaars 'anders-zijn'? Of worden de rollen van 'norm' ('wij') en 'ander' ('zij') opnieuw verdeeld, en zo ja, hoe? Wordt de aap bijvoorbeeld als menselijker (of mannelijker) of juist als dierlijker voorgesteld? En wat gebeurt er met de vrouw? Zij valt enerzijds onder de categorie 'mens' en vertegenwoordigt als zodanig het niet-dierlijke; tegelijkertijd is zij in de westerse geschiedenis lager in de hiërarchie gezet ten opzichte van de blanke man. Waarom komt juist de combinatie van een witte vrouw en een mannetjesaap zo vaak voor? Dat laatste blijkt in het bestudeerde materiaal immers het geval te zijn. ${ }^{30}$ Waarom wordt bijvoorbeeld de aap zo weinig in contact gebracht met een zwarte vrouw, die dubbel 'ander' is, namelijk 'zwart' en 'vrouw' (hooks r98r)? En is de aapsoort van belang? Maakt het bijvoorbeeld uit of het om een aap of een mensaap gaat, en of het daarbinnen een orang-oetan, gorilla, chimpansee of bonobo betreft? En verandert de constructie van de ontmoeting van de vrouw en de aap in de loop van de tijd? In dit boek komen ook deze vragen aan de orde in de interpretaties, om zo ook inzicht te verkrijgen in het westerse denken over de 'ander' en de veranderingen daarin. 
Onderzoeken naar de uitsluiting van 'anderen' zijn inmiddels vanzelfsprekender geworden. De onophoudelijke stroom emancipatorische studies naar 'de ander' in al zijn gedaanten loopt het gevaar zichzelf te blokkeren. Door steeds de aandacht te blijven vestigen op de 'ander', bestaat het gevaar dat sommigen geïrriteerd raken. Termen als 'politieke correctheid' of 'vrouwenstudies-moe' wijzen erop dat dit het geval is. En er bestaat nog een ander gevaar: wordt 'de ander' niet een holle huls als het er zoveel zijn? Wat betekent dat nog eigenlijk, anders-zijn? Ten opzichte van wie is men ander? Is niet iedereen op een bepaalde manier en in een bepaald opzicht 'ander'? En zijn we niet allemaal een beetje 'ambigu'? Volgens Haraway (1994) zijn mensen tegenwoordig bijvoorbeeld zo verbonden met hun materiële technologische omgeving dat we in zekere zin allemaal cyborgs zijn. Iedereen heeft iets 'dingelijks' over zich, al was het maar omdat je bijvoorbeeld een bril draagt of een deel van je geheugen uitbesteedt aan de computer. Je zou kunnen beargumenteren dat iedereen op een bepaalde manier de grenzen ter discussie stelt. De 'norm' is dan ook de constructie van een ideaal, niet een realiteit. Niemand valt in werkelijkheid volledig samen met de geconstrueerde norm. In ons dagelijkse handelen kan de norm echter wel gevoeld worden, bijvoorbeeld door de reacties van anderen, zoals bleek uit Mols verslag van haar zwangerschap als intellectuele vrouw.

De weerstand die soms wordt geuit tegen 'anderen' - of feministische studies - is begrijpelijk wanneer de termen 'man' en 'vrouw' essentialistisch worden ingezet, wanneer men bijvoorbeeld automatisch ervan uitgaat dat, als een vrouw en een man een conflict hebben, het geslacht een rol zal hebben gespeeld omdát ze een vrouw is. In haar lezing naar aanleiding van een boek van Zygmunt Bauman, 'Where the Strangers are' (1994), wijst Annemarie Mol erop dat de invullingen die we geven aan 'zelf' en 'ander' altijd relationeel en contextafhankelijk zijn. In plaats van het woord 'ander' gebruikt Mol het woord 'vreemdeling', deels omdat Bauman die term gebruikt in zijn filosofie, maar ook omdat ze vindt dat deze term als voordeel heeft dat hij niet direct gekoppeld is aan identiteitsdenken, in de zin dat hij directe associaties oproept met 'anderen', zoals de vrouw, de zwarte et cetera. Ze legt dit uit aan de hand van een anekdote over een bezoek aan Chicago. $\mathrm{Zij}$ wil bij vrien- 
den gaan logeren en neemt een taxi. De zwarte taxichauffeur waarschuwt haar dat de desbetreffende zwarte buurt gevaarlijk is en adviseert haar om hier niet alleen uit te stappen. Als ze wil, dan kan ze bij hem en zijn vrouw en kinderen blijven slapen. De taxichauffeur is weliswaar 'zwart', maar waarschuwt haar voor een gevaarlijke 'zwarte' buurt, en is in die situatie dus niet 'de ander' ten opzichte van haar zelf. Het volgende obstakel van anders-zijn dat hij uit de weg ruimt, is zijn 'mannelijkheid'. Hij noemt zijn vrouw en kinderen, opdat ze zich veilig zal voelen. Wat Mol met deze anekdote demonstreert is dat er niet een één op één relatie is tussen identiteit en anders- of vreemdzijn. Een 'zwarte' man hoeft geen vreemdeling te zijn. Het hangt af van de situatie, en wat er gebeurt en gezegd wordt in zo'n situatie, hoe posities van anders-zijn veranderen en in beweging komen. Het denken in termen van zelf en ander wordt weliswaar ingezet, maar is altijd relationeel, dynamisch (in beweging) en situationeel.

Door zich te concentreren op een specifieke ontmoeting, bekritiseert Mol een essentialistisch denken in termen van identiteit en anders-zijn. De situatie bepaalt welke 'vreemdheid' op bepaalde momenten van belang is:

They have loosened the link between strangeness and identity, tying it instead to shifting relations, and specific events. Instead of reproducing the opposition between the self and the other - however ambivalent - they've moved away from this dichotomy and drawn attention to a layered, complex, web of strangenesses. Furthermore, no attempt has been made to classify such strangenesses into two, or four, or even seven genres. Rather the story has encouraged me to make a list with no obvious beginning or end, a list that begs to be extended. (Mol 1994)

Wie 'ander' is, wordt bepaald door de situatie. De ander is niet per definitie de zwarte of de vrouw, schrijft Mol. Dat is terecht: kleur en sekse speelden in haar anekdote een andere rol dan ze verwacht had. Maar het waren wel deze twee verschillen die een rol speelden in de ontmoeting, en niet andere (bijvoorbeeld klasse, leeftijd, nationale verschillen). Je kunt je verhalen van ontmoetingen voorstellen waarin geslacht en kleur minder een rol spelen. In deze studie gaat het ook steeds om door kunstenaars en wetenschappers ge- 
construeerde ontmoetingen. Welke verschillen spelen een rol in de ontmoetingen tussen witte vrouwen en apen? Hoe gaan de personages ermee om, en welke interpretatie en betekenis geven lezers en recensenten eraan?

Een ander interessant aspect aan Mols lezing is haar bewuste keuze voor de anekdote, het vertellen van een verhaal. De anekdote is meer dan een illustratie van een probleem. De anekdote is de stijlfiguur die vorm kan geven aan de complexiteit en gelaagdheid die zij ziet in het denken in termen van 'zelf' en 'ander'. De tweedeling brokkelt uit je handen weg wanneer je concrete verhalen gaat vertellen. Juist in verhalen kan de beweging weergegeven worden en kan de lokaliteit tot uitdrukking komen. Verhalen kunnen 'beweging' vasthouden, en hoeven je niet direct in een of/of schema te duwen. 'It tries to open up more space,' aldus Mol (1994). Wie ambiguitteit, veranderingen en bewegingen in relaties, lokaliteit, specificiteit wil handhaven en reductie wil vermijden, doet er goed aan zich tot verhalen te wenden. ${ }^{31}$ In navolging van die gedachte zet ik een stap van de aap als 'gestolde' theoretische ander, naar de aap als personage in beweging, naar de aap als verhaal.

In dit hoofdstuk ben ik ingegaan op de verandering in het denken over de relatie tussen mensen en apen - van vijand in het christendom tot verwante in het darwinisme en gelijke in het Great Ape Project. De vrouw speelt daarin een rol - zij wordt steeds met de aap in contact gebracht - maar welke precies, dat moet nog blijken uit de verhalen. Het volgende hoofdstuk gaat over de vraag hoe de verhalen over vrouwen en apen methodisch onderzocht kunnen worden. Opnieuw gebruik ik Haraways Primate Visions daarbij als inspiratiebron en kritisch afzetpunt voor verdere gedachtevorming. Haraway gebruikt het begrip 'verhaal' om teksten over apen uit de wetenschap 'open' te breken voor interpretatie en om deze teksten onder meer met 'cultuur' te verbinden, bijvoorbeeld films en romans over apen, maar op de wijze waarop ze dat doet, valt nog het een en ander af te dingen. Het volgende hoofdstuk gaat ook over de rol van de lezer. Want daar waar verhalen verteld worden, zijn ook luisteraars en toehoorders die iets met die verhalen doen. 


\section{Verhalen over apen en vrouwen}

\section{De relatie tussen cultuur en wetenschap}

As a young student in the segregated South, where we never talked race, it was not important to situate a painter historically, to contextualize a work. The 'work' was everything. There are times when I hunger for those days: the days when I thought of art only as the expressive creativity of a soul struggling to self-actualize. Art has no race or gender. Art, and most especially painting, was for me a realm where every imposed boundary could be transgressed. It was the free world of color where all was possible.

bell hooks, Art on My Mind. Visual Politics (r995)

\section{PRIMATOLOGIE ALS VERHAAL}

Hoe verhalen over vrouwen en apen te lezen? En wat te denken van het gegeven dat niet alleen film en literatuur, maar ook de wetenschapspraktijk zich kenmerkt door een opvallende band tussen de vrouw en de aap? Haraway heeft, zoals we in het eerste hoofdstuk zagen, niet alleen gereflecteerd over de positie van de aap als projectiefiguur in de westerse cultuur, maar ook over de relatie tussen cultuur en wetenschap. Binnen de kunstgeschiedenis is nagedacht over de rol van apen in de kunsten, en binnen de literatuurwetenschap over lezen, interpreteren en de positie van de 'ander' in de literatuur, bijvoorbeeld vrouwen. In dit hoofdstuk zet ik mijn leeswijze uiteen door verschillende visies met elkaar te vergelijken, en zelf een positie in te nemen. Dat zijn de opvattingen van de kunsthistoricus H.W. Janson over de rol van de aap in de kunsten, 
zoals hij die uiteenzette in Apes and Ape Lore in the Middle Ages and the Renaissance (1952) en Maaike Meijers ideeën over interpretatie en de rol van vrouwen en andere 'anderen' in de literatuur, zoals ze die heeft verwoord in De lust tot lezen (1988) en In tekst gevat (1996). Maar ik begin met Haraways opvattingen over de relatie tussen cultuur en wetenschap.

'I take pleasure in confusing boundaries.' Eén van de grenzen die Haraway ter discussie stelt, is die tussen cultuur en wetenschap. $\mathrm{Ha}$ raways Primate Visions, een wetenschapsgeschiedenis van de primatologie, bestaat niet alleen uit een opsomming van onderzoekers en hun ontdekkingen. Zij staat tevens stil bij enkele machtige en imponerende beelden die rondom apen geproduceerd zijn en bij de momenten in de geschiedenis dat een aap de voorpagina's van het nieuws haalde: een bezorgde professor Yerkes in 1924 bij het sterfbed van zijn lievelingschimpansee Prince Chim, een van de Empire State Building neerstortende King Kong (1933), de eerste chimpansee die in de ruimte werd gelanceerd (196r), het eerste contact tussen een wilde chimpansee en Jane Goodall in Tanzania in 1974, en de brute moord op Dian Fossey, die in 1986 begraven werd in Rwanda naast haar lievelingsgorilla, de zilverrug Digit. ${ }^{2}$ Dit zegt iets over hoe Haraway geschiedenis opvat, namelijk als een soort fotoboek met snapshots, als reservoir van imponerende beelden uit cultuur en wetenschap. Deze 'bevroren' beelden probeert Haraway opnieuw open te breken tot bewegende verhalen door ze in hun historische, maatschappelijke en wetenschappelijke context te plaatsen.

In Primate Visions worden beelden uit de populaire cultuur moeiteloos afgewisseld met wetenschappelijke teksten uit de primatologie. Het is gebruikelijk om wetenschap en cultuur als gescheiden velden te zien. Wetenschap zou het domein van de feiten zijn, datgene wat vast ligt en waar is, terwijl cultuur het domein van de fictie en de verbeelding zou zijn, datgene wat nog open is voor interpretatie. Haraway relativeert en bekritiseert een dergelijke oppositie tussen waarheidsteksten en verbeeldingsteksten. Op twee manieren legt ze een verband tussen cultuur en wetenschap. ${ }^{3}$ Ten eerste zit er volgens Haraway in elke tekst een ideologische 'vingerafdruk'. ${ }^{4}$ Of teksten nu afkomstig zijn uit de culturele hoek, of uit de wetenschappelijke, elke tekst is gevormd door ideologische vooronderstellingen met betrekking tot gender, race en nature. Er is een bepaalde ideologie die tot uitdrukking komt in alle teksten. Hara- 
way leidt deze ideologie af uit de teksten. Ze maakt daarbij gebruik van de pars pro toto-strategie. De gedetailleerde beschrijving van een lokale, kleinschalige praktijk of een culturele uiting, bijvoorbeeld een film of een museumtentoonstelling, staat voor een grootschalige maatschappelijke situatie.

In het derde hoofdstuk van Primate Visions, 'Teddy Bear Patriarchy. Taxidermy in the Garden of Eden, New York City, 19081936', analyseert Haraway bijvoorbeeld de museumtentoonstelling 'African Hall', die in 1936 in The American Museum of Natural History in New York werd geopend. Deze tentoonstelling toonde een aantal diorama's die waren bedoeld om mensen een glimp te geven van hoe het was om te leven in de prehistorie, het tijdperk van de zoogdieren. In het bijzonder gaat Haraway in op één diorama, een opgezette gorillafamilie. Deze was vervaardigd door de taxidermist Carl Akeley, die in r92I zijn gorillafamilie wist te completeren door een zilverrug, een mannetjesgorilla, neer te schieten. Jarenlang werkte hij aan het diorama, dat pas in 1936 te bezichtigen was voor het publiek. Haraway wil de geschiedenis van dit bevroren beeld, 'this frozen image', traceren. De historische en politieke contextualisering van een tekst of beeld gaat bij Haraway vaak vliegensvlug, via een ogenschijnlijke terloopse opmerking als de volgende: 'So it could inhabit Akeley's monument to the purity of nature, this gorilla was killed in I92I, the same year the Museum hosted the Second International Congress of Eugenics' (27). Haraway legt een verband tussen de ene gorillafamilie van Akeley en de belangstelling voor eugenetica van het American Museum of Natural History, en uiteindelijk met de Amerikaanse politiek. Haraway suggereert een verband tussen cultuur en wetenschap via politiek. ${ }^{5}$ Wetenschap en cultuur zijn volgens Haraway een vorm van politiek met andere middelen.

De tweede manier waarop Haraway een verband legt tussen cultuur en wetenschap, en tevens het hiërarchische onderscheid tussen wetenschap en cultuur op grond van het vermeende waarheidsgehalte ter discussie stelt, is het deconstrueren van het onderscheid tussen feit en fictie. Feiten staan tegenover opinie of vooroordeel, maar niet tegenover fictie, stelt ze. Fictie is niet hetzelfde als 'liegen' of 'niet de waarheid spreken'. De woorden feit en fictie zijn beide gestoeld op menselijke actie en ervaring. Een feit is echter gesloten voor interpretatie, 'gestolde fictie' als het ware, terwijl fictie nog 
open is voor meerdere interpretatiemogelijkheden. Zowel wetenschap als (populaire) cultuur zijn volgens Haraway doorweven van feit en fictie. Er zit meer fictie in wetenschap dan we misschien wel zouden willen toegeven, en andersom is fictie gestoeld op kennis van feiten. Haraway gaat in haar boek vooral in op het eerste: het fictieve gehalte van wetenschap. Primatologische teksten worden door haar als 'SF' beschouwd. De term sF geeft een veld aan waarin wetenschap en fictie niet zo keurig van elkaar te scheiden zijn en staat voor science fiction, speculative fabulation, speculative futures, speculative fiction, science fantasy. Haraway spreekt ook van 'faction' (de vermenging van fact en fiction) en van 'scienticulture' (de verstrengeling van de humaniora en de harde wetenschap). Op deze wijze handhaaft ze in haar vocabulaire de verstrengeling van cultuur en wetenschap, in plaats van ze als van elkaar losstaande domeinen te zien. Haraways werk staat vol van dergelijke hybriden of 'implosions' zoals ze het zelf noemt, bijvoorbeeld 'technoscience' (om het onderscheid techniek versus wetenschap te bekritiseren) en 'politicoscientific' (om de vermeende grenzen tussen politiek en wetenschap ter discussie te stellen).

In primatologische teksten worden volgens Haraway steeds werelden geconstrueerd die met elkaar de strijd aangaan over de relatie tussen natuur en cultuur, mens en dier, lichaam en geest, oorsprong en toekomst. Haraway spreekt over wetenschap als een verhalenvertellende praktijk, a story-telling practice. 'Scientific practice may be considered as a kind of story-telling practice - a rule governed, constrained, historically changing craft of narrating the history of nature.' $(4)^{6}$ Wetenschap is een talige kwestie; wetenschappelijke theorieën zijn volgens Haraway ingebed in een narratieve structuur. Wanneer wetenschap wordt opgevat als een verhalenvertellende praktijk, dan impliceert dit dat de unieke positie die wetenschap ten opzichte van andere verhalen inneemt, wordt gerelativeerd. Wetenschappelijke teksten onderscheiden zich in deze opvatting niet langer essentialistisch van andere teksten omdat zij bij uitstek de waarheid zouden vertellen. Er is hooguit een gradueel en stilistisch verschil tussen wetenschappelijke teksten en fictionele of verbeeldingsteksten. Wetenschap is volgens Haraway een praktijk waarin een specifiek soort verhalen worden verteld. In navolging van de Italiaanse schrijver Umberto Eco stelt Haraway dat wetenschappelijke teksten stilistisch gezien meer 'geslo- 
ten' dan 'open' teksten zijn: 'Scientific conventions are full of ways to close off interpretation while still producing the effect for readers of having read a self-critical text' (318). Daarbij valt te denken aan het functionele gebruik van passieve werkwoordsvormen, tabellen et cetera. Om erachter te komen wat voor soort verhalen er binnen de wetenschap worden verteld, en om deze gesloten verhalen open te breken, richt Haraway zich op de rol die metaforen in het wetenschappelijke discours van de primatologie spelen. The point in locating a metaphor is not to discard it as polluted, but to show how it is enabled and in turn enables specific kinds of accounts. A metaphor will destabilize some similarities and rely, often silently on others' (3I4).

De aandacht voor het metaforische karakter van wetenschap blijkt uit de manier waarop Haraway laat zien hoe boeken over apen zijn geconstrueerd. Haraway gaat bijvoorbeeld in op het eerste invloedrijke standaardwerk over apen dat Robert Yerkes samen met zijn vrouw Ada schreef, The Great Apes (1929). Zij besteedt daarbij veel aandacht aan het vocabulaire van Yerkes en de keuze van bepaalde woorden, zoals 'personality', 'control', 'drive', 'profit', 'competition', 'motivitation' en 'human engineering'. Haraway koppelt deze 'business language' en de aandacht voor persoonlijkheid en het individu binnen het apenonderzoek aan de bredere historische context: het tijdperk van economische depressie en de Jazz Ideal of self-expression' (66). Het apenonderzoek, zo wil Haraway laten zien, is allesbehalve waardevrij: het is doordrenkt van maatschappelijke en ideologische idealen en dit komt via een bepaald samenhangend vocabulaire tot uitdrukking.

Een ander voorbeeld is de wijze waarop Haraway het werk van de primatologe Jeanne Altmann leest. Altmann deed onderzoek naar de rol van het moederschap in bavianengemeenschappen en begreep dit gedrag in termen van twee metaforen, 'dual career mothering' en 'budget'. Volgens Altmann was het opmerkelijk hoeveel taken baviaanvrouwtjes op zich namen: zorgen, eten, dragen, voor gevaar waken en socialiseren. De baviaanvrouwtjes waren in haar ogen eigenlijk een soort managers die in meerdere dingen tegelijk investeerden. Haraway schrijft dat de metaforen die Altmann gebruikt voor een deel teruggrijpen op metaforen uit de sociobiologie, het denken in termen van strategieën en investeringen, maar dat Altmann er toch in slaagt een nieuw verhaal te vertellen, doordat ze 
de aandacht richt op vrouwtjesapen: The basic plot and cultural form were given by the constraints of Darwinian theory, but the scientist dramatist constructed who counts as an actor, a privileged status in western mythic, philosophical, political and scientific narrative' (3r3).

Haraway karakteriseert primatologische teksten als een kruispunt van verschillende verhalen. Door middel van oneliners karakteriseert ze de primatologie bijvoorbeeld als 'salvation history' (9), 'Judeo Christian science' (9), 'first contact narrative' (168) en 'survival literature' (369). Met de eerste twee karakteriseringen van de primatologie, als verlossingsgeschiedenis en joods-christelijke wetenschap, doelt Haraway erop dat verhalen over apen altijd zijn ingeschreven in verhalen over de oorsprong van de mens; echo's van het bijbelse oorsprongsverhaal klinken door in publicaties over apen, soms in termen van de strijd tussen het christelijke scheppingsverhaal en de evolutietheorie. Met de karakterisering van primatologie als 'first contact'-verhalen, doelt Haraway op het verlangen van de wetenschapper naar het contact met de 'ander', in dit geval de apen. In die zin lijkt primatologie bijvoorbeeld op science fiction, stelt Haraway, waarin vaak de dramatische ontmoeting tussen de mens en een buitenaards wezen centraal staat. Tegenwoordig is primatologie steeds meer overlevingsliteratuur geworden, verhalen over een gevecht tussen leven en dood. 'All members of the Primate Order - monkeys, apes and people - are threatened' (3), schrijft Haraway.

Wetenschap mag dan wel een verhalenvertellende praktijk zijn, een opvatting die de traditionele hiërarchische relatie tussen wetenschap en cultuur relativeert, maar dat wil, zo benadrukt Haraway, geenszins zeggen dat elk verhaal evenveel waard is of dat verhalen onschuldig zijn. Er is altijd iemand die baat heeft bij een bepaald verhaal, terwijl een ander eronder lijdt. Cui bono? Who lives? Who dies? Dus: wie heeft er belang bij dat bepaalde verhalen (zo) verteld worden? Dat zijn de vragen die ten grondslag liggen aan het werk van Haraway. Hoewel ze, in navolging van Lakoff en Johnson, ervan uitgaat dat metaforen een performatief effect hebben, dat wil zeggen dat ze constitutief zijn voor het dagelijkse handelen en leven, stelt Haraway dat wetenschap niet gereduceerd kan worden tot een talige praktijk. Hoe we dingen zeggen is niet zonder gevolgen voor de inrichting van ons bestaan: vocabulaires vertalen zich in materiële structuren. 'Stories are a material practice?' 
'Reading Haraway is never a smooth autobahn'. ${ }^{8}$ Haraways werk wordt vaak als moeilijk toegankelijk en stilistisch complex beschouwd. Ze legt in haar werk een grote voorliefde voor het opeenstapelen van bijvoeglijke naamwoorden met een hoog abstractieniveau aan de dag. ${ }^{9}$ Bovendien expliciteert ze haar werk-, denk- en schrijfstijl niet. In Primate Visions (of haar latere werk) vind je geen methodologische principes, noch expliciete uitleg van haar, moeilijk navolgbare, associatieve werkwijze. Haraways stijl wordt door haarzelf getypeerd als 'metaphoric'10, door anderen onder meer als 'narratief' (De Laet 1991), 'kaleidoscopisch' (Zenderland 1990) of 'moeilijk en hybride' (Dobbelaar \& Slob 1995). De bombastische schrijfstijl en de niet-geëxpliciteerde werkwijze van Haraway is volgens sommigen ronduit ergeniswekkend, omdat niet precies duidelijk wordt wat Haraway nu eigenlijk wil beweren: '...the reader is left 230 arduous pages later with many images but without answers and with little insight into the mind that crafted this volume' (Brent 1994). ${ }^{11}$ Dit laatste zal Haraway hoogstwaarschijnlijk als een compliment opvatten. $\mathrm{Zij}$ verzet zich steeds tegen het geven van eenduidige antwoorden; ze stelt liever complexe vragen. Dat zij zichzelf hier en daar tegenspreekt, is problematisch voor wie coherentie, systematiek en eenduidigheid verlangt. Zelf beschouwt ze contradictie als een productieve ambiguiiteit en karakteriseert ze haar eigen werk als het opzoeken van de weerstand. De ruis ('noise') geeft aan dat je op de juiste weg zit. ${ }^{12}$

Haraways stijl is doorwrocht en lastig voor een lezer die gewend is aan duidelijke 'richtingwijzers' in non-fictie ('eerst doe ik dit, dan dat, om daarna mijn hypothese y te bewijzen'). Maar de stijl is ook inspirerend en consistent met haar inhoudelijke overtuigingen, namelijk dat 'feit' en 'fictie' minder keurig van elkaar te scheiden zijn dan we vaak aannemen. Haraways associatieve aanpak maakt een brede culturele, soms gewaagde analyse mogelijk waarbij de ene vondst tot de volgende gedachte leidt. Ze werkt niet met een schema of een model waarin alles klopt, maar is juist gericht op de 'rommeligheid', het constructiewerk dat wetenschap is. Dankzij haar associatieve werkwijze houdt ze oog voor de rijkheid en meerduidigheid van verhalen. Althans, dat geldt vooral voor haar analyse van wetenschappelijke teksten. 
Zo verrassend en rijk als Haraways analyses van (populair-)wetenschappelijke boeken zijn in Primate Visions, zo reducerend zijn sommige van haar analyses van (populaire) cultuur, film en literatuur met name. ${ }^{13}$ Mijn voornaamste kritiek op Primate Visions betreft niet de associatieve stijl, maar de wijze waarop wordt omgegaan met culturele uitingen. Als het gaat om culturele uitingen (romans, films), strookt Haraways leespraktijk niet altijd met haar opvatting, dat zij gestolde beelden wil openbreken tot bewegende verhalen. In plaats daarvan 'sluit' ze de culturele beelden opnieuw, door ze op te vatten als illustratie van een bepaalde politiek. Uitspraken van Haraway die hier op wijzen zijn bijvoorbeeld 'The film is an argument about [...]' (179) of 'Two recent fictions confirm the analysis' (179) of 'Both images must be read with the triple code of gender, science, race. Together, the images form an ironic diptych summarizing arguments in this book' (I6I) (cursiveringen van mij, s s). Wanneer Haraway een film of een roman interpreteert, maakt ze vaak een sprong van een historische gebeurtenis naar de desbetreffende film of roman, om die vervolgens opnieuw te koppelen aan een ideologie. Wat er precies gebeurt, is, mede door de 'grote' woorden, moeilijk te volgen.

HAM's [de eerste aap in de ruimte, genoemd naar het wetenschappelijk militaire instituut die de aap trainde, Holloman AeroMedical, sJ] parabolic path is rich with evocations of the history of western science. [...] It describes the path of ballistic weapons, and it is the trope for 'man's' doomed projects in the writings of the existentialists in the r95os. The parabola traces the path of Rocket man at the end of World War II in Thomas Pynchon's Gravity's Rainbow. An understudy for man, Ham, wet only to the boundary of space in suborbital flight. (138)

HAM, his human cousins and simian colleagues, and their englobing and interfacing technology were implicated in a reconstitution of masculinity in Cold War and space race idioms. The movie The Right Stuff (1985) shows the first crop of human astronau(gh)ts struggling with their affronted pride when they realize their tasks were competently performed by their simian cousins. They and the chimps were caught in the same theater of the Cold War, where the masculinist, death-defying, and skill-requiring heroics 
of the olf jet aircraft test pilots became obsolete, to be replaced by the media-hype routines of projects Mercury, Apollo, and their sequelae. (138)

In bovenstaande voorbeelden worden respectievelijk een roman en een film ingezet als illustratie van een grotere gebeurtenis, van een politiek decor. Ook de wijze waarop Haraway een film als King Kong (1933) analyseert, getuigt van deze ideologiekritische neiging tot inlijven (Haraway 1989: 160-162). ${ }^{4}$ De (symbolische) betekenisverschillen van apensoorten in culturele representaties komen niet aan de orde bij Haraway, bijvoorbeeld de vraag waarom King Kong nu juist een onwerkelijk grote gorilla is, en waarom er in het experiment uit de hierboven genoemde film The Right Stuff nu juist voor chimpansees is gekozen. Kortom, hoe zit het eigenlijk met de verschillende aapsoorten ? $^{15}$

Films en romans roepen tal van vragen op, die niet bevredigend beantwoord kunnen worden door uitsluitend te letten op 'de' ideologische betekenis van een film of boek. Zijn ze werkelijk zo (ideologisch) eenduidig als Haraway ze soms voorstelt? Zijn culturele en kunstzinnige uitingen niet juist bij uitstek de plek waar ambiguiteit gehandhaafd kan blijven, waar er plaats is voor meerdere betekenismogelijkheden en verschillende betekenissen?

Een bijkomende vraag is de volgende. Enerzijds is volgens Haraway elke tekst doordrenkt van en gevormd door dominante ideologische machtsstructuren. Teksten reflecteren bovendien niet alleen een bepaalde ideologie, ze dragen er ook aan bij dat deze gehandhaafd blijft en bewerkstelligen en beïnvloeden deze ook. Anderzijds zegt ze dat het tegengif ook gezocht kan worden in teksten; teksten bieden volgens haar ook de mogelijkheid om kritiek te leveren op ideologie. Maar, gegeven dat we allemaal 'gevangen' zitten in bepaalde dominante ideologische denkbeelden, wordt het niet helemaal duidelijk waarom sommigen er wel in slagen zich daaruit te bevrijden, terwijl anderen erin 'vast' blijven zitten.

Haraway beschouwt een tekst als een middel om te interveniëren in discussies en om handelingspraktijken te beïnvloeden. Zo noemt ze een boek van de Amerikaanse primatologe Linda Fedigan 'her first large intervention in the sexual and linguistic politics of primatology' (cursivering van mij: sJ, 318). Teksten bieden kennelijk ook een mogelijkheid om een hardnekkige ideologie te kenteren. 
In haar analyses van het werk van vrouwelijke primatologen, bijvoorbeeld van Jeanne Altmann, laat Haraway zien hoe deze wetenschappers nieuwe ideëen inbrengen. Uit het idee dat wetenschap een talige praktijk is, volgt dat schrijven niet secundair is aan het wetenschappelijke proces, maar van groot belang. In schrijven zit definitiemacht besloten. Als bepaalde verhalen ons niet bevallen kunnen we proberen 'terug' te schrijven of in te grijpen met een nieuw verhaal.

Haraway gebruikt ter illustratie een voorbeeld van twee literaire critici, Susan Gubar en Sandra Gilbert (Haraway 1989: 281-283). Zij schrijven over de twee dochters van John Milton, de grote blinde Britse dichter die Paradise Lost schreef. Om zijn werk te kunnen completeren, had hij de hulp van zijn dochters nodig. Zij lazen hem passages uit de bijbel voor. Gubar en Gilbert speculeren over de mogelijke invloed die de dochters konden uitoefenen. Moesten zij hun vaders grotere doel dienen, of rebelleren en riskeren dat ze daarmee zijn vertrouwen verloren? Konden zij hun vader een nieuw verhaal op de mouw spelden? Dit voorbeeld illustreert volgens mij niet alleen de macht van het schrijven, maar ook de macht die bij de lezer als betekenisgever van een tekst besloten ligt. De dochters van Milton konden ervoor kiezen bepaalde woorden te benadrukken, bepaalde passages uit te lichten of ironie in hun stem te leggen. Wetenschap is een verhalenvertellende praktijk, schrijft Haraway, maar dat betekent dat er ook lezers nodig zijn die betekenis geven aan verhalen.

Wetenschap is niet alleen a story-telling practice, maar ook a reading practice. Betekenisgeving vindt plats in het vertellen van verhalen, maar ook in het lezen daarvan. Wie een tekst leest, kan zijn of haar eigen vragen aan de tekst stellen, of tegendraads lezen. De gesignaleerde spanning die in het werk van Haraway zit, verhalen als bevestiging van een bepaalde ideologie én als middel om nieuwe betekenissen te creëren, is niet alleen een eigenschap van een tekst, maar hangt ook af van de leeshouding die de lezer aanneemt. Haraway is vooral bezig met de constructie van het verhalende karakter van wetenschap, met de wijze waarop de aap geconstrueerd wordt in en door wetenschap en cultuur, maar expliciteert niet haar leeswijze. Voor de natuurwetenschappen, waar men streeft naar de 'waarheid', mag het een revolutionair inzicht zijn dat wetenschap een constructie is, maar in de hu- 
maniora is het inzicht dat de wereld vol verhalen zit, minder verrassend. Je kunt je afvragen voor wie Haraway precies schrijft, voor natuurwetenschappers, voor mensen uit de humanoria of voor allebei? Als het op haar methode van literatuur lezen en analyseren van films aankomt, reduceert zij culturele uitingen tot illustraties van ideologieën. Van wetenschap als verhalenvertellende praktijk zet ik de stap naar wetenschap en cultuur als leespraktijk. Hoe verhalen (over apen) te lezen? Hoe te interpreteren? Welke ruimte is er tussen vormgevende ideologie en tekst? En doen esthetische waarden of leesplezier nog ter zake? Voor deze vragen wend ik mij tot het vak dat zich bij uitstek met dit soort vragen bezighoudt: de literatuurwetenschap.

\section{DE LUST TOT LEZEN IN TEKST GEVAT}

Als er één culturele ruimte is waarvan gezegd wordt dat ambiguïteit behouden of gerepresenteerd kan worden, dan is het wel de literatuur. ${ }^{16}$ Literatuur zou in dit opzicht bijvoorbeeld verschillen van wetenschap, waar getracht wordt te streven naar eenduidigheid, wetmatigheid, systematiek en gegrondheid. Zo luidde althans de opvatting van de New Critics, een invloedrijke groep critici uit Amerika en Engeland van na de Tweede Wereldoorlog, die beweerden dat ambiguïteit (ook wel polyvalentie, multi-interpretabiliteit, meerduidigheid) het kenmerk van literatuur bij uitstek was (Graff 1998). De taak van de interpreet was het aanwijzen van de betekenismogelijkheden van een tekst.

Nog altijd wordt binnen de literatuurwetenschap een debat gevoerd over tekstinterpretatie tussen de hermeneutici enerzijds, waartoe ook de New Critics gerekend konden worden, en de deconstructivisten anderzijds. Hermeneutici zijn vooral gericht op betekenis- en zingeving aan teksten, terwijl post-structuralisten en deconstructivisten vasthouden aan indeterminacy, onbeslisbaarheid met betrekking tot de betekenis van teksten (Blans 1988). Het is volgens deconstructivisten principieel onmogelijk om te komen tot de juiste interpretatie van een tekst. (Graff 1998). Terwijl de hermeneutici van mening zijn dat het aantal mogelijke betekenissen beperkt is, en dat ambiguiteit lokaliseerbaar is, zijn deconstructivisten ervan overtuigd dat de 
reeks van betekenissen in principe oneindig is. ${ }^{\nabla}$ Dat komt onder andere doordat de context waarin een tekst gelezen kan worden principieel altijd uit te breiden is. De betekenis wordt mede gevormd door het interpretatiekader, de context, die wordt gekozen door de lezer. Meerduidigheid of onbepaaldheid is niet zonder meer een eigenschap van een tekst, het is ook een leeshouding die de geoefende literatuurlezer geleerd heeft om aan te nemen bij het lezen van literatuur. Het literaire waardeoordeel wordt erdoor bepaald en in ermee samenhangende termen uitgedrukt. Het gaat niet om wat er verteld wordt, maar of en hóe, een verhaal meerduidig is. Naast lezers die zich richten op ambiguïteit en openheid van de individuele tekst, zijn er ook lezers die juist niet op zoek zijn naar de uniciteit en bijzonderheid van de individuele literaire tekst. $\mathrm{Zij}$ gaan ideologiekritisch te werk en onderzoeken de wijze waarop stereotypen herhaald worden.

Het werk van Maaike Meijer wordt gekenmerkt door beide leeshoudingen. Haar leestheorie, zoals die uit De lust tot lezen. Nederlandse dichteressen en het literaire systeem (1988) spreekt, is vooral geïnspireerd door de aandacht voor het 'vreemde' en de 'ambiguiteit' in een tekst. Hoewel De lust tot lezen zich op poëzie richt, is de leestheorie van algemenere strekking en ook toepasbaar op verhalen. In In tekst gevat. Inleiding tot een kritiek van representatie (1996) is Meijer meer op zoek naar de wijze waarop teksten normen (hiërarchische verhoudingen omtrent sekse en kleur met name) bevestigen en instandhouden. De twee boeken lijken soms tegengesteld wat inzet betreft. De lust tot lezen demonstreert de plezierige mogelijkheden van de lezer bij tekstinterpretatie, In tekst gevat wijst vooral op de minder aangename macht die de tekst op de lezer uitoefent. Hieronder vergelijk ik de leestheorie zoals die naar voren komt uit De lust tot lezen (1988) met die van In tekst gevat (1996).

In De lust tot lezen schrijft Meijer dat de betekenis van een tekst totstandkomt in de ontmoeting tussen de tekst en de lezer; de tekst is in haar theorie 'de ander'. In haar ogen zijn interpretaties nooit juist of af, omdat iedere lezer een ander interpretatiekader kan aannemen. Bij het lezen van literaire teksten, dient de lezer het liefst niet op zoek te gaan naar herkenning of zelfbevestiging, maar zich open te stellen voor 'het andere' dat de tekst te bieden heeft, datgene wat niet klopt met het wereldbeeld van de lezer, datgene wat interpretatie behoeft. Meijer pleit voor interpretaties die gericht 
zijn op discontinuitteit: die verslag doen van de wijze waarop tekst en lezer botsen, de wijze waarop teksten 'ontregelend' en 'bevreemdend' werken.

Tegenover de klassieke hermeneutische methode van interpretatie, waarbij gepoogd wordt de juiste betekenissen van het gedicht te achterhalen, plaatst Meijer een alternatief dat zij 'tegen-interpretatie' noemt. Meijers bezwaar tegen de klassieke tekstimmanente interpretatie is tweeledig. Ten eerste signaleert Meijer een discrepantie tussen poëzie en interpretatie. De traditionele interpretatie wil een gedicht 'ontmaskeren', terwijl het gedicht zich hier juist tegen verzet. Meijer beschrijft de klassieke interpretatie als een methode die de gedichten in de interpretatie berooft van alles wat ons erin fascineerde. Door het analyseren van de receptiegeschiedenis van een aantal dichteressen, laat Meijer zien hoe in interpretaties 'open plekken' soms op een wijze worden ingevuld die de tekst 'dood slaat'. Met andere woorden, de klassieke interpretatie wil de vreemdheid van het gedicht uitleggen en verwijdert vakkundig datgene wat ons aantrok in een gedicht. Meijer noemt dit de paradox van de interpretatie.

Het tweede bezwaar is gericht op wat ze de 'tekst of lezer'-kwestie noemt. Terwijl de klassieke interpretatie methode ervan uitgaat dat de tekst een betekenis in zich draagt die de lezer eruit kan halen, ziet Meijer een actieve rol voor de lezer weggelegd in het maken van betekenis. Meijer pleit als feministe, zoals ze het zelf omschrijft, 'voor een actief cultureel kiesrecht: baas in eigen boek!' (Meijer 1988: 17). De alternatieve leesstrategie die Meijer voorstaat beschouwt zij als een wijze die zich 'uit de rationele wereld naar de irrationele, beeldende, sensuele, gevoelsmatige begeeft' (Meijer 1988: 69). Meijer is dus niet tegen de interpretatie, maar voor een tegeninterpretatie. De tegeninterpretatie is niet een uitleg van het gedicht, maar een 'beschrijving van hoe het gedicht ons ontdoet van gewone waarneming, en hoe het de in ons gevestigde vaste taal- en denkstructuren aan het wankelen brengt' (Meijer 1988: $\Pi$ ). Meijer noemt dit de erotische interpretatie. Deze omschrijving lijkt veel op wat een open interpretatie genoemd kan worden. De open interpretatie vult de open plekken niet op, maar geeft aan hoe een open plek in een tekst functioneert.

In haar boek Verlangen naar de val. Zelfverlies en autonomie in hermeneutiek en ethiek (1992) wijst Annelies van Heijst op een dub- 
belheid in Meijers De lust tot lezen. Aan de ene kant kiest Meijer in het lezer-tekst dilemma voor een overwegend lezersgericht standpunt. De lezer draagt in hoge en actieve mate bij aan betekenisgeving van de tekst. De lezer wordt hier opgevat als een autonoom subject dat welbewust haar keuzes maakt. Aan de andere kant pleit Meijer voor discontinuïteit Ze verwerpt een leeshouding die op herkenning is gericht, omdat dit het kritisch bewustzijn uitschakelt. Een discontinue leeshouding is vruchtbaarder, omdat juist de vreemdheid in een tekst nieuwe betekenissen oplevert. Volgens Van Heijst bevindt Meijer zich op het breukvlak van twee concepten. Enerzijds beschouwt Meijer het subject als volledig autonoom, met een duidelijke identiteit die in staat is tot het toe-eigenen van betekenis. Anderzijds denkt Meijer in termen van discontinuïteit: openstaan voor het vreemde en ontvankelijkheid. Maar hoe kan een lezer die autonoom betekenissen construeert, openstaan voor de vreemdheid van een tekst? ${ }^{18}$

In In tekst gevat is het dilemma dat door Van Heijst werd gesignaleerd in De lust tot lezen niet minder aanwezig. In dit boek wordt niet zozeer de vreemdheid van een tekst, als wel de vanzelfsprekendheid en starheid van een tekst benadrukt. In tekst gevat kan worden geplaatst in de ontwikkeling van literaire naar culturele studies. Meijer bespreekt in dit boek niet alleen literaire werken, maar ook reclames, een liedje en het onderschrift van een foto. Naarmate literatuur meer als een cultuurproduct wordt opgevat, krijgt de culturele context waaruit het literaire product voorkomt ook meer aandacht. Meijer benadrukt met name twee hiërarchische lijnen waarlangs de culturele context georganiseerd is: sekse- en kleurverhoudingen. In culturele representaties worden sekse- en kleurverhoudingen gereproduceerd. Meijer onderzoekt hoe teksten vervreemding van en angst voor de 'ander' juist bewerkstellingen, en vraagt zich af hoe zulke 'anders-makende' mechanismen kunnen worden blootgelegd, en aangepakt. Welke tekststrategieën zorgen ervoor dat de 'ander' als object wordt gezien? Zulke vragen kunnen volgens Meijer worden beantwoord door nauwgezette tekstanalyse, waarin je de methoden van de literaire analyse (narratologie, retorica, stilistiek, intertekstualiteit) inzet voor een ander, een niet strikt literair doel. In feite is dat wat Haraway ook wil doen: literaire methoden gebruiken voor het analyseren van wetenschap. 
Ook hier is er sprake van een conflict tussen enerzijds de autonomie van het subject die door Meijer wordt gepostuleerd als het gaat om een zich verzettende en kritische leeshouding en anderzijds een poststructuralistische representatietheorie, waarin het subject zelf het product is van een veelheid van teksten. Een belangrijke vraag is, kortom, hoe machtig de lezer eigenlijk is. In In tekst gevat speelt deze vraag, omdat hier de cultuurtekst als zeer machtig wordt voorgesteld, zozeer, dat literaire teksten in de interpretaties van Meijer soms meer weg hebben van politieke pamfletten of sociologische studies, waardoor 'de lust tot lezen' danig wordt geremd.

Het gaat mij niet zozeer om het oplossen van dit 'tekst of lezer'probleem (dat is volgens mij niet mogelijk, laat staan productief) bij het geven van betekenis, maar om de leeshouding die de lezer kan aannemen. Hij of zij kan op zoek gaan naar ambiguitteit of onbepaaldheid, of juist naar structurerende conventies binnen een tekst. Het beste van De lust tot lezen en van In tekst gevat betekent een combinatie van plezier in lezen en interpreteren en tegelijkertijd een cultuurkritische leeshouding. Deze leeswijze wil teksten in beweging zetten, maar ook laten zien hoe teksten beweging kunnen blokkeren. Elke vorm van interpreteren impliceert een stilzetten, een opvullen. Wie leest en interpreteert, breekt een bevroren verhaal open, maar sluit het ook weer door bepaalde leesmogelijkheden als dominant te selecteren en vast te leggen op papier. Want is Van Heijsts kritiek op Meijer niet iets te stellig? Is het misschien wél mogelijk om je 'autonoom' op te stellen voor het vreemde, namelijk door je bewust open te stellen voor de mogelijkheid dat het 'andere' je in/vanuit de tekst overvalt: dat je dat risico neemt en opzoekt, dat je voor de (tijdelijke) dominantie van het 'andere' of het 'vreemde' kiest? De lust tot lezen benadrukt het plezier van het lezen, aandacht voor de nuances van de individuele tekst en aandacht voor de wijze waarop anderen interpreteren, de wijze waarop de receptiegeschiedenis een rol speelt in het vaststellen van de betekenis van een tekst. In tekst gevat biedt een methode om teksten en verschillende vertogen met elkaar in gesprek te brengen, een leeswijze die voor dit boek van belang is omdat ik een serie teksten over vrouwen en apen uit cultuur en wetenschap met elkaar wil verbinden. Met deze leeswijze vestig je de aandacht erop dat een tekst niet in een vacuüm ontstaat, maar in relatie tot andere 
teksten totstandkomt. Juist in de dialoog met andere teksten ontstaan spanningen binnen een tekst, die ambiguïteit produceert. Maar het is de lezer die de 'andere' teksten kiest, en zich daarbij kan richten op de wijze waarop teksten botsen of elkaar bevestigen. De intertekstuele leeswijze biedt de mogelijkheid tot het lezen van een tekst als bevestiging van de 'norm' en als 'ander'.

\section{INTERTEKSTUALITEIT}

Onder intertekstualiteit verstaat Meijer 'het hergebruik van bestaande teksten in een nieuwe tekst.' (Meijer 1996: 13) ${ }^{19}$ Uitgangspunt van de interteksuele leeswijze is dat de betekenis van een tekst totstandkomt door de relatie met eerdere teksten. Het gaat er bij een intertekstuele analyse volgens Meijer niet om een klassiek bronnenonderzoek te doen waarin je de mate van afhankelijkheid van een 'brontekst' vaststelt, maar om de functie van de 'intertekst' te onderzoeken en te kijken welke nieuwe betekenissen intertekstualiteit oplevert. Intertekstualiteit is volgens Meijer een leeswijze. Ze merkt hierbij op dat intertekstualiteit breed moet worden opgevat. Anders dan Riffaterre, die, aldus Meijer, de term alleen wil reserveren voor traceerbare literaire vormen van ontlening en bewerking, wil Meijer de term ook laten slaan op niet direct traceerbare fragmenten en op niet-literaire teksten. Met name de niet-literaire teksten bieden de mogelijkheid om de culturele en historische context van een literaire tekst in beeld te brengen.

Meijer onderscheidt drie niveaus van intertekstualiteit: de traceerbare intertekst, het genre als intertekstueel kader en de bredere cultuurtekst. Deze drie zal ik hieronder toelichten en illustreren aan de hand van een voorbeeld uit mijn onderzoek. Ten eerste is er de directe aanwijsbare ontlening aan een bestaande tekst die nog traceerbaar is, bijvoorbeeld omdat een werk of een regel geciteerd wordt. In Mijn aap schreit van Albert Helman wordt bijvoorbeeld zeer vaak door de hoofdpersoon verwezen naar werk van andere schrijvers. Zo leest de hoofdpersoon bij het venster Strindbergs Der Vater, 'omwille van de vele kerkse voorbijgangers op een zondagmiddag', en kijkt hij laatdunkend neer op zijn moeder, die 'genoeg heeft aan Thomas a Kempis'. Dit zijn traceerbare verwijzingen, die 
betekenisvol kunnen zijn. Ze zeggen iets over de hoofdpersoon, namelijk dat hij een belezen figuur is die zijn klassieken kent, en dat hij op epaterende wijze de voorkeur aan Strindberg geeft boven Thomas a Kempis, waarmee hij aangeeft dat hij zo zijn twijfels heeft over het geloof.

Ten tweede noemt Meijer het literaire genre als intertekstueel kader. Een tekst is gemodelleerd naar de conventies van een genre (tragedie, detective, bekentenisroman et cetera) en verhoudt zich hiertoe op een bepaalde wijze. In Mijn aap schreit luidt de ondertitel bijvoorbeeld 'een korte roman'. Helman postioneert zich in de traditie van korte verhalen. Daartoe is ook een reden: in Mijn aap schreit foetert de ikfiguur over mensen die te 'dikke boeken' schrijven, terwijl 'onze beste romans niet langer behoefden te zijn dan een tiental woorden'. (Helman 1928: 30). Soms is het literaire genre waartoe een werk behoort meerduidig. Zo zijn de boeken van Jane Goodall, Dian Fossey en Biruté Galdikas een mengeling van autobiografie, avonturenroman en populaire wetenschap. Zoals Haraway aangeeft, bevatten deze verhalen allusies op diverse genres, zoals het religieuze scheppingsverhaal en science fiction. Dat blijkt alleen al uit de titel van Galdikas' boek De spiegel van het paradijs. Mijn jaren bij de orang-oetans van Borneo waarmee al direct bij verhalen over de schepping en de oorsprong van het leven wordt aangehaakt.

De derde vorm van intertekstualiteit is ingewikkelder, omdat de precieze bron niet aanwijsbaar of te achterhalen is. In elke tekst resoneren cultuurteksten. Onder cultuurtekst verstaat Meijer:

Een conglomeraat van geaccepteerde, steeds weer terugkerende motieven en wijzen van representatie rondom een thema dat zich steeds weer organiseert in nieuwe culturele teksten, ongeacht of deze literair, journalistiek, wetenschappelijk of van andere herkomst zijn. (Meijer 1996: 33)

De cultuurtekst kan in de individuele tekst opgespoord worden door breed intertekstueel onderzoek. Volgens sommige literatuurwetenschappers, zoals Jonathan Culler, is dit onbegonnen werk. De intertekstuele ruimte ligt immers nooit vast omdat een tekst oneindig verwijst. Hoewel Meijer aangeeft dat de lezers verschillende echo's van intertekstualiteit zullen horen in een tekst, meent ze dat 
er geen reden is voor pessimisme. Wanneer je intertekstualiteit opvat als een leeswijze, dan kan de lezer een beperkt aantal interteksten aanwijzen die hij of zij relevant acht. Bij de intertekstuele leeswijze moet de lezer steeds beslissen waar de interpretatiecontext begint en ophoudt. Het succes van deze leeswijze hangt dus af van de wijze waarop de lezer bepaalde interteksten productief maakt in zijn of haar interpretatie van een tekst.

In dit onderzoek behelst het derde niveau de bredere opvattingen over mens-aaprelaties zoals die op een bepaald moment in een cultuur worden uitgedrukt. De tekst 'aap' heeft een lange iconografische traditie, die beperkingen oplegt en mogelijkheden verschaft. ${ }^{20}$ Een van die betekenissen die steeds opduikt is die van de aap als geil dier en minnaar van de vrouw. ${ }^{21}$ De aap heeft dus een serie gestolde betekenissen. Volgens de kunsthistoricus H.W. Janson (1952) kan een aap in een tekst of op een afbeelding dan ook symbolisch gedecodeerd worden. De aap staat voor een menselijke eigenschap, bijvoorbeeld voor 'gierigheid', 'lelijkheid' of 'geilheid' (in combinatie met een vrouw). Ook Gerigk (1989) schrijft dat wanneer een aap figureert in een tekst, dit in feite een vermomming is voor de mens, een imago hominis. Hij presenteert een typologie van acht soorten mensen die door de aap vertegenwoordigd worden, en illustreert deze typologie met verhalen uit de literatuur waarin een aap een belangrijke rol speelt. ${ }^{22}$ Volgens hem staan apen vaak voor een onbehagen in de cultuur: 'Der Mensch als Affe ist der bildliche Ausdruch für das Unbehagen in der Kultur' (Gerigk 1989: 32). De aap kan dit onbehagen blootleggen, omdat hij optreedt als een speciale figuur in literaire teksten, die in de symbolische positie verkeert om ontregelend op te treden en conventies bloot te leggen. In literaire dierensatires worden apen vaak ingezet om menselijke tekortkomingen te ontmaskeren. De aap is in dit opzicht vergelijkbaar met de schelm en de gek. Omdat schelmen, gekken en apen zich bewegen tussen twee werelden, krijgen zij een symbolische functie. Ze hebben het recht om anders te zijn, om tegendraadse dingen te zeggen, af te wijken, te parodiëren, dingen niet te begrijpen, dingen te verklappen en te onthullen (Bakhtin 1981: 158-166).

De aap wordt niet door iedereen als symbool geïnterpreteerd. In The Ape in Myth and Art (1998) corrigeert Solly Zuckerman de schilder Picasso, omdat deze naar zijn mening niet goed naar 'ech- 
te' apen heeft gekeken. Zuckerman beschouwt de aap louter als een realistisch waarneembaar dier en niet als een symbolisch beladen figuur uit de kunsttraditie. Zowel de strikt symbolische interpretaties van de aap, zoals H.W. Janson en Gerigk die voorstaan, als de realistische visie van Zuckerman, zijn in zekere zin reducerend. De aap wordt in beide opvattingen ontdaan van zijn ambiguïteit, door te bepalen dat de aap mens is of dier. Janson gaat er daarbij, anders dan Gerigk en net als Haraway, van uit dat de aap een constructie is. Volgens Janson is de aap een symbolische constructie (die gedecodeerd kan worden) en volgens Haraway een ideologische constructie (die ontmaskerd kan worden). In dit boek probeer ik symbolische, ideologische of realistische lezingen van de aap zo lang mogelijk uit te stellen, door ervan uit te gaan dat de aap een constructie is van een hoeveelheid teksten uit verschillende disciplines en dat de lezer een rol speelt bij het interpreteren en selecteren van deze teksten. De functie van dit uitstellen is het uitvergroten van ambiguïteit, omdat juist deze interessant is aan de ontmoeting tussen de vrouw en de aap omdat zo (historische) veranderingen in het denken over de ander zichtbaar worden. Soms kom ik uiteindelijk wel op een symbolische, ideologische of realistische lezing uit, en beslis ik op grond van argumenten de betekenissen van de aap te 'sluiten'.

De cultuurtekst als intertekst is interessant omdat hiermee verbanden gelegd kunnen worden tussen literaire en niet-literaire teksten, door populair-wetenschappelijke teksten over apen als intertekst op te voeren. De thema's die in de wetenschap op de agenda staan en tot uitdrukking komen in wetenschappelijke teksten en debatten, kunnen bijvoorbeeld ook worden opgevat als cultuurtekst, als intertekst bij de interpretatie. In de diverse hoofdstukken waarin de interpretatie van een film of roman centraal staat, gebruik ik wetenschappelijke teksten als intertekst. Bij mijn interpretatie van King Kong (1933), komt bijvoorbeeld het debat dat in de jaren dertig gevoerd wordt over de aard van de gorilla - zachtaardig of kwaadaardig - aan de orde.

Er zijn echter ook haken en ogen aan de notie cultuurtekst. Hoe kan verandering verklaard of gedacht worden? En waar is, in al deze aandacht voor de rol van de lezer, de auteur gebleven? 
Cultuurteksten impliceren volgens Meijer een verstarde code van representatie. Het gaat om een manier van representeren die zo vanzelfsprekend is, dat de lezer zich er nauwelijks van bewust is dat er een cultuurtekst wordt herhaald. Het is belangrijk om deze cultuurtekst als categorie te introduceren, omdat het effect van de tekst zich niet op individueel niveau afspeelt, maar op het niveau van de cultuurtekst:

Effect kan niet worden besproken op het niveau van de individuele tekst - die is vaak te vluchtig om een blijvend effect te sorteren maar moet worden beschouwd op het niveau van de cultuurtekst. De cultuurtekst is het culturele model dat veelomvattender is dan de éne tekst, en dat in individuele teksten steeds opnieuw wordt hernomen. Het is de eindeloze herhaling van bepaalde culturele schema's die werkelijkheidsvormend en subject-vormend is. (Meijer I996: I6)

Meijer beschouwt intertekstualiteit als een belangrijk hulpmiddel voor feministische tekstkritiek, en ideologiekritisch onderzoek in het algemeen. Volgens Meijer hebben vrouwen (en andere 'anderen', bijvoorbeeld homoseksuelen en zwarten) een specifieke relatie tot intertekstualiteit omdat zij schrijven in een culturele ruimte waarin betekenissen reeds in een dominante richting zijn vastgelegd. Op alle drie de niveaus van intertekstualiteit is sekse al op een bepaalde manier ingeschreven. Veel vrouwelijke auteurs proberen zich dan ook te verweren tegen bestaande tradities, en tegelijkertijd nieuwe betekenissen te scheppen:

Bij veel vrouwelijke auteurs zie ik een dubbele strategie: aan de ene kant is er sprake van een polemisch ingaan tegen teksten van mannelijke voorgangers en de daarin geïmpliceerde visie op sekse. Aan de andere kant is er sprake van een herkennende, waarderende herneming van vrouwelijk voorgangers, die daarbij vaak worden bevrijd van denigrerende of belemmerende beeldvorming. (Meijer 1996: 43) 


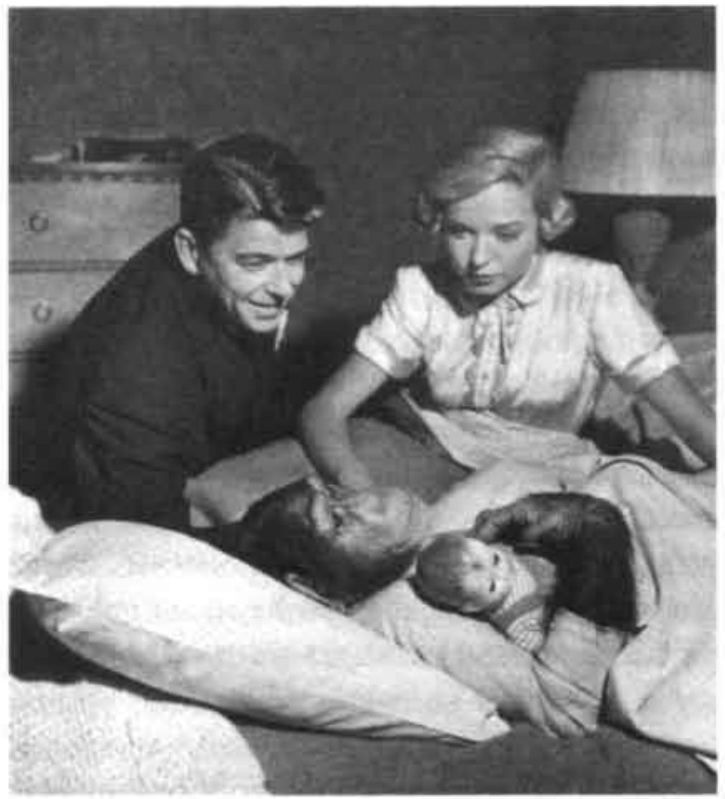

5 Reagan in Bedtime for Bonzo (1951). Foto: Ida Wyman (1984).

6 Bush en de aap.

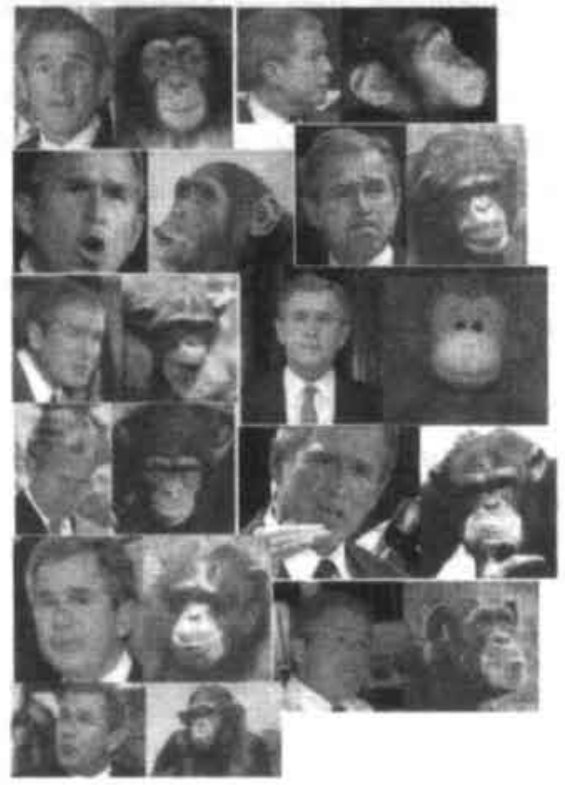


De teksten van mannelijke voorgangers noemt Meijer patriarchale teksten en de teksten van vrouwelijke voorgangers bevriende teksten. Soms lukt het een vrouwelijke schrijfster niet te ontsnappen aan de logica van het mannenverhaal en blijft het verhaal gevangen in de wurggreep van de voorgaande teksten. Als voorbeeld van een tekst waarin de schrijfster er niet in geslaagd is zich los te schrijven noemt Meijer De wetten van Connie Palmen. Volgens Meijer levert deze tekst nauwelijks subversief commentaar op voorgaande teksten. Hoewel de klassieke rollen van de man als jager en de vrouw als prooi in het verhaal worden omgedraaid, vervalt de vrouwelijke mannenjaagster Marie uiteindelijk in de conventie. Aan het slot van het boek ervaart Marie haar ambitie als tegenstrijdig met haar liefde voor een man; de ambitie wijkt voor de liefde. Volgens Meijer is het gedicht 'Snapshots' van Adrienne Rich een voorbeeld waarin de auteur er wél in is geslaagd om zich met bevriende teksten te verbinden. In dit gedicht citeert Rich instemmend een passage uit Wollstonecrafts Thoughts on the Education of Daughters en creeert hiermee een feministisch kader voor de interpretatie van het gedicht.

Terwijl Meijer enerzijds intertekstualiteit als strategie ziet voor vrouwelijke auteurs om te ontsnappen aan patriarchale tradities, beschouwt ze anderzijds de auteur niet als de unieke schepper van zijn werk, maar als een doorgeefluik van culturele codes:

Het gaat hier niet om individuen maar om machtige culturele conventies, om collectieve structuren van representatie, die de macht van deze auteur verre te boven gaan en die diep verankerd zijn in onze taal en onze cultuur. Het gaat hier om de tekst na de dood van de auteur, de tekst 'na Barthes', de tekst die niet als bezit van de individuele auteur kan gelden: de tekst als proces, als bovenpersoonlijk krachtenveld. De auteur mag als het ware de pen even vasthouden, maar de pen bewoog al uit zichzelf. (Meijer I996: 95)

Meijers auteursopvatting is echter problematisch, omdat niet verklaard kan worden waarom sommige auteurs er wél in slagen aan de cultuurtekst te ontsnappen (zoals, volgens Meijer, Christa Wolfs Kassandra) en andere niet (zoals, volgens Meijer, Connie Palmens De wetten). Om dit te begrijpen lijkt er toch een moment van indi- 
vidualiteit nodig. Je kunt je ook afvragen in hoeverre dit negatieve oordeel over De wetten afhangt van de vorm van feminisme die Meijer voorstaat, en of een meer op plezier of op ambiguitteit gerichte leeshouding tot een ander oordeel had geleid. Meijer legt veel nadruk op verstarde codes die in teksten terugkeren waardoor ze weinig oog heeft voor de open plekken van een tekst. Volgens Meijer is er maar weinig unieks te vinden in een tekst:

In de individuele tekst is maar heel weinig nieuw [...]. Individuele teksten, of ze nu pornografisch zijn dan wel poëtisch, of het nu nieuwsteksten betreft dan wel films, politieke debatten of advertenties, herhalen veelal dat wat al gezegd is in de stilistische conventies van hun specifieke medium. (Meijer 1996: 102)

Meijer loopt het risico het utopisch potentieel van literatuur en kunst om nieuwe betekenissen te scheppen te ondermijnen. Het lijkt me dan ook belangrijk om ook de aandacht te richten op het individuele moment dat een auteur/lezer heeft om betekenis te maken. Een belangrijk gevolg van het relativeren van de almacht die Meijer aan de cultuur toekent (zoals Haraway dat bij politiek doet) en van het handhaven van een notie van individualiteit, is dat auteurs en lezers verantwoordelijk gesteld kunnen worden voor hun werk.

Meijer hecht veel betekenis aan de sekse van de auteur, en de worsteling van de vrouwelijke auteur met de traditie. Het verdelen van teksten in 'bevriend' dan wel 'patriarchaal' is echter minder eenvoudig dan Meijer suggereert; ook bestaat het gevaar dat dit 'goed'-'fout'- denken, een soort zwartwitfeminisme, verstarrend uitpakt. Vrouwelijke (feministische) auteurs zoeken lang niet altijd zonder meer steun bij bevriende vrouwelijke teksten of afzetpunten bij 'patriarchale' teksten. Veel vrouwelijke auteurs laten zich maar moeilijk vangen in het hokje 'feministisch' dan wel 'anti-feministisch' (Jensen 20ora). En worstelen niet ook mannelijke auteurs met de traditie? Wie bijvoorbeeld Mijn aap schreit van Albert Helman leest, maakt kennis met een jonge verteller, die zich regelmatig tot de klassieken wendt om antwoorden op grote vragen te vinden, maar zich ook afvraagt of dit nu de boeken zijn waaraan hij zijn levenswijsheden wil ontlenen. Opvallend is bovendien dat de verhalen waarin vrouwen een aap prefereren boven een man, vaak door 
mannen geschreven zijn. Dat lijkt vanuit het perspectief van een mannelijke auteur niet logisch.

Aandacht voor de verteller nuanceert de gedachte dat een mannelijke of vrouwelijke auteur automatisch op grond van zijn geslacht een bepaalde visie zou uitdragen. In hoeverre iemand een subjectpositie toebedeeld krijgt, hangt ook af van het vertelperspectief. Veel verhalen over vrouwen en apen zijn van mannelijke auteurs, maar niet alle verhalen zijn verteld vanuit het perspectief van een man. In de verhalen die in dit boek worden geïnterpreteerd, wisselt het perspectief. Achtereenvolgens ligt dit bij een man (hoofdstuk 3), een vrouw (hoofdstuk 5), een alwetende verteller (hoofdstuk 6) en een aap (hoofdstuk 7). Soms wisselt het perspectief ook binnen het verhaal (hoofdstuk 4). Een auteur heeft de mogelijkheid tot 'mentale travestie', het zich verplaatsen in iemand van de andere sekse, een andere kleur of een andere soort (Schutte 1999). En dat geldt ook voor de lezer. Het maakt niet alleen uit wat voor soort verhalen er over apen worden verteld, maar ook door wie de verhalen en beelden gemaakt zijn, bij wie het perspectief in de verhalen ligt, wie de verhalen leest en vooral hoe hij of zij die verhalen leest.

\section{HET VERHAAL ALS AAP}

Haraway neemt onder feministische denkers een bijzondere positie in, omdat zij behalve aandacht voor gender en etniciteit/kleur ook soort op de agenda heeft gezet. Haar werk biedt inzicht in de rol van de aap als 'ander' in onze cultuur. Haraway beschouwt de verhalen die er over apen worden verteld als constructies die volgens haar meer over de mensen zeggen die ze vertellen, dan over de apen. Allerlei vooronderstellingen over gender, race en natuur klinken erin door. Het is dus van belang om de aandacht te vestigen op de vraag wat voor soort verhalen er over apen verteld worden. Als de aap een medium is om na te denken over de mens, wat komt er dan als 'menselijk' ('vrouwelijk' en 'mannelijk') naar voren uit de teksten en beelden?

Haraway beschouwt de wetenschap over apen, de primatologie, als een verhalenvertellende praktijk. Ze laat zien dat wetenschappe- 
lijke teksten, die de 'feiten' over apen op tafel zouden leggen, veel heterogener en verbeeldingrijker zijn dan we geneigd zijn te denken. Wetenschappelijke teksten over apen zijn bovendien geen onproblematische doorgeefluiken van de waarheid, maar zijn doortrokken van ideologie; wetenschap is politiek met andere middelen. Door de notie verhaal te introduceren, en een strikt onderscheid tussen cultuur (domein van de fictie) en wetenschap (domein van de feiten) te problematiseren, opent Haraway ook de geschiedenis van de primatologie voor niet-wetenschappelijke teksten. Wie wil weten wat een aap is, kan zich niet alleen tot de wetenschap wenden, maar ook tot verbeeldingsteksten. Net als wetenschappelijke teksten, worden films en romans door Haraway vooral beschouwd als illustraties van een ideologie. Is ook cultuur, zoals uit Haraways analyses naar voren komt, zonder meer politiek met andere middelen?

Wie In tekst gevat van Meijer leest, zou geneigd zijn dat te beamen. In dit boek stelt Meijer een cliché over de kunsten ter discussie, zoals Haraway dat voor wetenschappelijke teksten doet. Net zomin als wetenschap waarde- en normenvrij is, is fictie 'waardevrij'. Meijer laat in haar analyses zien dat kunst soms minder rijk en creatief is dan we denken. De intertekstuele leeswijze biedt de mogelijkheid om verbanden te leggen tussen teksten uit verschillende discoursen, zoals cultuur en wetenschap. Meijer gebruikt die verbanden vooral om te laten zien dat stereotypen 'overal' zijn. Net als bij Haraway dreigen verhalen daarmee opgeslokt te worden door ideologie, waarbij de lezer machteloos moet toekijken hoe conventies van sekse en kleur steeds weer teksten structureren en hoe stereotypen herhaald worden. Er lijkt geen ontsnappen aan, noch lijkt er ook nog maar sprake te zijn van zoiets als plezier in het lezen. Is de lezer een gevangene van de almachtige cultuurtekst?

Zowel Meijer en Haraway geven echter aan dat de 'verbeelding', of het 'andere verhaal', ook de mogelijkheid biedt tot ideologiekritiek en tot verandering. Maar als cultuur niets anders is dan ideologie, hoe kunnen verhalen dan ook het middel tot 'bevrijding' zijn? Met name in De lust tot lezen, waarin Meijer sterker de nadruk legt op de tekst als 'ander' en een op plezier, lust en erotiek gestoelde leeswijze hanteert die ze 'tegen-interpretatie' noemt, laat ze zien hoe de leeshouding aangenomen kan worden om aan binair denken te ontsnappen. In De lust tot lezen benadrukt Meijer meer de ruimte van de individuele lezer om betekenis aan teksten te ge- 
ven. In die leeswijze gaat het om ambiguïteit, om het signaleren van open plekken. Deze aanpak richt zich op het bijzondere van de individuele tekst en heeft aandacht voor de nuances en wendingen daarbinnen.

In dit boek gaat het mij om het zo nauwkeurig en gedetailleerd mogelijk lezen van een kleine selectie verhalen over apen en vrouwen. De bedoeling is om deze verhalen te 'openen' en hun meerduidigheid en verbeeldingsmogelijkheden te laten zien, als ook hun definitiekracht en stereotypen waarvan ze gebruikmaken. Wie oog wil blijven houden voor het specifieke en het vreemde van verhalen, en de verschillen tussen verhalen, moet zich toestaan niet al te strak ideologisch te werk te gaan en zich een zekere mate van associatieve vrijheid gunnen. Anders dreigt het gevaar dat verhalen toch gereduceerd worden tot een illustratie bij een bepaalde leeswijze of een bepaald thema of politiek project, in plaats van dat verhalen de lezer iets aanreiken.

De werkwijze en opbouw van de volgende hoofdstukken, die in het teken staan van interpretatie, is als volgt. Steeds vormt één specifiek verhaal over een vrouw en een aap het uitgangspunt. In dat verhaal vindt een ontmoeting plaats tussen een vrouw en een aap. Met deze ontmoeting tussen 'de ander en de ander' begint het hoofdstuk. Deze vormt de aanleiding om vragen te stellen over het verhaal. Wat gebeurt er in die ontmoeting en welke reacties genereert de ontmoeting tussen de vrouw en de aap bij andere personages? De ontmoeting werpt een interpretatieve vraag op voor de lezer, een soort 'trigger' die de lezer aan het denken zet. Vanuit een ogenschijnlijk banaal thema voor een boek ('seks tussen de vrouw en de aap') komen we terecht bij een aantal belangrijke vragen die de mens in de twintigste eeuw bezighouden ('identiteit: wie zijn wij als mensen? Wie ben ik? En wie zouden we graag willen zijn of juist niet?'). Deze vragen verbind ik met andere teksten. Door zo te contextualiseren - een verhaal te interpreteren in relatie tot enkele andere teksten, bijvoorbeeld uit de wetenschap - ontstaat nog een ontmoeting, bijvoorbeeld tussen 'verbeeldingsteksten' en 'wetenschappelijke' teksten. Zo kan ik onderzoeken op welke wijze fictieve teksten vorm geven aan en rol spelen in bepaalde debatten over mens-aap-relaties, en andersom, wetenschappelijke ontwikkelingen plaatsen in een bredere culturele context.

$\mathrm{Na}$ mijn eigen interpretatie van een vrouw-aaptekst, bespreek ik 
interpretaties van anderen en volg ik (een gedeelte van) de receptiegeschiedenis. Welke betekenis geven recensenten en interpreten aan verhalen over apen en vrouwen? Juist de receptie van een film of boek maakt zichtbaar hoe lezers omgaan met ambiguitteit en verschillende, soms zelfs tegengestelde betekenissen geven aan dezelfde teksten. In de receptie wordt de ambiguïteit ook vaak 'opgelost' en zo wordt het stollingsproces van de representatie zichtbaar; dankzij de receptie wordt de beeldvorming 'hardnekkig'. Door de receptie te bespreken kan ik ook in discussie gaan met interpreten en alternatieve interpretaties voorleggen. Daarna volgt een conclusie waarin ik verbindingen leg tussen de verhalen uit dit boek, hun verschillen en overeenkomsten. Het bovenstaande geeft in grote lijnen de opbouw van de hoofdstukken weer, maar ieder hoofdstuk heeft ook zijn specifieke winst. Zo komt er in ieder hoofdstuk een nieuw soort 'aap' naar voren. In hoofdstuk 3 komt de aap als Christusfiguur naar voren, in hoofdstuk 4 de aap als zwarte ander, in hoofdstuk 5 de aap als kind, in hoofdstuk 6 de aap als ideale man en in hoofdstuk 7 de aap als schrijver.

De ambiguïteit van de aap, wiens culturele betekenis heen en weer slingert tussen continuitteit en discontinuïteit ten opzichte van de mens, is een metafoor voor de wijze waarop ik verhalen lees. Die bevindt zich tussen het verhaal als norm en als 'ander', tussen het zoeken naar continuïteit en discontinuiiteit in de beeldvorming met betrekking tot apen. De verhalen zijn in die zin ook metaforisch op te vatten als 'aap': een onbekende, onbepaalde en ambigue plaats van herkenning en vervreemding, van verzet en plezier. 


\section{Waarom een man een aap vermoordt}

\section{Mijn aap schreit van Albert Helman}

Forgive, O Lord, my little jokes on Thee

And I'll forgive Thy great big one on me.

Robert Frost, 'Forgive, O Lord', 1962

War der Mensch wirklich dazu geschaffen, den Aristoteles und Thomas von Aquin zu studieren, Griechisch zu können, seine Sinne abzutöten und der Welt zu entfliehen? War er nicht von Gott geschaffen mit Sinnen und Trieben, mit blutigen Dunkel-heiten, mit der Fähigkeit zur Sünde, zur Lust, zur Verzweiflung?

Herman Hesse, Narziss und Goldmund, 1957

\section{DE MOORD OP EEN AAP}

Halverwege Mijn aap schreit. Een korte roman, die in 1928 gepubliceerd werd door de Nederlandse schrijver van Surinaamse afkomst Albert Helman (pseudoniem van Lou Lichtveld, 1903-1996), heeft een jongeman een koortsachtige droom, die ik hieronder in zijn geheel citeer. ${ }^{1}$

Ik liep in een vreemd huis dat schemerdonker was. Daarin waren veel steenen trappen met ijzeren balustraden en ornamenten van kleine glazen kubussen. Als presse-papiers.

Een van de kamers opende ik. Daar lag een vrouw, naakt. Zij 
wrong krampachtig met haar lichaam en kreunde luid; zij vroeg mij met zuchten en kreten water te halen. Haastig rende ik de trappen op en af. Nergens was er water. Als een gek liep ik de kamers in en uit, ik wilde vragen, maar daar was niemand. Eindelijk kwam ik op een steenen binnenplaatsje waar onkruid groeide tusschen de voegen. Midden op het plaatsje stond op een voetstuk een aap van zwart basalt. Hij keek mij strak aan, en scheen onmerkbaar te giechelen. Zijn staart stond als een groot donker vraagteeken achter hem omhoog. Ik was wanhopig en radeloos, want het kreunen van de vrouw klonk met lange echo's door heel het huis. Water, water?

Ik zag het giechelen van de aap, rende op hem af en wilde hem verscheuren, maar mijn vingers gleden af langs de gladde steen; het was als grepen ze naar natte zeep. Toen heb ik een van de steenen uit de grond losgewoeld, en die met alle kracht gesmeten naar het beeld. De kop sprong stuk en werd een gloeiende ster. En de ster waaierde uit, en werd weer een kleine fontein, waaruit ik het water opving in mijn holle handen. Voorzichtig liep ik naar de kamer terug, waar de vrouw lag. De weg was nu zeer kort. Ik wilde haar te drinken geven, doch als ik met mijn hand haar hoofd raakte, zag ik de schedel gebroken in een gapende wonde, waarin het roode bloed vlekte tussen de witte hersens. $\mathrm{O}$, schrik! Tussen haar lange haren op het kussen lag de steen die ik daareven gegooid had.

Ik wilde roepen, maar het dek dat over haar knieën lag, bewoog zich, en ik moest er naar staren. Het was alsof het lichaam zachtjes omhoog kwam, en tussen de knieën kroop opeens de kop van een aap te voorschijn, die een klein rood tongetje tegen mij uitstak. En de kamer was aanstonds vol grote spiegelruiten waarachter duizend apen hun rood vlammend tongetje naar mij uitstaken... Alles begon te wankelen en te draaien; het plafond brak naar beneden, stroomen water gutsten omlaag over mij heen... Toen werd ik wakker. $\left(5^{2}\right)$

Bovenstaande passage vormt een van de dramatische hoogtepunten van Mijn aap schreit. Hierin vertelt Helman over een jongeman, tevens de ikverteller van het verhaal, die een aap koopt van een jager. Wanneer hij ziet hoeveel aandacht de aap krijgt van vrouwen, bijvoorbeeld van zijn moeder en van het kleine meisje 
Marietje, voelt de verteller hevige jaloezie. Met name de aandacht van de jonge aantrekkelijke Martha voor zijn aap stoort hem. Hij vermoedt dat de aap verliefd op Martha is, en dit leidt tot hevige woede. In zijn droom uit hij de wens om de aap te verscheuren. Maar de aap giechelt en ontsnapt aan hem. Hij treft iets later opnieuw de aap aan; deze ligt tussen de benen van een vrouw en steekt zijn tong naar hem uit.

De droom is een voorbode op wat komen gaat. De verteller besluit kort na zijn droom om het dier, dat volgens hem 'de schuld van alles; alles' (57) is, te doden:

Doodelijk haatte ik hem, vanaf de eerste seconde dat ik hem zag. En nu moest ik hem een dood uitdenken, die zoo wreed en onmenschelijk was, dat zijn dood een andere dood werd dan het sterven alleen van een leven. Het moest iets zijn zóó exquis als geen Romein kon verzinnen en geen kannibaal. (6o)

Hij besluit cyaan te kopen en doet dit door het eten van zijn aap. Terwijl de aap sterft, speelt de verteller op zijn fagot trage muziek 'van donkere, dikke tonen, die waren als vette modderbellen welke zwellend komen bersten aan de oppervlakte van het moeras [...] Onbarmhartig plofte ik de tonen uit de diepste bas, en dan weer hooger, als een jongleur blies ik de tonen lijk kleurige ballen daaruit op: groene en blauwe' (6o-6r). Hij speelt vervolgens een melodie van Mozart 'die de liefste is, en het meest aan de vreugde der aarde gehecht' (6r). Het is een daad van sadisme. De vreugdevolle muziek is niet alleen ongepast, maar maakt de aap ook bang, en dat is wat de verteller wil: dat zijn aap angstig sterft. De jager, van wie hij de aap ooit kocht, vraagt hem later hoe hij tot zijn daad kwam. 'Uit haat en ergernis,' luidt het antwoord, 'en om mijzelf te bevrijden' (67).

De belangrijkste vraag die het verhaal in eerste instantie bij mij oproept, is waarom de verteller de aap zó verschrikkelijk haat dat hij besluit het dier uit de weg te ruimen. Waarvan wil de verteller zich bevrijden? De interpretaties die ik van Mijn aap schreit aantrof, van Frank Martinus Arion (1977), Michiel van Kempen (1998b) en H. Fierens (1968), verklaren de gruweldaad van de verteller in psychoanalytische termen. De aap wordt in deze interpretaties opgevat als het alter ego van de verteller, dat het onbewuste, het drift- 
en gevoelsleven en het instinctmatige vertegenwoordigt. Doordat de verteller zijn seksuele energie niet kan uiten, worden zijn gevoelens omgezet in agressie jegens de aap. Met het doden van de aap zou de verteller, volgens Arion, afrekenen met zijn 'zachte Zelf'. Hij schrijft: 'Het is iets zwaks, dat voelen we wel, het is zelfs iets verwijfds...' (Arion 1977: 28). Het zelf van de aap staat volgens Arion tegenover de jager. Na de moord wil de verteller zelf zo'n jager worden, een eenzame sterke man die zonder vrouwen verder leeft.

Een freudiaanse verklaring van de daad ligt inderdaad zeer voor de hand. Niet alleen is bekend dat Helman in zijn jeugdjaren een uitvoerige studie maakte van Freud (Van Kempen r998a: 13), maar tevens is het verhaal doordrenkt van freudiaans jargon ('fixatie', 'fetish', 'bewustzijnsvernauwing', 'hysterie', 'angst', 'het Zelf'), en lijkt bovenstaande droom zo weggelopen uit Freuds Die Traumdeutung. Maar mijns inziens maken de interpretaties van Arion, Van Kempen en Fierens onvoldoende duidelijk waarom de verteller het nu juist op een aap heeft voorzien en waarom de innige band van de aap met vrouwen zo veel woede in hem losmaakt. Worstelt de jongeman met zijn eigen seksualiteit en zijn verhouding tot vrouwen en het vrouwelijke? Bovendien is het zeer opmerkelijk dat de interpreten allen menen dat de aap in dit verhaal het instinctmatige vertegenwoordigt. De aap kenmerkt zich, zo zal ik laten zien, in de visie van de verteller nu juist door een voortdurende ambivalentie: soms kent hij de aap verstand toe, dan weer vindt hij het een dom beest dat niets anders doet dan diens behoeften bevredigen.

In dit hoofdstuk breng ik de theorie uit de vorige twee hoofdstukken in praktijk door een alternatieve interpretatie te geven. Dat is niet een psychoanalytische tekstinterpretatie, waarbij de aap gereduceerd wordt tot het driftleven van de verteller, maar een interpretatie waarin ik Helmans roman zo precies mogelijk lees en tegelijkertijd contextualiseer door deze te plaatsen in het debat over de oorsprong, de status en de aard van de mens (v/M). De relatie tussen het individuele verhaal en de context leg ik in dit hoofdstuk vooral vanuit expliciete of impliciete aanwijzingen uit Mijn aap schreit. Soms verwijs ik naar debatten over de relatie tussen apen en mensen die in die tijd gevoerd werden.

In mijn interpretatie beargumenteer ik dat de ontmoetingen tussen zijn aap en verschillende vrouwen de verteller steeds confronteert met de vraag wie hij is, waar hij vandaan komt, wat zijn plaats 
is in de hiërarchie en hoe hij moet leven. Stamt hij af van de apen of is de mens door God geschapen? Wat is zijn plaats ten opzichte van God, het dier en de vrouw? Is er sprake van een 'great chain of being' waarbij God bovenaan staat, gevolgd door de man, daarna de vrouw en de aap onderaan? En hoe moet hij leven? Moet hij zich laten leiden door zijn driften, zijn verstand gebruiken of terugvallen op het geloof? Beschikt hij over een vrije wil of is hij gedetermineerd?

Darwinisten, freudianen en christenen vertegenwoordigen, als het om antwoorden op deze vragen gaat, concurrerende visies; in alle drie de visies nemen dieren in het algemeen en de aap in het bijzonder een belangrijke plaats in. ${ }^{2}$ Wat de oorsprong en de status van de mens betreft, botsen christelijke en darwinistische opvattingen in de ogen van de verteller, wat de aard van de mens betreft worstelt hij vooral met christelijke versus freudiaanse opvattingen. Helmans aap kan niet gevangen worden in één betekenis; de ambiguïteit van de aap geeft juist de spanning tussen de verschillende visies weer. Door de aap te doden, zo zal ik beargumenteren, probeert de verteller af te rekenen met deze spanning. Nu hoeft hij niet langer via de aap en de vrouw geconfronteerd te worden met zijn eigen twijfels over de oorsprong en de natuur van de mens.

Mijn aap schreit werd gepubliceerd door uitgeverij De Gemeenschap. Rondom het gelijknamige tijdschrift van deze uitgeverij had zich een groep jonge katholieke schrijvers verzameld, onder wie Albert Helman, Albert Kuyle, Anton van Duinkerken en Jan Engelman. De redactie, waar Helman deel van uitmaakte van 1925 tot I93I, pleitte voor vernieuwing van de katholieke geloofsbeleving en beweerde wars te zijn van religieuze dogmatiek. Het tijdschrift fungeerde echter wel als het literaire gezicht van de katholieke zuil en was onderworpen aan kerkelijke censuur (Ruiter en Smulders 1996: 227), zoals ook het overige werk dat door De Gemeenschap werd uitgegeven. ${ }^{3}$ Mijn aap schreit heeft deze censuur gepasseerd, en dit is, wanneer men de kritisch-religieuze lading van de tekst in ogenschouw neemt, opmerkelijk te noemen. Niet alleen om deze heuristische en literair-historische redenen is het de moeite waard om Mijn aap schreit van Helman opnieuw onder de aandacht te brengen. Binnen Helmans omvangrijke oeuvre is de meeste aandacht uitgegaan naar zijn koloniale romans De stille plantage (1931) en De laaiende stilte (1952). Aan Mijn aap schreit, dat volgens Michiel van 


\section{Albert Helman}

Mijnaapschreit

\section{Het euvel Gods}

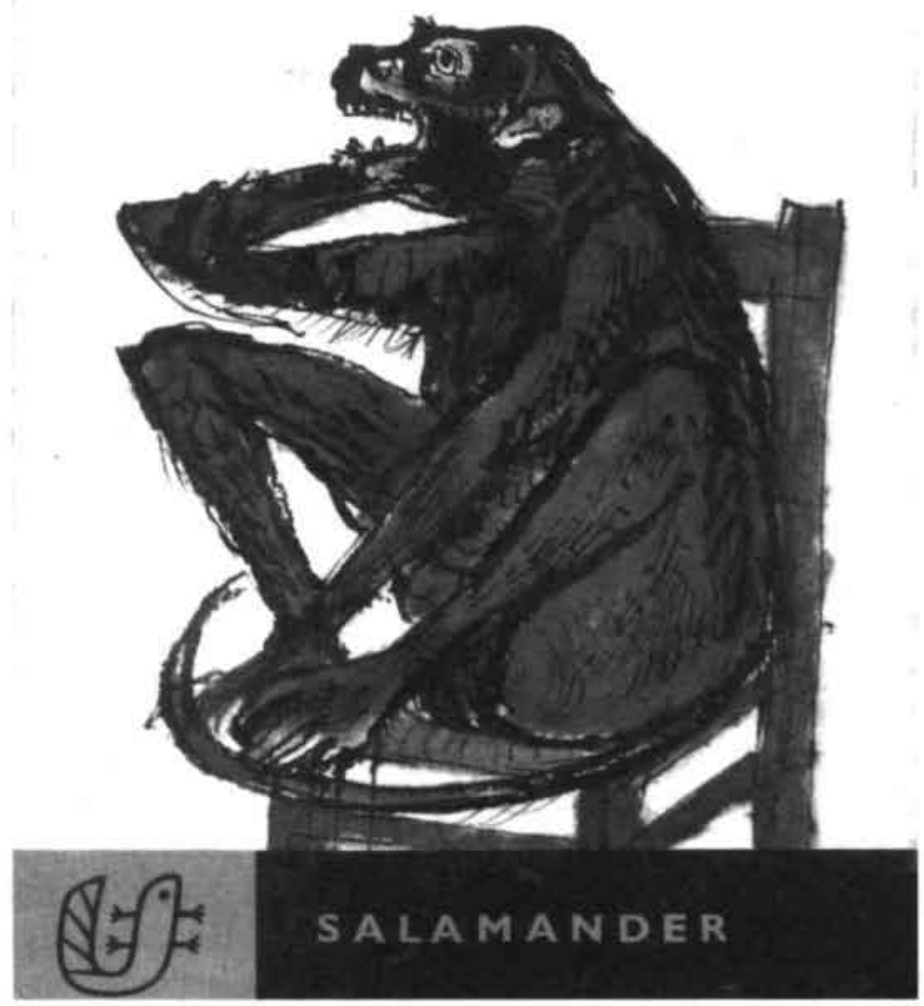

7 Omslag van Mijn aap schreit en Het euvel Gods van een herdruk uit 1957, verschenen bij Querido. Oorspronkelijk verscheen Mijn aap schreit in 1928 in een aparte editie. In Omnibus (1947) schreef Helman in het voorwoord dat hij ze gecombineerd had voor de herdruk omdat de vijftien verhalen uit Het euvel Gods volgens hem volkomen aansloten bij Mijn aap schreit. 
Kempen (1998b: 30) behoort tot 'het beste wat Helman geschreven heeft', is weinig aandacht besteed. Dat is jammer, want Mijn aap schreit is inderdaad een prachtig verhaal, dat niet alleen shockeert door de wrede moord op de aap en de esthetisering van dit geweld door middel van de lyrische beschrijving van het sterven van de aap, maar ook ontroert door de wijze waarop Helman via de ontmoeting tussen de vrouw en de aap de pijnlijke worsteling van een man met de grote levensvragen voelbaar maakt: wie ben ik, waar kom ik vandaan en hoe moet ik leven?

\section{DENKHOOFD OF EETHOOFD?}

Wat het meeste opvalt aan Mijn aap schreit is de ambivalente houding van de hoofdpersoon tegenover zijn aap. Enerzijds is hij hevig gefascineerd door de gelijkenis tussen hem en de aap. Anderzijds ergert hij zich ook aan hem, en wil hij niets liever dan het dier op een afstand houden. Een van de vragen die de verteller bezighoudt, is of zijn aap zich in zijn gedrag domweg laat leiden door zijn driften, of dat hij verstandelijke vermogens inzet. De verteller koppelt het verstand aan de staart van de aap en beschouwt deze als een instrument dat vecht tegen onzedelijkheid:

De staart kon langzaam bewegen als een wijsvinger die vermaant naar een overspelige vrouw; hij kon driftig heen en weer gaan als de geesel tijdens het Miserere van een monnik [...] In de staart zetelde zijn verstand, de staart richtte zich naar wijsheid, de staart was zijn wil, het instrument van zijn verlangen, de slinger van zijn evenmaat, de treurnis van zijn heimwee naar het bosch. Door zijn staart werd de aap gelijk aan een mensch. (I2)

Aangezien de verteller 'wijsheid', 'evenmaat' en 'wil' in de staart van de aap lokaliseert, vat hij zijn aap niet zonder meer op als een door drift gedreven dier, maar dicht hij hem ook verstandelijke vermogens toe. Dit is opmerkelijk, omdat de aap nu juist bekendstaat als icoon voor domheid en geilheid (Janson 1952). De koppeling van het verstand aan de staart is ook verrassend, omdat de staart nu juist ontbreekt bij de mens, het meest 'dierlijke' is aan de aap en in literaire 
werken nu juist vaak als fallussymbool verbeeld. ${ }^{4}$ Het koppelen van wat wij doorgaans als een menselijke eigenschap beschouwen, 'verstand', aan nota bene de dierlijke staart is wellicht provocerend bedoeld: de aap wordt toegerust met menselijke eigenschappen.

Maar de verteller is niet altijd standvastig in het toekennen van verstand aan de aap, en de koppeling daarvan aan de staart. ${ }^{5}$ Afhankelijk van de loyaliteit die de aap aan hem betuigt, wisselt de visie van de verteller. Zo irriteert het hem mateloos dat het dier er geen bezwaar tegen lijkt te hebben verkocht te worden door de jager, en is dat volgens hem een teken dat zijn aap 'geen greintje verstand' (14) bezit. Wanneer de verteller bovendien opmerkt dat de aap veel aandacht van de moeder van de verteller krijgt, vindt hij dat de aap 'giechelt' op zijn 'domste manier', en gaat hij vlug een boek halen, waarmee hij zijn eigen geestelijke superioriteit lijkt te willen onderstrepen. Tegen zijn moeder zegt hij: 'Ben je niet vies van dat beest? Ze zijn zoo onzindelijk' (rg). De verteller gebruikt hier het woord 'beest' als een soort verwijderingsstrategie om hem op afstand te houden. Maar zijn moeder antwoordt hem dat hij dat zelf ook was, toen hij een kind was. De verteller ergert zich aan deze vergelijking, en probeert zich te concentreren op zijn boek, hetgeen hem niet lukt: 'Voortdurend dwaalden mijn blikken van het boek naar de aap. 't Werd een obsessie en plotseling smeet ik hem het Tauchnitzdeeltje naar zijn kop' (19-20). In het verhaal komen meer van dergelijke woede-uitbarstingen voor; de verteller gooit onder meer een liniaal, een presse-papier, een vloeikussen en een wandelstok naar de aap. De presse-papier en het vloeikussen zijn beide hulpmiddelen bij het schrijven. Tezamen met de liniaal, het instrument van de meetkunde, zijn het objecten die hier de rationaliteit en de symbolische vermogens van de mens ten opzichte van de aap onderstrepen. De wandelstok herinnert aan het viervoetig verleden van de mens en is als het ware een extra been, dat men gebruikt om staande te blijven.

$\mathrm{Na}$ zijn eerste woede-uitbarsting verklaart de verteller het verstand bij de aap afwezig, en karakteriseert hij zichzelf als een mens met een 'denkhoofd' (20). Zijn aap noemt hij 'niets dan een staart, een staart met pooten en een eethoofd' (24). Niet alleen lijkt de verteller nu te zijn vergeten dat hij eerder nog verstand toekende aan de staart van de aap, maar tevens contrasteert hij de vretende aap met de delibererende mens. De staart wordt door hem later in het 
verhaal bovendien wél met het seksuele, het driftleven, geassocieerd door deze als een machtige fallus voor te stellen: 'zijn staart stond stijf overeind als een vlaggestok' (40).

Gedurende het verhaal komt de verteller steeds voor vragen te staan. Kan zijn aap verliefd worden op een vrouw, net als een man? Kan zijn aap spelen? ${ }^{6}$ Kan zijn aap stelen, net als een mens? Wat moet zijn aap eten, hetzelfde als een mens? Deze dilemma's stellen de verteller steeds voor de vraag in hoeverre zijn aap op hem lijkt. Wanneer de verteller over het eten moet beslissen, twijfelt hij bijvoorbeeld tussen 'Nutricia's kindermeel', een typisch door mensen gemaakt cultuurproduct voor kinderen, of 'een kleine zeldzame sapotille, die alleen in de binnenlanden van Guyana groeit' (I6), een tropische vrucht afkomstig van de sapotilleboom, een typisch natuurlijk produkt. De verteller kiest voor een soort tussenoplossing: 'halfrijpe vruchten' en 'frissche sla' (r7). Dit suggereert dat hij zijn aap, die eerst in de vrije natuur leefde, maar nu een huisdier is geworden, beschouwt als iets tussen 'natuur' en 'cultuur' in. Hij is een soort tussenfiguur geworden: niet helemaal dier meer, maar ook nog niet gelijk een mens, oftewel: dier én mens tegelijkertijd.

Terwijl hij in de tuin het eten voor de aap verzamelt, heeft deze stiekem al het eten van de verteller verorberd. 'Ik was eerst nijdig, maar langzamerhand begon ik te beseffen dat hij verstandiger was geweest dan ik die geen rekening had gehouden met de onweerstaanbaarheid van het oer-sentiment honger, dat hij in geen geval verloochenen kón [...]' (17). Het is alsof de verteller zijn aap hier een lichamelijke vorm van denken toekent, een instinctief handelen dat hij 'verstandiger' noemt dan het menselijk denken. De aap combineert, in zijn ogen, verstandig en instinctief handelen.

\section{TRAVESTI'S VAN HET IK}

En dagelijks zien we apen die stapelverliefd zijn op vrouwen

Montaigne, 'Apologie voor Raymond Sebond'. Essays II 548

Op een dag komt de verteller thuis en treft hij zijn aap humeurig aan. Hij ziet er wat vermagerd uit; bovendien heeft hij paperassen 
op de grond gesmeten en ligt er 'een deeltje van Goethe in de hoek gekeild' (36). ${ }^{7}$ In zijn rechterpoot houdt hij een stuk papier geklemd, dat hij niet wil afstaan aan de verteller. Deze is woedend en achtervolgt hem. Met veel moeite en geweld - hij slaat de aap weet de verteller het papier uit de handen van de aap los te wringen. Het blijkt een foto te zijn van Martha, een vrouw van 27 jaar. Het is duidelijk dat de verteller haar zeer aantrekkelijk vindt: hij omschrijft haar als een 'mooie sterke' vrouw met 'breede heupen en een strakke borst, jong en vol' (35). Nu hij zijn aap met haar foto heeft betrapt, verdenkt de verteller de aap ervan dat hij verliefd is op Martha. Die gedachte maakt hem woedend, maar wel begrijpt hij nu waarom zijn aap zo lusteloos was: 'hij had de notie van de sexen' (30). Wanneer Martha hem op een dag bezoekt, en zij de zieke aap opmerkt, uit de verteller zijn vermoeden dat de aap verliefd op haar is. Martha is kwaad; ze slaat hem en schreeuwt hem toe dat hij gemeen is. Hij verontschuldigt zich voor zijn 'grap', waarna Martha zich schaamt en bloost. Het zou kunnen dat Martha in eerste instantie zo boos werd omdat de verteller suggereert dat ze een type is waarop een aap verliefd kan worden, en haar daarmee ook 'aapachtig' vindt, hetgeen niet bepaald een compliment is. Eerder had Martha namelijk met stelligheid verkondigd dat een aap alleen op een andere aap verliefd kan worden, en niet op een andere soort. ${ }^{8}$ De verteller aarzelt hier kennelijk over, waarmee hij te kennen geeft te twijfelen aan de bijbelse opvatting dat iedere soort geschapen is door God, derhalve uniek is en onveranderlijk, en dat verschillende soorten niet met elkaar kunnen kruisen.

Enkele dagen na het voorval ontmoet de verteller dr. Schneider, een gynaecoloog, en bespreekt hij met hem de kwestie. Dr. Schneider is van mening dat Martha van de verteller houdt: ' $\mathrm{Ze}$ is infantiel aan de aap gefixeerd, maar ze bedoelt jou' (42). De verteller gelooft er weinig van, en voelt zich enigszins beledigd omdat hij met de aap wordt vergeleken. Dr. Schneider trekt verdere vergelijkingen tussen mens en dier als hij zijn verlangen uit om de dierpsychiatrie in te gaan:

Aan de dier-psychiatrie is er nog zoo weinig aandacht besteed. Toch kan men veel bereiken. Worden sommige gekken niet juist als dieren? Ik ken een gek die meent dat hij een meikever is [...]. Via de menschelijke dier-phobieën is er van de dieren-psyche nog zooveel te achterhalen. (43) 
Terwijl dr. Schneider op die manier pleit voor het vergelijken van mensen met dieren, op continuïteit tussen beide, en daarbij geestig de rollen omdraait (via mensen kunnen wij iets van dieren leren in plaats van andersom) sputtert de verteller tegen: 'Om u de waarheid te zeggen, heb ik steeds gedacht dat de dieren geen eigenlijke psyche hadden' (43). Maar dr. Schneider meent van wel: 'En de gevoels-complexen dan, en de instincten? Beschouw eens aandachtig je eigen aap. Hij zal je ongetwijfeld veel kunnen leeren' (43). Dr. Schneider suggereert dat de verteller veel van zijn aap kan leren wat gevoel en instinct betreft. Blijkbaar is hij van mening dat de verteller zijn driften, anders dan de aap, onderdrukt.

Wanneer de verteller Martha enkele dagen later treft, doet hij er alles aan om de aap bij haar uit de buurt te houden. Maar ze heeft dit in de gaten en reageert verbolgen: 'Dus je wilt zeggen dat ik de schuld van dit alles ben... Overal vind je míj de schuld van' (49). Dan begint ze te 'schreien' en geeft ze te kennen dat ze de verteller nooit meer wil zien. Voor Martha wordt hetzelfde, enigszins archaïsch aandoende woord gebruikt als voor de aap (zie de titel van de roman), namelijk 'schreien'. Martha gebruikt tevens de woorden 'de schuld van alles', die de verteller later letterlijk zal herhalen om de schuld te geven aan zijn aap. Doordat de verteller dezelfde woorden kiest voor zijn aap als hij eerder voor Martha gebruikte, vind er een gelijkschakeling plaats tussen vrouw en aap. Hier wordt zichtbaar hoe de verteller (onbewust) instemt met de lagere positie, namelijk 'dichter bij de dieren', die aan de vrouw ten opzichte van de man wordt toegekend binnen de darwinistische evolutietheorie.

De verteller heeft diezelfde nacht een droom, waarmee ik dit hoofdstuk begon. Wanneer er in verhalen of romans dromen voorkomen, dan worden deze vaak beschouwd als sleutelpassages. In zijn boek Die Traumdeutung (1900) interpreteerde Freud de dromen van enkele van zijn patiënten, en noemde hij de droom de 'hoofdweg naar het onbewuste' (geciteerd in Schrover 199r: 139). De droom drukt volgens Freud onbewuste verlangens uit, die in het normale leven niet geuit of verwezenlijkt kunnen worden. Op deze wijze worden, zo stelde Freud, verdrongen verlangens bevredigd in dromen. Droommateriaal bestaat vaak uit zogenaamde dagresten. Veel van de elementen die de verteller droomt, kwamen we al eerder tegen in het verhaal. Eerder had de aap hem gebeten in zijn pols tijdens een bezoek van Martha, en beschreef hij zijn hand als een 
'bloed-hand' (48). Verder denkt hij, vlak voor het slapen gaan, 'te veel aan Martha' (50), stortregent het buiten en is hij nat van de koorts. De elementen 'bloed', 'naakte vrouw' en 'water' keren in zijn droom terug. Hij stelt zich voor dat hij zich in een vreemd huis bevindt, dat bestaat uit kleine glazen kubussen 'als presse papiers'. Eerder in het verhaal gooide hij met een presse-papier naar de aap.

Wanneer de verteller zich haast naar het binnenplein op zoek naar een fontein, treft hij daar een aap op een voetstuk die hem strak aankijkt en giechelt. De staart, die hier als een 'donker vraagteeken' omhoog staat, symboliseert in deze passage noch verstand, noch de fallus, maar een mysterie, de vraag, het onbekende. Het onbekende staat op zijn beurt wellicht voor het driftleven, dat de verteller niet lijkt te kunnen accepteren. De verteller voelt zich wanhopig, want hij hoort de vrouw op de achtergrond kreunen en om water vragen. De verteller vergeet enkele ogenblikken zijn missie en staart naar de aap, die hem blijkbaar voor een 'vraag' stelt. Die vraag heeft wellicht te maken met de seksuele energie die de verteller voelt: moet hij hier aan toegeven? De vraag om water van de vrouw, zodat zij haar dorst kan lessen, zou hier opgevat kunnen worden als een metafoor voor seks, of iets algemener, 'levenswater'. De verteller wil de aap 'verscheuren'. 'Verscheuren' is een woord dat bij een roofdier past; het geeft blijk van een driftmatige impuls van agressie en duidt erop dat de levensdrift 'voortplanting' (zijn libido) wordt omgezet in een doodsdrift, namelijk agressie. Het roept tevens connotaties op van ontmaagding, wanneer we ervan uitgaan dat de verteller zijn gevoelens voor de vrouw op de aap projecteert. Hij gooit met een steen naar de aap, en de kop springt stuk en wordt een gloeiende ster. Maar met het vernietigen van de aap, heeft de verteller zich niet verlost van het giechelen en staren van de aap. Wanneer de verteller bij de vrouw aankomt, blijkt de aap ook hier weer op te duiken. De verteller wil haar te drinken geven, maar wanneer hij haar aanraakt, ontdekt hij dat haar schedel is gebroken, en dat er bloed uitstroomt. Hij wordt geconfronteerd met zijn gewelddadige reactie jegens de aap. De steen, die voor de aap bedoeld was, is bij haar terechtgekomen. Daarmee wordt de vrouw geïdentificeerd met de aap en komen zij in deze passage beide in meer algemene zin voor de dierlijke, verdrongen schaduwzijde van de verteller te staan. De aap komt met zijn kop tussen de knieën van de vrouw te voorschijn. Dit beeld kan op tweeërlei wijze geïn- 
terpreteerd worden. Ten eerste lijkt het op een geboorte van de aap uit de vrouw. Als de vrouw Martha voorstelt, van wie eerder gezegd werd dat ze 'niet van kinderen hield' (35), dan kan dit erop duiden dat de verteller hier moet constateren dat ze blijkbaar van apen houdt. Een andere mogelijkheid is dat de aap hier wordt voorgesteld als de minnaar van de vrouw: hij steekt zijn tongetje uit, hetgeen tegelijkertijd een erotische suggestie is en een 'ikke lekker wel en jij niet'-gebaar. De verteller ziet vervolgens spiegelruiten waarachter duizend apen hun tong uitsteken. Het beeld van de ene aap is dus enorm uitvergroot, in plaats van vernietigd. De aap kan niet gedood worden, en symboliseert de Wiederkehr des Verdrängten, 'the return of the repressed'. De verteller is zeer vernederd: hij is buitengesloten van het verbond tussen de vrouw en de aap. Niet hij, maar de aap is haar minnaar en haar kind. De aap is daarmee zijn concurrent.

Dat de verteller zich vergelijkt met en spiegelt aan de aap blijkt ook uit een passage die op de droom volgt:

Het was alsof je in een huis moest wonen met niets dan je eigen portretten. Een museum vol 'pictures of Dorian Gray'. En niets, niets om je aan vast te klampen. 't Is alles van hetzelfde: alle boeken zijn zelfportretten, alle dingen. Waar je ook gaat, ik, ik, ik, overal ik. Nergens kom je buiten jezelf, kijk je buiten jezelf. De verraderlijke leer van Delphi heette: Ken uzelve! Maar kennen wij iets anders dan onszelf, dat kleine opdringerige Zelf waarvan wij bezeten zijn? Moeder, mijn broertje, Martha, het meisje, de aap, 't is alles mijzelf; alle travesti's van Ik. O, wanneer ik eindelijk eens het Andere vond, dan, dan pas, zou ik kunnen liefhebben en gelukkig zijn. (57)

Het menselijk bewustzijn wordt hier voorgesteld als een spiegelpaleis. De verteller ziet overal waar hij kijkt zichzelf, en noemt alle mensen om hem heen, inclusief de aap, 'travesti's van Ik'. Voortdurend ziet hij zich geconfronteerd met zijn eigen portretten. ${ }^{9}$ Het 'Andere' kan hij blijkbaar niet vinden, want hij ziet in alle anderen die in het verhaal genoemd worden vermommingen van zichzelf, en hij kan het anders-zijn van zijn moeder, zijn broertje, Martha, het meisje en de aap niet in positieve zin erkennen. Aan al deze personages kent hij gedurende het verhaal eigenschappen toe die hij zelf lijkt te 
ontberen, zoals gevoel en instinct. De aap, nota bene een mannetjesaap, kent hij bijvoorbeeld vrouwelijke eigenschappen toe, als 'giechelen', wat opnieuw duidt op een darwinistische gelijkschakeling van vrouwen en apen. Samen vormen de vrouw en de aap het 'andere' voor hem; in hun toenadering tot elkaar wordt dat nog duidelijker, hun 'andersheid' wordt erdoor uitvergroot. Het is alsof zij een verbond sluiten waar hij niet bijhoort. Pas wanneer hij het 'andere' vond, zou hij gelukkig zijn, zo erkent hij. De uitspraak 'Ken uzelve' van het orakel van Delphi, noemt hij verraderlijk, omdat het immers niet mogelijk blijkt buiten jezelf te treden; 'ken uzelve' is meer een noodlot dan een deugd, daar je jezelf overal tegenkomt. Hij spreekt van het 'kleine, opdringerige Zelf', hetgeen erop duidt dat het Zelf niet iets positiefs is. Door 'zelf' met een hoofdletter te schrijven, suggereert hij tevens letterlijk de opgeblazenheid van het Zelf, dat in wezen niets voorstelt en 'klein en opdringerig' is, in tegenstelling tot een absoluut Zelf, dat een hoofdletter met recht zou mogen dragen.

De verteller realiseert zich dat de 'ander' altijd geconstrueerd is in relatie tot het zelf, en dat je het in die zin ook zelf bent. De verteller verlangt naar het echte, absoluut Andere, ook met een hoofdletter, als ware het een religieus verlangen naar het 'gans Andere', de God die wij niet zelf verbeeld hebben. Hij verlangt naar de Ander die hem niet spiegelt, maar helemaal Zichzelf is. Als er niet zo'n absoluut 'Andere' is, van hem fundamenteel onderscheiden, dan is hij als mens zelf ook niet uniek. Dat lijkt hier een pijnlijk besef.

Overal waar de verteller kijkt, ziet hij zichzelf, ook in de boeken die hij 'zelfportretten' noemt. Deze opmerking zou kunnen slaan op de boeken die in Mijn aap schreit worden genoemd. Zij spiegelen het verhaal op een ander niveau, en fungeren als zelfportretten van de verteller. ${ }^{10}$ Zo leest de overigens wel zeer belezen verteller een Tauchnitzdeeltje (15), Dostojewsky (30), Herbart (30), Goethe (36); Strindbergs Der Vater leest hij zittend in het venster 'omwille van de vele kerkse voorbijgangers op een zondagmiddag' (47); verder leest hij Schopenhauers Die Welt als Wille und Vorstellung (55), The Picture of Dorian Gray van Oscar Wilde (57), Socrates en Plato (59) en Thomas a Kempis (62). ${ }^{11}$ De verhalen en auteurs hebben gemeenschappelijk dat zij zich allen bezighielden met de vraag hoe goed te leven en moreel te handelen. Moet men zich laten leiden door zijn verstand of zijn gevoel? De verteller vraagt zich in Mijn aap schreit voortdurend af hoe de aap handelt: driftmatig of op grond van zijn 
verstand. Hierover krijgt hij geen uitsluitsel. Nu eens kent hij zijn aap verstand toe, dan weer noemt hij hem een dom wezen. Het lijkt erop alsof de verteller zijn eigen worsteling op de aap projecteert; de aap is zijn spiegel. Het grote dilemma waarmee de verteller worstelt is de balans tussen gevoel en verstand. De aap fascineert hem, omdat die toegeeft aan zijn lichamelijke impulsen. De verteller noemt dit 'verstandiger' (17) en op deze wijze combineert de aap, in de ogen van de verteller, verstand én gevoel. De verteller is hiertoe niet in staat; zijn grote belezenheid en erudiete gestrooi met citaten uit de wereldliteratuur en filosofie duiden erop dat hij een verstandsmens is; hij probeert, en is daarbij allerminst bescheiden, al zijn boekenkennis te mobiliseren om zijn dilemma onder woorden te brengen, en om een afstand tussen hem en de aap te bewerkstelligen. Maar zijn aap confronteert hem steeds weer met zijn onvermogen.

\section{MISSING LINK}

Daarna waren de aap en ik, neen - Ik en de aap - alleen. Met grote stappen ging ik naar hem toe en keek hem aan van boven mijn mensch-zijn, vanaf mijn denkhoofd, met al de minachting die ik voelen kon. Armoedig, wanstaltig beest! Z'n loome lijf, zijn groote platte kop, zijn stumperig-lange armen, die kronkelende gummislang van zijn staart. Hoe kon de mensch toch in godsnaam... (20)

Deze passage lezen we in Mijn aap schreit vlak nadat de verteller vol jaloezie heeft geconstateerd dat de aap erg veel aandacht van zijn moeder krijgt. De verbetering halverwege de eerste zin, van 'de aap en ik' in 'Ik en de aap', wijst erop dat de verteller worstelt met de hiërarchie tussen hem en de aap. Hij plaatst zich met zijn 'denkhoofd' en zijn 'mensch-zijn' boven zijn aap. De laatste zin maakt hij niet af: 'Hoe kon een mens toch in godsnaam...' De verteller blijft hangen in de zin zodra hij het woord 'godsnaam' laat vallen. Wellicht lag op zijn lippen 'afstammen van de aap' of 'verwant zijn aan de aap', maar het prefix 'god-' confronteert hem, zo lijkt het, met een kwestie, waarover hij niet hardop verder wil of kan denken.

De ambivalente positie van de aap, die zich als huisdier tussen 
natuur en cultuur bevindt, komt tot uitdrukking in een discussie die de verteller met zijn broertje heeft over de missing link, waarbij ze praten over de rol van de aap als tussenfiguur.

'Hij wordt nog maar steeds niet beter, arme aap,' zei mijn broertje. 'Weet je eigenlijk wel wat een aap is?' vroeg ik, om hem te plagen. 'Natuurlijk', antwoordde hij. 'We hebben het pas nog geleerd. Apen zijn zoogdieren van de eerste klasse. Ze worden verdeeld in apen van de oude en apen van de nieuwe wereld. Het verschil zit ' $m$ in het breede of smalle neustusschenschot, en in de tandformule. De apen van de oude wereld hebben geen, of een korte staart, die van de nieuwe wereld meestal een lange staart en grijpvoeten.' 'Je vergeet wat,' zei ik. 'Ze hebben evenals de mensen een duim die opponeerbaar is. Je moet niet alleen de verschillen leren, maar ook de overeenkomst.'

M'n broertje dacht na. 'Ja', herinnerde hij zich, 'er is ook nog zoo'n kwestie omtrent de gelaatshoek. Maar het is allemaal flauwekul, want er is een schakel zoek tusschen mens en aap en die schakel zal wel nooit te vinden zijn. 't Verstand, zie je...' (45).

'Heb je wel eens gehoord van de Pithecanthropos Saman en van de Homo Heidelbergensis?' vroeg ik. (45)

De broer van de verteller suggereert dat de missing link nooit gevonden zal worden, omdat er een grote evolutiesprong is gemaakt, waarbij mensen 'verstand' kregen. De verteller sputtert tegen door twee 'missing links' te noemen. Met de zelfbedachte wetenschappelijk klinkende term 'Pithecanthropos Saman' doelt de verteller op een mensaap (pithecanthropos). 'Saman' is Indiaans voor 'sjamaan', een bemiddelaar tussen het gevoel en de ratio, natuur en cultuur, de mens en het goddelijke. De 'Homo Heidelbergensis' verwijst naar een mensaap, die in 1907 werd opgegraven in Heidelberg in Duitsland. De geschatte leeftijd van het skelet ligt tussen de 400.000 en de 700.000 jaar.

De verteller bekijkt vervolgens zijn broertje. 'Ik merkte nu pas dat zijn schouders nog breder begonnen te worden, dat zijn gezicht iets hards kreeg. In zijn stem begon mij een onechte mannelijkheid te hinderen' (46). Doordat de verteller zijn betoog over de missing link hier onderbreekt met een observatie van zijn broertje die een zwaardere stem krijgt en bredere schouders, vergelijkt hij de evolu- 
tie van aap naar mens met die van kind naar volwassene. Deze analogie was, in de tijd dat Mijn aap schreit werd geschreven niet ongebruikelijk. Het is zeer wel mogelijk dat de verteller hier refereert aan Freud, die de ontwikkeling van de menselijke soort als geheel (fylogenese) met de ontwikkeling van het individu (ontogenese) vergeleek (Corbey 199I). Hij beschouwde beide ontwikkelingen als een evolutie van primitief naar beschaafd. Net zoals de ontwikkeling van de menselijke soort als geheel een weg van wildheid naar beschaving was, zo ontwikkelde het kind zich van een 'primitief' wezen naar een 'beschaafde' volwassene. ${ }^{12}$

De vergelijking van de verteller van de aap met zijn broer wordt onderbroken door de aap die zijn etensbak omgooit. Het lijkt wel alsof de aap gedachten zou kunnen lezen; alsof hij het niet met die vergelijking eens is en stelling neemt tegen de gedachte dat hij een voorloper van de mens zou zijn, een antropocentrische gedachte. Het broertje interpreteert de actie van de aap als een verkoudheid. Maar de verteller meent dat dit niet kan:

'Als die dieren in de natuur zijn, vatten ze nóóit een kou. Waarom nu wel?'

'Kijk hem daar eens liggen, 't is net een mensch', zei Broer, en hij legde voorzichtig zijn verfrommelde schooljongenszakdoek over hem heen.

Ik wist wat dit beduidde. Hij had plotseling gezien dat mijn aap naakt was. Naakt gelijk een mensch. (46)

In deze passage wordt het 'naakte' lichaam van de aap bedekt met een zakdoek. In het bijbelboek Genesis (Gen. 2:25 en 3:7) zien Adam en Eva na de zondeval dat zij 'naakt' zijn. Eerder schaamden zij zich hier niet voor, maar nu bedekken zij zich. De gangbare uitleg is dat vanaf dit moment seksualiteit en erotiek iets zondigs zijn. Hier wordt de aap voorgesteld als de naakte mens. Dit is een bekend motief binnen het christendom, waar de aap vaker wordt voorgesteld als de gevallen mens (Janson, r952). Daarmee kom ik op een belangrijke intertekst die door Mijn aap schreit heen geweven is: de bijbel. 
Mijn aap schreit geeft vorm aan de discussie die tot in de jaren twintig heerst over de (botsing tussen) het wetenschappelijke darwinisme en de christelijke dogmatiek. In Mijn aap schreit wordt vaak naar de bijbel of het geloof verwezen. Om te beginnen staat Mijn aap schreit ingeklemd tussen een 'referentie' en een 'clausule', een motto en een besluit, die beide afkomstig zijn uit de Summa Theologica van Thomas van Aquino. ${ }^{13}$ De filosoof Thomas van Aquino (1225-1274) kennen wij vooral van zijn logische godsbewijzen, de idee dat de rede in dienst van het geloof zou moeten worden gesteld, en de idee dat de rede het ethisch richtsnoer van het menselijke handelen diende te zijn. De referentie luidt: 'Locus ab auctoritate quae fundatur super ratione humana est infirmissimus.' (Thomas Aquinas, Summa Theol. I, quaest. I a. 8. Ad 2.) De clausule luidt: 'Cum enim gratia non tollat naturam, sed perficiat, oportet, quod naturalis ratio subserviat fidei: sicut et naturalis inclinatio voluntatis obsequitur caritati.' De citaten zijn beide te vinden in het eerste deel van de Summa Theologica in de verhandeling over God, in het antwoord dat Thomas van Aquino geeft op de vraag 'Whether a Sacred Doctrine is a Matter of Argument.' "Thomas van Aquino verdedigt zich hier tegen de idee dat het geloof ('a sacred doctrine') niet bewezen zou kunnen worden door de rede, een stelling die door Boëthius werd geponeerd:

To argue from authority is most proper to this doctrine, since its principles are obtained by revelation, and thus we must believe the authority of those to whom the revelation has been made. Nor does this take away from the dignity of this doctrine, for although the argument from authority based on human reason is the weakest, yet the argument from authority based on divine revelation is the strongest. But sacred doctrine makes use even of human reason, not, indeed, to prove faith [...], but to make clear other things that are put forward in this doctrine. Since therefore grace does not destroy nature, but perfects it, natural reason should minister to faith as the natural bent of the will ministers to charity. (8) [cursiveringen van mij, $\mathrm{sJ}$ ]

Het beste bewijs van God is de goddelijke openbaring, stelt Thomas. Omdat het geopenbaarde inzicht voor de meesten niet is weg- 
gelegd, zijn er door autoriteiten (filosofen) redelijke argumenten opgesteld. Argumenten die tegen het geloof worden ingebracht, kunnen met de rede weerlegd worden. Door het verhaal tussen deze twee Thomascitaten in te zetten, stuurt de auteur de lezing van Mijn aap schreit en wijst hij op een kern: dit verhaal gaat over de verhouding tussen het geloof - gebaseerd op gevoel - en de rede. Daarmee komen twee botsende paradigma's uit de bredere historische en culturele context bij elkaar: de logica van de wetenschap en het gevoel van het geloof. Via de worsteling van de verteller met de status van zijn aap, geeft de verteller uitdrukking aan zijn worsteling met vragen omtrent verstand en geloven. Dit komt met name naar voren in de passage waarin de verteller zich afvraagt wat hij zijn aap te eten zal geven. Terwijl hij in de tuin eten voor zijn aap heeft verzameld, blijkt dat deze stiekem het eten van de verteller al heeft opgeschrokt. De verteller vraagt zich af of er sprake is van diefstal:

Later kwam ook de gedachte bij mij op, dat wat hij gedaan had toch diefstal was; maar deze vrucht van calvinistisch atavisme bleek te dwaas, want kort te voren had mijn aap zeer duidelijk blijk gegeven geen verstand te bezitten. En onwetend zondigt men niet, zelfs niet voor de wet. (I8)

De gedachte dat de aap, of hij nu verstand heeft of niet, een dief is, noemt de verteller een vrucht van calvinistisch atavisme. Immers, volgens de calvinistische leer deed het er niet toe of men zich er wel of niet bewust van was kwaad te doen; schuldig was men altijd. Daar de aap echter eerder liet merken dat hij geen verstand bezat, kan hij ook niet zondigen, zo meent de verteller. ${ }^{15}$ Wanneer zijn aap geen verstand heeft, zijn de consequenties volgens de verteller echter ook niet gering:

Vanzelf drong nu de consequentie tot mij door, dat ik voortaan mijn aap alles zou te vergeven hebben, en dat het alleen goed zou kunnen gaan tusschen ons, wanneer ik op alles verdacht zou wezen. Dit waren werkelijk zeer hooge eischen die hij aan mij stelde. Ik voelde mij onrustig bij deze nieuwe plicht van observatie en voorkoming. (I4) 
Wanneer de aap niet voor zijn daden verantwoordelijk gehouden kan worden, betekent dit dat de verteller hem alles moet vergeven. Dat vindt hij een hoge eis, want nu zal hij, daar hij zijn aap niet kan straffen, zijn fouten moeten zien te voorkomen, hetgeen voor hem een 'plicht van observatie en voorkoming' betekent. De verantwoordelijkheid komt nu bij hem terecht.

De verteller besluit, in de passage waarin de aap het eten van de verteller stiekem heeft verorberd, dat zijn aap voortaan hetzelfde zal eten als hij. Hiermee schakelt hij zijn aap gelijk aan de mens, op primair vlak, en hij zegt: 'het was een gelijkberechtiging, een assimilatie, die mij evenzeer verlaagde, als ze hem verhief' (17). De woorden 'verlagen' en 'verheffen' doen denken aan de religieuze idee dat God zich door zijn menswording via Jezus tot de mensen heeft 'verlaagd', en daarmee de mens tegelijkertijd heeft 'verheven' tot het goddelijke. ${ }^{16}$ Op sommige momenten is hij zo in de ban van zijn aap, dat deze uitgroeit tot een godheid voor de verteller.

Telkens zag ik duidelijker de wezenlijkheid van zijn rust en de macht van zijn onbewogenheid. Hij groeide zoo groot als een leeuw, grooter nog: als een Sfinx, als een ontzaglijk steenen dier dat mij verpletteren kon. Zóó was het geheim van duizenden jaren: dat dieren goden voor menschen worden. $(22)^{\eta}$

De verteller verliest hier duidelijk zijn superioriteitsgevoel, en de aap wordt vergeleken met de Sfinx, de raadselachtige figuur bij uitstek. ${ }^{18}$ Ook in de droom wordt de aap als een godheid voorgesteld. Hij staat 'op een voetstuk' en is van steen. De verteller staat in de droom volledig vastgezogen op de grond en kan slechts staren, zoals ook in deze passage.

De verteller piekert, zoals bleek uit de paragraaf over de missing link, niet alleen over het evolutiedenken in relatie tot het geloof, maar ook over het humanisme. Dat blijkt uit een dialoog met zijn moeder, die ziet dat de aap zijn staart over de jas van haar zoon heeft gelegd.

'Pas op', zei ze 'Je krijgt al de haren van dat beest op je jas'.

Mijn aap verstond en sloeg een vaasje van de schoorsteen; toen ging hij zitten mokken in een hoek.

Ik was woedend en wist niet goed waarom.

Immers ik verstond niet deze eerste openbaring van het humanisme der komende eeuwen. (20) 
Wanneer de moeder de verteller waarschuwt dat hij apenharen op zijn jas krijgt van 'dat beest', reageert de aap verontwaardigd. Wellicht protesteert hij tegen tegen de term 'beest', waarmee ze afstand schept tussen mensen en dieren. Haar waarschuwing impliceert ook dat de moeder niet wil dat haar zoon op een aap gaat lijken (door al dat apenhaar). De verteller voelt woede, zonder dat hij precies begrijpt waarom. Hij begrijpt niet wat de 'eerste openbaring van het humanisme der komende eeuwen' inhoudt. Het humanisme is de stroming die de mens als uniek beschouwt en ervan uitgaat dat de mens zijn waardigheid ontleent aan het mens-zijn. Dieren zijn binnen het humanisme, net als in het christendom, een andere, 'lagere' categorie. Door de mens centraal te stellen, legden de humanisten de eerste grondslagen om de positie van God te relativeren. Mensen ontlenen hun waardigheid niet aan God, maar aan hun eigen mens-zijn. Het kan zijn dat de verteller bedoelt, dat zijn moeders opmerking over 'dat beest' gezien kan worden als een typische openbaring van humanistisch gedachtegoed. Maar nog waarschijnlijker is dat het zelfstandige gedrag van zijn aap hem ergert. Hij vreest het humanisme 'der komende jaren', een nieuw soort humanisme, namelijk een niet-christelijk humanisme, waarin niet Christus, maar de aap als ijkpunt voor het mensbeeld dient. En dat is misschien de reden dat aan de aap Christusachtige eigenschappen worden toegeschreven. ${ }^{19}$ De aap wordt namelijk in diverse passages voorgesteld als Jezus, de zoon van God op aarde.

\section{ECCE SIMIUS! DE AAP ALS CHRISTUSFIGUUR}

Hoewel nergens expliciet gemaakt, is de vergelijking tussen de aap en Christus door het hele verhaal geweven. Zo komt in een bepaalde passage 'het meisje' langs bij de verteller. $\mathrm{Zij}$ is, na de moeder, de tweede vrouw in het verhaal die het zeer goed met de aap kan vinden (daarna volgen Marietje, een meisje van vijf, en Martha):

Zij streelde hem over zijn rug, zij aaide hem onder zijn hals, haar smalle witte vingers streken over zijn kop. Toen dacht ik nog met een gelukkige glimlach: wat is ze lief, wat is ze mooi, als de vrouw met den eenhoorn - ook bijbelsch geloof ik - koestert zij de aap. (27) 
In de vrouw en de eenhoorn is, in de christelijke iconografie en later in het volksgeloof, het beeld van Christus en Maria gezien, waarbij Jezus als eenhoorn is voorgesteld, die alleen door een reine maagd, Maria, gevangen kan worden (Timmers 1987). In deze passage krijgt het meisje dus iets van Maria en de aap iets van Christus.

Net als de aap heeft de verteller geen naam, en ook het meisje niet. Dit werkt een meer allegorische interpretatie in de hand. Bovendien wordt de soort van de aap in Mijn aap schreit niet gespecificeerd. Wanneer het meisje de verteller vraagt naar de naam van de aap, zegt hij dat hij gewoon 'aap' heet. 'Dat is weer echt iets voor jou. Aap, aap, zoo bloot, zoo koud, zonder de minste poëzie [...]. Noem hem Rex of Ichnaton of Henkie of Anatole' (28), zegt het meisje in reactie op de verteller. Een persoonlijke naam geven is het toekennen van identiteit en onverwisselbaarheid met anderen. Het meisje typeert hem die geen naam wil geven als een verstandsmens zonder poëzie. De eerste twee namen die ze noemt zijn verheven. 'Rex' is opnieuw een verwijzing naar Jezus. Toen Jezus aan het kruis hing, hing er een bordje met 'I.N.R.I' aan het kruis: Jesus Nazarenus Rex Judaeorum (Jezus van Nazareth, Koning der Joden). 'Ichnaton' is verwijzing naar de Egyptische zonnegod, een farao, die werd beschouwd als mensgeworden afgezant van de goden. Net als Jezus, kenmerkt de farao zich door dubbelheid: menselijk en goddelijk tegelijk. 'Henkie' contrasteert met deze religieus beladen namen en is heel gewoon en alledaags. 'Anatole' verwijst wellicht naar de Franse auteur en nobelprijswinnaar Anatole France (1844-1924), die zijn roman La vie de Jeanne d'Arc (1908) deels gebaseerd had op Ernest Renans Vie de Jésus. France was sceptisch op godsdienstig gebied en in zijn werk komt dit tot uitdrukking in de tegenstelling hedonisme versus christelijke strengheid (Kunitz \& Haycraft 1942: 483-485).

De namen van de vrouwen in Mijn aap schreit roepen ook associaties op met de bijbel. Aan Maria en Martha is later toegeschreven dat zij symbool staan voor twee geloofshoudingen, doordat zij op verschillende wijze voor Jezus zorgen. Martha is praktisch en zorgzaam en Maria contemplatief (Van Dalen-Oskam \& Mooijaart, 2000: 248). In dit verhaal zijn de rollen omgedraaid: Martha is hier de contemplatieve; ze heeft rechten gestudeerd en wil geen kinderen; Marietje, een meisje van vijf, voelt zich zeer verwant met het aapje en speelt met hem. Door de rollen om te draaien worden de 
namen Martha en Maria ontdaan van hun vermeende bijbelse ondubbelzinnigheid, en wordt hun dubbelzinnigheid benadrukt.

Als de verteller ontwaakt uit zijn droom, hoort hij gezang op de gang: 'er werd gezongen, een traag, droevig lied, met halve, ingehouden stem. Van dichtbij. Ik moest het weten, dit geluid was zoo droevig, onmenschelijk bijna' (53). Het blijkt de aap te zijn. De verteller is zeer aangedaan:

Ik moest de kreten in mij omlaagdwingen, want iets in mij wilde schreeuwen, kòn het niet meer houden: Mijn aap schreit! Ziet, ziet mijn - aap - schreit. (54)

Opvallend is dat 'Mijn aap schreit!' is gecursiveerd; het vormt de titel van Helmans kleine roman, alsof de emotionele lading hiermee nog eens wordt benadrukt. Intrigerend zijn hier de gedachtestreepjes die daarop volgen, rondom 'aap', alsof de verteller vertraagt en met enige denkpauze blijft hangen op het woord aap, waardoor het een open plek wordt, die ook anders ingevuld kan worden. De aandacht wordt hierdoor nog eens extra op deze zin gevestigd. De formulering doet denken aan de woorden 'Ecce homo!', de woorden waarmee Pilatus de gegeselde en met doornen gekroonde Christus aan het volk toonde om hun medelijden op te wekken (Joh. 19:5). $\mathrm{Al}$ eerder had de broer van de verteller op de menselijkheid en het lijden van de aap gewezen. 'Kijk hem daar eens liggen, 't is net een mens' (46) zei de broer na de discussie over de missing link. De menselijkheid van de aap wordt hier benadrukt.

De vergelijking van de aap met Jezus komt in de sterfscène tot een hoogtepunt. Na de nacht waarin zijn aap schreide en de verteller zich zeer met hem verbonden voelde, merkt zijn moeder bij het ontbijt op dat ze de aap niet langer in huis wenst. Ze vindt dat haar zoon niet te genieten is geweest sinds de aap in huis is gekomen. 'Nu heeft dat beest het opeens weer gedaan...' merkt de verteller op. Wanneer zijn moeder de kamer heeft verlaten, bekijkt hij zijn aap: In de gang waar mijn hoed hing, kroop de aap naar mij toe. Een zonnestraal door glas vergeeld viel dwars over zijn rug. Was het dit licht dat me dol maakte? Ik schopte hem opzij. (57) Eerder in het verhaal lazen we: 'En op een van onze wandelingen zag ik, hoe een smalle, zwarte streep van haren liep van zijn kop tot aan zijn staart.' (24) De zonnestraal die dwars op zijn rug valt, maakt samen met de 
zwarte streep die over zijn hele rug loopt, een kruis. Het lijkt erop dat de aap een eigen kruis begint te dragen.

Tijdens een wandeling komt de verteller tot inzicht: 'Zeker, moeder had gelijk. Hij was de schuld van alles; àlles' (57). Dit doet denken aan de kern van de verlossingsgedachte in het christendom: Jezus heeft de zonden van de wereld op zich genomen. Eerst veroorzaakte Eva schuld, omdat zij tegen beter weten in at van de boom van de kennis van goed en kwaad. Eva wordt, zo zou je kunnen stellen, symbolisch verbeeld door Martha, die eerder in het verhaal gevoelig bleek te zijn voor schuld: 'Dus je wilt beweren dat ik de schuld van dit alles ben... Overal vind je mij de schuld van.' (49) Later nam Jezus de schuld op zich en diende als voorbeeld voor de mens. Deze zou zijn leven moeten navolgen, 'na-apen' in zekere zin.

De verteller neemt vervolgens de beslissing de aap te doden. Hij wil een dood voor de aap bedenken die niet-menselijk is, en brengt dit, hoogdravend en dramatisch in een zelfde soort taal als Plato's Phaedo, als volgt onder woorden:

Zoo zou hij ons menschen tòch zijn grootste smaad aandoen, te sterven als een mens, als welk een mensch, o Socrates! En ik zou de Platoon wezen die zijn Phaidoon moet schrijven? Nooit, nooit zou ik zoo-iets dulden. Sterven zòu hij, maar niet als een mensch. Dit laatste, de dood, ons heiligste mysterie, het laatste levensgeheim dat wij leren ten koste van àlles, zou hij parodieeren, zou hij mij voorspellen, zóó miniem? Nooit, nooit zou ik het dulden. En nu merkte ik het plotseling, hoe ik hem haatte met een haat die gegroeid was vanaf mijn prille jeugd. Doodelijk haatte ik hem, vanaf de eerste seconde dat ik hem zag. $(59-60)^{20}$

Dat de aap bij leven als een mens en de mens als een aap kan zijn, dat is voor de verteller kennelijk nog wel te accepteren. Maar juist in de grenssituatie tussen leven en dood, die sterven heet, moet de grens tussen aap en mens blijkbaar opnieuw worden gemarkeerd. Dat de aap als een mens zou sterven, is blijkbaar de grootste smaad die hij de mens kan aandoen. Dit lijkt op een spiegeling van een bijbels motief, waar Christus, de mensgeworden God sterft uit liefde. God verlaagde zich tot de mens en stierf als mens uit liefde voor de mens; de aap verhoogt zich tot de mens en sterven als een mens is een smaad. Socrates wordt vaker in verband gebracht met 
Christus en gezien als een soort wijze voorloper of prefiguratie van hem. Ook hij moest sterven, en wel om twee redenen. Hij zou de jeugd bederven, en hij zou de mensen aanmoedigen in nieuwe goden te geloven, andere dan welke de staat erkende. Socrates stond erom bekend dat hij mensen tot zelfinzicht en zelfkennis bracht; niet door ze antwoorden te geven, maar door ze, via een dialoog, waarin hij vragen stelde, tot een uitspraak te laten komen. Plato is Socrates' leerling en schreef zijn filosofieën op. In de Phaedo beschreef hij de laatste dagen van het leven van Socrates. Socrates is een vragensteller, net als de aap in dit verhaal. De aap wordt door de verteller vaak voorgesteld als een levend vraagteken, iemand die hem voor een dilemma plaatst. In bovenstaande passage vergelijkt de verteller zichzelf met de leerling van Socrates, die als aap wordt voorgesteld. De aap houdt de verteller, zoals Socrates zijn leerlingen, een soort waarheid voor. Net als Socrates, zo besluit de verteller, krijgt de aap gif toegediend. Dan vervolgt de verteller met de beraming van zijn moord. 'En nu moest ik hem een dood uitdenken die zoo wreed en onmenschelijk was dat zijn dood een andere dood werd dan het sterven alleen van een leven. Het moest iets zijn zó́ exquis als geen Romein kon verzinnen en geen kannibaal' (6o). De Romeinen hebben de kruisiging bedacht als een vernederende doodstraf voor slaven, en kannibalisme houdt in dat je mensenvlees eet. Gecombineerd roepen de kruisiging en het eten van mensenvlees opnieuw een associatie met Jezus op: 'Neemt en eet want dit is mijn lichaam.' De dood van de aap is er één van vernedering en bespotting, net als bij Christus. Terwijl de aap sterft ligt hij er als volgt bij: 'De aap lag op zijn rug, met zijn handen en voeten gespreid als gekluisterd op een andreas-kruis' (6r). Een andreas-kruis is diagonaal en niet horizontaal en verticaal. Andreas was een volgeling van Jezus en wilde niet op hetzelfde kruis als zijn meester sterven. Nu wordt de aap dus met een volgeling van Christus geassocieerd, niet met Christus zelf. ${ }^{21}$ De verteller vergelijkt zichzelf met een opperpriester die in een tempel zit: 'De kamer werd bleek en hoog, een witte tempel van Baäl, en ik zat daar, groot en sterk, als een opperpriester die het offer voltrekt van een nieuw ritueel.' (6I) Ook neemt hij afstand van het christelijke geloof, door naar Baäl te verwijzen. In plaats van een meer christelijke houding ten opzichte van dieren, in termen van een soort rentmeesterschap, wil hij de aap helemaal dood hebben. Door deze te 
doden, is de aap definitief 'omlaag' gezet, en is de hiërarchie tussen hem en de aap verzekerd.

\section{AMBIGUÏTEIT VERMOORD}

Wat is de betekenis van de voorstelling van de aap als Christus in Mijn aap schreit? Een voor de hand liggend antwoord luidt dat Jezus hét archetypische beeld is van lijden in de westerse geschiedenis. De associatie van de aap met de aan het kruis genagelde Jezus sorteert een dramatisch effect. De lezer begrijpt dat het hier om een groots lijden moet gaan. Het beeld kan als provocerend worden gezien, met name voor gelovige lezers. ${ }^{22}$ Dat geldt tevens voor de passages waarin de gelovige als een aap wordt voorgesteld, een na-aper van Jezus, hetgeen ook niet bepaald vleiend is voor sommige christenen.

In Mijn aap schreit impliceert de vergelijking tussen de aap en Jezus echter meer. In mijn interpretatie krijgt de voortdurende ambivalente houding van de verteller jegens zijn aap, een symbolische betekenis. De aap vertegenwoordigt in Mijn aap schreit steeds ambiguïteit, namelijk natuur én cultuur, dier én mens, verstand én drift, en zoals Jezus, God én mens. Wanneer de verteller te kennen geeft de aap te haten, dan zou dit kunnen betekenen dat de verteller in feite Jezus haat, en genoeg heeft van het navolgen van diens goede voorbeeld. Het is immers opmerkelijk dat de verteller te kennen gaf de aap te haten 'met een haat die gegroeid was vanaf mijn prille jeugd' (6o), terwijl hij de aap pas op latere leeftijd aanschafte. De negatieve gevoelens ten opzichte van Jezus als het goede voorbeeld, komt in het verhaal tot uitdrukking wanneer de verteller laatdunkend neerkijkt op zijn moeder, die 'genoeg heeft aan Thomas a Kempis' (62). Het middeleeuwse werk van Thomas a Kempis, De imitatione Christi, gold enkele eeuwen als het boek dat een toonbeeld was voor het gedrag van een goede gelovige. Het imitatie-aspect van de goede gelovige die Jezus na wil volgen, werd in de veertiende eeuw door Boccaccio vergeleken met apengedrag; hij noemde de gelovigen 'the apes of Christ' (Janson 1952: 293) en 'a Good Christian the ape of the Saviour'. De betekenis van het Latijnse 'simius', dat ook primair betekent, veranderde in deze tijd 
steeds meer van een inadequate imitator naar iemand die ernaar streefde het ideaal te bereiken (Janson 1952: 293).

De ambigue status van de aap keert terug in de manier waarop de aap zelf zijn mening lijkt te openbaren in het verhaal. Zo protesteert de aap in het verhaal tegen het christelijke humanisme, de eerste maal wanneer hij een vaasje van de schoorsteen slaat, als de moeder van de verteller zegt dat ze hem een vies beest vindt. Binnen het humanisme is er sprake is van een discontinuïteit tussen mens en dier. De mens onderscheidt zich op grond van zijn verstand van het dier. Het protest van de aap suggereert dat hij het niet eens is met dit onderscheid tussen mens en dier, en dat hij vindt dat mens en dier fundamenteel gelijkwaardig zijn. Maar de aap protesteert ook tegen het evolutiedenken, wanneer hij zijn etensbak omgooit als de verteller hem met de volwassenwording van zijn broer vergelijkt. Het evolutiedenken is een continuïteitsdenken waarin de fundamentele overeenkomsten tussen mens en aap worden benadrukt. Met zijn protest hiertegen geeft de aap te kennen niet op dezelfde lijn met de mens geplaatst te willen worden. ${ }^{23}$ Het protest van de aap is dus dubbelzinnig: hij wil niet in een van de mens verschillende, noch in een aan de mens gelijke positie worden geplaatst. De aap wil, zo zou men kunnen stellen, noch fundamenteel anders dan de mens zijn, noch als voorloper van de mens worden beschouwd, maar aap én mens zijn. Dit spiegelt de tweenaturenleer, waarin Jezus wordt beschouwd als volledig mens en volledig God.

De dood van Jezus wordt in de bijbel voorgesteld als de verlossing van de mensheid, omdat hij alle zonden van de wereld op zich nam. Op vergelijkbare wijze betekent de dood van de aap de schijnbare redding voor de verteller, die na de moord dan ook te kennen geeft dat hij zich bevrijd voelt. Maar waarvan wilde de verteller zich nu eigenlijk bevrijden? En waarom voelde de verteller zich steeds 'bevreesd' als hij met zijn aap werd geconfronteerd? Mijns inziens kan de verteller de ambiguiteit van de aap niet aan. In de aap ziet hij zijn grote levensdilemma's teruggekaatst, zijn worsteling met de vraag hoe zijn leven te leiden, op grond van instinct, van verstand of het geloof. De aap fungeert als een spiegel voor de verteller, omdat hij een bekend icoon is voor geilheid én een beladen dier in het christendom wegens de associaties met de evolutieleer en het ter discussie stellen van de goddelijke schepping. Door de aap te doden, rekent de verteller niet alleen af met de dubbelzin- 
nigheid van de aap, maar ook met zijn eigen twijfel. ${ }^{24}$ In de omgang met zijn aap wordt hij immers voortdurend geconfronteerd met de status en hiërarchie van dier, mens, Jezus en God, en met de onmogelijkheid om, anders dan de aap, een verstands- én gevoelsmens te zijn. Wanneer hij zijn aap met vrouwen ziet, frustreert hem dat en vraagt hij zich af of hij zijn lusten moet volgen (Freud) of moet onderdrukken en 'zedelijk' en 'verstandelijk' moet leven (de bijbel). De ontmoeting tussen de vrouw en de aap kan vanuit de verschillende theorieën anders bezien worden. Volgens de door de verteller gereconstrueerde darwinistische visie zou de verteller, net als zijn aap, beter zijn driftleven moeten volgen en zich laten leiden door zijn instincten, en met de vrouw het bed induiken. Het christendom maant hem aan voor zijn verstand te kiezen (een 'denkhoofd' te zijn in plaats van een 'eethoofd') en het voorbeeld van Jezus te volgen en zijn seksualiteit te onderdrukken. De psychoanalyse confronteert hem met zijn eigen 'vrouwelijkheid' en zijn verlangen om het contact - een liefdesrelatie - met 'de ander' te vinden.

$\mathrm{Na}$ de dood van de aap ontmoet de verteller wederom de jager van wie hij ooit de aap kocht. Hij bekent hem zijn aap te hebben vermoord. De jager stelt voor dat de verteller ook jager wordt: 'Alleen jagen en doden geeft je de wilde vreugde van wezenlijke wreedheid. De geur van het gevaar prikkelt je meer dan de fijnste sigaar. Alle dieren zullen je kennen met ontzag en vreeze' (67). Met zijn woorden geeft de jager aan dat hij een God onder de dieren ('vreze Gods') is. Het kiezen voor het jagersbestaan impliceert het opheffen van de ambivalente positie. De verteller heeft nu een functionele naam (jager) en een duidelijke taak (doden). Anders dan Christus wil de verteller het lijden ontlopen; daarom doodt hij de aap en kiest hij door middel van het jagersbestaan voor de mogelijkheid om alle toekomstige apen te doden. ' $\mathrm{Nu}$ ga ik alle apen schieten die ik vinden kan [...] De eerste die ik vind is voor Martha.' (68), besluit de verteller. Mogelijkerwijs geeft deze uitspraak blijk van de wens van de verteller om Martha een soortgelijk proces als hij door te laten maken. Martha is van alle vrouwelijke personages in Mijn aap schreit het meest ambigu. De overige vrouwen, het meisje, Marietje en zijn moeder, worden impliciet gelijkgeschakeld met de aap, doordat zij worden voorgesteld als wezens die dichter bij de natuur staan. De verteller zegt diverse keren dat de mens een 'rechtopstaand wezen' (19) is, terwijl de aap 'de wereld bezag vanuit 
een viervoudig standpunt van handen en voeten' (I8) en 'kruipt' (14). Marietje, het vijfjarige meisje, 'kruipt' (22) en Martha gaat 'op haar knieën' en 'voorover op haar handen' (25) bij de aap zitten. ${ }^{25}$ Martha onderscheidt zich van deze vrouwen door zich net als de verteller een verstandsmens in plaats van een driften- en gevoelsmens te betonen. Immers, zij studeert rechten en wil bovendien geen kinderen. Zoals hij worstelt met zijn eigen ambiguïteit, zo worstelt hij ook met de hare. ${ }^{26}$ Maar het blijft de vraag waarom hij haar een dode aap zou willen aanbieden. Wellicht wil de verteller haar ook van de dubbelzinnigheid verlossen. Een andere, plausibelere, verklaring is dat de verteller zint op wraak: Martha heeft zijn liefde immers niet beantwoord. Het zou goed kunnen dat hij het haar kwalijk neemt dat al haar aandacht uitging naar de aap in plaats van naar hem, en dat hij haar daarom een dode aap wil aanbieden. ${ }^{27}$

Gedurende de hele roman probeert de verteller zich ervan te overtuigen dat hij superieur is aan de aap, maar uit alles (zoals de droom), blijkt dat de aap voor hem iets belangrijks vertegenwoordigt. In één passage erkent de verteller wel zijn lijden, wanneer hij ziet dat zijn aap schreit en hem in zijn armen neemt. 'Mijn aap schreit', de woorden die ook de titel van de roman vormen, drukken het diepe lijden en de pijn van de verteller uit. Met zijn innerlijke lijden weet de verteller zich geen raad; hij kiest voor de dood als oplossing, voor het opheffen van de twijfel. De ambiguïteit blijft niet behouden, en in die zin is Mijn aap schreit een tragisch verhaal. In de receptiegeschiedenis van Mijn aap schreit (de in de inleiding geciteerde interpretaties van Arion, Van Kempen en Fierens) is later de moord als het ware herhaald, door de ambiguiteit van de aap te reduceren tot het driftleven van de verteller. In mijn interpretatie heb ik gepoogd de ambiguîteit van de aap te handhaven, door juist te laten zien hoe deze tegenstrijdigheden in zich verenigt. In die zin is deze interpretatie anders dan een psychoanalytische tekstinterpretatie (waarbij de aap staat voor het alter ego van de mens), een symbolische interpretatie à la Janson (waarbij de aap 'Christus' symboliseert, de man 'het darwinisme' dat zegeviert) of een harawayaanse interpretatie (waarbij Mijn aap schreit opgevat zou worden als een illustratie van een ideologisch conflict tussen het darwinisme en het christendom).

De verteller worstelt in zijn persoonlijke leven met de wijze waar- 
op wetenschappelijke theorieën antwoord hebben gegeven op de vraag waar de mens vandaan komt en wat zijn natuur is. Culturele en wetenschappelijke teksten hebben de gedachten van de belezen verteller gevormd. Met name het darwinisme en de ideeën van Freud conflicteren met zijn religieuze opvattingen. Over sommige vraagstukken, die pas veel later in de wetenschap zullen opduiken (zoals gereedschapgebruik van apen en moreel besef van apen), wordt in Mijn aap schreit al gespeculeerd. De verteller laat allerlei mogelijke opties passeren op grond waarvan hij zou verschillen van zijn aap (emotie, moreel besef, vrije wil, spel, verstand), maar steeds weer wordt gesuggereerd dat zijn aap hierin niet van hem verschilt. Naast het freudiaanse jargon duiken in Mijn aap schreit met regelmaat ook darwinistische termen op, bijvoorbeeld 'atavisme', 'instinct', 'ziel', 'missing link', die hij vaak in een adem verbindt met citaten uit de bijbel, zoals 'calvinistisch atavisme'. In Mijn aap schreit worstelt de verteller met grote vragen: wie ben ik, waar kom ik vandaan en hoe moet ik leven? Hij put daarbij uit twee grote stromingen, het christendom en het darwinisme, die met elkaar strijden om het antwoord over de afstamming van de mens.

De verteller ondervindt jaloezie en haatgevoelens jegens zijn aap als hij bemerkt hoeveel aandacht deze van zijn moeder van andere vrouwen krijgt. De aap is, zo zou ik willen stellen, in sommige passages een concurrent van de verteller, iemand die erin slaagt een balans te vinden tussen zijn driftleven en zijn verstand. De aap staat in verschillende traditie symbool voor iets, en de verteller is zich daarvan zeer bewust; tegelijkertijd is zijn aap ook gewoon een 'levende' aap. Precies met die spanning, waarbij zijn aap gevangen zit in verschillende, tegenstrijdige 'cultuurteksten' en tegelijkertijd ook een dier is, worstelt de verteller.

\section{'AAP, IN HET DIEPST VAN HUN GEDACHTEN'. MIJN AAP} LACHT

In 1953, vijfentwintig jaar later, publiceerde Helman de roman Mijn aap lacht. Deze roman gaat over een aap, die een gelukkig leven leidt in het oerwoud. Hij beschrijft het leven van verschillende 
apensoorten en hun eigenaardigheden. De brulapen en de slingerapen lossen de problemen op door te vechten. De vunsapen - een soort bonobo's avant la lettre - maken alles goed met seks, en de klauwapen zijn gefixeerd op hun gezondheid en hygiëne. Via omzwervingen komt de aap bij de mensen terecht, waar hij een aap in gevangenschap wordt. Hij krijgt vooral de slechte kanten van de mens te zien, zoals achterbaksheid, geld- en machtzucht en bedrog.

Helman ontkende stellig dat er een relatie was met Mijn aap schreit. ${ }^{28}$ Met uitzondering van de duidelijke verwantschap tussen de titels zijn ze inderdaad zeer verschillend. Als geheel is Mijn aap lacht een stuk eenduidiger dan Mijn aap schreit. De roman kan - en dat is ook gebeurd - geïnterpreteerd worden als een roman over de onderlinge verhouding tussen de verschillende bevolkingsgroepen van Suriname, die allegorisch worden verbeeld via verschillende apensoorten. ${ }^{29}$ Ook geeft de roman eenduidig antwoord op de vraag naar de oorsprong, de status en de aard van de mens. Twijfelde de ikverteller in Mijn aap schreit aan de positie van geloof ten opzichte van wetenschappelijke ideeën over de afstamming van de mens, in Mijn aap lacht wordt religie, en met name de instutionele drager van het geloof, de kerk, als onderdrukkend gepresenteerd. ${ }^{30}$

Anders dan Mijn aap schreit, heeft de schrijver in dit verhaal vooral de postkoloniale problematiek verwoord: de hiërarchie tussen het Westen en de Nederlandse kolonie Suriname. ${ }^{31}$ Wat de hiërarchie tussen blank en zwart betreft, maakt de roman de ongelijkheid duidelijk, maar is er ook de mogelijkheid de roman zo te lezen dat er gesuggereerd wordt dat zwarte mensen dichter bij de apen zouden staan. De ontmoeting tussen de vrouw en de aap is ook een andere dan in Mijn aap schreit: in Mijn aap lacht kan de aap het goed vinden met een zwarte kokkin. Hoewel Helman enerzijds zwarte personages een stem geeft in zijn romans, worden vrouwelijke personages, zoals de zwarte kokkin, net als in Mijn aap schreit, met een zekere stereotypie geportretteerd. ${ }^{32}$

Ernst van Alphen (1992) heeft erop gewezen dat er meer ambivalenties zijn in het werk van Helman: enerzijds snijdt hij koloniale kwesties aan en de onderdrukking van zwarten door witten; anderzijds keren veelvuldig vergelijkingen tussen zwarten en dieren, apen met name, terug. ${ }^{33}$ In zijn analyse van De Stille Plantage (I932) laat hij zien hoe vaak huidskleur gemarkeerd wordt, en hoe 
uitvoerig de fysieke eigenschappen van zwarten worden beschreven. Hij citeert de volgende passage van Helman waarin de slaven pistoolschoten verwelkomen 'met wilde vreugdekreten die beantwoord werden door het krijsend lachen van de bange apen dieper in het bos.' (76) Volgens Van Alphen stelt Helman zwarten impliciet gelijk aan apen, wanneer hij schrijft dat zwarten 'aap, in het diepst van hun gedachten' zijn. (76) Helman zou een 'neokolonialistisch' beeld van Suriname schetsen, en zich bedienen van stereotypen. Een voorbeeld van zo'n stereotype is de slaaf Isidore in De Stille Plantage en het representeren van zwarte mensen als dieren. ${ }^{34}$ De vergelijking tussen de aap en de zwarte treffen we in Mijn aap schreit éénmaal aan: bij de beschrijving van het uiterlijk van het aapje lezen we bijvoorbeeld: 'Z'n gezicht kwam vol rimpels, als van een stokoude neger' (15). In Mijn aap lacht worden zwarte mensen en dieren (soms apen) vaker met elkaar vergeleken.

In een recente biografie over Helman, keert Michiel van Kempen (1998b) zich tegen deze 'politiek correcte' kritiek op Helman. ${ }^{35}$ Volgens hem is het niet juist om zijn werk te beoordelen op 'een set van normen en waarden, zonder dat duidelijk wordt wat die set nu eigenlijk inhoudt'. In zijn interpretatie van Mijn aap lacht richt Van Kempen (1995) de aandacht op muzikale en lyrische bouwprincipes van de tekst. De twee leeswijzen corresponderen met de twee manieren die ik in hoofdstuk twee introduceerde: Van Alphen leest op welke wijze stereotypen in tekst worden gevat, terwijl Van Kempen aandacht heeft voor het esthetische plezier dat de tekst oplevert. Tussen die twee benaderingen hoeft niet per se gekozen te worden, samen laten ze de spanning binnen de tekst zien. Daar waar het om apen in het werk van Helman gaat, valt zowel voor de verdediging van Van Kempen als voor de kritische observaties van Van Alphen wat te zeggen. Mijn indruk is dat Helman zich terdege bewust moet zijn geweest van de vergelijking die hij in zijn werk veelvuldig maakte tussen apen en zwarten. Hij zet het stereotype soms bewust in om de vinger op de zere plek te leggen, soms op meer, soms op minder geslaagde wijze (hetgeen tot de ambivalentie leidt die Van Alphen constateert). Zo is het citaat dat Van Alphen aanhaalt ter ondersteuning van zijn kritische lezing van het werk van Helman 'aap, in het diepst van hun gedachten' mijns inziens bedoeld als een herschrijving van de eerste regel van Willem Kloos' sonnet: 'Ik ben een God in 't diepst van mijn gedachten'. Op het eerste gezicht doet 
die variant komisch en wat burlesk aan, maar wie de betekenis ervan tot zich laat doordringen, ziet ook dat het herinnert aan de pijnlijke traditie waarbij de zwarte ander voorgesteld wordt als dichter bij de aap dan de blanke mens. Tegelijkertijd brengt Helman meerdere registers bij elkaar omdat de 'aap' in de mens ook weer verwijst naar Freud. Het citaat raakt aan de vergelijking die in Mijn aap schreit een rol speelt, waarbij de relatie tussen mens en aap wordt vergeleken met de relatie tussen mens en God, en de aap zelfs uitgroeit tot een soort Christusfiguur.

De aap als Christusfiguur, als zwarte ander en missing link keren terug in het volgende hoofdstuk over King Kong, het tragische verhaal over een grote gorilla die verliefd wordt op een meisje en later sterft. King Kong verschijnt vijf jaar na Mijn aap schreit. Net als Mijn aap schreit, geeft deze film vorm aan de vraag waar mensen vandaan komen, wat hun aard is en wat de hiërarchie tussen man, vrouw, zwart, wit, mens en dier is. Maar de context is anders; Mijn aap schreit refereert vooral aan de rol van de aap in debatten over de oorsprong en de aard van de mens zoals die tot in de jaren twintig gevoerd werden, waarbij het darwinisme en het christendom conflicterende posities innemen. Continuïteitsdenken wordt in onderzoeken naar de relatie tussen dieren en mensen vanzelfsprekender, bijvoorbeeld in spelgedrag en de psychologie van dieren. King Kong speelt zich af in de jaren dertig, als de wetenschappelijke onderbouwing van het darwinisme een steviger plaats krijgt in dieronderzoeken. De ontmoeting tussen de vrouw en de aap is bovendien te situeren in een koloniale context, en staat ook voor een andere confrontatie: die tussen de westerse blanke mens en de zwarte ander. Wat Mijn aap schreit deelt met King Kong is het einde: een moord van de man op de aap, en het volgende hoofdstuk gaat dan ook, net als dit hoofdstuk, in op de vraag waarom de aap moet sterven en waarom daar een meisje aan te pas komt. 
Gorilla's tussen feit en fictie

\section{De tragische dood van King Kong}

KONGFRONTATIE

'It was beauty killed the beast.' De laatste woorden van de filmklassieker King Kong (Cooper \& Schoedsack 1933) vormen zonder twijfel een van de beroemdste slotzinnen uit de filmgeschiedenis. ${ }^{1}$ De reuzengorilla is zojuist van het Empire State Building gestort. Te midden van een nieuwsgierige menigte bekijkt het personage Carl Denham het enorme lichaam van Kong. Niet de afgevuurde kogels kostten hem de kop, maar de schoonheid van een vrouw, zegt Denham. Terwijl het bloed uit de kop van de grote gorilla gutst, voelt de kijker hevig mee met de pijn van een aap die het niet kon helpen dat hij verliefd werd op een mooie vrouw. De tragische geschiedenis van de grote verliefde gorilla verstilde tot een bekende en veel geciteerde afbeelding: King Kong met in zijn handen een klein weerloos meisje van miniatuurformaat.

Wie meer dan zestig jaar na dato King Kong bekijkt, kan de film bijna niet anders zien dan als de prachtigste ondubbelzinnige kitsch die Hollywood produceerde. ${ }^{2}$ Ann, het meisje, is megablond, kirt en gilt aan één stuk door; Charlie, de Chinese kok kan de ' $r$ ' niet goed uitspreken en zegt voortdurend 'gill' in plaats van 'girl'; inboorlingen voeren in bizarre apenpakjes een soort rituele dans uit; en de matroos Jack is een man van weinig woorden, zoals het een stugge zeebonk betaamt. Voortdurend herinnert de film, die ook een metafilm is omdat hij gaat over een filmploeg die een film gaat maken over King Kong, je er in superlatieven aan dat een meesterwerk in de maak is. Het personage Carl Denham, de regisseur, prijst zijn film keer op keer aan: 'It's the greatest picture in the 
world! It's a thrill of a life time!' Het prominent aanwezige motief van 'the beauty and the beast' laat op het eerste gezicht even weinig ruimte over om naar betekenissen te gissen. ${ }^{3}$ Reeds in het eerste shot van de film verschijnt een sierlijk, op perkament geschreven 'Old Arabian Proverb': 'And the Prophet said: “And Lo, the Beast looked upon the face of Beauty. And it stayed its hand from killing. And from that day, it was as one dead." De zelfbedachte spreuk moet doorgaan voor een wijs en zeer oud Oosters gezegde. Wie de zelfbedachte spreuk over het hoofd heeft gezien, wordt gedurende de film nog tientallen malen op het motief gewezen. Wanneer Denham ziet dat Ann een mooie jurk aan heeft, is hij verheugd dat ze haar 'beauty costume' heeft aangetrokken, en als hij haar ziet spelen met Iggy, een klein aapje, zegt hij op een veelbetekende toon: ' $A h$ ! The beauty and the beast.'

Maar wat voor 'beast' verschijnt er op het witte doek? En wat voor een 'beauty'? Technisch gezien valt King Kong volkomen in het niets bij Steven Spielbergs hedendaagse griezelmonsters. De reusachtige gorilla uit de oorspronkelijke filmversie van 1933 beweegt zich nogal houterig en wekt tegenwoordig in zijn aandoenlijkheid eerder de lachlust op dan de angst. Zijn gedrag is soms angstaanjagend - hij stampt enkele mensen plat -, maar hij vertedert ook. Hij behandelt Ann, het mooie blonde meisje op wie hij verliefd is, niet zozeer als een lustobject, maar eerder als een kostbaar stukje speelgoed waarop hij heel zuinig moet zijn. Als hij haar in zijn grote hand vasthoudt, is hij blij als een klein kind, zorgend als een moeder en beschermend als een vader. Er is weliswaar de bedreiging dat Kong Ann seksueel zal belagen, maar hij overschrijdt die grens niet. Hij gedraagt zich als een echte gentleman. $\mathrm{Zij}$ gilt intussen de longen uit haar lijf, maar kijkt de grote gorilla ook met grote, gefascineerde ogen aan.

Desondanks is King Kong de geschiedenis vooral ingegaan als een killer king, een angstaanjagende sensatie van het witte doek, een wrede vrouwenverkrachter en een moordzuchtig monster. Ann was zijn slachtoffer, het mooie blondje dat in zijn handen viel. Vanaf de jaren vijftig kwam de film bekend te staan als een 'horrorklassieker'. ${ }^{4}$ Erb (1998) betwijfelt of het publiek in 1933 de film als 'horror' ervaarde. Volgens haar werd King Kong in eerste instantie aangekondigd als een film met een romance tussen een gorilla en een meisje, en ervoer het publiek de film in 1933 als een jungle-film in de 
traditie van Trader Horn en Tarzan, eerder dan een thriller of een horrorfilm. Maar op grond van het 'horror'-gehalte stelde de beroemde primatologe Dian Fossey, wier leven verfilmd werd in Gorillas in the Mist (1988), de Hollywoodaap verantwoordelijk voor het negatieve imago van gorilla's, die in plaats van als 'gentle giants' te worden gekoesterd, als 'killer kings' werden uitgemoord. King Kong was in haar ogen een 'valse' representatie van een gorilla. Ze was niet de enige primatoloog die refereerde aan King Kong. Met name in populair-wetenschappelijke publicaties over gorilla's zou de 'fictie'-gorilla opduiken als afzetpunt voor een 'echte' gorilla (bijvoorbeeld in Godwin 1990; De Waal 1997; Galdikas 1995; Wrangham en Peterson 1998).

Zijn gorilla's zachtaardig of kwaadaardig - hebben ze het op vrouwen voorzien? De film King Kong en zijn ontstaans-, interpretatieen receptiegeschiedenis laten zien hoe in de culturele en wetenschappelijke verbeelding van de gorilla, vanaf de negentiende eeuw, met diens ambigue positie is geworsteld. Nauw verweven met de vraag naar de zacht- of kwaadaardigheid is daarbij steeds de vraag gerezen tot welke categorie deze Afrikaanse mensaap behoort: tot de mensen of tot de apen? In dit hoofdstuk ga ik in op de vraag hoe King Kong is geconstrueerd en geïnterpreteerd, als dierlijk of als menselijk, als zachtaardig of kwaadaardig wezen. De context waarin ik de film bespreek, is de wetenschappelijke discussie die in de jaren twintig en dertig van de twintigste eeuw wordt gevoerd over de status en de aard van de gorilla - ook vrouwen speelden daarin een rol; verhalen deden de ronde dat gorilla's dol op ze zouden zijn.

Over de status en de aard van de gorilla bestond geen consensus. Begin jaren dertig trad een kentering in gangbare opvattingen over de gorilla als monster en vrouwenverkrachter, zoals die aanvankelijk door de Amerikaanse avonturier en reiziger Paul du Chaillu was gepostuleerd. Het echtpaar Yerkes probeerde in hun studie The Great Apes (1929) wetenschappelijk te onderbouwen dat gorilla's zachtaardige, vriendelijke en aan de mens verwante dieren waren. De wetenschappelijke strijd over de aard van de gorilla kwam tot uitdrukking in de constructie van de gorilla in King Kong, mede omdat de filmmakers zich baseerden op conflicterende wetenschappelijke informatie bij hun constructie van de gorilla. Dat resulteerde in ambiguïteit, en door de receptiegeschiedenis te analyseren wordt duidelijk hoe men worstelt met de ambiguitteit van de grote gorilla 
(mens/dier/god, kwaad/goed, wel/geen vrouwenverkrachter). Cultuurcritici, zo zal ik betogen, zagen en zien King Kong vooral als symbolische representatie van een mens, die toebehoort aan een specifieke sociale/culturele categorie. Mede afhankelijk van hoe ze de relatie tussen de gorilla en het meisje interpreteren (verkrachting of beschermende aandacht), zetten ze King Kong daarbij neer als onschuldig slachtoffer of als agressor. Wetenschappers beschouwen en beschouwden King Kong vooral als een - valse - representatie van een aap, maar ook zij worstelen voortdurend met zijn tweeslachtige gedrag.

\section{GORILLA: MOORDZUCHTIG MONSTER OF ZACHTAARDIGE REUS?}

De discussie rondom de ambiguitteit van de gorilla - mens of aap, zachtaardig of kwaadaardig - is de erfenis van de verwarring die gorilla's ten tijde van hun ontdekking in de negentiende eeuw opriepen. Hoewel de Carthaagse zeevaarder Hanno in de vijfde eeuw voor Christus al melding maakt van wrede en bijtende, harige, grote wilde mensen die hij 'gorilla's' noemt, wordt de officiële ontdekking van de gorilla meestal in 1847 gedateerd (Yerkes \& Yerkes 1929: 35). In dat jaar zonden de missionarissen Thomas Savage en Jeffries Wyman enkele schedels uit Afrika naar de Amerikaanse anatoom Richard Owen. Savage vermeldt in een begeleidende brief dat ze afkomstig zijn van een aapsoort die verwant is aan de inmiddels bekendere orang-oetan. Hij gaat ervan uit dat de nieuwe aapsoort, die hij Troglodytes gorilla noemt, minstens even gevaarlijk is. 'They are exceedingly ferocious, and always offensive in their habits. ${ }^{5}$ Zonder ooit een levende gorilla te hebben gezien, haakte hij daarmee blindelings aan bij de kennis die sinds het eind van de zeventiende eeuw van andere antropoïden was vergaard. Deze kennis voerde terug tot de anatoom Edward Tyson, die in 1699 - veelal beschouwd als het jaar waarin het westen de mensapen ontdekte de eerste 'wilde man' voor wetenschappelijk onderzoek uit Angola naar London had overgebracht en beschreven in zijn boek OrangOutang, sive Homo Sylvestris: or the Anatomy of a Pygmie compared with that of $a$ Monkey and Ape and a Man (1699). 
Volgens Tyson kon het agressieve gedrag van de antropoïden worden geillustreerd door enkele gevallen van kidnapping van een blonde vrouw door een aap, gevolgd door een beestachtige uitleving van al zijn seksuele lusten. ${ }^{6}$ In de eerste helft van de negentiende eeuw ontwikkelde deze bestiale fantasie van geslachtsgemeenschap tussen vrouw en aap zich tot een wetenschappelijke en literaire obsessie. Bekend is bijvoorbeeld The Murders in the Rue Morgue (I84I) van Edgar Allan Poe, waarin een orang-oetan twee vrouwen verkracht. Spoedig na zijn ontdekking in 1847 stootte de gorilla, de grootste, zwartste en schuwste onder de mensapen, over wie nog weinig bekend was, de orang-oetan van zijn troon en kreeg de reputatie de gevaarlijkste 'rape-ape' onder de mensapen te zijn. ${ }^{7}$ Het reisverslag Adventures and Explorations in Equatorial Africa van Paul du Chaillu (I86I) droeg hier in belangrijke mate aan bij. In navolging van Savage beschreef Du Chaillu in spierballentaal hoe hij als eerste blanke man een gorilla had doodgeschoten:

His eyes began to flash fiercer fire as we stood motionless on the defensive and the crest of short hair wich stands on his forehead began to twitch rapidly up and down, while his powerful fangs were shown as he again sent forth a thunderous roar. And now truly he reminded me of nothing but some hellish dream creature - a being of that hideous order, half-man half-beast [...] we fired, and killed him. (Du Chaillu 1945: 7I)

Net als de andere antropoïden was de gorilla volgens Du Chaillu een monsterlijk en gevaarlijk dier dat het met de mens kwaad voorheeft. Uitvoerig verhaalt $\mathrm{Du}$ Chaillu van rondgaande verhalen van de negerbevolking. Met name getrouwde vrouwen vreesden het dier. Behalve dat ze gekidnapt konden worden, bestond het gevaar dat, indien zij hun echtgenoot met het dier (levend of dood) zouden aantreffen, ze van een gorilla zouden bevallen. ${ }^{8} \mathrm{Du}$ Chaillu deelde echter met Savage de mening dat de rondgaande verhalen over de neiging van de gorilla om vrouwen te kidnappen klinkklare nonsens waren, te wijten aan 'false and vain imaginings of ignorant Negroes and credulous travellers' (347). ${ }^{9}$ Het beeld van de gevaarlijke gorilla die dol was op vrouwelijk schoon werd dan ook niet door hem, maar door zijn vriend P.T. Barnum verder gepropa- 
geerd. Deze stelde in zijn rondreizende circus in Europa de gorilla Gargantua tentoon onder vermelding van de tekst 'My Strength is as the Strength of Ten, but there's Murder in My Heart.' ${ }^{10}$ In deze traditie presenteerde een Franse beeldend kunstenaar in 1859 tijdens de Salon de Paris zijn sculptuur Gorilla Carrying off a Woman', een grote brute gorilla, met in de ene hand een steen en onder zijn andere arm een meisje. ${ }^{11}$

Bijna veertig jaar later, in 1923, nam de taxidermist Carl Akeley, die bezig was met een diorama van een opgezette gorilla-familie voor The American Museum of Natural History in New York, als eerste stelling tegen de manier waarop Paul du Chaillu de gorilla als monster had gepresenteerd. Hij stelde in In Brigthest Africa dat de gorilla juist een nobel en vredelievend dier was. 'I believe that the gorilla is normally a perfectly amiable and decent creature. I believe that if he attacks man it is because he is attacked or thinks that he is being attacked' (Akeley r923: 196). Akeley beschrijft dat de rondgaande verhalen van vrouwen-kidnappende apen - hoewel ontkend door Du Chaillu - hem ertoe hadden bewogen de vrouwen thuis te laten tijdens de jacht.

We had made good in our boasted undertaking of taking ladies on a real gorilla hunt, presumably the last word of danger and adventure in the popular mind. Another popular illusion gone to smash! It was adventure full of beauty and charm and hard work, but absolutely without danger. The gorilla is not dangerous, but he is impressive. (Akeley 1923: 232)

De opvatting dat de gorilla zachtaardig was, werd in 1929 gesteund door het echtpaar Ada en Robert Yerkes in een van de wetenschappelijke standaardwerken van de primatologie, The Great Apes. En ook zij stelden Du Chaillu verantwoordelijk voor het feit dat gorilla's decennialang ten onrechte als monsters waren afgeschilderd:

Following the discovery of the giant ape to science, and its establishment as a new genus of anthropoid, came its exploitation before the credulous public. For this the lay traveller and explorer Paul du Chaillu was chiefly responsible. The publication of his Explorations and Adventures in Equatorial Africa (I86I) marks the dramatic climax of his efforts. Lacking knowledge of biology 
and adequate scientific training, his statements and even his specimens from the first aroused the suspicion from scientific authorities. (Yerkes \& Yerkes 1929: 34)

Door de wetenschappelijke kwaliteiten van Du Chaillu in diskrediet te brengen, proberen de Yerkes mensen ervan te overtuigen dat hij een 'vals' beeld van de gorilla de wereld in heeft geholpen. Robert Yerkes suggereert voorts dat het Du Chaillu's eigen gedrag - namelijk het opzoeken van de confrontatie met de gorilla - moet zijn geweest die dit agressieve gedrag heeft uitgelokt bij de gorilla's. Hij stemt in met Akeleys visie en voegt eraan toe: 'Of the two, I was the savage and the aggressor:' (403) Anders dan Du Chaillu, omschrijven Ada en Robert Yerkes de gorilla als 'peaceful and shy'; 'certainly not by nature cruel, vindictive' (456). Het echtpaar Yerkes onderbouwt de poging tot rehabilitatie onder meer door te benadrukken dat de gorilla een vegetariër is, door veel tabellen op te nemen (waaronder een tabel de verschillende 'emotionele' gemoedstoestanden van de gorilla) en hun boek te illustrereren met veel foto's van gemoedelijk uitziende gorilla's. Martin en Osa Johnson (1931) droegen het gedachtegoed van Akeley en het echtpaar Yerkes verder uit in hun documentaire Congorilla uit 1931, een liefdevol portret waarin voor het eerste bewegende beelden van etende en spelende gorilla's in hun eigen omgeving werden getoond..$^{12}$

Desalniettemin bleef er de twijfel bestaan. Er was in de jaren dertig geen wetenschappelijke consensus over de aard van de gorilla en zijn natuurlijke gedrag jegens vrouwen. Zelfs het echtpaar Yerkes - dat zijn onderzoek hoofdzakelijk baseerde op de observatie van slechts één vrouwtjesgorilla (de 'zachte' sekse dus!), in gevangenschap - schreef aarzelend: 'It is far from easy to decide whether the animal is naturally cruel or kindly, sympathetic or unfeeling, selfish or altruistic, so great are the variations observed: (Yerkes 1929: 455) En het echtpaar Johnson mocht dan het medium van de documentaire film gebruiken om met het kwaadaardige beeld van de gorilla af te reken, de fictiefilm zette in de jaren twintig en dertig de traditie van de gorilla als moordzuchtig monster onverminderd voort. In de traditie van de junglefilm raakten filmmakers gefascineerd door nieuwe technische mogelijkheden die het zich snel ontwikkelende visuele medium bood om het prehistorische dier uit te beelden. ${ }^{13}$ Naast gevaarlijke dinosauriërs keerde 
met regelmaat een mensachtige en bloeddorstige mensaap terug. ${ }^{4}$ De ontstaansgeschiedenis van King Kong, die in de volgende paragraaf uiteengezet wordt, waarna een korte interpretatie van de film volgt, maakt zichtbaar welke beslissingen de filmmakers namen over de aard en de status van de gorilla, hoe wetenschappelijke debatten daarin een rol speelden en waarom er een meisje in de film kwam.

\section{KING KONG (I933)}

De representatie van de gorilla in de film King Kong sloot aan bij verschillende wetenschappelijke, literaire en filmische tradities. Eigenlijk was de gorilla het resultaat van een compromis tussen twee regisseurs. De ene regisseur Merian Cooper stond van meet af aan een moordend monster voor ogen, naar het model van zijn favoriete boek, het zojuist besproken Adventures and Explorations in Equatorial Africa van Du Chaillu (Goldner \& Turner 1976). De eerste gedachten van Ernest Schoedsack gingen echter uit naar een menselijke en sympathieke Kong. ${ }^{15}$ Een zwakke plek zou hem sympathiek maken, en die zwakke plek was een vrouw. Volgens Erb (1998: 3I-65) leverde Ruth Rose (Schoedsacks vrouw) een belangrijke bijdrage als scriptschrijfster. Zij legde de nadruk op de romance tussen Kong en het meisje, verzachtte daarmee de gorilla, en bracht naar haar eigen zeggen zo een 'woman's angle' in het verhaal. Een aspect dat volgens haar de film aantrekkelijker zou maken voor een breder publiek.

Het compromis dat de twee heren sloten, betrof om te beginnen het uiterlijk. Schoedsack, die zich wilde baseren op de wetenschappelijke feiten, belde uitvoerig met het New York Natural History Museum om exacte gegevens over de anatomie van een gorilla te verkrijgen; tevens werden daar verschillende geluidsopnamen van gorilla's gemaakt. Cooper, die vooral geïnteresseerd was in de technische spektakelmogelijkheden van het medium film, besloot echter op grond van deze informatie dat Kong op ten minste drie punten van een 'echte' gorilla moest afwijken. Ten eerste meende hij dat het geluid van een echte gorilla te zacht en te liefjes klonk. In plaats van de bandopnamen uit de dierentuin gebruikte hij daarom het vertraagd afgespeelde geluid van katten, terwijl hij voor Kongs impo- 


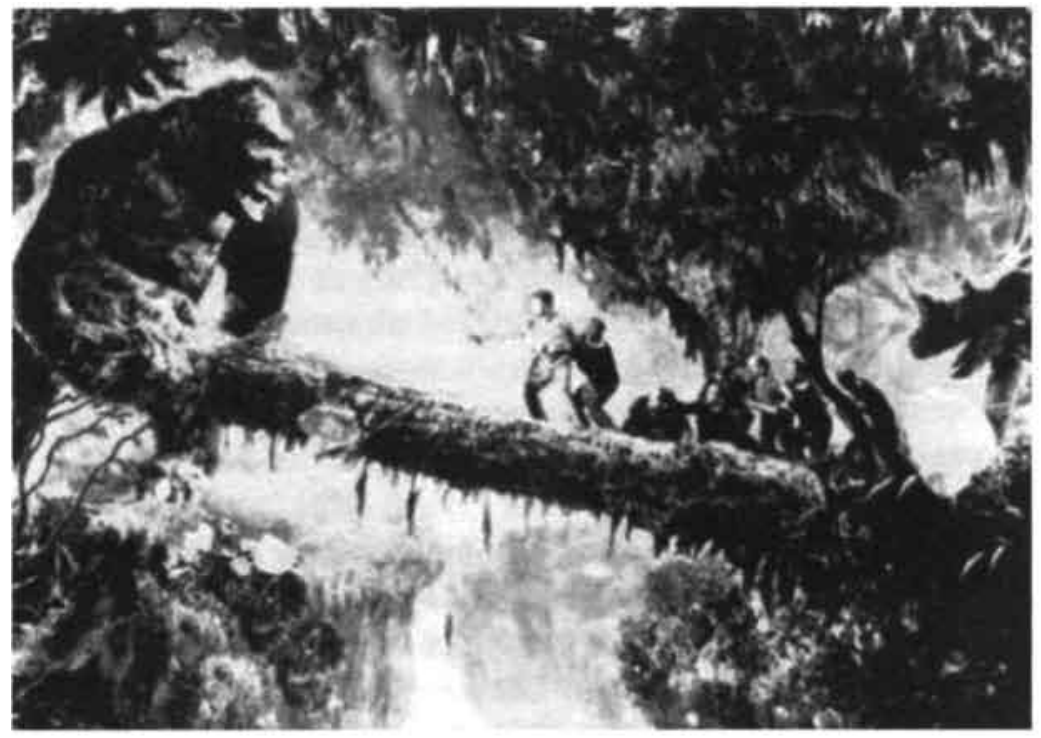

8 King Kong (1933).

sante borstroffel het versterkte geluid gebruikte van een borstroffel van een man. Een groot dier maakt een groot geluid, vond hij. Ten tweede negeerde Cooper de informatie die over de maten van een volwassen mannetjesgorilla werd ingewonnen. In plaats van 'approximately 67 inches', zoals de dierentuin berichte, werd King Kong ' 50 feet', letterlijk opgeblazen tot de mythische proporties van een reus. Ten derde miste Kong een penis, om, zoals vele Hollywood-producties uit die tijd, expliciete seksualiteit te verhullen. Wellicht maakte dat hem, meer in de lijn van Schoedsack, minder bedreigend. Gegeven de lengte en het gewicht van een gorilla, is zijn penis maar klein (gemiddeld vijf centimeter in erectie bij een volwassen mannetje). Paul du Chaillu verwijderde de genitalieën van de gorilla's die hij vanuit Afrika naar Europa bracht. Ramona en Desmond Morris opperen in Men and Apes dat Du Chaillu dit misschien deed om de onspectaculaire waarheid over de afmetingen van het geslachtsdeel te verbergen. Het zou het imago van de gorilla als agressief horrormonster en vrouwenverkrachter, zoals hij die had beschreven in zijn boek Adventures and Explorations in 
Equatorial Africa (1861), wellicht ondergraven. Mogelijkerwijze is dit ook de reden dat Kong geen penis heeft, hoewel de makers zich van de waarheid natuurlijk niks hadden hoeven aantrekken. Het lijkt er echter wel op dat zijn penis in één van de scènes symbolisch vervangen is door een boom. Daar houdt Kong een grote boomstam voor zich uit waar hij de mensen die hem belagen vanaf probeert te schudden. ${ }^{16}$ Interessant is ook dat alle interpreten van de film er automatisch vanuit zullen gaan dat King Kong een mannetje is, maar dat hier geen fysieke aanwijzingen voor zijn te vinden in de film. De gorilla is geslachtsloos en combineert in zijn gedrag allerlei 'mannelijke' en 'vrouwelijke' aspecten: beschermend als een vader, zorgend als een moeder, verongelijkt als een kind. Het is met name de romantische lijn, tussen de gorilla en het meisje, die 'heteroseksueel' wordt gelezen en die Kong tot 'het mannetje' ('he') maakt. Richten we ons op het eigenlijke verloop van de film, dan blijkt dat vooral de soort status van King Kong - mens, dier of god - voor de personages als voortdurend onderwerp van twijfel wordt opgevoerd.

De film begint in een haven. Het is een mistige avond en twee mannen met lange regenjassen staan voor een groot schip, Venture genaamd, dat morgen zal vertrekken. Aan boord bevindt zich, zo weten ze, de beroemde regisseur Carl Denham 'who ain't scared of nothing' en die een film gaat maken in 'jungle and places'. In de volgende scène maken we kennis met hem. Hij overlegt met Captain Englehorn, die zich zorgen maakt over alle gasbommen die Denham mee wil nemen. 'Did you ever hear of Kong?' vraagt Denham. Englehorn antwoordt: 'Some native superstition, isn't it? A god, or a spirit or something [...] Neither beast nor man. Something monstrous, all-powerful, still living, still holding that island in a grip of deadly fear' King Kongs status is onduidelijk: hij wordt hier in één adem genoemd als het product van bijgeloof van de eilandbewoners, een god, een geest en iets tussen mens en dier in.

Denham heeft intussen andere zorgen. Hij moet op zoek naar een mooie actrice voor de hoofdrol van zijn nieuwe film: 'The public, bless' em, must have a pretty face to look at... If this picture only had love interest it would gross twice as much.' Ann Darrow, een arm maar mooi weesmeisje, is de gelukkige. ${ }^{\nabla}$ Denham redt haar uit een penibele situatie: hij betaalt de appel die ze probeerde te stelen en belooft haar 'money, adventure and fame'. In de jaren dertig, tijden van depressie in de Verenigde Staten met meer dan twaalf mil- 
joen werklozen, moet het in de ogen van de kijker 'an American dream come true' zijn geweest. ${ }^{18}$ Denham, Ann en de crew zeilen naar het eiland waar ze Kong willen filmen. Op het eiland aangekomen zien ze een groep gekleurde eilandbewoners in apenpakjes een bizarre dans uitvoeren. Ze dansen om een op een altaar vastgebonden donkere vrouw, wier geslachtsdelen worden verborgen onder een krans bloemen. 'Kong Kong!' roept de menigte. Wanneer het opperhoofd de filmcrew ontdekt, is hij woedend dat de ceremonie is verstoord. Als hij Ann ziet, klaart zijn gezicht echter op. Hij wil haar onmiddellijk ruilen tegen zes van 'zijn vrouwen', als bruidsoffer voor het gorillamonster Kong. Denham weigert haar af te staan. Ann wordt daarom gekidnapt door inboorlingen, maar gelukkig weet de crew Ann te redden uit hun handen. Jack, een van de bemanningsleden, verklaart haar die avond zijn liefde. 'But you hate women!' roept Ann uit. ${ }^{19}$ 'You're not women,' mompelt Jack, en dat is voldoende: hun lippen ontmoeten elkaar in een vurige kus. Het prille geluk wordt echter wreed verstoord. Kong heeft een glimp van Ann opgevangen en kidnapt haar. ${ }^{20}$ Ann raakt buiten westen.

In de volgende scène inspecteert hij Ann. Voorzichtig pelt hij de kleding van haar af. Kong doet enerzijds aan als een grote kleuter die gefascineerd met een barbiepopje speelt. Anderzijds is er een erotische lading: hoe ver zal Kong gaan? Kong snuffelt zelfs aan Anns kleding: hij wappert met een stukje jurk heen en weer voor zijn enorme neusgaten om haar geur op te snuiven, een scène die door de makers uiteindelijk geschrapt werd, omdat te expliciet seksueel zou zijn. ${ }^{21}$ Als Ann bijkomt, kijkt ze Kong verschrikt met grote ogen aan, en spartelt vergeefs met haar benen. Kong kietelt haar een aantal keer met een van zijn reusachtige vingers. Wanneer hij lawaai hoort, laat hij Ann prompt uit zijn handen vallen; zijn aandacht is afgeleid. Opnieuw doet dat kinderlijk aan. Zowel Ann als King Kong zijn ambigu. Kong is kinderlijk en mannelijk tegelijkertijd, terwijl Ann slachtoffer is én een femme fatale: zich bewust van haar schoonheid - zoals al bleek op de boot waar ze Jack om haar vingers wond - die King Kong ten val brengt.

Jack, Denham en de overige bemanningsleden van het schip gaan achter Kong aan, een gevaarlijke onderneming waarbij enkele mannen sneuvelen tijdens aanvallen van slangen en andere griezelige grote op dinosauriërs lijkende dieren. Kongs kracht wordt gedemonstreerd door hem met gemak enkele van deze dieren te laten 


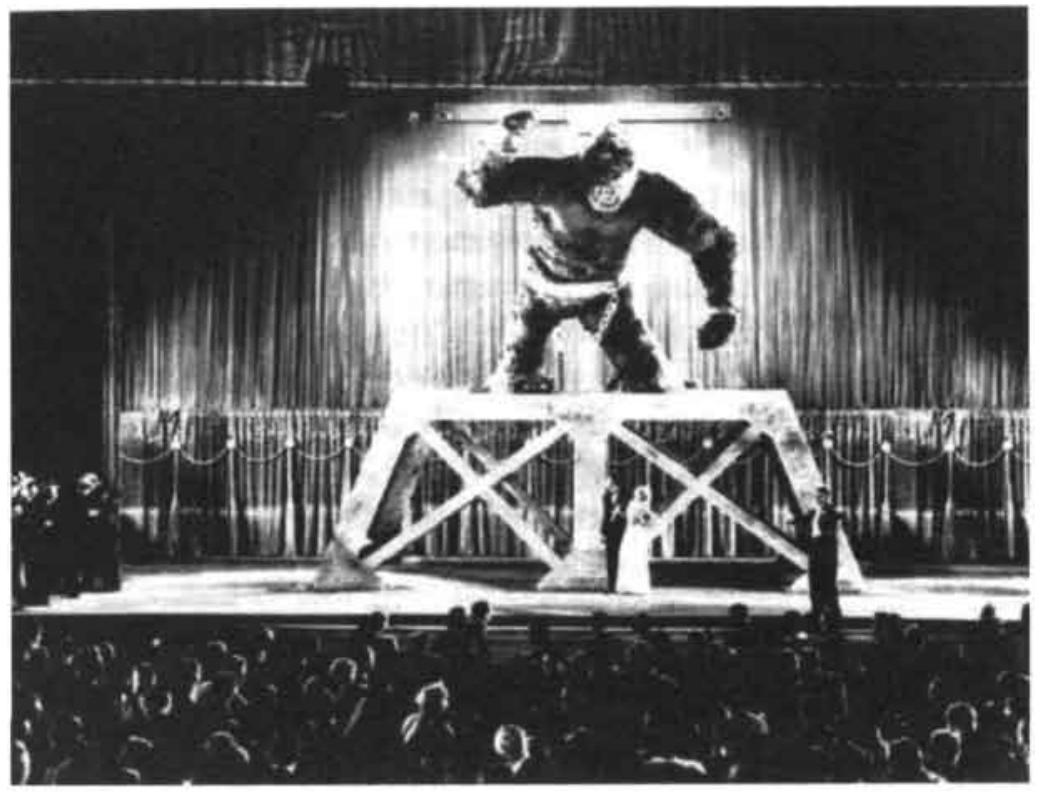

9 King Kong tentoongesteld in een theater in New York als Christusfiguur (1933).

verslaan. Uiteindelijk slagen de mannen erin Ann te bevrijden, en Kong met gasbommen te verdoven. Wanneer ze Kongs reusachtige lichaam naar het strand hebben gesleept, vraagt een van de bemanningsleden nog aarzelend wat voor soort dier het is: 'It is a gorilla, isn't it?'

Het dramatische hoogtepunt van de film is de scène waarin Kong, meegenomen naar New York, wordt tentoongesteld in een theater. Overal hangen posters in de stad die opnieuw zijn mysterieuze status en herkomst benadrukken: 'Kong, the Eighth Wonder of the World'. Het publiek loopt massaal uit. 'It's a kind of gorilla,' vermoedt één van de opgedofte gasten. 'Gee, haven't we got enough of them in New York already', grapt een ander terug. Dan verschijnt Denham op het podium. 'Ladies and gentleman, seeing is believing... I want you to see the greatest thing our eyes have ever beheld. He was a king and a god in the world he knew, but now he comes to civilisation merely a captive, a show to gratify our curiosity. Look at Kong, the eight wonder of the world!' Hier wordt Kong 
in een adem 'it', 'thing', 'he', 'king', 'god' en 'wonder' genoemd. Met 'it' and 'thing' krijgt Kong een dingachtige en dierlijke status; met 'he' een menselijke status, en met 'king', 'god' en 'wonder' een bovenmenselijke status. Als de gordijnen wegschuiven, zien we Kong, vastgeketend aan een stalen kruis. Deze voorstelling, de associatie van de aap met de aan het kruis genagelde Jezus (ook zijn naam doet denken aan 'Koning der Koningen' als men het tweede 'kong' leest als het Scandinavische 'konge' of het Duitse 'König') sorteert een dramatisch effect. ${ }^{22}$ Terwijl de kijkers in de zaal 'oooo' uitroepen, als ware Kong een 'freak', beziet de kijker van de film even de wereld vanuit Kongs standpunt omdat de camera, direct na een close-up van zijn droevige ogen, naar het publiek zoomt. Daarna zoomt de camera in op zijn ongelukkige uitdrukking: men begrijpt dat het hier om een groots lijden moet gaan. Enkele fotografen proberen een plaatje van hem te schieten, maar Kong, geïrriteerd door de onbehagelijke flitsen, weet uit zijn stalen ketens los te breken en stampt woedend op het publiek af. Hij loopt de straat op, walst auto's plat en stopt af en toe iemand in zijn mond om er even op te kauwen.

Door de wereld even vanuit Kong te laten zien en door de mensen in het theater met gorilla's te vergelijken ('Gee, haven't we got enough of them already in New York'), wordt enerzijds de continuiiteit tussen de mens en de gorilla benadrukt. Anderzijds wordt Kong met zijn woedeaanvallen tentoongesteld als een bedreiging voor de mens. Maar de gorilla wordt alleen kwaad wanneer hij daartoe wordt geprikkeld. Dat gebeurt bijvoorbeeld wanneer de fotografen hinderlijke flitslichten op hem afvuren, of wanneer Ann van hem wordt afgepakt. Dit doet sterk denken aan de opvatting van het echtpaar Yerkes: 'If he attacks man it is because he is being attacked or thinks that he is being attacked.'

In de slotscène dendert Kong door de straten van New York op zoek naar Ann, die een hotelkamer is ingevlucht. Wanneer hij haar gevonden heeft, neemt hij haar mee het Empire State Building op. Daar wordt de verliefde gorilla door bommenwerpers bekogeld. King Kong kijkt gekweld de camera in, valt dan naar beneden en sterft. Jack en Ann vallen elkaar opgelucht in de armen en Denham spreekt zijn beroemde woorden. 'It was beauty killed the beast.'

Voor de constructie van King Kong baseerden de makers zich deels op 'nieuwe' wetenschappelijke feiten waarin de zachtaardige 
kant van de gorilla werd benadrukt; deels baseerden zij zich op de 'mythe' van de aap als vrouwenverslindend monster, zoals die bijvoorbeeld door Edgar Allen Poe en Du Chaillu naar voren was gebracht. De ambiguïteit van King Kong, wat soort, gender, race en seksualiteit betreft, komt op allerlei manieren in de film naar voren: soms wordt hij met mensen vergeleken, dan weer wordt zijn dierlijkheid benadrukt, en soms groeit hij uit tot een godheid. Zijn geslacht is niet altijd duidelijk (geen penis) en hij wordt gepresenteerd als koning van de inheemse bevolking van het eiland, die er als 'mini-King Kongs' uitzien. Of hij nu wel of niet een 'vrouwenverkrachter' is, wordt ook niet duidelijk; de suggestie is er, maar hij valt Ann niet daadwerkelijk lastig. De gorilla schommelt wat aard betreft tussen de opvattingen van Du Chaillu en de Yerkes' in: hij is zachtén kwaadaardig.

\section{KONG ALS ANDER}

king kong according to the new york times

is a metaphor for:

'the Natural Child, the Last Romantic

the Noble Savage, the Oppressed Proletarian,

the Black man entering modern history in chains

the Third World Emissary:

well

what $i$ wanna know is

what about king kongs wife \& his kids

mrs kong \& the little kongs

whatever happened to them after he deathwished \& tripped

himself right

outta their lives

did they have an insurance policy to fall back on

simian social security?

Hattie Gossett, Fragment uit 'king kong! kingg kongg!! kinggg konggg!!' (1998) 
King Kong stierf op het witte doek, maar hij leefde door in de westerse cultuur. Toeristen die het Empire State Building bezoeken, laten zich nog altijd giechelend fotograferen met een opblaasgorilla en kopen knuffel-King-Kongs voor hun kinderen. Kong keerde terug in zowel 'wetenschap' als 'cultuur', en daarbinnen zowel de 'hoge' als de 'lage' cultuur. Met name in de jaren tachtig en negentig, onder invloed van filmwetenschappen, gender- en black en cultural studies, waar een groeiende belangstelling voor de populaire cultuur waarneembaar is, verschenen ook veel academische interpretaties van de film, en hebben verschillende cultuurcritici geprobeerd om de betekenis van de love story tussen de aap en het meisje te doorgronden. In deze paragraaf maak ik een selectie van interpretaties uit de (populaire) cultuur en van enkele cultuurcritici. Wat soort en gender betreft, wordt Kong in de populaire cultuur en door cultuurcritici vrijwel altijd gezien als een mens van het mannelijk geslacht. Sommigen voegen daar race aan toe: hij is een zwarte man. Over zijn aard is men het niet altijd eens: mede afhankelijk van hoe de relatie met het meisje wordt geïnterpreteerd, is Kong als een kwaadaardige agressor beschouwd of als een zachtaardig slachtoffer. Wordt Kong als onschuldig slachtoffer gezien, dan kan hij goddelijke proporties krijgen en uitgroeien tot Christusfiguur. Ik begin echter met wat in eerste instantie veel vaker gebeurde: Kong opgevat als 'killer king'.

Vaak is King Kong geïnterpreteerd als kwaadaardig. De gorilla staat in de top honderd aller tijden. Hij is 'a mighty black killer' in 'The King Kong Song' van de Zweedse popgroep Abba en The Kinks stellen de aap in het nummer 'King Kong' (r969) voor als een machiavelliaan met een machinegeweer: 'I'm King Kong and I'm ten feet long / got a big six gun and everybody is scared / I'm King Kong, got a hydrogen bomb / I can blow up your houses so you better beware. ${ }^{23}$ Wanneer Kong als een kwaadaardig monster wordt gezien, is zijn relatie met Ann ondubbelzinnig: hij is de killer/rapeman en Ann zijn slachtoffer. Schrijvers zo divers als Jeanette Winterson en Thomas Pynchon verwezen in hun werk naar de gorilla, respectievelijk in Written on the Body (1992) en Gravity's Rainbow (1973), waarbij zij vooral de nadruk legden op King Kong als seksuele agressor. ${ }^{24}$ Sommige feministen hebben Kong opgevat als symbool voor de mannelijke verkrachter of als een reproductie van het stereotiepe 'beauty and beast'-thema, waarin het monster gevoelig blijkt voor het vrouwelijke schoon (Warner 1996). Volgens een eer- 
dere, freudiaanse lezing van de film was de keuze voor het Empire State Building niet toevallig: 'Skyscrapers are, of course, phallic symbols, and Kong is made to cling to the tallest of them all'. (Morris \& Morris 1966 : $5 \mathrm{I}$ )

De scherpste cultuurkritische interpretatie kwam uit de hoek van de black studies. Volgens diverse interpreten is de film racistisch. Kong zou niet alleen een kwaadaardige man, maar een zwarte moordlustige man zijn. Hij zou staan voor de monsterlijke zwarte ander, die een bedreiging vormt voor de westerse beschaving, en het bovendien op de blanke westerse vrouw heeft gemunt. Daarmee is King Kong een blaxploitation film (Snead 1994).

Er zijn inderdaad goede redenen om King Kong als zwarte ander te interpreteren; de film maakt deel uit van een koloniale iconografische en ethnografische traditie waarin zwarte mensen als apen worden voorgesteld (Jahoda 1999; Tobing Rony 1996). De zwarte eilandbewoners dragen ridicule kostuums die naar circusapen verwijzen. De oorspronkelijke bruid van Kong, een zwijgzame naamloze donkere vrouw, is niet goed en mooi genoeg voor Kong en wordt vervangen door een blanke blondine. Fatima Tobing Rony vertelt in haar studie The Third Eye. Race, Cinema and Ethnographic Spectacle (1996) dat ze zich, ook in de jaren negentig, als zwarte vrouw ongemakkelijk voelt wanneer ze de film ziet: I am watching myself being depicted as Savage. I am the Bride of Kong.' (Tobing Rony 1996: 3) Zij beschouwt de film als een visueel spektakel, waarin zwarten worden voorgesteld als 'freakish ethnographic specimens' (159). Paul Hoch schreef in zijn boek White Hero, Black Beast (1979) dat de blanke man als held naar voren kan komen, omdat hij de blanke vrouw, door Hoch 'het centrum van de westerse witte civilisatie' genoemd, beschermt tegen de zwarte man, afgebeeld als een beast, een zwarte aap: 'The threatened assault of the blonde goddess by the black ape seems to have become America's archetypal nightmare: the monstrous beast running "amok" among the white virgins at the very core of Western civilisation' (48). Kong moet dood: 'By seeking the white goddess he committed the supreme racial sin'(49). ${ }^{25}$ King Kong symboliseert het zwarte gevaar, en als zodanig betekent zijn dood de uitroeiing daarvan. Kong wordt vermoord en het blanke heterohuwelijk zegeviert.

King Kong werd, kortom, in de zwarte traditie het symbool van raciale uitbuiting. Nobelprijswinnaar Derek Walcott verwijst na- 

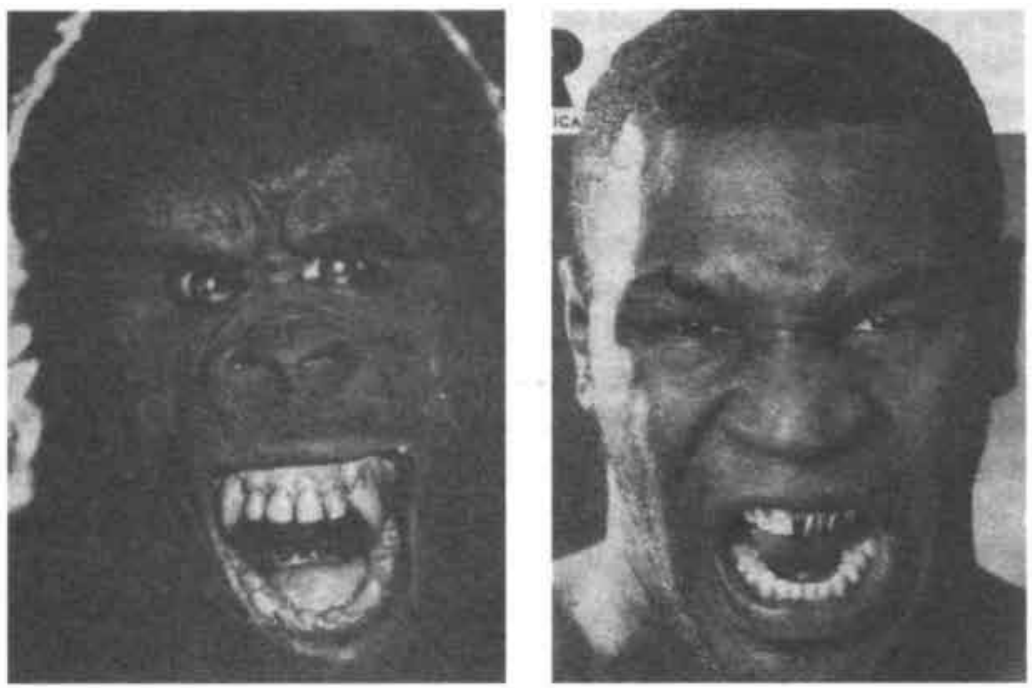

ro King Kong en Mike Tyson.

drukkelijk naar de interpretatie van King Kong als zwarte man wanneer een zwarte crimineel voor 'King Kong' en 'gorilla' wordt uitgescholden in zijn toneelstuk Dream on a Monkey Mountain (1970: 279). Een van de meest frappante voorbeelden van een meer positieve toe-eigening van King Kong als zwarte 'killer king' en black powwer is de wijze waarop de zwarte bokser Mike Tyson - om zijn vechtlust duidelijk te maken - zich tijdens zijn carrière liet portretteren als King Kong. ${ }^{26}$

Maar, als Kong inderdaad het zwarte monsterbeest voorstelt en de film racistisch is, waarom voelen 'we' dan ook medelijden en sympathie met de grote aap? Waarom spreken sommige interpreten, bijvoorbeeld Hoch die King Kong 'Othello' noemt, van een tragische dood? Meedenkend in de symbolische lijn van de cultuurcritici, zou je kunnen zeggen dat King Kong door de blanke mannen wordt vermoord omdat hij als 'zwarte ander' te dichtbij komt: in zijn affaire met het blanke meisje overschrijdt hij het taboe op interraciale relaties, omdat hij een lieve 'neger' is.

Sommige interpreten beschouwen Kong zelfs helemaal niet als een agressor, maar als een zachtaardige held, een onschuldig slachtoffer en een sympathieke outsider. Erb laat in haar studie 
naar de receptie van King Kong, Tracking King Kong (1998), zien dat Kong niet alleen voor heteroseksuelen een identificatieplek biedt, maar dat verschillende groepen mannen, 'mainstream', 'gay' en 'black', zich met King Kong identificeren. De zwarte man die zegt zich tegenover een blanke vrouw als King Kong te voelen, ziet King Kong als symbool voor de angstaanjagende zwarte ander. In de mainstream-receptie (dat wil zeggen blanke mannelijke receptie) is Kong sterk veelal geseksualiseerd en geromantiseerd, maar wordt hij ook 'gederacialiseerd'. Werd King Kong enerzijds voor heteroseksuele blanke mannen een symbool voor viriliteit en mannelijkheid - getuige bijvoorbeeld een Amerikaanse reclame waarin een populaire blanke acteur poseert in een King Kong-jas ${ }^{27}$ - anderzijds is de gorilla, misschien wel dankzij zijn vrouwelijke en zachtaardige eigenschappen, ook een campfiguur geworden in de jaren zestig en zeventig, en ingezet als symbool voor de 'softe' man, de uitgestoten blanke mannelijke homo. ${ }^{28}$

King Kongs ambiguiteit staat toe dat hij meerdere rollen op zich kan nemen - macho én mietje - en als zodanig werden hij en Ann in de strijd tussen de seksen een geliefd thema voor parodieën en humor. ${ }^{29}$ In de jaren negentig duikt Kong op als de onschuldige en Ann als de werkelijke agressor; de aap wordt gemanipuleerd en is een slachtoffer van de charmes van een femme fatale. In een van de afleveringen van de populaire televisieserie Ally McBeal (1999) scheldt de jonge succesvolle advocate Ally McBeal - bepaald niet zachtaardig - seksistische mannen uit voor een 'male chauvinist King Kong pig'. De gedupeerde mannen kijken wat beteuterd toe. En het stripmagazine MAD laat zien hoe de arme gorilla tranen met tuiten huilt omdat de wrede Ann het lieve dier onaardig behandelt en krijst: 'EEK... EE... OO... O1... Filthy beast! Don't touch me!' ${ }^{30}$ De rollen van 'beauty' en 'beast' zijn onder invloed van maatschappelijke en culturele ontwikkelingen (zoals het fenomeen girlpower) omgedraaid: Ann wordt voorgesteld als een 'beast' die de zachtaardigheid, de 'beauty' van de man/gorilla niet onderkent.

Niet altijd wordt de relatie tussen de aap en het meisje echter als geseksualiseerd voorgesteld. King Kong is in de verfilming van John Irvings The Cider House Rules (2000), geïnterpreteerd als verlaten weeskind, en Ann als zijn moeder. ${ }^{31}$ Soms verdwijnt het meisje helemaal op de achtergrond, en gaat het om King Kong tegenover de rest van de wereld. In de populaire cultuur is de gorilla vaak ver- 
beeld als (zwarte) Christusfiguur. ${ }^{32}$ Bumperstickers met de tekst 'King Kong died for your sins' worden nog steeds verkocht. Net als Christus wordt King Kong onschuldig geofferd en aan het kruis gehangen. Ook zou zijn val staan voor het Amerikaanse onbegrip tegenover joodse immigranten in de jaren dertig. ${ }^{33}$

Hoe je tegen de dood van King Kong aankijkt, hangt mede af van de wijze waarop je zijn relatie met Ann interpreteert. Meedenkend in de lijn van de gender- en blackstudies cultuurcritici, lijkt de dood van King Kong bijvoorbeeld vooral de oplossing voor het probleem van de witte heteroseksuele man. De gorilla wordt door blanke mannen gedood en zo wordt het 'zwarte' monsterbeest uitgeschakeld. Snead voegt hieraan toe dat King Kong voor witte heteroseksuele mannen vooral fungeert als een projectiefiguur waarop zij hun heimelijke verkrachtingsfantasieën kunnen projecteren. Volgens de historicus Thomas F. Gossett is het een vaak voorkomende fantasie - de witte man die zich met het zwarte mensbeest identificeert: 'they wish they could be negroes, at least on Saturday nights. ${ }^{34}$ (geciteerd in Hoch 1979: 55) Snead stelt dat de witte man zich zo schuldig voelt over zijn heimelijke verkrachtingsverlangens dat de aap dood moet: de dood van King Kong betekent de verlossing. ${ }^{35}$ De zwarte kijkers en de witte vrouw blijven na Kongs dood wat verloren achter. De witte vrouw kan zich nog proberen te concentreren op het witte heterohuwelijk, maar de zwarte kijker moet met lede ogen toezien hoe Kong, de zwarte viriele gentleman, van het scherm is geveegd.

Kongs ambiguiteit is moeilijk verdraagbaar en tegelijkertijd maakt zijn meerduidigheid hem tot een flexibele projectiefiguur. Omdat Kong bijna alle aspecten van 'anders-zijn' in zich verenigt (hij is zwart, dierlijk en vrouwelijk), identificeren vrijwel alle kijkers, zowel witte als zwarte mannen en vrouwen, zich met Kong. Het hangt af van de sociale en ideologische positie van de kijker, en de historische context waarin deze de film ziet, naar welke kant de balans doorslaat, of hij als kwaadaardig of zachtaardig wordt beschouwd. King Kong werd in de loop van de receptiegeschiedenis steeds 'zachtaardiger' en, mede onder invloed van de kritische black studies en de veranderende maatschappelijke verhoudingen, meer als 'slachtoffer' en 'outcast' geïnterpreteerd, als projectiefiguur van een blanke mannelijke fantasie, en bijvoorbeeld als zwarte man, homo, jood, Jezus, en soms verschillende combinaties tegelijkertijd: 


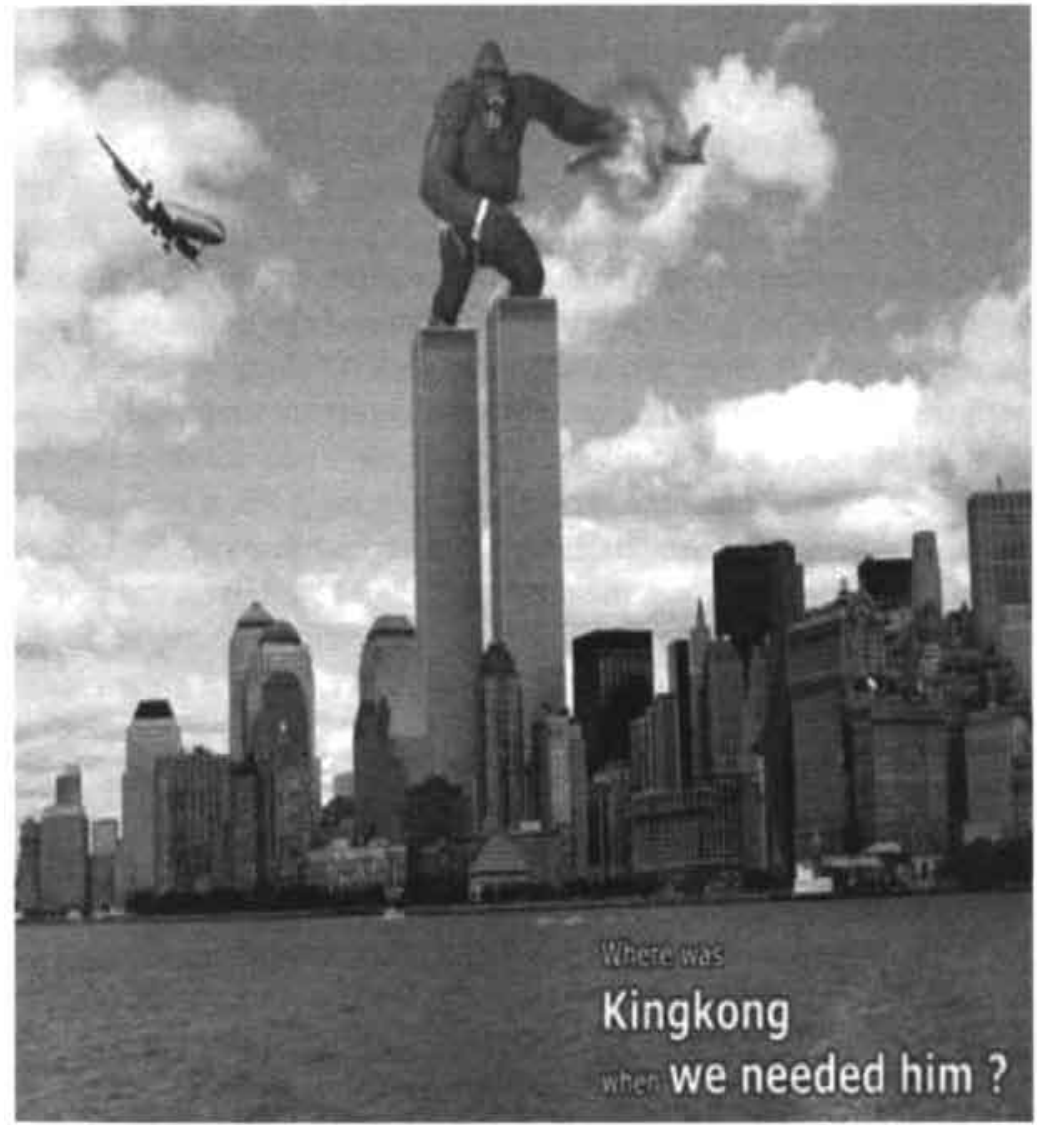

u King Kong op de Twin Towers.

'zwarte Jezus' bijvoorbeeld. Kong vertegenwoordigt het 'goede' dat het 'kwade' kan verdrijven, getuige bijvoorbeeld de afbeelding die werd gemaakt na de terroristische aanslagen op het World Trade Center op II september 2oor. King Kong staat op de Twin Towers vliegtuigjes van zich af te slaan, en we lezen: 'Where was King Kong when we needed him?'36 Ann daarentegen wordt van een slachtoffer steeds meer opgevat als een manipulatieve femme fatale die haar charmes welbewust inzet om de aap om haar vingers te winden. 
Kortom, de culturele receptiegeschiedenis van King Kong maakt steeds een worsteling zichtbaar met de aard en de status van de gorilla. Is hij menselijk of zelfs goddelijk (reminiscenties aan Christus)? Vrouwelijk of mannelijk? Is hij zachtaardig of kwaadaardig? De keuze van zijn aard, die mede afhangt van hoe de relatie met het meisje wordt geïnterpreteerd, bepaalt of Kong als mens, dier of als Christus wordt gezien (soort), als verkrachter, homo of weeskind (gender/seksualiteit), als zwarte verkrachter of als joodse of zwarte outcast (race). Dankzij zijn ambigüteit is King Kong in deze interpretaties zowel 'norm' (de man als verkrachter) als 'ander' (de zwarte outcast). De 'ander' kan van alles zijn, zo blijkt uit de receptiegeschiedenis. In de remakes en sequels van King Kong zien we dat ook terug. Veranderde maatschappelijke verhoudingen beïnvloeden de interpretatie van Kong, die dankzij zijn ambiguïteit meerdere betekenissen kan krijgen en uitgroeit tot een projectiefiguur, en zo de gemoederen blijft bezighouden.

\section{VAN SON OF KONG TOT QUEEN KONG}

$\mathrm{Na}$ het succes van King Kong besluiten Schoedsack en Cooper al spoedig tot het maken van een vervolg. Ofschoon Kong in de oorspronkelijke film 'de enige in zijn soort' wordt genoemd - een mevrouw Kong ontmoeten we niet, noch weten we wie zijn vader of moeder zijn - blijkt King Kong op miraculeuze wijze een zoon te hebben in Son of Kong (1934). In deze film is de gorilla overigens niet meer zwart, maar veel witter, alsof hij omgeven is door een lichtkrans, hetgeen, net als zijn naam, opnieuw associaties met Jezus oproept. ${ }^{37}$ De film begint met een shot van een poster van King Kong. Denham kijkt ernaar en betuigt zijn spijt voor de kidnapping van Kong naar New York. Hij zegt iets te willen doen voor Kongs nazaten: 'I know it sounds funny, but... I felt I owed his family something: Opnieuw reist Denham met een filmploeg af naar een onbewoond eiland, waar ze een grote gorilla aantreffen die dreigt te verdrinken in drijfzand. Gelukkig weten de mannen, die zich als helden gedragen, de gorilla te redden. De gorilla, die de zoon van King Kong blijkt te zijn en ook de naam van zijn vader draagt, hoeft dan ook niet van zich af te bijten en gedraagt zich lief. De crew kan 
echter niet voorkomen dat ook King Kong junior, net als zijn vader, aan het eind van de film aan zijn verwondingen sterft.

De dood van King Kongs zoon weerhield de makers er niet van ook nog eens te komen met een kleinzoon in Mighty Joe Young (1949), waarin een reuzengorilla is uitgegroeid tot grote kindervriend en kinderen gaat redden uit een brandend huis. Daarmee is in beide films de liefdesrelatie tussen de vrouw en de gorilla op de achtergrond geraakt en elke erotische spanning verdwenen. De relatie tussen de heldin van de film en de gorilla is niet als die tussen een man en een vrouw, maar lijkt op die van een moeder en een kind. ${ }^{38}$

Bovengenoemde remakes van King Kong, waarin de gorilla een ondubbelzinnig zachtaardig karakter heeft, oogsten minder succes dan het origineel of flopten zelfs (Erb 1998). In de latere King Kongfilms werd dan ook weer de nadruk gelegd op de boosaardige kanten van King Kong. Films als King Kong versus Godzilla (1963), waarin King Kong het Japanse monster Godzilla ontmoet, en King Kong escapes (1967), waarin King Kong de strijd aanbindt met een robot-replica van zichzelf, portretteerden de gorilla als een gevaarlijke moordmachine. In de Amerikaanse versie van de film wint King Kong de strijd, de Japanners maakten hun eigen versie met daarin een overwinning voor Godzilla. De liefdesgeschiedenis is helemaal op de achtergrond geraakt, en het is vooral de Koude Oorlog die in deze films als historische context figureert waarin King Kong onder meer de strijd aanbindt tegen communisten. Deze films zouden echter nog minder publiek trekken dan eerdere remakes en nooit het grote publiek bereiken zoals de originele King Kong en de vervolgfilms Son of Kong en Mighty Joe Young. Wel kregen deze films een cultstatus; wie de King Kong-films wil zien, kan daarvoor tegenwoordig terecht bij cultvideotheken.

In 1976 verschijnt een remake van de originele King Kong van de regisseur John Guillermin waarin de erotische relatie tussen de vrouw en de aap weer een centrale plaats in neemt. Werden de scènes waarin Kong de kleding van Ann van haar lichaam pelt en eraan ruikt in 1933 erotisch te expliciet bevonden, in deze film verschijnt Jessica Lange in haar rol van Ann in een gerafeld jurkje dat binnen de kortste keren doorzichtig wordt als ze een bad neemt in een waterval. Terwijl de grote zachtaardige gorilla liefdevol toekijkt naar het waterballet van Ann, zwelt romantische muziek aan en kreunt Ann een paar keer van genot. De kijker wordt voortdurend 


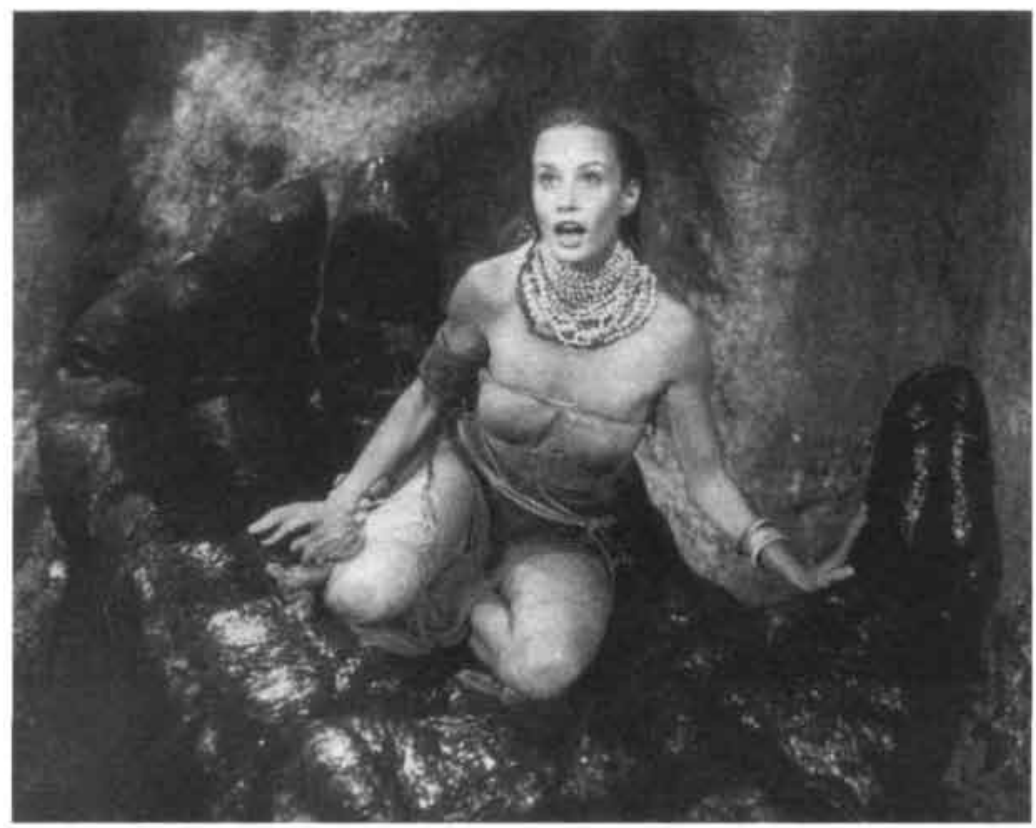

12 Jessica Lange en King Kong in King Kong (1976).

geprikkeld om zelf een stapje verder te denken. Vreemd genoeg is deze film, hoewel seksueel explicieter, minder spannend dan de originele King Kong. King Kong heeft zijn ambiguïteit verloren, en dat geldt ook voor Ann. Kong is zachtaardig en Ann schreeuwt niet meer van angst, maar kirt van vreugde en genot, terwijl King Kong zachtjes haar haren droogblaast. Met het opheffen van de dubbelzinnigheid, is ook de spanning opgeheven.

Pogingen om de traditionele rollenpatronen kritisch om te buigen (de vrouw vindt het geluk in een huwelijk met een witte man en moet oppassen voor enge zwarte apen die haar belagen) kwamen er ook. Queen Kong (1976) was een feministische parodie op King Kong. ${ }^{39}$ Daarin zien we hoe regisseuse Luce Habit haar zinnen zet op Ray Wray (een variant op Fay Wray die in 1933 de rol van Ann speelt), in haar ogen een macho, als de nieuwe hoofdrolspeler van haar film. Hij steelt een originele King Kong poster uit I933 maar wordt door Ann betrapt. Luce neemt hem mee op haar schip The Liberated Lady en vaart met hem naar Afrika, waar 


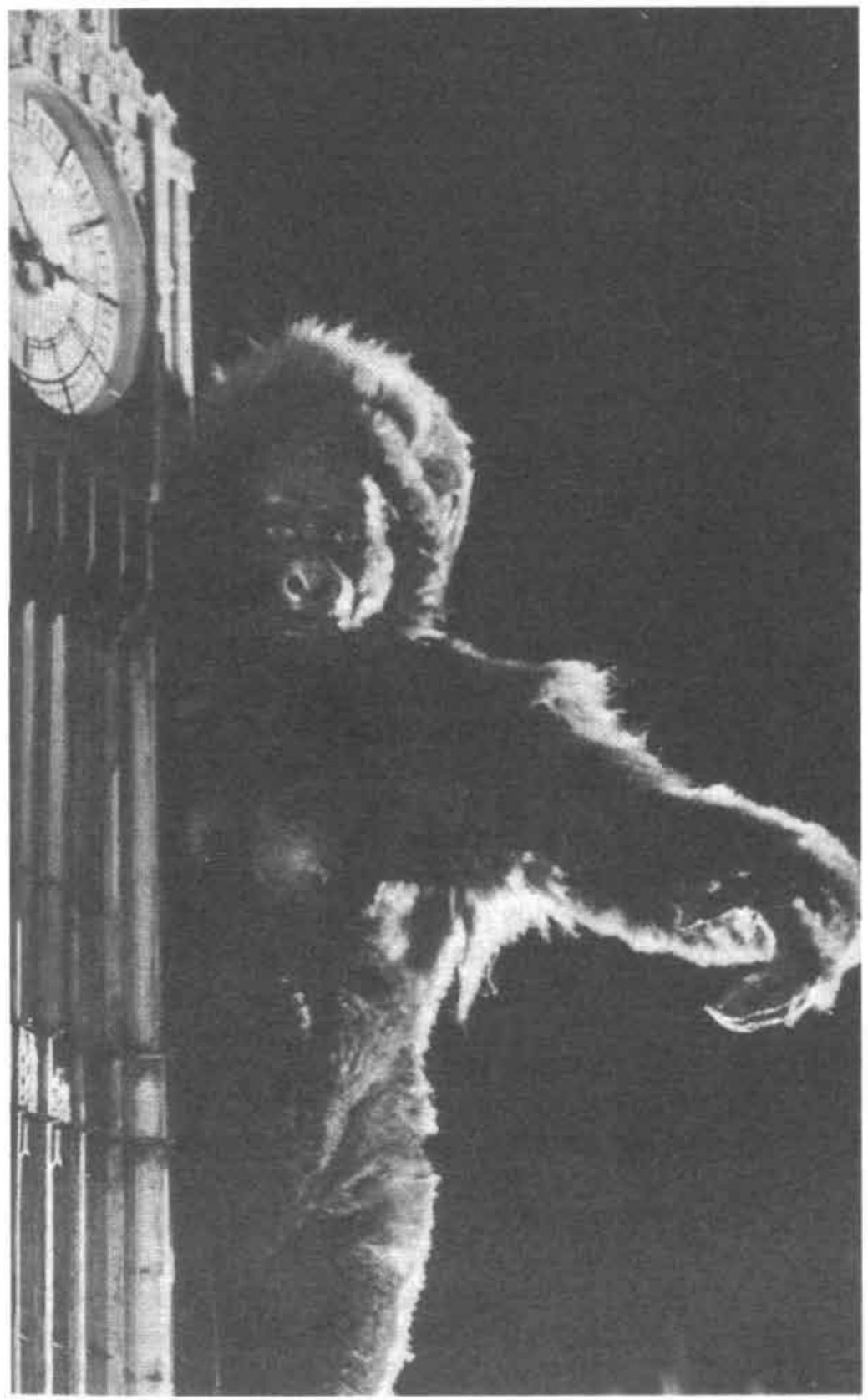

13 Queen Kong gaat de Big Ben op. 
Queen Kong, de grote vrouwtjesgorilla, hem kidnapt. Queen Kong wordt door de crew meegenomen naar Londen, waar alle macho's op haar jagen. Ze beklimt de Big Ben. Ray Wray is inmiddels hartstochtelijk verliefd geworden op Queen Kong, die, zoals hij inziet, het lot van alle onderdrukte vrouwen symboliseert. De film heeft een happy end: Ray en Queen Kong zijn dolgelukkig samen. De film flopte jammerlijk. Een monsterlijke vrouwtjesaap die op mannenjacht gaat, kon het publiek niet bekoren. De flop werd verklaard door de hardnekkigheid van bepaalde genderconventies (Annan 1976). Het publiek wil datgene wat 'klassiek' was aan een klassieker intact zien: the beauty is een vrouw, the beast een mannetje.

In King Kong Lives (1986) poogt Guillermin de klassieke succesformule te combineren met de boodschap van vrouwelijke zelfstandigheid uit Queen Kong. In King Kong Lives wordt King Kong na zijn val van het Empire State Building, uit zijn 'coma' gered door een succesvolle operatie door een vrouwelijke chirurg. De gorilla krijgt een gigantisch kunsthart. De benodigde bloedtransfusies komen van een grote vrouwtjesgorilla, die door een jonge aantrekkelijke ondernemer in het oerwoud is gevangen. Er ontwikkelt zich een relatie tussen de vrouwtjesgorilla en King Kong en deze relatie wordt gespiegeld (met dezelfde scènes) door de opbloeiende liefde tussen de dokter en de ondernemer. 'We too are primates,' zegt de ondernemer halverwege de film nog eens om de continuïteit tussen de gorilla's en de mensen te onderstrepen. Toch geldt de overeenkomst niet voor alle mensen. Sommige slechteriken pesten en plagen de grote gorilla's. Maar zij krijgen hun verdiende loon en worden, desnoods, door de mannetjesgorilla opgegeten (het vrouwtje blijft zachtaardig). Ook deze film mist wat de eerste King Kong tot een succes maakte: de grensoverschrijdende suggestie van bestialiteit. Soms wordt er gezinspeeld op erotiek tussen de vrouwelijke chirurg en King Kong en de vrouwtjesgorilla en de entrepreneur, maar de film windt er geen doekjes om: soort zoekt soort.

In de remakes en sequenties van King Kong, alsmede de receptie daarvan, zien we dat beslissingen worden genomen over de aard en het gedrag van King Kong. De King Kong-verfilmingen maken een ondubbelzinnige keuze tussen Kong als zachtaardig of moordzuchtig monster. De voor het grote publiek bedoelde remakes kozen ervoor om Kong steeds zachtaardiger (en ook witter en vrouwelijker) 
te maken, terwijl de kleine producties in de jaren zestig King Kong reduceerden tot een agressor. Kong is, zo kunnen we concluderen uit de culturele receptiegeschiedenis, een projectiefiguur wiens ambiguïteit keer op keer wordt vermoord.

\section{GORILLA'S UIT DE MIST}

Orville Goldner en George Turner, de schrijvers van The Making of King Kong (1976), wuifden de groeiende seksisme- en racismekritiek die in de jaren zeventig de kop opstak luchtig van de hand, door erop te wijzen dat de filmmakers zich veel moeite getroost hebben om wetenschappelijke informatie te verzamelen over gorilla's: 'Kong was not darker in hue than any other gorilla [...] he smashed the gates solely because he wanted to recapture Fay Wray. Goldner en Turner doen een stapje terug van de symbolische interpretatie van de aap als maatschappelijke ander, door Kong in eerste instantie te beschouwen als een representatie van een gorilla. King Kong heeft mede vanwege zijn prominente aanwezigheid in de populaire cultuur - niet alleen veel reacties opgeroepen vanuit de hoek van cultuurkritische filmwetenschap, maar vanaf de jaren r970 ook vanuit de primatologie. In deze paragraaf wil ik het contrast zichtbaar maken met de culturele interpretaties van King Kong.

Anders dan de filmwetenschappers beschouwden wetenschappers, net als Goldner en Turner, King Kong niet als een mens (vrouwenverkrachter of de zwarte ander), maar als een valse representatie van een gorilla. Dian Fossey zette King Kong zelfs in de beklaagdenbank: volgens haar was het de schuld van de Hollywoodaap dat de echte gorilla's uitgemoord worden. In aansluiting op George B. Schaller, die als eerste een grootschalig veldonderzoek opzette en in zijn The Year of the Gorilla (1964) afrekende met Du Chaillu's beeld van de kwaadaardige gorilla, stelde Fossey dat gorilla's in werkelijkheid geen 'killer kings à la King Kong' waren, maar 'gentle giants' zijn. 'Fictionalized portrayals of gorilla savagery toward humans are grossly exaggerated, schreef Fossey in National Geographic. (Fossey 1970: 54) In een interview naar aanleiding van deze publicatie, gaf Fossey een voorbeeld van een 'fictionalized portrayal' van de gorilla onder verwijzing naar 'King 
Kong and other ancient and false myths about the ferocity of the gorillas. Gorillas, no matter how fierce they look, are gentle, playful, shy and good to each other, more likely to flee than fight. They don't want to eat you. They are vegetarians. ${ }^{140}$ Het dieet van de gorilla bestaat, zo suggereerde Fossey, niet uit New Yorkers, maar uit groenvoer. Ook andere bekende primatologen, bijvoorbeeld Frans de Waal, verwezen in hun werk naar King Kong, om 'mythe' van 'echt' af te bakenen en zo de contouren van een 'echte' gorilla scherp neer te kunnen zetten: 'the gorilla (gorilla gorilla) is the King Kong of Hollywood fame...[But] only in extreme cases, such as when they defend their family group against hunters, do they attack people. They really are gentle giants.' (De Waal 1997: 18).

Net als het echtpaar Yerkes pogen de primatologen daarmee scherpe scheidslijnen tussen enerzijds 'fictie', 'mythe' en 'verbeelding' en anderzijds 'feiten', 'wetenschap' en 'waarheid' te trekken. Met het construereren van de grenzen tussen fictie en wetenschap, worden ook de grenzen tussen menselijk en dierlijk geconstrueerd. King Kong wordt ingezet om de contouren van de 'ware aard' van de gorilla duidelijk neer te zetten. Het aanbrengen van scheidslijnen tussen 'echt' en 'vals' is een strategie van de wetenschap om zich te onderscheiden van fictie.

De mythe dat gorilla's gevaarlijk zijn, heeft volgens wetenschappers louter te maken met hun uiterlijk, de norse gezichtsuitdrukking en het imposante gebit. Zo beschrijft Fossey bijvoorbeeld hoe ze een foto wilde nemen van haar lievelingsgorilla, de zilverrug Digit, die een wond had.

Voorzichtig haalde ik mijn camera te voorschijn om een foto van het litteken te kunnen maken, maar ik was te dichtbij om scherp te kunnen instellen. $\mathrm{Na}$ ongeveer een halfuur hield de regen op en zonder enige waarschuwing wierp Digit het hoofd achterover en gaapte luid. Ik drukte snel af. De toen genomen foto toont mijn zachtmoedige Digit als een King-Kongmonster dat met wijdopen mond op de meest indrukwekkende wijze zijn reusachtige hoektanden laat zien.' (Fossey 1985: 214)

Wetenschappers als Schaller en Fossey poetsten het imago van de gorilla op door te laten zien dat de gorilla's zoals mensen zijn en door de menselijkheid van de gorilla's te benadrukken, daarbij wij- 
zend op de 'gentleness' van de gorilla. Zij waren daarin zeer succesvol. $^{41}$ Het beeld van King Kong als 'killer king' bleek een krachtig retorisch middel om het onderscheid tussen 'Hollywood' en 'wetenschap', 'fictie' en 'feit' steeds te bevestigen. Wie tegenwoordig een populair-wetenschappelijke documentaire over gorilla's op National Geographic Channel of Discovery Channel ziet, heeft nog altijd een grote kans dat King Kong daarin figureert als afzetpunt voor de 'echte' gorilla. In drie in 1998 uitgezonden documentaires, die alle gaan over de gorilla als bedreigde uitstervende soort, duikt King Kong op als retorisch afzetpunt. De Duitse documentaire Der Stumme Schrei der Menschaffen toont ons, behalve een foto van Du Chaillu, die wordt gekarakteriseerd als een voorbeeld van een 'dramatisch verteller', een 'fantast', nog een voorbeeld van een 'Falsche Geschichte'. We zien een grote foto van King Kong en de voice-over noemt hem 'Undeutlich Gefährlich'. De jaren 1932 en 1933 werden, aldus de stem, gekenmerkt door 'Gorilla Fieber', waarin Martin en Osa Johnson dode gorilla's naast de jagers toonden, en King Kong de wereld veroverde. Dankzij hem hebben gorilla's vandaag de dag 'Keine überlebungschanzen'. Dezelfde opinie wordt uitgedragen in Discovery Channel documentaire Wild Life waarin King Kong wordt afgedaan als 'a false story'. In de televisiedocumentaire Tender Giants (1998) geeft een vrouwelijke voice-over ${ }^{42}$ ook Hollywood de schuld van de moorden die op gorilla's worden gepleegd:

It is difficult to watch these animals swifting delicately through the leaflets and not to question the image of gorillas perpetuated in Hollywood films. The truth is that real gorillas do not waste a lot of energy on roaring or posturing. They are too busy eating. Maybe the reason we make up such alarming tales about gorillas is simply to distance ourselves from them. Otherwise the resemblance between the two species may be too close for comfort. The one human trait that gorillas never display as they travel the forest is the very one our mythology attributes to them: the need to kill.

De beelden van de documentaire moeten het bewijs leveren. Anders dan fictiefilms zijn zij immers een 'passieve' en 'objectieve' registratie door het oog van de camera van de natuur. Zoals het echtpaar Yerkes Du Chaillu's representatie van gorilla's afwees als 'onwaar' tegenover hun 'ware' kennis, maken ook deze documentaires een 
onderscheid tussen 'verhalen' of 'verzinsels' enerzijds en 'kennis' en 'waarheid' anderzijds.

Toch is de strijd om de status en de aard van de gorilla - mens of dier, kwaadaardig of zachtmoedig - in de wetenschap nog altijd niet beslecht. De primatologen Richard Wrangham en Dale Peterson stelden onlangs in hun boek Agressieve mannetjes dat met name Fossey op haar beurt een nieuwe mythe in het leven heeft geroepen: dat van de gorilla als zachtaardige reus (Wrangham \& Peterson 1998: I38-I44). Daarmee heft Fossey volgens Wrangham en Peterson de 'feitelijke' ambiguitteit van de gorilla op. Je zou ook kunnen stellen dat mythologisering in zichzelf al een manier is om ambiguïteit op te heffen, omdat één krachtig en eenduidig beeld naar voren wordt geschoven. Hoewel gorilla's meestal goedaardig en vreedzaam zijn, kan volgens de primatologen Wrangham en Peterson, het statistische gegeven dat het gemiddelde gorillavrouwtje ten minste één keer in haar leven met kindermoord te maken krijgt, niet worden ontkend. Gorillamannetjes vermoorden namelijk regelmatig de kinderen van een vrouwtje van een andere zilverrug. De gorilla als babykiller is een gegeven dat Fossey, aldus Wrangham en Peterson, in haar werk naar de achtergrond plaatste omdat ze bang was dat dit gegeven het beeld van gorilla als goedaardig opnieuw zou schaden.

\section{'IT WAS BEAUTY KILLED THE BEAST'}

Critici, film- en cultuurwetenschappers hebben King Kong vanaf I933 tot in de jaren negentig vooral als symbolische mens geïnterpreteerd, die zachtaardig of kwaadaardig van aard was. Daarbij veranderden de interpretaties van Kong steeds met hun tijd mee: in de jaren zestig was Kong een vechtmachine die ingezet werd tegen Koude-Oorlog-agressie, in de jaren zeventig werd Kong door feministen als vrouwenverkrachter gezien - of, in komische versies als slachtoffer van de manipulatieve Ann -, in de jaren tachtig en negentig kwam er, mede dankzij de opkomst van black studies, meer aandacht voor de koloniale aspecten van de film en was Kong een 'black other'. Anders dan cultuurcritici, hebben de wetenschappers King Kong beschouwd als een dier, een valse, want 
kwaadaardige representatie van een gorilla. Hoewel de filmmakers wetenschap gebruikten als inspiratiebron voor hun representatie van de gorilla, waren (en zijn) wetenschappers druk bezig om verschil te maken tussen wetenschap en cultuur, tussen feit en fictie, om zo het verkeerde 'culturele' beeld te vervangen door het 'echte' wetenschappelijke beeld. Gepoogd wordt, van Yerkes tot Fossey, om de 'echte' wetenschappelijke aap die zachtaardig is, te onderscheiden van de kwaadaardige fictieaap. Dat vrouwen bang zouden moeten zijn voor gorilla's is volgens Fossey ook onderdeel van de fictie; zij demonstreert dat door zich te midden van de apen te laten fotograferen.

Aan één aspect gingen zowel de cultuurcritici als de wetenschappers echter voorbij: het afwijkende formaat van Kong, 50 voet, zo'n 15 meter. King Kong doet in zijn uiterlijk en zijn gedrag weliswaar denken aan een gorilla en een mens, maar dankzij zijn enorme afmetingen onttrekt King Kong zich in feite aan beide categorieën. Als hij een mens is, dan een niet-bestaande. Is hij een gorilla, ook dan kan hij niet 'echt' zijn; hij is immers opgeblazen tot reusachtige proporties. De representatie van de gorilla in King Kong is niet alleen het resultaat van een curieuze mix uit de wetenschappelijke en culturele traditie omdat hij in zijn uiterlijk en gedrag de ideeën combineerde van Du Chaillu, Akeley, het echtpaar Yerkes, en van Congorilla en The Murders in the Rue Morgue. Met zijn gigantische proporties staat hij ook in de traditie van de mensenetende reuzen. King Kong was niet de eerste reuzenaap. In Jonathan Swifts Gullliver's Travels (I850) figureerde al een reuzenaap, een vriendelijke tedere 'gentleman' waar Gulliver aanvankelijk bang voor is, maar die hem geruststelt door hem te knuffelen. Ook P.T. Barnums kermisgorilla 'Gargantua' legde een verband met de reuzentraditie. Zijn naam refereert aan het werk Gargantua (1534) van François Rabelais, dat over een reus gaat. 'Gargantua' betekent de 'grote', ontleend aan 'que grand tu es!' Ook het wetenschappelijke onderzoek, geillustreerd door bijvoorbeeld Fosseys uitspraken herinneren aan de reuzentraditie. Zij spreekt immers van 'gentle giants', zachtmoedige reuzen, en gaat, net als het echtpaar Yerkes, nadrukkelijk in op het eetgedrag van de gorilla's.

Niet alleen zijn uiterlijk is ambigu. King Kong heeft, net als de meeste reuzen, de bijzondere eigenschap zowel eng als aandoenlijk te zijn. Hij verenigt tegenstrijdige aspecten in zich: hij is lief én ge- 
vaarlijk, gevoelig en agressief, groot maar kinderlijk. Dat King Kong vooral de geschiedenis inging als een 'killer king' is te wijten aan zijn ambiguïteit. Mary Douglas heeft in haar werk Purity and Danger (1966) aangetoond dat hybriditeit en ambiguïteit kenmerken zijn van 'impurity', oftewel onzuiverheid en in de meeste culturen gekoppeld worden aan gevaar. Juist omdat King Kong zachtaardige aspecten heeft, zal hij als 'extra' gevaarlijk worden beschouwd. King Kong sterft in de film, niet omdat hij slecht en gevaarlijk is, maar juist omdat hij dubbelzinnig is. De slotzin van King Kong, 'It was beauty killed the beast', bevat, zo zou je in de lijn van deze interpretatie kunnen stellen, in zijn dubbelzinnigheid een kern van waarheid. Het is echter niet alleen de schoonheid van het meisje die het tragische lot van de gorilla bepaalt, maar ook de schoonheid van de gorilla zelf. Die maakt hem ambigu en deze ambiguiteit is moeilijk verdraagbaar, zo blijkt keer op keer uit de receptiegeschiedenis. In die zin werd zijn eigen schoonheid hem fataal.

\section{GORILLA'S TUSSEN FEIT EN FICTIE}

In het hoofdstuk over Mijn aap schreit interpreteerde ik het doden van de ambigue aap door de man als een manier om zijn twijfels omtrent de status en de aard van de mens, en in het bijzonder zijn positie als man, op te heffen. De moord is een poging om zijn hiërarchische status ten opzichte van de vrouw en de aap te handhaven. $\mathrm{Na}$ de dood van de aap kiest hij voor een ondubbelzinnig moordend bestaan als jager, 'apendoder', die hem als mens boven de dieren verheft. In dit hoofdstuk kwam het doden van de aap onder meer naar voren als een heldhaftige poging van de blanke heteroseksuele man om zijn status ten opzichte van de zwarte ander en de vrouw te handhaven. Zowel in Mijn aap schreit als in King Kong wordt de aap op gewelddadige wijze om het leven gebracht, en wordt een poging gedaan om de onrust die de ambigue aap veroorzaakt op te heffen. Doordat het sterven van de apen echter tragisch is - in beide verhalen met reminiscenties aan Christus' kruisdood - lukken de pogingen om de aap ondubbelzinnig te maken echter niet.

In Mijn aap schreit blijft de verteller eenzaam en vervreemd van alle mensen achter. De aap laat hem niet met rust: die achtervolgt 


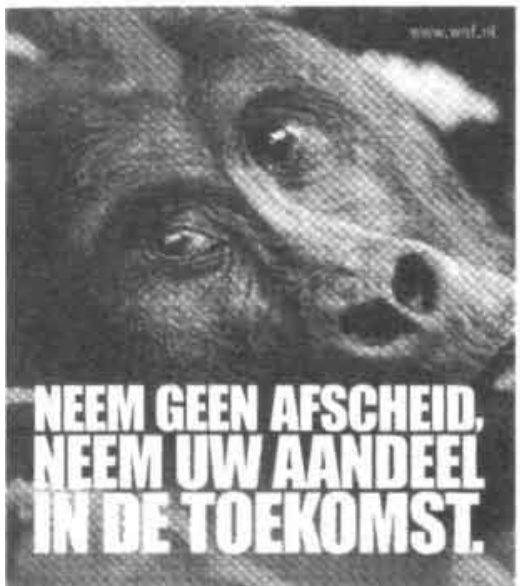

Help het Wereld Natuur Fonds

om de leefgebieden van

beschermde diersoorten

veitig te stellen. Want alleen

$z 0$ kunnen we ervoor zorgen

dat bijvoorbeeld de gorilla,

de jaguar, de watvis

en de zeeschildpad ook in de

toekomst in hun natuurijke

omgeving kunnen blijven leven.

\section{STEUN HET WNF. GIROT5.}

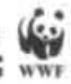

I4 Advertentie van het Wereld Natuur Fonds.

hem en duikt op in zijn nachtmerries, duizend maal vermenigvuldigd en in die zin uitvergroot. King Kong is niet alleen letterlijk uitvergroot tot mythische proporties, maar staat keer op keer op uit zijn dood in allerlei culturele en wetenschappelijke uitingen.

De receptie van King Kong is veelzijdiger dan die van Mijn aap schreit. Door de veelzijdige receptie in beeld te brengen, wordt de ambiguïteit, het betekenispotentieel van de gorilla, uitvergroot in beeld gebracht. Hoe wij de gorilla zien, hangt echter ook af van de maatschappelijke en wetenschappelijke omstandigheden. In de receptie wordt de ambiguiteit vaak weer 'verkleind' of gereduceerd tot eenduidigheid. Niet alleen werd de gorilla door cultuurcritici geïnterpreteerd als een kwaadaardige agressor, als vechtjas of mannelijke verkrachter, maar ook als symbool van allerlei geslachtofferde zachtaardige 'anderen', bijvoorbeeld de zwarte, de jood, de homoseksueel of de wees. Ook wetenschappers bemoeiden zich met de film; zij legden niet de nadruk op King Kong als symbolische mens, maar als representatie van een gorilla. Op deze wijze werd de film deelnemer in het debat over de aard van de gorilla.

Wie of wat een gorilla is, is voortdurend in beweging geweest; zowel cultuurcritici als wetenschappers worstelden en worstelen met de ambiguitteit van de gorilla. Een recente actie van het Wereld Natuur Fonds laat zien dat King Kong nog altijd een rol speelt in de 
definitie van het imago van de gorilla. In de 'week van de gorilla' (1999) werden mensen een week lang via televisie en kranten aangespoord om een 'gorilla-aandeel' te kopen. ${ }^{43}$ Tijdens deze week kreeg men bij monde van wetenschappers informatie over gorilla's, en opnieuw dook King Kong in een van de uitzendingen (TROS) op als 'een van de bekendste gorilla's ter wereld', en werd er in één adem bij vermeld dat gorilla's 'in het echt' geen meisjes 'kidnappen' of 'mensen opeten'. Daarna kwam een afbeelding van Dian Fossey in beeld, de wetenschapster die de wereld liet zien hoe zachtaardig gorilla's 'werkelijk' waren.

De succesvolle pogingen van onder meer Dian Fossey om het imago van de gorilla te veranderen, van beast naar beauty, lopen parallel met een groeiende opkomst van vrouwen in de primatologie. Drie vrouwen verwierven internationale faam: naast Fossey ook Jane Goodall en Biruté Galdikas. $\mathrm{Zij}$ doen lange-termijn veldstudies naar respectievelijk de chimpansee en de orang-oetan, en brengen de leefwijze van deze aapsoorten in kaart. Maar zij representeren niet alleen apen; ze worden ook zelf deel van een representatieindustrie. Fossey zou volgens sommigen te ver doorslaan in haar liefde voor de gorilla's en in plaats van als een beauty, steeds meer als beast in de media naar voren komen. Over deze wetenschapsters, hun liefde voor apen en de wijze waarop zij onderdeel gingen uitmaken van een representatie-industrie, gaat het volgende hoofdstuk. 
Waarom wetenschapsters van apen houden

De representatie-industrie rondom Jane Goodall, Dian Fossey en Biruté Galdikas

REPRISE: THE BEAUTY AND THE BEAST

In vergelijking met andere subdisciplines van de biologie kenmerkt de primatologie zich door een opvallend hoog aantal blanke vrouwelijke onderzoekers (Haraway 1989: 293-300; Fedigan 1994). Niet alleen het aantal, maar ook de publieke bekendheid van sommige van deze onderzoeksters is opmerkelijk. De Britse chimpanseedeskundige Jane Goodall, de Amerikaanse gorilla-onderzoeker Dian Fossey en de Amerikaanse orang-oetanwetenschapper Biruté Galdikas werden wereldberoemd, en vormden voor veel jonge vrouwen een rolmodel. Onder meer Jeanne Altmann, Linda Marie Fedigan, Adrienne Zihlman en Sarah Blaffer Hrdy volgden hun voorbeeld.

De ontmoeting tussen de vrouwelijke onderzoeker en de aap in de jaren zestig, zeventig en daarna heeft belangrijke veranderingen teweeggebracht in ons mens- en aapbeeld. Meestal wordt het drietal Goodall, Fossey en Galdikas geroemd omdat zij het imago van de mensaap als killer-ape hebben gecorrigeerd. Met succes hebben zij de mensaap 'gedisambigueerd' door diens zachtaardigheid en menselijkheid te benadrukken. De mens kwam in hun werk daarentegen als de 'kwaadaardige' soort naar voren, een bedreigende factor voor het voortbestaan van de vredelievende aap. De 'beauty and the beast'-rollen van King Kong werden daarmee omgedraaid: de aap had schoonheid in zich, de mens een beest. De zachtaardigheid van de apen kwam echter onder druk te staan toen vormen 
van geweld werden geconstateerd onder de mensapen. Ondanks deze spanningen, slagen Fossey, Goodall en Galdikas erin om de apen als unieke, zachtaardige en menselijke individuen te blijven representeren.

Het werk en leven van vrouwelijke primatologen vormt een belangrijke bron van inspiratie voor documentaire- en filmmakers, biografen en romanciers. Met name over Jane Goodall, Dian Fossey en Biruté Galdikas verscheen een hausse aan boeken, films en documentaires. Vaak worden de drie vrouwen in een adem genoemd of gezamenlijk opgevoerd als de 'Trimates' of als de 'apenvrouwen' (bijvoorbeeld in Montgomery 199I, Jahme 2000). Rondom deze drie vrouwelijke onderzoekers is een 'representatie-industrie' ontstaan, een enorme imagomachinerie waarin bepaalde verhalen en beelden steeds recycled worden. Ik gebruik het woord 'representatie-industrie', omdat er, anders dan in de voorgaande hoofdstukken, niet één primair werk is waarop de 'receptie' zich vervolgens baseert, maar een netwerk van beelden die naar elkaar verwijzen.

In dit hoofdstuk analyseer en interpreteer ik de representatieindustrie rondom Goodall, Fossey en Galdikas. Eerst ga ik in op de vraag waarom zo veel vrouwen in de primatologie werkzaam zijn. Voelen zij zich meer aangetrokken tot het dierenonderzoek? Haraway (1989) stelt dat er van een 'natuurlijke' liefde van vrouwen voor dieren geen sprake is: blanke westerse vrouwen zijn op grond van culturele stereotypen bij uitstek geschikt als bemiddelaar tussen 'natuur' en 'cultuur'. Na een kritische uiteenzetting van Haraways ideeën hierover, analyseer ik drie boeken van Goodall, Fossey en Galdikas die als autobiografie te lezen zijn en als populair-wetenschappelijke studies naar mensapen. In mijn interpretaties laat ik zien welke retorische strategieën zij inzetten om de lezer ervan te overtuigen dat mensapen zachtaardige en menselijke wezens zijn. De wijze waarop zij zichzelf als empathische onderzoeker positioneren en de stijl van de boeken die zij publiceren, is daarbij van belang, en stelt tevens de grenzen tussen 'cultuur' en 'wetenschap' ter discussie.

Terwijl Goodall, Fossey en Galdikas de representatie(-industrie) van apen sturen en koloniseren, wordt hun eigen imago gestuurd door anderen (filmmakers, biografen et cetera). De representatieindustrie rondom de drie wetenschapsters en hun wetenschap in fictie en non-fictie onderzoek ik aan de hand van drie voorbeelden. 
Achtereenvolgens interpreteer ik William Boyds Brazzaville Beach, gebaseerd op het leven van Jane Goodall, de film Gorillas in the Mist (1988) over Dian Fossey, en Linda Spaldings The Follow uit 1998 en de thriller Gone Wild van James Hall uit 1995 over Biruté Galdikas. Zoals de representatie van de mensaap heen en weer slingert tussen menselijk en dierlijk, zachtaardig en kwaadaardig, zo beweegt ook de representatie van Goodall, Galdikas en Fossey zich tussen deze uitersten. Zij worden, net als apen, projectiefiguren omdat zij 'ambigu' zijn en daarom 'sites of cultural anxiety', 'plekken' van onrust en verwarring. ${ }^{1}$ De onrust blijkt uit de enorme omvang van de representatie-industrie en uit de pogingen om de ambiguïteit te reduceren tot eenduidigheid. De primatologen worden voorgesteld als zachtaardige, bewonderenswaardige heldinnen (beauty) van wie de mensheid veel zou kunnen leren, óf als boosaardige heksen die te ver zijn doorgeslagen (beast). Soms is de receptie ambivalent en slingert deze heen en weer tussen beauty en beast, positieve of negatieve projectiefiguur.

Haraways opvattingen over culturele stereotypen en de plaats van de blanke vrouw op de hiërarchische ladder zijn statisch en minder geschikt om veranderingen in ons mens-, vrouw- en aapbeeld te beschrijven. Onder invloed van maatschappelijke en culturele ontwikkelingen verandert de positie en de beeldvorming van de apenonderzoekster namelijk ook. Dankzij de tweede feministische golf wordt haar positie als wetenschapper vanzelfsprekender en kan zij haar vrouwzijn benadrukken - in ogen van de media een beauty zijn - zonder dat dit afbreuk doet aan hoe er gedacht wordt over haar wetenschappelijke kwaliteiten. ${ }^{2} \mathrm{Om}$ dat te illustreren, besluit ik met de komst van een vierde 'apenvrouw', Ellen van Krunkelsven, die eind jaren negentig werd uitgeroepen tot 'de Vlaamse versie van Jane Goodall' en tot beschermvrouwe van de bonobo (Draulans 1998).

\section{DE APENONDERZOEKSTER ALS BEMIDDELAAR}

Een veel gehoorde verklaring voor het hoge aantal vrouwen in de primatologie is de 'big brown eyes hypothesis' (Fedigan 1994: 533). Vrouwen zouden graag apen onderzoeken omdat ze dol zijn op lie- 
ve, harige, kleine dieren; hun moederlijke, zorgende kant zou erdoor worden aangesproken. Volgens de primatologe Linda Marie Fedigan is deze hypothese niet houdbaar. Zij wijst erop dat apen niet 'klein, schattig, grappig of lief' zijn; integendeel, het zijn grote dieren die gewelddadig kunnen zijn. In haar artikel 'Science and the Succesful Female: Why there are so Many Female Primatologists' (1994) geeft Fedigan een aantal verklaringen waarom het aantal vrouwen in de primatologie zo hoog is. Ze noemt de primatologie onder meer een aantrekkelijk discipline voor vrouwen: er is een vrouwvriendelijke atmosfeer in het vakgebied en er zijn veel vrouwelijke rolmodellen: Dian Fossey, Jane Goodall en Biruté Galdikas bijvoorbeeld. ${ }^{3}$ Het zijn plausibele verklaringen, maar het blijft de vraag waarom de 'big brown eyes hypothesis' zo krachtig is.

In Primate Visions geeft Haraway een aannemelijke verklaring hiervoor, wanneer zij uitlegt waarom volgens haar juist blanke westerse vrouwelijke wetenschappers 'liefde' voor apen wordt toegedicht, en waarom juist zij als geschikt voor het onderzoek naar apen worden beschouwd. Volgens Haraway is één van de hardnekkigste culturele clichés binnen het apenonderzoek het idee dat vrouwen betere toegang tot de apen zouden hebben omdat zij dichter bij de natuur zouden staan. Het is inderdaad opmerkelijk hoeveel vrouwelijke primatologen geroemd zijn om hun vermogen tot inleving en identificatie. Echter, zo merkt Haraway op, het is niet omdat ze vrouwen zijn, dat ze betere toegang krijgen, het is omdat vrouwelijkheid op een bepaalde manier is geconstrueerd. Empathie of inlevingsvermogen is één van die dingen die aan vrouwelijkheid en de vrouwelijke ervaring wordt gekoppeld. 'Empathy is both part of a code in a narrative and a culturally specific way to construct what counts as experience.' (Haraway 1989: 317)

Het is volgens Haraway niet toevallig dat een vrouwelijke blanke westerse wetenschapper de rol van communicator en mediator tussen mens en natuur opgelegd krijgt. $\mathrm{Zij}$ is symbolisch beladen met wat Haraway de 'triple code' noemt. De eerste code is 'gender'. Vrouwzijn maakt iemand geschikt als mediator: 'Woman is closer to nature than Man and so mediates more readily' (I49). De tweede code is 'science'. De vrouwelijke wetenschapper is volgens Haraway een 'oxymoronic social subject' (28I), een intern tegenstrijdig sociaal subject. Daarmee bedoelt Haraway dat vrouwelijkheid traditioneel gezien niet gekoppeld aan datgene waarin een wetenschapper uit- 
blinkt: rationaliteit. ${ }^{4}$ Een vrouwelijke wetenschapper is dus een rare verschijning: de term wetenschapper wordt geassocieerd met 'rationeel', 'denken' en 'geestelijk', maar de verschijning 'vrouw' met 'irrationeel', 'object van begeerte' en 'lichamelijk'. 'Such a scientist does not hold the camera; she is still the one photographed for millions to view', schrijft Haraway (1989: 150). Daaraan kan worden toegevoegd dat het hoge aantal vrouwen in de primatologie is ingebed in een bredere cultuurhistorische context van de rol van vrouwen in de wetenschapsbeoefening. Wanneer onderzoek zich van het laboratorium verplaatst naar het veld is het aantal vrouwen hoger (Abir-am \& Outram 1987). Ook het object van onderzoek maakt uit. Zodra het 'object' van onderzoek een 'subject' is dat op grond van cultureel stereotypen 'lager' staat dan de vrouw, denk aan pedagogiek, antropologie van de niet-westerse samenleving, gerontologie en biologie, is het aantal vrouwen hoger (Abir-am \& Outram 1987).

De derde code is 'race':

A Western woman of color would have made the cultural particularity of the story of the woman in the forest too obvious because she could not have as easily carried the ambiguity of marked and unmarked categories required for the narrative resolution of the dilemma in universal terms [...] Colored women are often so closely held by the category animal that they can barely function as mediators in texts produced within white culture. In those cultural fields colored women densely code sex, animal, dark, dangerous, fecund, pathological. (153-154)

Het zou, aldus Haraway, nooit een zwarte vrouw kunnen zijn die optreedt als bemiddelaar, omdat zijzelf in de westerse cultuur als dierlijk is voorgesteld. De blanke vrouw is de perfecte bemiddelaar, omdat zij enerzijds valt onder de categorie mens en als zodanig genoeg afstand tot het dier heeft om het niet-dierlijke te vertegenwoordigen; tegelijkertijd is zij in de westerse geschiedenis ook buitengesloten geweest van de definitie mens, en staat zij, omdat ze geassocieerd wordt met het natuurlijke en ander ten opzichte van de blanke man, dicht genoeg bij de dieren. Haar ambiguïteit maakt haar dus geschikt als bemiddelaar.

Haraway illustreert haar ideeën over de bemiddelende rol van de apenonderzoekster door middel van een kritische analyse van de 
natuurdocumentaires van National Geographic over Jane Goodall, die typisch is voor de manier waarop ze ideologie illustreert met fictie en populaire cultuur (zoals in hoofdstuk twee al uitvoeriger aan de orde is geweest). Ze laat zien dat deze documentaires de boodschap uitdragen dat de natuur een kostbaar gegeven is dat beschermd moet worden, en dat Goodall fungeert als de mediator tussen cultuur en natuur. De media scheppen een beeld waarin zij degene is die het contact met de apen weet te maken. Maar in haar bemiddelende rol draagt ze niet zozeer kennis over. Een mannelijke voice-over doet de gewichtige wetenschappelijke uitspraken, terwijl Goodall de plezierig ogende gids is. 'She is less a twentieth century scientist than a girl guide,' (182) schrijft ze. We hebben hier te maken met 'women's science', niet met 'feminist science', concludeert Haraway. Haar grootste bezwaar betreft de representatie van Goodall als vrouw alleen in de wildernis. In werkelijkheid werkte Goodall in een groot netwerk van wetenschappers, assistenten en vrienden. Haraway laat het complexe netwerk zien dat het mediaproduct Jane Goodall mogelijk maakte, onder andere door in Primate Visions een foto af te drukken van het hele onderzoeksteam, waarop Goodall slechts één te midden van de velen is én een van de weinige blanke mensen (Haraway 1989: 173). Haraways inzet is hier nadrukkelijk politiek: wetenschap is groepswerk en niet het produkt van één genie. Vaak wordt het groepswerk, en met name de rol van zwarte inheemse bevolking daarin, uit de uiteindelijke tekst geschreven of gereduceerd tot het geniale idee van één (blanke) persoon. Maar wetenschappers worden gevormd en geproduceerd door netwerken en instituten. 'Major institutes have produced women scientists in the field.' (Haraway 1989: 167)

Naast de hiërarchische positie van de blanke vrouw, is er een historische reden voor het hoge aantal vrouwen in de primatologie. De paleontoloog Louis Leakey, die in de jaren zestig aan het hoofd stond van paleontologische opgravingen in Olduvai Gorge in Tanzania, stelde veel vrouwen aan omdat hij inderdaad van mening was dat 'onbevooroordeelde' vrouwen beter geschikt waren dan mannen om het veld in te gaan. ${ }^{5}$ Vrouwen zouden beter oog voor detail en meer inlevingsvermogen hebben. ${ }^{6}$ Omdat vrouwen bovendien baby's baren, zouden ze beter in staat zijn tot non-verbale communicatie; anders dan mannen, zouden ze de behoeften van een wezen dat niet kan praten, begrijpen. Leakey stelde achtereen- 
volgens Goodall, Fossey en Galdikas aan om in hun lange-termijn veldstudies de leefwijze van respectievelijk chimpansees, gorilla's en orang-oetans in kaart te brengen. Goodall werd in $196 \mathrm{r}$ door Leakey naar Tanzania gezonden; Fossey vertrok in 1963 gedurende een korte periode naar Congo en ging in 1967 naar Rwanda om zich daar blijvend te vestigen; Galdikas reisde in I971 naar Borneo in Indonesië. Goodall, Fossey en Galdikas worden daarom ook wel 'Leakey's ladies' genoemd (Montgomery r99I; Jahme 2000). Leakeys keuze voor Goodall en Fossey was omstreden; geen van beide vrouwen had een universitaire opleiding genoten. Goodall was serveerster en secretaresse geweest en Fossey had als hulpverlener met autistische kinderen gewerkt. Galdikas had als enige een academische opleiding voltooid, namelijk biologie. Leakey vroeg haar tijdens het sollicitatiegesprek echter niet naar haar kwaliteiten als onderzoeker. Hij onderwierp de drie vrouwen aan enkele intelligentietesten met speelkaarten om hun oplettendheid en oog voor detail te testen. Ze merkten alledrie op dat Leakey sommige kaarten licht had gebogen. Maar Fossey was er nog niet met deze test; Leakey vroeg haar om haar blindedarm te laten verwijderen. Volgens hem was dat een medische noodzaak voor iemand die in Afrika apen wilde onderzoeken. Onzin, zo bleek later: hij wilde slechts haar volharding toetsen. (Galdikas 1995: 73, Fossey 1984: 30, Montgomery 199r: 78)

Dat Leakey de vrouwen aan een test (of zelfs twee) onderwerpt, is opmerkelijk. Het suggereert dat hij iets minder clichématig is in zijn opvattingen over gender dan vaak wordt aangenomen, bijvoorbeeld door Haraway, en dat haar positie verworven moet worden. Leakey gaat er immers niet van uit dat álle vrouwen oog voor detail hebben, maar dat het een eigenschap is die bij sommige vrouwen aangetroffen kan worden. ${ }^{7}$ Kennelijk moet haar 'vanzelfsprekende' bemiddelende positie bewezen of bevestigd worden.

De representatie van de drie beroemdste leading ladies, de "trimates' van de primatologie - Goodall, Fossey en Galdikas - houdt de mythe van de liefde van vrouwelijke onderzoekers voor apen in stand. Steeds weer wordt benadrukt hoe dicht ze bij de apen staan. We zien op diverse afbeeldingen hoe ze de apen aanraken, knuffelen en verzorgen. $\mathrm{Bij}$ deze representaties van primatologen vervagen de scheidslijnen tussen vrouwen en apen. De primatologen zouden zich zozeer met de (vrouwtjes)apen identificeren - of al- 


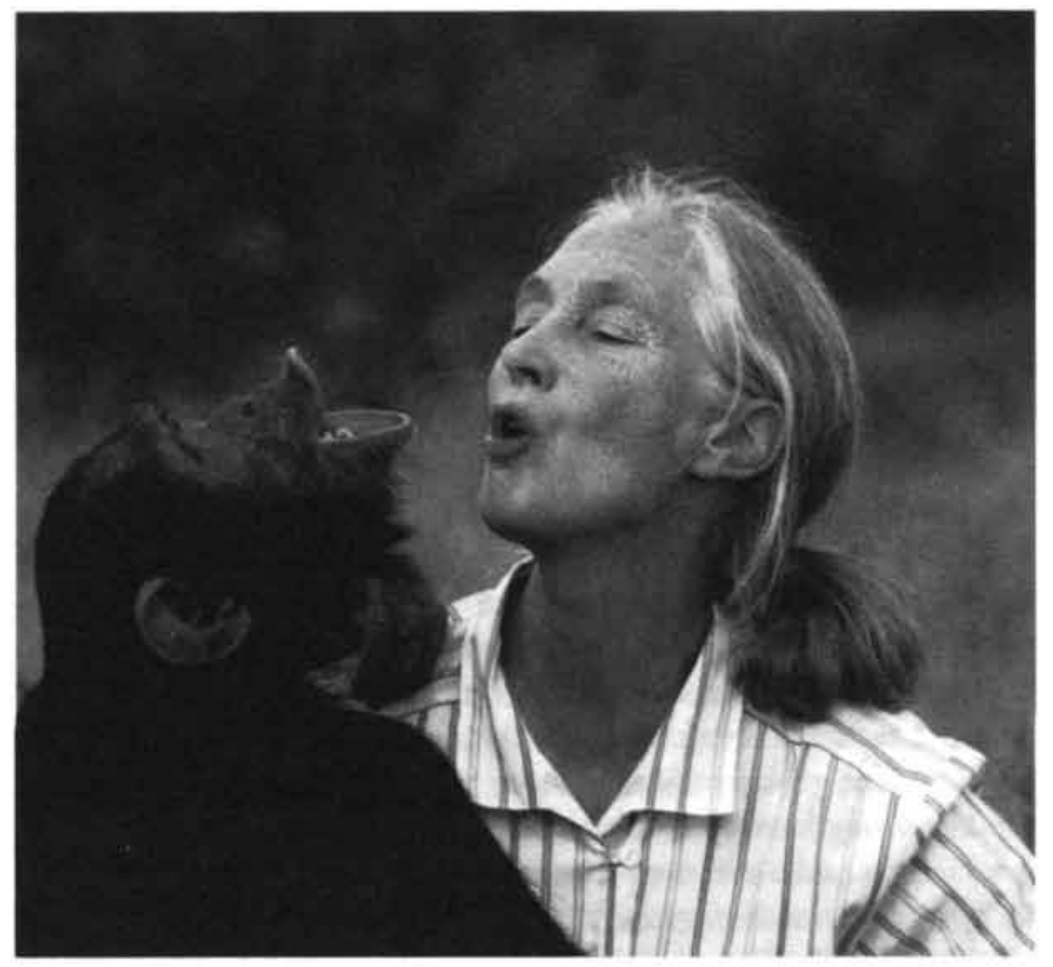

15 Jane Goodall met een chimpansee. Foto: Michael Neugebauer. Foto van omslag Jane Goodall, Hoop voor de toekomst (2000).

thans, zo geportretteerd worden - dat ze ermee samen beginnen te vallen. Haar ambigue positie roept naar mijn mening ook een zekere spanning op, bijvoorbeeld tussen de rollen van de primatologe als aantrekkelijke vrouw en als moeder.

Galdikas liet zich voor National Geograpic tussen de orang-oetans fotograferen. Met haar rode haar verdwijnt ze bijna zelf tussen de orang-oetans. Jonge orang-oetans klemmen zich aan haar vast, wat associaties oproept met een moeder in een kindercrèche. Maar de afbeelding heeft ook erotische connotaties. Het geheel doet ook een beetje denken aan groepsseks; apen klemmen zich aan Galdikas' borsten vast. Op een andere foto gluurt een orang-oetan stiekem onder haar blouse; van Jane Goodall is een soortgelijke foto gemaakt. ${ }^{8}$ Op het omslag van Reason for Hope (2000) in het Neder- 
lands verschenen onder de titel Hoop voor de toekomst en met dezelfde foto op de omslag, zien we de gezichten van Jane Goodall en een chimpansee. Ze kijken naar elkaar en tuiten hun lippen. Hierdoor wordt de gelijkenis tussen de mens en de chimpansee benadrukt. Het lijkt bovendien alsof ze op het punt staan om elkaar een kusje te geven. Ook verschenen foto's van haar, waarop ze in een innige omstrengeling met de dieren om zich heen zit en waarmee haar eigen aapachtigheid werd benadrukt. ${ }^{9}$

Deze omslag is heel anders dan we bijvoorbeeld aantreffen bij de populair-wetenschappelijke boeken van Frans de Waal, die niet tussen de apen wordt afgebeeld, maar als auteur (of helemaal niet) op de achterflap poseert. ${ }^{10}$ Het is natuurlijk mogelijk dat ook mannelijke primatologen de empathische onderzoekstactiek toepassen, maar het inlevingsvermogen wordt in representaties vaak aan vrouwen gekoppeld. Terwijl we Jane Goodall in diverse programma's - bijvoorbeeld in de door de VPRO uitgezonden reeks van Wim Kayzer Van de schoonheid en de troost (2000) en in een aflevering van Ivo Niehes $T V$-show op reis (200o) - de verschillende roepen van een chimpansee horen nadoen, staan mij geen beelden of geluiden bij van bijvoorbeeld Frans de Waal die een bonobo nadoet. ${ }^{11}$ Ook zijn er over Goodall, Fossey en Galdikas talloze verhalen verschenen waarin de lezer uitvoerig wordt geïnformeerd over het persoonlijke leven van de vrouwen, zoals hun liefdesleven; een vergelijkbare representatie-industrie rondom mannelijke apenonderzoekers is er niet. Hoewel vrouwen 'bij uitstek' geschikt zouden zijn, resulteert de bemiddelende positie van de vrouwelijke wetenschapper in spanningen die een voortdurende stroom van visuele en verbale representaties genereren, waarin de spanning al dan niet wordt opgelost.

Goodall, Fossey en Galdikas zijn echter niet alleen het onderwerp van representaties geweest, maar hebben ook zichzelf gepresenteerd in hun boeken. Welke visie op apen hebben zij daarin overgedragen en hoe hebben ze daarbij zichzelf als (vrouwelijke) onderzoeker neergezet? 
DE POPULAIR-WETENSCHAPPELIJKE AUTOBIOGRAFIEËN VAN JANE GOODALL, DIAN FOSSEY EN

BIRUTÉ GALDIKAS ${ }^{12}$

Rondom waren de bomen nog gesluierd door de laatste geheimen van de nachtelijke dromen. Het was erg rustig, volkomen vredig. De enige geluiden waren nu en dan het tjirpen van een krekel en het zachte gemompel waarmee het meer, ver beneden, de kiezels streelde. [...] Het nieuwe heldere licht van de zon had bijna de zilverachtige onbestemde verlichting van zijn eigen, door de maan weerspiegelde straling overwonnen. (Goodall r991: 7)

$\mathrm{Al}$ jarenlang verlangde ik naar Afrika te gaan vanwege hetgeen dat werelddeel bood aan ongereptheid en grote verscheidenheid van in het wild levende dieren. (Fossey 1984: 27)

Het licht van de namiddagzon scheen spookachtig door Akmads lange, kastanje bruine haar, waardoor zich rond haar gezicht een lichtgevende stralenkrans aftekende. Ik wilde het kleine, rimpelige, naakte gezichtje van Akmads pasgeboren jong fotograferen. [...] Het magische zachte licht, kenmerkend voor de schemering in Borneo, etste dit tafereel in goud, een moment waarop de tijd stil kwam te staan. (Galdikas 1995: 13-I4)

Bovenstaande citaten, afkomstig uit respectievelijk Goodalls Oog in oog met de chimpansees. zo jaar in het oerwoud van Gombe, Fosseys Gorilla's in de mist en Galdikas' De spiegel van het paradijs. Mijn jaren bij de orang-oetans van Borneo, verplaatsen de lezer naar een stukje overgebleven paradijs op aarde. Daar schijnt de zon zilverachtig, wordt nieuw leven geboren en ondergedompeld in goud, tjirpen de krekels, staat de tijd stil en heerst vrede. We zijn beland in de hof van Eden, zo maakt de titel van Galdikas' boek, De spiegel van het paradijs, ons nog eens duidelijk. Met name de boeken van Galdikas en Goodall zijn doorspekt met allusies op het paradijselijke scheppingsverhaal; het vocabulaire is religieus getint. Galdikas schrijft dat ze zeker wist dat ze 'geboren' was om de apen te onderzoeken toen ze een 'kristalhelder klokgelui' (Galdikas 1995: 64 ) hoorde, en Goodall is een mystieke ervaring nabij wanneer ze beschrijft dat ze 'overweldigd' is door de natuur en vervuld van een 
diep gevoel van vrede dat 'elk begrip te boven gaat' (Goodall ig9I: I6).

De paradijselijke beschrijvingen geven de lezer het beeld van een vredige en mooie jungle. Dat stemt overeen met de opvatting over de mensapen die de auteurs willen overdragen, namelijk dat apen zachtmoedige en menselijke individuen zijn en dat mensen iets van hen zouden kunnen leren. Steeds duiken adjectieven als 'edel', 'zachtmoedig', 'menselijk', 'nobel', 'onschuldig' en 'uniek' op om de apen te karakteriseren. Goodall, Fossey en Galdikas gaan met hun ideeën van de zachtaardige aap in tegen een jarenlange traditie die de mensapen als gevaarlijk heeft afgeschilderd. Het motto van Fosseys boek (waaraan het ook zijn titel ontleent) luidt: 'Het mistig licht / dat hen zo flatteert / verbergt hun ware aard'. Omdat het imposante uiterlijk van de gorilla bij sommigen de indruk wekt dat het dier gevaarlijk is, schrijft Fossey, wanneer een gorilla geeuwt op een afbeelding er 'onschuldige geeuw' als onderschrift bij (Fossey r984: r28-r39). Galdikas wil de orang-oetan, die een 'mystieke status' heeft en lange tijd 'onzichtbaar' was, 'zichtbaar maken', en Goodall ziet de apen als een 'venster' op een andere wereld, waardoor we soms steeds 'verder en helderder' kunnen kijken.

De motivatie om mensapen in hun natuurlijke leefomgeving te bestuderen is tweeledig: meer over de aap in kwestie leren, en via de aap meer over de (vroegere) mens te weten komen. ${ }^{13}$ Steeds wijzen Goodall, Fossey en Galdikas op de continuiteit tussen mensen en mensapen. Ten eerste benadrukken zij hoe menselijk de mensapen zijn. Goodall, Fossey en Galdikas rekenen de mensapen tot hun 'familie' en geven vrouwen- of mannennamen aan de dieren, waarmee ze hun individualiteit en geslacht onderstrepen. Soms vernoemen ze de apen zelfs naar eigen familieleden. ${ }^{4}$ De individualiteit van de mensapen komt ook tot uiting in de opzet van de boeken. Bij Goodall en Galdikas staan de hoofdstukken vaak in het teken van één aap. De hoofdstukken hebben titels als 'Georgina', 'Goblin' of 'Melissa'. Galdikas wisselt die af met hoofdstukken over onder anderen Louis Leakey, 'Louis', en haar man Rod, 'Rod'. Daardoor word je als lezer even op het verkeerde been gezet, omdat je bij aanvang denkt dat 'Louis' en 'Rod' ook apen zijn. Fosseys hoofdstukken zijn gecentreerd rondom gorillafamilies. Doordat zij, net als Goodall en Galdikas, de apen opvoert als personages met emoties als jaloezie, angst, verlegenheid, verdriet, pijn of vreugde, wordt opnieuw onder- 
streept dat apen eigen unieke karakters hebben. De lezer verplaatst zich in de gedachten van een orang-oetan, gorilla of chimpansee als zelfstandig handelende actor. Soms wordt dit gedrag begrepen in termen van menselijk gedrag: 'Gigi tuurde, keek overal om zich heen en begon toen te huilen en te jammeren als een kind dat haar moeder kwijtgeraakt is' (Goodall 1991: 184). Galdikas benadrukt ook de uiterlijke gelijkenis tussen orang-oetans en mensen. 'Akmad was een dame. Ze had een zachtaardige manier van doen. [...] Ze leek zo menselijk, als een oranje dwergje, met haar intelligente, rustige en leergierige gezicht [...] haar gezicht, haar handpalmen en haar voetzolen waren onbehaard terwijl haar kleine blote oortjes van vorm bijna identiek aan het menselijke oor, uit haar hoofdhaar staken' (I8). Later beschrijft Galdikas haar dochter Jane (vernoemd naar Jane Goodall) met soortgelijke adjectieven: 'Jane is leergierig, vlug van begrip, ontwapenend, openhartig' (500). Alledrie spreken in het voorwoord hun dank uit aan de apen. Fossey bedankt de berggorilla's, de 'unieke en edele schepsels die zij zijn' (II); Goodall bedankt 'al die unieke levendige persoonlijkheden' en Galdikas draagt haar boek niet alleen aan haar eigen man en kinderen op, maar ook aan drie orang-oetans, Cara, Carl en Cindy, alsof zij het ook zouden kunnen lezen. Het verplaatsen in de aap versterkt de visie van de primatologen dat het zachtaardige dieren zijn. In Mijn aap schreit en King Kong was dit verplaatsen in de aap en zijn gevoelens ook iets dat het eenduidige beeld van de kwaadaardige aap verstoorde, omdat we gingen 'meevoelen' met de aap.

De tweede manier om de continuïteit tussen mensen en mensapen te benadrukken, is te wijzen op de aapachtigheid van de mens. Deze wijze komt sterk naar voren in de participerende onderzoeksmethoden van Goodall, Fossey en Galdikas. Om contact met de apen te krijgen gaan de vrouwen het gedrag van de mensapen imiteren. Fossey beschrijft hoe ze net als de gorilla's op bladeren kauwt, op haar borst trommelt (waarmee ze later stopt als ze zich realiseert dat dat voor gorilla's een teken van opwinding en alarm is), hurkt om op gelijke hoogte te komen met de gorilla's en gromt. Goodall schrijft dat ze de oe-oe-geluiden van de chimpansees imiteert, en Galdikas zit urenlang alleen in het bos in dezelfde houding als haar orang-oetans om hen op hun gemak te stellen. Ze eindigt haar boek met de boodschap dat 'er geen scheiding bestaat tussen de natuur en ons zelf. (527) Alle drie de vrouwen dragen 
steeds dezelfde zandkleurige kakikleding, geen felle kleuren, zodat ze minder opvallen in het groene oerwoud en zodat de apen aan ze kunnen wnenen. ${ }^{15}$ Fossey, Galdikas en Goodall gaan, kortom, op hun onderzoeksobject lijken door zich steeds met de apen te vergelijken of zich als een aap te gedragen. Daardoor wordt het moeilijker om een scherpe lijn te trekken tussen de mensen en de mensapen.

De uit de antropologie geleende onderzoeksmethode, de bestudering van apen in hun natuurlijke leefomgeving door middel van participerende observatie, betekent dat de mensapen worden bestudeerd alsof het vreemde volken zijn; ze worden als mensen bestudeerd. Goodall schrijft uitvoerig over de weerstand die deze onderzoekshouding oproept binnen gevestigde ethologische kringen. Omdat ze geen wetenschappelijke basisopleiding heeft gehad, gebruikt ze geen wetenschappelijke terminologie, maar past ze begrippen toe die we voor mensen gebruiken, bijvoorbeeld 'jeugd' en 'puberteit'. Het eerste artikel dat Goodall opstuurt naar een wetenschappelijk tijdschrift krijgt ze gecorrigeerd terug. Alle 'he's' en 'she's' zijn vervangen door 'it', en 'who' door 'what'. Goodall maakt de aanpassingen niet omdat ze 'er geen behoefte aan had voor mijzelf een rol in de wereld van de wetenschap te creëren, maar gewoon tussen chimpansees wilde blijven leven' (2I). Ze schrijft dat Robert Hinde haar een 'schitterend advies' geeft over hoe ze 'haar opstandigste ideeën met een wetenschappelijke lintje kan verpakken'. In plaats van de chimpansees bepaald mensengedrag toe te schrijven, bijvoorbeeld 'Fifi was jaloers' moet ze zeggen 'als Fifi een mensenkind zou zijn geweest, zouden we zeggen dat ze jaloers was' (22). Goodall schrijft dat een van haar belangrijkste constateringen, het gebruik van gereedschap bij de chimpansees, met ongeloof wordt ontvangen in de wetenschappelijke gemeenschap, en dat er zelfs wetenschappers zijn die beweren dat ze de chimpansees zelf zou hebben geleerd hoe ze gereedschap moeten gebruiken. ${ }^{16}$ Veel weerstand komt er ook tegen het feit dat ze actief ingrijpt in de leefgemeenschap van de chimpansees. Om ze beter te kunnen bestuderen maakte ze een bananenvoederplaats bij haar onderzoekscentrum, waarmee ze niet alleen haar positie als onafhankelijk en afstandelijk onderzoekster liet varen, maar ook het natuurlijke gedrag van de chimpansees beïnvloedde.

Ook Fossey en Galdikas krijgen veel kritiek op hun empathische onderzoekshouding. Galdikas vertelt over het moment dat Fossey 
en Digit samen in hun historische ontmoeting - de eerste aanraking tussen een wilde gorilla en een mens - voor de camera werden vastgelegd. Terwijl het tafereel zich ontvouwde viel moeilijk te zeggen wie de waarnemer was en wie werd waargenomen' (508). Ze schrijft dat het enthousiasme bij de wetenschappelijke collega's over de empathische onderzoeksmethode gering is: 'Het was de taak van een wetenschapper een passieve waarnemer te zijn en geen speelkameraadje.' (509) De lagere wetenschappelijke status wordt echter ook in de hand gewerkt doordat Goodall, Fossey of Galdikas zelf steeds benadrukken dat zij geen wetenschappelijke carrière ambieerden. ${ }^{D}$ $\mathrm{Zij}$ vonden (en vinden) het redden en beschermen van apenlevens belangrijker dan een prestigieuze publicatielijst.

Hun persoonlijke en participerende wetenschap komt ook tot uitdrukking in het soort boeken dat ze publiceren. De categorisering van deze boeken is niet makkelijk. Wat vorm, toon en opzet betreft, bevinden de boeken zich tussen 'populaire wetenschap', 'roman' en 'autobiografie' in. Ze hebben het populair-wetenschappelijke doel een breed publiek te informeren over het leven van de mensapen. Goodalls werk verschijnt onder andere in de 'Elsevierinformatief'-reeks (In de schaduw van de mens. Mijn leven met de chimpansees), waarin vooral populaire wetenschap verschijnt, maar wordt op de achterflap aangeprezen als een 'roman'. De apen krijgen immers namen en karakters en een verhaallijn met emoties, als waren ze romanpersonages. Ook beschrijven ze in de ikvorm de gevoelens van de onderzoeksters en hun persoonlijke leven, waardoor de boeken een dagboekachtig karakter krijgen. De lezer krijgt daarmee het gevoel een 'authentiek' ooggetuigenverslag te lezen. Wie echter een aantal van deze boeken achter elkaar leest, krijgt sterk de indruk dat het om een (succesvolle) formule gaat, een constructie van authenticiteit. De persoonlijke toon van de boeken heeft de functie om empathie op te roepen bij de lezer, om zo de mensen aan te sporen meer aandacht, geld en mededogen op te brengen voor hun naaste familielid, de zachtaardige en goede mensaap. Bovendien zijn de boeken sterk naar elkaar gemodelleerd (wat ook blijkt uit de vele verwijzingen van Galdikas naar de boeken van Goodall en Fossey). Ze maken gebruik van dezelfde structuur en topoi, zoals de vrouw die alleen in Afrika een onbekend gebied verkent, op gevaren stuit, maar deze overwint. In plaats van een 'authentiek' verslag zou de 'populair-wetenschappe- 
lijke autobiografie' of 'autobiografische populaire wetenschap' het genre bij uitstek worden voor de bevlogen vrouwelijke wetenschapper, en een nieuw stereotype worden. Dit hybride genre, waarbij de grens tussen populair en academisch moeilijker te trekken is, en boeken zowel voor een publiek van leken als voor primatologen zijn bedoeld, is steeds gewoner geworden binnen de primatologie. ${ }^{18}$

'Zelf-representatie' door Goodall, Galdikas en Fossey en 'receptie' door derden zijn moeilijk van elkaar te onderscheiden; de 'zelfrepresentatie' maakt deel uit van de representatie-industrie. Dat de zelf-representatie en representatie-industrie niet goed uit elkaar te houden zijn, komt ook omdat Goodall, Fossey en Galdikas zelf het stereotiepe beeld van de 'typische' vrouwelijke wetenschapper die 'moedert' over de apen veelvuldig in hun werk gebruiken. Hoewel Goodall en Fossey speciale aandacht besteden aan het verschil tussen vrouwtjes- en mannetjesapen, en soms uitdrukkelijke aandacht vragen voor de vrouwelijke ervaring, schrijven zij niet vanuit een feministisch perspectief. ${ }^{19}$ Goodall en Galdikas, die zelf ook kinderen hebben, gaan vaak in op de rol van het moederschap in het leven van vrouwtjes-mensapen. Biruté Galdikas reflecteert - als enige - over haar positie als vrouwelijke wetenschapper. Zij schrijft dat ze als Noord-Amerikaanse, opgegroeid in de jaren zestig, ervan overtuigd was dat vrouwen niet anders waren dan mannen, en dat het laatste boek dat ze las voor het ze het veld inging de feministische klassieker De vrouw als eunuch (1970) van Germaine Greer was. Voor haar was het een schok te ontdekken dat de orang-oetans in menselijke termen 'uitgesproken seksistisch' waren. Ze ontdekte dat orang-oetanmannen zich gemakkelijker voelen bij een vrouw dan bij een man, die ze agressief bejegenen omdat ze die als een concurrent beschouwen. Ondanks dit feministisch bewustzijn, is haar werk doorspekt van essentialistische opvattingen over wat vrouwelijk en mannelijk is, wat onder meer blijkt uit de wijze waarop ze het moederschap een 'natuurlijke' rol toedicht in het leven van iedere vrouw. ${ }^{20}$

Connotaties van erotiek (suggesties van bestialiteit) en moederschap treffen we niet alleen aan in de representatie-industrie, maar ook in de eigen teksten van Goodall, Fossey en Galdikas. Alledrie hebben ze bijvoorbeeld een 'lievelingsaap', steeds een mannetje. Voor Goodall is dat David Greybeard ('David Grijsbaard' in het Nederlands), voor Fossey de zilverrug Digit, en voor Galdikas Sugi- 
to. Goodall schrijft dat David Grijsbaard haar 'eerste venster op de wereld van de chimpansees opende' en dat hij degene is van wie ze 'het meest heeft gehouden'. Wanneer Grijsbaard sterft, is haar verdriet 'het grootst'. Goodall plaatste zelfs een overlijdensadvertentie in een nationale Engelse krant, en daarmee was ze de eerste die op deze manier en op deze plek melding maakte van het overlijden van niet een mens, maar een dier. ${ }^{21}$ De passage waarin ze schrijft over de dood van David Grijsbaard, wordt direct gevolgd door een opmerking over het verdriet dat Goodall had toen ze haar echtgenoot Derek verloor aan kanker, waardoor je als lezer ook David Grijsbaard met hem vergelijkt. Voor Galdikas is Sugito haar 'eerste kind' (26o). Omdat de jonge orang-oetan zijn moeder heeft verloren, neemt Galdikas de rol op zich. Ze zorgt voor de aap, en dat betekent dat de aap zich om haar vastklemt, dag en nacht. Wanneer Sugito ouder wordt, ontstaat er concurrentie tussen haar man Rod en Sugito. Sugito valt hem vaak aan en sloopt veel van zijn spullen. Uiteindelijk laat Rod Sugito verwijderen uit hun huis, als Biruté er niet is. Biruté is woedend. 'Sugito gaf me het grootste compliment dat een man of vrouw kan ontvangen. Voor hem was ik verreweg de belangrijkste persoon op de hele wereld.' (262) Galdikas beschrijft dat haar man vindt dat ze te ver gaat in haar liefde voor apen, en dat hij het vermoeiend vindt om iedere nacht het bed met haar en een orang-oetan te moeten delen. Net als Galdikas wordt ook Fossey getypeerd als 'the woman who loved apes too much'; gerefereerd wordt dan bijvoorbeeld aan de relatie tussen haar en Digit, de op 3I december 1977 door stropers vermoorde zilverrug, die zij haar 'geliefde' plachtte te noemen (Jahme 2000). Ook zijn er liefdevolle, erotisch aandoende, uitspraken over vrouwtjesgorilla's te vinden in haar dagboek: 'She stared intently into my eyes, and it was eye-to-eye contact for thirty or forty seconds. Not knowing quite what to do, for I had never had this reaction from gorillas before, I squished myself flat on the bed of vegetation. Whereupon she smelled my head and neck, then lay down beside me... and embraced me! ... embraced me... embraced me! GoD, she did remember!' (geciteerd in Mowat 1987: 286)

De erotische spanning wordt opgevoerd doordat de lezer, zoals in (of dankzij!) King Kong, zich afvraagt: zal de aap een stapje verdergaan? Tederheid en agressiviteit zoals in de concurrentie tussen Rod en de aap gaan hand in hand, maar Galdikas legt de 'schuld' bij Rod, 
opdat de aap zijn 'onschuld' kan behouden. Toch zal aan deze 'onschuld' worden getornd, als blijkt dat apen in staat zijn tot gewelddadig gedrag, waaronder verkrachting bij orang-oetans.

\section{MENSAPEN: MENSELIJKER DAN DE MENS?}

One morning at the dawn of man

A bunch of monkeys sat around in the sand

It was heaven, grooming, picking the fleas

They were happy, they were simple,

They were monkeys

\section{One of the ape-man picked up a rock}

He nodded his head as he got his first thought

He measured the weight, he felt it was sharp

Time for Eden to end

And mankind to start

Bright Blue Gorilla, 'The World is Mad' (1995)

Dankzij de inbreng van Goodall, Fossey en Galdikas verliezen de mensapen de laatste restjes van hun brute imago. Ondanks hun pogingen tot definitieve disambiguering van de mensaap, blijft er een merkwaardige spanning zichtbaar in hun werk, die te maken heeft met de wijze waarop de term 'menselijk' wordt ingezet. Op mensapen toegepast betekent de term iets positiefs, namelijk zachtaardig; in het geval van mensen is 'menselijk' synoniem voor 'wreed'.

De essentie van mens-zijn is het vermogen tot onbaatzuchtige betrokkenheid. [...] Onbaatzuchtige betrokkenheid is het helpen van hulpelozen, zonder een beloning te verwachten. Tegenover de inbreuk van de plunderende mens is de reusachtige berggorilla zo weerloos als een jong poesje, ondanks zijn omvang en ondanks zijn kracht. (Galdikas 1995: 512)

Enerzijds bestaat de kern van menselijkheid uit onbaatzuchtig gedrag, anderzijds worden mensen als 'plunderende' monsters afge- 
schilderd en tegenover de zachtmoedige aap geplaatst. 'Mensen dachten dat we gek waren om alleen en ongewapend het oerwoud in te trekken. Wat we deden was gevaarlijk, maar niet omdat de mensapen die we bestudeerden ons bedreigden. Het gevaar draagt een mensengedaante.' (Galdikas 1995: 504) Bij Fossey komt deze spanning op soortgelijke wijze tot uitdrukking. Hoe meer Fossey leert van de vredige dieren, hoe meer ze de 'brute' mensen gaat haten. De mensen kunnen iets van apen leren, en niet andersom. Ondanks de spanning tussen enerzijds het portretteren van de gorilla's als menselijke 'gentle giants' en anderzijds het afschilderen van de mens als een liefdeloos en wreed wezen, doet Fossey een beroep op de vrijgevigheid van de mens. Net als in de boeken van Goodall en Galdikas, worden de adressen van dierenbeschermingsorganisaties vermeld en worden de lezers uitgenodigd om geld te storten. Van de drie vrouwen lijkt Fossey de meeste twijfels te koesteren omtrent de gulheid van de mens. Ze voegt toe dat 'giften voor de belasting aftrekbaar zijn' (ro).

Het imago van de zachtaardige chimpansee, de gorilla en de orang-oetan waar Goodall, Fossey en Galdikas zich zo hard voor inzetten, loopt een deuk op wanneer verschillende vormen van geweld bij de mensapen ontdekt worden. ${ }^{22}$ Jane Goodall is de eerste die begin jaren zeventig constateert dat chimpansees oorlog met elkaar voeren, elkaar vermoorden, pasgeboren kinderen doden (infanticide), op jacht gaan en vlees eten, soms zelfs vlees van de eigen soort (kannibalisme). Fossey ontdekt infanticide bij de gorilla's en Galdikas krijgt te maken met verschillende vormen van geweld bij de orang-oetans: agressie, vechtende mannetjes en mannetjes die vrouwtjes met geweld tot geslachtsgemeenschap dwingen. Ook beschrijft Galdikas de verkrachting van haar kokkin door een mannetjes orang-oetan die vanaf zijn geboorte opgroeit onder de mensen. Hoe verklaren en integreren zij deze aspecten in hun beeld van de zachtaardige mensaap? Maakt het gewelddadige gedrag de mensapen menselijker of juist niet?

Goodall beschrijft in Oog in oog met de chimpansees hoe de gemeenschap van chimpansees die zij al tien jaar onderzocht zich in 1974 opsplitst in twee groepen, een noordelijke en een zuidelijke groep, en er een oorlog uitbreekt die vier jaar zal gaan duren. Groepjes mannen uit de noordelijke groep trekken er regelmatig op uit om te 'patrouilleren' langs de grenslijn van hun territorium. Dit 
patrouilleren mondt enkele malen uit in aanvallen op leden uit de zuidelijke groep. Goodall is getuige van een aanval van zes mannen op een mannetje, die zich van geen kwaad bewust rustig in een boom zit te eten. Ze overmeesteren hem, slaan hem en brengen ernstige verwondingen aan, waaraan hij later overlijdt. Niet alleen de mannen zijn het doelwit van de aanvallen, ook een vrouwtje wordt het slachtoffer van een dergelijke aanval. Uiteindelijk wordt de gehele zuidelijke gemeenschap door de noordelingen uitgemoord. Naast de gruwelijke moorden, zijn er ook kannibalistische feestmaaltijden. Passion en Pom, een moeder en haar dochter, vermoorden samen zes pasgeboren baby's om ze vervolgens op te eten. Goodall legt een verband met het menselijke geweld; in tijd van de vierjarige chimpansee-oorlog, landen Zaïrese rebellen in Gombe. Vier van haar studenten worden door de rebellen ontvoerd en er wordt losgeld geëist. Goodall is diep geschokt. Dat de mens tot zulke dingen in staat is, verbaast haar geenszins. Maar dat ook de chimpansee in staat is tot oorlog, tast haar beeld van de zachtaardige mensaap aan.

Ik had zo veel jaren geloofd dat chimpansees, hoewel ze in veel opzichten griezelige overeenkomsten met mensen vertoonden, over het algemeen wat 'aardiger' waren dan wij. Plotseling kwam ik erachter dat ze onder bepaalde omstandigheden net zo wreed konden zijn, dat er ook een donkere kant aan hun karakter was. En dat deed pijn. [...] Ik worstelde meerdere jaren om de nieuwe kennis te verwerken. (Goodall 199I: I09, cursivering van mij, sJ)

De ontdekking van geweld bij de chimpansees betekent dat Goodall haar beeld van de zachtaardige chimpansee moest bijstellen. Toch volhardt ze in het idee dat de chimpanse 'aardiger' is dan de mens, ondanks de 'griezelige overeenkomsten'. Het wrede gedrag maakt de mensaap, zo zou je verwachten, dus menselijker. Goodall noemt 'wreedheid' 'beslist de allerergste van de menselijke zonden' (24r), maar tegelijkertijd omschrijft ze het als 'een ongelukkig trekje van onmenselijkheid', en uit ze de hoop dat medeleven het overwint van wreedheid door een beroep te doen op de menselijkheid van de mens. Ze blijft daarbij vasthouden aan wat volgens haar een belangrijk verschil tussen het mensen- en het chimpanseegeweld is: alleen mensen zijn in staat tot opzettelijke wreedheden, doelbewust pijn en 
leed veroorzaken. Chimpansees hebben niet hetzelfde besef van het leed dat ze hun slachtoffers aandoen. ${ }^{23}$ Daarmee lijkt Goodall te willen voorkomen dat haar moeizaam bevochten zachtaardige imago van de mensaap opnieuw omslaat naar de andere kant. We moet het hun vergeven. Immers, ze weten niet wat ze doen. ${ }^{24}$ Dit idee van 'onbewust' geweld staat mijns inziens op gespannen voet met de idee dat mensapen intelligente dieren zijn met verstandelijke vermogens, die juist wel beseffen wat ze doen.

Galdikas heeft een soortgelijke shockerende ervaring waardoor haar beeld van de nobele orang-oetan wordt verstoord. Tijdens een van de dagen dat ze de orang-oetan Cara volgt in het woud, komt Galdikas klem te zitten tussen twee boomstammen. Wanneer ze boven zich gekraak hoort, blijkt dat Cara haar in de val heeft gelokt en pogingen doet een enorme tak af te breken om deze richting Galdikas te duwen. Galdikas is doodsbenauwd: Cara doet een poging om een dode boom als wapen te gebruiken om haar te vermoorden. Toch is dit voor Galdikas geen doorslaggevende ervaring om haar beeld van de orang-oetan bij te stellen: 'Ik zag Cara niet als een psychopathische moordenares of een 'moordende mensaap.' Ze probeerde gewoon haar woongebied in het bos te bevrijden van een ongewenste binnendringer' (155). Mogelijkerwijs speelt hier mee dat Cara een vrouwtjesaap is, al doet Galdikas hier geen uitspraken over. Het roept de uitspraak van Robert Yerkes (hoofdstuk drie) in herinnering, dat de gorilla's alleen gewelddadig gedrag vertonen wanneer zij zich door mensen in het nauw gedreven voelen.

Opvallend is dat Galdikas niet spreekt van 'verkrachting' wanneer ze schrijft over de seksuele levens van de orang-oetans. Ook maakt Galdikas weinig woorden vuil aan de verkrachting van haar kokkin. 'Zijn verkrachting van de kokkin was er een uit een lange reeks incidenten' (495). ${ }^{25}$ Het verbaast haar niet dat een orang-oetan, die al sinds zijn jeugd onder de mensen verblijft, zich aangetrokken voelt tot mensenvrouwen. Ook Galdikas stelt dat men het de mensapen niet kan kwalijk nemen dat ze gewelddadig zijn. Maar ze gaat daarin iets verder dan Goodall, door te stellen dat het geweld dat ze plegen wordt uitgelokt door de mens. Ze stelt veel in het werk om te voorkomen dat de orang-oetan, die ze met veel moeite heeft 'gedisambigueerd' - door een eerdere vorm van disambigu denken (de aap als agressief, lelijk, dom) te verbannen door 
een andere vorm van disambigu denken (de aap als lief, zacht, intelligent) - opnieuw ambigu wordt met het risico dat hij opnieuw de reputatie krijgt van een wreed dier.

Binnen de primatologie zijn twee interpretatielijnen zichtbaar, waarbij de ene richting de zachtaardige kant van de mensapen benadrukt, en de andere agressiviteit als kenmerkend voor de mensapen beschouwt. De primatologen Richard Wrangham en Dale Peterson vertegenwoordigen de tweede richting. $\mathrm{Zij}$ stellen in hun boek Agressieve mannetjes (1998) dat van de drie 'apenvrouwen' Fossey het sterkst een nieuwe 'mythe' in het leven zou hebben geroepen: die van de gorilla als zachtaardige reus. Infanticide onder gorilla's is een gegeven dat Fossey, aldus Wrangham en Peterson, in haar werk naar de achtergrond schoof, omdat ze bang was dat dit gegeven het beeld van gorilla als goedaardig opnieuw zou schaden. Wie de passages erop naslaat in Gorilla's in de Mist, moet inderdaad concluderen dat infanticide sporadisch en vrij terloops wordt besproken. Galdikas neemt het voor Fossey op door een positieve interpretatie van het geweld onder de gorilla's te geven. In haar ogen maakt het geweld de gorilla's 'intelligent' en 'gecompliceerd' (510) en agiteren de mensen de dieren door hun leefgebied te infiltreren. Opvallend is natuurlijk dat hetzelfde wrede gedrag van de mens niet 'gecompliceerd' wordt geacht, maar 'wreed'.

Anders dan Wrangham en Peterson benadrukt ook Frans de Waal het vermogen tot verzoenend gedrag in mensen, mensapen, apen en andere dieren, wat al blijkt uit de titels van zijn boeken. 'Ik ben een te grote optimist om te menen dat geweld dieper in de menselijke natuur wortelt dan vrede,' zo luidt de openingszin van Verzoening. Vrede stichten onder apen en mensen (1988). Hoewel hij agressief gedrag beschouwt als een wezenskenmerk van het dierlijke en menselijke leven, wijst hij er in dit boek op dat agressie een sociale functie heeft die mensen ook bindt, omdat er strategieën ontwikkeld zijn om agressie te beteugelen: verzoening. In Van nature goed. Over de oorsprong van goed en kwaad in mensen en andere dieren (1998) vraagt hij zich af of mensapen en andere dieren, net als de mens, in staat zijn tot moreel gedrag, dat wil zeggen het vermogen tot onbaatzuchtigheid en altruïstisch gedrag. ${ }^{26}$ Aan de hand van diverse foto's, anekdotes en voorbeelden toont hij aan dat altruïsme niet uitsluitend aan de mens kan worden toegeschreven, maar ook aan bijvoorbeeld chimpansees en dolfijnen. 
Zowel De Waal als Wrangham en Peterson richten zich op vraag wat de mens en wat mensaap zo menselijk maakt, zachtaardigheid of gewelddadigheid. Steeds weer staan daarmee definities van menselijkheid op het spel. De Waal is zich sterk bewust van de wijze waarop retoriek werkt en waarop een term als 'menselijk' steeds weer wordt ingezet. 'Wij gaan er niet alleen prat op dat we mens zijn, maar ook dat we menselijk zijn. Wat een briljante vondst om de moraliteit aan te wijzen als het waarmerk van de menselijke aard door onze soortnaam ook te gebruiken voor barmhartige neigingen!' (De Waal 1996: 9)

Hoewel De Waal op dezelfde interpretatielijn zit als Goodall, Fossey en Galdikas als het gaat om de zachtaardigheid van de mensapen, en ook hij zijn ideeën vaak autobiografisch verwoordt door te beginnen met een anekdote of een persoonlijke verklaring om dan over te gaan op het algemene, is er rondom zijn persoon en werk niet een representatie-industrie ontstaan, zoals bij Fossey, Galdikas en Goodall. Deels is dat wellicht te verklaren doordat zijn werk toch een iets ander karakter draagt. In zijn argumentaties doet hij sterker een beroep op het logisch redeneervermogen van de mens en minder op het empathisch inlevingsvermogen. Hij handhaaft sterker de scheiding tussen zichzelf en de dieren, en wijdt niet uit over zijn persoonlijke leven (zijn huwelijk bijvoorbeeld), en schrijft in die zin minder 'autobiografisch'. Daarmee presenteert hij zichzelf als een 'mannelijke' wetenschapper. Anders dan Goodall, Fossey en Galdikas roept hij minder onrust op en is zijn positie minder 'ambigu'. Achtereenvolgens analyseer ik nu de wijze waarop Goodall, Fossey en Galdikas en hun werk werden voorgesteld in fictie en non-fictie. Werden de vrouwelijke apenonderzoekers geprezen/verguisd omwille van hun (genderspecifieke) methoden? Hoe worden zij en haar werk gerepresenteerd? Wordt er nadruk gelegd op hun vrouw-zijn en zo ja, hoe? Worden zij als geseksualiseerd wezen voorgesteld (beauty) of als de geestelijke wetenschappers (brains)? In hoeverre hebben zij de macht over hun eigen imago; sturen zij of worden zij gestuurd? 
Being with Jane Goodall is like a walk with Gandhi

Boston Globe (geciteerd op de achterflap van Reason for Hope)

Anders dan Fossey en Galdikas, die enorm veel kritiek over zich heen kregen, bleef Jane Goodall gedurende haar leven een aangenaam soort respect behouden. Galdikas (1995) schrijft dat Goodall zich in het begin van haar carrière niet uit het veld liet slaan door sensatieachtige berichten als 'blondine heeft liever een chimp dan een man' dankzij haar 'rustige waardigheid en Britse evenwichtigheid'. Zij trad haar critici zelfs beminnelijk tegemoet. In latere publicaties zou Goodall (200o) te kennen geven dat het imago van aantrekkelijk blondje haar wel stoorde, maar dat ze er zelf aan meewerkte vanwege de goede zaak, namelijk aandacht voor de chimpansees. Goodall balanceerde op een koord: wilde ze wetenschappelijk serieus genomen worden, dan diende ze haar 'vrouwelijkheid' niet te zeer op de voorgrond te schuiven; wilde ze een breed publiek overtuigen van de zachtaardigheid van de aap, dan diende ze haar vrouwelijkheid in te zetten als empathisch wapen, en met een vriendelijke glimlach en een meisjesachtig paardestaartje haar publiek te verleiden. In publicaties bevestigde ze het beeld van de jonge aantrekkelijke vrouw. Erotisch getinte passages treft men volop in haar boeken aan - zelfs een enkele sado-masochistische $^{27}$-, maar ze ging daarbij nooit over de schreef: Goodall portretteerde zichzelf en werd geportretteerd als een good girl.

In deze paragraaf analyseer ik de wijze waarop Goodall is gerepresenteerd in de roman Brazzaville Beach (1990) van de Britse schrijver William Boyd. ${ }^{28}$ Voor Brazzaville Beach baseerde Boyd zich op krantenartikelen over Jane Goodall. Hope Clearwater, de hoofdfiguur uit Boyds Brazzaville Beach, is net als Jane Goodall een jonge vrouw die in Afrika onderzoek naar chimpansees doet en oorlog, kannibalisme en infanticide ontdekt. Ik heb niet alleen voor dit voorbeeld gekozen omdat het een zeer bekende (en dus invloedrijke) representatie is, maar ook omdat de wijze waarop Hope in haar wetenschapsbeoefening oog heeft voor het geweld onder de apen nadrukkelijk gekoppeld wordt aan haar positie als vrouwelijke wetenschapper. Juist omdat zij, anders dan de mannelijke perso- 
nages, niet vastzit in de gevestigde mannelijke hiërarchie van de wetenschap, heeft zij oog voor ambiguïteit. Opmerkelijk in deze roman is bovendien dat Hope Clearwater zich met de apenoorlog gaat bemoeien: zij schiet drie apen dood. Dat lijkt minder goed te passen in het plaatje van Jane Goodall als good girl. Waarom schiet Hope, die volgens vrienden 'meer om een apenleven geeft dan dat van een mens', haar geliefde apen dood? In de hoofdstukken over King Kong en Mijn aap schreit interpreteerde ik het doden van de ambigue aap door de man als een manier om met twijfels en onzekerheden omtrent de aard en de hiërarchische status van de mens - en de status van de man in het bijzonder - om te gaan. In Brazzaville Beach vermoordt een vrouw maar liefst drie apen, en ook dit gegeven maakt de roman interessant voor nadere lezing. Is Hopes moord een ander soort doden dan in King Kong en Mijn aap schreit?

De keuze voor Hope als hoofdpersoon en verteller in Brazzaville $B e a c h$ was niet toevallig. In een interview met NRC Handelsblad (I-31991) vertelde Boyd dat zijn plan om een roman over primatologie te schrijven automatisch in een vrouwelijk perspectief resulteerde. 'Lezend over primatologie viel het me op dat zo veel deskundigen vrouwen waren. Bingo. Zo gaat dat, eerst vind je het onderwerp van de chimpansees en daaruit volgt dan bijna automatisch het vrouwelijke vertellersperspectief.' Hope kijkt, enkele jaren na 1964, in een lange flashback terug op twee ingrijpende gebeurtenissen uit haar leven, die elkaar als twee afzonderlijke verhaallijnen in het boek afwisselen. De eerste lijn speelt zich af in Groot-Brittannië en beschrijft de teloorgang van haar huwelijk met John Clearwater. Hij is een wiskundige die geobsedeerd raakt door het zoeken naar een alomvattende formule van het fenomeen turbulentie. Johns karakter verandert: hij pleegt overspel, stopt met drinken en gaat regelmatig graven, omdat hij zegt zich dan beter te kunnen concentreren. Uiteindelijk draaft John door: hij graaft een grote kuil - letterlijk zijn eigen graf - gaat erin liggen en pleegt zelfmoord. Het tweede verhaal gaat over Hopes leven na haar mislukte huwelijk, als apenonderzoekster in Afrika in Grosso Arvore. Haar baas, professor Eugene Mallabar, is een zeer bekende primatoloog die op het punt staat zijn chef d'oeuvre te publiceren, Primate: the Society of a Great Ape, een groots werk over chimpansee-samenlevingen. Daarin wil hij opnieuw de stelling van zijn eerdere boek, The Peaceful Primate uitdragen, namelijk dat chimpansees vriendelij- 
ke en vreedzame dieren zijn. Hope ontdekt tijdens haar veldwerk echter dat er aan de zachtaardigheid van de dieren getwijfeld moet worden: kannibalisme, oorlog en infanticide komen voor. Wanneer Hope hier met haar professor over praat, beschuldigt hij haar ervan dat ze het gedrag van de chimpansees met haar aanwezigheid heeft beïnvloed. 'What have you been doing to them?' schreeuwt hij haar toe. ${ }^{29}$ Kort daarna gaat Hopes werkruimte, een hut waarin ze haar aantekeningen bewaart, in vlammen $\mathrm{op}^{30}$, en volgt er zelfs een poging tot moord.

De belangrijkste overeenkomst tussen Hope en Jane Goodall is, naast Hopes ontdekkingen van oorlog, infanticide en kannibalisme onder de apen, de wijze waarop ze zich empathisch op de apen richt. Ze geeft de chimps namen, bijvoorbeeld Conrad, Rita-Lu en Rita Mae, waarmee zij hen als personen behandelt. Haar professor Mallabar is hier tegen; hij ziet de apen als onderzoeksobjecten. Een typerende dialoog tussen Hope en Mallabar is bijvoorbeeld deze:

How was your day?' he said after a while.

'Oh...Clovis smelt his finger for a couple of hours.'

'Clovis?' He shook his fork at me.

'XNMI. Sorry'. (Io) ${ }^{31}$

Niet alleen de status van de mens in relatie tot de mensaap, maar ook het gedrag - kwaadaardig of zachtaardig - wordt ter discussie gesteld. Brazzaville Beach werpt de vraag op hoe gewelddadig de mens is, en in hoeverre de mens lijkt op de aap. Door Mallabar wordt aangenomen dat de chimpansee een vredelievend dier is. Terwijl Mallabar zijn boek over de zachtaardige voorouder van de mens wil afronden, valt in Brazzaville Beach echter de ene na de andere dode onder de mensen en de mensapen. John pleegt zelfmoord, de noordelijke chimpansees moorden de chimps van de zuidelijke groep systematisch uit, Hope schiet drie apen neer, en het decor van de roman wordt gevormd door vechtende soldaten in burgeroorlog.

Terwijl de biologe Hope, in haar meer concrete wetenschapsbeoefening in het veld worstelt met de vraag wat zij moet doen met de informatie die afwijkt van het standaardbeeld dat de wetenschap voorhoudt, denkt ze terug aan de periodes van haar huwelijk en de worstelingen van haar man, de wiskundige John. Hij raakte geobse- 
deerd door het zoeken naar die ene formule waarmee hij onvoorspelbaarheid, onzekerheid en afwijking kan beschrijven. John wil niet-lineaire processen in een zuivere formule vangen. Hij probeert ook een 'zuiver leven' te leiden en zich niet door aardse zaken te laten afleiden $\mathrm{Hij}$ stopt met drinken en weigert met Hope naar de film te gaan of met haar te vrijen. In plaats daarvan leest hij voortdurend detectives, waarin uiteraard steeds een oplossing gevonden wordt voor een raadsel. John wil de afwijkingen in al hun zuiverheid en helderheid kunnen vangen: 'Clarity of vision is vital in my field. You can't do mathematics in a mist.' $(215)^{32}$

Johns obsessie met formules en Hopes apenonderzoek representeren de verschillende wijzen waarop twee wetenschapsgebieden proberen het leven in kaart te brengen. De wiskunde houdt zich bezig met abstracte formules, terwijl de biologie levende wezens en de natuur als onderwerp heeft. Zowel Hope als John zijn bezig met de vraag wanneer een afwijking binnen het systeem significant wordt. Diezelfde vraag stelt Hope ook aan haar huwelijk met John, dat steeds slechter gaat. Wanneer ze ontdekt dat hij overspel pleegt, vraagt ze zich af of hoe deze 'afwijking' zo lang onopgemerkt is gebleven. John en Hope zijn ook op een verschillende manier bezig met wetenschap. Van Hope weten we dat ze vroeger onderzoek deed naar het classificeren van oude heggen in het bijzonder, en dat ze gek was op de wirwar van patronen. $\mathrm{Zij}$ haalde de heggen niet uit elkaar maar hield ze vervlochten. John doet wanhopig zijn best om afwijkingen in een formule te vangen en tot een vorm van regelmaat reduceren; hij wil beheersen, maar wordt gek.

Net als John is ook Mallabar uit op orde, op een samenhangend en eenduidig beeld van de chimpanseesamenleving. Mallabars poging om Hope te vermoorden is een poging om 'de afwijking' binnen zijn systeem, zijn wereldbeeld, te elimineren. Mallabars beeld van de chimpansees is eenduidig. Hij is uit op de bevestiging van zijn ideeën, namelijk dat apen ondubbelzinnig zijn: zachtaardige wezens. In dit opzicht lijkt zijn inzet op die van Goodall, Galdikas en Fossey in het begin van hun carrières, hoewel Goodall later voor dezelfde situatie als Hope kwam te staan. Mallabar beschouwt de apen als objecten van onderzoek, terwijl Hope ze ziet als subjecten. Hope zit minder vast in traditionele denkbeelden met betrekking tot de natuur van de chimpansee; zij zit ook minder vast in de hiërarchische structuur. In haar positie als vrouw heeft ze geweld on- 
dervonden; ze herkent het bij de apen..$^{33}$ Hierdoor kan zij afwijking waarnemen. Ze ondermijnt Mallabars belangrijkste stelling: dat chimpansees vreedzame dieren zijn van wie de mens kan leren. $\mathrm{Zij}$ ziet de apen in hun ambiguiteit, als 'waarlijke' subjecten die zowel zachtaardige als kwaadaardige aspecten in zich verenigen. Daarmee heft ze wel een andere ambiguitteit op: chimpansees blijken, doordat ze gewelddadig zijn, 'menselijker' dan gedacht.

Het geweld onder de mensen wordt vooral door de mannen gepleegd. De mannelijke personages in Brazzaville Beach komen er niet al te best van af. Alle mannen in Hopes leven bedriegen haar op een of andere manier: John pleegt overspel, haar vroegere promotor Hobbes (!) eigende zich Hopes onderzoeksresultaten toe, Mallabar slaat Hope, haar Afrikaanse minnaar Usman liegt tegen haar en haar vader noemt haar 'Hopeless'. De roman roept de vraag op of mannen niets meer dan agressieve apen en machiavellistische wellustelingen zijn, en of de zachtaardigheid van de mensheid niet vooral vrouwen betreft. Meer in het algemeen suggereert Brazzaville Beach dat alle mensen, ook vrouwen dus, sterk op mensapen lijken. Wanneer nieuwe personages in de roman geïntroduceerd worden, worden zij op soortgelijke uiterlijke en vleselijke manier beschreven als de chimpansees, van wie steeds wordt aangegeven hoe groot een eventuele roze zwelling is, hoe hun imponeergedrag is en of ze aantrekkelijk zijn volgens haar chimpanseebegrippen. Van de mannen wordt bijvoorbeeld steeds de hoeveelheid haar vermeld. John, Hopes echtgenoot, heeft een 'haarloos' lichaam en is steeds 'fris geschoren'. Mallabar daarentegen heeft 'a two inch stripe of hair running vertically down his front from throat to navel'. Hopes vader is zeer trots op zijn grote weelderige haardos en zijn baard. John heeft een geestelijk en abstract beroep en is niet in staat controle en macht uit te oefenen, zoals Mallabar. John, degene met het minste haar onder de mannen, heeft de slechtste overlevingskansen. Hij gaat dood. Ook vrouwen worden uitvoerig beschreven: met name hun formaat borsten, de omvang van hun buik en het type (schaam)haar. ${ }^{34}$

Maar op de laatste bladzijde wordt Hope gewelddadig, en dit is het punt waarop de roman sterk afwijkt van het levensverhaal van Jane Goodall. Hope ziet hoe acht volwassen mannetjes een aanval doen op Conrad en hem aan stukken scheuren en gruwelijk verminken. Hope schreeuwt dat de apen moeten stoppen en richt een pistool op de apen. 'But what was a gun to them, Homo troglody- 
tes? And what was I? Just another, strange, bipedal ape, displaying, noisy, threatening.' (307) Dan stormt Pulul, een grote volwassen chimpanseeman, op haar af. Hope schiet. 'My first shot caught him in the chest, high on one side, and knocked him spinning off his feet. Then Darius leapt across the stream and galloped towards me. I shot him full in the face when he was about six feet away. I saw shards of his disintegrating skull fly up into the air like spun coins' (307). Direct daarna doet Darius een aanval. Ze schiet hem in zijn gezicht. Ze schiet ook nog op twee andere apen, maar mist en ze vluchten weg. Dan is er een stilte. Als ze naar Pulul loopt, ziet dat deze nog leeft, maar zwaar gewond is, schiet ze hem dood. Darius is al dood, hij ligt op zijn rug, zijn armen uiteen als een zonnebader. ${ }^{35}$ (266) Dan loopt ze naar Conrad en ziet hoe hij daar ligt, stervende. Ze ziet dat hij haar aankijkt. Hope kan zijn blik niet duiden. 'Accusing? Pleading? Hostile? Baffled?' (308) Ook Conrad helpt ze uit zijn lijden en schiet hem dood. Ze voelt zich opgelucht: 'I felt much better. I was glad I had killed Darius and Pulul' (308).

Is er sprake van moord uit betrokkenheid en liefde? Of is haar doden een vorm van zelfbescherming tegen een gevaarlijke aap die haar aanvalt? Zij doodt Darius en Pulul niet uit onzekerheid (zoals in Mijn aap schreit gebeurt) of uit heldhaftigheid (King Kong) maar omdat zij een andere aap aanvallen; vervolgens verlost ze het slachtoffer, Conrad, uit zijn lijden. Hopes doden is, zo zou ik willen suggereren, een vorm van 'participerend doden'. Zij kiest partij in de oorlog van de chimpansees, partij voor degene die het geweld overkomt en die te machteloos is om zich tegen de groep te verzetten. Terwijl ze zich tegenover haar professor Mallabar, haar vader, haar vroegere professor Hobbes en haar man John machteloos voelt, kiest ze hier partij voor de zwakkere, voor Conrad. Met het doden van de stervende en lijdende dieren wil ze niet haar superioriteit handhaven of ambiguitteit uitroeien, maar meer leed voorkomen en de chimpanseeoorlog beëindigen. Tegelijkertijd is het echter een daad van zelfbescherming, waarmee ze zich actief als mens tegenover de apen moet plaatsen en het verschil onderkent. Ze barst niet in tranen uit, vrij koel beschrijft ze de uiteenspattende schedel van de aap.

Na haar moordpartij stopt Hope met het veldwerk. Ze werkt nog steeds voor Mallabar, maar spreekt hem zelden. Hij vertoeft veel in Amerika om lezingen te geven over zijn nieuwe, succesvolle boek 
Primate: the Society of a Great Ape. Over het incident met Darius, Conrad en Pulul heeft ze met geen woord gerept en de lijken zijn nooit gevonden, of hun vondst is verzwegen. Hope is terechtgekomen in een 'grote' voetnoot in Mallabars boek, waarin hij zijn erkentelijkheid uitspreekt over haar bijdrage aan het project. De chimpanseeoorlog, infanticide en kannibalisme blijven onvermeld. Hope weet niet zeker wat ze in de toekomst gaat doen: 'What now? What next? All these questions. All these doubts. So few certainties. But then I have taken new comfort and refuge in the doctrine that advises one not to seek tranquility in certainty, but in permanently suspended judgement. I walk along the beach enjoying my indecision, my moral limbo' (313). Het slot van Brazzaville Beach is ontmoedigend: niet de waarheid wint, maar de machtigste. En de waarheid is datgene wat de machtigste verkondigt. Hier wordt het imago van de 'zachte' en 'goede' wetenschapster gecreëerd, die de wetenschap (van mannen) intact laat en de goede vrede bewaart. Ondertussen weet ze wel beter, maar ze streeft er niet naar haar gelijk te halen in de hiërarchie van de wetenschappelijke wereld. Toch heeft Hope, anders dan de meeste mannen in de roman, haar innerlijke rust gevonden en onzekerheid en twijfel in haar leven weten te integreren. $\mathrm{Zij}$ kijkt uit op de rustgevende golven van Brazzaville Beach. Van haar moord heeft ze geen spijt. 'I knew my conscience would never be troubled, because I had done the right thing, for once. The chimpanzee wars were over' (308)

Hope wordt in Brazzaville Beach geportretteerd als een jonge aantrekkelijke en hardwerkende vrouw die tegen wil en dank wordt onderdrukt door de machtige mannen in de wetenschap, waarin 'ambiguitteit' niet wordt geaccepteerd. In het werkelijke leven van Jane Goodall ging dat anders: zij verdween niet als voetnoot in de geschiedenis, maar trad vaak op de voorgrond. Sommige recensenten van Brazzaville Beach legden zich dan ook toe op de vraag in hoeverre Brazzaville Beach een waarheidsgetrouwe roman is. Times Literary Supplement liet de roman door een bioloog bespreken, die hem typeert als een 'fictional remake' van Jane Goodalls verhaal. Hij vraagt zich af of het ethisch verantwoord is dat Boyd wat losjes omspringt met de feiten, 'altering the textbook facts of primatology for fictional purposes'. (Times Literary Supplement, 14-9-1990) Dit alles tot grote ergernis van Boyd zelf: 
Overigens blijkt het mij telkens opnieuw dat wetenschappers er een grote hekel aan hebben wanneer romanschrijvers zich op hun terrein wagen. Zowel op het beeld dat ik geef van Hope Clearwaters chimpanseeonderzoek, als op dat van John Clearwaters wiskundig onderzoek heb ik felle kritiek gekregen omdat ik bepaalde details veranderd had. Ongelooflijk! Alsof mijn roman wetenschappelijke pretenties zou hebben. De Times Literary Supplement liet Brazzaville Beach nota bene bespreken door een bioloog.

Iets daarvoor merkt hij op dat de romanschrijver per definitie een twijfelaar is, iemand die in grijstinten denkt en geen absolute waarheden kent. Hij is ook opgelucht dat ook steeds meer wetenschappers - de recensent van TLs daargelaten - 'ambiguïteit, toeval en gebrek aan precisie' belangrijker gaan vinden omdat dit klopt met zijn ervaring van de wereld. (de Volkskrant, 20-9-199I) Elders merkt hij op dat deze kwaliteiten de wetenschap menselijker maken. (Vrij $\mathrm{Ne}$ derland, 2I-9-199I)

Wordt Hope Clearwater in Brazzaville Beach met ambiguïteit geportretteerd, een good girl die als het nodig is een geweer ter hand neemt, latere documentaires (onder andere 'Hoop voor de toekomst' van National Geographic), portretteren de oudere Goodall als een soort heilige, boven elke vorm van seksualiteit verheven. In de jaren negentig propageerde Goodall een holistische vorm van denken, waarbij de mens en de natuur één zijn. Daarmee haakte ze aan bij de modes van haar tijd, zoals het new-agedenken. Het blijft moeilijk 'zelf-representatie' en 'beeldvorming' te onderscheiden, omdat Goodall in de dingen die ze zegt in de documentaire en in de begeleidende publicaties, het beeld bevestigt. In Hoop voor de toekomst (2000) schrijft Goodall uitvoerig over de rol van het christelijke geloof in haar liefde voor de chimpansees. Ze volgt haar ontwikkeling als gelovige en vertelt onder meer over haar vroegste jeugd. Als jong meisje identificeert ze zich met Jezus en is ze geobsedeerd door kruisiging. Voortdurend wordt ze gekweld door de vraag waarom de menselijke soort zo destructief is, zo egoïstisch en inhalig en soms ook 'werkelijk kwaadaardig'. Goodall is echter optimistisch gebleven en gelooft in de bekering van de kwaadaardige mens. $\mathrm{Zij}$ reist vandaag de dag wereld over om haar 'boodschap' te verspreiden die haar 'van buitenaf wordt ingegeven': Het is een boodschap van geloof, hoop en liefde, 'hoop voor de toekomst van het leven op aarde' 
(Goodall 2000: 13). Daarbij heeft ze haar eigen naam mee. 'Jane' roept Tarzans levensgezellin in de herinnering, een associatie die Goodall zelf ook legde, toen zij in een interview te kennen gaf dat zij een betere Jane voor Tarzan zou zijn geweest; ${ }^{36}$ Goodall betekent 'all-good'. Hoe treffend gekozen is ook de naam van het personage in Brazzaville Beach dat William Boyd naar Goodall modelleerde! Hope draagt de belofte in zich dat het dankzij de vrouw wellicht goed komt met de mensheid, een belofte waarmee Jane Goodall, getuige haar boek Reason for Hope, mee in zou stemmen.

\section{KARAKTERMOORD IN GORILLAS IN THE MIST}

Het werkelijke leven is soms harder dan het leven van een romanpersonage. Terwijl Hope Clearwater uit Brazzaville Beach de moordaanslagen overleeft, eindigt het echte leven soms met de dood van de vrouwelijke primatologe. Dian Fossey werd op 28 december 1985 vermoord in het gorillapark in Rwanda. Een van Fosseys studenten, Wayne McGuire, werd direct na de moord gearresteerd, maar wegens gebrek aan bewijs later weer vrijgelaten. De onopgeloste mysterieuze moord is volgens Marianna Torgovnick (1996: 3 ) de reden van de voortdurende fascinatie voor Dian Fossey. 'Because the victim was female, the mystery has a special erotic thrill, with the added racial charge of a white female victim paired with a potentially black male killer. Because the setting was Africa, the crime feeds ideas of African dangers, African deadliness, "African madness".

Zoals Fossey probeerde de gorilla's 'uit de mist' te halen, zo hebben ook biografen en filmmakers geprobeerd Fossey te doorgronden en haar 'ware' karakter te achterhalen. Fosseys levensverhaal zou verteld worden als een 'cautionary tale', een waarschuwingsverhaal ('doe het niet zoals zij'), of een 'inspirational tale' ('volg haar voorbeeld') (Torgovnick 1996: 3). Was Goodall een 'good girl' en daarna een 'heilige', Fossey kwam naar voren of als een heldhaftig persoon, of als een doorgedraaide vrouw vol seksuele frustraties, een 'hoer/heks'. Voorbeelden van 'cautionary tales' zijn de biografieën The Dark Romance of Dian Fossey (1987) van Harold Hayes en Alex Shoumatoffs reisverslag van zijn bezoek aan Fosseys kamp in African Madness (1989). Hayes en Shoumatoff schetsen het 
beeld van een seksueel gefrustreerde vrouw die vanwege haar 'reusachtige' gestalte geen man kon vinden en de troost zocht bij de alcohol en de apen en langzaam maar zeker gek werd. Zij leggen een rechtstreeks verband gelegd tussen haar dierenliefde, haar ongelukkige jeugd (haar vader had haar op jeugdige leeftijd in de steek gelaten) en het gevoel afgewezen te zijn in de mensenliefde. Hayes en Shoumatoff schrijven dat Fossey veel vijanden had gemaakt gedurende haar leven, waaronder enkele stropers, parkbewakers, werknemers, onderzoekers. Beide auteurs nemen McGuire in bescherming en stellen dat een moord door iedereen gepleegd had kunnen worden. Hoewel Galdikas' De spiegel van het paradijs en de film Gorillas in the Mist (Michael Apted 1988) 'inspirational tales' over Fossey lijken, slaat de balans door naar de negatieve kant. Galdikas is ambivalent in haar karakterschets van Fossey. Enerzijds identificeert ze zich met Fossey, die voor haar een 'zuster' was en die zich, net als zij, steeds verkeerd is begrepen. Tegelijkertijd komt ze ook in haar portret naar voren als een met haar uiterlijk gepreoccupeerde 'heks'.

Bij onze eerste kennismaking deed Dian me denken aan de Sneeuwkoningin van Narnia, uit de serie van C.S. Lewis, de 'Witte Heks', wier toverkracht ervoor zorgde dat het in Narnia altijd winter was, maar dat het nooit Kerstmis werd. [...] Ik was verbaasd dat deze wetenschapster, die ik bijna vereerde, zich zo bezighield met haar uiterlijk. In de wildernis was ze moedig volwassen gorillamannen van 180 kilo tegemoet getreden en toch leek ze haar gevoel van eigenwaarde te ontlenen aan haar aantrekkelijkheid als vrouw. Ik schreef het toe aan het feit dat ze in de jaren veertig en vijftig was opgegroeid en buitengewoon lang was in een tijd waarin vrouwen van haar lengte niet echt in trek waren. Ongetwijfeld wisten sommige lange vrouwen uit die tijd hun 'onvrouwelijke' lengte te compenseren door zich op overdreven wijze op te tutten met stroken en kantjes. (Galdikas 1995: 82, 366)

Farley Mowats biografie Woman in the Mists. The Story of Dian Fossey and the Mountain Gorillas of Africa en Walking with the Great Apes (199i), de jubelende groepsbiografie van Goodall, Galdikas en Fossey van Sue Montgomery, zijn daarentegen te lezen als hagiografieën. 


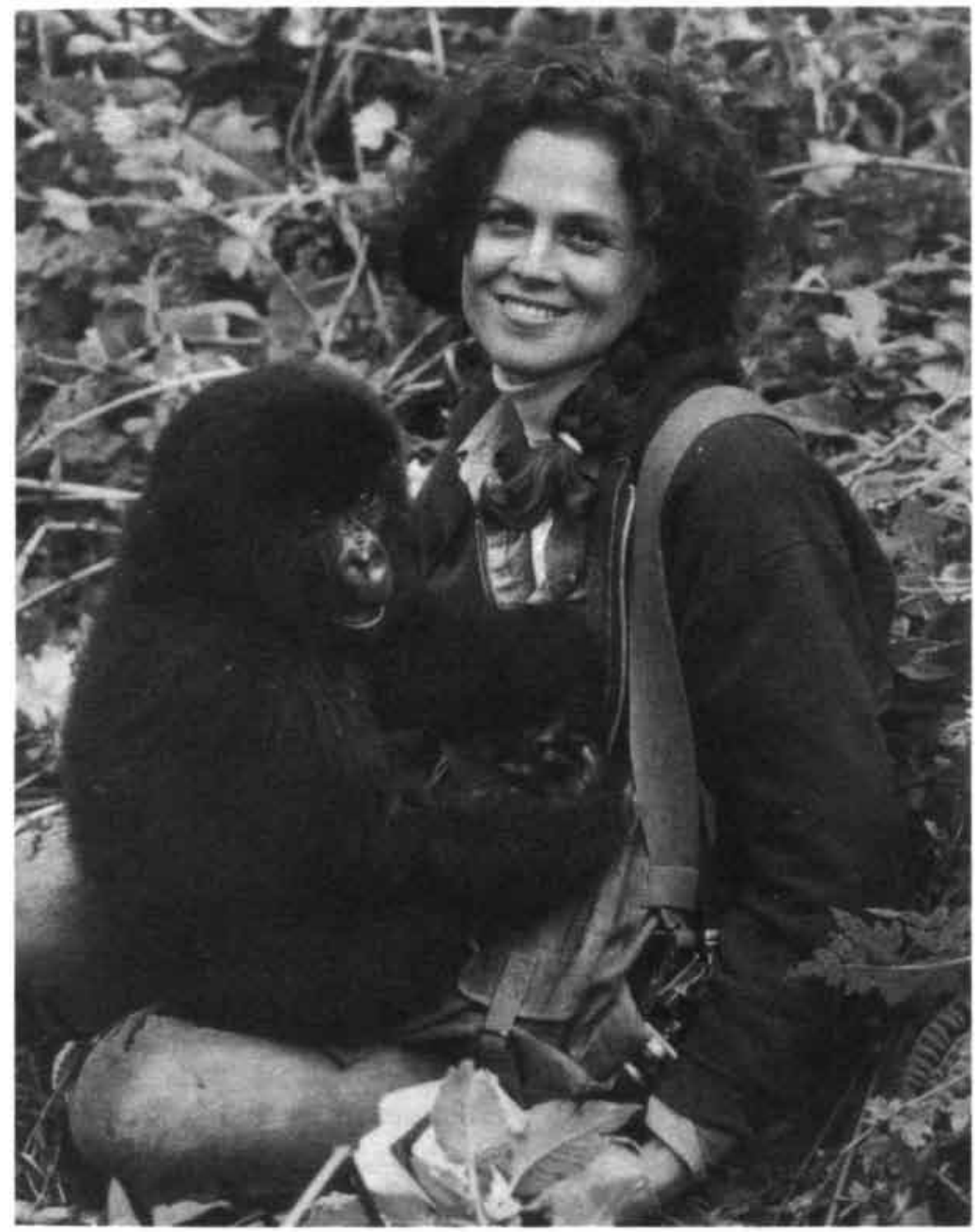

16 Sigourney Weaver als Dian Fossey in Gorillas in the Mist (1988).

Tussen de enorme hoeveelheid publicaties - een ingewikkeld web van artikelen die op hun beurt naar andere literatuur verwijzen - zou de bekende Hollywood-verfilming van Fosseys leven, Gorillas in the Mist. The Story of Dian Fossey, een belangrijke rol spelen in de publieke oordeelsvorming over Fossey en haar werk. In deze paragraaf zal ik om deze reden ingaan op de wijze waarop 
Fossey en haar werk daarin worden gerepresenteerd. Behalve op Fosseys Gorillas in the Mist, is de film gebaseerd op het boek van Harold Hayes, en dit is niet onbelangrijk. Zijn invloed is duidelijk waarneembaar. De film is, net als Hayes' boek, gericht op vraag waarom Fossey om het leven werd gebracht, een whydunit, en minder op de vraag wie de moordenaar was (whodunit). De film geeft daarop een duidelijk antwoord: wie de moordenaar is, weten we niet, maar dat ze veel vijanden had, staat als een paal boven water, en er was een goede reden voor: Fossey was een moeilijke vrouw. $\mathrm{Al}$ in de eerste scène van de film, waarin Fossey zichzelf aan Louis Leakey voorstelt en hem vraagt of ze naar Afrika mag, komt ze over als een weinig flexibele en licht geagiteerde vrouw. ${ }^{37}$ In de tweede scène, de aankomst van Fossey in Afrika, wordt al duidelijk dat Fossey gewend is aan de luxe die een blanke westerse vrouw zich kan veroorloven en zich niet gemakkelijk neerlegt bij het wat chaotischer leven in Afrika. Ongeduldig rookt ze een sigaret - we zien haar voortdurend roken of drinken in de film - en moppert ze over het feit dat haar bagage niet mee kan naar haar werkplaats. Fossey staat erop dat de koffers meegaan, omdat haar 'föhn, make-up, slipjes en bh's' zich erin bevinden. 'If they don't go, I don't go.' Ook de op hand zijnde burgeroorlog kan Fossey niet van haar plan afbrengen: 'If any civil war comes my way it has better watch its ass,' merkt ze frivooltjes op. De aandacht voor het uiterlijk, die Fossey typeren als een ijdele vrouw, keert steeds terug in in de film. Fossey is bijvoorbeeld verontwaardigd dat National Geographic geen 'nagellak of een föhn' vergoedt, en Leakey vermaant haar per brief dat ze te veel uitgeeft aan 'snoep, sigaretten, lippenstift en shampoo'. Hij spoort haar aan om een goedkoper merk sigaretten te roken.

Een belangrijke rode draad door de film is de liefdesrelatie tussen Fossey en de fotograaf Bob Campbell, die haar voor een documentaire voor National Geographic opzoekt in Afrika. Hij is degene die vastlegt hoe Fossey voor het eerst contact legt met een mannetjesgorilla, een van de hoogtepunten in haar onderzoek. Over dat onderzoek komen we niet veel te weten, behalve dat de hulp van Afrikaanse spooronderzoeker onontbeerlijk is. Fossey treedt hem echter, en dat geldt ook voor haar overige Afrikaanse personeel, neerbuigend tegemoet; zij is de baas, en dat zullen de mannen weten.

Hoewel Campbell getrouwd is, begint hij een affaire met Fossey. 
Samen in bad bekijken ze de film die hij over de gorilla's heeft gemaakt. Verbluft constateert ze dat ze zelf ook steeds in beeld is.

'Why am I in this movie so much?'

'Cuz you're the story - you're what people are interested in.'

'I am the Gorilla Girl.'

'While I'm having gorilla's as bridesmaides.'

Hier tekent Fossey protest aan tegen de wijze waarop haar werk wordt gerepresenteerd: niet de apen, maar het meisje heeft de hoofdrol gekregen. Haar protest haalt weinig uit: Campbell maakt - net als in de film King Kong - haar duidelijk dat ze het publiek moeten geven wat ze willen: een romantische lijn waarin een meisje van apen houdt.

Het huwelijk wordt hier voorgesteld als een bestiale aangelegenheid: als Campbell met Fossey trouwt, is dat ook een huwelijk met de gorilla's. Maar er komt geen huwelijk. Campbell krijgt een nieuwe baan aangeboden in Borneo en Fossey besluit niet met hem mee te gaan. Ze is te zeer gehecht aan haar gorilla's. 'Ik ben verslaafd; zegt ze.

We concluderen even later dat de mislukking van de relatie haar geen goed heeft gedaan. De film verspringt naar 'vijf jaar later' en we treffen Fossey aan op een markt, met een bezeten uitdrukking in haar ogen. Ze is op weg naar een instituut om ervoor te zorgen dat het leefgebied van de gorilla's beschermd wordt, en dat zij haar werkvergunning mag verlengen. Ze maakt zich ernstig zorgen om de stropers.

De tweede belangrijke verhaallijn is Fosseys gevecht tegen de stropers. Haar eerste ontmoeting met een dier in Afrika betreft geen gorilla, maar een gewond hert, dat in de val is gelokt. Fossey verlost het hert met een schot uit zijn lijden. Als ze ontdekt dat haar gorilla's door stropers worden doorverkocht aan westerse dierentuinen, gaat ze praten met een Afrikaanse ambtenaar. Ze zegt hem dat 'haar gorilla's' recht hebben op bescherming. Hij vermaant haar dat het niet haar gorilla's zijn, en stelt dat Fossey zich niet inleeft in de positie van de Afrikanen, die de ruimte met de gorilla's delen om hun inkomen, voedsel bijvoorbeeld, te vergaren.$^{38} \mathrm{De}$ film geeft hier een van de verwijten weer die Fossey tijdens haar leven vaak hoorde en die in de Fossey-receptie vaak aan de orde komt, namelijk 
dat ze te weinig oog zou hebben voor koloniale, nationale en etnische verhoudingen en zich te veel zou richten op het contact met de gorilla's. Ze plaatste de Rwandezen als vijanden tegenover haar gorilla's, zonder zich te realiseren dat deze het woongebied delen met de gorilla, en dat mens en dier ecologisch samenleven. Zij ziet het leefgebied van de gorilla's als een oerstaat die verpest wordt door de mens. (Armbruster 1997). Ook anderen merken op dat ze te weinig inlevingsvermogen had voor de niet-westerse kijk op dieren. ${ }^{39} \mathrm{Ze}$ zag de gorilla als 'ander' die beschermd moest worden omdat deze menselijk was, maar plaatste zich als een koloniale heerser boven de Afrikaanse bevolking. Maar anderen menen dat Fossey een 'Afrikaan' is geworden (Galdikas 1995: 515).

Desondanks weet Fossey in Gorillas in the Mist een overeenkomst met de Afrikanen te sluiten over een stroopverbod op gorilla's. Wanneer blijkt dat men zich daar niet aan houdt, en Digit wordt vermoord, neemt Fossey het recht in eigen hand. Terwijl Fossey in haar werk de mensachtigheid van de gorilla's benadrukte en ze als 'gentle giants' neerzet, kreeg in haar eigen leven teleurstelling over de mens de overhand. We zien hoe een woedende Fossey eerst de hutten van de stropers in brand steekt, vervolgens een jong kind bang maakt door een Halloweenmasker op te zetten en later een stroper vastbindt en mishandelt. Ze laat hem zelfs de uitwerpselen van een gorilla opeten. Enkele studenten beginnen te huilen.

De film maakt duidelijk dat de dood van Digit een zware slag is voor Fossey. Urenlang zit ze op bed, bekijkt zijn foto en draait bluesmuziek. 'Je bent zo mooi' herhaalt ze steeds. Eerder hadden we de foto van Bob Campbell op haar nachtkastje gezien; die is nu verdwenen. In de laatste scène zien we de begraafplaats waar Fossey ligt. Een tekst vermeldt dat Fossey, 'Nyiramachabelli', veel voor de gorilla's heeft betekend en dat de dader van de moord op Fossey nog altijd niet gevonden is. 'Nyiramachabelli' was de bijnaam die ze van de lokale bevolking had gekregen, die volgens Fossey zelf 'woman who lives alone in the mountains without a man' betekende (Montgomery 199I). Volgens Hayes (r99o) sloeg de bijnaam op haar temperament en betekent het in werkelijkheid 'vulkaanuitbarsting'. De camera zoomt in op het graf ernaast. 'My beloved Digit' staat erop. Fossey ligt ernaast begraven, naast haar lievelingsgorilla, de zilverrug Digit. De moordenaar loopt intussen vrij rond, maar als kijker kan men inmiddels niet anders dan enige sympathie opbren- 
gen voor de daad. De vraag wie de moordenaar was, verdwijnt op de achtergrond, omdat duidelijk is gemaakt dat, gezien het dwarse karakter van Fossey, er talloze kandidaten waren. De moord wordt geslikt omdat er een andere moord aan voorafging: karaktermoord. Deze karaktermoord kan, zoals de moord op de apen, geïnterpreteerd worden als een moord op ambiguilteit. Haar andere naam, 'gorillagirl', die in de film wordt gebruikt om haar grensoverschrijding tussen vrouw en dier te benoemen, komen we in een andere context nog tegen. Gorillagrrls is een uitdrukking die tegenwoordig gebruikt wordt om strijdlustige feministen te typeren. Dat zijn sterke vrouwen die hun tanden durven laten zien, bepaald niet van de zachtmoedige soort.

\section{EEN RECHTSZAAK TEGEN FICTIE:}

THE FOLLOW EN GONE WILD

Net als Fossey, is Galdikas vaak afgeschilderd als een heks die te ver is doorgeslagen in haar liefde voor apen. Galdikas heeft zich echter actief verweerd tegen het negatieve beeld dat van haar in de media werd geschetst. Galdikas' actieve ingrijpen in de representatie-industrie blijkt uit de wijze waarop ze in De spiegel van het paradijs de strijd aangaat met haar critici. Galdikas wil controle uitoefenen op wat men over haar schrijft. Zij probeert, in het web van representaties, 'de ware Galdikas' veilig te stellen van wat in haar ogen valse voorstellingen zijn. Naar aanleiding van de publicatie van Linda Spaldings The Follow (1998), waarin Galdikas geportretteerd wordt als een egoïstische vrouw, spande Galdikas bijvoorbeeld een rechtszaak aan tegen de auteur wegens 'smaad en laster'. Ook in Gone Wild (1995) van James Hall komt ze naar voren als een lastige vrouw. Omdat dit boek, net als Brazzaville Beach, een 'fictionele' interpretatie van Galdikas' leven is waarin de hoofdpersoon een andere naam heeft, kon Galdikas hiertegen geen juridische stappen ondernemen. Hieronder zal ik eerst kort schetsen wat het beeld is dat in het algemeen van Galdikas naar voren komt in de media en de wijze waarop ze probeert zich te verzetten, om vervolgens in te zoomen op bovengenoemde voorbeelden.

Net als bij Goodall en Fossey is er in de representatie-industrie 


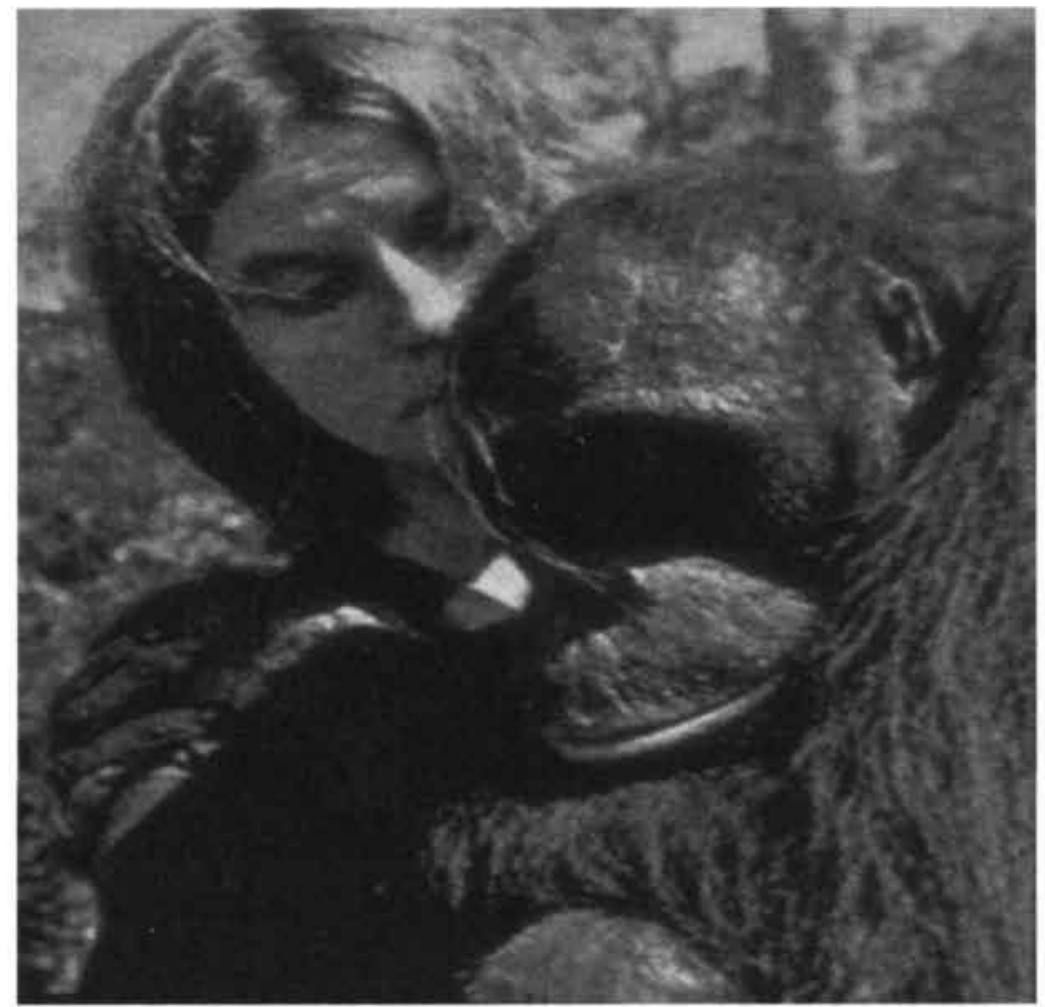

17 Biruté Galdikas met een orang-oetan. Foto: Rod Brindamour.

rondom Galdikas veel aandacht voor haar uiterlijk. Benadrukt wordt vaak dat Galdikas van de drie apenvrouwen de minste schoonheid en de minste charismatische uitstraling heeft (Draulans 1998; Hayes 1990; Spalding 1998). Galdikas wordt vooral als moeder gerepresenteerd en de orang-oetans als 'haar kinderen'. Ze is vaak gefotografeerd met een of meerdere jonge apen die zich aan haar vastklampen. Zij kreeg zelfs de bijnaam 'Ibud' ('moeder') een naam die zij zelf overigens met trots aanhaalt. Niet alleen om uiterlijke redenen kreeg Galdikas het zwaar te verduren: de scheiding van haar westerse man en haar huwelijk met Pak Bohap, een man van de inheemse Dajakstam (berucht vanwege het koppensnellen), veroorzaakten ook enige opschudding. Torgovnick (1996: 16) stelt dat de echtscheiding van Galdikas en haar nieuwe huwelijk met 
Pak Bohap haar minder populair maken in de ogen van westerlingen. Ze overschreed een zekere acceptatiegrens: 'Gone native, gone orang-utan, Galdikas no longer suits the Western public's image of the lady scientist.' Volgens anderen bleef zij echter het prototype van een westerling die meer geïnteresseerd is in het verdienen van geld dan het leed van de orang-oetans. Riska Orpa Sari, een jonge vrouw van de Dajakstam, schrijft in haar autobiografie: 'Die arme orang-oetans lijden aan allerlei ziektes waar niet genoeg medicijnen voor zijn, terwijl Biruté voorbijraast in haar mooie boot vol toeristen en met haar zachte, moederljke stem aan de wereld vertelt hoe vreselijk ze het vindt dat er zo veel dood in het park heerst en de schuld geeft aan PHPA [Perlindungan Hutan Pelestarian Alma, sJ].' (Orpa Sari 1999: 225)

Galdikas verzet zich op tweeërlei wijze tegen dit publieke imago: ten eerste plaatst ze, bijvoorbeeld in De spiegel van het paradijs en in interviews, haar eigen verhaal tegenover dat van anderen, in plaats van, zoals Goodall dat deed, mee te werken aan het publieke imago. Ten tweede spant ze rechtszaken aan wanneer het geschetste portret haar niet bevalt.

In De spiegel van het paradijs treffen we regelmatig opmerkingen aan waarin ze zich verdedigt tegen de critici. Zo legt ze bijvoorbeeld uit waarom zij, anders dan Goodall en Fossey, minder 'mooi' wordt gevonden. Dat is te wijten aan de wetenschappelijke arbeid die ze heeft verricht. Toen ze aan haar proefschrift werkte, en dus veel achter de computer zat, vlogen de kilo's eraan (Galdikas 1995: 430). Kortom, sexy-zijn en een proefschrift schrijven, laten zich slecht combineren. ${ }^{40}$

Galdikas kwam ook publiekelijk in opstand tegen haar critici. Linda Spalding, schrijfster van The Follow, werd aangeklaagd en voor de rechter gedaagd. ${ }^{41}$ The Follow is een bijzondere biografie, omdat de biografie niet alleen over Galdikas gaat, maar tegelijkertijd fungeert als een autobiografie van Spalding. Bij Spalding klinkt Donna Haraways idee van simian orientalism als een echo na, maar dan toegepast op de biograaf, die zichzelf definieert door naar een ander te kijken: 'A quest is as much about the seeker as the sought. We look in the mirror of another face to find ourselves. This is a signature act of all primates.' (4) Spalding ondervindt 'simian orientalism' aan den lijve: '...I realized that our relations with nonhumans are as subjective as everything else in our lives. We see them accor- 
ding to our own experience' (I84). In dit geval fungeert Galdikas als een negatieve projectiefiguur; door naar haar te kijken, kunnen wij leren hoe het niet moet.

Spalding schrijft haar biografie over Galdikas in de ikvorm, waardoor haar eigen relatie tot Galdikas benadrukt wordt. Dat heeft ook een praktische reden, vertelt Spalding in de inleiding. Galdikas was niet bereid om mee te werken aan Spaldings boek over haar leven. Toen Spalding haar verzocht om een interview, gaf Galdikas te kennen dat het boek over haar leven al is geschreven, namelijk door haar zelf. Toch gaf Spalding niet op. Ze reisde af naar Borneo in de hoop Galdikas alsnog te kunnen spreken. Spalding vergelijkt zichzelf met een onderzoeker die dagen achtereen orang-oetans in het bos achtervolgt (dat wordt een 'follow' genoemd): 'All week I'd been comparing myself to her when she was following an orang-utan. I'd been trying to habituate her, exactly as she habituated them' (22). Van Galdikas ontstaat een uiterst onsympathiek beeld. Galdikas blijkt pas enige interesse voor Spalding op te kunnen brengen, als deze te kennen geeft dat haar man, Michael Ondaatje, een beroemd auteur is met contacten in de filmwereld. Galdikas wil graag een film over haar leven laten maken. Wanneer Spalding haar vertelt dat zij een keer de naam van Sharon Stone heeft laten vallen toen haar man nadacht over een geschikte actrice voor de verfilming van zijn boek The English Patient, vraagt ze niet naar het werk van haar man, maar richt ze zich direct op de mogelijkheden voor de verfilming van haar eigen boek: 'Who's producing it? Could you give me a name? What prize? Would my book be eligible?' (22)

Als Spalding haar vraagt wie de rol van Galdikas zelf in de verfilming van haar leven zou moeten vertolken, antwoordt Galdikas prompt 'Sharon Stone'. Spalding schrijft: 'An ofI [Orang-outan Foundation International, sJ] who was carrying the orang-utan costume in a cardboard box, said that was a perfect choice. I smiled.' (16) Wie vervolgens de foto van de zwaarlijvige en stevig gebrilde Galdikas, die in The Follow staat afgedrukt, onder ogen krijgt, kan niet anders dan met Spalding beamen dat de gelijkenis met Sharon Stone minimaal is. Spalding houdt het bij een veelzeggende glimlach, maar noteert gedurende het hele boek de mogelijke kandidaten die de revue passeren: Julia Roberts, Isabella Rossellini, Stephanie Powers.

Van Galdikas ontstaat al met al het beeld van een egoïstische en 
ijdele vrouw. Dat beeld wordt bevestigd door de andere personages aan wie Spalding in haar boek het woord geeft. Omdat Galdikas geen tijd voor haar heeft, richt Spalding zich tot de mensen die met haar samenwerken. Sommigen geven een weinig positieve indruk van Galdikas. Zo vertelt een jonge dokter dat Galdikas haar werkvergunning al enkele jaren kwijt is, en vermeldt hij dat Galdikas veel van het geld dat voor orang-oetans bestemd is, in eigen zak steekt. Spalding raakte bevriend met Riska Orpa Sari, een Dajak-meisje, met wie zij nog lang bleef corresponderen. Orpa Sari geeft ook een uiterst kritisch beeld van Galdikas. De brieven aan Spalding werden door haar bewerkt tot een autobiografie, waarbij Spalding het voorwoord verzorgde (Orpa Sari 1999). Zo beünvloeden en versterken de verschillende representaties elkaar. De rechtszaak die Galdikas aanspant tegen Spalding, wordt in Galdikas' nadeel beslist. Spaldings boek mag in de winkel blijven liggen. Het negatieve imago van Galdikas wordt door de publiciteit rondom de rechtszaak in zekere zin alleen maar versterkt: Galdikas is een lastige tante op wie je geen kritiek mag hebben.

Niet minder negatief is het beeld dat James Hall van Galdikas schetst in zijn spannende thriller Gone Wild (1995), een boek waar ook Spalding naar verwijst. Hall heeft zich duidelijk laten inspireren door Galdikas' werk en leven. De thriller is gecentreerd rondom een waargebeurd incident, dat de geschiedenis inging als de 'Bangkok Six'. Zes orang-oetans worden gekidnapt uit Borneo, maar dankzij een tip tijdens hun transport in Bangkok worden ze op het nippertje bevrijd door Galdikas, die ze mee terugneemt naar Borneo en ze adopteert. De 'Bangkok Six' veroorzaakte veel opschudding, omdat de omvang van de internationale dierensmokkel daardoor scherp in beeld kwam. Een beruchte dierensmokkelaar werd gearresteerd. ${ }^{42}$ Hoewel Hall zijn thriller baseert op een waargebeurd incident, heeft hij de hoofdpersoon, een vrouwelijke primatologe die in Borneo orang-oetans onderzoekt, een andere naam gegeven. Toch is de hoofdpersoon onmiskenbaar gebaseerd op Galdikas. De voornaam en achternaam van de heldin, Allison Farleigh, bestaan uit precies evenveel letters als Biruté Galdikas, en beginnen met een letter eerder uit het alfabet. Farleigh is verder een roodharige (net als Galdikas en net als de orang-oetans); ook andere biografische details vertonen overeenkomst, bijvoorbeeld de overspelige echtgenoot. In Gone Wild neemt Allison Farleigh het op tegen drie beruchte dierensmokke- 
laars, Orlan(do), Ray en Patrick. Zij hebben niet alleen een van haar dochters vermoord, maar beramen ook een moord op Allison, die voor hen een belemmering vormt om de orang-oetans naar hartelust te kunnen smokkelen. Allison worstelt intussen met haar huwelijk. Ze verdenkt haar man van overspel, en zoekt troost bij haar vriend, de orang-oetan Broom. De relatie tussen Broom en Allison speelt een belangrijke rol in het boek: er is de suggestie van bestialiteit doordat concurrentie wordt gesuggereerd tussen Broom en Allisons echtgenote. Omdat hij ook wordt voorgesteld als haar kind (ze verwisselt bijvoorbeeld zijn luiers), ontstaat er een soort Oedipale driehoek.

The ape stepped to the side and examined Allison's face, then he glanced down and took hold of her left hand, held it in both of his. His grip was sensitive but powerful. And before she knew what he was doing, he had slipped her wedding ring off, her grandmother's four-carat diamond, and popped it into his mouth. (I4)

Uiteindelijk blijkt Allisons man onder een hoedje te spelen met de dierensmokkelaars. Haar dochter is er intussen vandoor met $\mathrm{Pa}$ trick, een van de handelaars, hetgeen Allison die zo begaan is met de liefde voor de apen, niet lijkt op te merken. Patrick heeft een megalomaan plan om een dierenpark op te zetten met alle dieren die met uitsterven bedreigd worden, en daar een toeristische attractie van te maken die flink wat geld moet opleveren. Hij helpt het uitsterven een handje, dan worden zijn eigen dieren waardevoller. De thriller loopt goed af, de boeven worden gepakt.

Net als Spalding schetst Hall het beeld van een vrouw die alle realiteitszin kwijt is en die zich minder om het lot van haar dochters lijkt te bekommeren dan om de orang-oetans. Toch is zijn portret iets ambivalenter dan dat van Spalding, want Farleigh is wel de klassieke thrillerheld die 'het kwaad' weet uit te roeien. Tegen Hall kan Galdikas geen juridische stappen ondernemen. Hall noemt nergens expliciet Galdikas' naam en weet zich daarom beschermd door het label 'fictie'. Hoewel Galdikas probeert de representatieindustrie onder controle te houden, kan zij niet voorkomen dat zij, net als Fossey, als een moeilijke en ijdele vrouw geportretteerd wordt. Het blijkt bovendien niet mogelijk om die representatieindustrie te sturen; die leidt een eigen leven. 


\section{BARBIE BIJ DE BONOBO'S}

Bonobo's zijn seksueel zeer sociaal en als soort verdienen ze een Nobelprijs voor de Liefde. [...] Het is mijn vermoeden dat wij als soort ook die richting op gaan. We zijn er nog lang niet en de chimpansee in ons laat zich nog te vaak gelden, maar we shall overcome one day.

Ronald Giphart, Ik omhels je met duizend armen (2000: 86)

Met hun empathische onderzoekshouding doorbreken Goodall, Fossey en Galdikas de klassieke subject-objectverhouding in de wetenschap. Ook schreven ze persoonlijke boeken die niet voldeden aan de traditionele 'afstandelijkheid' van de wetenschap. De boeken zijn een wonderlijke mengeling tussen de autobiografie, de roman en populaire wetenschap, waarin een vrouwelijke geëngageerde dierenwetenschapper zich in de ikvorm opwerpt als beschermster van een bepaalde dierensoort. De dichotomie tussen cultuur (opgevat als het domein van de verbeelding) en de wetenschap (opgevat als het domein van de feiten) wordt daarmee door Goodall, Fossey en Galdikas ter discussie gesteld. Ondanks hun grensoverschrijdende werk, wordt deze manier van onderzoek doen en het beeld van de vrouwelijke wetenschapper die van apen houdt en daarvan verslag doet in openhartige populair-wetenschappelijke romans een nieuw, gegenderd stereotype. Dat blijkt uit de navolging van wat een 'succesformule' blijkt te zijn, en het feit dat de primatologie nog altijd de meeste vrouwelijke onderzoekers kent van de biologische subdisciplines.

De blanke vrouwelijke dierwetenschapper die 'in haar eentje' apen onderzoekt in de wildernis van een niet-westers land neemt een ambigue positie in als het gaat om haar symbolische, hiërarchische positie binnen de dichotomieën vrouw en man, lichaam en geest, blank en zwart, westers en niet-westers, en mens en dier. Volgens Haraway maakt dit haar geschikt als mediator tussen natuur en cultuur. Maar, zo heb ik laten zien, deze mediërende rol dient actief geconstrueerd te worden; zij is niet vanzelfsprekend. Uit de representatie-industrie blijkt dat de juistheid van haar positie ook steeds bevochten moet worden. Dat blijkt onder meer uit het feit dat Leakey de vrouwen aan een test onderwierp, maar het blijkt vooral uit de receptie. Met name haar ambigue positie als aantrekkelijke 
vrouw, moeder en wetenschapster en als blanke vrouw in een nietwesters land veroorzaakt een spanning. Wanneer één van de grenzen overschreden wordt in ogen van de critici, veroorzaakt dit spanningen die in visuele en verbale representaties al dan niet worden opgelost. De ambiguïteit van de vrouwelijke wetenschapper wordt bijvoorbeeld opgeheven door haar als gedeseksualiseerd voor te stellen, bijvoorbeeld als heilige of als bezorgde moeder, of door juist haar wetenschappelijke kwaliteiten op de achtergrond te schuiven en haar te seksualiseren zodat ze in de stereotiepe rollen van vrouwelijke seksualiteit past. In plaats van als denker wordt ze bijvoorbeeld voorgesteld als de beauty, niet de brains. Aan het begin van hun carrière werden zowel Goodall, Galdikas als Fossey geportretteerd als onschuldige zachtaardige jonge vrouwen, mooie behulpzame assistenten van Leakey. Van de drie primatologen, is eigenlijk alleen Goodall erin geslaagd om dat positieve imago tot op oudere leeftijd te handhaven en een 'wijze' vrouw te worden. De andere twee lukten dat niet. Fossey werd afgeschilderd als een 'heks' en Galdikas als een 'bitch', twee negatieve vrouwelijke stereotypen. In plaats van beauty werden ze verbeeld als een soort beast. Daarmee worden worden de vrouwelijke apenonderzoekers in de receptie 'gedisambigueerd', doordat zij worden voorgesteld of als zachtaardige heldinnen of als kwaadaardige heksen. Anderzijds dragen zij hier ook zelf aan bij, en is het niet goed meer mogelijk een onderscheid te maken tussen zelfrepresentatie en representatie. Anders dan Goodall en Fossey, heeft Galdikas daartoe pogingen gedaan, door te proberen om de 'ware' Galdikas en de 'valse' Galdikas zoals die in de receptie naar voren komt, te onderscheiden, en zich actief te bemoeien met het beeld dat van haar in de media wordt geschapen. De lezer kan zich verzetten tegen de 'disambiguering' door de beelden en teksten te lezen op ambiguitteit, en de elementen die niet passen binnen het stereotype uit te vergroten. Een voorbeeld daarvan is de aandacht te vestigen op de scène uit Brazzaville Beach waarin Hope drie apen doodschiet, en daarmee enerzijds een 'mannelijke' daad verricht door de grens tussen mens en mensaap te bevestigen, maar met haar moord tegelijkertijd ook haar betrokkenheid bij de mensapen toont.

Soms zijn er (nog) geen 'eigen' woorden beschikbaar van een onderzoekster, maar is zij al in de 'formule' van de representatie-industrie ingepast. Dat geldt voor de Antwerpse biologe Ellen Van 


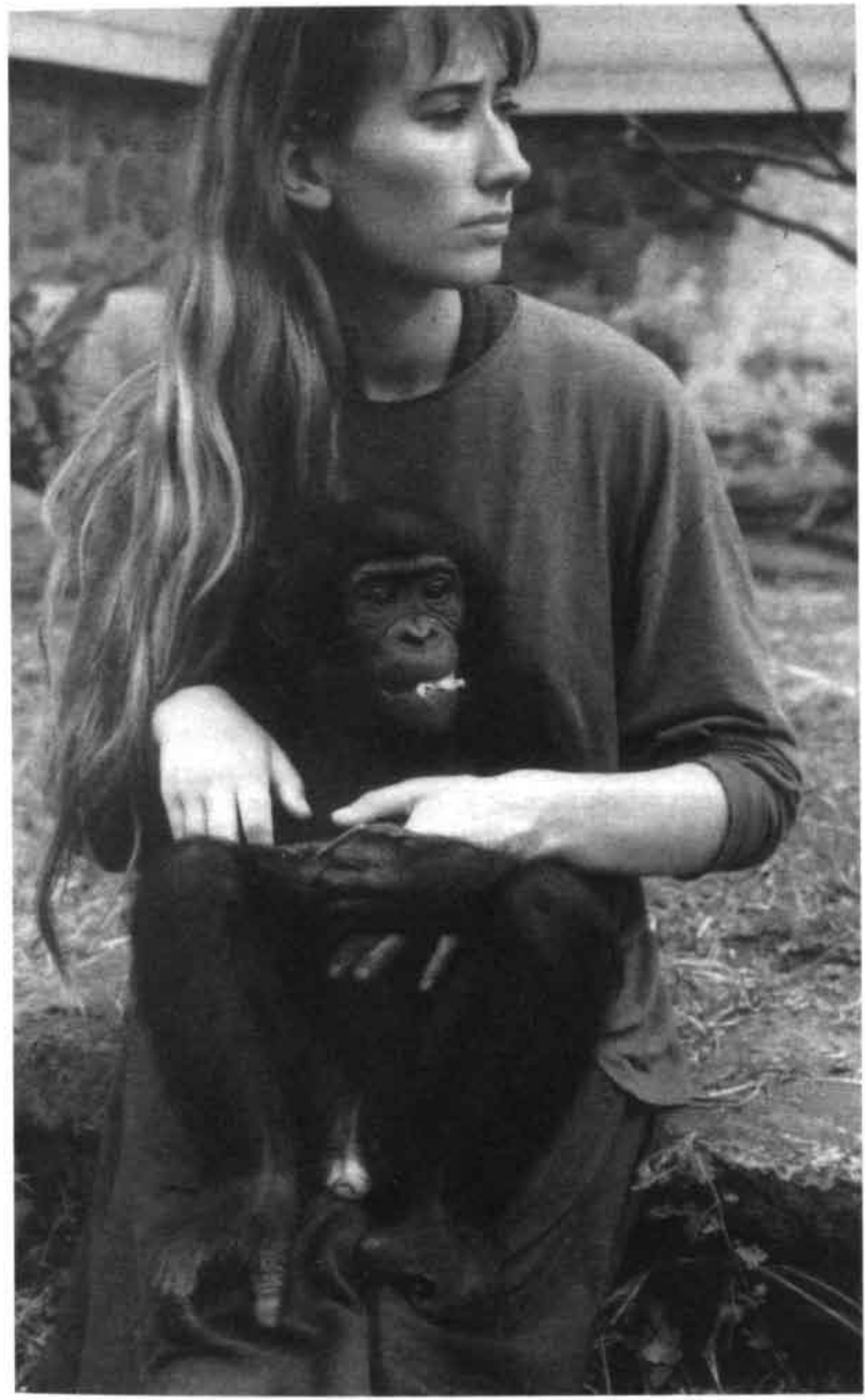

18 Ellen van Krunkelsven. Foto: Dirk Draulans. 
Krunkelsven, die door de Vlaamse journalist Dirk Draulans in De mens van morgen (1998) wordt opgevoerd als de Vlaamse opvolger van Fossey, Goodall en Galdikas. ${ }^{43} \mathrm{Hij}$ stelt haar voor als 'hoedster' van de vierde 'minst bekende maar meest bedreigde mensaap', de bonobo. Draulans bezocht Van Krunkelsven in de wildernis van Congo, waar zij de bonobo in zijn leefgebied bestudeert, en maakte een reisverslag. De mens van morgen is opgebouwd uit korte hoofdstukjes en is een mengeling van diverse genres. Het is geschreven in de ikvorm, maar sterk journalistiek wat toon betreft: niet Draulans' ervaringen, maar die van Van Krunkelsven en zijn waarneming van haar zijn het belangrijkste onderwerp van het boek. Hij positioneert zich als een getuige die echter, tegen wil en dank, betrokken raakt omdat hij verliefd wordt op de primatologe.

Wat betreft de dichotomische spanningsvelden van de vrouwelijke apenonderzoeker in de wildernis, is het met name de spanning tussen het vrouw-zijn en het wetenschapper-zijn van Van Krunkelsven waarmee Draulans worstelt. Hij gaat uitvoerig in op de schoonheid van Ellen en haar ongetrouwde status. Het is moeilijk kiezen uit de overdonderende hoeveelheid citaten waarin Ellens lichaam beschreven worden.

Ik kreeg een schok toen ik Ellen zag staan, onderaan de trap, in haar vuile lichtgroene veldtenue en op slippers. Ik had Ellen nog nooit gezien. Ik had zelfs nooit een foto van haar gezien. Ik had me wel een beeld van haar gevormd gebaseerd op de veronderstelling dat alle veldbiologenmeisjes er min of meer hetzelfde uitzien: klein, mollig meisje met kort stekelhaar en een rond brilletje in een slobberig sweater, zonder enige sensualiteit, het type dat zowel in de modder van de vrije natuur als in een sterrenrestaurant een jeans en een slobberig sweatshirt draagt. Ik kan garanderen dat de klassieke veldbiologe niet de vrouw is voor wie ik val. [...] God had daar aan de trap een mooi slank meisje met lange blonde haren geplant, dat me intens in de ogen keek en lachte op een manier die ik als verleidelijk interpreteerde. (23)

Het boek is een (auto)biografisch reisverhaal, populair-wetenschappelijke studie (naar de vrouw en de aap), en bovenal een romantische queeste gesitueerd in de wildernis, met een glansrol voor Draulans zelf als viriele minnaar. Van Krunkelsven en Draulans 
krijgen een relatie, die hij direct relateert aan de levensverhalen van Fossey en Goodall: 'Dian Fossey was een relatie begonnen met de eerste mediaman die echt in haar werk was geïnteresseerd. Ook Jane Goodall had een relatie met een (andere) cameraman...' (49) Wanneer Draulans het heeft over het opmerkelijke seksleven van de bonobo, vergelijkt hij dat met zijn eigen seksleven met Ellen. Hij komt tot de conclusie dat er een verschil is tussen de bonobo's en de mensen. De aap en de vrouw, zij vallen in zijn betoog samen en hun uiterlijke en eigenzinnige karaktereigenschappen lijken nogal op elkaar. Met dit verschil dat de man, anders dan de bonobo, een intensief seksleven in de jungle niet vol kan houden. Naarmate ze dieper in het woud trekken, neemt Draulans' eigen sekslust af: 'Zwarte haren zaaiden uit Ellens benen. Haar boezem was geschramd en zat vol rode beten, waarvan er een ontstoken was, weinig sexy, maar mijn duimen waren meestal zo moeilijk te plooien omdat bijen ze bleven bestoken, dat ik mijn hand niet om haar borsten kon vouwen, zonder mijn vingers te martelen' (283).

Draulans kent geen moment van terughoudendheid bij het schrijven van dergelijke typeringen. Toch moet je er als lezer een klein beetje om grinniken. Draulans gaat het veld in om te bestuderen hoe vrouwen apen bestuderen en doet daar zo nu en dan op een wel zeer clichématige manier verslag van, waarin hij zelf probeert als machoman uit de bus te komen. Met Spaldings notie van 'biographical simian orientalism', zouden we kunnen zeggen, dat het boek maar weinig over vrouwen en apen vertelt, maar veel over de positie van de man, zijn voortdurende neiging om zijn mannelijkheid te bevestigen via de pogingen om 'de vrouw en de aap' te duiden. Hier wordt ook de mogelijkheid van de lezer duidelijk om een 'tegen-interpretatie' te geven. In alles voel je dat dit heldenverhaal met een korreltje zout genomen moet worden. Het is eind jaren negentig, en vrouwen mogen zich na de girlpower weer als 'lustobject' etaleren, een 'sexy wetenschapster' is geen oxymoron meer, omdat nadenken en een sexy uiterlijk en het innemen van een feministische positie elkaar niet langer uitsluiten, maar kunnen versterken; van een wetenschapster met lippenstift kijken we niet vreemd meer op (Jensen 20orc), al raakt een man als Draulans danig van slag.

Draulans vermeldt tot slot dat hij zijn boek liever de titel 'barbie bij de bonobo's' had gegeven. Ellen had met haar 'lange goudblon- 
de lokken, haar geprononceerde jukbeenderen, haar volle boezem, haar smalle taille en haar slanke benen' meer weg van barbiepop dan een bonobomeisje (107). Van Krunkelsven heeft echter, ondanks de paaipogingen van Draulans - het 'schitterende korte grasgroene rokje' dat hij voor haar kocht - haar veto tegen deze titel uitgesproken. Draulans blijft een beetje beteuterd achter. Hij beschrijft hoe Ellen soms meer aandacht heeft voor de apen dan voor hem, en dat hij op zoek moet naar een nieuwe titel. Hij noemt zijn boek De mens van morgen. Onder verwijzing naar het werk van Sarah Blaffer Hrdy, die beweerde dat vrouwtjesapen (en niet mannetjes) bepalend zijn voor de seksuele selectie en deze bewering doortrok naar de mensenwereld, refereert Draulans daarmee aan de bonobo als modelmens voor de toekomstige samenleving: 'De bonobo is een tot de kleinste details afgewerkte illustratie van wat daarvan de gevolgen kunnen zijn: vrouwen aan de macht in een wereld met veel seks, waarin rellen en geweld beperkt zijn.' (88) De bonobo vertoont van alle mensapen de meeste overeenkomsten met de mens, maar is een stuk vredelievender omdat hij conflicten oplost door middel van seks in plaats van geweld. ${ }^{44}$ Deze aap zou, wegens zijn seksuele gedrag (de enige apensoort waarbij het mannetje en het vrouwtje elkaar aankijken tijdens de copulatie) het meeste op de mens lijken. Voor homoseksuelen was de ontdekking van deze vergeten aap een groot feest. De bonobo is een aap die in allerlei combinaties seks bedrijft. Vrouwtjes doen met vrouwtjes aan 'gg rubbing', het stimuleren van elkaars genitaliën, mannetjes doen het met mannetjes, en van seks met meerdere tegelijk zijn ze ook niet vies. Frans de Waal en Frans Lanting wisten precies hoe zij de beste marketingstrategie voor hun boek Bonobo: The Forgotten Ape (1997) moesten uitstippelen. Ze zochten in Californië hun uitgever, en lanceerden het boek in San Francisco..$^{45}$ Daar is het inmiddels een bestseller en vindt het boek gretig aftrek onder homoseksuelen, voor wie het boek een ironische bevrijding symboliseert: de natuur heeft gesproken en getoond dat homoseksualiteit 'natuurlijk' is. Feministen waarderen de matriarchale structuur. De bonobo is, zo kan je stellen, populair is bij de maatschappelijke ander, en wordt in meerdere teksten voorgesteld als een veel belovende apensoort van wie mensen veel kunnen leren. Volgens Draulans is de bonobo zelfs de ideale mens van morgen. Als er zo'n mens komt, dan is dat volgens Draulans vooral de merite van vrouwen, die, 'zo- 
als in de film King Kong, de aap rond haar vingers wond', en hem 'tam en menselijk' maakte (Io).

In de jaren negentig krijgt Draulans' wens dat de bonobo de mens van morgen moge zijn, een letterlijke invullling. Een wereldwijde organisatie pleit voor de toekenning van mensenrechten aan mensapen, en daarmee voor de opheffing van de hiërarchie tussen mensapen en mensen. De aap is niet langer een voorbeeld voor de mens, hij ís een mens. Het volgende hoofdstuk gaat over dit voorstel van uitbreiding van de mensensoort tot primaten, en de reacties daarop. In romans en films wordt aan de aap als nieuwe mens een speciale rol toegedicht. Vrouwen die teleurgesteld zijn in het mannelijk deel van de mensheid zoeken hun toevlucht bij donkerbehaarde superapen. De aap is de nieuwe ideale man. 
De aap als ideale man en nieuwe mens

\section{Het Great Ape Project}

Over vijf jaar de eerste vrouw in het Witte Huis, over tien jaar de eerste zwarte, over twintig jaar de eerste chimpansee?

Lydia Rood, Broeders van de zesde dag (2000)

\section{DE SOORTEN VOORBIJ}

In De vrouw en de aap van Peter Høeg wordt Madelene hartstochtelijk verliefd op de aap Erasmus. Madelenes echtgenoot, de zoöloog Adam, houdt Erasmus opgesloten in een kooi in zijn laboratorium en wil zijn hersenen onderzoeken, omdat hij vermoedt dat Erasmus behoort tot een onbekende apensoort. Madelene, die al jaren geen aandacht meer krijgt van haar man, identificeert zich hevig met de opgesloten aap. Ze dwarsboomt de wetenschappelijke experimenten van haar man door Erasmus te kidnappen. Samen gaan ze naar een paradijselijk bos en de vrouw en de aap vrijen er lustig op los. Erasmus blijkt niet alleen een fantastische minnaar, maar ook een buitengewoon gevoelig en intelligent wezen, kortom: de ideale man. Madelene heeft intussen ook een arts geraadpleegd over Erasmus, en die spreekt de aap toe en vertelt hem dat hij een bijzondere aap is. ' $\mathrm{U}$ bent niet dat wat voorafgaat. $\mathrm{U}$ bent eerder dat wat na ons komt.' (223)

De vraag die De vrouw en de aap, hier in kort bestek samengevat, opwerpt, luidt: waarom wordt Erasmus voorgesteld als de nieuwe mens, als datgene wat in evolutionaire zin ná de mens komt? En 
waarom vindt Madelene haar geluk in de armen van deze superaap? De vrouw en de aap verschijnt in 1996 . Als het om de relatie tussen mensen en dieren gaat, worden er in wetenschap en cultuur van de jaren negentig discussies gevoerd over de menselijke identiteit in het algemeen en 'de nieuwe mens' in het bijzonder. Terwijl debatten over de nieuwe, makkbare, virtuele en technologische mens een hoge vlucht nemen en razendsnelle ontwikkelingen van nieuwe media als het internet de grenslijnen tussen 'mens' en 'ding' ter discussie stellen $^{1}$, maken bepaalde ontwikkelingen in de medische wetenschap een scherp onderscheid tussen 'mens' en 'dier' steeds moeilijker houdbaar. ${ }^{2} \mathrm{Bij}$ de discussie over xenotransplantatie, het doneren van dierlijke organen aan de mens, staat de vraag centraal hoe menselijk iemand nog is die een varkensnier heeft of een apenhart. ${ }^{3}$ Voorstanders van xenotransplantatie wijzen erop dat er geen sprake is van een essentialistisch verschil tussen mens en dier, maar eerder van genetische continuïteit. Onderzoeken hebben aangetoond dat de mens 98,4 procent van zijn genetische materiaal deelt met de mensaap. ${ }^{4}$ In het licht van deze bevindingen binnen de genetica, vindt de internationale organisatie die zichzelf omschrijft als het Great Ape Project (GAP), dat er naast ethische en politieke redenen, nu ook voldoende wetenschappelijk bewijs is om de soortgrens overboord te zetten. Het GAP vindt dat de tijd rijp is om mensenrechten aan mensapen toe te kennen en ze dezelfde juridische en ethische bescherming te bieden.

In dit hoofdstuk wil ik laten zien dat de opheffing van de soortgrens niet los gezien kan worden van een discussie over vrouwelijkheid en mannelijkheid, seksualiteit, en de relatie tussen cultuur, moraal, politiek en wetenschap. Door te contextualiseren - wetenschap te plaatsen in een bredere culturele context, en fictie te interpreteren in het licht van een wetenschappelijke ontwikkeling - wil ik duidelijk maken dat de discussie over 'de nieuwe mens' ook een discussie over 'de nieuwe mannelijkheid' impliceert. Terwijl het GAP niet ingaat op de mogelijkheid van seksuele gemeenschap tussen mensen en mensapen ${ }^{5}$ - een van de implicaties die het opheffen van de soortgrens mee zou kunnen brengen - verkennen romans bestialiteitsfantasieën ${ }^{6}$ volop. ${ }^{7}$ Om enkele voorbeelden te noemen: Will Selfs The Great Apes (1997), Ark Baby (1998) van Liz Jensen, Laura Zigmans Animal Husbandry (1998) en Sparkle Hayters The Last Manly Man (1999) nemen de gelijkenis tussen mensen en apen tot 
uitgangspunt; sommige van deze romans suggereren, net als $D e$ vrouw en de aap, dat vrouwen er beter met een aap vandoor kunnen gaan. ${ }^{8}$ Dat laat de mannelijke personages onzeker achter: waarom gaan hun vrouwen er met apen vandoor?

Dit hoofdstuk begint met een kritische uiteenzetting van het GAP. Het GAP presenteert zichzelf als 'wetenschappelijk', maar leunt sterk op retorische strategieën. $\mathrm{Na}$ een bespreking van deze strategieën, analyseer ik de receptie van het GAP. De reacties van wetenschappelijke tijdschriften en kranten op het GAP bestaan voornamelijk uit recensies van het boek The Great Ape Project (Cavalieri en Singer 1993), waarin de belangrijkste doelstellingen van het GAP zijn geformuleerd. Door middel van een uitvoerige analyse van De vrouw en de aap, de roman die ik heb uitgekozen als exemplarisch voorbeeld van een verhaal waarin de aap als ideale man en 'nieuwe' mens wordt opgevoerd, en een kortere beschouwing van de romans van Zigman, Self, Jensen en Hayter, komt de culturele receptie van het GAP aan bod. Ik onderzoek dus eerst hoe 'cultuur' en 'wetenschap' door het GAP worden geconstrueerd, dan hoe wetenschap (of preciezer: het GAP) in een aantal romans wordt gerepresenteerd. Daarmee zet ik een 'intertekstuele' dialoog op tussen literatuur en wetenschap. De vrouw en de aap, zo beargumenteer ik, is te lezen als een kritische boodschap voor de man: vrouwen die teleurgesteld zijn in hun mannen zoeken troost bij apen. Als mannen dergelijke 'GAP'-achtige situaties willen voorkomen, dan dient verbetering van de menselijke soort vooral gezocht te worden in een nieuwe mannelijkheid, die gekenmerkt wordt door ambiguïteit. De ideale man, gepersonifieerd door de aap Erasmus combineert mannelijke en vrouwelijke eigenschappen. Kortom, de mannelijke machoman heeft zijn beste tijd gehad.

\section{DE RETORIEK VAN HET GAP}

Het GAP wordt beschreven als 'an idea, embodied in a book, that has led to the development of an organisation'. ${ }^{9}$ Het 'idee' is om mensapen mensenrechten toe te kennen. Het 'boek' heet The Great Ape Project. Equality beyond Humanity (Cavalieri en Singer 1993) en bevat 31 artikelen, waarin 36 wetenschappers, filosofen en dierenethici - onder anderen coryfeeën als Jane Goodall en Richard 
Dawkins maar ook Nederlandse antropologische filosofen die begaan zijn met het lot van dieren, zoals Barbara Noske en Raymond Corbey - beargumenteren dat mensapen mensenrechten moeten krijgen. De 'internationale organisatie' is opgericht om actie te ondernemen: het verzamelen van handtekeningen, het indienen van wetsvoorstellen die mensapen wettelijke bescherming moeten geven, en het opzetten van een internationale lobby.

In het manifest 'A Declaration on Great Apes', opgenomen als openingsstuk van The Great Ape Project, formuleren de dierenethici Peter Singer en Paolo Cavalieri de doelstellingen van het GAP en leggen ze de drie belangrijkste eisen op tafel:

We demand the extension of the community of equals to include all great apes: human beings, chimpanzees, gorillas and orang-utans. 'The community of equals' is the moral community within which we accept certain basic moral principles or rights as governing our relations with each other and enforcable at law. Among these principles or rights are the following:

\section{The Right to Life}

The lives of members of the community of equals are to be protected. Members of the community of equals may not be killed except in very strictly defined circumstances, for example, self-defence.

\section{The Protection of Individual Liberty}

Members of the community of equals are not be arbitrarily deprived of their liberty; if they should be imprisoned without due legal process, they have the right to immediate release. The detention of those who have not been convicted of any crime, or of those who are not criminally liable, should be allowed only where it can be shown to be for their own good, or necessary to protect the public from a member of the community who would clearly be a danger to others if at liberty. In such cases, members of the community of equals must have the right to appeal, either directly or, if they lack the relevant capacity, through an advocate, to a judicial tribunal.

3 The Prohibition of Torture

The deliberate infliction of severe pain on a member of the com- 
munity of equals, either wantonly or for an alleged benefit to other is regarded as torture, and is wrong.

Mensapen zijn volgens Cavalieri en Singer zo menselijk dat een essentialistisch onderscheid tussen mensen en mensapen onhoudbaar is. Er is geen reden om de unieke status van de mens te handhaven. Cavalieri en Singer eisen drie principes of rechten voor alle leden van de gemeenschap van gelijken. Deze lijken onschuldig, maar de consequenties van het accepteren ervan zijn aanzienlijk. Het zou bijvoorbeeld inhouden dat het doden van een mensaap als 'moord' beschouwd kan worden, en daarmee strafbaar is; dat een mens daarvoor levenslang kan krijgen of zelfs ter dood kan worden veroordeeld (namelijk in Amerikaanse staten die de doodstraf kennen). Het betekent ook dat mensapen niet in gevangenschap gehouden zouden mogen worden. Daaronder valt het misbruiken van mensapen ten behoeve van medisch onderzoek (zij verdienen dezelfde bescherming als mensen), en het houden van mensapen in dierentuinen, omdat dit louter tot vermaak van de mens is bedoeld en voor de dieren zelf niks oplevert.

Het GAP gaat een stap verder dan andere internationale dierenbeschermingorganisaties. Hoewel beide organisaties een beter bestaan aan dieren willen geven en zich verzetten tegen medische experimenten met dieren, gaat het bij dierenbeschermingsorganisaties, zoals de term al aangeeft om 'bescherming', terwijl het GAP 'bevrijding' op het oog heeft, en fundamentele gelijkstelling tussen mensen en dieren. ${ }^{10}$ Het GAP is niet alleen tegen het geweld tegen dieren, maar strijdt ook voor gelijke rechten voor dieren. De roep om mensenrechten voor mensapen is meer dan zomaar een publiciteitsstunt om aandacht voor de mensapen te vragen: het GAP stelt dat een essentialistische soortgrens tussen mensapen en mensen verwerpelijk is. Om de lezer hiervan te overtuigen, worden naar mijn mening vier retorische strategieën ingezet, die erop gericht zijn de empathie van de lezer te vergroten. Deze vier strategieën zal ik achtereenvolgens toelichten.

De eerste strategie is het benadrukken van de menselijkheid van de mensapen, zoals ook Fossey, Goodall en Galdikas dat deden. 'The apes are our closest relatives,' schrijven Cavalieri en Singer (1993: 5) in hun manifest, en ook bij andere auteurs treffen we deze gedachte veelvuldig aan. De familieverwantschap tussen mensen en 
mensapen wordt op twee manieren toegelicht. In een tweetal artikelen wordt de aapachtigheid van de mens benadrukt (Dawkins, Diamond). Verreweg de meeste auteurs richten zich echter op de menselijkheid van de mensaap. Veel eigenschappen die wij aan mensen toekennen en als 'menselijk' beschouwen, kunnen ook bij mensapen worden aangetroffen. ${ }^{11}$ De drie belangrijkste aspecten waarop mensapen en mensen worden vergeleken zijn taal, cognitie en emotie, en The Great Ape Project bevat drie secties die ieder aan een aspect zijn gewijd. De meeste aandacht gaat uit naar de talige capaciteiten van de mensapen. In de sectie 'Conversation with apes' wordt achtereenvolgens beargumenteerd dat chimpansees, orang-oetans en gorilla's over het vermogen beschikken om taal te leren. ${ }^{12} \mathrm{Niet}$ alleen uit hun vermogen tot taalverwerving blijkt dat mensapen beschikken over cognitieve vaardigheden, maar ook beschikken mensapen over een kenmerk dat vaak als typische menselijk wordt beschouwd, namelijk zelfbewustzijn. ${ }^{13}$ Tot slot hebben mensapen een emotioneel leven dat sterk lijkt op dat van de mens. ${ }^{4}$ En zo passeren alle eigenschappen die voorheen als exclusief menselijk werden beschouwd de revue. Steeds weer zijn de auteurs erop uit om aan te tonen dat ook mensapen deze eigenschappen bezitten, en dat het onmogelijk is om een bepaalde capaciteit als uniek menselijk aan te wijzen. Opvallend daarbij is de nadruk op positieve eigenschappen die mensapen zouden hebben. Het zouden slimme en emotionele dieren zijn: ze voelen pijn, verdriet en vreugde en zijn in staat tot altruïstisch gedrag. Ze zijn zeer intelligent, in staat om taal te leren, en hebben dezelfde levenslange relaties met hun familie als de mens. In sommige bijdragen komt de idee naar voren dat het niet de mensaap is die moet leren als de mens te worden, maar dat de mens iets van deze zachtmoedige broeder zou kunnen leren: 'I watched the gorilla's eyes again, wise and knowing eyes, and wondered about this business of trying to teach apes language. Our language. Why? [...] I thought, maybe it is not that they have yet to gain a language, it is that we have lost one.' (Douglas Adams and Mark Carwardine, p. 23) Daarmee wordt een zeer aangenaam portret geschetst van de mensapen; vraagstukken als geweld en moord onder mensen en mensapen komen nauwelijks aan de orde. ${ }^{15}$

De tweede strategie is het individualiseren van de mensaap door middel van het introduceren van de term 'persoon'. 'Persona' komt uit het Latijn en betekent oorspronkelijk 'masker', het masker van 
een toneelspeler. Later is de term gebruikt voor mensen die 'acteurs' zijn, 'actores' die 'zelfstandig en rationeel' handelen; 'persoon' betekent dus niet hetzelfde als 'mens'. ${ }^{16}$ Dat betekent dat er personen zijn die geen mensen zijn (in de biologische zin dat ze tot de menselijke soort behoren), en dat er mensen zijn die geen personen zijn (wie dit zijn, wordt niet uitgelegd, wellicht gaat het hier om 'wilsonbekwame' mensen?). In de sectie 'Apes as Persons' wordt beargumenteerd dat mensapen geen 'bezit' zijn, en dat, wanneer zij dezelfde juridische rechten krijgen, zij daarmee ook de status van persoon moeten krijgen. De term persoon moet niet opgevat worden alsof er toch een menselijke essentie zou zijn die mensapen en mensen 'menselijk' maakt. Juist omdat er niet zoiets gevonden kan worden als de menselijke essentie of de dierlijke essentie is de term persoon geschikt. Sapontzis (1993) onderkent dat er haken en ogen zitten aan de toekenning van de term persoon aan mensapen. Zij kunnen bijvoorbeeld wel rechten krijgen, maar niet alle bijbehorende plichten. Tot stemmen kun je ze bijvoorbeeld niet dwingen.

Wanneer mensapen als personen worden beschouwd, betekent dat ook dat ze 'individuen' zijn, met een eigen karakter en biografie. De wetenschappers die jarenlang met mensapen hebben gewerkt, zoals Jane Goodall, Francine Patterson, Roger Fouts en Deborah Fouts, proberen de lezer ervan te overtuigen dat mensapen unieke en verschillende individuen zijn met ieder een eigen emotionele biografie. In haar bijdrage aan The Great Ape Project, schrijft Jane Goodall vanuit het perspectief van een vrouwtjeschimpansee. Haar artikel is persoonlijk en verhalend opgezet, een strategie die, sterker dan een wetenschappelijk argumentatie, bedoeld is om empathie bij de lezer op te wekken.

De derde strategie is te wijzen op de 'wetenschappelijkheid' van het GAP. Cavalieri en Singer benadrukken in het manifest dat het om 'wetenschappelijke' artikelen gaat en dat het wetenschappelijke bewijs de doorslag moet geven om mensapen mensenrechten toe te kennen. 'We shall provide ethical argument, based on scientific evidence about the capacities of chimpansees, gorillas and orang-utans $[\ldots] ?(5)^{\nabla}$ Wat de 'scientific evidence' inhoudt, wordt niet gespecificeerd, maar wellicht verwijzen deze woorden naar de bijdragen in het boek die het sterkst leunen op 'bewijzen' uit de moleculaire genetica. In de bijdrage van Richard Dawkins wordt gewezen op de genetische gelijkenis tussen mensen en mensapen: 'Molecular evi- 
dence suggests that' $(84)$, schrijft hij, zonder te verwijzen naar relevante bronnen. Volgens Dawkins is het onderscheid tussen mensapen en mensen een produkt van de wijze waarop onze geest functioneert. Wij zijn altijd gespitst op verschil. Maar onze ontstaansgeschiedenis is er een van voorouderlijke hybriden. In Dawkins' artikel staat een door een computer gegenereerde afbeelding van een tussenvorm tussen mens en chimpansee.

This arresting picture is hypothetical. But I can assert, without fear of contradiction, that if somebody succeeded in breeding a chimpanzee/human hybrid the news would be earth-shattering. Bishops would bleat, lawyers would gloat in anticipation, conservative politicians would thunder, socialist wouldn't know where to put their barricades. The scientist that achieved the feat would be drummed out of politically correct common-rooms-denounced in pulpit and gutter press; condemned perhaps, by an Ayatollah's fatwah. Politics would never be the same again, nor would theology, sociology, psychology, or most branches of philosophy. The world that would be so shaken, by such an incidental event as a hybridisation, is a speciesist world indeed, dominated by the discontinous mind. (86)

Dawkins stelt hier de 'a-politieke' wetenschapper die geïnteresseerd is in de mogelijkheden van hybriditeit tegenover 'politiek correcte' denkers en zelfs fundamentalisten. Het zijn politieke en psychologische argumenten die het wetenschappelijk onderzoek naar hybriditeit in de weg staan, wat duidt op discriminatie van soort, 'speciecism'.

Ook Jared Diamond voert in zijn bijdrage de genetische verwantschap van 98,4 procent tussen mensen en mensapen op als bewijs dat mensapen en mensen tot dezelfde familie behoren. Maar, wat, zo zal de scepticus willen weten, is dan de 1,6 procent genetisch verschil tussen mensapen en mensen? Diamond: 'At least some of the 1.6 per cent that differs between us and chimps is already known to be junk.' (99) Net als in het artikel van Dawkins, ontbreken de voetnoten waarin verwezen wordt naar het desbetreffende wetenschappelijk onderzoek; de lezer zal hen op hun woord moeten geloven.

Ondanks deze nadruk op wetenschappelijkheid, toont het GAP 
zich zeer bewust van de retorische overtuigingskracht die nodig is om mensen over de streep te krijgen. Niet 'droge' wetenschappelijke taal, getallen en grafieken zullen een lezer overtuigen, maar wel roerende verhalen. En dus staan er zeer toegankelijke 'verhalende' stukken in The Great Ape Project, bijvoorbeeld van de sciencefiction auteur Douglas Adams, die op hun beurt zijn gelardeerd met getallen en feitelijke 'bewijzen'. Ook bevelen zij de lezer op hun website een aantal romans aan, waaronder Peter Høegs De vrouw en de aap..$^{18}$ Door de lezer door te verwijzen naar romans presenteert het GAP zich als een bredere culturele beweging, waarin niet alleen wetenschappers, maar ook kunstenaars participeren.

De vierde strategie is het vergelijken van mensapen met jonge kinderen en verstandelijk gehandicapten.

To the objection that chimpanzees, gorillas and orang-utans will be unable to defend their own claims within the community, we respond that human guardians should safeguard their interests and rights, in the same ways as the interest of young or intellectually disabled members of our own species are safeguarded. (Cavalieri en Singer 1993: 5)

Omdat mensapen niet voor zichzelf kunnen opkomen, moet de mens - zoals hij dat ook bij kinderen en verstandelijk gehandicapten doet - als spreekbuis optreden. In de bijdrage van de pedagoog Christoph Anstötz wordt uiteengezet dat de discriminatie van verstandelijk gehandicapten gebaseerd is op dezelfde principes die ook hebben geleid tot de discriminatie 'against other sentient beings who are also unable to defend their own interests' (158). Anstötz komt tot de volgende conclusie: 'There is nothing that humans with the most serious intellectual disabilities can do or feel that chimpanzees or gorillas cannot' (I65). ${ }^{19}$

Behalve de vergelijking van mensapen met jonge kinderen en verstandelijk gehandicapten, wordt de onderdrukking van de mensapen ook vergeleken met de slavernij zoals die bij de Grieken en Romeinen bestond. Cavalieri en Singer winden er in hun afsluitende betoog geen doekjes om: de mensapen zijn de slaven van vandaag. Zoals een menselijke slaaf als 'bezit' werd gezien - 'animated property' (levend eigendom) in de woorden van Aristoteles - als iemand die niet 'vrij' was, geen bezit mocht hebben en geen fa- 
milie, en bovendien vaak mishandeld werd, zo kijken wij in de hedendaagse maatschappij tegen dieren aan. Dieren zijn dikwijls het eigendom van mensen en ze worden vaak mishandeld en van hun familie weggenomen. Volgens Cavalieri en Singer is er echter ook een verschil tussen slaven en dieren: slaven kunnen spreken en dus in opstand komen. Toch, zo beweren Cavalieri en Singer, heeft dit feit niet of nauwelijks bijgedragen aan de beëindiging van de slavernij. De slaven waren afhankelijk van anderen, mensen met meer macht, die het voor ze opnamen. Wat de dieren betreft, is het niet meer dan logisch dat mensen het voor ze opnemen. De bevrijding van de mensapen en het verwerpen van 'the species boundary' wordt door Cavalieri en Singer gebracht als een logische erfenis van en volgende stap binnen het Verlichtingsdenken. Na de bevrijding van witte slaven, zwarten (inclusief zwarte slaven) en vrouwen, zijn nu mensapen aan de beurt, zo redeneren ze.

Cavalieri en Singer zijn zich overigens terdege bewust van mogelijke kritiek op het GAP. In hun boek, maar met name op de GAP-website, proberen ze het gras voor de voeten van de critici weg te maaien door een overzicht te geven van mogelijke tegenwerpingen, waarop ze vervolgens een reactie geven. Weerstand tegen het GAP komt volgens het GAP zelf vooral uit de hoek van mensen die daar een eigenbelang bij hebben en daarom aan mensapen geen gelijke rechten willen toekennen. ${ }^{20}$ Namen of organisaties worden niet genoemd, maar te denken valt, zo wordt gesteld, aan wetenschappers die mensapen gebruiken voor experimenten in hun laboratoria of bijvoorbeeld dierentuineigenaren. Dan zijn er ook nog de sceptici die meer filosofische problemen hebben met het GAP. Vier mogelijke bezwaren worden door Cavalieri en Singer genoemd en weerlegd.

Ten eerste: waarom bijvoorbeeld trekt het GAP de lijn bij mensapen? Wordt daarmee niet een nieuwe grens gecreëerd, namelijk tussen mensapen en de rest van het dierenrijk? Waarom niet ook dolfijnen of bijvoorbeeld walvissen in aanmerking genomen? Het GAP stelt dat het wel degelijk de bedoeling is om de soortgrens als geheel ter discussie te stellen, en dat mensapen een geschikte kandidaat zijn, juist omdat er rondom deze dieren zo veel wetenschappelijk bewijs is voor hun 'menselijkheid'. 'The GAP is not seeking to move the species barrier to simply erect it in another place, but to demolish it altogether [...] We need to start somewhere. And with the nonhuman great apes irrefutable scientific evidence is available now 
to show that they are complex individuals with complex interests.'21

Een tweede bezwaar is dat bij de toekenning van rechten ook automatisch verantwoordelijkheden horen, een verplichting die de mensapen niet zullen kunnen vervullen. Opnieuw worden hier jonge kinderen en andere 'disabled members of the human community' opgevoerd als vergelijking. Ook zij zijn personen met rechten maar zonder plichten en verantwoordelijkheden.

Een derde mogelijk punt van kritiek betreft het verwijt van antropomorfisme; kennen wij niet ten onrechte menselijke eigenschappen aan deze dieren toe? Nee, stelt het GAP, en zij verwijzen daarbij opnieuw naar de 'scientific evidence' die laat zien dat mensapen complexe wezens zijn met allerlei kwaliteiten die wij doorgaans ook aan mensen toekennen.

Een vierde argument wijst erop dat het misschien beter is eerst hulpbehoevende mensen te helpen, in plaats van energie in de mensapen te steken. Onder mensen is het al beroerd genoeg gesteld met mensenrechten. Maar, zo stelt het GAP, het is niet zo dat mensen zouden hoeven lijden onder al die aandacht voor mensapen. Het doel van GAP is niet het 'verlagen' van de menselijke status, maar te benadrukken dat alle leden van de morele gemeenschap recht hebben op respect en affectie.

Het GAP wil een fundamentele gelijkschakeling tussen mensen en mensapen. Enerzijds wordt een sterk beroep gedaan op 'wetenschappelijkheid' en 'feitelijke' bewijzen, maar tegelijkertijd gaat het project verbindingen aan met romanciers en proberen ze de lezer juist met een bredere culturele argumentatie en met empathische verhalen over de streep te trekken. De ambiguïteit van het project, zoals de spanning tussen 'wetenschappelijke' fundering en een bredere 'culturele' inbedding, wordt een belangrijk punt van kritiek. Want ondanks de poging van Cavalieri en Singer om hun critici een slag voor te zijn, maakt het GAP een golf van protest los.

\section{'CULTURAL' OF 'SCIENTIFIC' TEXT?}

Het GAP kreeg wereldwijde aandacht en sorteerde een concreet resultaat: het droeg direct bij aan wetswijzigingen in Nieuw Zeeland en Groot-Brittannië waar de mensapen dezelfde positie kregen toe- 
gekend als mensen in medische experimenten. ${ }^{22}$ Maar kritische geluiden waren er ook; deze waren vooral gericht op de interne tegenstrijdigheden en onduidelijkheden in het project. De meeste aandacht ging uit naar de boekuitgave van The Great Ape Project, omdat dit de schriftelijke weergave van het project is, en hieronder zal ik dan ook ingaan op de receptie daarvan. De meeste recensies van The Great Ape Project staan sympathiek tegenover de inspanningen van het GAP als het gaat om een menswaardige en respectvolle behandeling van de mensapen, maar betwijfeld wordt of het daarvoor ook nodig is om de mensapen mensenrechten toe te kennen. Opvallend is dat in de receptie nadrukkelijk een poging wordt gedaan om bepaalde grenzen helder te krijgen, zoals die tussen 'cultuur' en 'wetenschap', en 'persoon', 'dier' en 'mens'. Van de vier retorische strategieën van de GAP-voorstanders, die ik hierboven heb genoemd, worden met name de laatste drie onder vuur genomen: het inzetten van de term 'persoon', de 'wetenschappelijkheid' van het project en de vergelijking van mensapen met kinderen, verstandelijk gehandicapten en slaven. Tot slot is er één recensent die de kwestie hybriditeit op de agenda zet. Achtereenvolgens zal ik deze kritieken toelichten.

De filosoof David DeGrazia (1997) wijst erop dat degene die mensapen 'mensenrechten' wil toekennen omdat ook zij personen zijn (zoals Cavalieri en Singer stellen), moet kunnen omschrijven wat er onder de termen 'persoon', 'recht' en 'menselijk' wordt verstaan. Hij vraagt zich af waarom dan bijvoorbeeld dolfijnen niet ook kunnen worden opgenomen in de gemeenschap van gelijken. Ook zij beschikken immers over 'moreel' gedrag en ook zij communiceren met elkaar. Zijn dolfijnen dan geen personen? Hij wijst erop dat elke filosoof die een poging doet essentialistische grenzen te trekken tussen 'humans' en 'nonhumans', 'persons' en 'nonpersons' op een doodlopende weg zit. Het blijkt onmogelijk te zijn om een uitsluitende set criteria aan te geven die een wezen tot een persoon maken. Elke eigenschap die wordt opgevoerd, bijvoorbeeld autonomie, vrije wil, taal of zelfreflectie kan ofwel bij een dierensoort worden aangetroffen of niet bij alle mensen (denk aan baby's, comapatiënten of zieke mensen). 'Persoon' is een uiterst vaag begrip, meent DeGrazia, en hij stelt dan ook dat dit begrip geen enkele uitkomst kan bieden in morele discussies over het al dan niet toekennen van rechten aan apen en de vraag of apen (en dolfijnen) als 'personen' beschouwd 
moeten worden. We moeten in gradaties leren denken, in termen van bijvoorbeeld 'borderline persons' waartoe bijvoorbeeld kinderen, dolfijnen en mensapen gerekend zouden kunnen worden (De Grazia, 1997: 316). ${ }^{23}$

Ook wat het wetenschappelijke gehalte betreft, moet The Great Ape Project het ontgelden. Jonathan Marks, bioloog, schrijft in zijn recensie in Human Biology dat The Great Ape Project 'the most interesting cultural text' is die hij sinds tijden is tegengekomen, met name omdat het boek stelt dat een 'scientific justification' nodig is voor het beoogde doel, namelijk mensen ervan overtuigen dat het verkeerd is om mensapen te mishandelen of te vermoorden. Zijn oordeel is echter vernietigend als het om de wetenschappelijke overtuigingskracht van het GAP gaat:

As a book about science, specifically its cultural use as an ideological validation mechanism, the tome is a masterpiece [...]. As a book of science, on the other hand, it is of regrettable little value. (Marks 1994: $\mathrm{II3}$ )

The point is certainly right: Apes deserve human treatment. But the scientific proof of it is elusive. (III)

Marks wijst op onbeargumenteerde premissen en de tegenstrijdigheden die het project volgens hem 'onwetenschappelijk' maken. Zo stelt hij dat in de eerste vier essays steeds wordt beargumenteerd dat de mensaap mensenrechten moet krijgen omdat hij onze 'closest relative' is. Maar essay 2 zegt dat over gorilla's, essay 5 over orang-oetans en andere essays over chimpansees. Hij vraagt zich bovendien af hoe logisch uit familieverwantschap voortvloeit dat er mensenrechten moeten komen voor mensapen. Ook is het hem niet duidelijk waarom genetische continuïteit tussen mensen en mensapen (waarvan hij overigens ook laat zien dat het zeer onduidelijk is om van deze uitspraak de betekenis in te schatten) automatisch een reden is om mensapen mensenrechten te verlenen. Hij opent de aanval op het genetisch essentialisme zoals dat uit sommige bijdragen (hij noemt Dawkins en Diamond) spreekt: 'Genetically we are apes. Therefore we are apes. Never mind that anatomically, ecologically, demographically, behaviorally, and mentally we are easily different from apes.' Bovendien, als het om genetische gelij- 
kenis gaat, dan is de wetenschap zelf ambivalent. Marks bekritiseert het essay van Jared Diamond, die met getallen goochelt die de lezer moeten overtuigen van de genetische gelijkenis.

Sure, we are similar genetically to the chimpanzee, but the use of a number with a decimal point gives the impression of underlying scientific precision that is actually not present. [...] again, science itself is dubious here; it is the set of scientific terms and factoids that makes this interesting. (Marks 1994: $\mathrm{III}_{5}$ )

Uit de recensie van Marks blijkt dat met het ter discussie stellen van de soortgrens ook een discussie gemoeid is over wat 'cultuur' is en wat 'wetenschap'. Volgens hem is het GAP vooral een 'cultural text', niet een 'scientific text'. Maar ook als 'cultural text' laat The Great Ape Project steken vallen. 'Planet of the Apes probably did more for raising consciousnesses about the treatment of apes in captivity that all the scientific factoids brought to bear in this volume.' (III) Interessant aan deze kritiek is dat Marks enerzijds The Great Ape Project een 'cultural text' heeft genoemd en het project ervan 'beschuldigt' niet te voldoen aan wetenschappelijke criteria. Anderzijds pleit Marks in bovenstaand citaat echter juist voor een ontmoeting tussen cultuur en wetenschap in de zin dat de wetenschap baat zou kunnen hebben bij 'meer cultuur'; de overredingskracht van 'cultuur' is sterker: een film als Planet of the Apes bereikt meer dan een wetenschappelijk traktaat.

Marks slotoordeel luidt dat het boek vooral een 'politiek' doel dient, en 'wetenschappelijk' gezien nogal 'dun' is.

So ultimately, how seriously can this book be taken? Humanizing the apes serves a political goal - the book's main objective - but the science alongside it, ostensibly validating it, is decidedly thin. [...] Empathetic treatment for apes? Self-evident. Human rights for apes? An idea born of decadence and misanthropy. Take it to Sarajevo, and explain it to them. (Marks 1994: $\mathrm{II7}$ )

Met andere woorden, het bepleiten van rechten voor mensapen is decadent en kan alleen bedacht zijn door een mensenhater of iemand die spreekt vanuit een luxe positie. ${ }^{24}$ Wie midden in een oor$\log$ zit, heeft wel wat anders aan zijn hoofd - namelijk de bescher- 
ming van de rechten van de mens. Dat, zo zou een kritische lezer kunnen opmerken, is een tegenstrijdigheid in het betoog van Marks. Hij heeft eerst politiek en wetenschap uit elkaar getrokken en het GAP als een politieke en culturele actie betiteld zonder wetenschappelijk draagvlak, en haalt vervolgens op retorische wijze de politiek binnen als argument om het project af te wijzen.

Ook heeft Marks moeite met de doelstelling van het project, namelijk het omverwerpen van de soortgrens die niet zou bestaan. Maar uit alle essays komt nu juist naar voren dat de grens vaag is, niet afwezig. Een chimpansee is als een achtergebleven kind, zo luidt immers de stelling van Cavalieri en Singer. Marks wijst er voorts op dat er in de bundel vooral gepleit wordt voor de menselijkheid van de mensaap, maar dat men zich te weinig afvraagt of het omgekeerde daarmee niet automatisch ook geldt. Als de mensaap als een mens is, te vergelijken met een achtergebleven kind van drie jaar, is de mens dan niet ook als een mensaap? 'We are given the conclusion that chimps should consequently be treated like retarded children, but somehow not that retarded children are like another species.' (m6)

De genetische gelijkenis van mensapen wordt frequent aangevoerd als argument, maar de kwestie van intersoortelijke gemeenschap wordt niet aangeroerd:

Bonobos and chimpanzees, which have the same number of chromosomes $(2 \mathrm{n}=48)$, can produce hybrids, and siabons have been produced via interbreeding siamang $(2 \mathrm{n}=5 \mathrm{O})$ and lar gibbons $(2 n=44)$. We cannot deny the possibility that humans $(2 n=46)$ and chimpanzees could birth hupanzees. (Tuttle 1994: 603)

Het is een opmerkelijk punt dat de antropoloog Russell Tuttle hier, overigens als enige onder de recensenten, aansnijdt. Als mensen en mensapen zo dichtbij elkaar staan, ja, als mensapen zelfs mensen zouden zijn, waarom zouden ze dan ook geen nageslacht kunnen verwekken? Omdat Cavalieri en Singer mensapen met kinderen vergelijken blijft de kwestie van hybriditeit misschien op de achtergrond: seks met kinderen is natuurlijk uit den boze. In de huidige wetenschap is intersoortelijke gemeenschap een taboe; in de achttiende eeuw echter stelde Rousseau bijvoorbeeld een kruisingsexperiment voor tussen vrouw en aap, in de hoop een antwoord te 
vinden op de prangende vraag of apen en mensen tot dezelfde soort behoorden. Ook wetenschappers speculeerden destijds over deze optie. Sommigen waren van mening dat een experiment niet eens nodig zijn. Volgens de geleerden Bontius en Blumenbach lokten voornamelijk Oost-Indische vrouwen de gemeenschap met apen zelf uit en genoten ze ervan. ${ }^{25}$ Is in de huidige wetenschap het kruisen van de menselijke soort met een andere soort niet denkbaar? Staat de wetenschap hier voor een taboe dat de fictie niet kent? Is bestialiteit tegenwoordig een fantasie die aan het domein van de kunsten is voorbehouden? Zo ja, hoe ziet die fantasie er dan uit?

\title{
TERUG NAAR HET PARADIJS IN DE VROUW EN DE AAP
}

\author{
'Do you realize, Harry, that a young woman has hair on every part of her body?' \\ 'I hadn't thought about it'. Distate stains his throat. \\ 'Do,' Thothero says. 'Do think about it. They are monkeys. Harry, women are mon- \\ keys.'
}

John Updike, Rabbit Run (1960)

Als The Great Ape Project een 'wetenschappelijke' cultuurtekst is, dan is De vrouw en de aap misschien wel het best te omschrijven als 'gefictionaliseerde' wetenschap. Deze roman vertelt het wonderlijke verhaal van een vrouw die haar man in de steek laat voor een aap. Moest in King Kong de vrouw enigszins op haar hoede zijn voor de wellustige mannetjesaap, nu wordt de ontrouw aan de menselijke soort voor vrouwen, ooit een ten hemel schreiende grensoverschrijding, als iets aantrekkelijks gepresenteerd. Høegs roman doordenkt de consequenties van het opheffen van de soortgrens op een andere wijze dan het GAP, namelijk door wetenschappelijke toekomstscenario's te schetsen en culturele taboes aan de orde te stellen. Uit De vrouw en de aap blijkt dat een discussie over de nieuwe mens en de opheffing van de soortgrens, niet alleen tot een discussie leidt over wat 'cultuur' is en wat 'wetenschap' - zoals in hierboven besproken receptie - maar ook een discussie over vrouwelijkheid en mannelijkheid impliceert.

De vrouw en de aap wordt verteld vanuit het perspectief van de 
jonge, rijke en mooie Deense jonge vrouw Madelene. Als het boek aanvangt, is ze precies 529 dagen de echtgenote van Adam Burden. Samen met hem woont ze in een groot herenhuis in koloniale stijl in Londen. Het feit dat ze het aantal dagen zo precies heeft bijgehouden, duidt erop dat Madelene zich opgesloten voelt in het huwelijk; ze telt de dagen van haar 'gevangenschap'. Het huis waarin Madelene woont wordt omschreven als een soort dierentuin: de wintertuin is omgeven door 'ijzeren tralies' en is haar 'reservaat' (47).

Adam heeft nauwelijks aandacht voor Madelene. Hij is gefixeerd op zijn carrière en hoopt dat hij de directeur zal worden van een nieuwe, prestigieuze dierentuin in Londen. Om indruk te kunnen maken op het comité dat daarover beslist, doet hij onderzoek naar de aap Erasmus, die illegaal per boot is gesmokkeld naar Londen. Adam heeft hem opgesloten in een kooi in zijn laboratorium en wil zijn hersenen onderzoeken, omdat hij vermoedt dat Erasmus behoort tot een onbekende apensoort.

Madelenes leven is een sleur, opgebouwd uit niets dan herhalingen. Ze zoekt troost bij de fles. Haar alcoholisme wordt omschreven als 'de diepe, innige wens om jezelf te vernielen' (3I). ${ }^{26}$ Madelene drinkt bovendien niet gewoon uit een glas, maar haalt haar alcohol in het tuinhuis, waar haar man laboratoriumspullen bewaart:

Van een plank met staaldraad pakte ze een hevel, uit een kast een pyrexkolf, van een droogrek een maatglaasje. Ze verwijderde de rubberdop van een kogelfles in houtwol en tapte 2,8 deciliter 99,6 procent zuivere alcohol voor gebruik in ziekenhuizen en laboratoria. Uit een plastic jerrycan met gedestilleerd water vulde ze vervolgens de kolf bij. De vloeistof bevatte nu vijfenvijftig procent alcohol. (3I)

Het is alsof Madelene zichzelf tot zoölogisch object van haar man maakt, door zich vol te gieten met alcohol en zichzelf op deze wijze letterlijk op sterk water te zetten.

Wanneer Madelene vermoedt dat haar man iets voor haar verbergt, gaat ze op onderzoek uit. Normaliter verlaat Madelene nooit haar 'territorium', maar na een extra glaasje alcohol vat ze moed en stapt ze naar het laboratorium van haar man. Daar ziet ze de aap en gaat bij hem de kooi binnen. 'Proost,' zegt ze tegen de aap, terwijl ze nog een slokje neemt. Als hun blikken elkaar kruisen, heeft 
ze het idee dat de aap haar innerlijk lijden opmerkt. 'Hij zag haar naakt, onopgemaakt, en erger nog, hij zag haar treurige innerlijk, de onzekerheid, de waardeloosheid' (34).

De aap is niet de enige die Madelenes werkelijke gevoelsleven ziet. Ook haar boezemvriendin Susan, met wie Madelene haar jeugd doorbracht in een internaat en met wie ze stiekem een lesbische affaire had, kijkt 'door Madelenes schmink en alcohollucht' (39) heen. De relatie die Madelene met Susan had, was gebaseerd op 'instinctieve zekerheid'. Erover praten deden ze niet, want 'ze wisten dat hoe minder woorden je gebruikt hoe verdorvener het is.' (38) Het taalloze maakt hun relatie 'dierlijker'; praten is immers typisch iets van de cultuurmens. Het zien van de ander in deze relatie duidt op gelijkwaardigheid en respect. Maar niet alleen Susan, ook de aap bekijkt Madelene niet als object, maar als subject. Madelenes relatie met Adam wordt daarentegen beschreven met een objectiverende metafoor: Adam is een 'roofdier' en Madelene is zijn prooi. Toen hij haar 'veroverde', droeg hij bijvoorbeeld 'een bontjas', had zijn stem een diepte die alleen diegenen hebben 'wier brul uit het onderlichaam komt' en was hij zonder 'natuurlijke vijanden' (4I) als de leeuw. Aanvankelijk vond Madelene dit woeste aspect van haar man zeer prettig. Algauw blijkt dat Adam echter meer belangstelling heeft voor andere zaken, zijn werkelijke 'hol' (42) is een wereld vol boeken, de bibliotheek. Hij is een cultuurmens, die de natuur eerder bestudeert dan vertegenwoordigt.

Madelene identificeert zich hevig met de aap:

Ze had de indruk dat ze zelf een aap was, want weliswaar kon ze deze kooi verlaten en ook het huis, maar erg ver kon ze niet komen, voordat ze met haar hoofd tegen de economische, sociale of echtelijke versperringen zou lopen die ook haar leven begrensden. (34)

Zij kan zich de eenzaamheid van de aap levendig voorstellen en bedenkt daarbij dat het de aap ontbreekt aan hulpmiddeltjes om de eenzaamheid te verzoeten. 'Ooit gehoord van apen die dronken?'

Madelene beraamt een plan om de aap te bevrijden. Ze steelt de sleutel van haar man, maar na de kidnap neemt Erasmus de leiding over: als een soort King Kong springt hij met haar in zijn armen over de daken van Londen. $\mathrm{Na}$ een reis van zeven etmalen komen ze aan 
in een grote tuin, 'geen knus paradijs, maar het dierenpark zoals Adam en Eva dat moeten hebben meegemaakt' (r7o). Madelene begrijpt waar ze zijn beland: 'in het pornografische hof van Eden', een tuin der Lusten, waarin naar hartelust kan worden gevreeën. Ze heeft geen besef meer van tijd, maar eet, drinkt, slaapt en wast zich wanneer ze daar zin in heeft. En Erasmus en Madelene vrijen er lustig op los. Ze hoeft haar 'dierlijke' behoeften niet meer te onderdrukken, zoals ze tijdens haar huwelijk met Adam deed:

Elke keer wanneer het dier binnen in haar had geknord, dan had zij het een maaltijd toegeworpen, een halve kilo bonbons, een liefkozing, een cocktail, een glas zuivere alcohol, niet om honger maar om repressieve redenen, om de angst en onbehaaglijke geluiden te onderdrukken. (175)

Gedurende de romance, gaat Madelene zelf steeds meer op een aap lijken. Ze 'hurkt', 'neemt plaats op een tak' en na verloop van tijd staat haar haar 'recht overeind om het vangen van de hoofdluizen te vergemakkelijken' (193). ${ }^{27}$ De aap, zo zou je dit kunnen interpreteren, helpt Madelene om het laagje beschaving van zich af te schudden en toe te geven aan haar dierlijke verlangens. Ze werpt het 'onnatuurlijke' van haar 'cultuurlijke aristocratische' leven van zich af, terwijl de overige mensen in Londen machinematig leven en 's avonds alleen maar voor de tv hangen. Ook is Madelene nu van de drank af en leidt ze voor het eerst sinds haar jeugd een leven zonder verdoving.

Op haar beurt leert Madelene de aap praten. ${ }^{28}$ Dat gaat op een Tarzan en Jane-achtige manier. Ze tikt haar borst eerst aan en zegt: 'Madelene'. Na de persoonlijke voornaamwoorden 'ik' en 'jij' stapt ze over naar de woorden voor het menselijk lichaam. 'Voet'. 'Onderbeen'. Zo gaat ze langzaam via haar benen naar boven, om halverwege met hese stem de aap te leren dat daar 'kriebelientje' is, waarna een broeierige vrijpartij volgt. De taal dient niet voor filosofische gesprekken; de relatie tussen Madelene en Erasmus is grotendeels gevoelsmatig, lichamelijk en kan het zonder woorden stellen. 'Goeiemorregugoegeslapen' is de eerste volzin die Erasmus uitstoot, gevolgd door 'Kan er geen kind komen?' Net als voor de 'taalloze' relatie tussen Madelene en Susan gold, wordt ook hier geïmpliceerd dat de mens baat heeft bij meer taalloosheid, bij com- 
municatie die gebaseerd is op gevoel en lichamelijkheid in plaats van op rationele en verbale communicatie. Meer dan 'primitieve taal' heb je niet nodig. Ook met taal pretendeert de mens verheven te zijn boven anderen. Zo spreekt Madelene 'gelatiniseerd upperclass Engels' maar heeft geen relatie meer met woorden als 'bloedend tandvlees, honger, harde sjanker', en dus zit ze opgesloten in een 'talige huls'. Voor Erasmus is de enige reden om taal te leren dat hij de mens dan eens de waarheid kan zeggen. Maar in feite geldt: hoe minder taal, hoe beter. De volmaakte liefde tussen twee wezens krijgt in zwijgen gestalte. Erasmus vertelt Madelene bovendien dat waar hij vandaan komt, zijn soort zichzelf 'mensen' noemen, terwijl ze de mensen 'dieren' noemen.

In een van de slotscènes van De vrouw en de aap worden we deelgenoot van de missie van Erasmus in de mensenwereld. Nu blijkt dat Erasmus zeer bewust erop aanstuurde dat Madelene hem leerde spreken; hij heeft de taal nodig om zich tot de mensen te kunnen wenden. Uit zijn toespraak, die in elke huiskamer via de televisie is te volgen is, blijkt dat hij wil onderzoeken of een vreedzaam naast elkaar bestaan van mensen en dieren mogelijk is. Tot zijn spijt moet hij concluderen dat de mens er nog niet klaar voor is.

Maar het is niet 'de mens' die er niet klaar voor is, het is in feite de man die dwarsligt, zo weet de lezer. Van elk personage in De vrouw en de aap wordt namelijk aangegeven hoe zijn of haar relatie tot dieren is, en de mannen komen er niet al te best van af. Bally, de smokkelaar van Erasmus, beschouwt dieren als wezens van een lagere orde. Johnny, ook smokkelaar, gokt op honden en paarden. De vader van Adam is een jager, Madelenes vader is werkzaam in de dierenindustrie en verantwoordelijk voor de 'jaarlijkse Deense produktie van 20650000 varkens en 813000 runderen en kalveren' (27). Adam ten slotte doet wetenschappelijke experimenten met proefdieren. De vrouwen in de roman zijn een stuk diervriendelijker: Andrea Burden, de zus van Adam, is de voorzitter van The Animal Welfare Foundation, en Susan, de beste vriendin van Madelene zit in het bestuur van de Royal Society for the Protection of Animals. Erasmus staat tijdens zijn speech naast een vrouw die omschreven wordt als 'vice-voorzitter van de Royal Zoological Society, woordvoerster in dierenethische kwesties, een intellectueel, een aanhangster van een totaal verbod op dierproeven, de persoon die meer dan wie ook tweeënvijftig naties ertoe had gebracht zich aan te sluiten 
bij The Great Ape Project, dat aan de mensapen op de wereld dezelfde juridische, economische, ethische en sociale status wil verlenen als aan mensen'. Direct na de speech trekt ze haar kleren langzaam uit en onthult dat ze een aap is. Tot grote schrik van het publiek laten ook anderen, twaalf in totaal, ambtenaren en vertegenwoordigers van belangrijke dierenorganisaties zien dat zij apen zijn. Zij trekken hun rokkostuums uit en onthullen hun harige lijven. Het aanwezige publiek is hevig geshockeerd. De mensen thuis voor de televisie kijken ongerust om zich heen: hun eigen partner zou wel eens een aap kunnen zijn. Misschien zelfs wel de koningin! Erasmus, die inmiddels van Madelene heeft leren praten, geeft voor zijn vertrek de mensheid nog een wijze les mee. 'Als wij weg zijn, zullen jullie ons vergeten, totdat we terugkomen. Er is maar een ding dat ik jullie wil verzoeken te onthouden tot het zover is. Dat is hoe moeilijk het is te weten waar, in ieder van ons, datgene wat jullie de mens noemen ophoudt en datgene wat jullie het dier noemen begint' (231).

Terwijl het GAP een 'nieuwe' mens voor ogen heeft, namelijk een bredere categorie waartoe ook de mensapen behoren en steeds in het algemene spreekt over 'de mens' en 'de mensaap', worden in De vrouw en de aap kwaadaadige en zachtaardige eigenschappen over de seksen en de soorten verdeeld. Wat een vergelijking tussen mensen en mensapen betreft, komt de mensaap er in vergelijking tot de mens beter van af. De vrouw en de aap neemt in een aantal debatten over mensen en apen een specifiek standpunt in, bijvoorbeeld als het gaat om taal, cognitie en emotie, de speerpunten van het GAP. Wat taal betreft, zagen we al dat Erasmus in staat is deze te leren. Wat cognitie betreft, wordt gezegd dat Erasmus een soort is die 'na' de mens komt, zijn opvolger is; zijn hersenomvang is ongekend groot, veel groter dan die van de mens. En wat emoties betreft, toont Erasmus zich een gevoelige aap, van wie de mensen alleen maar kunnen leren, vrouwen, maar met name mannen. Høegs mannelijke personages zijn niet meer dan slechteriken, belust op macht, geld, seks en roem. De sympathie gaat in De vrouw en de aap uit naar de vrouwelijke personages, gevoelige en intelligente wezens, en veelal politiek geëngageerd, werkzaam in bijvoorbeeld dierenbeschermingsorganisaties, waaronder het GAP. ${ }^{29}$ Volgens de roman van Høeg maakt hun positie als buitenstaander dat zij met een kritische blik naar de rol van wetenschap in de westerse maatschappij kunnen kijken, met name naar de wijze waarop mannelijke weten- 
schappers als Adam zich jarenlang met dieren hebben beziggehouden, namelijk als objecten, die lijkt op de wijze waarop mannen vrouwen jarenlang hebben geobjectiveerd.

Vooral Adam schrikt van de affaire tussen zijn vrouw en de aap. Wanneer hij vermoedt dat Madelene er een minnaar op nahoudt, is hij 'confuus' en 'ziek van jaloezie' (I24). Aanvankelijk heeft Adam er geen notie van dat het om 'zijn' aap gaat. Als Madelene op een dag samen met Johnny, de dierensmokkelaar, en Erasmus op weg is naar een belangrijke conferentie over de fusie van de dierentuinen in Londen, ziet hij hun schaduwen. De aanblik van zijn vrouw, die vergezeld wordt door een 'gebochelde', geeft zijn zelfvertrouwen een extra deuk. 'Wat hij zag waren zijn vrouw en haar twee minnaars, twee wezens die totaal gespeend waren van raffinement, en door zijn hersenen trok de enorme hoeveelheid erotische vernederingen die deze nieuwe, derde persoon mogelijk maakte' (I26). Zijn eerste impuls is een geweer te halen en een moord te plegen. 'Hij zou direct naar Madelenes kamer gaan, de deur intrappen en de minnaar neerslaan' (126). Maar Adam weet zich te beheersen en concentreert zich weer op zijn werk, de speech die hij moet gaan houden voor het comité.

Als het zover is, en Adam zijn speech houdt, wordt deze onderbroken door Erasmus, die de microfoon pakt en de zaal vertelt over zijn missie. Na de speech treft Erasmus Adam met een geweer aan. Erasmus spreekt Adam toe. 'Wij zeggen, dat je als je een vijand tegenkomt eerst moet proberen om vrede te stichten. Als dat mislukt moet je charmeren. Als dat mislukt moet je betoveren [...] Als dat mislukt, moet je vernietigen' (242). Adam denkt enkele minuten na en besluit zijn wapen neer te leggen. Hij zegt tegen zijn vrouw dat het tussen hun tweeën wel nooit meer goed zal komen en wenst zijn vrouw en de aap samen veel geluk: 'Ik ben er achter gekomen... nu... hier... dat het zo het beste is. Met jou en mij zou het nooit meer goed gekomen zijn. Ik... had het niet kunnen verdragen.' (242) Madelene en Erasmus vertrekken samen op een boot, De Ark, naar het Noorden, terwijl Madelene de eerste tekenen van haar zwangerschap bemerkt. Het slot, Adam die in de aap zijn meerdere erkent, is revolutionair te noemen. Anders dan in King Kong en Mijn aap schreit, waarbij de aap om het leven wordt gebracht door de man, bloeit de liefde tussen vrouw en aap hier ten volle op en eindigt in een romantisch en clichématig hoogtepunt. ${ }^{30}$ 


\section{VAN RAPE-APE TOT IDEALE MAN}

Neem een aap, geef hem een draagbare telefoon en $u$ hebt een idee van de man.

Michel Houellebecq, Elementaire Deeltjes (1999)

Waarom houdt Madelene meer van de aap dan van haar eigen man? In De vrouw en de aap kiest Madelene voor de aap omdat zij zich herkent in zijn anderszijn. Ze identificeert zich met zijn eenzaamheid wanneer hij opgesloten is. Voelde zij zich aanvankelijk als een doods cultuurmens wier leven bestond uit herhalingen, in de nabijheid van de aap is Madelene weer vitaal en levenslustig; ze wordt zelf aapachtiger. Dankzij de aap komt Madelene weer in contact met het dierlijke in zichzelf. Terwijl haar man de aap slechts beschouwt als een onderzoeksobject dat zijn carrière vooruit kan helpen, waardeert en respecteert Madelene de aandacht die Erasmus voor haar heeft. Ze verwerpt de dominante mannelijke rationele cultuur die dieren en vrouwen tot objecten maakt. Wanneer ze moet kiezen tussen haar man en de aap, kiest ze voor Erasmus, omdat ze 'met gesloten ogen' voelt wat haar man is: 'de Dood' (174). De verhandelingsachtige titel, 'De vrouw en de aap', suggereert dat de strekking van de roman van algemenere aard is, dat dit verhaal niet specifiek over Madelene en Erasmus gaat, maar over alle vrouwen en apen ter wereld.

Enerzijds neemt de auteur het daarmee op voor de 'ander' - dier en vrouw -, maar anderzijds wordt deze ander als de onbedorvene gestereotypeerd. Vrouwen en apen vertegenwoordigen in Høegs literaire universum een soort ongerepte natuur, nog niet verpest door eisen die de hedendaagse maatschappij stelt. ${ }^{31} \mathrm{Ze}$ staan dichter bij de natuur, hun gevoelens en emoties. Daarmee wordt deels de hardnekkige mythe, waarbij het 'vrouwelijke' en het 'dierlijke' een paradijselijke, natuurlijke oerstaat vertegenwoordigen (waaruit, als we Høeg volgen, de door de cultuur verpeste mens zou moeten putten om weer te 'genezen'), bevestigd.

Behalve Madelene, vinden ook andere vrouwen hun geluk in de armen van een aap. $\mathrm{Al}$ in de jaren zeventig, maar met name in de jaren tachtig en negentig verschijnt een golf komische films en boeken waarin de aap in vergelijking tot de man als de betere optie uit de bus komt. Naast De vrouw en de aap, zien we bijvoorbeeld hoe, in de remake van King Kong (1976) Jessica Lange in haar rol als 


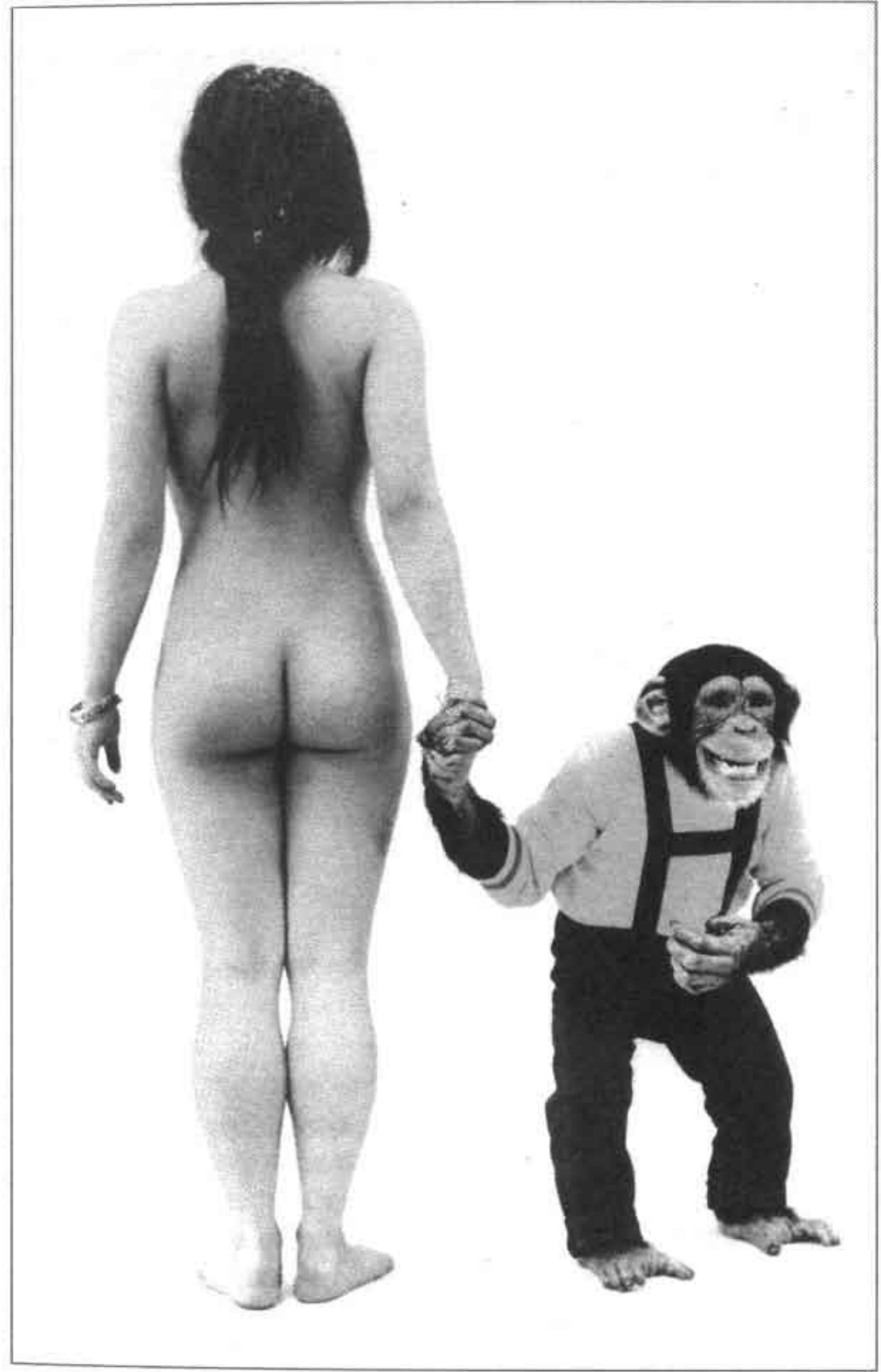

19 'Naked ape' (r969). Foto: Peter Dicampos. De foto was een pastiche op Desmond Morris' bestseller The Naked Ape (1967). 
Ann met volle teugen geniet van de aandacht van de gorilla. Ze laat zich door hem baden in een waterval en bij afwezigheid van een föhn in de jungle, blaast King Kong zachtjes haar haren droog. In Tarzan, the Apeman (198I) laat Bo Derek, in haar vertolking van Jane, alle mannen die naar haar hand dingen links liggen; ze is liever verwikkeld in een stoeipartijtje met een enorme orang-oetan en Tarzan. De aap en de aapmens sjorren beurtelings aan haar broekje en proberen boven op haar te klauteren. ${ }^{32}$ En in Nagisa Oshima's geestige film Max, Mon Amour (I986) neemt de jonge huisvrouw Margaret wraak op haar overspelige echtgenoot Peter door overspel te plegen met Max, een aap. Wanneer hij erachter komt dat zijn vrouw af en toe stiekem een hotelkamer huurt, begint hij te vermoeden dat zijn vrouw hem een koekje van eigen deeg bereidt en er, net als hij, een minnaar op nahoudt. Als hij verneemt dat dit inderdaad zo is, maar dat het een chimpansee betreft, raakt Peter volkomen bezeten van dit idee. Hij probeert op allerlei manieren erachter te komen of zijn vrouw het ook echt doet met de aap. Hij bespiedt haar door het sleutelgat, en wij kijkers spieden verwachtingsvol met hem mee. Peter is vreselijk bang dat de chimpansee een betere minnaar is dan hijzelf, en dat zijn vrouw bij hem iets tekort komt op seksueel gebied. Wanneer hij zijn eigen maîtresse bezoekt, roffelt hij als een aap met beide handen op zijn borst en bespringt haar vervolgens in een poging Max na te doen. Peter huurt zelfs een hoer in om te kijken hoe dat eraan toegaat, gemeenschap tussen een vrouw en een aap. Maar de aap wil niet. Dan lijkt Peters diepste vrees bevestigd: dat het zijn vrouw niet alleen om de seks gaat, maar dat zij intimiteit, echte liefde voelt voor Max. Ondanks de conventionele vertelstructuur, waarbij de camera steeds meekijkt met de man en aan de zwijgende Margaret maar een beperkte mate aan subjectiviteit wordt gegund, ontsnapt deze film aan de Hollywoodconventie. ${ }^{33}$ Niet alleen wordt de voyeur in Peter - en de kijker die steeds door de ogen van Peter kijkt en zich dus ook in de voyeuristische positie bevindt - voortdurend gefrustreerd, maar ook zien we hoe de stoere Peter, net als Adam uit De vrouw en de aap, steeds milder wordt en noodgedwongen de verhouding van zijn vrouw accepteert.

De aap is, kortom, van een potentiële vrouwenverkrachter tot de ideale man getransformeerd. ${ }^{34}$ Haraway noemt de aap een projectiefiguur voor de westerse blanke man, en de blanke vrouw een ge- 


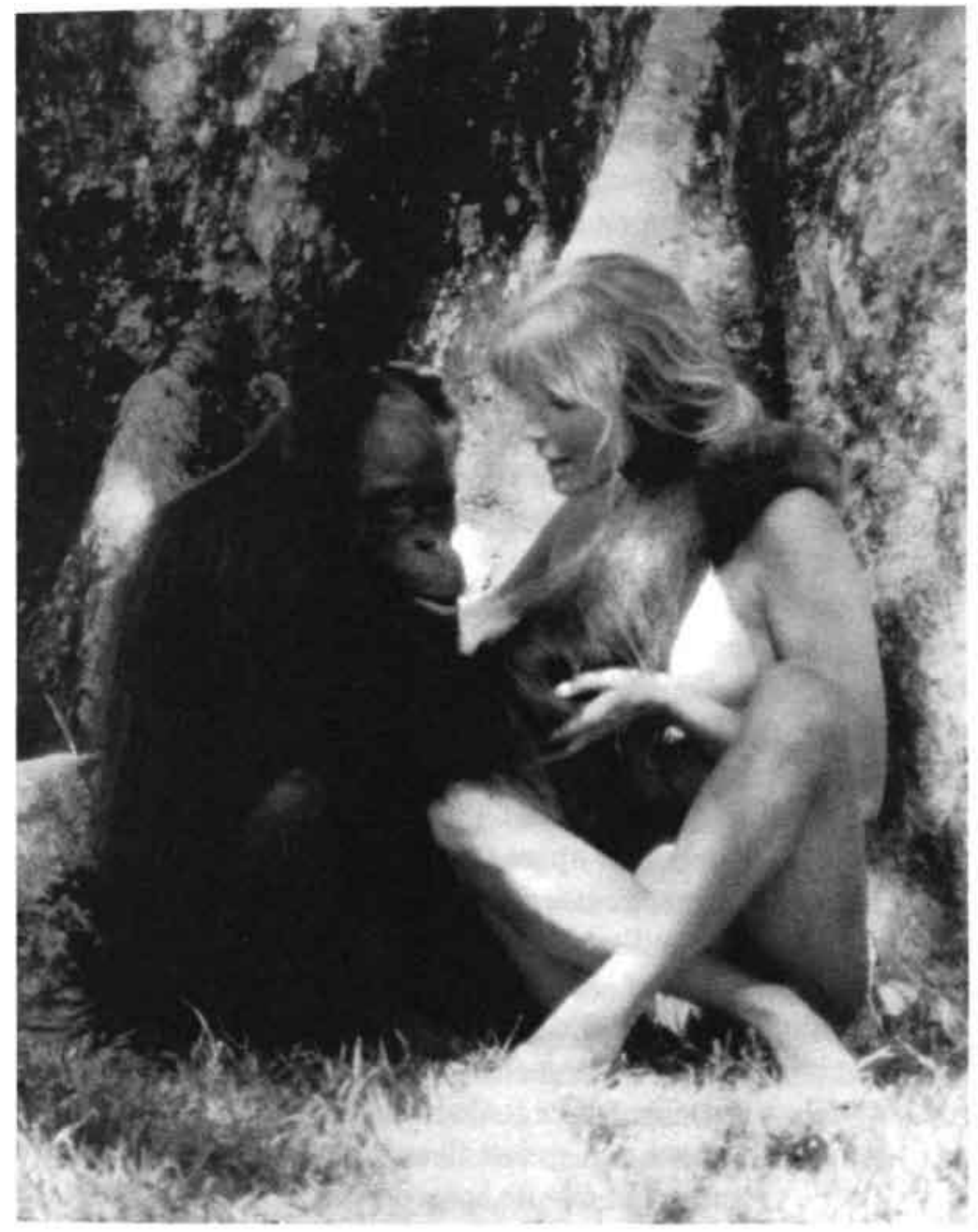

20 Bo Derek met orang-oetan in Tarzan, the Apeman (1981).

schikte bemiddelaar tussen natuur en cultuur. Hoewel deze ideeën overwegend vanuit een synchroon perspectief worden beschreven en Haraways vocabulaire in die zin weinig geschikt is voor het verklaren en beschrijven van veranderingen in ons aap-, dan wel vrouw- en manbeeld (de ander verandert bij haar niet), kunnen ze toch behulpzaam zijn om de omslag in de huidige beeldvorming te 
begrijpen. Wanneer we Haraway volgen, dan is er een omslag geweest in de rol van de aap als projectiefiguur. Inderdaad is dat, in algemene zin, het geval. In de twintigste eeuw zijn de menselijkheid van de aap en de aapachtigheid van de mens steeds meer benadrukt, en is er een beweging waarneembaar van discontinuiteitsdenken tussen mensen en apen, waarbij vooral de verschillen van belang worden geacht, naar continuiteitsdenken, waarbij vooral de overeenkomsten worden benadrukt. De aap is, mede dankzij de inbreng van vrouwelijke primatologen - zoals beschreven in het vorige hoofdstuk - steeds meer 'familie' van de mens geworden en tegenover onze familie zijn we stuk aardiger geworden. ${ }^{35}$ Misschien niet in de laatste plaats omdat we daarmee ook een sympathieker beeld van onszelf kunnen scheppen. Dit is bovenal een culturele constructie.

Maar ook de rol van de vrouw is, mede dankzij het feminisme van de jaren zeventig, veranderd. Niet langer is zij het mooie blondje, zoals in King Kong. $\mathrm{Zij}$ is een rebellerende vrouw geworden. Madelene pikt het niet door haar man genegeerd te worden. Aanvankelijk protesteert zij in stilte, door te drinken, waarmee ze vooral zichzelf schade toe brengt. Daarna neemt haar protest andere vormen aan: overspel, op zoek naar de man die wel voldoet. Door haar affaire met Erasmus groeit haar zelfrespect gelijktijdig met haar respect voor dieren.

De vrouw wordt door Haraway de ideale bemiddelaar tussen natuur en cultuur genoemd. De vraag is: voor wie bemiddelt zij precies? Het blijft immers opmerkelijk dat vooral veel mannen in deze tijd culturele voorstellingen bedenken waarin zij het moeten afleggen tegen apen, en waarin gedetailleerd uit de doeken wordt gedaan hoe de vrouwen het met de apen doen. De tv-biologen Midas Dekkers en Desmond Morris geven een mogelijke verklaring voor dit fenomeen in hun non-fictiewerk. Desmond Morris merkt in zijn boek Intimate Behavior (I971) op dat mensen vaak hun toevlucht tot dieren zoeken als ze teleurgesteld zijn in hun medemens. Dieren, aldus Morris, dienen als substituut voor intimiteit. Ze zijn, anders dan de mens, onschuldig want zij roepen geen vragen op en stellen geen vragen. Vanuit dit perspectief kun je de door mannelijke auteurs verzonnen affaires tussen vrouwen en apen opvatten als een manier om 'mannelijkheid' ter discussie te stellen. ${ }^{36}$ Volgens Midas Dekkers is de geslachtsgemeenschap tussen vrouw en dier al 
eeuwenoud, en bij uitstek een fantasie van, voor en door mannen. In zijn boek Lief dier. Over bestialiteit (1992) laat hij zien dat vrijwel elke bestiale fantasie tussen vrouw en dier voortkomt uit het brein van mannen. Wanneer zij uitdrukking willen geven aan hun mannelijke potentie en agressiviteit, dan is het beest daarvoor het beste symbool. Mannen identificeren zich volgens Dekkers veelal met de actieve partij: 'Hij is de hengst, de reu, de stier, het wellustig monster dat met zijn XL-orgaan de onverzadigbaarste vrouwen vol zaad pompt.' (170) Maar Erasmus uit De vrouw en de aap lijkt niet op de zaadpompende macho van Dekkers. Erasmus is menselijker dan de man, met een rijk gevoelsleven en werkelijk respect voor vrouwen. Erasmus staat juist voor datgene wat de man, die als in Mijn aap schreit te veel een denkhoofd werd, is kwijtgeraakt: contact met de natuur.

De scenario's van mannen waarin vrouwen schipperen tussen een man en een aap, geven uitdrukking aan wat het afgelopen decennium lijkt te zijn uitgegroeid tot een waar cultureel cliché, dat bekendstaat als de identiteitscrisis van de man. Die worstelt nu met zijn rol, nadat de emancipatie van de vrouw en het dier, de aap in het bijzonder, zich onder zijn ogen heeft voltrokken of aan het voltrekken is. Met zijn satire speelt Høeg in op dit cliché; de absurditeit, een vrouw die er met een aap vandoor gaat, stelt de man voor een vraag. Wat vermag de man? Kan hij dezelfde blijven? Is hij iets kwijtgeraakt? Is hij jager of zorger, verstands- of gevoelsmens, onderdeel van de natuur of de cultuur? ${ }^{37}$ Dat dilemma wordt via de vrouw en de aap onderzocht. De mannelijke auteur zet haar in als een soort test: wie kiest ze? Het aanvankelijke doden van de apen in eerdere scenario's, zoals ik die in de inleiding noemde, kan geïnterpreteerd worden als een poging om de ambiguiteit uit te roeien en past binnen het discontinuïteitsdenken tussen mens en aap. Met het tragische doden van de apen door de mannen zegeviert een mannelijkheid die gedefinieerd wordt als cultuurlijk, rationeel en geciviliseerd. De man die weer een mannelijkheid wil waarin vrouwelijke eigenschappen, zoals gevoeligheid en emoties, geïntegreerd zijn, moet de aap in zichzelf weer tot leven wekken. ${ }^{38}$ Zolang de man daartoe niet in staat is, ligt voor Madelene de keuze voor de aap dan ook voor de hand. $\mathrm{Zij}$ weet dat alles wat een aap meer heeft dan een man mooi meegenomen is. 

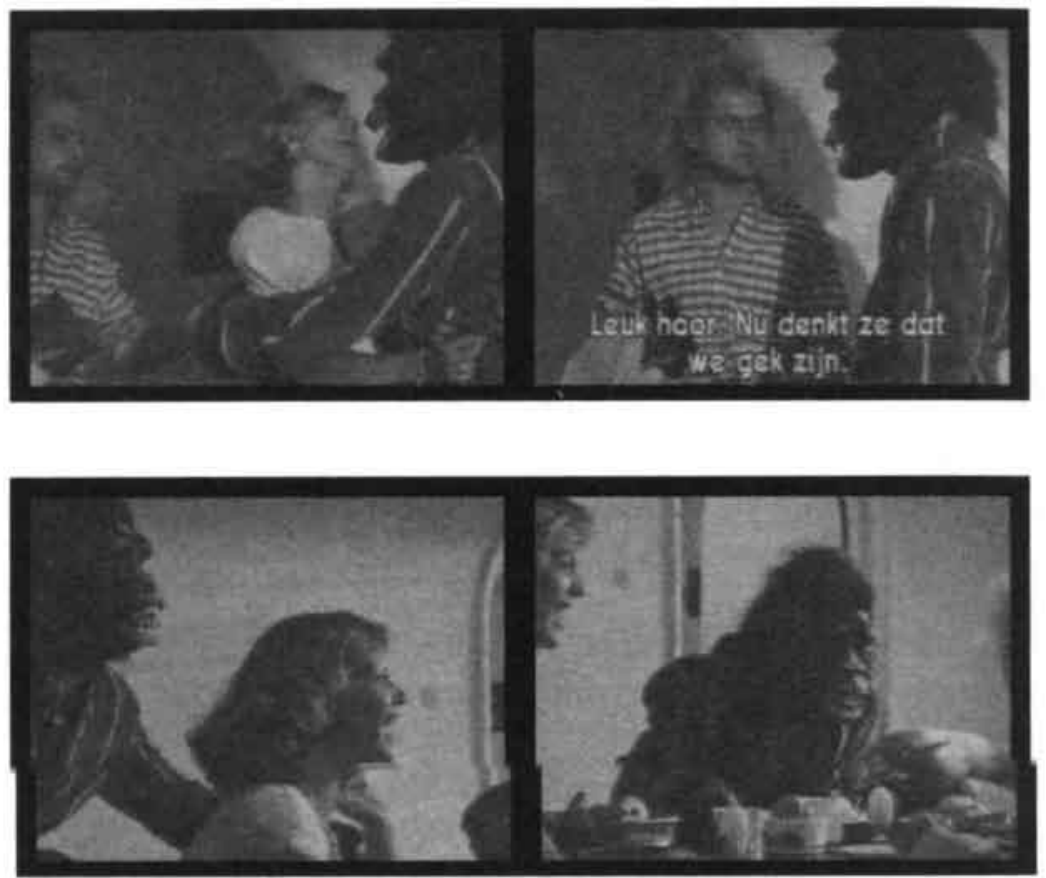

2I Filmstills uit Männer (r986).

\section{DE LAATSTE MANNELIJKE MAN}

'Over een paar jaar zitten de laatste mannen in de dierentuin.'

Robert Carlyle als Gaz in: The Full Monty (1997)

Erasmus slaagt erin tegenstrijdige aspecten in zich te verenigen: hij is menselijk, dierlijk en goddelijk tegelijkertijd. Zijn aantrekkingskracht dankt hij aan deze unieke combinatie, die het hart van zo veel vrouwen sneller doet kloppen: hij is zachtaardig en helfdhaftig, lief én macho, gevoelig en een heerlijk brok vlees. Hij oogt als een stukje ongerepte natuur, die in het geheel geen last heeft van de remmingen die de civilisatie ons oplegt. Hij volgt zijn intuittie en hij heeft zijn hart bovendien op de juiste plaats: hij komt op voor de 'anderen' in onze samenleving, vrouwen en dieren. Alle andere 
mannen die in De vrouw en de aap voorkomen, bijvoorbeeld Madelenes echtgenoot (een verdorven wetenschapper) en haar vader (dierenhandelaar) kunnen alleen maar van Erasmus leren. Erasmus is de civilisatie voorbij; hij is wat ná de mens komt. Een man, kortom, van wie alle vrouwen alleen maar durven dromen.

Hoewel de genoemde filmmakers en romanciers misschien niet direct de intentie hadden een kritische blik op de rol van mannen in de maatschappij te richten, is het een effect van de plotstructuren: bovengenoemde voorbeelden gaan over de teleurstellingen van vrouwen over het mannelijk geslacht. In De vrouw en de aap kiest de vrouw voor de aap, waarmee Høeg lijkt te willen zeggen, bij wijze van cultuurkritiek, dat de man ervoor moet zorgen dit type mannelijkheid (geciviliseerd en gericht op macht en prestige) achter zich te laten. Want teleurgestelde vrouwen wenden zich tot apen. De voorkeur is te geven aan een type mannelijkheid zoals Erasmus die vertegenwoordigt, waarin het gevoelsmatige, het lichamelijke en de aandacht voor anderen een plaats heeft. Dat de vrouw voor een aap kiest, en niet voor de man, impliceert kritiek op mannen.

Samengevat kun je stellen dat De vrouw en de aap te lezen is als een pleidooi voor de 'nieuwe' mens, waarbij verbetering van de menselijke soort vooral gezocht moet worden in de nieuwe mannelijkheid.

King Kong (1976), Max in Max Mon Amour, Erasmus in De vrouw en de aap en Tarzan in Tarzan the Apeman hebben bovendien allemaal iets opmerkelijks gemeenschappelijk. In de meeste films en romans die in dit boek besproken zijn, wordt gezinspeeld op een buitenaards dan wel goddelijk aspect. In King Kong vraagt men zich af wat King Kong nu eigenlijk is: 'Some native superstition, isn't it? A god, or a spirit or something... In Max, Mon Amour vraagt Peter als hij Max voor het eerst ziet: 'What is it? Is it a gorilla or a chimpanzee or something else?' Ook Tarzan is 'koning onder de apen', de missing link tussen man en aap, een soort superaap dus. Erasmus uit De vrouw en de aap ten slotte, is 'een soort dwergaap', en lijkt dus het meest op de bonobo (vroeger 'dwergchimpansee' genoemd), de make love not war-aap die, zoals we in hoofdstuk 5 van dit boek al zagen, allerlei eigenschappen van de ideale mens' krijgt toegedicht. Zijn geheimzinnige plek van oorsprong ('ergens uit het Noorden') en zijn onbepaalbare soort geven Erasmus een bovenmenselijke status. Deze status als superaap wordt 
versterkt doordat hij is 'uitverkoren' en 'met een missie' op aarde gekomen, namelijk de mensheid een les te leren. De aap wordt in De vrouw en de aap niet alleen voorgesteld als Adam, maar, net als in Mijn aap schreit en King Kong, ook als Christusfiguur. Hij vervangt Madelenes man Adam, en in die zin is hij 'de nieuwe Adam'. Ook heeft hij twaalf apostelen - de twaalf apen die tijdens zijn speech opstaan - met zich meegebracht. In De vrouw en de aap is het een burleske vergelijking, omdat de verlossing van de mens niet in het goddelijke moet worden gezocht, maar in het superdierlijke. De naam van de aap, Erasmus, is dezelfde als die van Darwins grootvader én als Desiderius Erasmus, de grote humanist uit de zestiende eeuw, die in zijn satire De Lof der Zotheid (I5I) de spot dreef met vastgeroeste normen en waarden in de middeleeuwse maatschappij en pleitte voor vrijheid van de mens en verdraagzaamheid ten opzichte van anderen. Dat Madelenes echtgenoot 'Adam' heet, kan ironisch begrepen worden. Het is de Adam van na de zondeval ('Burden'), geïnfecteerd door het Kwaad; Erasmus, de 'nieuwe' Adam, gedraagt zich eerder als de 'oude' Adam, de goede Adam van vóor de zondeval.

Erasmus, King Kong, Max en Tarzan lijken op apen, maar zijn geen apen; ze krijgen in hun onbepaaldheid bovenmenselijke proporties toebedeeld en worden als Superman, de film-, strip- en tvheld die dankzij zijn buitenaardse afkomst en zijn bovenaardse krachten steeds het kwade kan overwinnen, maar in zijn rol als Clark ook een gevoelige en zachtaardige man blijkt te zijn. Dat de vrouw voor een aap kiest, en niet voor de man, impliceert kritiek op mannen. Maar een vorm van kritiek die wel te verdragen is. Er is uitzicht op een nieuwe glansrol voor de man. In De vrouw en de aap wordt de aap als een nieuw soort superman voorgesteld die de vrouw 'helpt' om zichzelf te worden. Een man, kortom, die de belofte van de redding van de mensheid instandhoudt. En zo blijft de man ook nog steeds een beetje voor Verlosser spelen.

Op de laatste bladzijde van de roman, legt Madelene, zwanger van de aap, haar handen op haar buik en kijkt naar hemel.

'De laatste stukjes,' zei ze, 'zijn niet enkel blauwe hemel. Eerder een engel.'

'Wat is een engel?' vroeg de aap.

Madelene schudde het hoofd. 


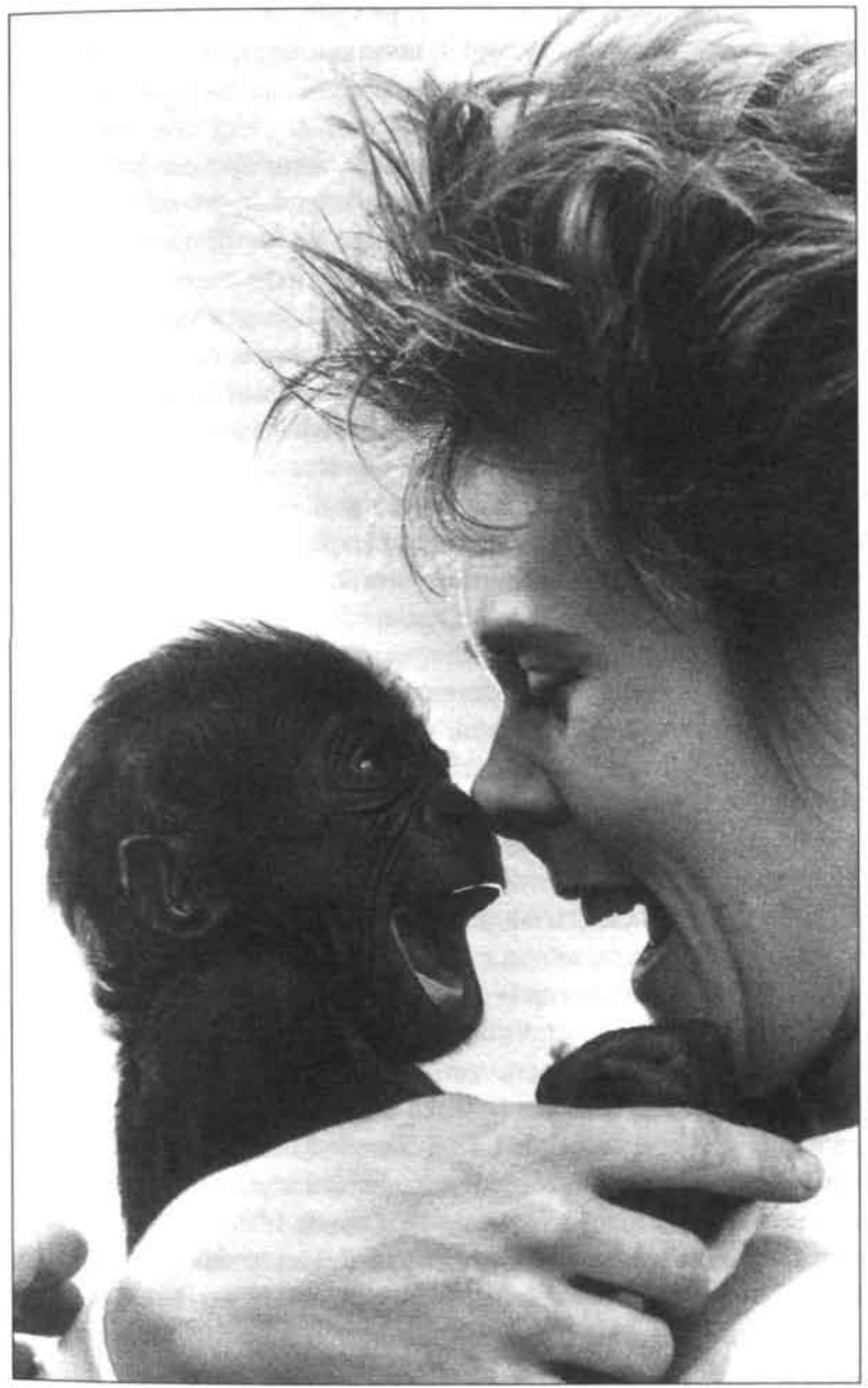

22 'Mummy' (I988). Foto: Peter Trievnor. 
'Dat heb ik nooit helemaal begrepen,' zei ze. 'Maar misschien is een engel voor een derde god, voor een derde dier en voor een derde mens.'

Het einde is raadselsachtig voor de lezer, maar lijkt een belangrijke wijsheid te bevatten. 'De laatste stukjes' - 'van de puzzel' vult de lezer aan - zijn een engel, en die is ambigu, en wordt door Madelene gezien als deels mens, deels god, deels dier. De engel verenigt alle aspecten van het anders-zijn in zich. Het lijkt een variatie op Edward Tysons uitspraak: 'Man is part Brute, part an Angel; and is that Like in the Creation that joins both together' (Geciteerd in De Rooy, 199r: 44). De toekomst, zo lijkt Madelene te willen zeggen, wordt 'engelachtig' als we opnieuw de verschillende aspecten van ons bestaan integreren, mens, dier en god, en onze ambigue aard erkennen. In zekere zin impliceert het open slot van De vrouw en de aap echter ook dat de spanning wordt opgelost. Immers: Madelene en Erasmus verdwijnen uit het aardse leven en de wereld verandert niet, omdat die er nog niet aan toe is ${ }^{39}$ Anderzijds is er de belofte dat het wel goed kan komen: Erasmus is immers de nieuwe man, datgene wat ná de mens nog komen zal, en Madelene is zwanger van zijn en haar nageslacht.

\section{LITERATUUR IN DE LACHSPIEGEL}

Naast De vrouw en de aap is er eind jaren negentig een golf van komische romans die de continuïteit tussen mensen en apen, en in het bijzonder mannen en apen, aan de orde stellen. Daarbij valt een aantal dingen op. Ook vrouwelijke auteurs pakken eind jaren negentig de pen op om zich te buigen over het thema 'de vrouw en de aap'. Zij verbinden, net als Høeg, de liefdesrelatie tussen vrouw en aap met de zoektocht van vrouwen naar de ideale man. Zowel in The Last Manly Man (r999) van Sparkle Hayter als in Laura Zigmans Animal Husbandry (r998) is een vrouw op zoek naar de ideale man en vraagt ze zich af waarom het haar nog altijd niet gelukt is Mr. Right te vinden. Heeft de tweede feministische golf alleen jonge vrouwen veranderd, terwijl de mannen achter zijn gebleven? In de romans Great Apes (r997) van de mannelijke auteur 
Will Self en Ark Baby (1998) van Liz Jensen wordt het Great Ape Project tot uitgangspunt genomen voor een roman. Self draait de rollen van mensen en apen om en geeft in het voorwoord aan waar de roman over gaat: de kwestie van apenrechten voor mensen. ${ }^{40}$ Jensens roman speelt zich af in 1999, in Groot-Brittannië, waar een nationale vruchtbaarheidscrisis is uitgebroken, en een grote geldprijs is uitgeloofd voor de vrouw die het uitsterven van de homo brittannicus weet te voorkomen. Het huisdierenbezit is verviervoudigd. Vrouwen leggen zich gepassioneerd toe op de zorg voor het dier dat het meest op de mens lijkt: de aap.

Behalve het thema (de identiteit van de mens en die van mannen in het bijzonder, aan de kaak gesteld door ze met apen te vergelijken), vertoont de stijl van bovengenoemde romans een opvallende overeenkomst. De toon is luchtig, geestig, soms op het hilarische en satirische af. De auteurs flirten in hun boek met allerlei wetenschappelijke theorieën, door naar hartelust te citeren uit invloedrijke werken over de relaties tussen mensen en dieren - van Darwin tot Jane Goodall. Ze bedrijven 'fictionele wetenschap', door scenario's die door de wetenschap worden voorgesteld, verder uit te denken. Maar ze blazen deze soms ook op tot absurdistische proporties en zetten zich daarbij af tegen de wetenschap: 'I am not a scientist, but a novelist, unconfined by dry empirical consideration,' schrijft Self in zijn voorwoord. Niet alleen de wetenschap wordt bespot, ook de pretenties van Literatuur met een hoofdletter worden collectief losgelaten, wat al in de uiterlijke vormgeving naar voren komt. De felgekleurde omslagen trekken de aandacht en zijn eerder geestig dan serieus of mooi. Op Great Apes staat het portret van een man die sprekend op een mensaap lijkt, op Animal Husbandry siert een koe met een oorbel het omslag, Ark Baby toont ons een vrouw met een aapje in haar boodschappentas, op The Last Manly Man zien we een mooie brunette met roodgestifte lippen die door een verrekijker naar een man gluurt, en ook de Engelse editie van Høegs De vrouw en de aap heeft voor een opvallend omslag gekozen: een grijnzende aap kijkt ons aan. Hij staat tussen de gespreide benen van een langharige blondine, een soort pin-up-pose. ${ }^{41}$ De naamgeving van de personages in de romans ligt er zo dik bovenop dat de romans een pasticheachtige kwaliteit krijgen. De machomannen heten 'Adam' (De vrouw en de aap) 'de heer Mann' (Ark Baby), Mandervan (The Last Manly Man). De hoofdfiguur in Animal Husbandry heet Jane Goodall - 'Not the Jane 
Goodall, but sometimes I think it was my name that led me from men to cows, from cows to monkeys, and then to all my research and theories' (5). Was het sterven van de aap in King Kong, Mijn aap schreit en Brazzaville Beach tragisch, nu is het de lach die overheerst als de vrouw het heft in handen neemt en de man beteuterd toekijkt.

Net als in De vrouw en de aap schuilt, als we deze romans moeten geloven, de toekomst van de mens vooral in de verbetering van het mannelijk geslacht. Maar anders dan in De vrouw en de aap, zoeken de auteurs van The Last Manly Man en Animal Husband$r y$ de redding van de mens niet in een terugkeer naar de natuur en een mannelijke herontdekking van de gevoelige en lichamelijke 'aap' in zichzelf. Sterker nog, mannelijke personages gedragen zich als onbeschaafde apen, alsof ze zijn blijven steken in de evolutie. In Animal Husbandry zet Zigman de toon met een citaat van W.S. Gilbert: 'Darwinian Man, though well-behaved at best is only a monkey shaved.' Televisieproducer Jane Goodall, het hoofdpersonage in Animal Husbandry, is bezig met het maken van een serie over 'de laatste mannelijke man' en moet een bittere pil verwerken. De macho's blijken nog lang niet uitgeroeid; het wemelt overal van het type 'womanizer', 'philander', 'cad', 'Casanova', 'Don Juan' en 'Romeo' (Zigman r998: 189). Televisiemaakster Hudson, hoofdpersonage van The Last Manly Man, verzucht dat ze, ondanks haar teleurstellende ervaringen met het mannelijk geslacht, de zoektocht naar de ideale man nog niet heeft opgegeven en nog altijd droomt van een plaats waar dualismen niet bestaan en mannen zich minder narcistisch en macho opstellen.

In Liz Jensens romans Ark Baby is de nieuwe man wel opgestaan: de ideale man is, net als in De vrouw en de aap, een hybride, het product van vrouw en aap. De titel verwijst naar de ark van Noach (net als de naam van het schip waarmee Erasmus en Madelene vertrekken). De suggestie is dat als de mensheid met uitsterven wordt bedreigd, er een nieuwe soort komt; 'ark baby' is Tobias Phelps, een kruising tussen een vrouw en een aap. Een aantal speelse verwijzingen naar het GAP volgt: hebben wezens als Phelps mensenrechten? Of kunnen ze ten prooi vallen aan een slechterik die misschien wel een nieuw ras 'slaven' zou willen kweken? Violet, de vrouw van Phelps, is optimistisch over de toekomst van deze nieuwe soort: 'Dat continent is de toekomst. Die wacht op ons. Wij zijn schepselen van de toekomst. Een onbegrensde hoop vulde mijn hart.' (3r3) 
Dit slot suggereert dat we voor intersoortelijke seks niet bang hoeven zijn. De toekomst is er een van hybriden, maar dat was het verleden ook: wij zijn altijd hybriden geweest. Mocht de mens dreigen uit te sterven, dan kan een 'omgekeerde evolutie' in gang worden gezet. De mens mag afstammen van een aap, voor zijn toekomst is hij opnieuw van de aap afhankelijk.

In Will Selfs Great Apes, over een Londense kunstenaar die denkt dat hij een mens is, maar in feite een aap is, wordt het GAP dankbaar aangegrepen voor satirische slapstick. Met zijn motto's van Cicero en Kafka, die aan de roman voorafgaan, plaatst Self zich in de 'hoge' literatuur, maar algauw blijkt dat hij zichzelf niet al te serieus neemt. Hij voegt in de 'Author's Note' een aantal voetnoten toe, die zijn inleiding een wetenschappelijke pretentie geven, maar die zo ridicuul zijn dat de lezer erom moet lachen. ${ }^{42}$ Wetenschap wordt in de lachspiegel van de fictie gehouden. Self geeft aan dat hij er geenszins op uit is geweest om mensen te 'primatomorfiseren'. Hij geeft aan dat het niet zijn bedoeling is om 'apenrechten voor mensen' te verdedigen. Ook de kaft roept een grijns op: we zien een foto van een man die erg op een aap lijkt. Is het een portret van de hoofdpersoon van de roman? Of van de auteur? Anders dan De vrouw en de aap en Ark Baby blijkt de aap bij Self geen betere mens, en is het niet zozeer de mensaap die een mensenstatus moet krijgen, maar blijkt de mens een lage' aap, die een apenstatus verdient een een 'toontje lager op de evolutionaire ladder' zou moeten zingen. Met dergelijke omkeringen, ridiculiseert Great Apes het GAP enerzijds als de zoveelste idioterie van de mens. De mens blijft, hoe hij zich ook omringt met mobiele telefoons of andere moderne apparatuur, een gemaskeerde aap. De boodschap van Self is - en eigenlijk geldt dat ook voor de andere romans die hierboven aan de orde kwamen - hiermee echter nog niet eenduidig. Zoals een Britse criticus schrijft: 'Is the author's position encoded in the differences between human and chimp behaviour, or the similarities? Are we being invited to admire chimpanzee traits - including incest, bullying and shit-slinging - as evidence of an innate honesty, the direct viscerality humans beings lack? [...] Are human beings apes or aren't they? [...]' (The Times Literary Supplement, 1997) De lezer blijft achter met een open plek, een apenstaart in de vorm van een vraagteken.

Net als De vrouw en de aap, zijn Animal Husbandry, Ark Baby, Great Apes en The Last Manly Man cultuurkritische romans, die 
commentaar leveren op het fenomeen man of bepaalde maatschappelijke en wetenschappelijke ontwikkelingen, zoals het GAP. De ernst van de boodschap (bijvoorbeeld: 'mannen moeten veranderen', 'mannen zijn altijd al apen geweest' of 'het GAP is een overbodige beweging want we zijn altijd al hybriden geweest') wordt echter ook steeds op losse schroeven gezet doordat de verhalen bij vlagen zo absurd zijn. Ze parodiëren hoogstaande literatuur, spotten met ernstige literatuur en presenteren zich in hun toon en uiterlijk als 'funbooks'. De boeken gaan niet alleen over de vervaging tussen mensen en mensapen, maar zijn zelf ook ambigu in genre en toon, en verkennen naar hartelust de grenzen van de wetenschap en de serieuze literatuur. Niet alleen de ideale man is een aap geworden; ook de literatuur kijkt in de lachspiegel en ziet een aap teruggrijnzen.

\section{DE LITERATUUR VOORBIJ}

Het is bij geen van de hierboven besproken romans goed mogelijk te bepalen of ze nu 'pro-GAP' zijn of niet. Binaire categorieën worden omgekeerd en er wordt gebroken met de traditionele beeldvorming (de aap is beter dan de mens en de man, de vrouw kidnapt de aap). De omkeringen en inversies van diverse verbeeldingsconventies in de romans zijn grappig en bij vlagen hilarisch. Op andere momenten weten de romans echter te ontroeren (dit geldt niet voor de roman van Self, die blijft karikaturaal). Wanneer bijvoorbeeld de monsterlijke Tobias uit Ark Baby zijn vader opzoekt, die terecht is gekomen in een speciaal opvanghuis voor geestelijken die de publicatie van Darwins On the Origin of Species niet hebben kunnen verwerken, roept hij dramatisch: 'Ik ben Darwins paradox!' Darwin achtte het kruisen van soorten immers niet mogelijk. Zijn vader, de dominee, antwoordt hem met schorre stem: 'Of een grap van God.'

Behalve de grenzen tussen 'serieuze' literatuur en humoristische slapstick, worden ook de grenzen tussen cultuur en wetenschap moeilijker te trekken. Essentialistische verschillen tussen wetenschap en literatuur worden opgeheven: de wetenschap wordt zich sterk bewust van zijn geconstrueerde, retorische en verhalende karakter, terwijl de literatuur andere 'waarheden' voorlegt met luchti- 
ge zelfspot en zelfreflectie. Het GAP presenteert zich nadrukkelijk als een breed cultureel project dat zich baseert op wetenschappelijke feiten. Verhalende elementen worden gebruikt om het project retorisch kracht bij te zettten. Omgekeerd wordt het GAP gebruikt als uitgangspunt voor fictie. Maar literatuur is niet zonder meer een illustratie van wetenschap; literatuur geeft op eigenzinnige wijze mede vorm aan bepaalde debatten, zodat de grens tussen literatuur en wetenschap soms vervaagt. Zigman laat haar hoofdpersonage een 'wetenschappelijke paper' schrijven die ze opneemt in het boek en Jensen gaat met Darwin in discussie over kruising van de soorten door een personage op te voeren dat zichzelf 'Darwins paradox' noemt. Terwijl het GAP geen aandacht besteedt aan de morele consequenties van het uitgangspunt dat mensapen mensenrechten zouden moeten krijgen, gaan de romans ruimschoots in op gevolgen: als binair denken overboord wordt gegooid, dan wordt 'soortvermenging', seks met apen, een reële optie. In de romans wordt dit enerzijds als hilarisch voorgesteld, en dus niet als reëel; anderzijds is het revolutionair te noemen dat bestialiteit niet wordt voorgesteld als iets vies. Sterker nog, voor vrouwen die teleurgesteld zijn in het mannelijk deel van de bevolking is het zelfs een uitkomst. De toekomst is aan de ambigue mens oftewel de gekruiste mens (Ark Baby, De vrouw en de aap). Dit is een toekomst waarin we voorbij het denken in termen van essentialistische verschillen zijn; een meer holistische visie waarin mannelijkheid, vrouwelijkheid, dierlijkheid en goddelijkheid geïntegreerd zijn. Een wereld waarin we moraal, politiek, cultuur en wetenschap niet zien als verschillende zaken, maar als zaken die geïntegreerd bestudeerd dienen te worden. Wetenschap is moraal en politiek met andere middelen, maar cultuur is ook waarheidsvormend en wetenschap met andere middelen.

Is alles dan opgelost? Is continuïteitsdenken het antwoord op ongelijkheid? Kondigt het opheffen van het soortverschil en het opheffen van het verschil tussen cultuur en wetenschap het einde aan van het binaire denken? Maar wat gebeurt er als álle grenzen ter discussie worden gesteld? Wat houden we over wanneer wetenschap in de lachspiegel van de fictie op de hak wordt genomen en de literatuur zichzelf ook een lachspiegel voorhoudt? Rest ons een bespotting ('veraping') van de wetenschap en van de literatuur? Hoe kunnen we de 'ambigue' teksten, die de grenzen tussen literatuur en wetenschap ter discussie stellen, lezen? Betekent de term 'cultuur' nog 
iets? En betekent het opheffen van het verschil dat er een einde komt aan de 'eeuwige' worsteling van de mens met zijn identiteit? Als je je identiteit niet op essenties kunt funderen, op je man-zijn of vrouw-zijn en zelfs niet langer aan je menszijn ten opzichte van dieren, als identiteit kortom niet langer aan verschil wordt ontleend, waaraan dan wel? In het afsluitende hoofdstuk maak ik de balans op. Een aap en een wetenschapper geven daarin hun visie op de toestand van de cultuur, en de rol van de vrouw en de aap daarin. 


\section{Waarom vrouwen van apen houden}

\section{Slotbeschouwing}

It's part of our condition to long for hard and for clear lines.

Mary Douglas, Purity and Danger (1966)

Wij westerlingen hebben een onbedwingbare neiging de wereld in tweeën te delen: goed tegenover kwaad, wij tegenover zij, vrouwelijk tegenover mannelijk, aangeleerd tegenover aangeboren, enzovoort. Dichotomieën helpen ons ons denken te structureren, maar dan wel door ingewikkeldheden en betekenisnuances te negeren. Het lukt maar weinigen twee tegengestelde ideeën tegelijkertijd in gedachten te houden, en toch is dat maar al te vaak precies wat we moeten kunnen om de waarheid boven tafel te krijgen.

Frans de Waal, De aap en de sushimeester (200r)

\section{WEG MET HET DUALISME!}

In de westerse cultuur wemelt het van de erotische voorstellingen van mannetjesapen en vrouwen. Deze opmerkelijke band tussen de vrouw en de aap vormde de aanleiding voor dit boek, waarin ik de representatie van deze liefdesgeschiedenis tussen de vrouw en de aap bestudeerd heb in een selectie van korte verhalen, romans, films, populaire wetenschap en wetenschappelijke teksten van de twintigste eeuw. De centrale vraag van deze studie luidde: hoe kunnen we die verbintenis interpreteren?

Om die vraag te onderzoeken selecteerde ik een aantal verhalen 
en beelden, die ik analyseerde en interpreteerde, en waarvan ik onderzocht welke betekenis anderen eraan toe hebben gekend. Hoewel het momentopnamen betrof uit verschillende perioden van de twintigste eeuw en ik de teksten steeds in een andere context heb besproken, en in die zin niet een algemene verbeeldingsgeschiedenis heb geschreven, is toch iets zichtbaar geworden van een ontwikkeling en betekenisverandering. Romanciers en wetenschappers geven in verschillende perioden nieuwe wendingen aan het thema, en dat geldt ook voor degenen die betekenis aan de verhalen en beelden geven, zoals we die terugzien in de receptiegeschiedenis van een werk.

Heel in het algemeen werd in het thema van de vrouw en de aap een ontwikkeling zichtbaar van het discontinuiteitsdenken (waarbij het verschil tussen mensen en apen wordt benadrukt) naar een steeds verdere toename van het continuiteitsdenken (overeenkomstigheid, gelijkheid en verwantschap). Dankzij de chronologische opzet van dit boek werd ook zichtbaar hoe het denken over soort, sekse, kleur, seksualiteit, natuur en de relatie tussen cultuur en wetenschap in de loop van de twintigste eeuw verandert, althans in de onderzochte teksten. Aarzelt de verteller uit Mijn aap schreit nog over de positie van de aap ten opzichte van de mens, en overpeinst hij de pro's en contra's van het darwinistische continuiteitsdenken, in De vrouw en de aap bereikt het continuiteitsdenken zijn hoogtepunt als de aap tot de gelijke van de mens en zelfs tot de 'nieuwe' mens wordt verheven. De waardering voor ambiguïteit veranderde daarmee ook. De aap wordt niet langer als vijandige ander van de mens beschouwd, die we zo ver mogelijk op een afstand dienen te houden, maar als gewaardeerd familielid die op ons lijkt, en van wiens 'anderszijn' we zelfs zouden kunnen leren; we worden dus aangespoord meer 'aap' te worden. In Mijn aap schreit interpreteerde ik bijvoorbeeld de moord van de verteller als een poging om de ambiguïteit van de aap, hemzelf en zijn wereldbeeld te reduceren; in De vrouw en de aap worden personages, bijvoorbeeld Adam, aangespoord meer 'ambigu' te worden teneinde een 'beter' mens te worden.

Het vrouwelijke personage speelt een sleutelrol in deze omslag. In Mijn aap schreit verwart de goede band tussen de vrouw en de aap de mannelijke hoofdfiguur en wordt de aap op een afstand gezet door hem te vermoorden. In King Kong wordt de erotische fan- 
tasie, die zich in Mijn aap schreit afspeelt in een droom, visueel uitgewerkt op het witte doek en komt de aap naar voren als een potentiële vrouwenverkrachter of als minnaar van de vrouw. De blanke mannen vermoorden de aap en 'redden' het meisje uit zijn 'gevaarlijke' handen. De vrouwelijke primatologen speelden vervolgens een belangrijke rol in de imagoverandering van de mensaap, doordat zij toenadering zochten tot apen in het wild: de mensaap wordt tot een zachtaardig familielid. Vervolgens ontpopt de aap zich tot superman in De vrouw en de aap (I996), waarin hij wordt voorgesteld als de ideale man voor een vrouw.

Het vrouwelijke personage ontwikkelt zich in de loop van de verbeeldingsgeschiedenis van een dom blondje tot een vrijgevochten vrouw, terwijl de man van zijn heldhaftige voetstuk valt en onzeker wordt over zijn positie. Oude en vertrouwde hiërarchieën gaan op de helling: naast ideeën over soort, sekse, kleur en seksualiteit, komt ook de relatie tussen cultuur en wetenschap onder vuur te liggen. Werden de grenzen tussen cultuur en wetenschap eerder streng afgebakend, bijvoorbeeld door wetenschappers als Dian Fossey, die de film King Kong als fictieve flauwekul beschouwt, in de jaren negentig zoeken wetenschappers toenadering tot kunstenaars en prijzen zij romans als De vrouw en de aap aan, om vervolgens zelf ook gebruik te maken van literaire en retorische middelen. Wat dit boek betreft, lijkt hoofdstuk zes een historisch hoogtepunt te markeren van het continuïteitsdenken. Mensapen zijn de gelijken van mensen geworden; volgens sommigen verdienen ze zelfs mensenrechten.

In deze slotbeschouwing breng ik de lijnen en belangrijkste bevindingen van deze studie bij elkaar aan de hand van twee teksten waarin gereflecteerd wordt over dezelfde kwesties als waarover ik in deze studie heb nagedacht. In de eerste tekst reflecteert een aap op de literatuur en de tweede bevat de reflecties van een apenonderzoeker op de wetenschap. Beide teksten zijn gekozen omdat ze een nieuw en relevant perspectief bieden op het denken in dualismen en omdat ze volgens mij gelezen kunnen worden als metateksten die gaan over het lezen van teksten.

In het korte verhaal 'Reflections of a Kept Ape' (1978) van de Britse schrijver Ian McEwan krijgt een aap het woord. Niet langer werpt de man zijn licht op de positie van de vrouw en de aap (Mijn aap schreit), of denkt de vrouw na over de aap en de man (De 
vrouw en de aap), maar beschouwt een mannetjesaap de positie, aard en status van de mens (M/v). Hij vertelt hoe hij denkt over de vrouw. Houden apen ook van vrouwen? Ook reflecteert hij over de literatuur. Vanuit het perspectief van McEwans aap bezien we de schrijver als een 'aap', die niets anders kan dan zijn voorgangers naapen. Wij mensen zijn als apen, ook in de culturele bezigheid waarmee wij ons zo uniek achten: de literatuur.

In het populair-wetenschappelijke werk The Ape and the Sushi Master. Cultural Reflections of a Primatologist, in het Nederlands vertaald als De aap en de sushimeester. Over cultuur bij dieren (20oI) voert Frans de Waal ook het perspectief van de aap op en roept hij mensen op zich in apen te verplaatsen. Hij wil een laatste achterhaalde westerse tweedeling ten grave dragen: de dichotomie tussen natuur en cultuur. Cultuur is volgens hem niet uniek menselijk; we treffen cultuur ook in de natuur aan, bijvoorbeeld bij apen. ${ }^{1}$ 'Weg met het dualisme!' concludeert De Waal in zijn kritiek op wat hij het 'laatste bolwerk' noemt. ${ }^{2}$

\title{
EEN SPIEGELPALEIS VAN APEN IN IAN MCEWANS 'REFLECTIONS OF A KEPT APE'
}

\begin{abstract}
N'attendez rien de bon du Peuple imitateur
Qu'il soit Singe ou qu'il fasse un Livre

La pire espèce, c'est L'Auteur.
\end{abstract}

Jean de la Fontaine, Fables (1668)

'Reflections of a Kept Ape' is een kort verhaal van de Britse schrijver Ian McEwan (1948), dat is opgenomen in zijn tweede verhalenbundel In Between the Sheets (1997). ${ }^{4}$ Een aap vertelt daarin over zijn relatie met de schrijfster Sally. ${ }^{5}$ Ooit was deze aap haar gelukkige minnaar, maar na een affaire van acht dagen - voor hem 'de acht gelukkigste dagen van zijn leven' - heeft zij de aap aan de kant gezet. Nu is hij alleen nog nuttig als hulp in de huishouding. De aap denkt weemoedig terug aan de affaire, maar moet met lede ogen toezien hoe zij hem negeert. Sally worstelt met haar writer's block, en vervalt in autoplagiaat als oplossing: ze schrijft haar eerste ro- 
man letterlijk over. Voor de aap is dat een aanleiding om na te denken over de creativiteit van de mens, van Sally in het bijzonder. De vraag die door dit verhaal wordt opgeworpen, luidt niet: is de mensaap een mens (hoofdstuk zes), maar: bestaat de tragiek van de mens eruit dat deze in wezen een aap is, dat wil zeggen: gedoemd tot het na-apen van anderen en het herhalen van zichzelf? En wat voor de mens geldt, is ook van toepassing op de schrijver. Is de hedendaagse 'postmoderne' schrijver gedoemd tot apengedrag: parodiëren, na-apen en recyclen?

Sally publiceerde tweeënhalf jaar geleden een roman over de vergeefse pogingen van Moira Sillito om een kind te krijgen. Op de kaft was een naakte vrouw te zien, die geknield zat in een kale woestijn met haar handen voor het gezicht. Dit pathetische omslag, het clichématige beeld van onvruchtbaarheid, wekt de indruk dat het een triviaal boek betreft. De aap vertelt bovendien dat de pers negatief over deze roman oordeelde. The Times Literary Supplement meende, dat het boek met 'matte weloverwogenheid' was geschreven, en ook de recensies in andere serieuze bladen waren negatief. Een feministisch tijdschrift, Refractory Girl, veroordeelde het boek op grond van 'banaal seksisme'. Ondanks de kritieken was het boek een groot kassucces; de aap deelt ons mede dat er van de paperbackeditie maar liefst een kwart miljoen werden verkocht. Hij vermoedt dat het boek autobiografisch is en dat Sally net als Moira een kind wil. Bij de lezer ontstaat het vermoeden dat ze, omdat ze die niet kan krijgen, schrijft over een vrouw die geen kinderen kan krijgen en de jonge aap (hij is tweeënhalf jaar oud, vertelt hij keer op keer) als surrogaatkind in huis heeft genomen.

Sally onderneemt van alles om haar writer's block op te heffen, bijvoorbeeld het drinken van koffie getrokken van exact dezelfde mix van koffiebonen (vier verschillende soorten) als de productieve Franse schrijver Balzac, of het gebruiken van hetzelfde papier als waarop ze haar vorige boek schreef. Wanneer alle rituele handelingen op niets uitlopen, onderneemt Sally letterlijke pogingen om 'zwanger' te raken van een nieuw idee voor een boek. ${ }^{6} \mathrm{Ze}$ begint immers een affaire met de aap, in de hoop dat de seksuele interactie haar zal bezwangeren met een nieuw idee. Omdat het opgelegde herhalingsgedrag geen vruchten afwerpt, hoopt ze dat het exotische uitstapje met 'de ander' haar wellicht van de kunstmatigheid zal verlossen en haar tot schrijven zal brengen. Wanneer ze 
met de aap vrijt, is ze dan ook met name geïnteresseerd in zijn 'anders-zijn', zoals blijkt uit de beschrijvingen die de aap geeft van hun vrijerijen:

She was delighted more in my unfamiliarity ('funny little black leathery penis' and 'your saliva tastes like weak tea') then in my essential self [...] The long prelude of mutual exploration, she counting my teeth with her ballpoint pen, I searching in vain for nits in her copious hair. Her playful observations on the length, colour, texture of my member, my fascination with her endearingly useless toes and coyly concealed anus. (26)

Terwijl de aap Sally vergelijkt met een apin, maar concludeert dat ze anders is, telt Sally de tanden van haar aap met een pen. Dat kan erop wijzen dat ze hoopt dat het 'anders-zijn' van de aap (die echter evenveel tanden heeft als de mens), direct haar schrijfinstrument zal bevruchten met ideeën. De eerste vrijpartij tussen de vrouw en de aap is niet onmiddellijk een succes:

Our first 'time' (Moira Sillito's word) was a little dogged by misunderstanding largely due to my assumption that we were to proceed $a$ posteriori. That matter was soon resolved and we adopted Sally Klee's unique 'face to face', an arrangement I found at first, as I tried to convey to my lover, too fraught with communication, a little too 'intellectual'. However, I rapidly made myself comfortable, and not two afternoons later was bringing to mind: And pictures in our eyes to get / Was all our propagation. (26)

Terwijl de aap ervan uitgaat dat hij Sally 'van achteren' zal nemen, wil Sally met hem de liefde bedrijven terwijl ze hem aankijkt. ${ }^{7}$ Twee dagen na de 'face to face' vrijpartij, schieten de aap de geciteerde versregels binnen van John Donne (1572-163I). De regels komen uit het gedicht, 'The Ecstasy'. De regels zijn als volgt te interpreteren. Wanneer geliefden elkaar aankijken, zien ze zichzelf weerspiegeld in elkaars ogen. De enige vorm van nageslacht die Sally en de aap samen kunnen krijgen, zo is de suggestie, zijn de weerspiegelingen in elkaars ogen. Hier wordt dus gesuggereerd dat de vrijpartij tussen de aap en Sally geen nageslacht oplevert.

Waarom neemt Sally nu juist een aap als minnaar? Sally's aap ont- 
leent vooral betekenis aan de iconografische traditie waarin de aap bekendstaat als inspirator en muze van de kunsten. ${ }^{8}$ De Romeinen waren al bekend met de aap, die in hun ogen uitblonk in het nadoen van mensen; simia (aap) was synoniem met 'imitator'. De uitdrukking ars simia naturae is in diverse historische periodes het devies voor kunstenaars geweest. De goddelijke schepping kwam tot uitdrukking in de schoonheid van de natuur, en de taak van de kunstenaar was het zo precies mogelijk nabootsen van die schepping.

Apen werden lange tijd echter ook geassocieerd met bedrog en lelijkheid en gezien als vijand van het christendom. Pogingen van de ijdele mens om het goddelijke te evenaren werden dan ook als 'aapachtig' afgekeurd. Wanneer men in de Middeleeuwen een kunstwerk slecht vond, wanneer het produkt niet 'echt' genoeg leek, en zelfs een aap 'nep' van 'echt' zou kunnen onderscheiden, dan was aap ook een scheldwoord voor een lelijk kunstwerk.

In de Renaissance raakte ook de kunstenaar zelf steeds meer geassocieerd met apen: de kunstenaar imiteerde in feite het gedrag van apen door zelf na-aapgedrag te vertonen in zijn poging de wereld te kopiëren. Soms werd de (portret)kunstenaar zelf op een schilderij afgebeeld als aap, vaak in spottende zin om de ijdelheid van de kunstenaar te bekritiseren. In Frankrijk ontstond in de achttiende eeuw een genre, singeries, satirisch bedoeld, waarin het portretschilderen belachelijk werd gemaakt. Ook de schrijver is met een aap vergeleken. Boccaccio had in de veertiende eeuw in zijn Genealogia al aandacht besteed aan de verdediging van de poëzie en zich geweerd tegen de idee dat de dichter 'de aap' van de filosoof zou zijn. De gedachte dat de romancier 'de aap van God' was, vond pas in de twintigste eeuw weer volop bijval, toen François Mauriac (1885-1970) in Le Roman (r928) schreef dat de schrijver van alle mensen het dichtst bij God stond. ${ }^{9}$ God heeft de wereld geschapen, en de kunstenaar 'herschept' die wereld als een kleine god. Zo doet hij een gooi naar de onsterfelijkheid. Daarom is de schrijver de aap van God.

Schrijvers die schrijven over schrijvers die niet kunnen schrijven zijn in de westerse cultuur volop aanwezig; meestal betreft het mannelijke auteurs. ${ }^{10}$ Niet alleen de schepper van kunst, maar ook het scheppingsproces is in de westerse cultuur vaak voorgesteld als een mannelijke aangelegenheid. Mannen, die geen kinderen kunnen baren, kunnen wel, met de pen, een fallussymbool, een 'geesteskind' scheppen. Kunst is een mannelijk surrogaat voor het moe- 
derschap. ${ }^{11}$ Voor vrouwen is de geschiedenis anders getekend. Juist omdat zij in principe wel kinderen kunnen baren, werd hun het 'baren' van boeken in culturele en maatschappelijke zin bemoeilijkt. ${ }^{12}$

Sally's rol als worstelende schrijver betekent een omkering van het klassieke patroon dat de kunstenaarroman kenmerkt, waarin vrouwelijke personages slechts fungeren als muze of als te overwinnen verleiding die de kunstenaar, een mannelijk personage, afhoudt van het geestelijke leven. Terwijl de aap verliefd wegdroomt, is Sally degene die geestelijke arbeid verricht door zich op haar kunstenaarschap te storten; symbolisch gezien neemt ze daarmee de 'mannelijke' positie van het genie in. Een apin van God!

De aap typeert zichzelf als een soort onderhouden vrouw (het woord 'kept' in de titel wordt vaker gebruikt voor een vrouw) die het huishouden doet. Hij 'nipt' aan zijn thee en zijn weinige kostbare bezittingen bestaan uit een roestvrije stalen spiegel, een nagelvijltje, een tandenstoker en een haarborstel, de min of meer klassieke inhoud van een damestasje. Een aap met een spiegel duidt in de iconografische traditie bovendien op dwaze verliefdheid (Janson 1952). De spulletjes wijzen erop dat de aap ijdel is en veel aandacht voor zijn lichaam heeft. Dat contrasteert met Sally, die zo opgeslokt wordt door haar geestelijke bezigheden, dat ze nauwelijks aandacht heeft voor lichamelijke verzorging, wat bijvoorbeeld ook blijkt uit het 'doodse' voedsel uit blik dat ze consumeert en haar weerstand om zich in levendige rode kleuren te kleden. Ook het personage Moira, die volgens de aap voor Sally zelf staat, leeft meer volgens haar ratio dan haar gevoel. De aap beschrijft een passage waarin zij een woordenboek pakt, om daarin een definitie van 'verliefd' op te zoeken: 'Falling in love is like floating on clouds' (27). Moira is zeer in haar nopjes met deze 'prachtige' definitie.

De aap, die naamloos blijft (waarmee net als in Mijn aap schreit zijn status als 'ander' wordt benadrukt) ${ }^{13}$ wil echter niet de 'ander' voor Sally blijven, maar promoveren tot haar gelijkwaardige partner, haar liefhebbende echtgenoot. Hij droomt van een traditionele klassieke man-vrouw-relatie, waarin hij de financiële zaken regelt en zij een mooie vrouw is:

I congratulated myself hourly on, my recent elevation from pet to lover and, stretched out on my back arms folded behind my head, 
legs crossed, I speculated upon further promotion, from lover to husband. Yes, I saw myself, expensive fountain pen in hand, signing hire purchase agreements for my pretty wife. I would teach myself to hold a pen. I would be man-about-the-house, scaling drainpipes with uxorious ease to investigate the roof gutters, suspending myself from light fittings to redecorate the ceiling. Down to the pub in the evening with my husband credentials to make new friends, invent a name for myself in order to bestow it on my wife, take up wearing slippers about the house, and perhaps even socks and shoes outside. (25)

De aap wil 'de man' in huis zijn. Vanwege zijn handige lichaamsbouw stelt hij zich voor hoe hij technische klusjes, zoals het indraaien van lampen, kan opknappen. Hij verlangt naar menswording, naar gelijkwaardigheid, en geeft aan dat hij zelfs sokken en schoenen zal dragen. Sally is degene die de geestelijke activiteit of de schijn daarvan verricht door zich op haar kunstenaarschap te storten; symbolisch gezien neemt ze daarmee de 'mannelijke' positie van het genie in. De nadruk op haar geestelijkheid (het steunen van haar kin op haar handen, spelen met ballpoints, zittend achter haar schrijfbureau) en de recensie die haar werk als mat en weloverwogen kwalificeert, doordacht in plaats van doorvoeld, zijn voorbeelden die blijk geven van haar 'mannelijke' eigenschappen. Ze gaat niet gevoelsmatig te werk, maar met haar ratio. Ondanks haar pogingen tot 'mannelijk' gedrag, mislukt Sally als schrijfster. Haar eerste roman wordt immers lauwtjes door de pers ontvangen en haar tweede roman is niet meer dan autoplagiaat in de meest mechanische zin.

Elk personage worstelt op zijn of haar manier met het verlangen naar het 'echte', of het er nu om gaat om een echte man te zijn en een volwaardige partner (de aap), een goed boek te schrijven (Sally) of een eigen kind te krijgen (Moira), maar ziet zich in plaats daarvan geconfronteerd met een 'aap', een surrogaat, iets dat erop lijkt maar het niet is, een afgeleide. Zo heeft de aap geen echte moeder omdat die in de dierentuin zit, maar een surrogaatmoeder, Sally. Op haar beurt koestert Sally (volgens de aap althans) een kinderwens en heeft ze een surrogaat, de aap, in huis gehaald. Haar personage Moira wil ook een kind, maar heeft geen man en moet, zo blijkt uit de stukjes die de aap uit Sally's roman citeert, zich wen- 
den tot een soort kloon, een 'aap', de broer van de man. De aap verlangt intussen naar menswording en wil een volwaardige 'man' zijn, maar is vrouwelijk in zijn gedragingen. Sally schrijft geen goed boek, maar baart een 'aap', een on-boek, namelijk een kopie van haar vorige boek. De aap is de verteller van 'Reflections of a Kept Ape' en is op zijn beurt de aap van Ian McEwan zelf, de echte schrijver en de aap van God, terwijl Sally de aap van 'de aap van God' is, iemand die probeert een echte schrijver te zijn, maar het niet is en apengedrag vertoont door zichzelf te herhalen. Waar de personages ook kijken: overal zien ze zich geconfronteerd met een aap. Met het verlangen naar echtheid geven zij hun tragiek prijs: ieder personage moet onder ogen zien dat hij in feite een aap is, gevangen in een web van 'apengedrag' en 'apentaal'.

Noch Sally of de aap slagen erin om uit hun 'herhalingsgedrag' te treden. Zij zitten, om met Maaike Meijer te spreken, gevangen in hun 'cultuurtekst' en zijn 'in tekst gevat'. Sally kan geen nieuw verhaal schrijven, en de aap leest steeds dezelfde tekst, namelijk het autoplagiaat van Sally. De aap fungeert, net als de aap in Mijn aap schreit, als mogelijk afzetpunt voor Sally om over zichzelf na te denken en over literatuur te reflecteren. De aap bezit immers een vorm van gevoeligheid en lichamelijkheid, terwijl zij te veel last heeft van kunstmatigheid, berekendheid en reflectie. De aap legt de tragiek van Sally bloot en haar tekortkoming: de mens die alleen nog maar in de herhaling kan vervallen. Terwijl de jongeman in Mijn aap schreit zijn worsteling probeert op te heffen door de aap om het leven te brengen, negeert Sally de aap. Sally ziet de betekenis van de aap niet onder ogen, maar doet alsof hij niet bestaat, en kan derhalve haar probleem niet oplossen. Anders dan in Mijn aap schreit krijgen we in 'Reflections of a Kept Ape' ook iets mee van de worsteling van de aap, omdat het verhaal vanuit zijn perspectief wordt verteld. De relatie tussen de vrouw en de aap loopt uit op een mislukking. Het is de soortdrempel die maakt dat er geen bevredigende relatie tot stand kan komen: immers, nageslacht tussen twee verschillende soorten is niet mogelijk, en het 'vreemde' zaad van de aap wordt afgestoten. Omdat Sally hem negeert, raakt de aap, net als zij, in een identiteitscrisis.

In 'Reflections of a Kept Ape' observeert de aap Sally's mislukte pogingen om echte literatuur te schrijven, en wordt haar tragische onvermogen om los te breken uit oude verhalen, haar zelfherhaling, 
ontmaskerd. Zij aapt uiteindelijk zichzelf na, en produceert zo 'apenliteratuur'. Terwijl zij er niet in slaagt 'echte' mooie taal op te schrijven en haar personages zelfs woordenboekdefinities van 'verliefd' laat opzeggen, citeert de aap er daarentegen lustig op los uit de wereldliteratuur, bijvoorbeeld John Donne. De aap vertelt een mooi verhaal: het verhaal dat wij als lezer voor ons hebben liggen. De aap is een schrijver, terwijl Sally gevangen zit in haar 'apengedrag'. Vrouwelijk schrijverschap is in die zin 'de aap' van mannelijk schrijverschap, een mislukte poging om iets na te doen. Immers, terwijl Sally faalt, slaagt de aap er toch in een verhaal te vertellen, namelijk 'Reflections of a Kept Ape'. Het is een wat droevige conclusie: de pogingen van de vrouw om mannelijkheid te integreren, komt naar voren als een idioterie en de aap kan niet promoveren tot een echte mens. Ambiguiteit, kortom, blijkt een niet te verwezenlijken ideaal. Vrouwen moeten vrouwen blijven, en apen apen.

\section{DE LEZER ALS AAP}

Enerzijds bevestigt 'Reflections of a Kept Ape' stereotypen. De lezer moet concluderen dat de menselijke cultuur in een crisis verkeert doordat vrouwen zonodig moesten emanciperen en 'mannelijk' doen. Hoe moeilijk ambiguïteit verdraagbaar is, bleek meerdere malen uit dit boek. In Mijn aap schreit slaagde de verteller er niet in 'het andere' in zijn persoonlijkheid toe te laten. Hij vermoordde zijn aap, die er in zijn ogen wel in slaagde tegenstrijdigheden te integreren, die zowel mannelijk als vrouwelijk, menselijk, dierlijk en goddelijk, een denkhoofd en een eethoofd was. In de receptie, de betekenisgeving, werd deze moord herhaald, doordat de interpreten de aap reduceerden tot het driftleven van de verteller. Ook in King Kong werd ambiguiteit, vertegenwoordigd en belichaamd door de aap, 'vermoord'. De aap, die zowel dierlijk, menselijk en goddelijk, mannelijk als vrouwelijk is, en tedere en agressieve eigenschappen krijgt toegedicht, sterft in de laatste scène. Net als bij Mijn aap schreit, wordt in de receptiegeschiedenis van King Kong de moord herhaald, door de aap te reduceren tot eenduidigheid. En als niet de aap sterft, dan wel het meisje, zoals in Gorillas in the Mist, waarin Dian Fossey wordt geportretteerd als iemand die de grenzen tussen mens en dier, 
westers en Afrikaans, mannelijk en vrouwelijk, overschreed. Het lijkt een nogal sombere constatering die als een rode draad door dit boek loopt: ambiguïteit is slecht te verdragen en wordt keer op keer 'vermoord'.

Anderzijds heb ik in hoofdstuk twee laten zien dat de lezer een 'tegen-interpretatie' kan geven. De lezer kan ervoor kiezen teksten te lezen als bevestiging van een bepaalde ideologie (zoals hierboven, en zoals in de leeswijze van Haraway en Meijers In tekst gevat besproken in hoofdstuk twee van dit boek), met het gevaar ze daartoe te reduceren. Maar de lezer kan ook op zoek gaan naar elementen die niet in een symbolische tekstinterpetatie passen door de nadruk te leggen op de vraagtekens die door tekst worden opgeroepen, het 'vreemde' of het 'andere' (zie bijvoorbeeld Meijers De lust tot lezen, zoals besproken in hoofdstuk twee van dit boek). Een mooi voorbeeld daarvan kwam naar voren in hoofdstuk vier, waar we zagen hoe King Kong geïnterpreteerd werd zowel als bevestiging van de norm (als 'killer king' en mannelijke macho) én als 'ander': als 'zachtaardige man', homo. En in hoofdstuk zes las ik de komische scenario's van vrouwen die er met een aap vandoor gaan als een kritiek op mannelijkheid.

Waarom nu, past McEwans 'Reflections of a Kept Ape' niet in de ideologiekritische lezing zoals ik die hierboven schetste? Waar zit interpretatieruimte? Wat zijn de elementen waarop ideologiekritiek geen vat heeft? Dat is de aap! De aap is niet alleen de muze van Sally, die probeert de creativiteit van de schrijfster aan te wakkeren; hij is ook de trouwste lezer van haar werk, die worstelt met de interpretaties die hij eraan moet geven. Op een zeker moment stuit de aap op enkele regels van Sally: 'in which case the whole thing could be considered from'. Het is de grootste open plek van het verhaal, regels die een zekere kern lijken te bevatten: als we dat nou eens zouden weten, datgene van waaruit de hele zaak beschouwd kon worden! En wellicht is dat, als er al een centrum van betekenis is, de kern van het verhaal: 'considered from'. Dat het hele verhaal beschouwd moet worden vanuit het perspectief van de aap. De lezer, die zich met de aap identificeert, piekert met hem mee over Sally's schrijfprobleem en haar beroerde eerste roman. De lezer worstelt samen met de aap met de open plek in het verhaal. De lezer is dus eigenlijk op zijn of haar beurt de aap van de aap van God, dat wil zeggen, van de schrijver. Albert Helman heeft de lezer 'een 


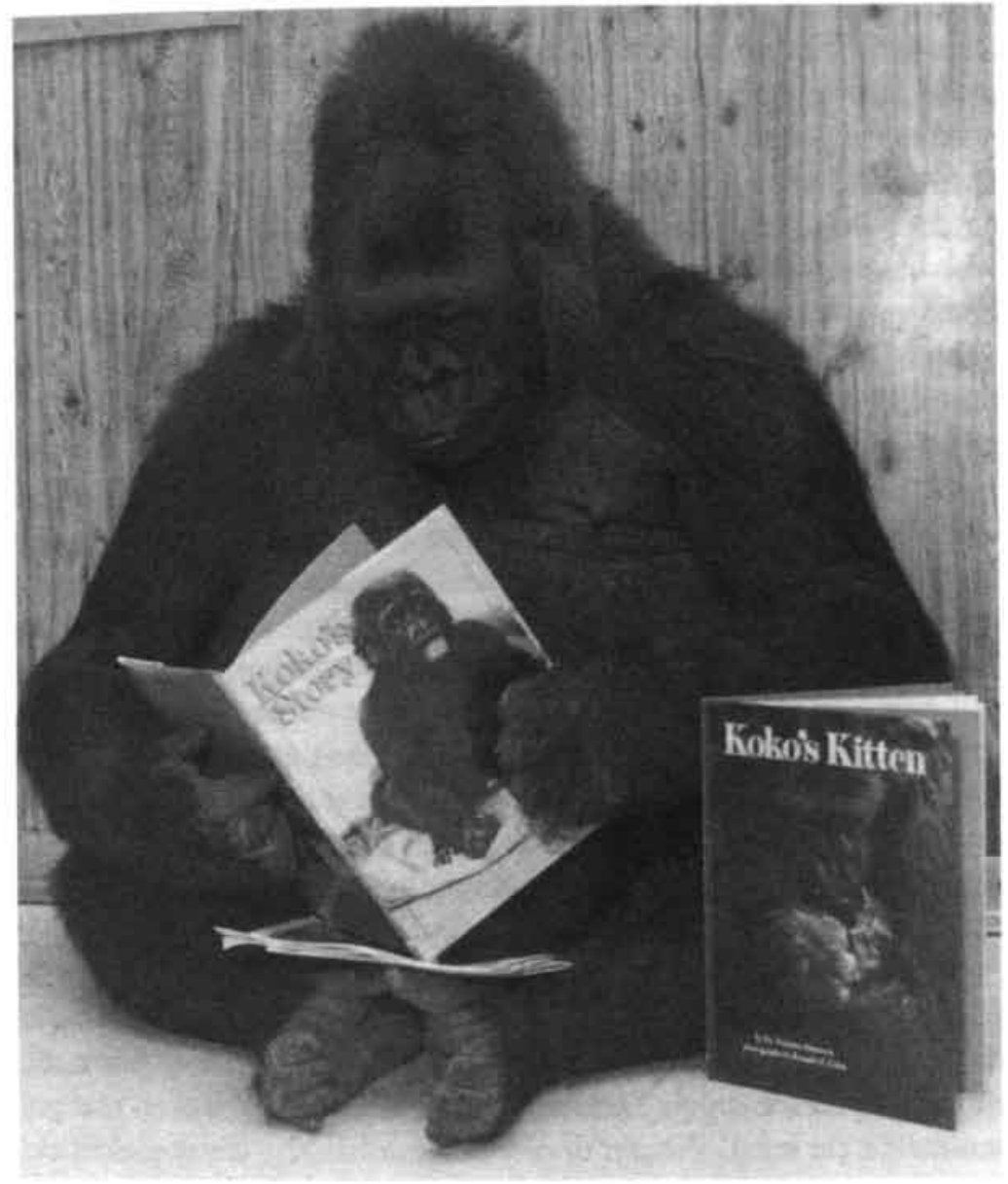

23 Koko de gorilla leest zijn eigen levensverhaal.

aap' genoemd: hij wijst erop dat de lezer op zijn beurt weer in dialoog treedt met de schrijver en al interpreterende voor de derde keer betekenis schept. (Van Verre 1980: 30). Anders dan Mauriac, stelt Helman dat de kunstenaar niet zozeer de schepping na-aapt, maar zijn eigen interpretatie aan de schepping geeft en derhalve iets nieuws creëert. In 'Reflections of a Kept Ape' lukt het de aap als lezer echter niet om Sally's probleem te begrijpen. In die zin faalt hij als lezer, als interpretator van open plekken. Niet alleen de 
schrijver, maar ook de lezer is een aap die probeert los te breken uit conventies, maar steeds dezelfde tekst leest en zich in het slechtste geval niet weet te bevrijden uit de 'cultuurtekst'. ${ }^{4}$

Met Sally's aap is nog iets vreemds aan de hand. De aap is pas tweeënhalf jaar oud, de leeftijd van een jong kind, en dat is precies de duur dat Sally worstelt met haar blokkade. De duur en leeftijd van haar kinderwens, writer's block, surrogaatkind en mislukte boek vallen samen. Een merkwaardige conclusie dringt zich op: Sally heeft geen kind gebaard, maar is moeder van een 'aap', een mislukt kunstwerk, een writer's block! De aap is het probleem, het writer's block zelf, én de oplossing voor dat writer's block: een tegenstrijdigheid, iets dat niet tegelijkertijd geldig kan zijn. De aap is niet alleen een open plek die ingevuld kan worden met betekenis, die uitbreidbaar is, maar ook een plek van tegenstrijdigheid: de aap is probleem en oplossing tegelijkertijd, hij is writer's block én muze. De aap is een tekst die nog geschreven moet worden, maar die zichzelf niet kan schrijven. De tekst implodeert en de lezer raakt verstrikt in metavragen over wat een tekst is, wat een aap, en hoe die samenvallen. 'Reflections of a Kept Ape' gaat in die zin over lezen en betekenisgeving. Sally zit gevangen in cultuurtekst en negeert de aap. Kijken naar de aap zou een bevrijding betekenen, want deze is fundamenteel onbepaald en kan nog worden ingevuld.

In 'Reflections of a Kept Ape' blijkt het onmogelijk de aap 'vast te pinnen' en een eenduidige betekenis aan de aap te geven. De aap is de tekst die nog geschreven moet worden, en de aap is de lezer die de tekst moet scheppen. Daarom laat dit verhaal zich wel en niet gemakkelijk (in tekst) vangen door een feministische ideologiekritiek. Het verhaal heeft namelijk ook op meesterlijke wijze zijn eigen ironie ingebouwd in het vertelperspectief. De vraag wordt immers opgeworpen, hoe slim en betrouwbaar de verliefde en dwaze aap als verteller is. Of Sally werkelijk worstelt met een kinderwens weten we immers niet zeker; dat kan ook ingegeven zijn door projectie van de verdrukte verlangens van de aap op Sally. Niet zij, maar hij wil kinderen! De aap kan alleen maar na-apen: hij aapt de echte schrijver na, een mens, een man.

De conclusie dat ambiguiteit steeds 'vermoord' wordt door de blanke mannelijke personages die hiërarchie in stand willen houden (Mijn aap schreit en King Kong), is maar de ene helft van een mogelijke interpretatie, namelijk de ideologiekritische. Wie de verhalen 
precies leest, ontdekt dat de aap in bijna elk verhaal als ambigu naar voren komt, en dat zijn soort (menselijk, dierlijk of goddelijk) en zijn aard (mannelijk of vrouwelijk, lief of slecht) steeds bediscussieerd en betwijfeld wordt. In Mijn aap schreit was de aap in de ogen van verteller menselijk, dierlijk en goddelijk. De aap had vrouwelijke (hij wordt 'verwijfd' genoemd) en mannelijke eigenschappen (als minnaar van Martha), maar was ook kinderlijk (hij werd vergeleken met een kind dat speelt). De naamloze aap is, in de ogen van de verteller, een 'vraagteken', een open plek die nog niet is opgevuld, maar waarbij de verschillende tradities (het christendom, theorieën van Darwin en Freud) wel mogelijke invullingen hebben gegeven aan de aap. De verteller worstelt met die 'symbolische' betekenisstolling in de traditie versus zijn reële aap, wanneer hij zijn aap met de vrouw ziet. Maar niet alleen de aap, ook de mannelijke en vrouwelijke personages komen als ambigu naar voren. Te denken valt aan Martha uit Mijn aap schreit, Ann uit King Kong (slachtoffer of femme fatale), Jack (macho of homo), de vrouwelijke primatologen, of Erasmus. De veelzijdige receptie, bijvoorbeeld van de film King Kong of van de vrouwelijke wetenschappers, laat ook zien dat er interpretatieruimte is, en hoe deze, onder invloed van maatschappelijke en wetenschappelijke ontwikkelingen aan verandering onderhevig is. Of deze ruimte wordt opgemerkt of benut, hangt af van de lezer, die ervoor kan kiezen literatuur te lezen als een 'aap', die andere teksten en stereotypen herhaalt, maar tegelijkertijd deze 'aap' niet gevangen zet, maar diens ambiguitteit uitvergroot en in tact laat.

\section{'CULTUUR' VOLGENS FRANS DE WAAL}

Vanuit het perspectief van McEwans aap lijkt de menselijke cultuur niet bijster creatief maar 'aapachtig'. Wie wil ontsnappen uit de clichés en de stereotypen, moet aandacht hebben voor het perspectief van de 'aap', daar waar het verhaal niet past in het cliché. Terwijl de metafoor 'de aap van God' in 'Reflections of a Kept Ape' letterlijk wordt uitgewerkt, constateert ook Frans de Waal in De aap en de sushimeester cultuur bij apen. En ook in zijn boek zien we een dubbele beweging: enerzijds relativeert hij de uniciteit en bijzonderheid van de mens door aan te geven dat mensen niet meer 
kunnen dan na-apen, anderzijds wordt de aap bijzonderder door hem scheppingsdrang toe te kennen en juist het 'aapachtige' aan te prijzen als cultuur. Bovendien worden we, net als bij McEwan, aangespoord de wereld te bezien vanuit het perspectief van de aap.

'Er bestaat zo veel weerstand tegen het idee van cultuur bij dieren dat je onwillekeurig gaat denken dat de tijd er rijp voor is' (I7). Zo veegt Frans de Waal in De aap en de sushimeester op retorische wijze zijn tegenstanders aan de kant. Wij moeten, aldus De Waal, ons laatste bastion, de dichotomie tussen natuur en cultuur, opgeven, en dat kost ons - gezien de weerstand - klaarblijkelijk moeite. Dat mensen zo gefixeerd blijven op de verschillen tussen mensapen en mensen demonstreert volgens De Waal 'met hoeveel gebrek aan zelfvertrouwen de menselijke uniekheid omgeven is'. (29)

De angst om continuiteit tussen mensen en dieren te erkennen, blijkt volgens De Waal met name uit de weerstand tegen het antropomorfisme in de dierwetenschappen. Antropomorfisme, het toekennen van menselijke eigenschappen aan dieren, is volgens De Waal echter onvermijdelijk omdat men altijd vanuit het perspectief van de mens zal kijken naar een dier - we kunnen niet anders. Antropomorfisme is volgens De Waal echter pas afkeurenswaardig wanneer men dieren op grond van onvoldoende informatie of wensdenken menselijke gevoelens of gedachten toeschrijft. De Waal pleit daarom voor een 'diercentristisch' antropomorfisme (in plaats van een antropocentrisch antropomorfisme), waarbij de onderzoeker zijn mens-zijn empathisch in kan zetten bij het zich verplaatsen in het dier, maar in eerste instantie probeert het perspectief van een dier, bijvoorbeeld een aap, in te nemen (De Waal 20or: 58-63). De Waal is dus optimistischer dan Thomas Nagel, die in zijn artikel 'What is it like to be a bat' (I974) stelde dat het onmogelijk is voor een mens om zich in een vleermuis te verplaatsen. De Waal meent dat je het antropomorfisme als heuristisch middel in kunt zetten voor je onderzoek. 'Je moet die inleving natuurlijk wel kritisch toepassen, anders krijg je een Bambi-biologie,' benadrukt De Waal nog eens in een interview naar aanleiding van zijn voorstel tot diercentrisch antropomorfisme. (NRC Handelsblad, 23 juni 20or)

Het antropomorfismedebat is volgens De Waal typisch westers en inherent aan het dualistische en hiërarchische denken, waarin de mens tegenover de natuur wordt geplaatst, en dientengevolge, de 


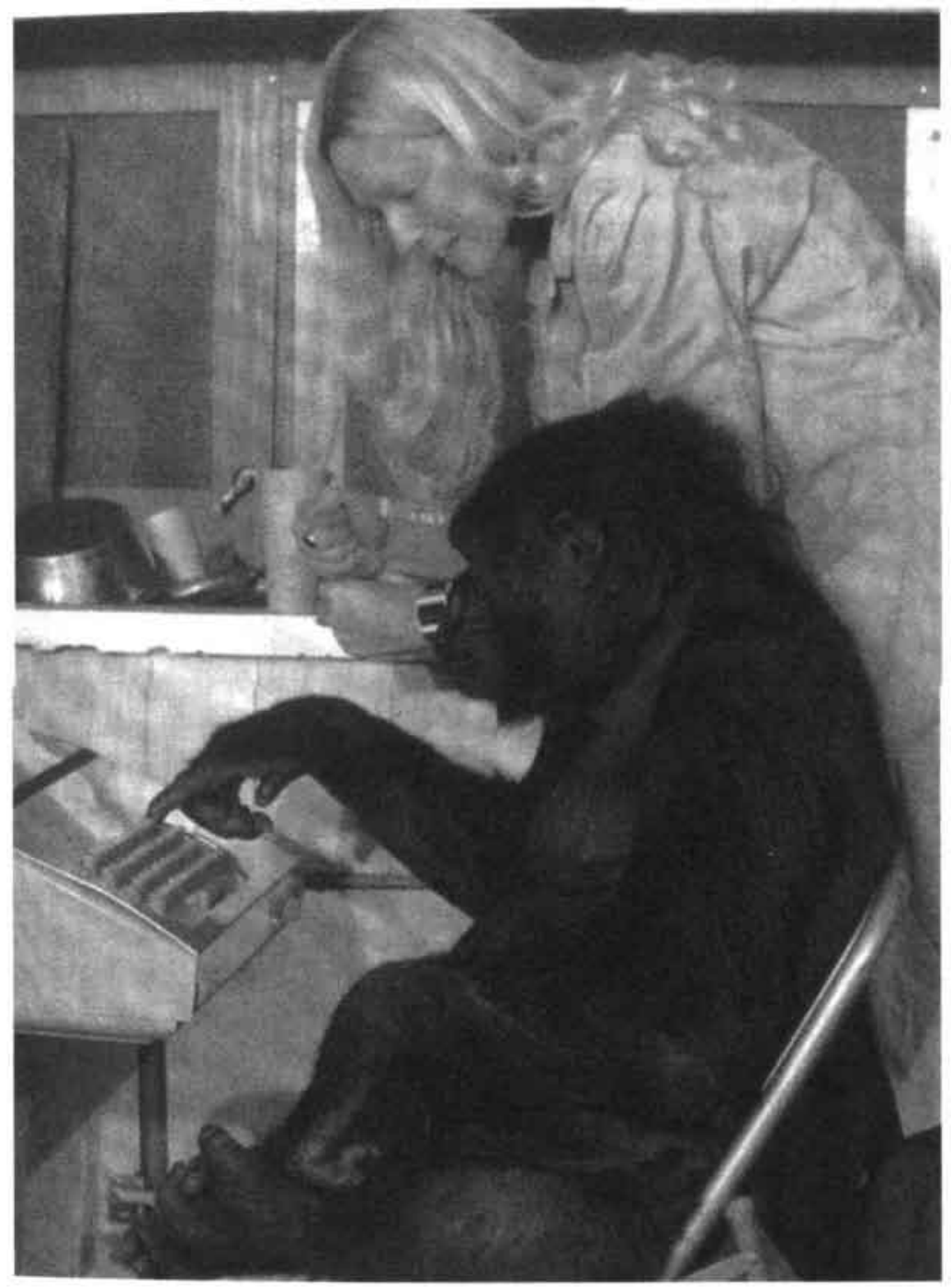

24 Koko de gorilla leert schrijven van dr. Francine Patterson.

dieren buiten de cultuur. Tegen die tweedeling trekt De Waal ten strijde. Dieren hebben volgens hem cultuur. ${ }^{15}$

De Waal geeft een aantal voorbeelden van cultuur bij dieren, zoals het afspoelen van voedsel door Japanse makakenvrouwtjes, het 
maken van grapjes door apen en 'dierenkunst'. De Waal betoogt dat er mensapen zijn die schilderen en inmiddels een 'oeuvre' hebben opgebouwd. Hij wijst op de complexe zangkunsten van spreeuwen (die Mozart probeerden te 'imiteren'!) en de nestversieringen van prieelvogels, en relativeert zo de menselijke creativiteit door deze naast die van de dieren te leggen. ${ }^{16}$

De Waal omschrijft 'cultuur' als de 'niet-genetische gedragsoverdracht', een definitie die hij ontleent aan de Japanse wetenschapper Imanishi (De Waal 20or: 169). Deze ruime definitie makt het mogelijk om cultuur bij dieren te zien. Dat wat je ziet, hangt immers af van het perspectief en hoe je definieert. 'Als niemand ooit een ruim cultuurbegrip geformuleerd had, zou waarschijnlijk niemand ooit naar cultuur bij dieren hebben gezocht,' stelt De Waal (134). Dat impliceert dat er niet zoiets bestaat als een neutrale waarneming die voorafgaat aan taal, maar dat taal de waarneming stuurt, en dat we in taal een werkelijkheidsvisie scheppen.

De Waal haalt veel van zijn wijsheden over cultuur bij apen uit het Oosten, met name Japan, waar primatologen in zijn ogen minder dualistisch te werk gaan dan in het westen. ${ }^{\nabla} \mathrm{Zij}$ hebben meer 'respect voor het onverwachte', dat wil zeggen oog voor dat wat niet past in het gedachtepatroon, in plaats van steeds maar te proberen dat wat men waarneemt in overeenstemming te brengen met de hypothese. Door interesse en respect voor datgene wat niet overeenstemt met wat je verwacht, verwerf je nieuwe inzichten. Het lijkt wel alsof De Waal een literatuur- en leestheorie formuleert, waarbij de aandacht voor de waarneming van het 'andere' en 'afwijkende' leidt tot nieuwe betekenissen. Hij moedigt ons aan de werkelijkheid als 'literatuur' te bekijken, waarin het gaat om 'afwijking'. Bij de 'tegeninterpretatie', zoals die door Maaike Meijer in haar leestheorie wordt geformuleerd, gaat het er ook om oog te houden voor de botsing tussen waarneming en tekst, het zich open te stellen voor 'het andere' in de tekst, datgene wat niet klopt met het wereldbeeld van de lezer, datgene wat interpretatie behoeft.

De Waals 'diercentrisch' antropomorfisme waarborgt dat hij twee kanten tegelijkertijd blijft zien. Enerzijds ziet De Waal, dankzij zijn gerichtheid op de afwijking en discontinuiteit tussen hypothese en waarneming, paradoxaal genoeg, meer continuitteit tussen mensen en dieren. Anderzijds behoudt De Waal ook nog altijd oog voor verschil tussen mensen en dieren: Tegelijkertijd lijdt het geen twijfel 
dat wij cultuur - met symbolen, taal, ideeën, betekenissen, waarde, onderwijs en navolging - een door geen enkel ander dier vertoonde stap verder brachten' (27). Zo ziet De Waal bijvoorbeeld verschil in de wijze waarop mensen en dieren kunst maken. Anders dan mensen, zijn mensapen er niet op uit om een blijvend visueel beeld te scheppen dat anderen pleziert, inspireert, uitdaagt, schokt, of welk effect dan ook heeft. Zodra het werk af is, kan het wat een mensaap betreft in de prullenbak; hij ziet er niet meer naar om. Toch gaat er een bijzondere kracht uit van mensapenkunst, die volgens De Waal blijkt uit de moeite die het kost om het na te maken. Een aap naapen blijkt bijzonder moeilijk voor mensen. De aanname dat mensapen mensen nadoen als ze een kwast in hun handen nemen, is volgens hem dan ook niet terecht.

Toch staat de aap bekend om zijn imitatiegedrag. De voorstellingen uit de zeventiende en achttiende eeuw, waarbij apen met kwasten peinzend vrouwelijke naakten zaten te schilderen, dienden als een bespotting van de menselijke kunstenaar, wanneer die slaafs werk van andere menselijke kunstenaars kopieerde. 'Na-apen' associëren wij tegenwoordig met iets negatiefs: plagiaat. De Waal interpreteert naapen echter als iets positiefs. Het zorgvuldig imiteren van de ander, komt voort uit het verlangen net als anderen te zijn en een dergelijke identificatie heeft een zelfversterkend karakter: 'ik wil zijn zoals jij'. De titel van zijn boek, De aap en de sushimeester, ontleent hij aan dit principe. Elke sushikok 'keek ooit de kunst af' toen hij nog leerling was. Zo is het ook met apen, die leren van hun ervaren soortgenoten hoe ze eetbare van oneetbare vruchten kunnen onderscheiden. Apen imiteren en leren van anderen, net als mensen dat doen.

\section{EEN LIEFDESGESCHIEDENIS IN CULTUUR EN WETENSCHAP}

Met De Waal hebben we in dit boek voorlopig een chronologisch eindpunt bereikt in het denken over mens-aap-relaties. We kunnen het dualisme natuur-cultuur opheffen, aldus De Waal. Hoe verhoudt zijn standpunt zich tot wat ik in dit boek heb laten zien?

Enerzijds benadrukt De Waal, net als ik dat heb gedaan, de wijze waarop taal werkelijkheidsvormend is. Samengevat kun je stellen 
dat ik steeds heb willen laten zien hoe de grenzen tussen 'wetenschap' en 'cultuur', 'feit' en 'fictie' geconstrueerd of bevochten worden, hoewel ze niet altijd gemakkelijk van elkaar te onderscheiden zijn. Soms gaan wetenschappers de strijd aan met fictie, zoals Dian Fossey, om zo de contouren van de 'waarheid' beter te kunnen schetsen. Soms zoeken wetenschappers juist nadrukkelijk een coalitie met 'fictie', zoals in het GAP, om een bredere culturele maatschappelijke steun te verwerven. Terwijl Fossey de fictiebeelden liefst de deur uit wil doen, probeert het GAP de culturele beelden over vrouwen en apen juist naar de eigen hand te zetten, omdat ze inderdaad zo invloedrijk zijn. Steeds heb ik in de hoofdstukken laten zien dat wat 'waar' is, wat 'wetenschap' en 'cultuur', 'feit' en 'fictie', niet zonder meer vaststaat, maar verandert in de loop van de tijd en bevochten moet worden. De vrouwelijke wetenschappers slagen er bijvoorbeeld in om ons 'aapbeeld' te veranderen en het imago van 'killer ape' naar een 'gentle ape' om te buigen. Daarvoor zetten ze de term 'menselijk' op handige wijze in, en gebruiken ze 'fictie' om een breder publiek te bereiken.

In hoofdstuk vijf, over de zelfrepresentatie van en de representatie-industrie rondom de vrouwelijke primatologen, bleek dat in de receptie pogingen worden gedaan om 'feit' en 'fictie' van elkaar te scheiden. De vrouwelijke primatologen zouden volgens sommige collega-wetenschappers met hun participerende en empathische onderzoeksmethoden 'te persoonlijk' te werk gaan en daarmee buiten de 'echte' wetenschap vallen, zoals ook blijkt uit de boeken die ze schreven, die wat genre betreft hybride zijn. Deze coalitie tussen wetenschap en literatuur zette zich voort in mijn analyse van het GAP, waarin ik heb laten zien welke retorische strategieën worden gehanteerd om de soortgrens te bekritiseren, zoals het introduceren van de term 'persoon' en het introduceren van verhalende elementen. Het GAP verwijst enerzijds naar diverse romans, waaronder $D e$ vrouw en de aap. Anderzijds, om autoriteit te claimen, stelt het steeds dat het zijn eis - gelijke rechten voor mensapen - fundeert op wetenschappelijke feiten. Dat geeft een zekere spanning die in de receptie stevig wordt aangepakt.

Als wetenschapper wil De Waal 'ambiguïteit' omarmen. Immers, hij wil oog houden voor zowel het perspectief van de mens als dat van de aap ('diercentrisch antropomorfisme'), en oog houden voor de 'afwijking'. Hij formuleert een interpretatiehouding die sterk aan- 
sluit bij de benadering zoals ik die uiteenzette in hoofdstuk twee, namelijk de combinatie van het heel precies lezen van de verhalen (closereading), waardoor je aandacht houdt voor de ambiguiteit ('afwijking') binnen een tekst, datgene wat niet 'past', en ze tegelijkertijd te plaatsen in een bredere maatschappelijke, ideologische en (wetenschaps)historische context door ze met andere teksten in gesprek te brengen. Als bioloog, een natuurwetenschapper, wil De Waal, zo lijkt het, de werkelijkheid bezien alsof het literatuur is. Terwijl literatuurwetenschappers bezig zijn geweest om de literatuur als een werkelijkheidsvormende kracht te zien, waarop ideologiekritische analyses kunnen worden losgelaten (zoals in de leespraktijken van Meijer en Haraway), wil De Waal de werkelijkheid als een tekst zien, die wij creatief kunnen lezen en interpreteren als wij anders kijken. Terwijl literatuur - waarin juist ruimte zou zijn voor ambiguitteit en de ander - dus het afgelopen decennium steeds meer gelezen is op hoe 'de norm' daarin wordt bevestigd, wil De Waal de werkelijkheid zoals die door de wetenschap wordt vormgegeven - waarin juist eenduidigheid en wetmatigheid gelden - ambigu lezen op de ruimte voor 'anders-zijn'.

Het klinkt aantrekkelijk, maar toch wringt er iets na het lezen van De Waals tekst. Precies de vinger erop leggen, is lastig, omdat De Waal retorisch zeer sterk is. Maar kent zijn onderneming niet dezelfde problemen als het GAP (waarnaar hij overigens niet verwijst) als het om de rekbaarheid van definities gaat? Zijn kijk op de wetenschap en op de relatie tussen mensen en dieren neigt soms wat zijn vocabulaire betreft naar holisme (hij spreekt bijvoorbeeld van 'het hele dier' - overigens met goede redenen) en net als bij het newagedenken komen zijn wijsheden uit het Oosten. Dankzij de 'nononsense' ethologische traditie waaruit hij ook put, is dat echter geen bezwaar, maar eerder een verrijking. Toch implodeert zijn voorstel om 'cultuur' op te rekken tot het dierenrijk, omdat de lezer verstrikt raakt in metavragen over retoriek en taal: zie je cultuur dankzij een definitie? Is alles cultuur? Kunnen we de wereld als fictie beschouwen, die wij via de taal naar onze hand kunnen zetten? Is het, na het oprekken van de definitie, nog wel mogelijk om verschil te zien, als alles onder cultuur valt? Het 'andere' en de 'norm' laten zich niet meer van elkaar onderscheiden, ze vallen samen; wordt 'ambiguiteit' dan niet een toverterm die eerder problemen holistisch toedekt dan verheldert? Zozeer als in de werkwijze van Ha- 
raway wetenschap en cultuur voorkomen als politiek met andere middelen, zo weinig 'politiek' doet De Waals visie soms aan. Eigenlijk is dat merkwaardig: De Waal blinkt uit met zijn kritiek op het dualistische denken zonder dat zijn tekst hetzelfde gevaar loopt als die van Haraway: namelijk als politiek manifest terzijde geschoven te worden. Vermoedelijk komt dat omdat hij zich zo nadrukkelijk als bioloog in de ethologische wetenschappelijke traditie inschrijft.

Er rijst nog een vraag. De Waal gaat niet in op mogelijke consequenties van het opheffen van het natuur-cultuurdualisme. In dit boek heb ik steeds laten zien dat je niet zomaar één dualisme kunt opheffen, zonder andere dualismen ter discussie te stellen. In hoofdstuk zes bleek hoe de opheffing van de soortgrens een discussie over mannelijkheid en vrouwelijkheid en seksualiteit impliceert, en uit de interpretatie van 'Reflections of a Kept Ape' hoe het nadenken over de vraag 'wat is goede literatuur?' ook vragen oproept over de menselijke soort, en wat mannelijkheid en vrouwelijkheid inhoudt. Voor de Waal geldt het volgende: met het oprekken van de definitie van cultuur tot het dierenrijk komt niet alleen de mens-dierdichotomie onder vuur te liggen, ook een ander dualisme komt op het spel te staan: die tussen cultuur bestudeerd door menswetenschappers en natuur bestudeerd door natuurwetenschappers. Nadat cultuurwetenschappers hun best hebben gedaan om 'wetenschap' te deconstrueren door te laten zien dat de 'natuur' door mensen geconstrueerd wordt, deconstrueert De Waal, nota bene een bioloog, een dierwetenschapper, op zijn beurt het begrip 'cultuur' zodat het niet alleen mensen insluit, maar ook dieren. En zo worden disciplinaire grenzen overschreden en wetenschappelijke territoria verlegd. Immers 'wetenschap' is ook onderdeel van de cultuur en 'cultuur' blijkt ook in de natuur te vinden te zijn. Er ontstaat - zie de ondertitel 'cultural reflections of a primatologist' - ook de suggestie van een 'culturele primatologie' (zoals we ook culturele antropologie hebben), de bestudering van de cultuur bij primaten (waar dus ook mensen onder vallen). Impliceert dit dat we de antropologie kunnen opheffen, en dat de grens tussen mens- en natuurwetenschappen wordt opgeheven? Met andere woorden, wat zijn precies de consequenties?

In mijn analyse van enkele romans in hoofdstuk zes, waarin het GAP als uitgangspunt wordt genomen, toonde ik aan dat fictie soms verder kan doordenken over maatschappelijke consequenties van 
het GAP. Terwijl de wetenschappers die zich voor het GAP inzetten, zich sterk bewust zijn van het feit dat wetenschap een menselijke constructie is en dat de retorische middelen kunnen worden aangewend om de lezer te overtuigen, legt de literatuur ons andere 'waarheden' voor. Literatuur is dus niet zonder meer een illustratie van wetenschap, maar geeft op eigenzinnige wijze mede vorm aan bepaalde debatten, zoals over de vraag of mensapen mensenrechten zouden moeten krijgen (De vrouw en de aap). Daarom is het zinvol de wetenschappelijke en literaire teksten naast elkaar te lezen en ze tot elkaars 'commentatoren' te maken, ook wanneer ze niet uit dezelfde periode dateren. En niet, zoals Haraway, literatuur in te zetten als illustratie van een politieke boodschap. Door teksten naast elkaar te lezen wordt het mogelijk ambiguiteit uit te vergroten in plaats van te verkleinen.

Leggen we 'Reflections of a Kept Ape' naast de 'Cultural Reflections of a Primatologist', wat levert dat dan op? Zowel McEwans aap als De Waals apen relativeren de menselijke creativiteit. Maar waar McEwan na-apen als tragisch beschouwt, als iets wat de menselijke cultuur belemmert, ziet De Waal na-apen als de positieve drijfveer van 'cultuur'. De herwaardering van het na-apen door De Waal biedt een uitweg uit de 'cultuurtekst' waarbinnen het herhalen louter beschouwd wordt als een vorm van plagiaat en negatief gewaardeerd. De Waal stelt: door na te apen kunnen wij creativiteit ontwikkelen. Binnen een dergelijke definitie van na-apen is Sally een schrijfster met potentie, die echter de fout begaat zichzelf na te apen in plaats van naar de aap te kijken.

Hoewel het na-apen dus verschillend gewaardeerd wordt, houden de apen van McEwan en De Waal ons uiteindelijk dezelfde leesles voor: het perspectief is allesbepalend, de gekozen invalshoek, het oog voor het 'andere', de 'afwijking' datgene wat niet past in het normale. Je zou evengoed voorzichtig kunnen stellen dat McEwan ons daarmee 6 ók een uitweg biedt uit het dreigende imploderende universum van De Waal, waarin cultuur hetzelfde is als natuur en men het zicht op verschil, ondanks de aandacht voor de 'afwijking', verliest in plaats van benoemt. Via de reflecties van McEwans aap realiseren we ons dat 'de aap' niet bestaat: er zijn mannetjesapen en vrouwtjesapen, vrouwen en mannen. Een vreemde conclusie dringt zich dan op. Terwijl De Waal zich juist zo 'diervriendelijk' opstelt en de 'aap' letterlijk en metaforisch opvat als de aandacht voor het 'af- 
wijkende', dreigt bij hem een a-politiek universum te ontstaan waarbinnen het onmogelijk lijkt te differentiëren tussen mannetjes en vrouwtjes, cultuur en wetenschap, mensapen en mensen. McEwans verhaal doet zich in eerste instantie voor als een klassiek geval van seksisme verpakt in literatuur (de vrouwelijke schrijfster faalt omdat ze boeken in plaats van kinderen wil baren; de echte schrijver is een man), maar blijkt, dankzij het perspectief van de verliefde aap, ó́k onmogelijk om zich in 'ideologiekritiek' ondubbelzinnig te laten determineren en biedt een weg uit gestolde betekenissen.

\section{DE TOEKOMST ALS AAP}

'To a monkey'

$\mathrm{O}$ lovely $\mathrm{O}$ most charming pug

Thy gracefull air and heavenly mug

The beauties of his mind do shine

And every bit is shaped so fine

Your very tail is most devine

Your teeth is whiter than the snow

You are a great buck and a bow

Your eyes are so fine a shape

More like a christains than an ape

His cheeks is like the roses blume

Your hair is like the ravens plume

His noses cast is of the roman

$\mathrm{He}$ is very pretty weoman

I could not get a rhyme for roman

And was oblidged to call it weoman.

Marjory Fleming (8 jaar), geciteerd in Hughes 1980.

Terug nu naar de band tussen de vrouw en de aap. Sterven of niet, dat is voor de aap de cruciale kwestie. In Mijn aap schreit wordt de aap uit jaloezie op zijn band met een vrouw met gif vermoord door de jongeman; in King Kong gaan blanke mannen met bommenwerpers en vliegtuigen de grote gorilla te lijf die in zijn handen een 
meisje vasthoudt; in Brazzaville Beach schiet de wetenschapster Hope met een pistool drie apen dood. Jane Goodall, Dian Fossey en Biruté Galdikas doen er alles aan om te voorkomen dat apen vermoord worden, bijvoorbeeld door te laten zien dat je dan een naast familielid vermoordt. In De vrouw en de aap staat de man met zijn geweer klaar, maar hij ziet af van de moord. En in 'Reflections of a Kept Ape' wordt de aap door de vrouw genegeerd, alsof hij dood is.

In mijn interpretaties van Mijn aap schreit en King Kong interpreteerde ik het doden van de apen door de mannen als een poging om de ambiguïteit op te heffen en de hiërarchie tussen vrouwen, mannen, dieren en mensen veilig te stellen. De tragiek van de verhalen en de reminiscenties aan de kruisiging van Christus in zowel King Kong als Mijn aap schreit suggereren dat het ondubbelzinnig maken niet volledig lukt: hoewel het goddelijk verklaren van de aap ook gezien kan worden als het opheffen van ambiguïteit, blijft de aap de mannen achtervolgen in hun herinnering. Een mogelijke interpretatie is dat sommige van deze mannen met hun eigen ambiguiteit worstelen, en dit op de aap projecteren. De verteller in Mijn aap schreit heeft bijvoorbeeld moeite met het integreren van het 'andere' in zijn persoonlijkheid. Ook Hope uit Brazzaville Beach worstelt met ambiguïteit: het gewelddadige gedrag van de 'zachtaardige' mensaap en haar rol als wetenschapster in een mannenbolwerk. Sally uit 'Reflections of a Kept Ape' negeert de aap, een manier, zo suggereerde $\mathrm{ik}$, om niet met haar mislukte pogingen om een goed boek te schrijven, geconfronteerd te worden. De vrouw en de aap daarentegen eindigt niet met de dood, maar met seks. Madelene, die met Erasmus meegaat, is zwanger van de aap en er is hoop op nieuw leven. In De vrouw en de aap wil Adam de aap doodschieten, maar de aap weet hem tot inkeer te brengen. In zekere zin wordt de ambiguitteit toch opgeheven, omdat de aap en de vrouw van het aardse toneel verdwijnen en naar een 'andere' betere wereld vertrekken.

De worsteling van de personages in de verhalen met de ambiguïteit van de apen, en de moord die daarop volgt, spiegelt zich in de receptie, waarin vaak de neiging bestaat om de ambiguitteit op te heffen. Vaak worden beslissingen genomen of de aap nu menselijk, dierlijk of goddelijk is (soort), mannelijk, vrouwelijk of kinderlijk (geslacht) en wat zijn aard is (kwaadaardig of zachtaardig). In Mijn 
aap schreit zagen de interpreten de aap eenzijdig als het alterego van de verteller dat het driftmatige vertegenwoordigt, terwijl de jongeman hem nu juist ook verstand toekent. King Kong ging de geschiedenis in als 'killer king' of 'gentle giant', als 'machoman' of 'homo', als 'zwarte ander' of als 'valse representatie van een dier'. Wetenschappers benadrukten voorts dat King Kong een fictieve gorilla is, die met 'echte' gorilla's zoals de wetenschap die observeert, niets te maken heeft. De representatie-industrie rondom de vrouwelijke wetenschappers spitst zich toe op de positie van vrouwelijke wetenschappers; zij komen naar voren als zachtaardige heldinnen of kwaadaardige heksen.

De obsessie met de gelijkenis en het verschil tussen mens en aap keert in alle fictie over apen terug. Steeds wordt er een formule gegeven die de mens van de aap zou onderscheiden: taal, make-up, tafelmanieren, drinken, denken, cultuur, kunst, geloof, humor, boeken, emotie, moraal, vrije wil, doelgerichtheid. Maar in de loop van de twintigste eeuw wordt dat verschil steeds meer ter discussie gesteld. De verhalen tonen ons doelbewuste, emotionele, morele, drinkende, lachende, huilende en schrijvende apen. De verhalen lieten ook een ontwikkeling zien, van het denken en worstelen met hiërarchische categorieën tussen mannen en vrouwen, zwarten en witten, mensen en dieren, cultuur en wetenschap naar het loslaten daarvan en zelfs het omhelzen van ambiguiteit als ideaal voor de toekomst. Ideaal, omdat daarin tegenstrijdigheden gelijktijdig omarmd kunnen worden, wat aard en gedrag betreft. Apen hebben menselijke eigenschappen, mannen incorporeren vrouwelijke eigenschappen, vrouwen mannelijke eigenschappen. En ze kunnen zachtaardig en kwaadaardig tegelijkertijd zijn.

Terwijl veel mannen in fictie de apen doden, zoeken de vrouwen over het algemeen juist toenadering tot de apen. Ze halen de aap aan, zoals in Mijn aap schreit, verzorgen en voeren de apen, zoals de vrouwelijke wetenschappers, of hebben zelfs seks met ze, zoals in De vrouw en de aap en 'Reflections of a Kept Ape'. Wie zich afvraagt 'waarom vrouwen van apen houden', legt het perspectief bij de mens. De Waal spoort ons aan dat perspectief om te draaien, iets wat in de literatuur en de film bij uitstek mogelijk is. Soms zijn het ook de apen die van vrouwen houden (Mijn aap schreit, King Kong, 'Reflections of A Kept Ape'), omdat die vrouwen met ze spelen (Marietje in Mijn aap schreit), zorgzaam voor hen zijn (Galdikas die 
adoptiemoeder is), mooi zijn (Martha in Mijn aap schreit, Ann uit King Kong) of eenzaam en hulpbehoevend (Madelene uit De vrouw en de aap, Sally die zichzelf 'na-aapt' in 'Reflections of a Kept Ape'). Juist in deze toenadering van vrouwen en apen gaan hierarchieën schuiven. Soms neemt de aap een 'lagere rol' in ten opzichte van de vrouw, en is hij kind, of object; dan weer neemt de aap de hiërarchisch hogere positie in, en is hij de minnaar die de vrouw keurt en aan een onderzoekje onderwerpt (King Kong, 'Reflections of a Kept Ape'). Maar vaak vinden binnen de ene ontmoeting hiërarchische verschuivingen plaats en 'wisselen' de rollen. Bij de vrouwelijke onderzoekersters neemt zij bijvoorbeeld aanvankelijk de plaats in van 'de mannelijke' onderzoeker, terwijl de aap haar 'object' is; tegelijkertijd wil zij de apen als 'subjecten' zien, waardoor de hiërarchie kantelt en zij als 'moeder' gezien wordt. De ontmoeting tussen de vrouw en de aap veroorzaakt bij personages en bij interpreten twijfel over soort (bijvoorbeeld De vrouw en de aap), mannelijkheid en vrouwelijkheid (Mijn aap schreit, De vrouw en de aap, King Kong), kleur en seksualiteit (King Kong, Gorillas in the Mist), de status van fictie ('Reflections of a Kept Ape'), en meestal al deze dingen tegelijk. Kennelijk lukt het niet om in de receptie van de ontmoeting tussen de vrouw en de aap de ambiguiteit van beiden vast te houden; ofwel de aap (King Kong), ofwel de vrouw gaat dood (Dian Fossey), verdwijnt in een voetnoot (Hope), of beiden verdwijnen uit het aardse leven ( $D e$ vrouw en de aap), of althans naar een voor mensen onbekende plek, 'ergens' in het Noorden.

Is de toenadering tussen vrouwen en apen een manier om 'ambiguiteit' in stand te houden - die tegenover het 'vermoorden van ambiguïteit' geplaatst kan worden? Enerzijds wel; anderzijds bleek uit hoofdstuk vijf dat daarmee een nieuw stereotype dreigt te ontstaan van de empathische vrouwelijke dierwetenschapper die meer affiniteit met apen heeft dan mannen. Maar hoe moeten we de seks tussen vrouw en aap eigenlijk zien? Is het nadenken daarover niet slechts een filosofische of literaire exercitie? Vrouwen gaan er in 'het echte leven' toch niet met apen vandoor? Ze kunnen toch niet 'echt' kinderen van apen krijgen? Een mogelijk antwoord is dat seks tussen vrouwen en apen niet als realistisch gezien moet worden. Dat doet bijvoorbeeld een mannelijke recensent, die in zijn recensie van De vrouw en de aap opmerkt dat het verhaal is 'ontsproten aan een mannenfantasie, en dat De vrouw en de aap niet op realistisch ni- 
veau gelezen moet worden, maar als metafoor voor een liefde die aan alle uiterlijkheden voorbijgaat. ${ }^{18}$ Toch is dat een te gemakkelijke uitweg. Want beeldvorming heeft wel 'echte' consequenties: beelden bepalen hoe we aankijken tegen mannen, vrouwen, apen. Bovendien, indachtig De Waal die de wereld als een (literaire) tekst leest, vanuit een bepaald perspectief, lijkt de vraag naar het 'realiteitsgehalte van de seks tussen vrouw en aap' verkeerd gesteld. Immers, het gaat niet om de vraag hoe de echte aap zich verhoudt tot de verbeelde aap. De werkelijkheid wordt waargenomen in taal, via de verbeelding in verschillende verhalen, waarvan we sommige 'feitelijk' noemen en andere tot het domein van de fictie rekenen, en die zijn steeds aan verandering onderhevig. Zonder deze vormgeving in cultuur en wetenschap bestaat de aap niet.

Maar waarom steeds die fascinatie voor seks? In zijn boek over bestialiteit, Lief dier, schrijft Midas Dekkers daarover het volgende:

Seks bedrijf je per definitie met een ander wezen, of dit er nu een is van hetzelfde of van het andere geslacht, een rasgenoot of iets exotischers. Elke seksuele relatie is een overschrijding van grenzen, een inbreuk op een ander rijk, aan elke seksuele relatie hangt een vleugje bestialiteit. Wat heb je aan een ander als hij niet anders is? Echte bevrediging vind je pas als je je te buiten gaat. (Dekkers 1995: 9)

Seks, aldus Dekkers, is een ultieme toenadering tot de ander en een overschrijding van grenzen. Eigenlijk is volgens hem alle seks een vorm van bestialiteit. Seks is bovendien de uiterste omhelzing van het leven. Terwijl moord het leven doet beëindigen, wil seks juist, zo wil althans het 'natuurlijke' cliché, het leven voortzetten, er is immers de belofte van nageslacht.

In Mijn aap schreit is seks tussen een vrouw en een aap een angstvisioen van de man. Hij vreest dat hij, in tegenstelling tot zijn aap, nooit contact zal hebben met het andere; in King Kong is er de suggestie van bestialiteit, en ook hier boezemt dat mannen angst in. In de verhalen van de vrouwelijke primatologen speelt de moederkindrelatie een belangrijke rol, maar is er ook de suggestie van erotiek: de apen zijn concurrenten van hun echtgenoten en worden soms op erotische wijze beschreven, alsof de vrouwen 'getrouwd' zijn met de apen. Maar, zoals Midas Dekkers overtuigend laat zien 
door middel van afbeeldingen en verhalen, vloeien 'verzorgen' en 'vrijen' soms ongemerkt in elkaar over en staan soms op gespannen voet met elkaar (Dekkers 1995: 198). In De vrouw en de aap kiest Madelene voor de aap uit onvrede met haar man; in 'Reflections of a Kept Ape' gaat Sally met een aap naar bed omdat het scheppen in taal haar niet lukt, en ze hoopt dat de aap haar zal inspireren. Anders dan in De vrouw en de aap lijkt seks met aap een 'ongevaarlijke' vorm van seks, eentje die geen nageslacht oplevert. In De vrouw en de aap draagt bestialiteit echter een belofte in zich. Het staat niet langer voor iets pervers en afkeurenswaardigs, maar voor een betere toekomst voor mensen. Wil de mannelijke helft van de bevolking er een stokje voor steken dat vrouwen er met apen vandoor gaan en hun nageslacht gaan dragen, dan moeten mannen gaan nadenken over zichzelf. Juist in de bestiale affaire zegeviert ambiguiteit omdat er sprake is van soortoverschrijding. Er komen zelfs mogelijk kinderen van deze ontmoeting, er is de belofte van een nieuwe soort.

Het resultaat van hun ontmoeting is onbekend. Het nageslacht zal waarschijnlijk ambigu zijn, deels mens, deels god, deels dier. De taal van de schrijver sluit zich hierbij aan. Hij probeert te ontsnappen aan de 'cultuurtekst' en aan de 'apentaal', door op zins- en woordniveau ambigu te zijn, zoals in de liefdesscène van De vrouw en de aap, waarmee ik dit boek ben begonnen. De aap uit dit citaat verenigt tegenstrijdigheden in zich - hij bezit een 'gevoelige meedogenloosheid', is 'behoedzaam' en tegelijkertijd 'grondig', waardoor zij vervuld raakt van 'pijn en wellust' - en ruikt naar 'dier, man, sterren, gloeiende houtskool, luchtbedden en verbrand rubber', een hybride verzameling van woorden. Talige verschillen, uiteenlopende woorden, zoeken elkaars gezelschap op in één zin. In deze ontmoeting van uiteeenlopende woorden is de norm zoek. De aantrekkingskracht van King Kong en Erasmus bestaat uit de unieke combinatie die het hart van zo veel vrouwen sneller doet kloppen: hij is zachtaardig én macho. Hij is als een stukje ongerepte natuur, en heeft in het geheel geen last van de remmingen die de civilisatie ons oplegt. Hij volgt zijn intuïtie, en als het moet pinkt hij zonder gêne een traantje weg. De aap is niet alleen de geslachten en de soorten voorbij, maar draagt de belofte in zich van een nieuwe wereld waarin mannen, vrouwen, wit of zwart, mensen, dieren en zelfs verschillende woorden elkaar vinden. De aap is de toekomst die zichzelf nog moet schrijven. 
Erasmus drong bij haar naar binnen met een soort gevoelige meedogenloosheid, langs de gulden middenweg tussen pijn en wellust, en tegelijkertijd beet zij hem in zijn oorlelletje, behoedzaam maar tevens grondig, tot ze op het puntje van haar tong de eerste vage, ijzerachtige smaak van bloed gewaarwerd, en haar neusgaten gevuld werden met een geur, een geurlandschap, een geurcontinent, van dier, man, sterren, gloeiende houtskool, luchtbedden en verbrand rubber. 


\section{Noten}

Inleiding. De vrouw en de aap

I Zie Haraway (1989: 293-300) en Fedigan (1994: 531) voor cijfers van het aantal vrouwelijke primatologen in de Verenigde Staten. Voor een mogelijke verklaring van dit hoge aantal, zie hoofdstuk 5 van dit boek.

2 Binnen de literatuurwetenschap heeft zich een discussie afgespeeld rondom de mogelijkheden een 'objectieve' analyse te onderscheiden van de 'subjectieve' interpretatie. Sommigen zijn van mening dat 'interpretatie' tot het domein van de literatuurkritiek moet worden gerekend in plaats van de literatuurwetenschap, zie bijv. Oversteegen 1986: 237244 en Fokkema \& Ibsch 1992 . Anderen menen dat men wel een onderscheid kan maken tussen analyse en interpretatie, maar dat beide tot het domein van de literatuurwetenschap behoren (Van Heusden 1994). Ik hanteer de woorden 'analyse', 'interpretatie' en 'receptie' hier als te onderscheiden categorieën, maar ben van mening dat deze niveaus lastig van elkaar zijn te onderscheiden. De elementen die men selecteert voor de analyse zijn bepalend voor de interpretatie. Interpretatie is vaak ook lastig los te koppelen van de receptie; niet alleen is de eigen interpretatie vaak beïnvloed door de receptie; ook de receptie dient geïnterpreteerd te worden.

3 Met 'westers' bedoel ik de cultuur van Europa en de Verenigde Staten. Het thema van de vrouw en de aap komt niet alleen in de westerse cultuur voor; Morris \& Morris (1966) tonen aan dat in Zuid-Amerika, Azië en Afrika soortgelijke verhalen over vrouwen en apen zijn verteld. In Zuid-Amerika is de mythe volgens Morris \& Morris geinspireerd op de bijzondere anatomie van de vrouwtjesslingeraap. Deze vrouwtjes hebben zo'n grote clitoris, dat deze voor een penis wordt gehouden. Aangezien alle slingerapen eruitzien als mannetjes, moesten zij hun seksuele partners bij een andere soort zoeken, Indiaanse 
vrouwen met name. Wat India betreft, noemen Morris \& Morris de Kama Sutra als bron, waarin de uitwerpselen van een mannetjesaap genoemd worden als het ingrediënt voor een liefdesdrank, die een man tot zich kan nemen om een vrouw te verleiden. De Afrikaanse verhalen zijn volgens Morris \& Morris bedacht door westerlingen die in de zeventiende, achttiende en negentiende eeuw op ontdekkingsreis gingen en op apenjacht (zie ook hoofdstuk 4 van dit boek). Vooral in de achttiende en negentiende eeuw, ten tijde van de ontdekking van nieuwe mensapensoorten, deden erotische verhalen de ronde. De meeste daarvan behoren echter tot de orale geschiedenis.

4 'Het verhaal van de prinses en de aap'. In: De vertellingen van duizenden-één-nacht, deel 5/6. Vert. uit het Arabisch door R. van Leeuwen. Amsterdam: Bulaaq, 502-503.

5 Zie Janson (1952), met name het hoofdstuk 'The Sexuality of Apes', 261287 .

6 Voltaire 1983: 62-65. Candide en 'Het verhaal van de prinses en de aap' komen aan de orde in hoofdstuk 6 , noot 34 , van dit boek.

7 Over de aap in de Duitse cultuur en literatuur is al veel geschreven. In Schaeffer \& Köhler (1994) vindt men een verzameling van de belangrijke Duitse teksten waarin apen figureren. Gerigk (1989: I2I-I68) wijdt in zijn boek over apen in de literatuur een hoofdstuk aan het thema van de vrouw en de aap. De Franse cultuur komt iets minder aan bod, maar aan sommige films en boeken, zoals Pierre Boulles La Planète des Singes (1963), wijd ik enkele woorden.

8 Films verdienen ten opzichte van literaire verhalen een mediumspecifieke aanpak, maar het gaat mij hier in eerste instantie om het verhaal, en niet zozeer om de formele verschillen tussen de media onderling. Wie geïnteresseerd is in de verschillen tussen populaire wetenschap en wetenschap, zie bijvoorbeeld Van Dijck 1998; voor verschillen tussen talige en visuele media, zie Mitchell 1994. Ik spreek in brede zin - of het nu gaat om een kort verhaal, film, roman of een (populaire) wetenschappelijke tekst - over 'verhalen'. Voor een verdere verantwoording, zie hoofdstuk 2 van dit boek.

9 Meestal betreft het een mannetjesaap in combinatie met een vrouw, maar het mannelijk geslacht van de aap is soms niet onomstotelijk duidelijk (zie bijvoorbeeld het hoofdstuk in dit boek over King Kong). Bij de primatologen betreft het zowel mannetjes als vrouwtjesapen, hoewel de drie primatologen Goodall, Fossey en Galdikas als lievelingsaap 
een mannetjesaap blijken te hebben. Relaties tussen vrouwtjesapen en mannen komen ook voor, zij het minder vaak. Zie daarover hoofdstuk I, noot 30 , van dit boek.

Io Dat geldt natuurlijk met name voor de vier mensapen (gorilla's, bonobo's, chimpansees en orang-oetans). De aandacht voor het verschil binnen de soort komt aan de orde in hoofdstuk $\mathrm{I}$ van dit boek.

II Het woord 'cultuur' hanteer ik hier in enge zin, om te verwijzen naar uitingen als film, literatuur, schilderkunst; het woord 'wetenschap' verwijst naar de praktijk waarin wetenschappelijk onderzoek wordt verricht. Wanneer je de term 'cultuur' breder opvat, kun je ook 'wetenschap' beschouwen als een vorm van cultuur, als een culturele uiting. In deze inleiding en de volgende hoofdstukken hanteer ik soms een pragmatisch onderscheid tussen 'wetenschappelijke' teksten en 'verbeeldingsteksten' en tussen 'kunstenaars' en 'wetenschappers'. In hoofdstuk 2 ga ik kritisch op de relatie tussen cultuur en wetenschap in. De primatoloog Frans de Waal pleit in De aap en de sushimeester. Over cultuur bij dieren (200I) voor een breed cultuurbegrip; daarover meer in hoofdstuk 7 van dit boek.

\section{De vele gedaantes van de aap}

I Binnen een belangrijke onderzoekstraditie met betrekking tot diergedrag, de ethologie, probeert men het 'menselijke' zo min mogelijk de onderzoeksresultaten van wetenschappelijk onderzoek te laten beïnvloeden. Antropomorfisme, het toeschrijven van menselijke eigenschappen aan niet-mensen, is hier als uit den boze. Illustratief in dit verband is het hanteren van 'niet-menselijke', meetbare en objectieve begrippen. Een voorbeeld komt van de Nederlandse primatoloog Jan van Hooff: 'In eerste instantie spraken we bijvoorbeeld van PCAc-tjes: Post Conflict Affiliatief Contact. Heel objectief, niks geen gedonder [...] Pas toen we getalsmatig konden bewijzen dat PCAC in alle aspecten overeenkomt met wat we bij mensen "verzoening" noemen, zijn we het bij chimpansees ook zo gaan noemen' (Geciteerd in Schilthuizen 1998)

Over de discussie rondom antropomorfisme in dierwetenschappen, zie Korthals 1998. Zie ook hoofdstuk 5 en 7 van dit boek.

2 De term 'primatologie' werd in 1941 voor het eerst gebruikt door Theodore Ruch toen hij een bibliografie van het onderzoek naar apen samenstelde (Haraway 1989: 24-25). Daarvoor bestond 'primatologie' nog niet 
als academische discipline of als noemer voor het onderzoek naar apen.

3 'Race' en 'gender' laten zich in het Nederlands lastig vertalen. 'Ras' is historisch gezien een beladen term, die associaties oproept met het nationaal-socialisme en de Tweede Wereldoorlog. In Nederland worden daarom vooral de termen etniciteit of (huids)kleur (wit/blank, zwart) gebruikt. De termen 'wit' of 'zwart' kun je, zoals Haraway terecht opmerkt, niet zonder meer gebruiken om te verwijzen naar huidskleur, maar dienen vooral opgevat te worden als een politieke categorisering. Er zijn in de Verenigde Staten immers ook witte mensen, zoals de IersAmerikanen, die toch niet voor 'wit' doorgaan en onderscheiden worden als een etnische groep. Wanneer ik in dit boek de termen etniciteit, kleur, blank, wit en zwart gebruik, dan is het op die politieke manier. Voor meer informatie over de termen 'white' en 'race', zie Haraway 1989: 40I, noot 15. Over de problemen die zich voordoen bij het vertalen van het woord 'gender' in de verschillende Europese talen, alsmede een historisch overzicht van de invullingen die aan het concept zijn gegeven, zie Haraway 1991: 127-149, zie ook noot 6 van dit hoofdstuk. De derde categorie van Haraway, 'nature', omvat bijvoorbeeld het soortonderscheid.

4 Het is opvallend dat Haraway het woord liefde gebruikt, daar waar Foucault uitdrukkelijk spreekt over de verwevenheid van seksualiteit, macht en wetenschap. De term liefde in combinatie met macht duikt vaker op in feministische teksten en oogt verrassend omdat liefde zich op deze wijze als een geconstrueerde categorie voordoet. Haraway verwijst met de term enerzijds naar dit geconstrueerde karakter van de 'natuurlijke' 'liefde' die vrouwen voor de natuur (bijvoorbeeld apen) zouden voelen. Anderzijds duidt de term 'liefde' ook op iets positiefs; het benadrukt de grote inzet van wetenschappers en hun persoonlijke verbondenheid met hun object van studie, namelijk apen. Zie voor de relatie tussen liefde, macht en wetenschap Rose (1994).

5 Haraway wijst op de enorme hoeveelheid onderzoeken die worden gedaan naar het seksuele gedrag van apen. De primatologie, en dierwetenschappen in het algemeen, fungeren als een legitiem veld waar naar hartelust onderzoek gedaan kan worden naar seks, en is een broeiplek voor ongeremde fantasieën en projecties, die in feite prijs geven hoe mensen over zichzelf denken.

6 Vgl. Haraway 1991. Haraway bekritiseert hierin het onderscheid tussen sekse en gender, waarbij sekse als het biologische geslacht wordt opgevat en gender als de culturele betekenis die aan sekse wordt toegekend. 
Een dergelijke tweedeling handhaaft een essentialistische opvatting van biologie die onproblematisch naar het biologische lichaam verwijst. Beide polen, sekse en gender, construeren elkaar. In deze studie gebruik ik het woord gender in deze betekenis.

7 Voor disability studies, zie Davis r997.

8 Welke 'ander' het beste afzetpunt biedt om de norm vast te stellen is aan historische verandering onderhevig. Voor een historische studie naar de wijze waarop na de Tweede Wereldoorlog primaten de rol van de primitieve mens hebben overgenomen als het gaat om verklaringsmodellen voor de mens zie, Van Reybrouck 200o. Van Reybrouck geeft tevens een verhelderende analyse van de wijze waarop de analogie - een onder archeologen, paleontropologen en primatologen veel voorkomende wetenschappelijke bewijsvoering - in een logische redenering fungeert.

$9 \mathrm{Om}$ deze reden worden dieren, mensapen met name, vaak vergeleken met kinderen en zwakzinnigen, die ook niet altijd met behulp van de taal hun eisen op tafel kunnen leggen. Zie bijvoorbeeld Cavalieri \& Singer I993. Voor een kritiek op deze gelijkschakeling tussen anderen, zie hoofdstuk 6 van dit boek. Voor een kritiek op de gelijkschakeling tussen dieren en zwakzinnigen, zie ook Mans 1998.

Io Het is enigszins paradoxaal een eenduidige definitie van ambiguitteit te geven. Ambiguïteit wordt gewoonlijk niet alleen gezien als een eigenschap van de werkelijkheid, maar ook van taal, literaire taal in het bijzonder. Literaire of talige ambiguiteit komt in het tweede hoofdstuk uitvoerig aan de orde. In dit hoofdstuk concentreer ik me op sociale ambiguìteit. Het onderscheid tussen een talige en sociale werkelijkheid is kunstmatig, omdat de werkelijkheid vaak talig wordt gekend, en omdat talige representaties de werkelijkheid niet alleen reflecteren, maar ook vormgeven. Over de relatie tussen taal, representatie en werkelijkheid, zie bijvoorbeeld Meijer 1996. De relatie tussen ambiguîteit en werkelijkheid is complex. Ambiguiteit is niet zonder meer een aanwijsbare eigenschap van bepaalde mensen, dingen of dieren in de werkelijkheid, maar een toeschouwersoordeel dat altijd gestoeld is op een vooronderstelling over de norm en de afwijking daarvan. Wanneer ik de aap 'ambigu' noem, is dat een uitkomst van dit onderzoek: uit de diverse teksten over apen die ik heb geraadpleegd, blijkt een worsteling met diens status, mens of dier.

II Volgens sommigen is dit begin 2000 met de opkomst van de 'Glam Mom' aan het veranderen. De bolle buik is sexier dan ooit. Zie Van der Jagt 200I. Voor een kritische reactie, zie Naomi Wolf 2001. 
Vgl. Kondo 1990. Als Amerikaanse Japanse opgegroeid in Amerika, wordt Kondo tijdens bezoeken aan Japan voortdurend geconfronteerd met haar dubbele positie. Hoe kan iemand er Japans uitzien en toch niet Japans zijn, veel spelfouten maken of dingen anders interpreteren? De reactie die ze het vaakst ondervond van Japanners was de poging om haar zo Japans mogelijk te maken, haar te 'de-Amerikaniseren' en op deze wijze de afstand tussen haar en de Japanners te verkleinen.

13 Een natuurwetenschapper die op zoek is naar wetmatigheden, streeft bijvoorbeeld over het algemeen naar eenduidigheid, terwijl een kunstenaar ernaar zal streven ambiguitteit te handhaven en positief te waarderen (althans, zo wil het cliché). De afkeer van ambiguitteit is niet een universele trek, maar kan volgens sommigen vooral beschouwd worden als een eigenschap van de moderne westerse cultuur, zie bijvoorbeeld Levines The Flight from Ambiguity (1985). Levine noemt Paines The Mask of Janus (1981), waarin deze laat zien dat in Melanesië en de Amharacultuur van Ethopië de liefde voor ambiguitteit wordt gecultiveerd. De waardering voor ambiguïteit is ook historisch aan verandering onderhevig. In het gedachtegoed van veel (westerse) postmodernisten worden begrippen als ambiguiteit, hybriditeit en transculturaliteit vaak verheerlijkt (Van der Geest 1995).

I4 Deze strategieën baseer ik op de boven- en ondergenoemde studies naar onder andere biseksuelen, hermafrodieten, apen en Amerikaanse Japanners, en op de interpretatieve studies in dit boek.

15 In haar onderzoek naar hermafrodieten laat Geertje Mak (1997) zien hoe zij vaak zelf de dood verkozen. In culturele uitingen, bijvoorbeeld film en literatuur, is de dood vaak een oplossing voor een interpretatieprobleem. Zie ook hoofdstuk 3 en 4 van dit boek.

I6 Voor een overzicht van classificatieproblemen van Aristoteles tot Dubois, zie Spencer 1995. Voor een studie van het mensaap-debat in de achttiende en het begin van de negentiende eeuw, zie Sens 20or. Voor een uitvoerige studie van Linnaeus tot Frans de Waal, zie Corbey (te verschijnen). Een samenvattend artikel van dit boek is te vinden in Corbey 2001 .

17 Hoewel verschillende getallen worden genoemd, gaat men er tegenwoordig van uit dat er ongeveer 190 verschillende apensoorten zijn (Swindler 1998). Het is gebruikelijk een onderscheid te maken tussen apen van de nieuwe wereld of breedneusapen en apen van de oude wereld of smalneusapen. Deze laatste groep bestaat uit de meer katachtigen, de slankapen, de gibbons, de mensapen (orang-oetans, gorilla's en 
de twee mensapen van het geslacht pan: bonobo's en chimpansees). Het Engels gebruikt 'monkey' voor aap, en het woord 'ape' voor mensaap.

18 Ook wordt gediscussieerd over de vraag welke mensaap het meest op de mens lijkt wat gedrag betreft, de bonobo of de chimpansee. Voor elke mensaapsoort zijn redenen aangedragen waarom juist deze mensaap dichter bij de mens zou staan. Sinds de studie naar het gedrag van de bonobo door Frans de Waal (r997) denkt men dat de 'make love not war'-aap, de bonobo, wat gedrag betreft het dichtst bij de mens staat, omdat deze apen, als enige van de mensapen, elkaar tijdens de copulatie aankijken. Binnen de primaten trad er een verschuiving op van de baviaan naar de chimpansee naar de bonobo als het beste verklaringsmodel voor de oorsprong en de aard van de mens (Van Reybrouck 2000).

19 Bij de speurtocht naar de missing link in de negentiende eeuw is de zwarte of primitieve mens vaak voorgesteld als iemand die op de evolutionaire schaal dichter bij de aap stond (Jahoda 1999). Maar nog steeds worden zwarten vaak voorgesteld als dierlijker en vaak aapachtiger in films en literatuur (Meijer 1996, Van Alphen 1992), of wordt 'aap' als scheldwoord gebruikt voor de zwarte ander.

20 Voor de samenvatting van het darwinisme en de evolutietheorie heb ik gebruikt gemaakt van Mayr 1992 en Howard 1982.

2I In feite ging het niet alleen om het vinden van de aapmens, maar om een hele reeks ontbrekende schakels. Haeckel trok in 1866 in zijn boek Generelle Morphologie veel aandacht met zijn Pithecanthropus, die hij opvoerde als hypothetische link tussen mensapen en mensen. Juist in die tijd, kort na het verschijnen van On the Origin of Species, kwam Paul Du Chaillu met de mededeling dat hij een gorilla had gezien, wat volgens hem een levende missing link leek te zijn (zie hoofdstuk 4 ), al had Owen, die in 1849 deze mensaap al had beschreven, nadrukkelijk vastgesteld dat het om een echte aap ging die niet in een mens kon veranderen. De Rooy vertelt in zijn boek Op zoek naar volmaaktheid over het kruisingsexperiment tussen vrouwen en apen dat de Nederlander Bernelot Moens in 1908 wilde uitvoeren om het raadsel van de ontbrekende schakel op te lossen. De Rooy wijst erop dat dergelijke kruisingsfantasieën niet pas sinds Darwin de kop op staken, maar dat fantasieèn over gemeenschap tussen tussen mensen en apen al veel ouder zijn (De Rooy r99r: 43).

22 Zie Noske 1992 en Kemperink 1993 en 1999 voor een bespreking van de 
implicaties van het darwinisme op de verhouding tussen de seksen.

23 Nog altijd verzetten creationisten zich tegen de gedachte dat mensen en apen een gemeenschappelijke voorouder hebben of dat mensen van apen zouden afstammen. 'Ik sta liever voor aap dan dat ik er een ben,' luidde de actieleuze van een groep Evangelisten in oktober 2000 (gezien op de Grote Markt in Groningen).

24 Hoofdstuk 6 van dit boek is gewijd aan het Great Ape Project.

25 Van Reybrouck (200o) attendeert erop dat gereedschapgebruik al eerder was geconstateerd - onder meer door de Jezuïeten in de zestiende en zeventiende eeuw, Darwin en Köhler. 'It was forgotten in the heroizing of Jane Goodall:' (Van Reybrouck 2000: 216-217). Zie ook hoofdstuk 3 van deze studie, waarin Helman in 1928 zijn aap eikels stuk laat staan met behulp van een steen. Over de mythevorming rondom Jane Goodall, zie hoofdstuk 5.

26 Dat apen religieus zijn, werd door Jane Goodall gesuggereerd in de documentaire Reason for Hope. A Life Less Ordinary van National Geographic (2000). Gevoel voor humor werd beargumenteerd in de National Geographic documentaire Leren van de grote mensapen. Over Jane Goodall, Dian Fossey en Biruté Galdikas (2000).

27 Dat we ons fixeren op het mens-dieronderscheid als het om apen gaat, is cultureel bepaald. Het geldt bijvoorbeeld in veel mindere mate voor niet-westerse landen, waarin de aap een goddelijke status toebedeeld krijgt, zoals Hanuman, de aap-God, aanbeden in Zuid-India. Deze goddelijke status kan echter ook opgevat worden als het 'disambigueren' van de aap door deze heilig te verklaren, zie de derde paragraaf van dit hoofdstuk.

28 Een sterk voorbeeld van de materiële impact van een definitie wordt beschreven door Irma van der Ploeg (1998). Zij laat zien hoe de definitie van een vruchtbaarheidsprobleem van 'een paar' via verschillende tekstuele translaties uiteindelijk resulteert in de behandeling van de vrouw op de operatietafel, en bepaalde sociale groepen uitsluit voor technieken als IVF.

29 Meestal concentreren onderzoekers zich op de representatie van één sociale groep in één of meer culturele uitingsvormen, denk aan onderzoek naar stereotypen van de vrouw in de film (bijvoorbeeld Haskell 1973), de zwarte vrouw in de westerse cultuur (bijvoorbeeld Collins I99I), de zwarte man in film en literatuur (Hoch 1979), witheid (Dyer 1997) of de lesbische vrouw (bijvoorbeeld Hoogland 1997), de zot (Mans r998), of het dier als ander (Noske r992, De Fontenay 1998). 
3o Er zijn enkele tegenvoorbeelden, waarin een man en een vrouwtjesaap een erotische affaire beleven, bijvoorbeeld in de films Queen Kong (1976) en Congo (1995), en de romans van John Collier Zijn apevrouw of: met een chimpansee getrouwd (1931), Bernard Malamuds De gratie Gods (1982) en Pierre Boulles De apenplaneet (1963) Het gaat daarbij meestal om parodieën en satires op het thema van de vrouw en de mannelijke aap. Voor een korte interpretatie van Colliers roman en Queen Kong, zie Jensen 1998. In Jenny Diski's Monkey's Uncle (1994) staat de liefdevolle band tusen een apin en een oudere vrouw centraal, en in Annemarie Jagoses Lulu. A Romance (1999) de relatie tussen een apin en een echtpaar. Diski en Jagose zijn te typeren als feministische schrijvers die bewust de traditionele rollenpatronen omdraaien. Amon Grunberg creëerde in zijn columns in NRC Handelsblad een vrouwelijk personage 'Aap' genaamd die met de schrijver, die als ikfiguur in zijn columns figureert, een affaire heeft.

3I Met haar oproep tot het vertellen van verhalen, schrijft Mol zich in een bredere trend in. Een aanzienlijk aantal studies besluit met evenveel enthousiasme met een oproep aan de lezer tot het bedenken van nieuwe verhalen en af te rekenen met het 'verbeeldingstekort', dat wil zeggen, het herhalen van oude verhalen en stereotypen (Van Dijck 1998; zie ook Haraway 1997 en Prins 1997). Met de teloorgang van 'de waarheid' en de opkomst van en de hoop die wordt gevestigd op het 'kleine lokale' verhaal, hebben vele vakgebieden een literary turn doorgemaakt, veelal gepaard met een reflexieve wending omtrent het schrijven over 'zelf' en 'ander', zoals in de antropologie, het recht, de ethiek (Geertz 1989).

\section{Verhalen over apen en vrouwen}

I Donna Haraway, wтмc (Onderzoeksschool Wetenschap, Technologie en Moderne Cultuur) Summerschool in Enschede r997.

2 Een zilverrug is een volwassen mannetjesgorilla. Zijn zilveren rug is een secundair geslachtskenmerk.

3 De relatie tussen wetenschap en cultuur wordt bestudeerd binnen de zogenaamde literature and science studies, en de cultural studies of scientific knowledge. Heel algemeen gesteld, houden literature and science studies zich bezig met vragen naar de relaties tussen literaire teksten en wetenschap. De termen 'literatuur' en 'wetenschap' worden daarbij op allerlei manieren gedefinieerd en ingevuld. Zo is er onderzoek gedaan 
naar de relatie tussen postmoderne literatuur en chaostheorie (Hayles 1990, Hayles 1991), literatuur en darwinisme (Beer 1983, Bulhof 1988, Kemperink 1998, Levine 1988, Shuttleworth 1984) en de relatie tussen literatuur en sociologie (Lepenies 1985). In Nederland verschenen twee overzichtsartikelen van Lies Wesseling over de relatie tussen literatuur en wetenschap (Wesseling 1996 en 1998). Wiel Kusters publiceerde onder meer artikelen over de relatie tussen geneeskunde en literatuur (bijv. Kusters 1991 en 1995b), de relatie tussen wetenschap en literatuur in het werk van Willem Frederik Hermans (Kusters 1999) en de relatie tussen poëzie en (biologische) wetenschap (Kusters 1997). Haraways werk is te situeren binnen de cultural studies of scientific knowledge, de door Joseph Rouse (1992) aldus aangeduide richting binnen het wetenschapsonderzoek die zich onder andere bezint op de rol van culturele artefacten bij de verbeelding van wetenschap. Hierbij valt ook te denken aan het werk van Van Dijck (1998) over de popularisering van de genetica en het onderzoek van Stacey (1997) naar de verbeelding van kanker in onze cultuur.

4 Naast de opvatting dat wetenschap en cultuur doortrokken zijn van ideologie, zijn er ook studies die het verband tussen wetenschap en cultuur op een andere manier leggen. Sommigen benadrukken sterker de talige verwevenheid van cultuur en wetenschap, en onderzoeken hoe bepaalde concepten 'reizen' en zich verplaatsen van het ene domein naar het andere. Gekeken wordt dan bijvoorbeeld hoe cultuur en wetenschap van dezelfde metaforen gebruikmaken (bijvoorbeeld Myers 1990; Beer 1983). Anderen zijn meer geïnterresseerd in de specifieke (cultuur)historische verbanden tussen cultuur en wetenschap (bijvoorbeeld Weijers I991). Haraway let, naast politieke verbanden, ook op gemeenschappelijk taalgebruik in wetenschap en cultuur, maar plaatst een bepaald vocabulaire onmiddellijk in een politieke context.

5 Volgens Schudson (1997) heeft Haraway er een handje van iets te gemakkelijk niet-geëxpliciteerde verbanden te leggen tussen twee zaken die op de wereld plaatsvinden. Want tegen de tijd dat de museumtentoonstelling werd geopend, in 1936 , was er van de eugenetische beweging vrijwel niets meer over, schrijft Schudson. Haraway expliciteert niet hoe het museum en zijn bestuur zich verhielden tot de eugenetica, terwijl ze het museum simpelweg zonder argumentatie poneert als een grote actor in cultuurpolitiek. 'She got the history wrong,' stelt Schudson (Schudson 1997: 55).

6 'Story' wordt door Haraway helaas niet gedefinieerd; de termen 'story', 
'text' en 'narrative' worden door Haraway door elkaar gebruikt. Binnen de literatuurwetenschap is het echter gebruikelijk een onderscheid te maken tussen verhaal ('story' of 'plot') en vertelling ('narrative'). 'Ik fiets' is bijvoorbeeld wel een vertelling, maar nog geen verhaal. Er is weliswaar sprake van een handeling, maar om de kwalificatie verhaal te krijgen, moet er sprake zijn van een ontwikkeling, een gebeurtenis (Van der Voort 1991: 24). 'Tekst' is een brede term die beide omvat. In dit boek worden 'tekst' en 'verhaal' door elkaar gebruikt. De aandacht gaat uit naar verhalende teksten, dat wil zeggen teksten waarin een verhaal wordt verteld (Bal 199o), Daarbij hanteer ik een ruim tekstbegrip. Ik reken niet alleen talige teksten, maar ook beeldteksten tot verhalende teksten. Bal (1990) maakt een onderscheid tussen verhalende teksten en verhaal. Een verhaal is wat er verteld wordt, verhalende teksten kunnen hetzelfde 'verhaal' op verschillende manieren vertellen. Het gaat mij uiteraard ook om hoe die verhalen verteld worden; wanneer ik de term 'verhaal' gebruik, gaat het om een verhalende tekst en refereer ik aan vorm én inhoud. Natuurlijk verdienen talige en beeldteksten deels een mediumspecifieke aanpak bij analyse, en die probeer ik zoveel mogelijk te waarborgen. Ik ben echter in eerste instantie niet geïnteresseerd in de verschillen tussen talige en visuele media (zie daarvoor Mitchell 1994), maar in de verhalen die er verteld worden.

7 Haraway, wTMc summerschool 1997 . Voor een uitvoerigere beschouwing over de relatie tussen woorden en dingen in relatie tot gender, zie Oudshoorn 1998. Voor een concreet voorbeeld van de wijze waarop een bepaald woordgebruik in de materiële en fysieke leefwereld ingrijpt, zie Van der Ploeg 1998.

8 Een Amerikaanse journaliste tijdens de wTMC summerschool 1997.

9 Bijvoorbeeld: The technical, textual, organic, historical, formal, mythic, economic, and political dimensions of entities, actions, and worlds implode in the gravity well of technoscience - or perhaps of any world massive enough to bend our attention, warp our certainties, and sustain our lives?' (Haraway 1997: 68)

Haraway, wTMc summerschool 1997.

II politisering van wetenschap. Gross en Levitt, schrijvers van het geruchtmakende boek Higher Superstition (1994), dat gelezen kan worden als een aanval op academici die uitspraken doen over het politieke karakter van met name de bèta-wetenschappen, schaarden Haraway onder de 'leftists', de groep linkse intellectuelen die volgens hun te ver zijn 
doorgeslagen in het ideaal van politieke correctheid en van 'harde' wetenschap geen kaas hebben gegeten.

12 Haraway, wTMc summerschool, 1997.

13 Deze kritiek geldt wat mij betreft nog sterker voor Modest Witness (Haraway 1997). In dit boek bespreekt ze opnieuw wetenschappelijke artikelen naast advertenties, science fiction en schilderkunst. Bijzonder in dit boek is de samenwerking met kunstenares Lynn Randolph. Elk hoofdstuk begint met een afbeelding van een schilderij van Randolph, die zich bij het maken van haar werk liet inspireren door Haraways ideeën. Een interessante poging om kunst en technocultuur met elkaar in gesprek te brengen, maar de manier waarop Haraway de schilderijen bespreekt, doet een beetje pijn in het hart van elke kunstliefhebber. Waar ze elders pleit voor meerduidigheid en ambiguitteit als het gaat om het vertellen van verhalen, laat ze hier niets aan de verbeelding over. $\mathrm{Ze}$ voorziet elk schilderij van een lange lap tekst en uitleg (die eenduidig is). Kunst is verworden tot een puzzel die opgelost moet worden. Lezen is bovendien verworden tot een soort zappen; Haraway introduceert de notie van hypertext voor haar associatieve leeswijze, en illustreert dit aan de hand van een schema waarin ze de ontwikkelingen op het gebied van wetenschap, technologie, maatschappij en cultuur in één tabel samenvat (Haraway 1997: 219-229). Voor een bespreking van dit boek, zie Jensen $1998 \mathrm{~b}$.

I4 Haraway beschouwt de liefde van de zwarte gorilla voor een blanke vrouw als een interraciale relatie. 'He [King Kong, s]] was the icon of the captive blank man's love for the white woman' (16r) Hoewel ze deze film nog wel iets uitvoeriger bespreekt, en inderdaad de vinger op een zere plek legt, blijven bepaalde vragen liggen. Haraway noemt de aap een projectiefiguur die ons vooral informatie geeft over mensen. $\mathrm{Ze}$ geeft een symbolische interpretatie van de aap in King Kong: de gorilla is volgens Haraway een icoon die staat voor 'de zwarte man'. Is dat eigenlijk wel zo? Waarom dan geen zwarte man gekozen, maar een aap? De vraag doet zich ook voor of King Kong, gezien zijn formaat, nog wel een 'aap' genoemd kan worden. In de film wordt hierover zelfs gedebatteerd. En waarom was King Kong in 1933, maar ook in de jaren erna, getuige de remakes, zo populair? Deze vragen komen aan de orde in hoofdstuk 4 van dit boek.

15 Het onderzoek naar en de verbeelding van orang-oetans komt nauwelijks aan bod in het boek van Haraway; is deze aap niet zo populair in onze verbeelding? Bonobo's komen ook niet aan bod, maar dat is min- 
der verwonderlijk. Hoewel deze apensoort voor het eerst in 1929 als cen aparte groep werd onderscheiden van chimpansees, is de bonobo pas in 1997 met het verschijnen van Bonobo: The Forgotten Ape (De Waal \& Lanting) als aparte mensapensoort bekend geworden.

16 Dat geldt voor de kunsten in het algemeen. Omdat dit boek gaat over verhalen over apen, richt ik mij in deze paragraaf op het vakgebied waarbinnen veel over verhalen is nagedacht, de literatuurwetenschap.

17 'For New Criticism texts were fundamentally ambiguous and interpretations were not. Today, texts are ambiguous and interpretations are indeterminate [m] The concept of indeterminacy proposes that a radical limitation that is built into the activity of literary interpretation, whose very attempt to find a determinate meaning in literary works prevents it from succeeding its enterprise'. (Graff 1998: 16). Ook tussenposities zijn mogelijk. Perloff (1981) beschouwt onbepaaldheid bijvoorbeeld niet als een eigenschap van alle teksten zoals Derrida, maar als een eigenschap voorbehouden aan een bepaald type teksten uit een bepaalde periode, namelijk de Symbolisten.

I8 Van Heijst ontrekt zich naar mijn mening overigens ook niet helemaal aan de dubbelheid van enerzijds het autonome subject en anderzijds het pleidooi voor het subject dat openstaat voor vreemdheid en discontinuïteit. Dat blijkt onder meer al uit de titel. 'Zelfverlies' vooronderstelt namelijk dat er zoiets als een zelf is dat te verliezen valt, en impliceert in die zin al een autonome subjectopvatting. In postmoderne subjectopvattingen daarentegen is het zelf een constructie, opgebouwd uit een veelheid van teksten.

19 De term intertekstualiteit is bedacht door Julia Kristeva, die in 1969 de term introduceerde naar aanleiding van het werk van de Russische literatuurwetenschapper Bakhtin (Kristeva 1980). Voor de niet-talige intertekstualiteit bedacht Anneke Smelik de term intervisualiteit (1995). Omdat ik een breed tekstbegrip hanteer, waar zowel beeld als taal onder vallen, spreek ik van intertekstualiteit, ook daar waar het gaat om niettalige verwijzingen. Ik heb weinig aandacht besteed aan de constructie van het beeld. Hoewel ik me bewust ben van mediumspecifieke theorieën over het beeld, benader ik in dit boek vooral de narratieve aspecten van de film.

20 Voor de betekenis van de aap in oudheid werd baanbrekend werk verricht door William C. McDermott (1938). H.W. Jansons Apes and Apelo$r e$ in the Middle Ages and Renaissance (1952) biedt een overzicht van de betekenis en symboliek van de aap in de kunstgeschiedenis in de Mid- 
deleeuwen en de Renaissance. Daarnaast zijn er nog een aantal inventariserende studies gedaan, bijvoorbeeld Das Affenbuch (Schaeffer \& Köhler 1994) en Der Mensch als Affe in der Deutschen, Französischen, Russischen, Englischen und Amerikanischen Literatur des 19. und 20. Jahrhunderts (Gerigk 1989) en The Ape in Myth and Art (Zuckerman 1998) en Men and Apes (Morris \& Morris 1966).

Zie Janson 1952: 26r-268 voor een overzicht van de vrouw en de aap. Naar afbeeldingen van vrouwen met dieren in het algemeen zijn ook studies verricht, bijvoorbeeld Beauty and the Beast. Visions and Revisions of an Old Tale (Hearne 1989), Lief dier. Over bestialiteit (Dekkers 1992). Michael Schwibbe van het Deutsches Primatenzentrum Göttingen was zo vriendelijk mij zijn ongepubliceerde manuscript Der 'geile' Affe (1999), een studie naar de iconografische traditie van de aap als wellustig dier - voornamelijk in de Duitse cultuur - toe te zenden.

De acht typen zijn: I. Der Kulturmensch als gelehriger Affe, 2. Der Affe als der Saboteur aller Kultur, 3. Der Affe als der Paria in der Revolte, 4. Die Schöne und das Tier, 5. Lucys Töchter, 6. Der Staat der Affen, 7. Experimente mit Affen, 8. Der Affe als Exemplum der unschuldigen Kreatur. Gerigk wijst er verder op dat de aap vanwege zijn dierlijkheid tegenover de geleerdheid van de mens wordt gezet: 'Wo ein Affe ist, da is auch ein Professor!' (31). Gerigk analyseert literaire werken (voornamelijk Duitstalig, onder andere verhalen van Kafka, Wilhem Hauff en Ingeborg Bachman) op een structuralistische en tekstimmanente wijze: hij kijkt naar de tegenstellingen die de tekst vormgeven en richt zich weinig op de context.

\section{Waarom een man een aap vermoordt}

I De paginanummers in dit stuk verwijzen naar de eerste druk. Een kortere bewerking van dit hoofdstuk werd eerder gepubliceerd in Nederlandse Letterkunde (Jensen 2000a).

2 In hoofdstuk 1, paragraaf 4, van dit boek, heb ik de rol van de aap in het darwinisme en het christendom al kort uiteengezet. Over de rol van dieren en apen in het werk van Freud, zie bijvoorbeeld Corbey 1991.

3 In Wij en de litteratuur (1931) heeft Helman een poëtica uiteengezet, die de uitgangspunten van De Gemeenschap onder woorden bracht. De auteur moet via drie steunpunten de lezer in een 'wij-besef includeren: via een religieus, een sociaal en een ethisch besef. Zijn eerste steunpunt is 
de verhouding tussen Ik en God: de creatie is een adoratie van de Schepper. Ten tweede verhoudt het Ik zich tot andere mensen, en ten derde is er de relatie tussen Ik en Mijzelf. De eerste, Helmans religieuze motivatie als auteur, verkondigde hij niet meer na zijn breuk met de katholieke kerk in de jaren veertig. Op latere leeftijd vertelde Helman een voorstander te zijn van een open Godsbegrip. 'Het begrip God, dat kinderlijke begrip van een vader die ergens is en voor ons zorgt, [is] langzamerhand overgegaan tot het begrip van een potentie, een mogelijkheid, een raadsel' (geciteerd in Van Verre 1980: n) Het woord 'raadsel' gebruikt Helman ook regelmatig voor de aap in Mijn aap schreit, waarmee de aap geassocieerd raakt met dezelfde ongrijpbaarheid die het 'goddelijke' voor Helman had.

4 De verbeelding van de staart als fallus past in de vroegchristelijke traditie waarin de aap een zinnebeeld is voor geilheid en de gevallen mens symboliseert. Staartloosheid werd opgevat als een poging om boven de door God bedoelde rangorde uit te stijgen door gelijk een mens te willen zijn (Janson 1952: 16). De staart als fallus, als onderscheidend teken tussen de zondige, geile aap en de zedelijke mens, is een terugkerend thema in de literatuur en de kunsten. Een bekend voorbeeld van de voorstelling van de apenstaart als fallus is het achttiende-eeuwse Reize door het Aapenland (1973; oorspr. 1788 ) van J.A. Schasz. Ook in een later boek van Helman, Mijn aap lacht (1953), speelt de staart een belangrijke rol.

5 De staart wordt als 'verstandig' tegenover de 'domme' grijns geplaatst. Om het tegenovergestelde van 'dom' te benoemen, kiest de verteller ook vaak de buik van de aap uit. Wanneer het gevoel beslag op de aap heeft gelegd, dan houdt hij 'zijn staart verborgen onder zijn buik' (36). In Kafka's 'Ein Bericht für eine Akademie', waarin een verteller tegenover een rechtbank verhaalt over 'zijn vroegere leven als aap' en het wanstaltige gedrag van de mens dat hij ervoer, lezen we iets soortgelijks: 'Ein klarer schöner Gedankengang, den ich irgendwie mit dem Bauch ausgeheckt haben muß, denn Affen denken mit dem Bauch' (Kafka 1994 [oorspr. 1917]: 121). Met de buik kan de aap, anders dan je misschien zou verwachten, helder denken. Tussen Kafka's verhaal en Mijn aap schreit zijn meerdere parallellen. In Kafka's verhaal willen enkele mannen het 'raadsel' van het 'wezen' van de aap oplossen, zoals ook de aap in Mijn aap schreit 'een vraagteken' vormt voor de hoofdpersoon.

6 In Mijn aap schreit gebruikt de aap eikeltjes om te knikkeren. Het spelvraagstuk bij dier en mens stond in de jaren twintig op de wetenschap- 
pelijke agenda van de psychologie, zie Buytendijk 1920 en 1933. Opvallend is dat Helman ook gereedschapsgebruik toekent aan zijn aap: de aap tracht zijn eikels stuk te slaan op een steen om ze op te eten. Gebruik van gereedschap bij apen, zo schrijft men meestal, werd voor het eerst in de jaren zestig door Jane Goodall geobserveerd en geaccepteerd als wetenschappelijk feit (Goodall r99i). Destijds werd het als een revolutionair inzicht beschouwd: niet langer onderscheidde de mens zich als homo faber van de aap. Mogelijkerwijs had Helman echter Köhlers The Mentality of Apes (1925) gelezen, waarin deze al constateerde dat apen met een stengel naar termieten hengelen. Zie ook hoofdstuk I van dit boek, noot 25 .

7 De verteller suggereert dat zijn aap zou kunnen lezen of doen alsof, en, daar hij het boek in de hoek heeft gegooid, ook nog eens een oordeel over het gelezene heeft. Het deeltje dat de aap in de hoek keilt, is mogelijkerwijze Goethes Die Wahlverwandtschaften uit 1809. Hierin gedraagt de kokette, ijdele en impulsieve Luciane zich zodanig, dat de lezer haar gaat identificeren met haar huisdier, een aap, die zij adoreert. Wanneer haar aap tijdelijk afwezig is, maakt dit haar doodongelukkig: 'Wenn ich nur sein Bildnis sehen könnte, so wäre ich schon vergnügt' (Goethe 1909: 171). Misschien bracht Lucianes verlangen naar een afbeelding Helmans aap op een idee. Een tweede optie is dat de aap verdiept was in het natuurwetenschappelijke werk van Goethe. In een van zijn biologische studies uit ${ }_{17} 82$ neemt Goethe stelling tegen de idee van de Nederlandse anatoom Petrus Camper dat de aap wel een tussenkaakbeen zou hebben en de mens niet (Goethe 1954: 154-166). Wanneer de verteller en zijn broer discussiëren over de missing link, merkt de laatste op zich iets te herinneren over 'de gelaatshoek' (43).

8 In deze passage zegt de verteller tegen Martha dat hij denkt dat zijn aap verliefd was op een kraai. Martha reageert lachend: Wat een fantast ben jij! Hoe kan dat nu: een aap verliefd op een kraai. Dat een aap verliefd wordt op een andere aap kan ik me nog voorstellen, maar op een kraai!' (34)

9 Hij verwijst hierbij naar Oscar Wilde, The Picture of Dorian Gray, een roman uit 1891 over een zeer ijdele man die zijn zelfportret heeft laten maken. Hij durft dit echter aan niemand te laten zien, omdat er een persoon wordt afgebeeld, die met de dag lelijker en ouder wordt, en de verdorven, gecorrumpeerde ziel van de ijdele man toont: 'alle boeken zijn zelfportretten' is een vrije weergave van Wilde: 'every portrait that is painted with feeling is a portrait of the artist, not of the sitter. The sitter 
is merely the accident, the occasion. It is not he who is revealed by the painter; it is rather the painter who, on the coloured canvas reveals himself. The reason I will not exhibit this picture is that I am afraid that I have shown in it the secret of my own soul.' (Wilde 1992: 13). Interessant is ook wat Helman zelf hierover zegt in Wederkerige portretten (1985): '...Wie kent het eigen uiterlijk anders dan door een spiegelbeeld, dat links en rechts omkeert, het fenotype op de plaats van het genotype stelt? De man voor zijn scheerspiegel, de vrouw voor die op haar toilettafel, zij zien zichzelf nooit anders, zij "herkennen" zichzelf alleen in deze inversie, als geïnverteerden...' (6r)

Io Het is ook mogelijk dat de verteller hier staat voor Helman zelf, en dat de schrijver op dit moment aangeeft dat Mijn aap schreit zijn zelfportret is, net als overigens zijn andere boeken. De persoon Helman, zoals die naar voren komt in de biografische essays van van Kempen (1998b), vertoont inderdaad enige overeenkomsten met de verteller, met name wat de belezenheid betreft. Helman stond te boek als een echte renaissanceman. Het autobiografisch gehalte van de tekst Mijn aap schreit zou erop neer komen dat Helman kampte met zijn 'vrouwelijke' zelf, een idee dat werd geopperd door van Kempen (1998b en 1998a: 7-8), zij het met de nodige reserves en gepaste kanttekeningen. Uit biografische gegevens kunnen we opmaken dat Helman gefascineerd was door apen, omdat hij vond dat hij zelf op een aap leek. Wegens zijn gebogen postuur, zijn grote oren en zijn 'aapachtig' gezicht werd hij vroeger op school vaak voor aap uitgescholden, iets wat hem bij vlagen vreselijk dwarszat. Als klein kind werd hij bovendien door zijn slechtziende grootmoeder 'besnuffeld' alsof hij een dier was. (Van Verre 1980).

II Herbart (1776-I84I) was pedagoog, en schreef onder andere over de merites van straffen en belonen als opvoedkundig middel. In Mijn aap schreit zien we hoe de verteller Herbarts ideeën steeds probeert toe te passen door zijn aap te bestraffen, maar dit later opgeeft: 'Ik schold op hem, maar sloeg hem niet meer' (36). Der Vater (De Duitse vertaling van August Strindbergs Fadren, uit 1887) gaat over een huwelijk tussen een ritmeester en zijn vrouw, dat op de klippen loopt. Hij is zachtaardig en geleerd, zij is hardvochtig, weigert zich te conformeren aan de rol van huisvrouw, en voert een pleidooi voor een open huwelijk. De man moet tragisch het onderspit delven: hij sterft ten gevolge van alle ondraaglijke spanningen. Tijdens een ruzie roept de ritmeester over de relatie tussen mannen en vrouwen: 'Het is net rassenhaat dit. Als het waar is dat wij van de apen afstammen, moeten het twee soorten zijn. 
We lijken immers in niets op elkaar' (Strindberg 1989: 56). Dat de verteller van Mijn aap schreit zo verdiept is in dit boek, getuigt wederom van zijn preoccupatie met de thema's religie en seksualiteit. Het Tauchnitzdeeltje kan van alles zijn. Bernard Tauchnitz (1816-1895) was uitgever van veel boeken over muziek en literatuur, waaronder Romeinse en Griekse klassiekers. Het zou bijvoorbeeld The White Monkey (1925) van John Galsworthy kunnen zijn. In deze roman, die onderdeel uitmaakt van een negendelige serie, beschrijft Galsworthy de ondergang van een bourgeoisiefamilie die wanhopig probeert vast te houden aan normen en waarden en zich verzet tegen de verslindende consumerende mens. Deze immorele mens wordt in het verhaal gesymboliseerd door het beeld van een witte vretende aap, die voorkomt op een schilderij in het verhaal. 'White monkey' was in deze tijd tevens een uitdrukking voor sommige groepen, waaronder de werkende klasse, de jood, de Oost-Europeanen en de dieren, om te verwijzen naar 'primitivisme' in deze mensen. Mogelijkerwijs wordt de aap hierom kwaad en smijt hij het daarom in de hoek. Overige verwijzingen worden elders in dit hoofdstuk toegelicht.

12 Freud vergeleek het gedrag van kinderen met het 'primitieve' gedrag van ongeciviliseerde volkeren. Beiden waren impulsief, negeerden regels en waren spontaan, zo stelde hij. De primitieve volkeren werden op hun beurt weer met dieren vergeleken. In Mijn aap schreit zien we iets soortgelijks op twee manieren terug: kinderen worden met apen vergeleken en de aap wordt regelmatig met een kind vergeleken. Wanneer de aap speelt met eikels als knikkers, rolt hij ze 'als een jochie' (26), en wanneer de aap schreit zit hij 'rechtop als een kind' (53).

r3 Het Latijn wordt hier, net als in veel van zijn andere boeken, door Helman niet vertaald, hetgeen Michiel van Kempen interpreteert als een 'typisch trekje van de eigenzinnige autodidact [...] die het onwetende plebs graag achter zich laat'. (Van Kempen 1995: 9) Bij latere drukken in 1957,1966 en 1983 zijn de beide Thomascitaten weggehaald, vermoedelijk door Helman zelf, die bij herdrukken vaak veel wijzigingen aanbracht. Naar de reden kunnen we slechts gissen; Helman had zich inmiddels tegen de katholieke kerk gekeerd, en wilde wellicht Thomas niet in de herinnering roepen. Ook de 'dedicace', de opdracht aan een goede vriend, en de ondertitel 'een korte roman' zijn in latere drukken weggehaald. Oorspronkelijk verscheen Mijn aap schreit in 1928 als een aparte editie. In latere drukken combineerde Helman Mijn aap schreit met de verhalen uit Het euvel Gods (Helman 1957). In Omnibus (1947) 
schreef Helman in het voorwoord dat hij ze gecombineerd had voor de herdruk omdat de thematiek van de vijftien verhalen uit Het euvel Gods 'volkomen aansloten bij Mijn aap schreit' (Helman 1947: 6). Aangezien die verhalen veelal gaan over irrationeel handelen van de mens en zijn relatie tot God, is dit opnieuw een aanwijzing dat de bijbelse intertekst van Mijn aap schreit van belang is voor de interpretatie. Anton van Duinkerken wijst hier ook op in zijn recensie van Mijn aap schreit in De Tijd op zondag (1928). Hij meent dat de roman een 'fabel' is over 'het ziek geworden instinct' en dat de moraal van het verhaal wordt neergelegd in de Thomastekst, die wordt onderbroken door het verhaal. Van Duinkerken meent dat het boek een grote kans loopt 'verkeerd verstaan en geinterpreteerd' te worden, maar benadrukt de vrijheid van de katholieke romanschrijver en voegt er gerustellend aan toe dat Helmans boek niet 'onzedelijk' is.

I4 Voor de vertaling van de citaten van Thomas heb ik gebruik gemaakt van The Summa Theologica of Saint Thomas Aquinas. Translated by the Fathers of the English Dominican Province. Revised by Daniell J. Sullivan. Volume I. Chicago: The University of Chicago, 1952.

15 De laatste zin 'en onwetend zondigt men niet, zelfs niet voor de wet', zinspeelt vrij direct op diverse bijbelpassages waarin gerefereerd wordt aan de vraag of zij die onwetend zijn ten aanzien van de goddelijke wet kunnen zondigen (bijvoorbeeld Ez. 45:20; Num. 22:34). Volgens de katholieke leer kan een onwetende mens niet verantwoordelijk worden gehouden voor het kwaad dat hij of zij aanricht.

I6 De idee dat de aap tot de mens staat zoals de mens tot God is een idee dat al in de oudheid werd geuit (Janson 1952). De aap is lange tijd, sinds de oudheid, een dier geweest dat beladen was met negatieve connotaties, zoals bedrog, hypocrisie en lafheid. In verschillende mythes in de oudheid werd gedacht dat mensen die hadden gezondigd 'omlaag' werden gezet en in apen werden veranderd. De aap werd in het vroege christendom veelal opgevat als de Satan van God, de duivel, en fungeerde als scheldwoord voor vijanden van het christendom. De aap werd 'simius Dei', na-aper van God, en figura diaboli, duivels figuur, genoemd. Helman zet dit op zijn kop, door de aap, na-aper van God, te vergelijken met Christus in plaats van de duivel (zie de paragraaf 'Ecce simius! De aap als Christusfiguur' van dit hoofdstuk).

17 Bijvoorbeeld bij de oude Egyptenaren en in het totemisme.

18 De aap wordt, door hem met een Sfinx te vergelijken, en zijn staart met een vraagteken, als een raadsel voorgesteld. Dit verwijst naar het ver- 
haal van Oedipus. Het raadsel dat de Sfinx Oedipus volgens Sophocles opgaf, luidde, in een (gemoderniseerde) vertaling van Vondel: 'Wat is het voor een dier? Het slaat maar één geluid. Het gaat op vier en twee en op drie voeten uit'. (geciteerd in Kusters 1995: 28) Oedipus weet het antwoord: de mens. Die loopt eerst, als kind, op handen en voeten, wordt dan tweebenig en heeft, als oudere, een stok nodig om te lopen. De stok komt ook voor in Mijn aap schreit: tijdens een woede-uitbarsting gooit de verteller een wandelstok naar zijn aap.

I9 De humanisten uit de zestiende eeuw (Erasmus onder anderen) waren christen-humanisten, dat wil zeggen dat het mensbeeld samenhing met de bijbelse notie dat de mens geschapen was naar Gods beeld en gelijkenis (genesis) en met de menswording van God in Christus. De mens was dus heel bijzonder door deze relatie met God. Voor de niet-christelijke humanisten die zich in de twintigste eeuw organiseerden, was Christus als ijkpunt, als ideale mens om na te volgen, verdwenen. Helmans mederedacteur bij De Gemeenschap, Anton van Duinkerken, discussieerde hierover met dr. Tielrooy, de latere redacteur van het antireligieuze tijdschrift Apollo, waar Helman in de jaren veertig bij terecht kwam (Van Kempen r999).

20 In de roman Red Earth and Pouring Rain (1995) van de Indiase schrijver Vikram Chandra treffen we een opvallende intertekstuele echo aan. Deze roman vangt aan met de beschrijving van de intense haat van een jongeman jegens zijn aap. Wanneer hij de aap in een boom ziet klimmen, lezen we: '[...] he felt an old adolescent anger awaken, sensed an old bitterness tinged with resentment and frustration leaping up again, ancient quarrels and terrors and reasons for leaving raising their heads, unquiet, undead, effortlessly resurrected: (Chandra r995: 6). De jongeman doet een poging de aap te vermoorden met een pistool, en de aap valt bloedend neer. Zijn verontruste moeder komt onmiddellijk toegesneld en herinnert hem eraan dat in India de doodstraf geldt voor het doden van de aap, die als heilig wordt beschouwd. De aap overleeft op miraculeuze wijze de schotwonden en gaat achter de typemachine zitten. Hij stelt zichzelf voor als de reïncarnatie van Hanuman, de god-aap uit de Indiase cultuur en de beschermheilige van de dichters. In Mijn aap lacht noemt Helman een van zijn personages (de dokter) Hanuman, en is de aap de verteller van het verhaal.

2I Misschien kiest Helman voor deze vergelijking om niet al te nadrukkelijk aan Christus te refereren en van blasfemie te worden beschuldigd.

22 Soms echter wordt het beeld van een dier als Christus gekozen om het 
dierenleed invoelbaar te maken en aandacht te vragen voor dierenemancipatie. De historica Amanda Kluveld haalt in Reis door de hel der onschuldigen. De expressieve politiek van de Nederlandse anti-vivisectonisten 189o-1940 een passage uit Eli, waar zijt gij (1938) van Jo Zeegers-Claessen aan, waarin een hond op de tafel wordt vastgebonden: 'De angst en smart doorboorden zijn hart. Dat waren de oogen van Christus, toen hij gekruisigd werd:' (Kluveld 2000: III) Voor de wijze waarop apen als Christus worden verbeeld, zie ook hoofdstuk 4 en hoofdstuk 6 van dit boek.

23 Wanneer het deeltje van Goethe dat de aap in de hoek smijt, diens biologische studie naar de overeenkomsten tussen de kaakstructuur van mensen en apen betreft, dan kan ook deze daad als een protest worden geïnterpreteerd tegen continuitteitsdenken. Zie Goethe 1954.

24 Spanningen en dubbelzinnigheden worden in de culturele verbeelding vaak opgelost met de dood. Soms is de dubbelzinnigheid vertegenwoordigd in één persoon. Zo is de gorilla in King Kong tegelijkertijd aantrekkelijk en afstotend. Dit dilemma wordt opgeheven, doordat de film King Kong eindigt met de dood van de gorilla.

25 Over de stereotiepe representatie van vrouwen in het werk van Helman, ook in relatie tot biografische gegevens over Helmans relatie met en opvattingen over vrouwen, zie Van Kempen r998b: 33-40.

26 Deze dubbelzinnigheid van Martha is opnieuw een restant van evolutiedenken en de negentiende-eeuwse visie op de vrouw, toen het idee heerste dat vrouwen die boeken lezen gevoelig zijn voor baarmoederproblemen, omdat zij 'vermannelijkt' zijn. Vrijwillige kinderloze, seksueel geïnteresseerde, carrière-beluste of intellectuele vrouwen zijn geen 'echte vrouwen, maar bizarre spelingen van de natuur, schoonheidsfoutjes van de evolutie' (Kemperink 1993: 131-132).

27 Het 'intermezzo' in Mijn aap schreit wijst ook in deze richting. Vlak voor het einde van het verhaal (rijkelijk laat dus voor een intermezzo), vertelt de grootmoeder, nadat de aap in de tuin is begraven, een oud sprookje van de indianen. Hierin looft een koning een beloning uit voor degene die hem kan helpen bij het plukken van de kokosnoten in de bomen die zo hoog waren dat niemand erbij kon. Op een dag klimt een jongeman de boom in, en brengt ze de koning. Als dank mag hij zijn dochter huwen. Elke ochtend gaat hij baden, en weigert hij het gezelschap van de ongelukkige prinses. Wanneer de min hem een ochtend achtervolgt, ziet ze dat hij bij de vijver al zijn kleren uittrekt. Hij blijkt een aap te zijn en begint een lied te zingen, waarop vijftig apen te voor- 
schijn komen en giechelend mee spartelen in het water. Als de koning het nieuws verneemt, schiet hij met pijl en boog de jongeman dood en zijn vanaf dat moment alle apen gehaat in het land. Ja, behalve misschien de prinses', merkt de verteller op als zijn grootmoeder klaar is. Een intermezzo geeft soms een samenvatting van het verhaal op een ander niveau. Van Kempen heeft geopperd dat hier een soort mythische indiaanse verklaring wordt geven voor het fenomeen apenhaat, en dat het verhaal hiermee wordt ingebed in een indiaanse context (bron: persoonlijke correspondentie, e-mail d.d. 20 sep. 1999). Het verhaal is echter niet uitsluitend indiaans, maar een archetypisch sprookje dat in varianten in veel culturen voorkomt. De analogie van het intermezzo en het verhaal als geheel bestaat eruit dat in beide verhalen een aap, die menselijke ambities tentoonspreidt, het moet bekopen met de dood. De prinses zou met Martha vergeleken kunnen worden. $\mathrm{Zij}$ blijft, net als Martha, van wie we weten dat ze volgens de verteller, net als alle vrouwen, 'zulk een overdreven mede-lijden met dieren' (38) heeft, van de aap houden.

28 Op de binnenflap van Mijn aap lacht schreef de uitgever bij monde van Helman: 'Wij willen er hier met nadruk op wijzen, dat "Mijn aap lacht" geen herschrijving is van zijn jeugdwerk "Mijn aap schreit", maar een volkomen nieuwe, andere, zeer oorspronkelijke roman [...]?

29 In een recensie in Vrij Nederland (27-6-1953) oordeelde Gerrit Kouwenaar om deze reden gematigd enthousiast over Mijn aap lacht. Volgens hem slaagt Helman er niet in zijn conclusies over evolutie, heimwee, onschuld en geluk, geloof 'artistiek aanvaardbaar' te maken. De aap is een spreekbuis geworden voor Helmans eigen ideeën. Bovendien vindt hij dat de wijze waarop de hypocrisie van de mensenwereld wordt aangetoond, namelijk door een aap het woord te geven in een mensenwereld, 'goedkoop': 'Merkwaardig is bovendien dat de elementen van domheid en slechtheid ook voor het verblijf van de aap bij de mensen in de jungle kunnen worden aangetroffen, maar daar kennelijk door de aap "doorzien en zoetjes geironiseerd" worden.' Zie ook Van Kempen 1995 voor een interpretatie van Mijn aap lacht.

30 Hoewel de aap aankondigt dat hij beslist geen darwinist is, ontpopt hij zich in de rest van de roman als een sterke criticus van het geloof: 'Van hun gedoe in kerken ontging me, ik moet het eerlijk bekennen, iedere, zin.' (146). In een hilarische scène probeert een dominee, een fervente antidarwinist, de aap neer te schieten, maar dat lukt hem niet. Op de eerste druk staat op de kaft een grijnzende aap op een kerktoren. In la- 
tere drukken is deze tekening vervangen door een 'darwinistisch' plaatje van een voet van een aap die zich ontwikkeld naar een mensenvoet.

3I Helman schreef Mijn aap schreit enkele jaren na zijn komst naar Nederland in 1921. Expliciete of impliciete verwijzingen naar de relatie tussen het Westen en Suriname treft men niet aan; wel is het zo, dat de vraag die Helman dikwijls in zijn romans uitwerkte, en die we ook in Mijn aap schreit terugvinden is: wie ben ik en waar hoor ik thuis? (Van Kempen 1998b: 96). Mijn aap schreit wordt gestructureerd door de oppositie natuur versus cultuur, en andere hieraan gerelateerde tegenstellingen, zoals buiten versus binnen, vrijheid versus gevangen en wildheid versus beschaving. Zowel de aap als de verteller verkeren in dit verhaal in existentiële eenzaamheid: ze voelen zich gevangen in hun huis. De aap is een huisdier geworden, een situatie die 'onnatuurlijk' is, en voelt zich het prettigst wanneer hij buiten in de vrije natuur is. Wanneer de aap bijvoorbeeld met de verteller gaat wandelen, lezen we: 'Reeds wanneer wij in de buitenwijken kwamen, begon hij te huppelen en dolle sprongen te maken, zonder vrees door zijn capriolen in het prikkeldraad te komen' (25). En: 'Dan zijn wij buiten, waar de weiden openliggen en waar het heesterhout begint. Mijn aap is uitgelaten en maakt een salto over den kop' (26). Vaak lijkt de verteller zich te identificeren met de opgeslotenheid van zijn dier. Als hij ziet dat de aap er levenloos en met 'fletse ogen' bij ligt, zet hij het raam open omdat het hém 'te eng en benauwd' (32) wordt. Ook omschrijft hij zichzelf als 'een man die met zijn aap de buitenwijken opzoekt, natuurlijk omdat hij iets in de binnenwijken niet vinden kan' (26). Compositorisch worden het gevoel van nergens echt thuis horen en de ambivalente houding van de verteller in Mijn aap schreit versterkt door de onbestemde locatie van het verhaal. Enerzijds lijkt het om Nederland te gaan, daar de verteller het land omschrijft als 'dit vlakke land' (68), en er 'fazanten' (I4) zijn, er 'bosch' (r3) is; maar anderzijds is er ook 'woud en moeras' (II) en kun je er 'aapjes vangen' (68), hetgeen naar Suriname zou kunnen verwijzen.

32 De aap kan het, van alle mensen, het beste vinden met een klein meisje dat hem opvangt als hij in de mensenwereld komt en met de zwarte kokkin die vaak haar 'handen tegen haar buik drukt', waarmee wordt aangegeven dat zij meer een gevoelswezen dan een verstandelijk wezen is. De blanke vrouwen worden als 'verdorvener' voorgesteld en maken zich schuldig aan racistische opmerkingen als '...een negermeid? Zo iets volkomen dierlijks' (124).

33 Wie erop let, vindt diverse verwijzingen naar apen in het werk van Hel- 
man. Veelal wordt 'aap' gebruikt als een scheldwoord of andere naam voor een neger of een gekleurde ander. In Waarom niet (1948) komt bijvoorbeeld een Javaanse man voor, over wie drie kinderen spreken: 'Een orang... orang... hoe noem je zo'n man ook weer. Baboe zei het altijd. Noem hem maar orang rotzak, vond Karel.' (Helman r948: 67).

34 Zie ook Meijer 1996: 158

35 Ook René Marres ging in discussie met Van Alphen (Marres 1994). Zijn belangrijkste verwijt is dat Van Alphen a-historisch zou lezen, dat het niet waar is dat 'zwart' overal voor iets ongunstig staat, en dat Van Alphen conclusies verbindt aan uitspraken die volgens hem door de algemene vertelinstantie onderschreven zouden worden, maar die in feite aan personages moeten worden toegerekend. Mijns inziens is de kritiek van Marres niet overtuigend. Van Alphen is veel genuanceerder dan Marres doet voorkomen. Van Alphen schrijft niet dat Helman een racist is, hij wijst op een ambivalentie in het werk van Helman en spreekt van '(anti)-racisme'. Ook is Marres' pleidooi tegen 'politiek correct' lezen volstrekt niet overtuigend. Marres hanteert al te makkelijk de tweedeling 'politiek' en 'literatuur' en meent dat onder het label 'literatuur' kennelijk alles geoorloofd is, omdat het label 'literatuur' erop staat en het dús geen politiek is.

\section{Gorilla's tussen feit en fictie}

I Lees: 'It was beauty that killed the beast'. In de film spreekt het personage Denham slang.

2 Volgens filmwetenschapper Cynthia Erb (1998) heeft King Kong behalve een kitsch-, ook een 'camp and pastiche-like quality' omdat de film, net als bijvoorbeeld de filmklassieker Casablanca (1942), veel ontleent aan diverse formules van verschillende genres uit de jaren twintig en dertig van de twintigste eeuw. Erb steunt hierbij op een theorie van Umberto Eco, zoals hij die formuleerde in 'Casablanca: Cult Movies and Intertextual Collages,' dat werd gepubliceerd in Sub-Stance I4, 2 (1985), 3-12.

3 'The beauty and the beast' verwijst naar een sprookje van Madame Le Prince de Beaumont, La Belle et la Bête uit 1757. In het oorspronkelijke sprookje wordt 'het monster' verliefd op een mooi meisje. Aanvankelijk ziet zij niks in hem, maar dan ontdekt ze onder zijn afstotelijke uiterlijk een tedere minnaar. Het monster verandert dan in een prins, en zo leven ze samen gelukkig verder. In King Kong gebeurt dat juist niet. Het 
monster wordt gevangen, maar blijkt ontembaar en wordt gedood. Voor de geschiedenis van dit motief, zie Warner 1996.

4 Dat King Kong onder 'horror' gegroepeerd werd, komt mogelijkerwijs omdat de film zich bedient van de formele conventies van de horrorfilm - personages worden soms met een angstige blik in de ogen gefilmd; de kijker ziet pas in het volgende shot het monster waar het personage zo bang voor is (Tudor 1989, Brunas, Brunas \& Weaver 1990).

5 Savage en Wyman publiceerden de bevindingen in de Boston Journal of Natural History. De hier geciteerde frase is geciteerd in onder andere Godwin r99o: 14 en in Schaller r964: 4. De volledige passage waarin Savage de aard van de gorilla beschrijft, is afgedrukt in Akeley 1923: 19II92.

6 Zie Schiebinger I993. Tyson noemde de aap die hij onderzocht in 1699 een 'orang-outang', maar uit de anatomische tekeningen kunnen we, zo schrijft Schiebinger, opmaken dat het ging om wat we nu classificeren als een chimpansee. Mogelijkerwijs legde Tyson de link tussen vrouwen en apen omdat de 'orang-outang' (in het Maleis letterlijk: 'wilde man') door Tyson ook 'Indiaanse Satyr' werd genoemd. Satyrs zijn beestachtige viervoetige wezens uit de Griekse en Romeinse mythologie, voorgesteld als een mansfiguur met een spitse neus, bokkepoten, veel haar, een korte staart en geil van aard. De Nederlandse anatoom Nicolaas Tulp had eerder ook al een beschrijving gegeven van de chimpansee, ook door hem 'orang-outang' genoemd. In 1641 publiceerde hij de studie $O b$ servationes medicarum libri III (Amsterdam r64I) waarin ook hij de link legde tussen de vrouw en de aap: '[ze zijn] zo sterk gespierd dat ze best gewapende mannen durven aan te vallen ook vrouwen, die ze soms met hitsigheid schaken en verkrachten, zodat de indiaanse vrouwen de bossen waar deze onbeschaamde beesten huizen, als de pest mijden.' Geciteerd in Landwehr I98r: I02. Voor de vroegste beschrijvingen van mensapen en de begripsverwarring omtrent de aapsoort, zie ook de essays in deel $\mathrm{r}$ van Corbey en Theunissen (1995).

7 In de verfilming van Edgar Allen Poe's The Murders in the Rue Morgue (1932) lijken de zwarte grote apen meer op gorilla's dan op de oranje behaarde orang-oetans uit het oorspronkelijke verhaal, zie de afbeeldingen in Brunas, Brunas \& Weaver 1990: 35 . In het algemeen kun je stellen dat de ontdekking van een nieuwe mensaap steeds weer inspireert tot nieuwe vertellingen en de mythe voedt tussen de vrouw en de aap. Schitterde in de oudheid de baviaan als macho (Duizend-en-één-nacht), zijn rol werd in de achttiende eeuw door de orang-oetan overgenomen (The 
Murders in the Rue Morgue), die op zijn beurt halverwege de negentiende eeuw tot de jaren dertig van de twintigste eeuw weer door de gorilla van de troon werd gestoten (King Kong), gevolgd door de chimpansee (Tarzan, Brazzaville Beach, 'Reflections of a Kept Ape') en tot slot de bonobo (De vrouw en de aap).

8 Wanneer Du Chaillu de eerste voetsporen van een gorilla vindt, lezen we: The women were terrified poor things! [...] And having here bestowed the women - who have a lively fear of the terrible gorilla, in consequence of various stories current among the tribes of women having been carried off into the woods by the fierce animal' (Du Chaillu r945: 5859). They believe firmly that should the husband of a woman with child, or the woman herself, see a gorilla, even a dead one, she would give birth to a gorilla, and not a man child.' (Du Chaillu 1945: 262).

9 Du Chaillu: 'It does not carry off women from the native villages' (348). Savage: The silly stories about their [gorillas, sj] carrying off women from the native towns, and vanquishing the elephants, related by voyagers and widely copied into books, are unhesitatingly denied. They have been averred of the chimpanzee, but this is still more preposterous. They propably had their origin in the marvelous accounts given by the natives, of the Engé-ena, to credulous traders.' (geciteerd in Akeley r923: 191).

Io Een foto van Gargantua is te zien in Mann 1940: 2I4.

II Een afbeelding van de sculptuur is te vinden in Corbey 1995: 339.

12 Het echtpaar Johnson was met Akeley meegeweest op safari in Afrika. Zie Akeley 1923: 158.

13 Over de technische aspecten van King Kong, zie Goldner \& Turner 1976.

14 Voorbeelden zijn de films Grass (1925) The Lost Game (1925), Chang (1927), Rango (1931) en The Most Dangerous Game (1932). In al deze films waren Cooper en/of Schoedsack, de makers van King Kong, betrokken als producer of regisseur en was Willis O'Brien de belangrijkste technicus; hij nam ook King Kong voor zijn rekening. Voor een overzicht van dit productie-netwerk, de inhoudelijke beschrijving van de films en de wijze waarop King Kong voortbouwt op en breekt met deze traditie, zie Goldner \& Turner 1976.

15 Op welke bronnen Schoedsack zich baseerde is mij niet bekend. De eerste versie van het script werd geschreven door Edgar Wallace, maar hij stierf voor de film werd gemaakt.

16 Voor een afbeelding, zie Rebello \& Allen 1988. Zie ook de afbeelding in dit boek, hoofdstuk vier. 
17 Volgens Snead (1991) verwijst de naam Ann Darrow naar Clarence Darrow, de advocate die de verdediging op zich nam van de Scopes 'Monkey' Trial in r925. In dit proces werd een docent uit een klein Amerikaans dorpje voor het gerecht gesleept omdat hij de evolutietheorie onderwees. De keuze van de makers voor deze naam wijst dan op een steunbetuiging aan de evolutietheorie.

18 Sommigen hebben om deze reden, en om het metafilmische karakter van de film, King Kong en de rol van de aap opgevat als een allegorie voor de moordende economische strijd van Hollywood-filmmakers in de jaren dertig om te overleven of als een film over de economische Depressie (De Rooy I99I, McGurl 1996) en de ondergang van een stad (Erb 1998), waarbij King Kongs poging te overleven in de jungle vergeleken kan worden met de wijze waarop New Yorkers in de stad moeten vechten om te leven (Carroll 1984 ).

19 De opmerking van Ann dat Jack niet van vrouwen houdt, kan aanleiding geven tot homo-erotische interpretaties van Jacks personage in de film. Anns oogverblindende schoonheid wordt er extra door benadrukt. Zelfs een homoseksuele man valt voor haar! Zijn gevangenschap als homoseksueel vindt zijn parallel in King Kongs relatie met Ann, een onmogelijk liefde. Jack en King Kong zijn beiden 'outcast'. De homoseksueel als King Kong is het thema van het toneelstuk Gorilla Queen (r967), een campy coming-out drama gecentreerd rondom het thema 'ongewone liefde', waarin een witte mannelijke avonturier, die stottert als Jack, eindigt via een serie maskerades (hij verkleedt zich ook als vrouw) in een apenpak als King Kong. Voor een analyse van Gorilla Queen, zie Erb 1998: 160-172. Zie ook noot 28 van dit hoofdstuk.

20 Torgovnick (1990) wijst erop dat de kidnap van blanke vrouwen een structurerend principe is in vele romans en films uit de jaren dertig. Er is meestal sprake van een drievoudige kidnap. De eerste kidnap geschiedt meestal door een blanke op macht beluste man, de tweede kidnap door een Arabier of een Afrikaan, de derde door een aap. Dit geldt voor King Kong (Ann wordt eerst 'gekidnapt' door Denham, dan door de inheemse eilandbewoners en vervolgens door de aap), en bijvoorbeeld ook voor veel van de Tarzanverhalen. Torgovnick gebruikt het Engelse woord 'abduction', dat de tweeledige betekenis heeft van kidnap en verkrachting. De verkrachting wordt meestal niet expliciet benoemd, maar wel gesuggereerd doordat de erotische spanning wordt opgevoerd.

2I In de ingekleurde versie van King Kong is deze scène hersteld. 
Vgl. Tarzan, die ook 'koning der apen' is. De titel 'koning' geeft aan dat de top van de hiërarchie van de mensachtigen (de apen of 'primitievelingen') is bereikt. Voor een kritische bespreking van de Tarzanfilms, zie Torgovnick 1990: 42-75. Over de naamgeving van fictionele dieren, zie Room 1993. Room wijst erop dat 'King Kong' prettig klinkt, zoals 'ping pong' en 'ding dong'.

23 Respectievelijk te vinden op de albums Abba, Waterloo (1974) en The Kinks, Arthur (or the Decline and Fall of the British Empire) (1969). Ook enkele (hardrock)groepen noemden zich naar de gorilla, vanwege diens viriele macho-imago, zoals de Zweedse hardrockgroep King Køng. Dat de gorilla met mannelijkheid wordt geassocieerd, blijkt voorts uit de benaming 'gorilla-sap' voor verboden dopingmiddelen die het lichaam sterker maken (Keysers 1993: 9).

Zie Winterson 1992:79; Pynchon 1973: 57, 247, 275, 688, 689. Voor een studie naar en een uitleg van deze verwijzingen in Pynchon, zie Weisenburger 1988 .

25 Ook Donna Haraway interpreteert de dood van Kong als een gevolg van zijn 'racial crossing': 'For the white inflamed imagination he was the icon of the captive black man's love for the white woman. [...] Beast and "primitive", Kong was lynched.' (Haraway 1989: 16I)

26 Voor afbeeldingen, zie Lott 1995: 37-43.

27 Voor een afbeelding, zie Gottesman \& Geduld, afbeeldingenkatern.

28 De aap als homoseksueel en vice versa is een terugkerend motief in de (populaire) cultuur. De romans Planet of the Apes (Boulle 1963) en De Gratie Gods (Malamud 1982) kunnen als homo-pastiches gelezen worden. In Planet of the Apes weigert de mannelijke hoofdpersoon Ulysse Mérrou om te paren met een vrouwelijke apin. Ulysse vindt haar afstotend en richt zich op de contacten met de mannelijke apen, wat homoerotisch geïnterpreteerd kan worden. De Gratie Gods is een satirische roman, waarin wetenschapper Cohn na een overstroming als enige overlevende strandt op een eiland, dat bewoond wordt door een aantal apen. De chimpansee Buz wordt zijn leerling: 'Cohn prees hem en zei dat hij een knappe jongen was. Ze legden de armen om elkaar heen en kusten elkaar teder' (62). De aap Buz vraagt of hij niet met hem mag trouwen. 'Buz trachtte steels zijn vingers tussen Cohns dijen te steken, en al wist zijn paps dat het goed bedoeld was, hij vond het niet goed dat zijn ventje aan zijn testikels kwam. Buz vlijde zich dicht tegen hem aan en al spoedig lag hij aan Cohns tepel te zuigen, dwars door dr. Bunders witzijden overhemd heen.' (78) 
29 Een Amerikaanse reclame uit 1976 voor bh's toont een jonge vrouw die zich in haar kamer uitkleedt terwijl King Kong begerig als een voyeur door haar raam naar binnen loert: 'A woman never knows what problems she may encounter. But we make sure her bra isn't one of them.' Voor een afbeelding, zie het afbeeldingenkatern in Gottesman \& Geduld 1976 .

30 MAD (2) winter 1997: 6 .

3I In deze film kijkt een groep weeskinderen één keer per week naar King Kong. In de scène waarin Kong Ann inspecteert, haar kietelt en aan haar jurk trekt, identificeert een jongetje zich met de kinderlijke en spelende Kong. Over Ann zegt hij: 'She's his mom!' In zijn ogen is Kong, net als hij, een wees die op zoek is naar de ideale moeder, Ann (in feite is Ann het weesmeisje). Het jongetje denkt dat hij te lelijk is en niet goed genoeg en dat er daarom geen adoptieouders zijn die voor hem kiezen. Net als King Kong voelt hij zich een outcast.

32 Hoch 1979: 48. Behalve King Kong als zwarte ander en Christusfiguur, duiken, omgekeerd, ook voorstellingen van de zwarte als King Kong en Christusfiguur op in de populaire cultuur. In de film The Green Mile (2000) wordt een reusachtige grote onschuldige zwarte man, gespeeld door John Coffey, ter dood veroordeeld en op de elektrische stoel gezet. Hij heeft bijzondere gaven en kan mensen genezen. Hij representeert het goede, en geeft uiteindelijk een blanke man een 'gift' mee, onsterfelijkheid. Niet alleen is hij 'ander' omdat hij zwart is, maar hij representeert nog een 'ander': hij is licht zwakzinnig. In NRC Handelsblad (8-3-200o) werd John Coffey omschreven als 'een zwarte kolos', voor wie we niet bangen hoeven te zijn: 'deze King Kong blijkt mak als een lammetje'. Ook wijst de recensent erop dat Coffey's initialen J.C. zijn en dat zijn executie op een kruisiging lijkt.

33 De interpretatie van Kong als joodse ander is te vinden in de documentaire 'Hollywoodism: Jews, movies and the American Dream' van Simcha Jacobovici (Canada 1998).

34 Een concreet voorbeeld van deze witte mannelijke 'was-ik-maar-eenpotente-neger'-fantasie is de filmcriticus K. Bernard, die zich achter een geslachtsneutraal 'wij' verbergt als hij schrijft: 'We do not want Kong to violate that blonde maiden...Yet at the same time this is precisely what we do want. We want it to grow big and approach the blonde maiden with bloodshot, lustful eyes... Tarzan or Kong with erections are unthinkable, but somewhere in the furry depth, beneath that loincloth, they lurk, waiting to spring to life at our call.' (Bernard 1976: 125). Hij 
doet er nog een schepje bovenop door zich voor te stellen hoe Fay Wray, voordat ze aan Kong wordt geofferd, eerst uitvoerig onderzocht wordt om te controleren of ze nog maagd is: 'The examination is conducted by the chief, the elders, and the midwives of the tribe. It is even conceivable that the entire tribe is witness. Fay Wray is stripped and laid bare on a (bamboo?) platform in a fir-lit-hut. Her legs are forced apart and black fingers probe, pull and manipulate her' (128).

35 Het ontbreken van de penis van King Kong kan in deze lijn geïnterpreteerd worden als het 'ontmannen' van het zwarte gevaar door de blanke filmmaker: de 'neger' is gecastreerd.

36 Een afbeelding stond in de Volkskrant 26-09-or.

37 Kenneth Bernard merkt in zijn - nogal wilde - interpretatie van de film op dat Son of Kong het resultaat is van de stoutste dromen van de kijker: er is geslachtgemeenschap geweest tussen de maagdelijke Fay Wray en King Kong, vandaar de wittere kleinere versie! Zie Bernard r976: 130.

$3^{8}$ Volgens Snead (1994) vormen de King Kong-films tezamen een allegorie voor de rassenverhoudingen in Amerika. Eerst is er 'plunder, exploitation and humiliation' in King Kong, dan 'guilt' in Son of Kong, en ten slotte 'repatriation' in Mighty Joe Young.

39 Moffat baseerde zijn boek Queen Kong (1976) op deze film (waarin hij de film nauwgezet volgt). Voor de samenvatting heb ik hiervan gebruikgemaakt. Een film die de feministen als dolgedraaid portretteert, is de complexe en bizarre film Bye Bye Monkey (Ciao Maschio) uit 1978 van Marco Ferreri. Daarin wordt het dode lichaam van King Kong opgevoerd als een symbolische overwinning van de radicale feministen. We maken kennis met een jongeman (gespeeld door Gerard Depardieu) die in een feministisch theatergezelschap wordt 'verkracht' en zwanger raakt van een aap. Eerder in de film zagen we een aapje zittend in de handpalm van King Kong, wiens lichaam verlaten op een strand lag. Zijn eigen 'aapje' wordt spoedig na de geboorte door ratten aangevreten en sterft.

40 Milwaukee Journal, 2I januari 1973, afgedrukt in Gottesman \& Geduld, 1976: 23 .

4I Biruté Galdikas schrijft over Fosseys werk: 'In enkele ogenblikken was het King Kong-imago van de gorilla als bloeddorstig moordenaar in de prullenbak van de filmgeschiedenis beland.' (Galdikas 1995: 509) Zie hoofdstuk 5 van dit boek over de imago-verandering van de mensapen.

42 Het gebruik van een vrouwelijke voice-over is niet toevallig. In programma's over het uitsterven van diersoorten, gorilla's bijvoorbeeld, 
wordt vaak voor een vrouwelijke stem gekozen, misschien omdat het minder connotaties oproept met 'afstandelijke wetenschap', maar meer met de betrokkenheid van een bezorgde moeder. Zie ook Haraway 1989 .

43 De economisering van het jargon suggereert dat de natuur deelbaar en maakbaar is en dat men geld kan inzetten op een concreet stukje gorilla en daarmee op de toekomst van de mens. In diverse winkels waren mooie ansichtkaarten te koop, niet van King Kong, maar bijvoorbeeld van een gorilla met zijn hand vol bloemen, die we associëren met liefde en vrede. De boodschap van de noodkreet moge duidelijk zijn: gorilla's behoren tot onze naaste familie. Wie een gorilla laat sterven, doodt ook zichzelf.

\section{Waarom wetenschapsters van apen houden}

I Naar Armbruster (1997: 214) die Fossey een 'site of cultural anxiety' noemt. Fossey roept volgens haar onrust en verwarring op, omdat ze enkele normen en waarden van de westerse samenleving overschrijdt. Volgens Armbruster doorbreekt ze met name de hiërarchische relatie tussen de mens als heerser over de natuur, door zich te midden van de gorilla's als hun gelijke te positioneren.

2 Voor een discussie over het mogelijke verband tussen de groeiende vrouwenbeweging en de opmars van vrouwen in de wetenschap, waaronder de primatologie, zie Fedigan \& Fedigan r989. Zie ook Strum \& Fedigan 2000.

3 Zie bijvoorbeeld ook het artikel 'Called "Trimates" Three Bold Women Shaped Their Field' van Virginia Morell (1993), dat opent met de woorden van een jonge vrouwelijke primatologe die zegt dat ze zonder Jane Goodall en Dian Fossey nooit het lef had gehad om het primatologische veldonderzoek in te gaan.

4 Zie ook Haynes 1994.

5 Fedigan (1994) noemt ook andere mannen: Sherwoord Washburn, Robert Hinde en Irven De Vore, die veel vrouwelijke primatologen trainden en stimuleerden om verder te studeren. Hinde trad zowel voor Goodall als Fossey op als begeleider van het promotie-onderzoek.

6 Zie Goodall 199I, Montgomery 199I, Galdikas 1995 en Jahme 2000 over Leakey.

7 In haar biografie over Leakey, Ancestral Passions (1995), portretteert 
Virginia Morell hem in de eerste plaats echter als een rokkenjager. Mogelijkerwijs genoot Leakey er ook van om de vrouwen 'uit te testen' en te kijken hoe ver ze zouden gaan, voor hem en voor de discipline.

8 Zie National Geograpic, Vol. 157 (6), June 1980, p. 833 en 851.

9 Voor afbeeldingen, zie Fossey 1970.

ro De Waal is etholoog en als hoogleraar psychologie verbonden aan het Yerkes Primate Center in Atlanta. Hij publiceerde Chimpanzee Politics. Power and Sex Among Apes (1982), Peacemaking among Primates (1989), Good Natured: the Origins of Right and Wrong in Humans and Other Animals (1996), samen met Frans Lanting in 1997 Bonobo: the Forgotten Ape en The Ape and the Sushimaster. Cultural Reflections of a Primatologist (2001), waarover meer in hoofdstuk 7 van dit boek. De werken zijn allemaal in het Nederlands vertaald.

II In een gesprek tussen Frans de Waal en Tijs Goldschmidt over dierencultuur in Vrij Nederland (opgetekend door Elizabeth Lockhorn) zijn foto's afgebeeld waarop Frans de Waal samen met Tijs Goldschmidt in een huiskamer apengebaren nadoen. Het onderschrift zorgt ervoor dat het onderscheid tussen mensen en mensaap daarbij in stand wordt gehouden: 'Goldschmidt (links) en De Waal demonstreren het handgreepvlooien. Apen pakken elkaars hand vast boven het hoofd en vlooien elkaar in een perfecte symmetrie onder de oksel.' Vrij Nederland, t6 juni 200I.

I2 Omwille van de leesbaarheid heb ik gebruik gemaakt van vertalingen. Oorspronkelijke edities verschenen in 1990 (Goodall), 1983 (Fossey) en 1995 (Galdikas). Goodall publiceerde meerdere autobiografisch getinte werken, onder andere In the Shadow of Man (1975), The Chimpanzees of Gombe. Patterns of Behavior (1986), Reason for Hope (2000) en Africa in my Blood. An Autobiography in Letters (Bezorgd door Dale Peterson, 2001). Ik heb gekozen voor Through a Window (1990), omdat dit boek een mooi overzicht biedt van Goodalls werk en er ook uitvoerig wordt ingegaan op de 'chimpansee-oorlogen', die een belangrijke rol spelen in Brazzaville Beach van William Boyd. In the Shadow of Man publiceerde zij aan het begin van haar carrière, The Chimpanzees of Gombe is een uitvoerig verslag van haar veldwerk en de resultaten, en Reason for Hope is vooral een religieus getinte autobiografie waarin zijzelf en haar ontwikkeling centraal staat (geen populaire wetenschap over apen dus) en Africa in my Blood een verzameling van de correspondentie van Goodall.

I3 In alle drie de boeken wordt kennis van de mens als drijfveer vermeld. 
'Deze vraag, deze wens om de oorsprong van de mens te begrijpen, dreef me naar het dichte oerwoud van Midden-Borneo om de orangoetan te bestuderen' (Galdikas 1995: 33). Het onderzoek naar het gedrag van chimpansees 'heeft ons weer geholpen bepaalde aspecten van het menselijke gedrag, onze enige plaats in de natuur wat beter te begrijpen' (Goodall r9gr: 15). 'Via deze [de mensapen, s]] kunnen wij misschien veel te weten komen over de gedragingen van onze vroegste prototypes uit de orde der primaten' (Fossey 1984: 16). Voor een kritiek op de manier van redeneren (de analogie), zie Van Reybrouck 2000, die bondig stelt: 'Chimpanzees are today's Tasmanians' (ro).

I4 Fossey noemt Uncle Bert en Puck naar haar oom en tante. Galdikas vernoemt de baby van Akmad naar haar zuster Aldona. Soms zijn de namen grapjes van de onderzoekers. Fossey noemt een pasgeboren gorilla Beetsme ('that beats me') omdat ze geen zekerheid heeft omtrent het geslacht en de achtergrond van de gorilla. Ook laten de wetenschapsters zich door fictie inspireren. Galdikas geeft een jonge orangoetan de naam 'Georgina', hetgeen wel eens gebaseerd kunnen zijn op haar favoriete knuffeldier toen ze klein was, het avontuurlijke aapje 'George' uit de gelijknamige stripverhalen, dat ze noemt als een van haar eerste inspirators van haar interesse in apen. Ze noemt een apin 'Lolita', met een knipoog naar Nabokov, omdat dit jonge vrouwtje steeds vergezeld is van mannen en een 'opgeilster' is, aldus Galdikas. Het geven van namen, zoals bij huisdieren, is niet alleen een manier om de individualiteit van de apen te duiden. Het duidt ook een bezitsrelatie aan en is een manier om iemands plaats in de hiërarchie vast te stellen. Wie de naam mag bepalen, is de eigenaar. Helman heeft zijn aap geen naam gegeven, maar spreekt wel van 'mijn' aap, zoals ook Goodall, Fossey en Galdikas dat soms doen, en spreken van 'mijn' apen.

15 Met dank aan David van Reybrouck die me op de 'body technology' van de apenonderzoekers attendeerde.

I6 Zie ook hoofdstuk I, noot 25, van dit boek, waarin, onder verwijzing naar Van Reybrouck (2000) geconstateerd werd dat Goodall niet de eerste was die gereedschap onder apen ontdekte.

17 Galdikas was van de drie aanvankelijk het meest academisch georiënteerd en schreef een ook in wetenschappeljke kringen gewaardeerd proefschrift in 1978 . Inmiddels zijn wetenschappelijke fondsen terughoudend geworden om haar onderzoek te subsidiëren, omdat na het proefschrift nauwelijks wetenschappelijke publicaties verschenen. Gal- 
dikas verdedigt zich onder meer door te stellen dat kwaliteit, niet kwantiteit de maat zou moeten zijn. Zie Morell r993: 425.

18 Haraway 1989, 128-129; zie ook Van Reybrouck 2000: 275, noot 45.

19 Pas in de jaren tachtig werd men zich er steeds meer van bewust dat de soort vragen die gesteld wordt tijdens apenonderzoek mede afhangt van de sekse van de onderzoeker. Het aantal vrouwelijke primatologen groeide en er kwam meer aandacht voor vrouwtjesapen, waardoor sommige clichébeelden onderuit werden gehaald. Haraway (1989) wijst er echter op dat het centraal stellen van de vrouwelijke ervaring - zoals Goodall en Galdikas dat vaak doen met hun aandacht voor het moederschap - niet voldoende is voor een feministisch perspectief. Omkering is een substitutie, die weliswaar een verontrustend effect kan sorteren, maar die in feite het ene verhaal vervangt door het andere, waarbij vast wordt gehouden aan een essentialistisch denken. 'Substitutes do not destabilize; they replicate. Substitutes are tied to identifications. Male-centered and masculinist accounts cannot or may not be replaced by female-centered and feminist accounts provided by women writing from the point of view of themselves being female or women [...] Destabilizing the positions in a discursive field and disrupting categories for identification might be a more powerful feminist strategy than "speaking as a woman". (Haraway 1989: 310) Een primatoloog die volgens Haraway wel feministisch te werk gaat, is bijvoorbeeld Sarah Blaffer Hrdy. In Nederland valt te denken aan het werk van Liesbeth Sterck. In haar proefschrift Females, Foods and Fights. A Socioecological Comparison of the Sympatric Thomas Langur and Long-Tailed Macaque (1995), laat zij onder meer zien wat de invloed is van de migraties van vrouwtjesapen op de sociale organisatie van primaten. Haar onderzoek is een voorbeeld van de wijze waarop een vrouwenstudies-perspectief op primatologie verrassende nieuwe inzichten oplevert. Deels onttrekt zij zich door middel van een persoonlijk curriculum vitae en een slotwoord aan de conventionele structuur van een proefschrift, deels bevestigt ze daarmee het stereotype van de betrokken vrouwelijke primatoloog.

20 Reflections of Eden zit bomvol verheerlijkende citaten over moederschap, waarbij de apen vaak de rol van 'kind' innemen: 'mijn orangoetanweesjes' (26), 'mijn pleegkind' (22), 'mannen zijn wat hun moeders hen hebben gemaakt' (260), 'god kon niet overal zijn, daarom maakte hij moeders' (149), 'Wat is lichter dan een veertje? Een kind voor zijn moeder' (171). 
2I Het omgekeerde, een mens die als aap in een overlijdensadvertentie wordt neergezet, gebeurde in 2001 bij het overlijden van Herman Brood. 'Ciao Monkey' kopten enkele berichten, daarmee doelend op het 'aapachtige' wilde leven van Brood en referend naar de titel van zijn jazzplaat die ging over zijn poging om af te kicken van de drugs. 'To have a monkey on one's back' is de spreekwoordelijke uitdrukking voor verslaafd zijn.

22 In Agressieve mannetjes (1998) geven de Amerikaanse biologen Richard Wrangham en Dale Peterson een overzicht van de typen geweld die bij de vier mensapen zijn ontdekt: vlees van soortgenoten eten (allemaal, behalve de bonobo), het doden van de eigen soort (allemaal, behalve de bonobo), verkrachting (orang-oetan), infanticide (gorilla, chimpansee), mishandeling (chimpansee), oorlog (chimpansee). Op grond van deze resultaten concluderen Wrangham en Peterson dat de chimpansee relatief gezien het agressiefste is van de mensapen en de bonobo het vreedzaamste (die lossen conflicten op door middel van seks).

23 Anders dan bijvoorbeeld Wrangham en Peterson (1998) die stellen dat zowel de mens als de chimpansee in staat zijn tot doelbewust geweld, en dat het geweld evolutionair verklaard kan worden. Volgens Goodall is er bij de oorlogen echter niet direct sprake van een evolutionair voordeel; er zou eerder sprake zijn van haat die wordt opgewekt bij het zien van een lid van de andere gemeenschap (Goodall r99r: 103).

24 Zie ook Hugo and Jane van Lawick Goodall, Innocent Killers (1970), over jagen bij wilde honden, de jakhals en de hyena.

25 Opmerkelijk is ook dat Galdikas niet de oorsprong van de naam orangoetan vermeldt (Tysons 'wilde man', zie hoofstuk 4 , noot 6 , van dit boek), vermoedelijk om niet de verkeerde, gewelddadige associaties met de orang-oetan als vrouwenverkrachter in herinnering te roepen.

26 In zijn eerste grote publicatie over apen, zijn boek Chimpansee politiek. Macht en seks bij mensapen (1982), legt De Waal veel sterker de nadruk op het mechanisme van macht bij de apen en dus bij de 'duistere' en 'machiavelliaanse' kant. Hij vertelt daarin ook hoe hij meemaakt dat twee van de apen een andere aap verwonden tot de dood toe. Deze gebeurtenis werd in eerste instantie verzwegen en bijvoorbeeld niet getoond in Bert Haanstra's film Chimps onder elkaar (1984) over de desbetreffende chimpanseekolonie die De Waal in de dierentuin van Arnhem bestudeerde, omdat men bang was dat mensen niet meer naar de dierentuin wilden komen (De Waal 1982).

27 'De lianen krulden zich rond de gespen van mijn schoenen en de riem 
van mijn camera, de dorens grepen zich vast in het vlees van mijn armen, mijn ogen deden pijn tot de tranen gingen vloeien toen ik mijn haar losrukte van de knoesten die van alle kanten uitstaken. Na tien minuten was ik doorweekt van het zweet, mijn hemd was gescheurd, mijn knieën waren geschaafd op de stenige bodem [...]' (Goodall r99I: 13).

28 Paginanummers in dit stuk verwijzen naar de editie uit 1990 van uitgeverij Sinclair Stevenson. Omwille van de leesbaarheid citeer ik in doorlopende zinnen het Nederlands. Daarbij maak ik gebruik van de Nederlandse vertaling door Van der Veer uit 1990.

29 Vgl. King Kong en Yerkes' stelling uit The Great Apes: 'Only when attacked do they become aggressive'. Jane Goodall kreeg veel kritiek toen zij actief ging ingrijpen in het leven van de chimpansees die ze bestudeerde door een voederplaats met bananen te installeren, opdat ze meer gelegenheid had ze te onderzoeken. Ook heeft ze enkele malen gewonde chimpansees verzorgd. (Goodall 199I, Montgomery 1991)

30 Dit gegeven ontleent hij wellicht aan Kelly Stewart, één van Dian Fosseys onderzoeksassistenten, wier onderzoeksaantekeningen van achttien maanden werk in rook opgingen. Hoewel dit door haar eigen toedoen zou zijn gebeurd (zij had natte kleren te dicht bij het houtfornuis in haar hut gehangen), vermoedde ze dat haar gegevens waren ingepikt. (Shoumatoff 1989: 34-35)

3I De namen van de chimps verwijzen, zoals ook Goodall, Galdikas en Fossey dat deden, soms naar beroemde schrijvers, Conrad bijvoorbeeld. 'Rita Mae' is de naam van een dominant vrouwtje, misschien naar de lesbische cultschrijfster Rita Mae Brown. Conrad is de laatste overlevende uit het zuidelijke kamp, wellicht is dat een grapje van Boyd: de 'survival of the fittest author'. Schrijvers worden ook wel 'de apen van God' genoemd (zie hoofdstuk 7). Het is ook mogelijk dat de twee apinnen die elkaars rivalen zijn 'Rita-Mae' en 'Rita-Lu', staan voor bijvoorbeeld 'Mae West' en 'Lulu'.

32 De mist staat voor dubbelzinnigheid: de mist doen wegtrekken en verlangen naar helderheid voor eenduidigheid. Hij heeft last van 'those misty fields' (215). Wellicht wordt ook verwezen naar Dian Fosseys Gorilla's in de mist en haar verlangen om de 'ware' aard van de gorilla 'uit de mist' te halen.

33 Volgens Edward Goods kan Hope het geweld waarnemen omdat zij weet wat het is om geweld te ondervinden: 'Is it accidental that Mallabar, to whom life has been so good, has invested so much in a possibly romantized idea of primate nature, while Hope, whose life has been 
pretty awful, find awfulness even in creatures she feels fond of?' (New York Review of Books 10-10-1991)

34 Dit tot grote ergernis van Robert Brain, die in zijn recensie in Times Literary Supplement schrijft dat Boyd te veel stereotypen gebruikt: 'Women's breasts may be flat or round, small or large, firm or slack, low or high, heavy or light, plump or deflated, lowslung or pointed. They may be shelves, they may be cones; they roll and swing and heave and swell, they even judder; nipples are domed or bulbous, tiny or large, round or oval, neat or coarse, even tight ; they are black, nutbrown, pink, salmon, pale; they pucker, redden, they even throb. One woman's nipples are likened to canapes on a cocktail tray. Frequently, to stress the shocking nature of breasts, the adjectives are preceded by adverbs such as "strangely", "oddly", "curiously", and even "worryingly". Women's body hair, terrifying in itself, comes in trufy clumps, wiry tufts, great hanks, crinkly triangles, dense bushes, vertical wisps. On the other hand men have body hair everywhere. They are matted or pelted, with dense thickets on chest and stomach, back and legs, shoulder-blades and buttocks. Faces and orifices sprout potent blue-black hair. This striking dimorphism, hairyman and breasty girl, bodes ill for King Kong and blonde girl in the jungle.'

35 Dit beeld roept associaties op met Christus. Maar anders dan in Mijn aap schreit en King Kong zijn er verder geen specifieke aanwijzingen dat hij 'onschuldig' en als zondebok geofferd zou worden; integendeel, zijn dood is 'verdiend'.

36 In 1999 kreeg Jane Goodall haar zin. Disney's Tarzan heeft Jane naar haar gemodelleerd (Jensen 1999).

37 In zijn filmbespreking wijst de wetenschapsjournalist Hendrik Spiering (zoals ook Robert Brain dat deed in zijn bespreking van Brazzaville Beach) op de discrepanties tussen de film en het werkelijke leven van Fossey: 'De film biedt een redelijk beeld van Fossey's leven, al kloppen allerlei details natuurlijk niet: Zo onmoet Fossey haar mentor Leakey niet tijdens een lezing in Amerika, maar in Afrika, en ook zat Fossey niet continu alleen op de berg, zoals de film suggereert, maar keerde ze regelmatig terug naar de vs, een keer zelfs voor langere tijd om haar proefschrift te schrijven (NRC Handelsblad, 8 jan. 20oI). Niet kloppend met de 'feiten' is ook de uitspraak van Louis Leakey, die in zijn college zegt dat 'van alle apen de berggorilla het dichtst bij de mens staat'. Deze kritiek illustreert hoe recensenten 'echt' van 'fictie' proberen te onderscheiden. 
38 Voor een kritische bespreking van Gorillas in the Mist precies op dit punt, zie Sippi 1989. In 'Aping Africa: the Mist of Immaculate Miscegenation', beargumenteert Sippi ( 1989 ) dat de film van Apted een lange 'hoera voor het Westen'-film is geworden vol stereotypen van de Afrikaanse ander. Ze wijst erop dat de boodschap die van de film blijft hangen, het ethische recht op het levensbehoud van de gorilla is, tegelijkertijd wordt opgediend met een noodzakelijke andere conclusie, namelijk dat dit onder de supervisie van de Amerikanen moet gebeuren. Hier ben ik het niet helemaal mee eens: de belangrijkste representant van het westen, Fossey, wordt ook afgeschilderd als een neurotische, ongelukkige vrouw die te weinig rekening houdt met de wensen van de Afrikaanse bevolking, en die het zonder de hulp haar Afrikaanse spoorzoeker niet redt.

39 Soms wordt dit ook positief geïnterpreteerd: 'Dian was typically, even exaggeratedly Western in her attitude towards children and animals. She adored kids; she treated poachers' children and even their dogs with great tenderness. In a land where animals are valued only for food or skins, she sided with the gorillas and duiker and buffallo. But in her "active conservation", she dopted the tactics and philosophy of an African' (Montgomery 1991: 220).

40 David van Reybrouck attendeerde me erop dat het hier mogelijkerwijs om een westers schoonheidsideaal gaat, en dat binnen de Dajakcultuur de volslanke vrouw positievere connotaties heeft.

$4 \mathrm{I}$ Bron: persoonlijke correspondentie met Spalding; e-mail 15-5-00.

42 Spalding heeft hem later geinterviewd en schrijft daarover in The Follow. Hij vertelt haar dat het hem verwondert dat nooit iemand zich heeft afgevraagd hoe het met de Bangkok Six afliep na de 'spectaculaire' redding van Galdikas. Bij navraag door Spalding blijkt dat vier van deze zes orang-oetans in Galdikas' adoptie-centrum stierven, en dat Galdikas hier liever over zwijgt.

43 Jahme (2000) voert ook een 'bonobovrouw' op, de Britse Jo Thompson.

44 Wrangham en Peterson (1998) specificeren 'de mens'. Volgens hen lijkt de zachtmoedige vrouwtjesbonobo het meest op de vrouw en de gewelddadige mannetjeschimpansee op de man. De oorlog tussen de seksen zou minder worden wanneer mannen zouden leren van de bonobo's. Voor een kritiek op deze stelling en de vooronderstellingen die hieraan ten grondslag ligt, namelijk over essentialistische vrouwelijke en mannelijke eigenschappen en sociaalbiologische argumentaties, zie Marks 1999.

45 David de Wied-lezing door Frans de Waal te Utrecht, 13 maart 1998. 
I Zie bijvoorbeeld Hayles 1999 en Haraway 1997 voor de implicaties van het internet in relatie tot de makbare mens en de introductie van de term 'cyborg'. Zie ook 'De elektronische mens. Nieuwe technologie versmalt kloof tussen mens en machine.' (NRC Handelsblad zo sep. 2000) Te denken valt verder aan debatten over nieuwe medische en cosmetische technieken die de mogelijkheid bieden om je lichaam en je gezondheid en je nageslacht te verbeteren. Zie bijvoorbeeld Fritz de Lange De nieuwe mens. Maakbaarheid van lijf en leven (2000).

2 Te denken valt aan het debat rondom De regels van het mensenpark (2000) van de Duitse filosoof Peter Sloterdijk, die ervan werd beschuldigd daarin een pleidooi te houden voor actieve biopolitiek.

3 Zie 'Het beest in ons. Dilemma's rond xenotransplantatie'. NRC Handelsblad, 5 februari 2000.

4 Zie bijvoorbeeld Cavalieri en Singer 1993; De Waal 1988. Richard Dawkins noemt in zijn bestseller The Selfish Gene (oorspr. jaar van uitgave: 1976) nog een hoger percentage, namelijk 99.5 procent (Dawkins 1977: 5).

5 De bijdrage van Richard Dawkins uitgezonderd, daar kom ik in de tweede paragraaf van dit hoofdstuk op terug. Binnen het debat over xenotransplantatie, dat overigens onbesproken blijft binnen het GAP, wordt door sommigen gesteld dat mensen die dierlijk materiaal hebben, geen gemeenschap meer zouden mogen hebben, omdat de risico's - bijvoorbeeld van overdracht van voor de mens gevaarlijke virussen - van het transplanteren van dierlijk organisch materiaal vooralsnog onbekend zijn. Dezelfde discussie speelt zich af bij het kruisen van soorten; vooralsnog is het wettelijk zo dat 'the development of any resultant hybrid should be terminated at the two cell stage.' Zie Squier 1998: 361.

6 De term bestialiteit betekent 'seks tussen mens en dier' en heeft meestal een negatieve connotatie en is zelfs een strafbaar feit. 'Intersoortelijke gemeenschap' klinkt wetenschappelijker en neutraler.

7 Misschien juist wel omdat romans 'veilig' onder vlag 'fictie' varen, een term die we geneigd zijn aan 'fantasie' of 'verzinsel' te koppelen. Susan Squier formuleert het zo: 'Literature is one of the most powerful sites of the articulation of desire, precisely because - functioning like Freuds concept of "negation" - simultaneously deauthorizing it as "only fiction". (Squier 1998: 365). Over de woorden 'feit' en 'fictie' opgevat als de 'waarheid' versus 'verzinsel', zie Haraway 1989: 3-5 en hoofdstuk I van dit boek. 
8 In de jaren zeventig, maar met name in de jaren tachtig en negentig verschenen al een golf komische films waarin de aap in vergelijking met de man als de betere optie uit de bus komt. Te denken valt aan onder andere de remakes van King Kong (1976) en Tarzan, the Apeman (1981), en Max Mon Amour (1986). Zie Jensen 1999.

9 Cavalieri \& Singer 1993; Cavalieri \& Singer 1995; Zie ook de officiële website van het GAP, www.greatapeproject.org. In dit hoofdstuk gebruik ik de afkorting GAP wanneer ik naar het project in zijn algemeenheid verwijs (het idee, de organisatie en het boek en andere publicaties van Cavalieri en Singer waarin zij hun project toelichten, bijvoorbeeld Cavalieri \& Singer 1995) en The Great Ape Project wanneer ik alleen naar het boek verwijs.

Io Singer hanteerde de term 'liberation' al in zijn boek Animal Liberation (1975), waarin hij een pleidooi hield voor de gelijkwaardige behandeling van dieren en suggesties deed voor veranderingen in de wet die de respectvolle behandeling van dieren zouden waarborgen.

II Soms wordt de menselijkheid van de mensaap en de mensaapachtigheid van de mens als twee zijden van dezelfde medaille beschouwd. Cavalieri en Singer schrijven bijvoorbeeld: 'We are human, and we are also great apes' (r). Tegelijkertijd pleiten zij voor de uitbreiding van de morele gemeenschap van mensen met mensapen, en het opvatten van mensapen als 'personen', en dus voor de menselijkheid van mensapen.

12 'Chimpanzees' Use of Sign Language' (Roger S. Fouts and Deborah H. Fouts); 'Language and the Orang-utan: the Old "Person" of the Forest' (H. Lyn White Miles); 'The Case for the Personhood of Gorillas' (Francine Patterson and Wendy Gordon).

13 'Gaps in the Mind' (Dawkins), 'Common Sense, Cognitive Ethology and Evolution' (Bekoff).

I4 Zie de bijdragen in de sectie 'Encounters with Free-living Apes': 'Chimpanzees - Bridging the Gap (Jane Goodall); 'Meeting a Gorilla' (Douglas Adams, Mark Carwardine), 'Chimpanzees are Always New to Me' (Toshisada Nishida).

15 Zie hoofdstuk 3 en 5 van dit boek, waarin ik twee interpretatielijnen met betrekking tot de aard van de mens en de mensaap aan de orde stel, namelijk 'van nature goed' (De Waal) of 'van nature gewelddadig' (Wrangham).

I6 Zie Cavalieri \& Singer 1995: 629 voor exacte definities en argumentatie.

17 Zie ook Cavalieri en Singers samenvatting van het GAP in The Great 
Ape Project: Premises and Implications' (1995), waarin ze benadrukken dat de bijdragen in het boek The Great Ape Project 'scientific contributions' zijn (628).

18 De andere romans zijn Lovelock (Orson Scott Card en Kathryn H. Kidd), Wish - A Biologically Engineered Love Story (Peter Goldsworthy), Theory of Mind (Sanjida O'Connell), Jennie (Douglas Preston) en Ishmael (Daniell Quinn). Behalve romans, vindt men ook suggesties voor kinderboeken, en links naar het kunstzinnige werk van mensen, bijvoorbeeld fotografie, maar ook het kunstzinnige werk van mensapen, zoals de tekeningen van de gorilla Koko. Met name de aanbeveling van de roman Ishmael is opmerkelijk. Ishmael is een new-ageroman waarin een gorilla optreedt als onderwijzer voor de mensheid. Hij deelt de mensheid op in twee soorten, 'the takers' en 'the leavers'. Het is de materialistische mens, de 'taker', die de planeet langzaam maar zeker aan het vernietigen is. Het GAP, dat juist zo wetenschappelijk wil zijn, associeert zich met new-age, en blijkt bij nader inzien een vreemde mengeling van ideeën uit het darwinisme, het christendom en het new-agedenken. Zo wordt bijvoorbeeld steeds gewezen op de materiële genetische gelijkenis en evolutietheorie, maar ook klassieke beginselen uit het christendom als het 'rentmeesterschap' van de mens' klinken door, omdat het toch de taak van de mens is om de mensapen in bescherming te nemen. Tot slot heeft het project new-ageachtige kenmerken, zoals het holistische denken en het individualisme.

19 De associatie van de aap met de zwakzinnige ander is mijns inziens een riskante, omdat deze associatie in de iconografie zelden een positieve is. De aap als zwakzinnige is een verbeeldingsconventie die helemaal teruggaat tot in de vijftiende eeuw, toen apen vaak werden afgebeeld als hulpje of neefje van de narren en idioten (Mans 1998; Janson 1952).

20 www.greatapeproject.org

2I Idem.

22 Nowak (1999). Nowak merkt op dat de keuze voor Nieuw Zeeland vooral strategisch is bedoeld om een precedent voor rechtszaken in andere landen te scheppen. Nieuw Zeeland heeft namelijk nog nooit medische experimenten op mensapen gedaan. Er leven maar 28 chimpansees en 6 orang-oetans en die worden goed behandeld. Ook in Groot-Brittannië en Australië wordt niet geëxperimenteerd met mensapen. In Verenigde Staten zou de wet echter wel implicaties hebben. Daar worden zo'n 1700 chimpansees gebruikt voor medisch onderzoek om vaccinaties en medicijnen tegen het HIV-virus te testen. Het 
biomedisch onderzoek naar chimpansees in Nederland werd in april 200I stopgezet door minister Hermans, die te kennen gaf spoedig een verbod op alle dierproeven met mensapen te laten opnemen in de Wet op Dierproeven. Wel wordt nog altijd onderzoek gedaan op andere apen, bijvoorbeeld resusapen en java-apen (NRC Handelsblad, 6 juli 200I, p.3).

23 'Borderliners' is ook een term die gebruikt wordt voor een ziektebeeld. Peter Høeg gebruikt in zijn boek De måske egnede (in het Engels vertaald als Borderliners) de term voor jonge moeilijk opvoedbare kinderen die niet in de maatschappij passen en tussen werelden in zitten, die van het 'normale' kind en het 'zwakzinnige kind'. Zie ook noot 3i van dit hoofdstuk.

24 Zie ook Tuttle (1994: 602-603): The authors are almost evenly divided among Europeans and North Americans, with only one Asian (hishida) and no African or South American. They represent a range of humanistic, natural historical and social scientific disciplines and perspectives, but there is no voice from the biomedical community.'

25 Voor de kruisingsfantasieën in de achttiende- en negentiende-eeuwse wetenschap, zie De Rooy 199r en Schiebinger 1993.

$26 \mathrm{Vgl}$. Dian Fosseys toevlucht tot de alcohol om haar eenzaamheid weg te drinken (althans, zo verklaren de meeste biografieën Fosseys buitensporige drankgebruik, zie hoofdstuk 5 van dit boek). Het alcoholisme van John Clearwater in Brazzaville Beach is van tegenovergestelde aard. John stopt met drinken naarmate hij meer bezeten raakt van zijn zoektocht om turbulentie in één alomvattende zuivere abstracte wiskundige formule te vangen. Johns geheelonthouding kan geïnterpreteerd worden als een poging om 'zuiver' te blijven, zodat hij abstract kan blijven denken, en door de alcohol niet aangeraakt te worden door het 'concrete' leven. Tegelijkertijd werkt zijn obsessie met wiskunde als een nieuwe drug: hij verkeert in een geestelijke roes.

27 Vlg. hoofdstuk 5 van dit boek, waarin Jane Goodall, Dian Fossey en Biruté Galdikas ook 'aapachtiger' worden en het gedrag van apen imiteren om zo contact met hem te krijgen.

28 Het thema van de aap die de menselijke taal leert en zo kennismaakt met de civilisatie is een terugkerend motief in de literatuur. Te denken valt bijvoorbeeld aan Colliers roman Zijn apevrouw of: Met een chimpansee getrouwd (1986/1931), waarin de apin Emily (haar naam verwijst naar Rousseaus opvoedkundige werk Émile) een bibliotheekpas steelt en zich verdiept Darwins Origin of Species, en passant ook nog Virginia 
Woolfs A Room of One's Own leest. Geleerde apen dienen veelal als een bespotting van de mens (Janson 1952), en in het geval van Collier, vooral als een bespotting van de feministische vrouw (zie Jensen r998c over Collier).

29 Ook historisch gezien hebben vrouwen zich actiever opgesteld in dierenbeschermingsorganisaties dan mannen, zie Kluveld 2000.

30 Veel romances in boeken of op het witte doek eindigen met een tocht van het gelukkig paar richting een paradijselijke omgeving, denk bijvoorbeeld aan het eind van de tienerhitfilm Grease, waarin het gelukkige paar per auto de lucht in wordt getild en richting 'de hemel' reist.

3I Ook kinderen worden in het werk van Høeg opgevoerd als onschuldige ander. Voor een interpretatie van Høegs oeuvre en zijn relatie tot wetenschap en een kritiek op de gelijkschakeling van kinderen, apen en vrouwen als 'onschuldige menselijke ander', zie Jensen I998a.

32 De Tarzan-films kunnen ook in de traditie geplaatst worden waarbij de vrouw kiest voor de aap als minnaar. In de Tarzanverfilmingen die zijn gebaseerd op Edgar Rice Burroughs' Tarzan the Apeman, moet Jane kiezen tussen Tarzan en Clayton, een slechterik. De aapmens wint uiteraard. Tarzan is dan wel geen aap, hij noemt zichzelf wel 'aap', en gedraagt zich als een aap. Zie Jensen 1999 over het personage van Jane en haar relatie tot Tarzan in de Tarzan-films.

33 Zoals Margaret protesteert, maar in de film niettemin zwijgend figureert, zo wordt Madelene weliswaar geportretteerd als een intelligente vrouw die op slimme wijze krijgt wat ze wil, maar wordt ze tegelijkertijd omschreven als een leeghoofdig modepopje: 'In haar zwarte tasje vergaarde ze wat een vrouw zoal nodig heeft: sleutels, geld, lippenstift, eyeliner, zakdoek, een tekening van een aap en een plastic flesje met alcohol.' (47) Voor een analyse van de ambivalente representatie van vrouwelijke personages in Høegs romans, zie Jensen r998.

34 Dit thema is niet helemaal nieuw, denk aan de vrouw en de aap uit $D e$ vertellingen uit duizend-en-één nacht en de twee vrouwen uit Voltaires Candide, die een aap als minnaar nemen. Tot groot verdriet van de vrouwen wordt de aap in beide verhalen neergeschoten door een man die denkt dat de vrouw wordt lastiggevallen (Candide) of die denkt dat hij een betere minnaar is (Duizend-en-één-nacht). Een verschil tussen De vrouw en de aap en deze verhalen is dat de aap in 'Het verhaal van de prinses en de aap' wordt vergeleken met een 'neger' en een 'slaaf, voorts wordt voorgesteld als een driftmachine (om mee te eten en seks te hebben) die de vrouw bevredigt en die later als een 'worm', als ware 
het een virus, bij haar naar buiten komt. In Candide wordt gesuggereerd dat het om twee inheemse meisje gaat, die deel uit maken van een groep 'inboorlingen'. Niet alleen huppelen ze 'naakt' rond, maar ook lezen we: 'pourquoi trouvez-vous si étrange que dans quelques pays il y ait des singes qui obtiennent les bonnes grâces des dames? Ils sont des quarts d'hommes, comme je suis un quart d'Espagnol.' (Voltaire 1983: 63) In De vrouw en de aap blinkt de aap ook uit wat betreft intelligentie en emotionele aandacht voor de vrouw.

35 Met de groeiende roep om rechten voor mensapen en het continuïteitsdenken verschijnt ook een aantal films waarin de aap opnieuw als negatieve ander wordt geportretteerd. Het is met name de discussie over de oorsprong van AIDs die ertoe leidt dat de aap opnieuw gecast wordt in de rol van de afschuwwekkende ander, omdat deze de potentiële drager van het virus zou zijn dat een ongeneeslijke ziekte veroorzaakt. De jaren negentig kent een aantal films waarin apen voorgesteld wordt als staatsvijand nummer één. Zowel in bijvoorbeeld Outbreak (1995) als Twelve Monkeys (1995) gaan mensen in isolerende pakken op apenjacht, om de boosdoener die de mens besmet heeft met HIV uit te roeien. De aap wordt in deze film niet voorgesteld als zachtaardig individu, maar als lid van een gevaarlijke diersoort die uitgeschakeld moet worden.

36 Overigens is het opmerkelijk dat teleurgestelde vrouwen zich in deze heteroseksuele mythevorming tot apen wenden, en bijvoorbeeld niet tot andere vrouwen. Madelene is hierop de uitzondering: zij gooit zich in de armen van haar boezemvriendin Susan, maar beide vrouwen stoppen met hun affaire wanneer zij de meisjeskostschool verlaten.

37 De problematisering van mannelijkheid blijkt voorts uit de explosieve groei van publicaties rondom de constructies van mannelijkheid (ook wel men-studies genoemd) of de opkomst van cursussen als 'Ruimte voor mannen.' In Nederland valt te denken aan Duindam (1999) en Meulenbelt (1998) en het themanummer van De Groene Amsterdammer over 'De Man' van 29 juli 1998. Het betreft overigens niet alleen een westers fenomeen, zie bijvoorbeeld het artikel 'Nimfjes van Rio paaien schaarse mannen': Met de woorden 'de Braziliaanse man is in crisis,' herhaalt de antropologe Mey Waddington het adagium dat al geruime tijd door heel Latijns Amerika schalt. De vrouwen emanciperen, studeren verder, krijgen banen en ook hogere functies. Ze komen erachter dat een man voor het materiële overleven niet meer noodzakelijk is. En de man? 'Die raakt in de war. Zijn overwicht is niet meer gebaseerd op 
zijn rol als voeder en hoeder van het gezin. Dus moet hij zijn superioriteit baseren op het simpele feit dat hij man is.' (NRC Handelsblad, 27 juni 2000).

38 Overspel van vrouwen kan de ertoe leiden dat de echtgenoot in kwestie gaat twijfelen over zijn eigen mannelijkheid. De aap confronteert hem met zijn identiteitscrisis of wordt door hem als afzetpunt ingezet. Twee voorbeelden zijn de komische films Morgan, a Suitable Case for Treatment (Karel Reisz, 1966!) en Männer (Doris Dorrie, 1985). In beide films tooit de bedrogen echtgenoot in kwestie zich met een apenmasker of pak en probeert op deze wijze de aandacht van zijn vrouw te trekken. In Morgan geeft de vrouw nog de voorkeur aan de man die alles onder controle heeft, veel geld heeft en een goede baan, terwijl in Männer de voorkeur uitgaat naar de kunstzinnige man die in contact is met zijn gevoel en aandacht heeft voor zijn vrouw. In de komische film Being John Malkovich (Charlie Kaufman, 1999) stopt een man zijn echtgenote met een chimpansee in een kooi. Hij hoopt zo geen last meer van haar te hebben: zowel hij als zijn vrouw zijn verliefd op dezelfde vrouw. De vrouw zoekt troost bij de aap.

39 De film Max, Mon Amour kent wat dit betreft het verrassendste slot van alle driehoeksverhoudingen tussen vrouwen, apen en mannen die ik ben tegengekomen. Net als in De vrouw en de aap legt de man zich neer bij de affaire van zijn vrouw met de aap. Hoewel hij zich aanvankelijk zeer gekrenkt voelt in zijn mannelijkheid, moet hij toegeven dat ook hij 'van de aap is gaan houden'. Hij laat zijn eigen machogedrag varen. $\mathrm{Ze}$ besluiten gedrieën samen in één huis verder te leven. De ambiguïteit blijft behouden en er worden geen definitieve keuzes gemaakt tussen de man en de aap.

40 Vgl. Pierre Boulles roman Planet of the Apes (1963, verfilmd in 1968 onder de gelijknamige titel door Michael Wilson). Hierin belandt een man op een apenplaneet, waar mensen als minderwaardige wezens worden beschouwd. Een apenvrouw voelt zich betrokken bij de 'mindere' mens en lijkt een beetje verliefd op een man, die ze redt uit handen van de apen die de mensen willen vermoorden. In zekere zin past deze apinman relatie dus naadloos in het proefschrift, omdat het een omkering van bestaande verhoudingen is en omdat de vrouw empathie voelt voor de 'lagere' soort. Net als bij King Kong is de film Planet of the Apes (1963) geïnterpreteerd als een allegorie voor rassenverhoudingen, waarbij de apen die de macht - 'ape-power' - over de witte mensen hebben gekregen, 'black power' symboliseren en de 'interraciale relatie' tussen 
een apin en een man mislukt. 'Blacks triumphs over whites', aldus David Annan (1974). De remake van de film Planet of the Apes (Tim Burton 200I) was volgens sommige recensenten minder politiek - 'Burton laat de maatschappijkritiek voor wat het is' schreef de Volkskrant (23-8-or) - maar laat zich mijns inziens naadloos interpreteren in de huidige context van het debat van gelijke rechten voor mensen (mensapen dus eigenlijk, gezien de omgekeerde verhouding) die niet als 'slaven' behandeld zouden mogen worden.

4I Vgl. de droom in Helmans Mijn aap schreit. Op het omslag van De vrouw en de aap is een tekening van Michael Di Biase te zien, die stilistisch lijkt op het werk van de schilder Rousseau, een naakte 'aapachtige' vrouw liggend op een sofa in de jungle (met de suggestie dat de jungle haar 'therapie' is).

42 Deze trend zet zich verder voort, bijvoorbeeld met Mark Z. Danielewski's House of Leaves (2001), waarin de auteur niet alleen de pretenties en idioterieën van wetenschappers ridiculiseert door bijvoorbeeld voetnoten bij voetnoten bij voetnoten in zijn tekst op te nemen, maar ook typografisch het fenomeen 'literatuur' op de kop zet. 'We haven't begun to push the boundaries on books yet', zei de auteur in een interview met The Guardian (geciteerd in Boeken, NRC Handelsblad 1-6-2001).

\section{Waarom vrouwen van apen houden}

I De Waal is niet de eerste die cultuur bij dieren opmerkt, hoewel de media dat suggereren. Zie bijvoorbeeld het interview in Intermediair ( 28 juni 200I) en de recensie van Tijs Goldschmidt in de Boekenbijlage NRC Handelsblad 8-6-200I. Joost Niemöller oordeelde onder andere om deze reden vrijwel als enige negatief over het boek van De Waal: 'Overigens: De Waal zit er ook niet mee om observaties als de zijne te presenteren die feitelijk al tientallen jaren voor hem gedaan waren door Lorenz' Niemöller verwijst daarbij naar onderzoek naar agressie bij apen. Wat cultuur betreft, zou je inderdaad kunnen opmerken dat McGrew (1992) in Chimpanzee Material Culture: Implications for Human Evolution al speculeerde over het idee van cultuur bij chimpansees; De Waal verwijst hier wel naar. Tegen Niemöller zou je kunnen inbrengen dat het de verdienste van De Waal is dat hij dergelijke onderzoeken voor een breed publiek toegankelijk en inzichtelijk maakt. Vgl. Jane Goodall, die de geschiedenis inging als degene die gereedschapgebruik bij chimpansees 
ontdekte, terwijl dit reeds in de zestiende eeuw was geconstateerd (zie hoofdstuk I, noot 25, van dit boek).

2 De Waal 20or: 234. Paginanummers verwijzen naar de Nederlandse vertaling door Bart Voorzanger.

3 Gebruikte editie: J. de la Fontaine 1995: 362.

4 Deze bundel verscheen in 1978 . Paginanummers in dit stuk verwijzen naar de editie uit 1997 van Vintage. Een Nederlandse vertaling van 'Reflections of a Kept Ape', door Heleen ten Holt, getiteld 'Overpeinzingen van een gemainteneerde aap' en verschenen vóór de Engelse publicatie van de bundel, is te vinden in Tussen de Lakens (McEwan 1977).

5 Uitvoerige interpretaties van 'Reflections of a Kept Ape' verschenen er nog niet. Binnen het inmiddels omvangrijke oeuvre van de gevierde Britse schrijver ging de meeste aandacht uit naar zijn verfilmde romans The Cement Garden (1978), over de incestueuze relatie tussen een broer en een zus, en naar The Comfort of Strangers (1981), over de uit de hand gelopen relatie tussen twee echtparen. Wel zijn er in vrijwel alle recensies en artikelen over de bundel In Between the Sheets toespelingen op het verhaal te vinden (bijvoorbeeld Treglown 1978, Moorehead 1978, Ryan 1994). Het verhaal zou met de bestiale affaire een 'echt McEwanverhaal' zijn, dat vrijwel altijd gaat over relaties tussen mannen en vrouwen, met name over de duistere en gewelddadige kant van hun 'abnormale seksuele gedragingen, zoals incest, pedofilie en verkrachting' (Ryan 1994). McEwans verhaal verdient een uitvoeriger interpretatie dan hier mogelijk is. Een eerste aanzet daartoe gaf ik in Jensen 200ob. Er zijn onder meer interessante thematische parallellen (vruchtbaarheid in relatie tot kunst, mannelijkheid en vrouwelijkheid) met het verhaal 'Sarrasine' van Balzac - een schrijver die genoemd wordt in 'Reflections of a Kept Ape'. Voor een inspirerende interpretatie van 'Sarrasine', zie Roland Barthes (1990).

6 Voor de wijze waarop de metafoor 'kunst is nageslacht' dit verhaal - als ook veel andere writer's block fictie - structureert, zie Jensen 20oob. In dat artikel passeren ook de mogelijke oplossingen die een auteur aanwendt om zijn writer's block op te heffen, waarvan, naast het gebruik van stimulerende middelen zoals Balzacs grote consumptie van koffie, seks (zoals Sally haar toevlucht zoekt tot een aap) een zeer bekende is. In de jaren twintig werden plakjes apentestikel in (mannelijke) acteurs en schrijvers ingeplant die zich zorgen maakten om hun creativeit (Hamilton 1986).

7 We weten niet om wat voor soort aap het gaat in 'Reflections of a Kept 
Ape'. Over zijn bouw lezen we: 'Perhaps I am a little too squat to be taken seriously, my arms a little too long' (20). Voorts heeft hij 'a funny little black leathery penis' (2I) en maakt hij een krijsend geluid. Nergens wordt genoemd dat hij een staart heeft, dus misschien is het een mensaap. Vermoedelijk is het geen gorilla, want die maken geen krijsend geluid. Het kan ook geen bonobo zijn, want van de mensapen zijn zij de enige die het juist wel 'face to face' doen (De Waal r998). Dan kan het gaan om een orang-oetan of een chimpansee, maar de eerste heeft meestal geen 'gedrongen' figuur. Dus waarschijnlijk gaat het in dit verhaal om een chimpansee. Ook in andere werken van McEwan wordt wel eens verwezen naar deze mensaap (Roger 1996). De aap in 'Reflections of a Kept Ape' weet verbluffend veel, kan veinzen, denken, lezen enzovoort, en dat maakt hem minder aapachtig, hoewel zijn fysiek steeds nadrukkelijk wordt beschreven.

8 Over de iconografische traditie van de aap als muze van de kunsten in de Middeleeuwen en Renaissance, zie Janson 1952: 287-325.

9 'Le romancier est, de tous les hommes, celui qui ressemble le plus à Dieu: il est le singe de Dieu,' zo luidt de openingszin van François Mauriacs Le Roman (1928). In het toneelstuk God (1975) van Woody Allen wordt het thema van de schrijver als de aap van God letterlijk uitgebeeld, door de worstelende toneelregisseur enkele telefoontjes met God te laten plegen over hoe het nu precies verder moet met zijn toneelstuk. De stem die we horen blijkt die van Woody Allen zelf.

ro De terminologie waarin er over het writer's block wordt gesproken is vaak mannelijk, denk aan de uitdrukking 'literaire impotentie'. Meestal betreft het blanke mannen. Over writer's block in relatie tot mannelijkheid en vrouwelijkheid en kleur, zie Jensen 2000 b (gender en writer's block in de literatuur) en Jensen 2oorb (gender, kleur en writer's block in Hollywoodfilms).

II Andere voorkomende 'surrogaten' zijn rijkdom en macht, het verzamelen en vermeerderen van geld, bezit of invloed.

I2 Mol formuleert het kernachtig: 'Boeken en baby's botsen!' (zie ook hoofdstuk 2 van dit proefschrift). Zie bijvoorbeeld de film Nynke (200I) over de problemen van de negentiende-eeuwse kinderboekenschrijfster Nynke van Hichtum om kinderen en schrijven te combineren. In Wie weegt de woorden. De auteur en haar werk (1985), constateert Anja Meulenbelt dat veel beroemde hedendaagse schrijfsters nog altijd al dan niet gedwongen kinderloos zijn of minder schrijven omdat zij ook voor kinderen zorgen. 'Een Vestdijkiaanse produktie zit er niet in,' verzucht 
bijvoorbeeld Tessa de Loo, die kinderen met schrijven combineert. Sommige schrijfsters proberen het idee dat de twee niet samen gaan om te buigen. Alice Walker bijvoorbeeld, die In Search of Our Mother's Gardens ( 1984 ) hoofdstukken schreef met titels als 'A writer because of, not in spite of her children' en 'A child of one's own', waarin ze betoogt dat kinderen een inspiratie zijn voor het moederschap en geen belasting.

13 Terwijl de aap naamloos blijtt, is de naam Sally een veelvoorkomende naam onder Britse vrouwen tussen de 35 en 40 jaar, en als generatienaam misschien gekozen door McEwan om een indicatie van Sally's leeftijd te geven. Haar achternaam, 'Klee', klinkt als 'clay', klei, en verwijst misschien naar haar verlangen om te creëren, iets nieuws te scheppen. De achternaam van haar personage 'Moira Sillito' is niet bepaald vleiend, als men 'silly' leest (wat weer op 'sally' lijkt).

14 Zie hoofdstuk 2 over In tekst gevat van Maaike Meijer.

15 De Waal heeft het soms over 'dieren', dan weer over 'mensapen'. Ook uit de vertaling blijkt dat beide categorieën met gemak worden afgewisseld. De Engelse editie benadrukt 'apen' in de ondertitel: 'Reflections of a Primatologist', de Nederlandse vertaling luidt: 'over cultuur bij dieren' [cursivering van mij, s]].

I6 Opvallend is dat De Waal in zijn hoofdstuk over 'dierenkunst' zwijgt over een kunstveld: de literatuur. Hoewel een aap nog nooit 'een Shakespeare' heeft geproduceerd, (al beweren sommigen dat dit slechts een kwestie van tijd en toeval is, bijvoorbeeld Richard Dawkins in zijn boek De blinde horlogemaker uit 1988 (pp. 62-69 en 169), die uitrekent dat er ${ }^{10}{ }^{46}$ apen nodig zijn om er een zin als 'Methinks it is like weasel', uitgesproken door Hamlet, of 'cogito ergo sum' eruit te laten rollen), is in meerdere talen het verband tussen apen en literatuur gelegd, denk aan de 'aap van God'.

17 Over de Japanse benadering van apen is meer geschreven. Voor een algemene studie naar de culturele betekenis van de aap in Japan, zie bijvoorbeeld ook Asquith 1995 en Ohnuki-Tierny 1987 en Haraway 1989: 244-275.

I8 Kester Freriks, 'Een parabel over onschuldige liefde.' NRC Handelsblad, I-IO-1996. 


\section{Bibliografie}

Abir-Am, P.G. \& Outram, D. (1987). Uneasy Careers and Intimate Lives.

Women in Science 1789-1979. New Brunswick: Rutgers University Press. Akeley, C.E. (1923). In Brightest Africa. New York: Doubleday.

Alphen, E. van (1992). De toekomst der herinnering. Essays over moderne

Nederlandse literatuur. Amsterdam: Van Gennep.

Annan, D. (1974). Ape: the Kingdom of Kong. Londen: Lorrimer Publishing. Aquinas, T. (1952). The Summa Theologica of Saint Thomas Aquinas. Trans-

lated by the Fathers of the English Dominican Province. Revised by Daniell J. Sullivan. (Vol. I). Chicago: The University of Chicago Press.

Arion, F.M. (1977). Albert Helman, de eenzame jager. Paramaribo: Cahier van het Instituut voor de opleiding van leraren.

Armbruster, K. (1997). " "Surely, God, These Are My Kin". The Dynamics of Identity and Advocacy in the Life and Works of Dian Fossey'. In: J. Ham \& M. Senior (red.), Animal Acts: Configuring the Human in Western History. Londen: Routledge.

Asquith, P.J. (1995). 'Of Monkeys and Men: Cultural Views in Japan and the

West'. In: R. Corbey \& B. Theunissen (1995), 309-327.

Bakhtin, M.M. (1981). The Dialogical Imagination. Four Essays by M.M. Bakhtin. Edited by M. Holquist. (Vert. uit het Russisch door C. Emerson en M. Holquist). Austin: University of Texas Press.

$\mathrm{Bal}, \mathrm{M}$. (1990). De theorie van vertellen en verhalen. Inleiding in de narratologie. Muiderberg: Coutinho.

Barthes, R. (1990). S/Z (Vert. uit het Frans door R. Miller). Oxford: Basil Blackwell.

Beer, G. (1983). Darwin's Plots. Evolutionary Narrative in Darwin, George Eliot and Ninetheenth-Century Fiction. Londen: Ark Paperbacks. 
Bernard, K. (1976). 'King Kong: a Meditation'. In: R. Gottesman \& H. Geduld (1995), 124-130.

Blans, G.H.T. (1988). 'Hermeneutiek en deconstructie'. In: T. de Boer (red.), Hermeneutiek. Filosofische grondslagen van mens- en cultuurwetenschappen. Amsterdam: Boom.

Blumenbach, J.F. (1775). Handbuch der Naturgeschichte. Goettingen: Dietrich. Boulle, P. (1963). De apenplaneet. (Vert. uit het Frans door S. Luwé-Vos). Utrecht/Antwerpen: A.W. Bruna \& Zoon.

Bouman, H. (1991). 'Trojaanse oorlogen tussen de primaten. De moordzuchtige chimpansees van William Boyd'. De Volkskrant, 20 sep.

Boyd, W. (1990). Brazzaville Beach. Londen: Sinclear-Stevenson.

Boyd, W. (1990). Brazzaville Strand. (Vert. uit het Engels door R. van der Veer). Amsterdam: Prometheus.

Brain, R. (1990). 'The Troubled Mind of the Body Watcher'. Times Literary Supplement, i4 sep.

Brent, L. (1994). 'Haraway's Monsters'. American Joumal of Primatology, 32(I), 69-70.

Brunas, M. Brunas, J. \& Weaver, T. (1990). Universal Horrors. The Studio's Classic Films, 1931-1946. Jefferson: Mc. Farland \& Company.

Buikema, R. \& Smelik, A. (red.), (r993). Vrouwenstudies in de cultuurwetenschappen. Muiderberg: Coutinho.

Bulhof, I. (1988). Origin of species. Betoverende wetenschap. Baarn: Ambo. Buytendijk, F.J.J. (1920). Psychologie der dieren. Haarlem: Erven F. Bohn. Buytendijk, F.J.J. (1933). Het spel van mensch en dier als openbaring der levensdriften. Amsterdam: Kosmos.

Carroll, N. (1984). 'King Kong: Ape and Essence'. In: B.K. Grant (red.), Planks of Reason. Essays on the Horror Film. Metuchen, New Jersey, Londen: The Scarecrow Press, 215-245.

Cartmill, M. (1990). 'Human Uniqueness and Theoretical Content in Paleoanthropology'. International Journal of Primatology, (3)11, 173-192.

Cartmill, M. (1993). A View to Death in the Morning. Hunting and Nature Through History. Cambridge et cetera: Harvard University Press.

Cavalieri, P. \& Singer, P. (red.) (1993). The Great Ape Project: Equality beyond Humanity. New York: St. Martin's Press.

Cavalieri, P. \& Singer, P. (1995). The Great Ape Project: Premises and Implications'. ATLA, 23, 626-63I.

Chaillu, P.B. du (1945). Explorations and Adventures in Equatorial Africa. Londen: Werner Laurie. Oorspr. jaar van uitgave: $186 \mathrm{I}$. 
Chandra, V. (1995). Red Earth and Pouring Rain. New York: Back Bay.

Clemens, J. (1999). Ten Thousand Fucking Monkeys. Victoria: Arena Printing.

Collier, J. (1986). Zijn apevrouw of: met een chimpansee getrouwd. Amsterdam: De Arbeiderspers. Oorspr. jaar van uitgave: 1931.

Collins, P. H. (1991). Black Feminist Thought. Knowledge, Consciousness, and the Politics of Empowerment. Londen: Routledge.

Corbey, R. (199I). 'Freud's Phylogenetic Narrative'. In: R. Corbey \& J. Leerssen (red.), Alterity, Identity, Image. Selves and Others in Society and Scholarship. Amsterdam: Rodopi. 37-57.

Corbey, R. \& Theunissen, B. (1995). Ape, Man, Apeman. Changing Views Since 16oo. Leiden: Leiden University Press.

Corbey, R. (200I). 'Negotiating the Ape-Human Boundary'. In: B. Beck \& T.S. Stoinksi \& M. Hutchins \& T.L. Maple \& B. Norton \& A. Rowan \& E.F. Stevens, \& A. Arluke (eds). Great Apes \& Humans. The Ethics of Coexistence. Washington et cetera: Smithsonian Institution Press. 163-175.

Corbey R. (te verschijnen). The Metaphysics of Apes. Negotiating the Human-Animal Boundary. Tulp to De Waal.

Cussins, C. (1997). 'Confessions of a Bioterrorist: Subject Position and Reproductive Technologies'. Reader (Part II) European Summerschool Science and Techology Studies, wTMc, Enschede.

Dalen-Oskam, K. van \& Mooijaart, M. (200o). Bijbels Lexicon. Woorden en uitdrukkingen uit de bijbel in het Nederlands van nu. Amsterdam: Bert Bakker.

Davis, L.J. (1997). The Disability Studies Reader. New York: Routledge.

Dawkins, R. (1977). De zelfzuchtige genen. Over evolutie, agressie en eigenbelang. Amsterdam: Contact.

Dawkins, R. (1988). De blinde horlogemaker. (Vert. uit het Engels door F. de Groot). Amsterdam: Contact.

De vertellingen van duizend-en-één-nacht, deel 5/6. (Vert. uit het Arabisch door R. van Leeuwen.) Amsterdam: Bulaaq.

DeGrazia, D. (1997). 'Great Apes, Dolphins, and the Concept of Personhood'. The Southern Journal of Philosophy, 35 (3), 301-320.

Dekkers, M. (1992). Lief dier. Over bestialiteit. Amsterdam: Contact.

Dijck, J. van (1995). Manufacturing Babies and Public Consent. Debating the New Reproductive Technologies. New York: New York University Press. Dijck, J. van (1998). Imagenation. Popular Images of Genetics. Hampshire et cetera: Macmillian Press. 
Diski, J. (1994). Monkey's Uncle. Londen: Phoenix.

Dobbelaar, T. \& Slob, M. (I995). 'Wees liever een cyborg dan een godin'. Filosofie Magazine, 4(1), 10-12.

Draulans, D. (1998). De mens van morgen. Amsterdam: Atlas.

Duffey, M. (199I). 'Monkeys in a Jungle'. $M E, 24$ juni.

Duindam, V. (red.). (1999). Ruimte voor mannen: in de hulpverlening, in de wetenschap en in de alternatieve hoek. Amsterdam: Van Gennep.

Duinkerken, A. van (1928). Recensie van Mijn aap schreit van Albert Helman. De Tijd op zondag, 16 juni.

Dyer, R. (1997). White. Londen: Routledge.

Erb, C. (1998). Tracking King Kong. A Hollywood Icon in World Culture. Michigan: Wayne State University Press.

Fedigan, L.M. \& Fedigan, L. (1989). 'Gender and the Study of Primates'. In: S. Morgen (red.), Gender and Anthropology: Critical Reviews of Implications for Teaching and Research. Washington: American Anthropological Association, 4I-64.

Fedigan, L.M. (1994). 'Science and the Succesful Female. Why there are so Many Female Primatologists'. In: The American Anthropologist 3 (96), 529-539.

Fierens, H. (1968). Het mensbeeld in het verhalend proza van Albert Helman. Leuven: Universiteit van Leuven.

Fokkema, D. \& Ibsch, E. (1992). Literatuurwetenschap en cultuuroverdracht. Muiderberg: Coutinho.

Fontaine, J. de la (r995). Fables. Présentées par Alain-Marie Bassy. Parijs: Flammarion. Oorspr. jaar van uitgave: 1668.

Fontenay, E. de (1998). Le silence des bêtes. La philosophie à l'épreuve de l'animalité. Parijs: Fayard.

Fossey, D. (1970). 'Making Friends with Mountain Gorillas'. National Geographic, 137 (I) 48-67.

Fossey, D. (1984). Gorilla's in de mist (Vert. uit het Engels door H. Heij). Utrecht: Veen.

French, Sean (1993). The Imaginery Monkey. London: Granta Books.

Freriks, K. (1996). 'Een parabel over onschuldige liefde'. NRC Handelsblad, I oktober.

Galdikas, B.M.F. (I980). 'Living with the Great Orange Apes'. National Geographic, 157 (6), 830-853. 
Galdikas, B.M.F. (1995). De spiegel van het paradijs: mijn jaren bij de orangoetans van Borneo. (Vert. uit het Engels door P. Out). Amsterdam: Atlas.

Garber, M. (1995). Vice Versa. Bisexuality and the Eroticism of Everyday Life. New York: Simon and Schuster.

Geertz, C. (1989). De antropoloog als schrijver. Kampen: Kok Agora.

Geest, S. van der (red.) (1995). Ambivalentie/ambiguiteit. Amsterdam: Het Spinhuis.

Gerigk. (1989). Der Mensch als Affe in der Deutschen, Französischen, Russischen, Englischen und Amerikanischen Literatur des 19. und 20. Jahrhunderts. Stuttgart: Guido Pressler Verlag Hurtgenwald.

Godwin, S. (1990). Gorillas. New York: Mallard Press.

Goeij, C.H.D. (1948). Zondvloed en zondeval bij de Indianen van WestIndië. Amsterdam: Het Indisch Instituut.

Goethe, J.W. (1909). Die Wahlverwandtschaften und Kleinere Erzählungen. Leipzig: Tempel. Oorspr. jaar van uitgave: 1809 .

Goethe, J.W. (1954). 'Dem Menschen wie den Tieren ist ein Zwichenknochen der oberen Kinlade zuzuschreiben'. In: J. W. Goethe (red.), Die Schrifte zur Naturwissenschaft. Bearbeitet von Dorothea Kuhn, mit 32 tafeln. Weimar: Hermann Böhlaus Nachfolgen, 154-166.

Goldner, O. \& Turner, G.E. (1976). The Making of King Kong. The Story Behind a Film Classic. New York: A.S. Barnes and Company.

Goldschmidt, T. (200I). 'Alles nageaapt'. Boekenbijlage NRC Handelsblad 8 juni.

Goodall, J. (1991). Oog in oog met de chimpansees. 30 jaar in het oerwoud van Gombe. (Vert. uit het Engels door T. de Jongh). Amsterdam et cetera: Veen.

Goodall, J. (2000). Hoop voor de toekomst. Rijswijk: Elmar.

Goods, E. (1991). 'Good Intentions'. New York Review of Books, ro oktober. Gossett, H. (1998). King Kong! Kinggg Kongg!! Kinggg Konggg!!! ms: The New Magazine for Woman, 4 aug., 94-95.

Gottesman, R. \& Geduld, H. (1976). The Girl in the Hairy Paw: King Kong as Myth, Movie and Monster. New York: Bounty Books.

Graff, G. (1998). 'Determinacy/Indeterminacy'. In: F. Lentricchia \& T. McLaughlin (red.), Critical Terms for Literary Study. Chicago: The University of Chicago Press, I63-r76.

Gross, P.R. \& Levitt, N. (1994). Higher Superstition. Academic Left and its Quarells with Science. Baltimore et cetera: The Johns Hopkins University Press. 
Hall, J. (1995). Gone Wild. New York: Delacorte Press.

Hamilton, D. (1986). The Monkey Gland Affair. Londen: Chatto \& Windus.

Haraway, D. (1989). Primate Visions. Gender, Race and Nature in the World of Modern Science. New York et cetera: Verso.

Haraway, D. (1991). 'Gender for a Marxist Dictionary. The Sexual Politics of a Word'. Simians, Cyborgs and Women. The Reinvention of Nature. Londen: Free Association Books, 127-149.

Haraway, D. (1991). Simians, Cyborgs and Women. The Reinvention of Nature. Londen: Free Association Books.

Haraway, D. (1994). Een cyborg manifest. Met een inleidend essay van Karin Spaink. (Vert. uit het Engels door A. Beuken). Amsterdam: De Balie.

Haraway, D. J. (1997). ModestWitness@Second-Millennium. FemaleManMeets-Oncomouse. Feminism and Technoscience. New York et cetera: Routledge.

Haskell, M. (1973). From Reverence to Rape. The Treatment of Women in the Movies. Chicago et cetera: The University of Chicago Press.

Hayes, H.T.P. (1990). The Dark Romance of Dian Fossey. New York: Simon and Schuster.

Hayles, N.K. (1990). Chaos Bound. Orderly Disorder in Contemporary Literature and Science. Londen: Cornell University Press.

Hayles, N.K. (red.) (r991) Chaos and Order. Complex Dynamics in Literature and Science. Chicago: University of Chicago Press.

Hayles, K. (1999). How We Became Posthuman. Virtual bodies in Cybernetics, Literature and Informatics. Chicago: University of Chicago Press.

Haynes, R. D. (1994). From Faust to Strangelove; Representations of the Scientist in Western Literature. Baltimore et cetera: The Johns Hopkins University Press.

Hayter, S. (1999). The Last Manly Man. Harpenden: No Exit Press.

Hearne, B. (1989). Beauty and the Beast. Visions and Revisions of an Old Tale. Chicago: The University of Chicago Press.

Heijne, B. (1991). 'William Boyd over Engelsen en chimpansees. Gehuil in het trappenhuis' NRC Handelsblad, I maart.

Heijne, B. (200o). De wijde wereld. Amsterdam: Prometheus.

Heijst, A. van (1992). Verlangen naar de val. Zelfverlies en autonomie in hermeneutiek en ethiek. Kampen: Kok Agora.

Helman, A. (1928). Mijn aap schreit. Een korte roman. Utrecht: De Gemeenschap.

Helman, A. (1931). Wij en de litteratuur. Utrecht: De Gemeenschap. 
Helman, A. (1947). Omnibus. Amsterdam: De Amsterdamsche Boek- en Courantmaatschappij.

Helman, A. (1948). Waarom niet. Amsterdam: Querido.

Helman, A. (1953). Mijn aap lacht. Amsterdam: Amsterdamsche Boek- en Courantmaatschappij.

Helman, A. (1957). Het euvel Gods en Mijn aap schreit. Amsterdam: Querido. Helman, A. (1985). Wederkerige portretten. Een alternatieve autobiografie. Zutphen: Terra.

Hendriks, R. (2000). Autistisch gezelschap. Een empirisch-filosofisch onderzoek naar het gezamenlijk bestaan van autistische en niet-autistische personen. Lisse: Swetz \& Zeitlinger.

Hesse, H. (1957). Narziß und Goldmund. Montagnola: Suhrkamp

Heusden, B. van (1994). Why Literature? An Inquiry into the Nature of Literary Semiosis. Proefschrift RUG.

Hoch, P. (1979). White Hero. Black Beast. Racism, Sexism and the Mask of Masculinity. Londen: Pluto Press.

Høeg, P. (1996). De vrouw en de aap (Vert. uit het Deens door G. Cruys). Amsterdam: Meulenhoff.

Holleman, T. (1998). 'Hij praat, hij jaagt en hij is handig. Botresten en werktuigen poetsen negatief beeld van neanderthaler op'. NRC Handelsblad, 28 november.

Hoogland, R. (1997). Lesbian Configurations. Cambridge: Polity Press.

hooks, b. (1981). Ain't I a Woman: Black Women and Feminism. Boston: South End Press.

hooks, b. (1995). Art on My Mind. Visual Politics. New York: The New Press. Howard, J.(1982). Darwin. Oxford: Oxford University Press.

Hughes, L. (red.) (1980). Monkeys. Londen: W.H. Allen.

Ingraham, C. (1999). White Weddings: Romancing Heterosexuality in Popular Culture. New York: Routledge.

Jagose, A. (1998). 'Lulu's Fifth Birthday. An extract from Lulu: A Romance'. Aedon, 5 (1), 60-72.

Jagt, M. van der (200I). 'Het fotomodel en het oerinstinct'. Vrij Nederland, 28 april, 42-43.

Jahme, C. (2000). Beauty and the Beasts. Woman Ape and Evolution. Londen: Virago.

Jahoda, G. (1999). Images of Savages. Ancient Roots of Modern Prejudice in Western Culture. New York: Routledge. 
Janson, H.W. (1952). Apes and Ape Lore in the Middle Ages and the Renaissance. Londen: The Warburg Institute, University of Londen.

Jardine, A. \& Smith, P. (red.) (1989). Men in Feminism. New York: Routledge. Jensen, L. (1998). Het kind van de ark. (Vert. uit het Engels door T. Stheeman). Amsterdam: Prometheus.

Jensen, S. (1998a). 'De vrouw, het kind en de aap. Over het werk van Peter Høeg'. De Gids, 8 (161), 558-565.

Jensen, S. (1998b). Bespreking van Modest Witness van Donna Haraway. Mediamatic, Spring I (9), 29-30.

Jensen, S. (1998c). 'Waarom vrouwen van apen houden. Over bestialiteit in literatuur en film'. Lover, 3 (25), 4-9.

Jensen, S. (1999). 'Jij Jane. De eeuwige band tussen vrouw en aap'. NRC Handelsblad, Cultureel Supplement, 3 december.

Jensen, S. (200oa). 'Ecce simius! Over Mijn aap schreit van Albert Helman'.

Nederlandse Letterkunde 5 (1), $62-85$.

Jensen, S. (2000b). 'De apin van God. Writer's block, nageslacht en een bizar verhaal van Ian McEwan'. Armada, 6 (19), 125-132.

Jensen, S. (200ra), De verlangenmachine. Vrouwen in de popmuziek. Amsterdam: Prometheus.

Jensen, S. (200rb). 'En de schrijver, hij plant zich voort. Schrijvers volgens Hollywood'. NRC Handelsblad, Cultureel Supplement, 20 april.

Jensen, S. (200Ic). 'Lippenstift feminisme. De neuroses van Ally McBeal en Bridget Jones'. NRC Handelsblad, Cultureel Supplement, II mei.

Kafka, F. (1994). 'Ein Bericht für eine Akademie'. Das Urteil. New York City: Schocken. Oorspr. jaar van uitgave: 1917, ㅍ-128.

Kempen, M. van (1995). 'De creatieve contestatie van een gladde aap. Mijn aap lacht van Albert Helman'. Oso, I4 (I), 8-22.

Kempen, M. van (1998a). Albert Helman. Kritisch Literair Lexicon, 71, 1-20.

Kempen, M. van (1998b). Kijk vreesloos in de spiegel. Albert Helman rgoz1996. Notities, nota's, noteringen. Haarlem: In de Knipscheer.

Kempen, M. van (1999). 'Caliban met welgevulde boekentas. Albert Helman als indiaan in de diaspora?' In: Armada, 16, 45-53.

Kemperink, M.G. (1993). 'Medische theorieën in de Nederlandse naturalistische roman'. De negentiende eeuw, $17, \mathrm{Ir} 5-167$.

Kemperink, M.G. (1998). " "Excelsior" is het devies van de natuur. Darwinisme in de Nederlandse roman (1860-1885)'. Nederlandse Letterkunde 3 (2), 97-126.

Kemperink, M.G. (1999). Jungle en paradijs. Darwinisme in de Nederlandse 
roman (1885-1910)'. Nederlandse Letterkunde 4 (1), I-16.

Kertész, I. (1999). Het fiasco (Vert. uit het Hongaars door H. Kammer). Amsterdam: Van Gennep/Van Halewijck.

Keysers, P. (1993). Doping. Het circus van list en bedrog. Leuven: Kritak/De Geus.

Kluveld, A. (2000). Reis door de hel der onschuldigen. De expressieve politiek van de Nederlandse anti-vivisectionisten I89o-1940. Amsterdam: Amsterdam University Press.

Kondo, D.K. (1990). Crafting Selves. Power, Gender and Discourses of Identity in a Japanese Workplace. Chicago et cetera: The University of Chicago Press.

Korthals, M. (1998). 'Antropomorfisme: Een ondeugd in de dierwetenschappen?' Kennis en Methode XxII (3), 293-309.

Kouwenaar, G. (1953). 'Heimwee naar het paradijs: zachte dieren en harde mensen'. Vrij Nederland, 27 juni.

Kunitz, S.J. \& Haycraft. H. (red.) (1942). Twentieth Century Authors. A Biographical Dictionary of Modern Literature. New York: The H.W. Wilson Company.

Kusters, W. (199I). 'Autisme. Over "vallende ster" van J. Bernlef. Tijdschrift voor Gezondheidszorg en Ethiek I (I), 20-23.

Kusters, W. (1995). Ik graaf, jij graaft. Aantekeningen over poëzie. Amsterdam: Querido.

Kusters, W. (1995b). "“Operatie Hersendood." De geneeskunde als slagveld'. Tijdschrift voor Gezondheidszorg en Ethiek 5 (1), 20-22.

Kusters, W. (1997). " "Elk ding is de som van zijn antwoorden”. Dick Hillenius: wetenschap en poëzie'. Tïjdschrift voor literatuurwetenschap, 2 (4), 330-337.

Kusters, W. (1999). 'Chaos, erosie, entropie. Wetenschap en literatuur bij Willem Frederik Hermans'. Nederlandse Letterkunde, 4 (I), 37-47.

Laarse, R. van der, Labrie, A. \& Melching, W. (red.) (r998). De hang naar zuiverheid: de cultuur van het moderne Europa. Amsterdam: Het Spinhuis.

Laet, M. de (1991). 'De aap als spiegelbeeld: een verontrustend visioen'. Kennis en Methode, I (Xv), I42-147.

Lakoff, G. \& M. Johnson (1980). Metaphors we Live By. Chicago: The University of Chicago Press.

Landwehr, J. (1981). De Nederlander uit en thuis. Spiegel uit het dagelijkse leven van bijzondere zeventiende-eeuwse boeken. Alphen aan den Rijn: A.W. Sijthoff. 
Lepenies, W. (1985). Die Drei Kulturen. Soziologie zwischen Literatur und Wissenschaft. München: Hanser.

Levine, D.N. (1985). The Flight from Ambiguity. Essays in Social and Cultural Theory. Chicago: The University of Chicago Press.

Levine, G. (r988). Darwin and the Novelists. Patterns of Science in Victorian Fiction. Cambridge et cetera: Harvard University Press.

Lockhorn, E. (2001). 'Duiven houden niet van Schönberg. Frans de Waal en Tijs Goldschmidt over dierencultuur'. Vrij Nederland, 16 juni, 65-68.

Lott, T.L. (1995). 'King Kong Lives: Racist Discourse and the Negro-Ape Metaphor'. In: Next of King: Looking at the Great Apes. Cambridge: MIr List Visual Arts Center, 37-43.

Lott, T.L. (1999). The Invention of Race. Malden: Blackwell.

Mak, G. (1997). Mannelijke vrouwen. Over grenzen van sekse in de negentiende eeuw. Amsterdam: Boom.

Malamud, B. (1982). De gratie Gods. (Vert. uit het Engels door D. van Oort). Amsterdam: Meulenhoff.

Mann, W. M. (1940). 'Man's Closest Counterparts'. The National Geographic Magazine (augustus), 213-235.

Mans, I. (1998). Zin der zotheid. Vijf eeuwen cultuurgeschiedenis van onnozelen, zotten en zwakzinnigen. Amsterdam: Bert Bakker.

Marks, J. (1994). 'Book Reviews - The Great Ape Project. Equality beyond Humanity'. Human Biology: Journal of the Society for the Study of Human Biology 66 (I), $1 \mathrm{m3}-\mathrm{m}$ 7.

Marks, J. (1999). 'Book Reviews - Demonic Males: Apes and the Origins of Violence'. Human Biology: Journal of the Society for the Study of Human Biology $7 \mathrm{I}(\mathrm{I}), \mathrm{I} 43$ - 146.

Marres, R. (1994). 'Het vermeende racisme van Helmans De stille plantage'. De nieuwe taalgids, 87 (5), 426-43I.

Masson, J. \& McCarthy, S. (1997). Wanneer olifanten huilen. Het gevoelsleven van dieren. (Vert. uit het Engels door P. Syrier). Amsterdam: Vassallucci.

Mauriac, F. (1928). Le Roman. Parijs: Choureau.

Mayr, E. (1992). Het recht van de sterkste. Amsterdam: Prometheus.

McDermott, W. (1938). The Ape in Antiquity. Baltimore: The John Hopkins Press.

McEwan, I. (1977). 'Overpeinzingen van een gemainteneerde aap'. (Vert. uit het Engels door H. ten Holt). In: Tussen de lakens. Amsterdam: De Harmonie, 28-47. 
McEwan, I. (1997). 'Reflections of a Kept Ape'. In: In Between the Sheets. Londen: Vintage, 19-37.

McGrew, W.C. (1992). Chimpanzee Material Culture: Implications for $\mathrm{Hu}$ man Evolution. Cambridge: Cambridge University Press.

McGurl, M. (1996). 'Making It Big: Picturing the Radio Age'. Critical Inquiry, 22, 415-445.

Meijer, M. (1988). De lust tot lezen. Nederlandse dichteressen en het literaire systeem. Amsterdam: Sara.

Meijer, M. (1996). In tekst gevat. Inleiding tot een kritiek van representatie. Amsterdam: Amsterdam University Press.

Merchant, C. (1983). The Death of Nature: Women, Ecology, and the Scientific Revolution. San Francisco: Harper and Row.

Meulenbelt, A. (red.) (1985). Wie weegt de woorden. De auteur en haar werk. Amsterdam: Sara.

Meulenbelt, A. (red.) (1998). De eerste sekse: meningen over mannelijkheid. Amsterdam: Van Gennep.

Midgley, M. (1994). 'Born Free, but Everywhere in Zoos'. The New York Times Book Review, 33.

Mitchell, W.J.T. (1994). Picture Theory. Essays on Verbal and Visual Representation. Chicago et cetera: The University of Chicago Press.

Moffat, J. (1976). Queen Kong. Londen: Everest Books.

$\mathrm{Mol}, \mathrm{A}$. (1983). 'Wie weet wat een vrouw is. Over de verschillen en verhoudingen tussen wetenschappen'. Tijdschrift voor Vrouwenstudies 6 (2I), 1023.

Mol, A. (1993). 'Petit Bâteau. Belevenissen van een intellectuele moeder'. Lover, $1,12-15$.

Mol, A. (1994). 'Where the Strangers are. A Reaction to Zygmunt Bauman: The Stranger Revisited - and Revisiting'. Ongepubliceerde lezing, gehouden in Groningen, 9 oktober.

Montaigne, M. (1993). 'Apologie voor Raymond Sebond'. Essays II. (Vert. uit het Frans door F. de Graaff). Amsterdam: Boom, 548. Oorspr. jaar van uitgave: 1580 .

Montgomery, S. (1991). Walking With the Great Apes. Jane Goodall, Dian Fossey, Biruté Galdikas. Boston: Houghton Miflin.

Moorehead, C. (1978). 'Who Else But Ian McEwan Would Put a Lover in Ape's Clothing?' The Times, 14 jan.

Morell, V. (1995). Ancestral Passions: the Leakey Family and the Quest for Humankind's Beginnings. New York: Simon and Schuster.

Morris, D. (1971). Intimate Behaviour. New York: Random House. 
Morris, R. \& Morris, D. (r966). Men and Apes. Londen: Sphere Books.

Mowat, F. (1987). Woman in the Mists. The Story of Dian Fossey and the

Mountain Gorillas of Africa. New York: Warner Books.

Myers, G. (1990). 'Making a Discovery: Narratives of Split Genes'. In: C.

Nash (red.), Narrative in Culture: The Uses of Storytelling in Sciences, Philosophy and Literature. New York: Routledge.

Niemöller, J. (200I). 'Het Paul Verhoeven effect'. HP/De Tijd, 29 juni, 6o-61. Noske, B. (1992). Huilen met de wolven. Een interdisciplinaire benadering van de mens-dier relatie. Amsterdam: Van Gennep.

Nowak, (1999). Almost Human. New Scientist, 13 feb., 20-2I.

Ohnuki-Tierny, E. (1987). The Monkey as Mirror. Symbolic Transformations in Japanese History and Ritual. Princeton: Princeton University Press.

Orpa Sari, R. (1999). Riska, het verhaal van een Dajakmeisje (Vert. uit het Engels door M. Koch). Amsterdam: Meulenhoff.

Oudshoorn, N. (1998). 'Representatie of script? Over gender, de woorden en de dingen'. Tijdschrift voor Genderstudies I (3), 5-12.

Oversteegen, J.J. (1986). Anastasia en de school van Richter. Utrecht: Hes.

Patterson, F. \& Linden, E. (1981). The Education of Koko. New York: Holt, Rinehart and Winston.

Perloff, M. (1981). The Poetics of Indeterminacy: Rimbaud to Cage. New Jersey: Princeton University Press.

Platt, R. (red.) (1995). Next of Kin: Looking at the Great Apes. Cambridge: Pegasus Press.

Ploeg, I. van der (1998). Prosthetic Bodies: Female Embodiement in Reproductive Technologies. Maastricht: Universiteit van Maastricht.

Poe, E.A. (1995). 'The Murders in the Rue Morgue'. In: The Murders in the Rue Morgue and Other Stories. Keulen: Könemann, 183-223. Oorspr. jaar van uitgave: $184 \mathrm{I}$.

Prins, B. (1997). The Standpoint in Question. Situated Knowledges and the Dutch Minorities Discourse. Proefschrift Universiteit van Utrecht. Pynchon, T. (1973). Gravity's Rainbow. New York: Viking Press.

Ramsoedh, H. (1995). 'Albert Helman: een inleiding'. Oso, I4 (I), 5-8. Rebello, S. \& Allen, R. (1988). Reel Art. Great Posters from the Golden Age of the Silver Screen. New York, Londen, Paris: Abbeville Press.

Reybrouck, D. van (2000). From Primitives to Primates. A History of Ethno- 
graphic and Primatological Analogies in the Study of Prehistory. Proefschrift Universiteit van Leiden.

Roger, A. (1996). 'Ian McEwan's Portrayal of Women'. Forum for Modern Language Studies xxxii (32), п-26.

Rood, L. (2000). Broeders van de zesde dag. Amsterdam: Prometheus.

Room, A. (1993). The Naming of Animals: an Appelative Reference to Domestic, Work and Showanimals, Real and Fictional. Jefferson: McFarland.

Rooy, P.D. de (1991). Op zoek naar volmaaktheid. H.M. Bernelot Moens en het mysterie van de afkomst. Houten: De Haan.

Rose, H. (1994). Love, Power, Knowledge: Towards a Feminist Transformation of the Sciences. Cambridge: Polity Press.

Rouse, J. (1992). 'What Are Cultural Studies of Scientific Knowledge?' Configurations, 1, 1-22.

Ruiter, F. \& Smulders, W. (1996). Literatuur en moderniteit in Nederland, I840-1990. Amsterdam: De Arbeiderspers.

Rumbaugh, D.M. (1977). Language Learning by a Chimpanzee: the Lana Project. New York: Academic Press.

Rutgers, W. (1993). 'De Indiaan in Albert Helman'. Oso, 12 (2), 16I-166.

Ryan, K. (1994). Ian McEwan. Plymouth: Northcote House.

Sapontzis, S.F. (1993). 'Aping Persons - Pro and Con'. In: Cavalieri, P. \& P. Singer, The Great Ape Project; Equality beyond Humanity. New York: St. Martin's Press.

Savage-Rumbaugh, S. \& Lewin, R. (1994). Kanzi: the Ape at the Brink of the Human Mind. Londen: Doubleday.

Schaeffer, T. \& Köhler, P. (1994). Das Affen-Buch. Zürich: Haffmans verlag. Schaller, G.B. (1964). The Year of the Gorilla. Chicago: The University of Chicago Press.

Schasz, J.A. (1973). Reize door het Aapenland; naar de druk van 1788 uitgegeven en met inleiding en aantekeningen door dr. P.J. Buijnsters. Zutphen: Thieme.

Schiebinger, L. (r993). 'The Gendered Ape: Early Representations of Primates in Europe'. In: M. Benjamin (red.), A Question of Identity. Women, Science and Literature. New Brunswick, п19-152. New Jersey: Rutgers University Press.

Schilthuizen, M. (1998). 'Een zielenknijper van apen'. Intermediair, 34 (13). Scholnick, R. J. (red.) (1992). American Literature and Science. Kentucky: The University Press of Kentucky. 
Schrover, E. (1991). 'Literatuur en psychoanalyse'. In: P. Zeeman (red.), Literatuur en context. Een inleiding in de literatuurwetenschap. Nijmegen: SUN, 136-164.

Schudson, M. (1997). Paper Tigers. Lingua Franca, (8), 50-56.

Schutte, X. (1999). Maskerade. Amsterdam: De Bezige Bij.

Schwibbe, M. (1999). Der Geile Affe. Ongepubliceerd manuscript. Deutschzes Primatenzentrum Göttingen.

Self, W. (1997). Great Apes. Londen: Penguin.

Sens, A. (2001). Mensaap, heiden, slaaf. Nederlandse visies op de wereld rond 1800 . Den Haag: SDU.

Shoumatoff, A. (1989). 'De vrouw die van gorilla's hield'. In: A. Shoumatoff (red.), Afrikaanse gekte. Amsterdam: Amber, 19-61.

Shuttleworth, S. (1984). George Eliot and Ninetheenth-Century Science. Cambridge: Cambridge University Press.

Sippi, D. (1989). 'Aping Africa: the Mist of Immaculate Miscegenation'. CineAction! (Fall), 18-28.

Small, M.F. (1984). Female Primates. Studies by Women Primatologists. New York: Alan R. Liss.

Smelik, A. (1993). 'Carrousel der seksen'. In: R. Braidotti (red.), Een beeld van een vrouw. De visualisering van het vrouwelijke in een postmoderne cultuur. Kampen: Kok Agora, 19-50.

Smelik, A. (1995). And the Mirror Cracked. A Rhetoric Study of Feminist Cinema. Amsterdam: Amsterdam University Press.

Smit, A. (200r). 'Er gaapt geen kloof tussen mens en dier'. Interview met Frans de Waal in: Intermediair, 26, 16-17.

Smith, P. (1996). Boys: Masculinities in Contemporary Culture. Boulder: Westview Press.

Snead, J. (199I). 'Spectatorship and Capture in King Kong: the Guilty Look'. Critical Quarterly, 33 (1), 53-69.

Snead, J. (1994). White Screens, Black Images. Hollywood from the Dark Side. Londen et cetera: Routledge.

Spalding, L. (1998). The Follow. Londen: Bloomsbury.

Spencer, F. (1995). 'Pithekos to Pithecanthropos: An Abbreviated Review of Changing Scientific Views on the Relationship of the Anthropoid Apes to Homo'. In: R. Corbey \& B. Theunissen (1995), 13-29.

Spiering, H. (200I). 'Mens en dier.' Wetenschapsbijlage NRC Handelsblad, 23 juni.

Squier, S. (1998). 'Interspecies Reproduction: Xenogenic Desire and the Feminist Implications of Hybrids'. Cultural Studies I2 (3), 360-381. 
Stacey, J. (1997). Terratologies: a Cultural Study of Cancer, Londen: Routledge.

Steinz, P. (200I). 'Monster zonder eigenschappen. Modern griezelen met Mark Danielewski'. NRC Handelsblad Boeken, $\mathrm{r}$ juni.

Sterck, L. (1995). Females, Foods and Fights. A socioecological comparison of the sympatric Thomas Langur and Long-Tailed Macaque. Utrecht: Utrecht University.

Strindberg, A. (1989). De vader. Treurspel. (Vert. uit het Zweeds door K. Woudstra). Amsterdam: Carrousel. Oorsp. jaar van uitgave 1887.

Strum, S.C. \& Fedigan, L.M. (red.) (2000). Primate Encounters. Models of Science, Gender and Society. Chicago: The University of Chicago Press.

Swindler, D. R. (1998). Introduction to the Primates. Seatlle et cetera: University of Washington Press.

Terrace, H.S. (1979). Nim. New York: Knopf.

Timmers, J.J.M. (1987). Christelijke symboliek en iconografie. Houten: De Haan.

Tobing Rony, F. (1996). The Third Eye. Race, Cinema and Ethnographic Spectacle. Londen et cetera: Duke University Press.

Torgovnick, M. (1990). Gone Primitive. Savage Intellects, Modern Lives.

Chicago \& Londen: The University of Chicago Press.

Torgovnick, M. (1996). 'A Passion for the Primitive: Dian Fossey among the Animals'. The Yale Review, 84 (4), I-8.

Treglown, J. (1978). 'Apelands'. The Nezw Review, 4 (47).

Tudor, A. (1989). Monsters and Mad Scientists: A Cultural History of the Horror Movie. Oxford: Basil Blackwell.

Tuttle, R. (1994). 'A Trans-Specific Agenda'. Science: a Weekly Journal devoted to the Advancement of Science, 264 (5158), 602-603.

Verre, T. van (1980). Tony van Verre ontmoet Albert Helman. Uit het leven van een dwarsliggende Indiaan. De Gooise Uitgeverij: Bussum.

Voltaire (1983). Candide ou l'optimisme. La princesse de Baylone et autres contes. Parijs: Le livre de poche. Oorspr. jaar van uitgave: tussen 1747 en 1775 .

Voort, C. van der (r99I). 'De analyse van verhalend proza'. In: P. Zeeman (red.), Literatuur en context. Een inleiding in de literatuurwetenschap. Heerlen: suN, 24-47. 
Waal, F. de (1982). Chimpansee-politiek. Macht en seks bij mensapen. (Vert. uit het Engels door F. Bos). Amsterdam: Becht.

Waal, F. de (1988). Verzoening. Vrede stichten onder apen en mensen. (Vert. uit het Engels door M. Dekkers). Utrecht: Het Spectrum.

Waal, F. de \& Lanting, F. (r997). Bonobo: the Forgotten Ape. Berkeley: University of California Press.

Waal, F. de (1998). Van nature goed. Over de oorsprong van goed en kwaad in mensen en andere dieren. (Vert. uit het Engels door F. Lakmaker). Amsterdam et cetera: Contact.

Waal, F. de. (200I). De aap en de sushimeester. Over cultuur bij dieren. Amsterdam: Contact.

Walcott, D. (1970). Dream on Monkey Mountain and Other Plays. New York: Farrar, Straus en Giroux.

Warner, M. (1996). From the Beast to the Blonde: Fairy Tales and Their Tellers. New York: Noonday Press.

Weijers, I. (r991). Terug naar het behouden huis: romanschrijvers en wetenschappers in de jaren vijftig. Amsterdam: suA.

Weisenburger, S. (1988). A Gravity's Rainbow Companion: Sources and Texts for Pynchon's Novel. Georgia: The University of Georgia Press.

Wesseling, L. (1996). 'Nosferatu. Over literatuur, wetenschap en historische traditie'. Tijdschrift voor Literatuurwetenschap, I (4), 25I-265.

Wesseling, L. (1998). 'Van ideeëngeschiedenis naar cultuurgeschiedenis. Over de ontwikkelingsgang van een interdisciplinaire onderzoekspraktijk: Tijdschrift voor Literatuurwetenschap, 3 (I), 49-65.

Wester, R. (1991). 'William Boyd: "Mijn komische visie op de wereld is zwart, heel zwart". Vrij Nederland, 2I september.

Wilde, O. (1992). The Picture of Dorian Gray. Hertfordshire: Wordsworth Classics. Oorspr. jaar van uitgave: 1891 .

Winterson, J. (r992). Written on the Body. Londen: Vintage.

Wolf, N. (2001). 'Het moederschap en het ontstaan van een moderne obsessie'. Vrij Nederland, 28 april, 38-42.

Wrangham, R. \& Peterson, D. (1998). Agressieve mannetjes. Over mensapen en de oorsprong van geweld bij de mens, (Vert. uit het Engels door $\mathrm{F}$. Lakmaker). Amsterdam: Nieuwezijds.

Wright, R. \& Rivera J. \& Hulse S. \& Shyan, M. \& Neiworth, J. (2000). 'Music Perception and Octave Generalization in Rhesus Monkeys'. Journal of Experimental Psychology, 129 (3), 29I-207. 
Yerkes, R.M. \& Yerkes, A.W. (r929). The Great Apes. A Study of Anthropoid Life. New Haven: Yale University Press.

Zenderland, L. (1990). 'A View from the Other End of the Telescope'. New Scientist, 58 , 21 april.

Zigman, L. (1998). Animal Husbandry. Londen: Hutchinson.

Zuckerman, S. (1998). The Ape in Myth and Art. Kelso: Verdigris Press. 


\section{Fotoverantwoording}

I Dave Gray.

2 Dave Gray.

3 http://www.diesel.com.

4 Van Dale Groot Woordenboek der Nederlandse Taal. $\mathrm{m}^{\mathrm{e}}$ herz. druk, 1984. Utrecht, etc.: Van Dale Lexicografie, 39.

5 Ida Wyman.

6 Internet.

7 Amsterdam: Querido.

8 http://www2.netdoor.com/\%7Ecampbab/kongz.html.

9 New York: A.S. Barnes and Company, 229, RKo.

Io Cambridge: MIT List Visual Arts Center, 40.

II Internet.

I2 Dino De Laurentiis Corporation.

r3 Londen: Everest Books.

I4 Wereld Natuur Fonds.

15 Rijswijk: Elmar.

16 New York: Mallard Press, 24.

17 Rod Brindamour, Orangutan Foundation International. http://www.primate.wisc.edu/pin/images/imgor55.gif

18 Dirk Draulans.

I9 Peter Dicampos.

20 John Derek.

2I Artwork Springtime Film Bv.

22 Times Newspapers.

23 The Gorilla Foundation: dr. Francine Patterson en dr. Cohn.

24 The Gorilla Foundation: dr. Francine Patterson en dr. Cohn. 


\section{Summary}

\section{Why Women Like Apes. \\ A Love Affair in Science and Culture}

Western culture is filled with examples of erotic relationships between dark-haired apes and blonde women. Not only do we find this association in many movies and novels; there is also a striking connection between the woman and the ape in the scientific practice of primatology. Many female primatologists have devoted their lives to the study of apes - Jane Goodall and Dian Fossey being the most famous examples. Their life and works have been the subject of many movies, novels, biographies and documentaries. The remarkable relationship between the woman and the ape raises the question why this combination recurs and why it is significant. In this thesis, I analyse a small number of examples taken from short stories to novels, films, documentaries and (popular) scientific books from the twentieth century, in which the relationship between the woman and the ape plays a crucial role. In doing so, I ask whether there are significant changes throughout time and, if so, how can these be explained.

In the first two chapters, I establish a theoretical and methodological framework for reading and interpreting stories about women and apes. The first chapter, The Ambiguous Ape. Thoughts on Otherness', deals with the categories of 'woman' and 'ape' in western society. Apes are often considered to be 'ambiguous', because they defy clear-cut categories of 'human' and 'animal'. Following Donna Haraway's critical study of primatology, Primate Visions. Gender, Race and Nature in the World of Modern Science (1998), I argue that apes as 'animal others' have always played an important role in defining the categories of 'human', 'animal', 'male, 'female, 'black', 'white', 'nature' and 'culture'. Like the ape, the woman has been defined as 
the 'other' in western society. In this thesis, I ask what happens when two 'others' encounter each other. The attention that Annemarie Mol pays to the dynamic, contextual, local and relational aspects of 'otherness', calls for a turn to storytelling, because the story is not a static entity, but capable of catching movement and change. Thus, a step is made from the ape and the woman as the 'theoretical' other, to the ape and the woman as constructed in storytelling.

The second chapter, 'Stories about Women and Apes. The Relationship between Science and Culture', asks whether and how it is significant that the association between the woman and the ape occurs in the scientific practice of primatology as well as in popular culture. With Donna Haraway, I argue that the distinction often made between 'culture' (the domain of fiction) on the one hand, and 'science' (the domain of facts) on the other, is blurrier than we might expect. Science is a storytelling practice, and primatology, the scientific discipline providing us with 'the facts' about apes, is often more heterogeneous and imaginative than we might think, as it draws on many discourses at once, including science fiction, survival literature, and romantic adventure tales.

Primatology, however, is not only a storytelling practice, as $\mathrm{Ha}$ raway argues, but also a reading-practice. Unlike Haraway, who reduces films and novels to illustrations of ideological arguments, I emphasise the reader's role in establishing meaning. The reader may choose to read stories as ideological arguments, or, read them in a more traditional 'literary' way, focusing on the ambiguities of texts. I argue for having the best of both worlds, that is to contextualise a particular story, by reading it in relation to other stories and noticing the way it conveys ideological arguments and stereotypes, and, at the same time, focusing on the specificity and ambiguities and alternative readings of an individual text. Reception-studies, which examine how others have interpreted and valued texts, also provide insights in which aspects readers find meaningful, how 'closure' of meaning takes place, and how different readings of the same text are possible throughout time.

In the remaining chapters these ideas are put into practice. They are devoted to the analysis, interpretation, reception and contextualisation of a specific short story, novel, film or popular scientific book from twentieth century western culture. In these stories, the relationship between the woman and the ape 'triggers' the plot: not 
only does it make other characters act and react, but it also troubles the critics.

Chapter three, 'Why a Man Murders an Ape', is based on a close reading of Mijn aap schreit. Een korte roman (My ape weeps. A short novel, 1928), written by the Dutch-Surinam novelist Albert Helman. Helman tells the story of a young man who loathes his ape so much that he decides to poison it. I discuss the novel by relating it to three major theories that have proposed models for thinking about the origin and nature of man: Darwinism, Freudian psychoanalysis and Christianity. I argue that the close connection between the female characters and his ape confronts the narrator with life's largest questions: who am I, where do I come from, and how should I live? Each time the narrator sees his ape with a woman, he compares himself to the ape. He wonders whether he should follow his instincts (Darwinism) or should repress his sexual desires and live a rational and moral life with Christ as a guiding example (Christianity). I argue that by murdering his ape, the narrator tries to end his continuous doubts on the origin of man and the nature of man. Unlike himself, the ape is capable of integrating 'otherness' in its identity. Therefore it becomes an ideal figure for the narrator, a Christlike figure. By murdering his ape, the narrator symbolically reinforces the traditional hierarchies between human and animal and man and woman. However, the murder is a tragic one, because the narrator feels 'estranged' from everyone else. I conclude the chapter by arguing that critics have symbolically repeated the murder of the ape, by reducing the meaning of the ape to the alter ego of the narrator, without recognising its ambiguity.

In his later work, Helman continued to write on the subject of the woman and the ape, both from a religious point of view as well as from a colonial perspective, using the ape as a symbol for blackness. The ape as Christlike figure and the ape as black other are elaborated further upon in the next chapter, which deals with a movie that provided us with the one of the best known images of the woman and the ape. In chapter four 'Killer King or Gentle Giant. King Kong between Fact and Fiction' I discuss the creation, interpretation and reception-history of the film King Kong (1933). The movie tells the story of a gorilla that is hopelessly in love with a blond girl. The construction of the gorilla and the girl can be traced back to debates on the nature of gorilla from the nineteenth century on- 
wards. Scientists and artists alike struggled with the gorilla's ambiguity, referring to it both as a 'rape-ape', a danger to women, and as a 'gentleman', a girl's best friend. Through combining different ideas from science and fiction, the directors of King Kong managed to create an ambiguous creature that was divine, animal and human, female and male, gentle and violent. However, as in Mijn aap schreit, the murdering of the gorilla at the movie's end, serves to reinforce the hierarchies between human and animal, nature and culture, female and male, black and white.

In the reception-history of the film, the struggle with the ambiguous nature of the gorilla once again becomes visible. Because of its ambiguity, King Kong becomes an ideal figure for projecting on to many roles, varying from a 'killer king' to a 'gentle giant'. One the one hand, cultural critics have argued that King Kong is intended to represent a human. They have interpreted the gorilla as a violent black rape-man or as gentle social outcast, a homosexual, Christ, a Jew, a child and an orphan. Scientists, on the other hand, have stated that King Kong is a false representation of an animal, a gorilla. They blamed the Hollywood monster for reinforcing the negative image of the gorilla, which, in part because of films like King Kong, is murdered in real life. They have tried to replace the 'false' cultural image with the 'real' scientific image, using King Kong as a rhetoric example of a false fictional portrayal of a gorilla. In my interpretation $I$ argue that both the cultural critics, who interpret King Kong as a human being, and the scientists, who see King Kong as a false representation of an animal, neglect to consider King Kongs enormous size. $\mathrm{He}$ is neither human nor animal; his size makes him a giant, in the tradition of stories about giants. I conclude that scientists have been very successful in promoting the image of the gorilla as a gentle giant. The important role of Dian Fossey and her female colleagues in establishing the image of the gentle ape, is the subject of the next chapter.

Chapter five, 'Why Female Scientists like Apes. The Image Industry of Jane Goodall, Dian Fossey and Biruté Galdikas' is concerned with the way female primatologists represented themselves and 'their' apes, and the way they have been represented by others in movies, films, novels, biographies and documentaries. An analysis of three popular scientific books by Jane Goodall, Dian Fossey and Biruté Galdikas, shows how twofold strategies are used to convey 
the idea that apes are gentle and humanlike. With their ethnographical fieldwork, placing themselves amongst the animals, they emphasise the apeness of humans. At the same time, the humanity of apes is demonstrated, by researching them as individuals, as if they were human beings. However, it is shown that the term 'human' presents the female primatologists with a contradiction. Applied to humans it means something negative, namely 'cruel', applied to apes, its connotation is positive, 'gentle'.

While Goodall, Fossey and Galdikas try to control the images of apes, their own image is controlled by filmmakers, novelists and biographers. Like the apes under examination, they become figures of projection, as they are presented either as beauties or as beasts. Another tension is also present: the female primatologist is represented as a sexy guide or as a mother of apes. I show how authors struggle with the ambiguous position of the white female primatologist in Third World countries, through analysing William Boyds Brazzaville Beach (1990), based on the life and works of Jane Goodall, Gorillas in the Mist (1992), in which Dian Fosseys life is portrayed, and finally The Follow (1998) and the thriller Gone Wild (1995), based on the life and work of Biruté Galdikas. Unlike Goodall and Fossey, Galdikas tried to influence and control the way she was portrayed. Spalding, for instance, was sued for her 'false' portrayal of Galdikas. However, Galdikas could not take action against Gone Wild, which also portrays her negatively, because this book was classified 'fiction'.

At the end of this chapter, I illustrate how the reader can 'counter-interpret' stereotypical images of female primatologists, by considering the significance of the fact that some of today's stories about female primatologists are told from a male point of view. Applying Haraway's notion of 'simian orientalism' to the biographer, I argue that the stories and images reveal us something about the uncertainty of masculinity. The next chapter follows from this: it is devoted to the identity crisis of man in the nineties, which coincides with a debate on the 'new' humanity.

In chapter six, 'Ape: an Ideal Husband. Debating the Great Ape Project', I analyse the rhetorical strategies used by the Great Ape Project, an international organisation which demands the extension of human rights to apes. On the one hand, the project emphasises that it is based on sound scientific proof. On the other hand, it 
continuously points the reader to fiction. Through a close reading of one the novels mentioned in the GAP, Peter Høeg's The Woman and the Ape, I show that the novel explores and exposes the moral consequences of The Great Ape Project in depth by presenting a future scenario. If the boundaries between animal and human are abolished, then 'inter-species' relationships become an option, and a new 'hybrid' race might be on its way. I argue that this novel, in which a woman leaves her husband and runs off with an ape, can be read as a warning for mankind: if these GAP-like situations are to be prevented, men had better take a serious look at themselves and learn from their ape rival. The representation of the ape as the new masculinity is ambiguous: it is divine, animal, human, feminine, masculine, tender and aggressive at once. By contextualising science, discussing its ideas in a cultural context and vice versa, interpreting fiction in relation to the debate on 'the new humanity', I thus show that the discussion about the 'new humanity' contains a discussion about masculinity and the position and role of men in society.

Whereas most love stories about the woman and the ape are written by male authors, the nineties have also witnessed an outburst of female authors taking up the subject. Like The Woman and the Ape, the satirical-comic novels Ark Baby (1998), The Last Manly Man (1998) and Animal Husbandry (1998) discuss The Great Ape Project and consequently point a critical finger towards men. But how serious are we to take these novels? No longer is the love affair between the woman and the ape told as a tragic tale, like in King Kong or Mijn aap schreit, but as something hilarious. I show that not only the boundaries between humans and apes and men and women are negotiated, but also those of serious literature and cultfiction, fact and fiction, science and culture. Chapter six ends with a question. What happens if all such boundaries are broken down? How do we, as men, women and authors establish an identity if difference no longer can be made between human and animal, female and male, literature and science, fact and fiction? And how are we as readers supposed to read the ambiguous ('apelike') texts?

These questions are taken up in the last chapter, 'Why Women Like Apes'. In this chapter, I summarise the main arguments of the thesis through a discussion of two texts. The first is a short story by Ian McEwan, 'Reflections of a Kept Ape' (1978), in which an ape reflects on his love for a female novelist. The second, The Ape and the 
Sushi Master. Cultural reflections of a Primatologist (2001), contains the reflections of a primatologist, Frans de Waal. Both texts draw attention to the perspective of the ape, in an attempt to destabilise the human point of view. Both also reflect on the definitions of 'text', 'reading', 'nature' and 'culture'. McEwan portrays 'human culture' as ape-like in a negative manner. Plagiarizing is all novelists ('apes of God') are capable of. De Waal, however, interprets 'aping' as a positive aspect of culture. It is through imitating that we reach creativity. I propose to read the two texts as commentaries on each other. In doing so, I show that De Waal's attempts to abolish the nature-culture dichotomy, implies the hierarchical shifts of the dichotomy between the natural sciences and the humanities. This leaves us with another question: are we moving toward a 'cultural primatology', in which cultural critics are most apt to study nature, and natural scientists are most inclined to study cultural artefacts? By focusing on ambiguities in McEwan's story, I show how the ambiguous ape can be interpreted, in a complex manner, as 'the text' itself to be written.

This thesis shows through stories about the woman and the ape that dichotomies are negotiated and refuted over and over again, and that one cannot refute one boundary, e.g. human-animal, without discussing others, for instance the male-female dichotomy. The chronology provides insights on views on gender, race, species, science and nature in the twentieth century changed during the twentieth century. Whereas the first two stories discussed in this thesis, Mijn aap schreit and King Kong, end with murder, chapter six showed how traditional hierarchies were criticised. Women chose to embrace apes, which represent ambiguity, and their sexual relationship with them predicts a future of a new hybrid species. This thesis cannot predict the future, but as has been shown, literature can provide us with 'what if'-stories. And one of them tells us, that the future is like an 'ape' yet to be written. 


\section{Personenregister}

Abir-am, P.G. $\quad$ 445

Adams, Douglas 195, 198

Akeley, C.E. 50, $113-114,137$

Alphen, E. van 105-106

Altmann, Jeanne $52,57,14 \mathrm{I}$

Annan, D. 132

Anstötz, Christoph 198

Apted, Michael 172

Arion, F.M. $77-78,103$

Aristoteles 75,198

Armbruster, K. $\quad 176$

Bakhtin, M.M. 65

Balzac 233

Barnum, P.T. II2, $\mathrm{I37}$

Barthes, R. 69

Bauman, Zygmunt 45

Blaffer Hrdy, Sarah $\quad$ I4I, I88

Blans, G.H.T. 58

Blumenbach, J.F. 205

Boccaccio 100, 235

Boëthius 92

Bohap, Pak 178-179

Bontius 205

Boyd, W. 19, 143, 163-164, 169, 171

Brent, L. 54

Brindamour, Rod 151, 156

Buikema, R. 27

Campbell, Bob r74-176

Cartmill, M. 27, 4I

Cavalieri, P. 38-39, 192-194, 196, 19820I, 204

Cawardine, Mark 195

Chaillu, P.B. du по, п2-116, 121, 133, 135, 137

Cicero 225
Collins, P.H. 30

Cooper, Merian I08, $\mathrm{n5}-\mathrm{H} 6, \mathrm{I2} 8$

Corbey, R. 9I, 193

Culler, Jonathan 64

Dalen-Oskam, K. van 96

Darwin 33. 35-38, 220, 223, 226-227, 243

Dawkins, R. 192-193, 195-197, 202

DeGrazia, D. 201-202

Dekkers, M. 38, 216-217, 256-257

Derek, Bo 214

DeVore, I. 22

Diamond, Jared $\quad$ 195, 197, 202-203

Dobbelaar, T. 54

Donne, John 234, 239

Dostojewsky, F. 88

Douglas, Mary $\quad 138,229$

Draulans, D. $16,143,178,186-189$

Duinkerken, A. van 79

Dyer, R. 27

Eco, Umberto 5 I

Engelman, Jan 79

Erasmus, Desiderius n9

Erb, C. 109, 115, 124, 129

Evans, Nicholas 28

Fedigan, L. $\quad 56,141$

Fedigan, L.M. I4I, I43-I44

Fierens, $\mathrm{H}$. $\quad 77-78,103$

Fossey, D. I5, 19, 38, 49, 64, 10, 133134, 136-137, 140-144, 147, 149-158, 161-163, 166, 171-177, 179, 182-184. 186-187, 194, 231, 239, 248, 253, 255

Foucault 24

Fouts, Deborah 196 
Fouts, Roger 196

France, Anatole 96

Freud $78,85,91,102,104,107,243$

Galdikas, B.M.F. $\quad 15,19,64$, 10, 140$144,147-158$, 160-163, 166, 172, 176$184,186,194,253-254$

Galdikas, Jane 152

Gandhi, I. 163

Garber, M. 30

Geest, S. van der 29

Gerigk, H.J. $\quad 65-66$

Gilbert, Sandra 57

Gilbert, W.S. 224

Godwin, S. по

Goethe, J.W. $\quad 84,88$

Goldner, O. II5, 133

Goodall, Derek 156

Goodall, J. I5, I9, 2I, 38, 49, 64, 140144, 146-160, 162-167, 169-172, 177 , $179,183-184,186-187,192,194,196$, $223-224,253$

Gossett, Thomas F. $\quad$ I26

Graff, G. 58

Greer, Germaine 155

Gubar, Susan 57

Guillermin, John 129, 132

Hall, J. I43, I77, 18I-182

Hanno III

Haraway, D. $18,2 \mathrm{I}-26,28,30,32,4 \mathrm{I}$, $45,47-58,6 \mathrm{I}, 64,66,70-72$, I4I-147, $179,183,214-216,240,249-251$

Haycraft, H. 96

Hayes, H.T.P. $171-172,174,176,178$

Hayter, S. I9I-192, 222

Heijst, A. van 6o-62

Helman, A. I7, 19, 63-64, 70, 75-76, 78-79, 8I, 97, 104-107, 240-24I

Hendriks, R. 29

Herbart, J. 88

Hinde, Robert 153

Hoch, P. 123-124, 126

Høeg, Peter 14-15, 17, 19, 48, 190, $198,205,210,212,217,219,222-223$

Hooks, B. 26, 44

Howard, J. 36

Hulse, S, 39

Imanishi, T. 246

Ingraham, C. 27

Irving, John 125
Jackson, Michael 29-30

Jahme, C. 142, 147, 156

Jahoda, G. I23

Janson, H.W. $16,18,33,48,65-66$,

8I, 9I, 100-IOI, 103, 236

Jardine, A. 30

Jensen, L. 19I-192, 223-224, 227

Jensen, S, 70, 187

Johnson, Mark 53

Johnson, Martin II4, 135

Johnson, Osa $\mathrm{II}_{4}, \mathrm{I35}$

Kafka, F. 225

Kayzer, Wim 149

Kempen, M. van $77-79,8 \mathrm{I}, 103$, 106

Kemperink, M.G. 38

Kloos, Willem 106

Kondo, D.K. 30

Krunkelsven, Ellen van $16,143,184$, 186-188

Kunitz, S.J. 96

Kuyle, Albert 79

Laarse, R. van der 37

Labrie, A. 37

Laet, M. de 54

Lakoff, G. 53

Lange, Jessica $15,129,212$

Lanting, F. $\quad 188$

Leakey, Louis $38,146-147,151,174$, 183-184

Lewin, R. $4 \mathrm{I}$

Lewis, C.S. 172

Lichtveid, Lou zie Helman, Albert

Linden, E. 39

Mans, I. 26

Marks, J. 202-204

Masson, J. 39

Mauriac, F. 235, 241

McCarthy, S. 39

McEwan, I. 20, 231-232, 238, 240, 243-244, 25I-252

McGuire, Wayne 171-172

Meijer, M. I8, 26, 49, 59-64, 67, 69$70,72,238,240,246,249$

Melching, W. 37

Milton, John 57

Mol, A. 18, 30-31, 42, 45-47

Montgomery, S. I42, I47, 172, 176

Mooijaart, M. 96

Morris, D. $38,116,123,216$

Morris, R. $\quad$ 16, 123 
Mowat, F. 156,172

Mozart, W.A. 246

Nagel, Thomas 244

Neiworth, J. 39

Niehe, Ivo 149

Noske, B. $28,36-37,193$

Ondaatje, Michael 180

Orpa Sari, R. $179,18 \mathrm{I}$

Oshima, Nagisa 2I4

Outram, D. 145

Owen, Richard III

Palmen, Connie 69

Patterson, F. $\quad 39,196$

Peterson, D. по, 136, 16I-162

Picasso 65

Plato 88, 98-99

Poe, Edgar Allen $\amalg 2$, I2I

Powers, Stephanie 180

Pynchon, T. 55, 122

Quinn, Daniel 28

Rabelais, François 137

Renant, Ernest 96

Rich, Adrienne 69

Riffaterre, M. 63

Rivera, J. 39

Roberts, Julia 180

Rooy, P.D. de 222

Rose, Ruth ${ }_{5} 5$

Rossellini, Isabella I8o

Rousseau, J.J. 204

Ruiter, F. de 79

Rumbaugh, D.M. 39

Said, Edward 23-24

Sapontzis, S.F. 196

Savage, Thomas III-п2

Savage-Rumbaugh, S, 4I

Schaller, G.B. 133-134

Schoedsack, Ernest Io8, п5-116, I28

Schopenhauer, A. 88

Schrover, E. 85

Schutte, X. 30, 71

Self, W. I9I-192, 223, 225-226

Shoumatoff, A. 171-172

Shyan, M. 39

Singer, P. $\quad 38-39,192-194,196,198-$ 20r, 204
Smelik, A. 27,30

Smith, P. 27, 30

Smulders, W. 79

Smuts, B. 22

Snead, J. 123,126

Socrates $88,98-99$

Spalding, Linda $143,177-182,187$

Spielberg, Steven I09

Stone, Sharon 180

Strindberg, A. 63-64, 88

Strum, S.C. $\quad$ I5

Swift, Jonathan 137

Tauchnitz, B. 88

Terrace, H.S. 39

Timmers, J.J.M. 96

Thomas a Kempis $63-64,88$, 100

Thomas van Aquino 75, 92

Tobing Rony, F. 123

Torgovnick, M. $26,171,178$

Turner, G.E. $\quad$ I5, 133

Tuttle, R. 204

Tyson, Edward m-ш2, 222

Tyson, Mike 124

Verre, T. van $24 \mathrm{I}$

Voltaire 17

Waal, F. de $\quad 20,32,38-39,1$ о, 134 , I49, I6I-162, 188, 229, 232, 243-25I, 254, 256

Walcott, D. 123

Warner, M. 122

Wilde, O. 88

Winterson, J. $\quad$ I22

Wolf, Christa 69

Wollstonecraft, M. 69

Wrangham, R. по, 136, 161-162

Wright, R. 39

Wyman, Jeffries III

Yerkes, A.W. $\quad$ 52, по-피, II3-II4, 120I2I, 134-135, 137

Yerkes, R.M. $\quad 49,52$, по-m, II3-II4, 120-121, 134-135, 137, 16o

Zenderland, L. 54

Zigman, L. I9I-192, 222, 224, 227

Zihlman, Adrienne $14 \mathrm{I}$

Zuckerman, S. $\quad 65-66$ 


\section{Curriculum vitae}

Stine Jensen werd geboren op 13 januari 1972 te Hillerød in Denemarken. Ze emigreerde op jonge leeftijd naar Nederland, Oegstgeest, waar ze het lager en middelbaar onderwijs genoot. Aan het Rijnlands Lyceum te Oegstgeest behaalde ze het gymnasiumdiploma. Na toekenning van een studiebeurs van het Danmark-Amerika Fonds, studeerde ze een jaar aan het Liberal Arts College of Wooster in Ohio. Daarna keerde ze terug naar Nederland om aan de Rijksuniversiteit Groningen te gaan studeren. Ze studeerde eerst cum laude af in de algemene literatuurwetenschap en behaalde een jaar later het doctoraaldiploma van de opleiding wijsbegeerte. De doctoraalscriptie die uit de laatste studie voortvloeide, werd bewerkt tot een boekpublicatie: De verlangenmachine. Vrouwen in de popmuziek (Prometheus 200I). In september 1997 werd ze als assistent in opleiding aan de Universiteit van Maastricht aangesteld en nam ze deel aan de aio-opleiding van de onderzoekschool wTMC (Wetenschap, Techniek en Moderne Cultuur). Het schrijven van haar proefschrift Waarom vrouwen van apen houden. Een liefdesgeschiedenis in cultuur en wetenschap (Bert Bakker, 2002) combineerde ze met diverse journalistieke activiteiten. Ze schrijft onder meer literatuurrecensies en stukken over populaire cultuur in NRC Handelsblad en ze schreef diverse artikelen over film, literatuur en popmuziek voor bijvoorbeeld De Gids, Armada, Filosofie Magazine en Marie Claire. Ze is redacteur van Biografie Bulletin; als gastredacteur verzorgde zij onlangs ook voor $A r-$ mada het nummer 'Het Apentheater', over het beeld van de aap in de literatuur. Momenteel is ze werkzaam als universitair docent televisiestudies bij de opleiding Algemene Cultuurwetenschappen aan de Faculteit der Letteren van de Universiteit van Nijmegen. 

In de westerse literatuur en film wemelt het van de erotische voorstellingen van apen en vrouwen. Niet alleen in de culturele verbeelding, maar ook in de hedendaagse primatologie - het wetenschappelijke onderzoek naar apen, mensapen en mensen treft men een innige band aan tussen vrouwen en apen. Elke apensoort lijkt zijn eigen toegewijde vrouw te hebben.

In Waarom vrouwen van apen houden maken we een reis langs de liefdesgeschiedenis tussen de vrouw en de aap in een selectie van korte verhalen, romans, films en (populaire) wetenschap van de twintigste eeuw. De revue passeren onder meer Albert Helmans Mijn aap schreit, natuuriijk de film King Kong, de representatieindustrie rondom vrouwelijke primatologen als Jane Goodall en Dian Fossey, en een golf van romans en films in de jaren negentig waarin de aap als ideale man opduikt.

De relatie tussen de vrouw en de aap wordt in Waarom vrouwen van apen houden steeds in verband gebracht met recente wetenschappelijke debatten. Het resultaat is een bijzondere verbeeldingsgeschiedenis, waarin niet alleen hoofdrollen zijn weggelegd voor de vrouw en de aap, maar ook voor de verwevenheid van cultuur en wetenschap, feit en fictie, en waarheid en verbeelding.

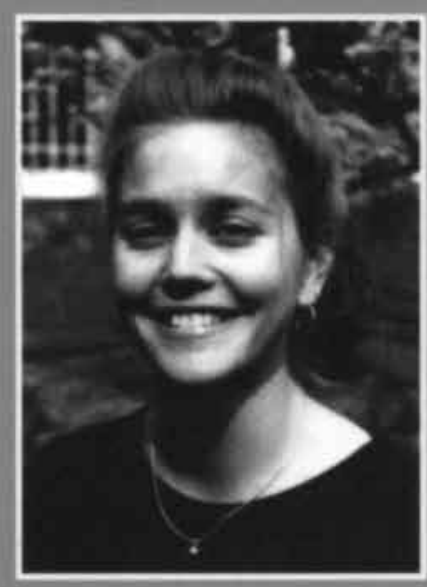

Stine Jensen is literatuurwetenschapper en filosoof. Zij is onder meer literatuurcriticus voor NRC Handelsblad. Eerder publiceerde zij De verlangenmachine. Vrouwen in de pop. muzick. 